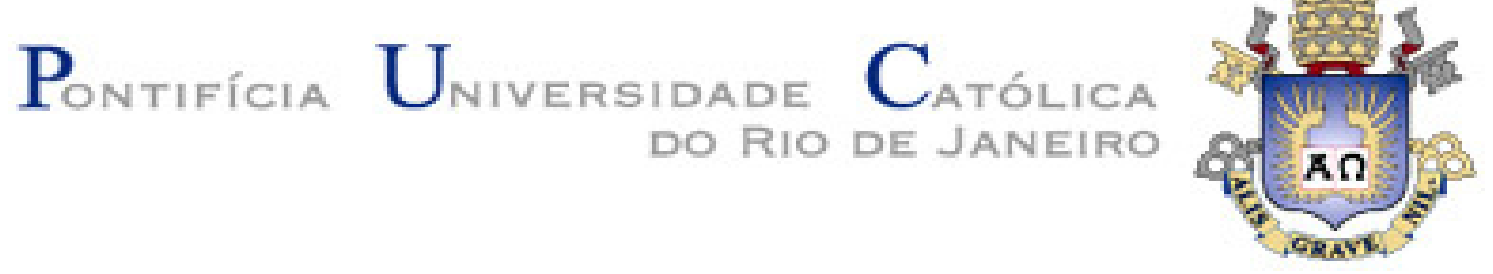

Carlota Salgadinho Ferreira

\title{
O quasi-realismo cético de David Hume
}

Tese de doutorado

Tese apresentada como requisito parcial para a obtenção do grau de Doutor em Filosofia ao Programa de Pós-graduação em Filosofia da PUC-Rio.

Orientador: Prof. Dr. Danilo Marcondes de Souza Filho Coorientadora: Profa. Dra. Célia Cristina Patrício Teixeira 


\title{
Pontifícia Universidade Católica $_{\text {a }}$

Carlota Salgadinho Ferreira

\section{O quasi-realismo cético de David Hume}

\begin{abstract}
Tese de doutorado
Tese apresentada como requisito parcial para a obtenção do grau de Doutor em Filosofia ao Programa de Pós-graduação em Filosofia da PUC-Rio, aprovada pela Comissão Examinadora abaixo:

Prof. Danilo Marcondes de Souza Filho

Orientador

Departamento de Filosofia - PUC-Rio

Profa. Célia Cristina Patrício Teixeira

Coorientadora

Departamento de Filosofia da UFRJ

Prof. Dr. Renato de Andrade Lessa

Departamento Direito - PUC-Rio

Profa. Dra. Lívia Mara Guimarães

Departamento de Filosofia - UFMG

Prof. Dr. Plínio Junqueira Smith Departamento de Filosofia - Unifesp

Prof. Dr. Marcos César Seneda

Departamento de Filosofia - UFU
\end{abstract}

Rio de Janeiro

19 de novembro de 2020 
Todos os direitos reservados. É proibida a reprodução total ou parcial do trabalho sem autorização da universidade, da autora e do orientador.

Carlota Salgadinho Ferreira

Ficha catalográfica

Ferreira, Carlota Salgadinho

O quasi-realismo cético de David Hume / Carlota Salgadinho Ferreira ; orientador: Danilo Marcondes de Souza Filho ; coorientadora: Célia Cristina Patrício Teixeira. - 2020.

372 f. ; $30 \mathrm{~cm}$

Tese (doutorado)-Pontifícia Universidade Católica do Rio de Janeiro, Departamento de Filosofia, 2020.

Inclui bibliografia

1. Filosofia - Teses. 2. Quasi-realismo. 3. Ceticismo moderno. 4. David Hume. I. Souza Filho, Danilo Marcondes de. II. Teixeira, Célia Cristina Patrício. III. Pontifícia Universidade Católica do Rio de Janeiro. Departamento de Filosofia. IV. Título. 


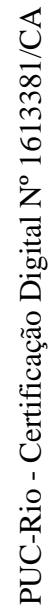

Aos meus pais 


\section{Agradecimentos}

Primeiramente, agradeço aos meus pais, que apoiam incondicionalmente o meu interesse filosófico e o aprofundamento do meu estudo, assim como a escolha de uma carreira académica transatlântica.

Agradeço ao meu orientador, professor Danilo Marcondes, e à minha coorientadora, professora Célia Teixeira, pelo apoio constante na investigação que resultou nesta tese, tanto sob a forma de valiosas sugestões durante o processo de escrita como da confiança na qualidade do meu trabalho, que sempre permeou as nossas conversas. Agradeço ainda particularmente ao professor Danilo pelo seu acolhimento e tranquilidade que me transmitiu desde que ingressei no doutorado.

Agradeço aos membros efetivos da banca, professores Renato de Andrade Lessa, Lívia Mara Guimarães, Plínio Junqueira Smith e Marcos César Seneda, e aos membros suplentes, professores Edgard José Jorge e Ulysses Pinheiro, pela disponibilidade para avaliar o meu trabalho.

Agradeço novamente ao professor Danilo e à professora Célia, assim como aos professores Edgard José e Luiz Carlos Pereira pelas excelentes aulas de filosofia moderna, epistemologia e lógica, cujos conteúdos foram determinantes para a reflexão e escrita sobre alguns tópicos da minha tese, me permitiram aprofundar conhecimentos que almejava e me despertaram interesses para pesquisas futuras. O professor Edgard merece ainda o meu agradecimento pela paciência em relação às minhas incessantes perplexidades céticas dirigidas à filosofia de Kant. Agradeço ainda aos professores Plínio Smith e Ulysses Pinheiro pelas valiosas sugestões teóricas e conversas, e à professora Déborah Danowski, por me ter facultado bibliografia rara.

No Grupo Hume UFMG/CNPq, agradeço, em primeiro lugar, à professora Lívia Guimarães e ao Vinícius França Freitas, pelo acolhimento no grupo (num primeiro momento), mas também pelos conselhos e conversas, determinantes para algumas escolhas teóricas e práticas no âmbito da pesquisa. Agradeço também aos membros do Grupo professor Marcos Balieiro, professor Cesar Kiraly, professor Marcos Seneda, Mario Tito Moreno, Wendel de Hollanda, Stephanie Zahredine e Hugo Arruda, pelo mesmo acolhimento, sugestões teóricas e interessantes discussões sobre Hume ao longo destes anos. 
Agradeço aos meus amigos Deysielle Chagas, Filepe Gall e Rodrigo Viana Passos, por todos os momentos desde que nos conhecemos, que inevitavelmente contribuíram para a minha disposição e ânimo na pesquisa e na escrita - e não raras vezes, para desanuviar da mesma. Agradeço também aos amigos e colegas da PUC-Rio Yasmin Haddad, Taigon Gonçalves, Michelle Bobsin, Bianca Tossato e Matheus Bastos, pelo acolhimento inicial, amizade, sugestões teóricas, bibliografia e excelentes trocas intelectuais ao longo destes anos.

Agradeço aos meus fidelíssimos amigos da graduação, Vasco Castro e Mário Correia, por se manterem presentes na minha vida académica e pela imensa força e confiança que me transmitiram quando decidi emigrar.

Agradeço, há muito tempo, ao professor Rui Ramos (in memoriam), por me ter despertado para o valor da filosofia, causando-me o mágico espanto que antecede e motiva a investigação filosófica.

Agradeço ainda aos funcionários do Departamento de Filosofia da PUCRio Edna Sampaio, Diná Santos e Daniel Teixeira, pela constante solicitude e amabilidade em tudo o que precisei.

O presente trabalho foi realizado com apoio da Coordenação de Aperfeiçoamento de Pessoal de Nível Superior - Brasil (CAPES) - Código de Financiamento 001. Finalmente, agradeço também à FAPERJ pelo financiamento da minha pesquisa nos anos letivos de 2018 e 2019. 


\section{Resumo}

Salgadinho, Carlota; Marcondes, Danilo (orientador). O O quasi-realismo cético de David Hume. Rio de Janeiro, 2020, 372 p. Tese de Doutorado Departamento de Filosofia, Pontifícia Universidade Católica do Rio de Janeiro.

O objetivo geral deste trabalho é propor uma interpretação das teorias causal e dos valores (moral e estético) de David Hume, que designo por quasi-realismo cético. Neste sentido, procuro justificar um confronto das análises elaboradas na literatura secundário sobre $\mathrm{o}$ filósofo - que têm estado sistemática $\mathrm{e}$ declaradamente apartadas. Para cumprir este objetivo, começo por apresentar de forma introdutória algumas pressuposições importantes para este trabalho (capítulo 1). Depois, procuro destacar e desenvolver algumas componentes das teorias causal e dos valores (moral e estético) de Hume que são determinantes para a discussão, subdividindo-as em componentes que designo por metafísica, epistémica e semântica (capítulos 2 e 3). Por último, procuro justificar a posição que assumo em relação a cada um destes aspetos considerados, compondo, assim, o conjunto de componentes do designado quasi-realismo cético - essencialmente inspirado na contribuição de Angela Coventry (por sua vez, inspirada no quasirealismo de Simon Blackburn), ao mesmo tempo que lhe acrescenta um elemento cético (capítulo 4).

\section{Palavras-chave}

Quasi-realismo; Ceticismo moderno; David Hume 


\section{Abstract}

Salgadinho, Carlota; Marcondes, Danilo (Advisor). The sceptical quasirealism of David Hume. Rio de Janeiro, 2020, 372 p. Doctoral Thesis Departamento de Filosofia, Pontifícia Universidade Católica do Rio de Janeiro.

The general aim of this work is to propose an interpretation of David Hume's theories of causality and values (moral and aesthetic), which I call sceptical quasi-realism. In this respect, I try to confront several analysis developed in secondary litterature about the philosopher - which have been sistematically and openly separated. To achieve this aim, I begin by introducing some presuppositions which are important for the purposes of this work (chapter 1). Then, I try to identify and develop some determinant features of Hume's theory of causality and values (moral and aesthetic) for the discussion, subdivided in features which I call metaphysic, epistemic and semantic (chapters 2 and 3). Finally, I attempt to justify the interpretation regarding each of this considered features, composing the set of features of what I call sceptical quasi-realism mainly inspired in Angela Coventrys contributions (which, in turn, is inspired in Simon Blackburns quasi-realism), adding a sceptical element to it (chapter 4).

\section{Keywords}

Quasi-realism; Modern Scepticism; David Hume 


\section{Lista de abreviaturas}

A notação das obras de Hume seguirá o seguinte padrão:

- O Tratado da Natureza Humana é abreviado para Tratado no corpo do texto e como T em notas de rodapé; a notação das referências adotada segue a seguinte regra: $\mathrm{T}$ livro, parte, secção, parágrafo em numeração cardinal (exemplo: $\mathrm{T}$ 1.1.1.1);

- A Investigação do Entendimento Humano é abreviada para 'primeira Investigação' no corpo do texto e IEH em notas de rodapé; a notação das referências adotada segue a seguinte regra: IEH secção, parte, parágrafo em numeração cardinal (exemplo: IEH 1.1.1);

- A Investigação sobre os Princípios da Moral é abreviada para 'segunda Investigação" no corpo do texto e IPM em notas de rodapé; a notação das referências segue a seguinte regra: IPM secção, parte, parágrafo em numeração cardinal (exemplo: IPM 1.1.1);

- Os ensaios "Sobre o Padrão do Gosto" e "O Cético" são referidos por extenso no corpo do texto e pela sigla referente ao seu título em notas de rodapé (respetivamente, $\mathrm{PG}$ e C), seguida pelo parágrafo a referir, em numeração cardinal (exemplo: PG 1; C 1);

- Os Diálogos sobre a Religião Natural, abreviado como Diálogos no corpo do texto e como D em notas de rodapé, seguindo a seguinte regra: D secção, parágrafo em numeração cardinal (exemplo: D 1.1). 


\section{Sumário}

Agradecimentos $\quad 5$

$\begin{array}{ll}\text { Resumo } & 7\end{array}$

$\begin{array}{lr}\text { Abstract } & 8\end{array}$

$\begin{array}{lr}\text { Lista de abreviaturas } & 9\end{array}$

1.0. Introdução 12

1.1 Impressões e ideias 16

1.2. Ideias claras e ideias confusas $\quad 20$

1.3. Separabilidade e Modalidades 27

1.4. Conhecimento e causalidade 31

1.5. Simpatia, gosto e moral 47

1.6. Razão e vontade 55

2. Causalidade: o debate sobre o Novo Hume 66

2.0. Introdução 66

2.1. Interpretação anti-realista 75

2.1.1. Interpretação standard: anti-realismo conceptual e epistémico/metafísico 75

2.1.2. Rejeição de alguns elementos da interpretação standard 83

2.2. Interpretação realista 90

2.2.1. Teoria das ideias: a inclusão das ideias relativas 90

2.2.2. O papel do PP na interpretação do realismo cético 101

2.2.3. 'Causalidade inteligível' 106

2.2.4. Relação do realismo com o ceticismo 113

2.2.5. A relação entre realismo causal e metafísico 123

2.2.6. Argumentos a favor do realismo causal 135

2.2.7. Crítica ao realismo cético 153

3. Teoria dos valores 168

3.0 Introdução 168 
3.1. Racionalismo e sentimentalismo, cognitivismo $\left(E_{C}\right)$ e não cognitivismo $\left(\mathrm{E}_{\sim \mathrm{C}}\right)$

173

3.1.1. Sentimentalismo, não cognitivismo 175

3.1.2. Cognitivismo 180

3.2. Descritivismo $\left(S_{D}\right)$ e não descritivismo $\left(S_{\sim D}\right)$

3.2.1. Descritivismo subjetivista ou fenomenalista $\left(S_{D S}\right)$

3.2.2. Descritivismo causal $\left(S_{D C}\right) \quad 218$

3.2.3. Emotivismo (S $\sim D E)$

3.2.4. Projetivismo e teoria do erro (S $\sim$ DTE $) 228$

3.2.5. Críticas à teoria do erro 239

3.3. Realismo e anti-realismo 242

3.3.1. Realismo $\left(M_{R}\right)$

3.3.2. Críticas à interpretação realista 253

3.4. Uma possível conciliação 257

4. A interpretação do quasi-realismo cético 278

4.0. Introdução 278

4.1. Descrição da proposta quase-realista de Angela Coventry 282

4.2. Características do padrão 288

4.3. Críticas ao quasi-realismo de Coventry 303

4.4. Juízos causais e juízos de valor 305

4.5. Projetivismo 316

4.6. Conceção (ideia adequada) e suposição (ideia relativa) 329

4.7. Ceticismo 348

4.8. Considerações finais 360

Referências 363 


\section{Esclarecimentos introdutórios}

\subsection{Introdução}

Desde os primeiros comentários, ainda no séc. XVIII até ao início dos anos 1980, às teorias da causalidade e dos valores (moral e estético) de Hume foram interpretadas como formas de anti-realismo, isto é, que para este filósofo, a causalidade e os valores (moral e estético) não se encontram nos objetos aos quais essa propriedade é atribuída, independentemente da existência de mentes (de seres humanos). No início dos anos 1980, surgem as primeiras obras de comentário ao filósofo (de John Wright e David Norton), que desafiando estas interpretações, atribuindo-lhe, ao invés - e independentemente - a defesa de uma forma de realismo (o primeiro, causal, o segundo, moral, extensível ao valor estético).

Por seu turno, em relação à questão de saber qual o alcance possível do nosso conhecimento da causalidade e se os valores (moral e estético) podem constituir uma forma de conhecimento, também mereceram a atenção dos comentadores e dividiram as suas opiniões. A posição unânime sobre esta questão relativamente à causalidade é que mesmo admitindo a possibilidade de a causalidade ultrapassar o campo da regularidade observável, não é possível conhecê-la para além deste.

Já em relação à possibilidade de que o valor possa oferecer alguma forma de conhecimento, as respostas dos comentadores sempre foram divergentes - pois já com James Noxon (1961, no caso do valor estética) e Pál Árdal (1966, no caso da moral) se reconhecia que os juízos sobre valores possuíam um padrão em virtude do qual podem ser verdadeiros ou falsos e corrigidos. Apesar disso, a posição mais antiga que os comentadores assumiram é a de que tais juízos não podem oferecer nenhum tipo de conhecimento, nem ter valor de verdade.

Em relação à possibilidade de se considerarem os juízos causais descritivos , nunca houve dúvidas de que sim - apesar da sugestão muito subtil de Stroud de que podem ser considerados expressivos (de uma crença). A controvérsia é sobre aquilo a que se referem esses juízos - se à causalidade restrita ao campo da regularidade ou àquela que ultrapassa este campo. Neste sentido, os proponentes da inovadora (mas contraintuiva) interpretação designada por realismo cético - cunhada por Wright - reivindicam a pertinência da segunda 
interpretação. Neste sentido, é necessário indagar sobre se Hume aceitaria uma ou outra posição. Por seu turno, a resposta à mesma questão em relação aos juízos sobre valores depende daquela que se oferecer à questão anterior: se se aceitar que os valores oferecem alguma forma de conhecimento, então os juízos são, pelo menos em parte, descrições de um facto; se se defender que não, os juízos não terão um caráter descritivo, mas apenas expressarão um sentimento de quem a profere.

Deste modo, os capítulos construtivos do presente trabalho dividem-se em três: sobre a discussão relativa à causalidade (capítulo 2), sobre a discussão relativa aos valores (capítulo 3) e sobre a contribuição que julgo ser a mais justa sobre estes tópicos, apesar de merecedora de algumas alterações (capítulo 4). Por sua vez, os capítulos subdividem-se em secções relativas a diversas questões dos âmbitos que designo metafísico, epistémico e semântico. As componentes metafísica, epistémica e semântica da teoria causal de Hume que são objeto desta discussão são: i) a redução ou não da causalidade a uma regularidade observável de eventos; ii) o estatuto fíccional ou não da crença na existência de uma causalidade para além dessa regularidade; iii) o sentido ou significado da ideia e dos juízos sobre relações causais. Por seu turno, componentes metafísica, epistémica e semântica da teoria dos valores de Hume que são objeto desta discussão são: i) a existência ou não de valores independentemente da mente dos agentes cognitivos; ii) o papel da razão na determinação dos valores, dada a constatação do sentimentalismo; iii) o sentido ou significado dos juízos de valor.

Porém, numa leitura relativamente atenta à estrutura ou organização da obra de Hume, facilmente se percebe que o filósofo trata separadamente, por um lado, as questões de saber em que consiste a causalidade e qual a origem desta ideia na mente e, por outro lado, as questões de saber em que consiste um valor e em que consiste atribuir um valor (tanto moral como estético) a um determinado objeto. As primeiras são tratadas no primeiro livro do Tratado da Natureza Humana e na Investigação sobre o Entendimento Humano, textos dedicados a questões epistemológicas. Muito resumidamente, são estas a origem das ideias de causalidade, de objeto externo, de identidade pessoal, de substância e em que se distinguem uma ideia de uma crença. As segundas são tratadas no terceiro (e parte do segundo) livro(s) do mesmo Tratado, na Investigação sobre os Princípios da Moral (no caso do valor moral) e nalguns ensaios dos Ensaios Morais, Políticos e 
Literários, a saber, "O Cético", "Sobre o Padrão do Gosto" (especificamente, sobre o valor estético) - este, complementado pelo "Da Delicadeza do Gosto e da Paixão". Aliás, sabe-se que as Investigações constituem réplicas mais breves do primeiro e do terceiro livro do Tratado.

Mas a separação que Hume estabelece entre os temas ultrapassa a dimensão da organização do texto. Por um lado, as questões que Hume coloca em relação aos valores são as mesmas que colocara relativamente à causalidade: em que consiste e qual a origem da sua ideia. Porém, nos textos em que aborda as questões epistemológicas, o leitor é deixado com uma conclusão cética em relação à natureza provisória do conhecimento empírico e à própria existência dos objetos que se supõe conhecer. Ainda assim, Hume não se mostra preocupado com as repercursões desta conclusão cética no tratamento das questões relativas à dinâmica das paixões (que ocupa a maior parte do segundo livro do Tratado) e aos valores: por exemplo, se compromete a justificação e a verdade da crença na existência de outras mentes e/ou pessoas e a concatenação causal entre as paixões e os seus objetos (sejam outras pessoas ou objetos inanimados). O filósofo discorre sobre esta concatenação como se nunca tivesse questionado o caráter definitivo do conhecimento empírico e a justificação da crença na existência dos seus objetos.

Devido a esta cisão, a perplexidade mais imediata que pode surgir perante o presente trabalho é relativa à justificação de um paralelo entre as teorias sobre a causalidade e sobre o valor moral e estético de Hume - que é o que pretendo explorar neste trabalho. Esta ambição justifica-se tanto nos textos de Hume como na literatura de comentário ao filósofo. Esta perplexidade pode ser respondida com recurso a uma explicitação de como tem vindo a ser tratado pela literatura de comentário ao filósofo.

É verdade que estes tópicos se mantêm maioritariamente separados na literatura de comentário ao filósofo, pois a maioria dos autores que se ocupa de um paralelo dos mesmos nunca inclui algum dos três tipos de juízos - causais, estéticos e morais. É o caso de John Mackie, Robert Fogelin, Peter Kail e Rachel Cohon - que apenas tratam o paralelo entre juízos causais e morais - e David Norton, Peter Jones e Dabney Townsend - que apenas tratam (subtilmente) o paralelo entre juízos morais e estéticos. 
Porém, tanto Barry Stroud como Angela Coventry se ocupam do paralelo entre os três tipos de juízo. Com efeito, Stroud nota que se é verdade que se tem uma ilusão ou ficção de que os valores constituem propriedades objetivas, também é verdade que a mente constrói a mesma ilusão ou ficção relativamente à causalidade para além do campo da regularidade, e que dadas as considerações sobre o caráter sensitivo da crença, se se considerar que os juízos morais são expressivos, também se deve admitir um elemento expressivo nos juízos causais. Além disso, destaca uma série de outros elementos que estes tipos de juízos teriam em comum, e, posteriormente, estende o paralelo aos juízos estéticos ${ }^{1}$.

Foi justamente a partir dos comentários de Stroud que surgiu o interesse por explorar esta questão. Paradoxalmente, o meu interesse por este paralelo devese ao facto de que num cenário em que as discussões sobre os três tipos de juízos se desenvolveram de forma maioritariamente isolada, qual é a pertinência dos comentários de Stroud, ou quão longe nos podem levar no exame da compreensão que Hume tinha destes juízos? Além disso, e, para mim, mais importante ainda: será que, levado a sério, este paralelo mostra que a filosofia de Hume é internamente consistente, ou será que se a olharmos mais de perto, se encontrará alguma inconsistência interna ou, pelo menos, algum elemento que até agora passara despercebido? Deste modo, o meu principal objetivo é, assim, mostrar que os avanços interpretativos de Coventry nos movimentam na direção correta para compreender este paralelo, mas merecem algumas alterações, para que um maior leque de evidências textuais de Hume seja incluído na interpretação que proponho - designada quasi-realismo cético.

De resto, o título deste trabalho deve-se, por um lado, a estas alterações que culminam, exatamente, na adição de um elemento cético à sua interpretação e à pertinência que reconheço na aproximação das teorias causal e dos valores de Hume a partir dos elementos que os proponentes do realismo cético trouxeram à discussão - o que explica a semelhança entre o título deste trabalho e o do livro de Wright (O realismo cético de David Hume).

Por fim, vale um esclarecimento sobre a maneira como trato a relação entre o Tratado e as Investigações, ou da continuidade teórica que se mantém entre estas obras. Neste trabalho, pressuponho que os eventuais traços de

\footnotetext{
${ }^{1}$ Cf. STROUD, 1977, pp. 176-8, 184-6; 1993, p. 253, 258-9.
} 
descontinuidade não são relevantes para este trabalho e mereceriam um trabalho dedicado exclusivamente a eles. Esta pressuposição deve-se ao facto de que Hume oferece a mesma resposta às questões que me ocupam neste trabalho em todos os textos analisados.

\subsection{Impressões e ideias}

Hume começa a investigação no interior do projeto geral da Ciência do Homem - de explicitar em que medida cada objeto de conhecimento é determinado pelos princípios da mente, que condicionam o seu acesso ao mesmo - com a distinção entre os dois tipos de perceções que compõem a mente, a saber, impressões e ideias - as primeiras são o que é dado aos sentidos (externos ou interno $^{2}$ ), e as segundas, as cópias, imagens ou reflexos mais fracos ou esbatidos daquelas e são suas representações. A distinção entre impressões e ideias assenta na força e vivacidade que cada uma adquire na mente ${ }^{3}$.

Hume divide as perceções do primeiro grupo em impressões de sensação (ou sensações, ou impressões primárias) e de reflexão (ou impressões secundárias $)^{4}$, sob o critério da sua origem. As sensações (o que toca os sentidos externos, incluindo o prazer e a dor do corpo $^{5}$ ) são o que aparece aos sentidos externos, sem nenhuma perceção precedente e têm uma origem desconhecida, e as impressões de reflexão ("paixões, desejos e emoções", "paixões e outras emoções

\footnotetext{
${ }^{2}$ Ao qual Hume se refere escassas vezes antes da segunda Investigação (cf. T 3.1.1.24; T 1.3.9.3; IEH 5.2.10; IEH 7.4; PG 13 [“órgãos internos"]; PG 23; IPM 1.3; IPM 1.9; IPM 5.41; IPM 6.34; IPM 8.10; IPM Ap 1.20, 21; IPM Ap 2.1). Pela menção a impressões internas especificamente como equivalentes a sentimentos ou às impressões de reflexão (cf. $\mathrm{T}$ 1.2.3.2; $\mathrm{T}$ 1.3.8.8; $\mathrm{T}$ 1.3.14.12, 20, 22; T 1.4.2.7; T 1.4.5.18; T 2.3.1.2; T 3.2.2.7; PG 16; IPM Ap 4.3), presume-se que signifique a a capacidade de sentir impressões de reflexão ou uma sensibilidade. É neste sentido a que the (s) farei referência.

${ }^{3} \mathrm{~T}$ 1.1.1.1-4.

${ }^{4}$ A designação primário/secundário aparece em $\mathrm{T}$ 2.1.1.1.

${ }^{5}$ Hume aceita que as impressões de reflexão constituem tipos de prazer e dor. Para além disso, mesmo as paixões diretas envolvem uma ideia ou associação de ideias, já que são despertas mediante a consideração do grau de probabilidade do confronto com o objeto que causa a paixão em questão. Aliás, é pelo facto de suceder a ideias que as impressões de reflexão merecem essa designação e são diferentes das sensações. Assim sendo, parece plausível pensar que o prazer e dor que são incluídos nas sensações são os que aparecem à mente automática e imediatamente por meio das sensações (talvez os únicos exemplos sejam a satisfação de faltas como a fome e a sede, um toque suave ou um dano físico).

${ }^{6} \mathrm{~T}$ 1.1.2.1.
} 
semelhantes" ${ }^{\text {"7 }}$ ) são o que resulta de uma ideia ou representação de uma impressão, por vezes também acompanhada de uma sensação ${ }^{8}$. Esta divisão permite a distinção entre os âmbitos do sentir (das impressões) e do pensar (das ideias) ${ }^{9}$. Impressão de sensação é o estado mental em que ainda não se representa um objeto, em que há algo que ainda não é representado que se apresenta aos sentidos - por exemplo, um copo. Impressão de reflexão é o estado mental em que se sente algo decorrente da representação de um objeto apreendido pelos sentidos (externos), como se fosse, em termos simples, o que se sente quando se pensa num determinado objeto (quando é concebido ou associado a outro) - por exemplo, o desejo de comer chocolate quando penso em chocolate, ou que tenho um chocolate na mala e posso comê-lo.

Ideia é a representação da impressão ou a forma como aparece à mente que não é aquela com que aparece aos sentidos. À distinção entre impressão de sensação e de reflexão acrescenta-se a distinção entre impressões e ideias simples e complexas, sendo o complexo o decomponível em partes menores (como, por exemplo, a ideia de maçã), e o simples, o que não pode ser mais decomposto em partes menores (como, por exemplo, a ideia de vermelho), não admitindo distinção nem separação. Portanto, o complexo é um aglomerado de simples ${ }^{10}$.

Esta distinção justifica-se pelo princípio de acordo com o qual todas as ideias simples ${ }^{11}$ decorrem de impressões simples - primeiro princípio da epistemologia de Hume, convencionalmente designado na literatura secundária por Princípio da Cópia ${ }^{12}$. Este princípio tem uma natureza a posteriori, isto é,

\footnotetext{
${ }^{7} \mathrm{~T} 2.1 .1 .1$.

${ }^{8}$ Há, porém, uma instância em que Hume admite a possibilidade do surgimento de uma impressão de reflexão sem interposição de uma ideia: "As impressões secundárias ou reflexivas são as que provêm de algumas das impressões originais [(isto é, de sensação)], quer imediatamente, quer pela interposição das suas ideias (itálico meu)" (cf. T 2.1.1.1). Noutro capítulo, pretendo ocupar-me da estranheza que esta evidência textual provoca na mecânica epistemológica de Hume.

${ }^{9} \mathrm{~T}$ 1.1.1.1.

${ }^{10} \mathrm{~T} 1.1 .1 .5$

${ }^{11}$ Cf. STROUD, 1977, p. 85; 1978, p. 42; YOLTON, 1980, p. 3; FLAGE, 1981, p. 68; THOMAS, 1982, p. 152; BLACKBURN, 2007, p. 101.

${ }^{12}$ Cf. T 1.1.1.4, 6-9; T 1.1.1.12; IEH 2.5. A designação 'Princípio da Cópia' ou similar (como 'teoria da cópia') é adotada convencionalmente na literatura secundária sobre Hume (cf. FLAGE, 1981, p. 63, 68; 2007, p. 147; GARRETT, 1997, pp. 41-2; COVENTRY, 2007, 4.1; MILLICAN, 2007b, xxxiv-v). De agora em diante designado por PC.
} 
resulta de uma observação constante da sucessão de ideias e impressões na mente ${ }^{13}$.

Entretanto, na anatomia da mente que Hume propõe, as impressões de reflexão constituem estados mentais apresentacionais ou originais que merecem uma atenção própria. As impressões de sensação (ou sensações, ou impressões originais) surgem do contacto de objetos (externos) com os sentidos e são o primeiro estímulo que surge na mente, ou seja, aparecem sem que outro estímulo esteja presente à mesma ${ }^{14}$. Sob esta designação encontram-se "todas as impressões dos sentidos, e todas as dores e prazeres corporais"15, e o estudo das suas causas cabe a ciências como a anatomia ${ }^{16}$. Por seu turno, as impressões de reflexão (ou reflexivas, ou secundárias) "procedem de algumas dessas impressões originais, seja imediatamente, seja pela interposição de suas idéias”. Hume explica genericamente como se geram as paixões na mente:

Primeiramente, uma impressão atinge os sentidos, fazendo-nos perceber o calor ou o frio, a sede ou a fome, o prazer ou a dor, de um tipo ou de outro. Em seguida, a mente faz uma cópia dessa impressão, que permanece mesmo depois que a impressão desaparece, e à qual denominamos idéia. Essa idéia de prazer ou dor, ao retornar à alma, produz novas impressões, de desejo ou aversão, esperança ou medo, que podemos chamar propriamente de impressão de reflexão, porque derivadas dela. Essas impressões de reflexão são novamente copiadas pela memória e pela imaginação, convertendo-se em idéias - as quais, por sua vez, podem gerar outras impressões ou idéias. Desse modo, as impressões de reflexão antecedem apenas suas idéias correspondentes, mas são posteriores às impressões de sensação, e delas derivadas. ${ }^{17}$

Sob esta designação, Hume inclui "as paixões e outras emoções semelhantes"18 ou, em palavras similares, "as paixões, os desejos e as emoções"19. Por enquanto - e para analisar a questão do juízo de valor (moral e não moral) também me contentarei com isso, prosseguindo nas definições e restringindo a

${ }^{13}$ Cf. COVENTRY, 2007, p. 42. Apesar disso, Garrett nota que o uso implícito que Hume faz deste princípio se dá como se o princípio tivesse uma natureza a priori (cf. GARRETT, 1997, pp. 43-4).

${ }^{14} \mathrm{~T}$ 1.1.4.3; T 2.1.1.1.

${ }^{15} \mathrm{~T}$ 2.1.1.1.

${ }^{16} \mathrm{~T}$ 1.1.2.3; $\mathrm{T}$ 2.1.1.2.

${ }^{17} \mathrm{~T}$ 1.1.2.1.

${ }^{18} \mathrm{~T}$ 2.1.1.1; cf. T 1.1.4.3; T 2.1.1.2. 
atenção às paixões. Além disso, Hume reconhecer a impossibilidade de oferecer uma definição exaustiva das paixões - em virtude do seu caráter não representativo, mas sensitivo ${ }^{20}$.

Hume afirma claramente que as paixões "estão fundadas na dor e no prazer" ${ }^{21}$. Aliás, para Hume, em si mesmas, constituem tipos de prazer e dor (ou desprazer $^{22}$ ). Por essa razão, diz-se que são, respetivamente, agradáveis ou desagradáveis. Por exemplo, considerar uma paisagem bela envolve um prazer ao contemplá-la, e uma que se considera feia envolve um desprazer, da mesma forma que considerar alguém honesto envolve um agrado na contemplação desta virtude, e desonesto, um desagrado na contemplação do seu vício (a desonestidade).

A proliferação das paixões dá-se mediante a concorrência de diversos fatores externos - como é o caso da posse de objetos ou qualidades concretas, como a beleza ou o domínio de uma habilidade intelectual ou técnica - e princípios da arquitetura cognitiva humana - como o hábito, a simpatia ou a comparação com os demais. Por exemplo, posso sentir orgulho ou vergonha (que se pode pensar que é um tipo do que Hume chama de humildade) de uma pessoa com quem mantenho uma relação próxima (como um parente, um amigo, um cônjuge), ou sentir inveja de alguém em virtude de possuir uma qualidade que simultaneamente almejava ter (e não tenho) e reconheço como fonte de um prazer para a pessoa que a detém ${ }^{23}$.

\footnotetext{
${ }^{19} \mathrm{~T}$ 1.1.4.3. Vale notar que Hume nunca se detém sobre o que entende por essas "emoções", ou "emoções semelhantes" às paixões, limitando-se a afirmar que estas constituem "a maior parte das nossas impressões de reflexão" (T 2.1.9.1).

${ }^{20} \mathrm{~T}$ 2.2.1.1; T 2.3.1.2.

${ }^{21} \mathrm{~T} 2.1 .9 .1$.

${ }^{22}$ Apesar de, nos livros II e III do Tratado, Hume utilizar pouco o termo unpleasant (cf. T 2.3.4.3; T 2.3.10.12) para se referir a paixões desagradáveis (aliás, esta é a tradução na edição brasileira), e inúmeras vezes o termo painful (nos mesmos livros daquela obra), tomo a liberdade de utilizar o termo desprazer/desprazeroso (a) para me referir às mesmas paixões. A minha opção deve-se ao caráter mais intuitivo desta do que daquela, pois que me parece remeter excessivamente para a sensação de dor.

${ }^{23}$ Para uma discussão sobre a classificação das paixões, recomenda-se: SMITH, N. K., 1941, p. 168; DAVIE, W. (1976). Hume's Catalog of Virtue and Vice. The Southwestern Journal of Philosophy, v. 7, n. 2, pp. 45-57; ÁRDAL, P. S. (1977). Another Look at Hume's Account of Moral Evaluation. Journal of the History of Philosophy, v. 15, n. 4, pp. 405-21; LOEB, L. E. (1977). Hume's Moral Sentiments and the Structure of the Treatise. Journal of the History of Philosophy, v. 15, n. 4, pp. 395-403; FIESER, J. (1992). Hume's Classification of the Passions and Its Precursors. Hume Studies, v. 18, n. 1, pp. 1-13.
} 


\subsection{Ideias claras e ideias confusas}

Apesar de ser exposto como princípio explicativo da origem das ideias (ideias simples derivam de impressões simples), aceito que este princípio possui, para além disso, valor epistémico e semântico: ideias que resultam de impressões podem constituir conhecimento e têm sentido. Com efeito, alguns filósofos modernos contrapõem a noção de ideia relativa à de ideia adequada ou positiva. Com efeito, uma ideia adequada consiste naquela que pode constituir ou ser considerada conhecimento, pois corresponde a uma representação genuína dos objetos (do conhecimento). A teoria da substância parece ter sido o principal palco da concessão da existência deste tipo de ideias ${ }^{24}$. A descrição das ideias relativas sugere que se identificariam com as ideias que não são adequadas (as inadequadas).

Identificando o campo das ideias adequadas ou positivas como aquele em que há uma descoberta efetiva da essência dos objetos dos quais se tem essas ideias, e ideias inadequadas com ignorância relativamente a essa essência, Locke apresenta esta distinção em passagens como:

[N]ada significa a palavra substância, a não ser uma proposição incerta disto que não sabemos o que, isto é, de algo acerca do qual não temos nenhuma idéia positiva particular e distinta, que julgamos ser o substratum, ou suporte, destas idéias que conhecemos. ${ }^{25}$

Assim elaborada uma ideia pouco clara e relativa de substância em geral, chega-se às ideias de tipos especificos de substâncias através da recolha de tais combinações de ideias simples, vistas pela experiência e pela observação dos sentidos do homem, como existindo em conjunto e, por isso, fluindo da estrutura específica interna ou da essência desconhecida dessa substância (...). [A]s nossas ideias complexas de substâncias, para além das ideias simples de que são constituídas, têm sempre uma noção confusa de algo a que pertencem e no qual subsistem (...). [A] substância supõe sempre algo para além da extensão, da forma, da solidez, do movimento, do pensamento ou de outras ideias observáveis, embora não saibamos o que seja. ${ }^{26}$

\footnotetext{
${ }^{24}$ Tal como esclarece D. Flage; cf. FLAGE, 2007, p. 139-43, 153n4.

${ }^{25}$ LOCKE, 1690, II, iii, 10.

${ }^{26}$ LOCKE, 1690, II, xxiii, 3; itálicos do tradutor. Cf. também LOCKE, II, II, xxiii, 2; xxxi, 1, 6, 11.
} 
Com base nessa distinção (entre ideia adequada e relativa), percebe-se, na seguinte passagem, que a noção de ideia relativa parece ser entendida como sinónimo de ideia confusa:

[Quem perguntasse] que coisa sustenta a Terra deveria mostrarse tão satisfeito pela resposta de um filósofo hindu que lhe dissesse que é a substância, sem saber que coisa é, como nós ficamos satisfeitos com a resposta e boa doutrina dos nossos filósofos europeus, quando nos dizem que é a substância, sem saberem o que ela é, é aquilo que sustenta os acidentes. Não temos, pois, nenhuma ideia do que a substância é, mas apenas uma ideia confusa e obscura do que ela faz. ${ }^{27}$

Por seu turno, Berkeley mostra aceitar uma distinção semelhante:

Diz-se "extensão" um modo ou acidente da matéria, e "matéria" o substractum que a suporta. Gostaria que me explicassem o que se entende por matéria, suporte da extensão. Direis: não tenho idéia da matéria, por isso não posso explicá-la. Respondo: Se não tendes idéia positiva, entretanto se lhe ligais algum significado, deveis ter uma idéia relativa da matéria (...). Se interrogarmos sobre isto os melhores filósofos, vê-los-emos concordes em atribuir a "substância material" apenas o sentido do ser em geral, juntamente com a noção relativa de suporte de acidentes [itálico meu]. A idéia geral do Ser parece-me a mais abstrata e incompreensivel de todas [itálico meu]; quanto ao suporte de acidentes, como já notamos, não pode entender-se no sentido comum das palavras; deve ser outro mas não nos dizem qual. Assim, quando considero as duas partes ou ramos do significado das palavras "substância material", convenço-me de que não têm sentido distinto. (...) Não se supõe que têm existência fora do espírito? E isto não repugna diretamente, além de ser inconcebivel [itálico meu] ${ }^{28}$

Por último, pode apresentar-se ainda a mesma distinção na filosofia de Reid - que contrapõe ideias relativas a ideias positivas ${ }^{29}$ :

De algumas coisas, conhecemos o que são em si mesmas; à nossa conceção de tais coisas, chamo direta. De outras coisas, não sabemos o que são em si mesmas, mas apenas que possuem certas propriedades ou atributos, ou certas relações com outras coisas; destas, a nossa conceção é apenas relativa. Para ilustrar isto com alguns exemplos: $\mathrm{Na}$ biblioteca da universidade, solicito um livro, carrego L, estante 10, número 10; o bibliotecário tem de deter tal conceção do livro que quero, assim como de distingui-lo de outros milhares que estão sob seu cuidado. Mas é a partir das minhas palavras que forma tal

\footnotetext{
${ }^{27}$ LOCKE, II, xiii, 19; itálico meu.

${ }^{28}$ BERKELEY, 1713, 16-17. Cf. também BERKELEY, 1710, 27, 68, 80.

${ }^{29}$ Apesar de Reid as chamar de 'diretas', a sua definição coincide com o que Locke e Berkeley chamam de 'positiva' (cf. FLAGE, 2007, p. 140).
} 
conceção? Elas não o informam nem sobre o autor, nem sobre o assunto, nem a linguagem, nem o tamanho ou a encadernação, mas apenas sobre sua marcação e lugar. A sua conceção é meramente relativa a estas circunstâncias; ainda assim, esta noção relativa permite-lhe distingui-lo de todos os outros livros na biblioteca. ${ }^{30}$

Diversos comentadores que se ocuparam desta distinção na filosofia de Hume alegam ser plausível pensar que o filósofo herdou o modelo e o uso dos termos de Locke e Berkeley (essencialmente) e que concedia a existência de ideias relativas, que permite estender a capacidade de formação de conteúdos mentais além do previsto pelo $\mathrm{PC}^{31}$.

Com efeito, deve reconhecer-se que na filosofia de Hume, esta distinção não é a mais clara, pois há poucas evidências textuais explícitas da mesma. Porém, a partir das passagens em que o filósofo se refere a estas ideias, pode dizer-se que o filósofo entende por ideia o que se pode conceber são as ideias, a saber, o que constitui cópia de uma impressão, restringindo o campo das ideias

\footnotetext{
${ }^{30}$ Tradução minha do original: "Of some things we know what they are in themselves; our conception of such things I call direct. Of other things, we know not what they are in themselves, but only that they have certain properties or attributes, or certain relations to other things; of these our conception is only relative. To illustrate this by some examples: In the university-library, I call for the book, press L, shelf 10. No. 10.; the library-keeper must have such a conception of the book I want, as to be able to distinguish it from ten thousand that are under his care. But what conception does he form of it from my words? They inform him neither of the author, nor the subject, nor the language, nor the size, nor the binding, but only of its mark and place. His conception of it is merely relative to these circumstances; yet this relative notion enables him to distinguish it from every other book in the library." (REID, 1788, pp. 9-10).

${ }^{31}$ D. Flage é o proponente mais insistente da interpretação de que as ideias relativas têm um lugar determinante na filosofia de Hume (pelo menos, desde 1981 até 2007). Entre os primeiros comentadores a conceder esta possibilidade estão J. Laird e J. Yolton (cf. LAIRD, 1939, p. 428; YOLTON, 1980; THOMAS, 1982, p. 149; OTT, 2006, p. 246 (indiretamente, ao reconhecer que ter ideias confusas não é o mesmo que não ter nenhum estado mental distinto de uma ideia, tampouco que poderiam ser reduzidas àquelas)). Além destes comentadores, os proponentes da interpretação do realismo cético também concedem este espaço - designadamente, para a ideia de uma causalidade que ultrapassa o campo da regularidade observável: J. Wright $(1983,2007)$, J. Broughton $(1987,2007)$, G. Strawson $(1989,2007)$, M. Costa (1989), E. Craig $(1987,2007)$ e P. Kail (2007a e 2007b). Entretanto, diversos autores rejeitam veementemente esta leitura da teoria das ideias de Hume. Winkler considera que a teoria empirista das ideias de Hume é 'impiedosa' e não admite qualquer brecha, pelo que qualquer ideia que não seja provinda de uma impressão deve ser considerada sem sentido e ininteligível (cf. WINKLER, 2007, p. 59; cf. também LOEB, 2001, p. 158). No mesmo espírito, Broackes julga a distinção técnica entre conceção e suposição constitui um elemento desviante da teoria das ideias, e o comentador duvida que Hume tenha levado a sério as próprias instâncias em que se refere às ideias relativas (cf. BROACKES, 1993, p. 104, 107). O modo como os proponentes do realismo cético se apropriaram desta concessão para a defesa da sua interpretação será apresentada em 2.2.1. Posteriormente, na seçcão 4.7, mostrarei que, de facto, se deve admitir que Hume concedia a existência destas ideias, apesar de, de forma alguma, justificar uma interpretação realista das teorias causal e dos valores de Hume - mas sim cética.
} 
(no sentido genuíno, ou ideias claras, ou ainda ideias adequadas) que são cópias de impressões (conceções ou ideias genuínas):

[C]omo nada jamais está presente à mente além das percepções, e como todas as idéias são derivadas de algo anteriormente presente à mente, segue-se que nos é impossível sequer conceber ou formar uma idéiade alguma coisa especificamente diferente de idéias e impressões. Dirijamos nossa atenção para for a de nós mesmos tanto quanto possível; lancemos nossa imaginação até os céus, ou até os limites extremos do universo. Na realidade, jamais avançamos um passo além de nós mesmos, nem somos capazes de conceber um tipo de existência diferente das percepções que aparecem dentro desses estreitos limites. ${ }^{32}$

Jamais podemos conceber nada além de percepções e, portanto, temos de fazer tudo se assemelhar a elas. ${ }^{33}$

[P]odemos perfeitamente supor em geral, mas é impossível concebermos distintamente, que os objetos tenham uma natureza que não seja exatamente a mesma que a das percepções. $^{34}$

Talvez a evidência textual mais clara de que Hume identifica as conceções (no sentido genuíno) com as ideias que se tem dessas cópias de impressões razão pela qual podem ser consideradas ideias claras ou adequadas - seja a seguinte:

[Uma vez que] todas as nossas idéias são copiadas de nossas impressões (...) [e que] todas as impressões são claras e precisas, as idéias, que delas são copiadas, devem ter essa mesma natureza $(\ldots)^{35}$

Por contraste, as ideias que não seriam conceções (ou ideias no sentido genuíno, mas sim suposições) parecem ser as que não são constituídas por cópias de impressões (ou de acordo com o PC), razão pela qual são consideradas confusas. Há diversas outras evidências textuais que mostram que Hume estabelece uma relação entre ideia não adequada, confusa e suposição, como também a chama. Também por esta razão, aquilo que é objeto de suposição é

\footnotetext{
${ }^{32} \mathrm{~T}$ 1.2.6.8; itálico meu. Com efeito, esta citação atesta sucintamente o que constitui uma ideia clara ou adequada e restringe a estas o campo da conceção. A conclusão do argumento (3) - que a mente é incapaz de conceber algo que não tenha absolutamente nenhuma característica em comum com as perceções - baseia-se em duas premissas: 1) o PC; 2) que a mente apenas possui perceções. Em particular, Wright nota esta herança de Hume da noção de conhecimento como representação adequada (cf. WRIGHT, 1983, pp. 88-9, 91).

${ }^{33} \mathrm{~T}$ 1.4.2.54.

${ }^{34} \mathrm{~T}$ 1.4.2.56.

${ }^{35} \mathrm{~T}$ 1.3.1.7.
} 
considerado inconcebível (o que marca a contraposição entre os dois tipos de conteúdo mental). A adoção deste critério pode explicar-se pelo uso dos termos 'clareza', 'adequação', 'ideia', 'conceção', 'suposição' para descrever ideias (de questões de facto) de forma contraposta, isto é, de tal forma que as ideias que são formadas diretamente a partir de impressões são colocadas como claras, e as ideias que o não são, confusas ou obscuras ${ }^{36}$.

Em relação àquilo em que consiste ter uma suposição ou ideia relativa, Hume explica que o seu objeto é algo especificamente distinto das perceções ${ }^{37}$, definindo o seu caráter relativo como a posse ou a atribuição de relações distintas daquelas que se mantêm entre as ideias claras (ou ideias no sentido genuíno):

$\mathrm{O}$ mais longe que podemos chegar no que diz respeito à concepção de objetos externos, quando se os supõe especificamente diferentes de nossas percepções, é formar deles uma idéia relativa, sem pretender compreender os objetos relacionados. Falando de um modo geral, nós não supomos que sejam especificamente diferentes; apenas atribuímos a eles relações, conexões e durações diferentes. ${ }^{38}$

[L]embremos que, como toda idéia é derivada de uma percepção anterior, é impossível que nossa idéia de uma percepção possa representar algo especificamente diferente daquilo que é representado pela idéia de um objeto ou existência externa. Qualquer diferença que possamos supor entre elas é incompreensível para nós; somos obrigados a conceber um objeto externo seja como uma mera relação se um correlato, seja como a mesma coisa que uma perceção ou uma impressão. ${ }^{39}$

$[\mathrm{P}]$ odemos supor, mas nunca conceber uma diferença específica entre um objeto e uma impressão. ${ }^{40}$

Tal como se percebe pelas duas primeiras citações acima, as citações mais explícitas de Hume sobre a distinção entre conceção e suposição são ao considerar que os objetos da perceção, enquanto exteriores e independentes (da mente) constituem ideias relativas, e não ideias claras.

\footnotetext{
${ }^{36}$ Cf. também T 1.1.6.1; T 1.1.7.6; T 1.2.2.8; T 1.3.14.6, 7, 14, 17 e 27; T 1.4.5.1; T 1.3.2.4; T 1.3.5.5; $\mathrm{T}$ 1.3.6.5; $\mathrm{T}$ 1.3.9.10; $\mathrm{T}$ 1.4.5.5; I 4.18; I 7.1.

${ }^{37} \mathrm{Na}$ secção 4.6, procurarei mostrar por que razão é mais razoável considerar que o objeto da suposição não é uma perceção do que considerar que se trata de uma perceção.

${ }^{38}$ T 1.2.6.9; itálico meu

${ }^{39} \mathrm{~T}$ 1.4.5.19; iálico meu.

${ }^{40} \mathrm{~T}$ 1.4.5.20; itálico meu. A este propósito, vale assinalar que tanto Locke como Berakeleu afirmam que a noção de substância em geral é sempre suposta na conceção de substâncias
} 
O mesmo ocorre no caso da causalidade, entendida como uma relação entre os objetos além e por trás da regularidade observável:

[A] ideia de poder é tão relativa quanto a de causa, e ambas contêm uma referência a um efeito ou a outro acontecimento que está constantemente conjugado ao primeiro. ${ }^{41}$

Deste modo, se se mantiverem as dicotomias ideias claras/não claras, adequadas/não adequadas e conceção/suposição, estas passagens sugerem que Hume aceita, de facto, a distinção entre o que se pode conceber e o que se pode supor, que o campo do concebivel se restringe ao das ideias claras - formadas pelo PC -, e que ideias não claras são objetos de suposições ou ideias relativas formadas a partir da combinação de diferentes relações das que se mantêm entre as ideias claras.

Além disso, Hume tanbém parece identificar clareza com inteligibilidade $^{42}$, compreensão com ter uma ideia clara $^{43}$ e suposição com a formação da ideia de algo que não se pode compreender ${ }^{44}$. Isto mostra que Hume identifica as conceções, ideias adequadas, claras, ou ainda ideias em sentido genuíno (que possuem um correlato com impressões dos sentidos) com pensamento com sentido, e suposições, ideias relativas ou confusas (que são construídas pela imaginação com base em relações distintas daquelas que se mantêm entre os objetos claramente concebíveis) com pensamento sem sentido ${ }^{45}$.

Esta associação de Hume do sentido à detenção de ideias ou conceções (no sentido genuíno) pode perceber-se em passagens como:

[N]ão temos nenhuma idéia de um poder ou eficácia em nenhum objeto, nem de uma conexão real entre causas e efeitos (...). Não compreendemos o sentido de nossas próprias palavras ao falar assim. ${ }^{46}$

$[\mathrm{O}] \mathrm{u}$ não temos nenhuma idéia de força e energia, e essas palavras são então absolutamente sem sentido, ou elas

particulares - o que indicia ainda mais uma semelhança no vocabulário utilizado por Hume em relação aos empiristas que o precedem.

${ }^{41}$ IEH 7.2.29n7.

${ }^{42}$ Cf. T 1.3.14.7; $\mathrm{T}$ 1.4.6.2.

${ }^{43}$ Cf. T 1.2.6.9.

${ }^{44}$ Cf. T 1.4.5.19.

${ }^{45}$ Diversos comentadores reconhecem a restrição que Hume faz do campo do sentido às ideias claras e distintas (formadas a partir do PC; cf. BENNETT, 1966, IX; BEAUCHAMP \& ROSENBERG, 1981, p. 3; OTT, 2006, pp. 244-245).

${ }^{46} \mathrm{~T}$ 1.3.14.27. 
significam apenas aquela determinação do pensamento, adquirida pelo hábito, a passer da causa a seu efeito usual. ${ }^{47}$

[S]empre que alimentarmos alguma suspeita de que um termo filosófico esteja sendo empregado sem nenhum significado ou idéia associada (...), precisaremos apenas indagar: de que impressão deriva esta suposta idéia? E se for impossível atribuir-lhe qualquer impressão, isso servirá para confirmar nossa suspeita. ${ }^{48}$

Quer dizer, a referência das primeiras pode ser identificada, pois a sua existência pode ser confirmada (por memórias ou, no limite, pela confiança num testemunho que as detém). O contrário ocorre no caso das segundas, cujo objeto de referência não pode ser identificado, pois a sua existência nunca pode ser aferida, de tal modo que pensar e falar nos objetos das conceções é falar e pensar em objetos se sabe que eles existem, mas pensar e falar nos objetos das suposições é falar e pensar em objetos cuja existência é, no mínimo, indeterminada - pois não sabemos se se referem ou não a alguma coisa num eventual mundo extramental.

Com efeito, parece haver mais de uma fonte de ideias na mente - a saber, os sentidos e a faculdade da imaginação, ao combinar ideias copiadas de impressões pela atribuição de relações. Isto é constatável em dois movimentos da parte de Hume. O primeiro está na própria definição de relação (que Hume afirma ser dupla), ao atribuir a sua criação à imaginação:
A palavra RELAÇÃO é comumente usada em dois sentidos (...): para designar a qualidade pela qual duas idéias são conectadas na imaginação, uma delas naturalmente introduzindo a outra (...); ou para designar a circunstância particular na qual, ainda que a união de duas ideias na fantasia seja meramente arbitrária, podemos considerar apropriado compará-las. ${ }^{49}$

O segundo movimento é a atribuição de uma série de ideias cuja origem não podem ser os sentidos, a saber, de causalidade, substância e identidade de um objeto consigo mesmo ${ }^{50}$.

Apesar disso, há apenas um critério para se considerar uma ideia adequada ou possível objeto de conhecimento, a saber, a precedência das impressões em

\footnotetext{
${ }^{47} \mathrm{~T}$ Ap 26.

${ }^{48}$ IEH 2.9. Cf. também T 1.3.14.14; IEH 7.2.26.

${ }^{49} \mathrm{~T}$ 1.1.5.1; itálico meu.

${ }^{50}$ Cf. 1.1 deste trabalho.
} 
relação às ideias. No caso das ideias relativas, à falta de um correspondente na experiência dos sentidos, só se pode considerá-las sem sentido. Portanto, a afirmação de Hume de que só existem, na mente, ideias que provieram de impressões é mais razoavelmente interpretada como restrita a uma definição estrita de ideia, a saber, ideia no sentido genuíno, ou ideia clara e distinta - por contraste com as ideias que provêem da operação da imaginação ${ }^{51}$, que são confusas $^{52}$.

\subsection{Separabilidade e Modalidades}

Para tratar o fenómeno da abstração ou da generalização e saber se este implica uma separação de ideias, Hume apresenta aquilo que pode ser chamado de Princípio da Separabilidade ${ }^{53}$ - que permite a distinção entre ideias simples e complexas - segundo o qual:

[T]odos os objetos diferentes são distinguíveis, e que todos os objetos distinguíveis são separáveis pelo pensamento e imaginação (...) [e, da mesma forma], todos os objetos separáveis são também distinguíveis, e todos os objetos distinguíveis são também diferentes. ${ }^{54}$

Deste modo, podem distinguir-se duas premissas ou componentes deste princípio: i) todos os objetos diferentes são separáveis e distinguíveis pela imaginação (ou, descrito como um condicional, se dois ou mais objetos são diferentes, então são distinguíveis e separáveis), e ii) todos os objetos separáveis e distinguíveis pela imaginação são diferentes (ou, descrito como um condicional, se dois ou mais objetos são separáveis e distinguíveis, então são diferentes).

Com efeito, parece viável pensar que, para dois ou mais objetos, ser diferente se refere a uma qualidade ontológica ou metafísica, mas ser separável ou

\footnotetext{
${ }^{51} \mathrm{Na}$ secção 4.6, eslcarecerei que a parte da imaginação responsável pelas ideias confusas só pode ser a imaginação fancy, ou seja, que se excluem as ideias formadas pelo entendimento do campo das ideias confusas.

${ }^{52} \mathrm{Na}$ discussão em torno da questão da admissão das ideias relativas como conteúdos mentais com sentido, a atenção foi maioritariamente voltada para a consideração das ideias da memória como ideias relativas e para a possibilidade de uma ideia relativa simples. Para uma leitura desta discussão, cf. Flage (1982, 1984, 1985, 1989, 1993, 2007), Friedman (1993a, 1993b), Thomas (1982) e Traiger (1985).

${ }^{53}$ De agora em diante designado por PS. Cf. GARRETT, 1997, 3; COVENTRY, 2007, 4.2.

${ }^{54} \mathrm{~T}$ 1.1.7.3.
} 
distinguível se refere a uma qualidade epistémica. Portanto, parece que a primeira qualidade se refere à forma como o mundo é, independentemente do acesso que mentes podem ter a ele. Por seu turno, a segunda qualidade parece referir-se ao resultado da ação de capacidades mentais, portanto, depende da forma como mentes acedem ao mundo (supostamente fora e independente delas). Note-se que Hume não questiona se é necessário que dois ou mais objetos diferentes sejam separados ou distinguidos pela mente, portanto, se é possível que o que é diferente não seja separado ou distinguido (por uma mente). Parece que, para Hume, o que é metafisicamente distinto se identifica com o que pode ser (epistemicamente) distinguido pela mente. Se se mantiver os dois lados do bicondicional - que se dois ou mais objetos são diferentes, então são distinguíveis e separáveis, e se dois ou mais objetos são separáveis e distinguíveis, então são diferentes - não parece ser possível o caso de dois ou mais objetos serem diferentes, mas permanecerem unidos, indistintos ou indissociados na mente. Por outro lado, parece que é possível, apenas com base nas capacidades cognitivas do sujeito do conhecimento - de distinguir e separar - determinar que objetos são, de facto, diferentes, e quais os que o não são. Portanto, em i), a possibilidade de se determinar a forma como o mundo é, apenas com base em capacidades cognitivas (neste caso, de separar e distinguir ideias) parece ser concedida.

Não é parte do propósito deste trabalho explorar esta questão. O que é relevante para o que vai ser tratado de facto é que este bicondicional constitui um critério ou razão que leva Hume a algumas conclusões que determinam a sua resposta (cética) às questões da crença na existência exterior e contínua e na identidade pessoal, onde se inclui a conclusão de que não é necessário que tudo o que passa a existir tem de ter uma causa (questões que serão apresentadas ainda no presente capítulo). Porém, tanto esta questão, como a questão de saber se, no interior da epistemologia de Hume, é pertinente manter os dois lados do bicondicional, estão diretamente ligadas à questão de saber qual parece ser o lugar Hume atribui às propriedades modais de possibilidade e de necessidade.

Com efeito, PC (apresentado na secção anterior) e o PS são utilizados como ferramenta de análise da origem de diversas ideias na mente - portanto, para determinar se algumas noções, ideias ou crenças têm (ou não) origem nos sentidos, ao que algumas delas se mostram como exceções, a saber: 
i) de ideias gerais ${ }^{55}$, porque a formação de uma ideia geral supõe uma variedade de experiências observáveis; caso o PC pudesse justificar o processo de abstração, uma ideia particular de copo seria suficiente para que se pudesse abstrair as suas propriedades (como ser de vidro);

ii) de causalidade ou conexão necessária, porque nenhuma relação causal é passível de ser observada pelos sentidos; por exemplo, vejo o movimento e o toque entre duas bolas de bilhar, mas não vejo a própria relação entre elas, que explica aquele movimento;

iii) de substância, pois caso esta noção tivesse origem nos sentidos, só poderia ser uma cor, um odor, um som ou um sabor - o que não é o caso, uma vez que a substância parece dizer respeito a algo que subjaz à sensação e que compreende várias possibilidades para a sensação; por exemplo, a substância "ouro" não se reduz à sua cor amarela, o seu peso ou a fusibilidade, mas consiste numa coleção de propriedades ${ }^{56}$;

iv) de um eu ou identidade pessoal ${ }^{57}$, porque numa "cadeia" de sensações particulares, cada uma delas é interrompida ou descontínua, contrariamente à ideia de eu (que se supõe ser o que subjaz a todas as impressões e ideias, como uma espécie de superfície onde aquelas ocorrem); portanto, não havendo nenhuma impressão (nem ideia que lhe possa corresponder) contínua, não é a sensação que justifica a ideia de um eu ou pessoa; para me considerar uma mesma pessoa ao longo do tempo, é necessário admitir que algo não muda apesar da interrupção de todas as impressões e ideias que compõem a minha vida mental; e como parece que tenho as minhas impressões e ideias, a noção de eu parece dizer respeito a algo que lhes subjaz;

v) de objeto externo, já que os sentidos só mostram coisas "percetíveis" e a noção de objeto externo corresponde a algo que subjaz à perceção, mas que está para além do campo percetivo ${ }^{58}$; a operação dos sentidos é tal que é impossível ter acesso (por eles) ao objeto (ou parte dele) tal como ele é independentemente da

\footnotetext{
${ }^{55} \mathrm{~T}$ 1.1.7, onde Hume explica que a formação de uma ideia geral se dá pela abstração dos graus de quantidade e qualidade dos particulares percebidos pelos sentidos e memorizados, o que supõe uma comparação entre esses particulares.

${ }^{56} \mathrm{~T}$ 1.1.4.1-2.

${ }^{57} \mathrm{~T}$ 1.4.6.2-4

${ }^{58}$ Tal não implica que o objeto externo não seja exatamente como ele é percebido pelos sentidos. Isto significa apenas que os sentidos não me podem dar algo que é independente da sensação.
} 
sensação, pois é uma contradição de termos "admitir que os sentidos continuam a operar mesmo depois de cessarem toda a espécie de operação" ${ }^{~} 5960$.

Por seu turno, Hume nas quais se definem a modalidade da possibilidade e das quais também é possível derivar uma definição de necessidade:

É uma máxima estabelecida da metafísica que tudo que a mente concebe claramente concebe inclui a idéia da existência possivel ou, em outras palavras, que nada que imaginamos é absolutamente impossivel. ${ }^{61}$

Tudo que pode ser concebido por uma idéia clara e distinta implica necessariamente a possibilidade de sua existência. E aquele que pretende provar a impossibilidade dessa existência por um argumento derivado de sua idéia clara está afirmando, na realidade, que não temos disso nenhuma idéia clara, porque temos uma idéia clara. Seria em vão buscar uma contradição em algo que é distintamente concebido pela mente. Se implicasse contradição, seria impossível concebê-lo. ${ }^{62}$

O contrário de toda questão de fato permanece sendo possível, porque não pode jamais implicar contradição, e a mente o concebe com a mesma facilidade e clareza, como algo perfeitamente ajustável à realidade. Que o sol não nascerá amanhã não é uma proposição menos inteligível e não implica mais contradição que a afirmação de que ele nascerá; e seria vão, portanto, tentar demonstrar sua falsidade. Se ela fosse demonstrativamente falsa, implicaria uma contradição e jamais poderia ser distintamente concebida pela mente. ${ }^{63}$

Parece plausível derivar pelo menos duas definições: i) aquilo que é concebível, isto é, cujo contrário não implica contradição, é possível; ii) aquilo cujo contrário não é concebível, isto é, implica contradição, é necessário ${ }^{64}$

Trata-se de reconhecer uma definição de categorias metafísicas (neste caso, modais) a partir de um critério epistémico (a capacidade de o agente cognitivo conceber o contrário sem contradição). No grupo i) incluem-se enunciados empíricos (como "chove") ou conclusões de enunciados empíricos (como "a chuva molha") - acerca das relações causais entre os eventos

\footnotetext{
${ }^{59} \mathrm{~T}$ 1.4.2.3.

${ }^{60}$ Cf. GARRETT, 1997, p. 58; COVENTRY, 2007, pp. 46-7.

${ }^{61} \mathrm{~T}$ 1.2.2.8.

${ }^{62} \mathrm{~T} 1.2 .4 .11$.

${ }^{63}$ IEH 4.1.2. Cf. também T 1.2.2.1; $\mathrm{T}$ 1.2.5.3; $\mathrm{T}$ 1.3.6.1; $\mathrm{T}$ 1.3.6.5; $\mathrm{T}$ 1.3.7.3 ; IEH 5.2.11.

${ }^{64}$ Não faz parte dos propósitos do presente trabalho questionar a pertinência deste princípio. Para duas abordagens deste tópico, cf. REID, 1785, IV; MILL, 1843, II, 5, 7; YABLO, 1993; TIDMAN, 1994.
} 
observados. No grupo ii) incluem-se enunciados como "chove ou não chove" e " $2+2=4 "$.

Note-se que estas definições supõem a validade irrestrita do princípio de contradição $^{65}$, e que este parece estipular um limite intransponível à mente para conceber ideias (soltas ou relacionadas). Porém, serão deixadas de lado as instâncias em que Hume diz julgar impossível o que não é concebível pela imaginação, a par da questão de saber se a definição i), extraída das considerações de Hume descreve exaustivamente todo o campo da possibilidade - se é possível algo fora do que é concebível sem contradição (por uma mente). Dito de forma sucinta, o presente trabalho não se ocupa do alcance das capacidades da imaginação, nomeadamente a respeito da impossibilidade de conceber a contradição. Assim sendo, a análise proposta já supõe a aceitação da validade irrestrita do $\mathrm{P}_{\sim \mathrm{C}}$ por parte de Hume, e as definições i) e ii) são apresentadas por serem as noções necessárias para justificar as propostas de Hume com respeito à natureza dos raciocínios demonstrativos (a priori) e causais (a posteriori), assim como uma interpretação cética da questão da existência do mundo exterior.

\subsection{Conhecimento e causalidade}

O projeto da Ciência do Homem é o de explicar os princípios da arquitetura sensitiva e cognitiva humana que determinam diversas formas de conhecimento mais exatamente, ciências. Porém, o inquérito sobre o que está por trás dessa arquitetura cognitiva é vão, devido a uma limitação empírica de observar as

\footnotetext{
${ }^{65}$ A partir de agora designado por $\mathrm{P}_{\sim \mathrm{C}}$. Apesar de Hume não o admitir explicitamente, diversos comentadores estão certos de que estas considerações de Hume - a fim de definir a distinção entre questões de facto e relações de ideias, e entre conhecimento e raciocínio probabilísticos e demonstrativos - asseguram a sua admissão do mesmo (cf. SMITH, 1905, p. 156; STANLEY, 1935, pp. 425-6). Por seu turno, como nota Stroud, este princípio introduz um elemento subjetivo na determinação das possibilidades metafísicas, uma vez que supõe a capacidade (da imaginação) para separar ideias. Com efeito, as refutações na lógica e na matemática mostram que a capacidade de determinar se algo implica contradição ou não não depende apenas de haver, de facto, alguma contradição envolvida ou não, e sim de uma capacidade da mente para discerni-lo nomeadamente, a capacidade de distinguir as ideias (cf. STROUD, 1977, p. 47, 50). Além disso, nas secções 2.2.2 e 4.6, tentarei deixar claro, uma discussão entre T. Lightner (1997) e P. Kail (2003a) também deixa clara que a incapacidade de conceber a contradição não esgota o campo das possibilidades metafísicas. Antes, a possibilidade da existência de alguns objetos não pode ser descartada porque este princípio não depende apenas do princípio de contradição, mas também da capacidade de conceber ideias claras. Na última seç̧ão, também tratarei a questão de saber se Hume aceitaria o princípio inverso ao PP, a saber, de que o que é inconcebível é impossível.
} 
próprias faculdades pelas quais o conhecimento é possível. Dados os interesses concretos do presente trabalho, a divisão das faculdades que será utilizada é exposta de forma breve.

No presente trabalho, admito a divisão das faculdades proposta por A. Coventry $^{66}$, que passo a explicar brevemente. Entendam-se as faculdades como capacidades ou disposições mentais. A memória é a capacidade de reter ideias em sucessão, de acordo com o surgimento das sensações, para além de as conceber com menor força e vivacidade do que a imaginação. A imaginação é a capacidade de transpor ideias da memória numa ordem e posição diferentes daquelas em que elas aparecem à memória e aos sentidos, para além de as conceber com menor força e vivacidade do que a memória ${ }^{67}$. Por sua vez, a imaginação abarca três modalidades: a imaginação fancy - encarada como a parte da imaginação cujo funcionamento parece ser aleatório ou que não tem uma regra definida; o entendimento ou razão, que se subdivide em razão relativa a relações de ideias (a que chamarei de demonstrativa) e relativa a questões de facto (a que chamarei de probabilística) ${ }^{68}$.

A razão - ou razão demonstrativa ou dedutiva - é encarada como a capacidade de relacionar ideias em jogo no conhecimento de relações de ideias e supõe a validade do princípio de contradição. O entendimento - ou razão indutiva $^{69}$ - é encarado como a capacidade de associar ideias de acordo com os princípios de associação (relações de semelhança, contiguidade e causalidade), no

\footnotetext{
${ }^{66}$ Cf. COVENTY, 2007, p. 37. Por seu turno, o entendimento é parte da imaginação em virtude do facto de que o funcionamento das relações filosóficas (cf. 1.6) se baseia na existência de relações naturais, que são parte da imaginação (cf. T 1.1.3.1). Por sua vez, a razão demonstrativa também é parte da imaginação porque mesmo para questionar o estatuto modal de uma certa conjunção de objetos, há um apelo à capacidade da imaginação (de poder ou não conceber o contrário de alguma coisa sem contradição), como procurei deixar claro na secção 1.3.

${ }^{67}$ Em T 1.1.3, Hume distingue as duas faculdades de acordo com ambos os critérios - da ordem e sucessão das perceções e da força e vivacidade com que as ideias são concebidas. Em T 1.3.5.3, Hume faz cair o critério da ordem e sucessão das perceções, mantendo apenas o da vivacidade com que cada uma concebe as ideias (maior para a memória e menor para a imaginação). No presente trabalho, partilho com Flage a distinção entre as faculdades da memória e imaginação com base nos critérios que chama de formal e fenomenal (formal FLAGE, 1984, pp. 168-71; 2007, p. 146). Para uma discussão mais detalhada acerca destes critérios, recomenda-se: K. SMITH, 1941, pp. 232-3; NOXON, 1976, p. 273 (artigo "remembering and imagining the past". In KING \& LIVINGSTON (eds). Hume: a re-evaluation. Spring, 1979; JOHNSON, 1987. 'Lively' Memory and 'Past' Memory. Hume Studies, vol. 13, n. 2, pp. 343 -359.

${ }^{68}$ Termos de Garrett (cf. GARRETT, 1997, p. 27). De agora em diante, emprego os termos 'razão' e 'entendimento' de forma intercambiada. Caso pretenda referir-me a um tipo de razão apenas, utilizarei os termos 'razão demonstrativa' ou 'probabilística'
} 
âmbito do conhecimento de questões de facto. $O$ entendimento e a razão demonstrativa são encarados como parte de uma razão geral, e esta, como parte da imaginação.

É possível ter ideias de objetos dos quais se teve e poderia ter tido uma sensação - como é o caso, respetivamente, de copos e elefantes voadores - assim como de objetos dos quais não se teve nem se poderia ter tido uma sensação - é o caso dos números e de figuras geométricas (perfeitas). Isto significa que o critério de verificação de proposições acerca desses dois tipos de objetos não é o mesmo, o que quer dizer que para se confirmar a verdade ou falsidade de proposições sobre o primeiro tipo de objetos, mas o mesmo não vale para proposições acerca de objetos do segundo tipo de objetos, em que se recorre aos dados dos sentidos: por exemplo, é necessário recorrer a sensações (ou memórias de sensações) para saber se o sol nasce, mas não para saber se $2+2$ são $4^{70}$.

Hume distingue dois tipos de objetos de conhecimento: questões de facto e relações de ideias, de acordo com o tipo de conhecimento possível relativamente a cada um deles. Por ser necessário um recurso à experiência para determinar o valor de verdade de um juízo acerca de questões de facto - que se prendem diretamente com objetos da sensação - o seu conhecimento é a posteriori. Isto significa que só é possível determinar o valor de verdade de proposições como "o copo está na mesa" recorrendo à sensação (do copo na mesa) e relacionando ideias que representam objetos da sensação. Por sua vez, sendo possível determinar o valor de um juízo acerca de relações de ideias sem recurso aos dados da sensação - apenas relacionando ideias abstratas (da Matemática) - o seu conhecimento é $a$ priori. Portanto, para determinar o valor de verdade de juízos como "a soma de todos os ângulos de um triângulo perfaz $180^{\circ}$ " basta relacionar as ideias envolvidas no juízo, sem recurso à sensação - porque as ideias abstratas (da

\footnotetext{
${ }^{69}$ Para distinguir da razão demonstrativa, que é sempre referida por Hume como simplesmente "razão".

${ }^{70}$ A experiência de observação parece operar como critério de verificação de juízos acerca de questões de facto, se não se consierar que o PC apenas descreve como ideias chegam à mente, ou como é que a mente "adquire" ideias, e que Hume aceitaria uma teoria da verdade como correspondência. Antes, pelo facto de que a existência de uma sensação é livre de dúvida, esta é uma fonte óbvia e segura de ideias (independentemente de haver outras fontes). Ou seja, é certo (porque não posso duvidar) que pelo menos desta maneira, ideias surgem na mente. Assim, uma interpretação normativa da existência do PC sugere facilmente a ideia de que o positivismo lógico se apoia nesta proposta de Hume.
} 
Matemática) não correspondem a objetos da sensação (pelo menos, da mesma maneira que ideias relativas a questões de facto o fazem).

Mas ainda que a justificação ou valor de verdade de proposições sobre relações de ideias seja independente da sensação, tal não implica que as relações de ideias não estejam presentes à mente em virtude de sensações passadas. As ideias de objetos abstratos são formadas a partir de uma comparação de qualidades dos objetos dos quais se tem sensações - como forma, figura, cor, quantidade e número - e por distinções de razão. Hume explica este processo através do exemplo dos globos e o cubo de mármore: se apenas tiver a impressão (ou a memória) de um globo branco (de mármore, de acordo com o exemplo de Hume), não distingo entre a sua forma e a sua cor, mas estas propriedades mostram-se inseparáveis (pelo menos, na figura que percebo), sendo necessário observar outro obejto, com outra cor ou outra forma - como um cubo branco ou um globo preto - para se estabelecer a distinção entre cor e forma ${ }^{71}$. Assim se formam, para Hume, todas as ideias abstratas - como linhas, pontos, figuras geométricas ou números. Uma vez formadas as ideias (de números, operações matemáticas, figuras geométricas), o valor de verdade das proposições acerca delas não é determinado por um recurso à experiência, bastando a aplicação de certas relações entre os objetos.

Antes de estabelecer uma distinção entre as relações que estão envolvidas no conhecimento destes dois tipos de objetos, Hume estabelece a distinção entre relações naturais e filosóficas. O filósofo distingue-as ao esclarecer a noção de relação:

A palavra RELAÇÃO é comumente usada em dois sentidos (...): para designar a qualidade pela qual duas idéias são conectadas na imaginação, uma delas naturalmente introduzindo a outra (...); ou para designar a circunstância particular na qual, ainda que a união de duas ideias na fantasia seja meramente arbitrária, podemos considerar apropriado compará-las. ( $\mathrm{T}$ 1.1.5.1; itálicos meus)

Portanto, uma relação (entre dois ou mais objetos) é natural se os objetos aparecem à mente como relacionados sem uma atividade da mente para tal - como se não houvesse consciência de se estabelecer a relação. Pelo contrário, uma

\footnotetext{
${ }^{71} \mathrm{~T}$ 1.1.7.18.
} 
relação é filosófica se envolve essa atividade, sendo as relações filosóficas, por assim dizer, forçadas ou intencionais ${ }^{72}$.

Hume parece entender que o conhecimento opera pelo encadeamento de raciocínios, que define claramente por referência às relações fillosóficas:

Todos os tipos de raciocínio consistem apenas em uma comparação e uma descoberta das relações, constantes ou inconstantes, entre dois ou mais objetos. ${ }^{73}$

Portanto, as relações envolvidas no conhecimento de questões de facto são a de semelhança, contiguidade (no espaço e no tempo) e causalidade. Resgatando o exemplo conhecido, quando observo repetidamente um bola de bilhar empurrar outra bola de bilhar e infiro uma ação da primeira bola sobre a segunda, percebo a semelhança entre as experiências observáveis, observo a contiguidade entre as bolas e, a partir disso, infiro uma ação da primeira bola sobre a segunda. As relações envolvidas no conhecimento de relações de ideias são a semelhança, quantidade ou número, graus de qualidade e contrariedade. Por exemplo, pode perceber-se apenas pelo pensamento (sem referência a sensações) que um quadrado é semelhante a um retângulo, duas linhas curvas são semelhantes (no sentido de serem ambas curvas), ou que têm graus de curvatura diferentes, ou que 4 descreve uma quantidade, ou que 4 é superior (em número ou quantidade) a 2 ou que $\mathrm{P}$ é contrário a $\sim \mathrm{P}$, ou que chover é contrário a não chover, ou ainda que chover não é contrário a pular, mas apenas a não chover.

Porém, algumas relações são tanto naturais como filosóficas: é o caso da semelhança e da causalidade ${ }^{74}$. Ao estabelecer relações filosóficas, o entendimento repete ou prolonga o aparecimento das mesmas relações na imaginação. Parece que as questões de facto aparecem associadas por essas relações seja essa associação resultado de uma atividade da mente ou não.

\footnotetext{
${ }^{72} \mathrm{~T}$ 1.1.5.1.

${ }^{73} \mathrm{~T}$ 1.3.2.2; itálico meu.

${ }^{74}$ Acerca da relação de semelhança, Hume parece aceitar que haja uma natural e outra filosófica, entendendo esta como "uma relação sem a qual nenhuma relação filosófica pode existir, visto que os objetos não admitirão comparação a não ser que tenham algum grau de semelhança" (cf. T 1.1.5.3). Com respeito à relação de causalidade, Hume é mais explícito: "Quanto aos outros objetos, como o fogo e a água, o calor e o frio, apenas se descobre que são contrários pela experiência e pela contrariedade das suas causas ou efeitos, sendo esta relação de causa e efeito uma sétima relação filosófica, bem como uma relação natural" (cf. T 1.1.5.9). Uma vez que Hume aponta apenas dois sentidos para o termo relação, a relação de semelhança (que baseia a relação filosófica de semelhança) deve ser uma relação natural.
} 
A transição entre ideias associadas por uma relação natural é mais fácil e suave (pode ser mesmo insensível) do que a transição entre ideias associadas por relações filosóficas.

No caso dos raciocínios causais, a crença numa determinada questão de facto é tão mais viva quanto mais prolongado for o hábito, o que não acontece no caso de uma demonstração, cujo resultado desperta sempre uma certeza. Porém, o hábito não está envolvido na demonstração na medida em que a justificação de um raciocínio demonstrativo não o envolve, contrariamente ao que acontece com os raciocínios empíricos (sobre questões de facto).

Além disso, vale ainda notar que a relação de identidade é estabelecida entre questões de facto, por uma união de perceções sucessivas, tal que se pode dizer, por exemplo, que a perceção de sol num tempo tl é idêntica à perceção de sol num tempo t2, t3 etc. Esta relação está envolvida na postulação do mundo externo e da identidade pessoal, que subjazem às perceções, mas não o são - o primeiro, como causa das sensações que é independente da atividade da mente, a segunda, como substrato do feixe de impressões e ideias que compõe uma atividade mental, independente de perceções particulares. Esta relação não está incluída nas relações envolvidas no conhecimento de relações causais porque, como será exposto na secção 10 do presente capítulo, essa relação presta-lhes uma função de auxílio ou de complementação.

Entretanto, aceita-se aqui a distinção tripla dos tipos de conhecimento que Hume enumera:

Entendo por conhecimento a certeza resultante da comparação de idéias. Por provas, os argumentos derivados da relação de causa e efeito, e que estão inteiramente livres de dúvida e incerteza. Por probabilidade, a evidência que ainda se faz acompanhar de incerteza. ${ }^{75}$

A diferença entre estes tipos de conhecimento é estabelecida de acordo com os graus de evidência possíveis perante cada um, segundo a qual penso ser razoável pensar que conhecimento respeita à demonstração ou conhecimento de relações de ideias (razão pela qual me referirei a este pelo termo demonstração), prova respeita à determinação de relações causais cuja probabilidade de ocorrência é de 1 (já que apenas essas probabilidades parecem ser inteiramente 
livres de dúvida para o agente cognitivo quando este espera um certo curso de acontecimentos em detrimento de outro), e probabilidade respeita à determinação de relações causais cuja probabilidade de ocorrência é inferior a 1 (porque envolve um certo grau de incerteza com respeito ao curso de acontecimentos em questão). Deste modo, julgo pertinente encarar os raciocínios que envolvem uma previsão do futuro com base em experiências observáveis do passado probabilísticos - como um tipo de conhecimento, em vez de restringir esta noção ao campo da demonstração.

Note-se que a prova é um caso especial de probabilidade, dado que ii) e iii) resultam da atividade da mesma faculdade mediante a atuação dos mesmos princípios e não dispensam a experiência observável (sensação). O que os distingue é que, no caso de ii), não existe nenhum curso de eventos contrário ao que se tem vindo a confirmar mediante a experiência observável, contrariamente ao que ocorre em iii), em que existem vários cursos de eventos prováveis - várias causas possíveis para o mesmo efeito ou vários efeitos possíveis para a mesma causa.

Os tipos de conhecimento i) e ii) geram uma certeza. Uma vez que, numa demonstração, não é admitida a possibilidade do contrário do resultado obtido, pode admitir-se que a evidência que este proporciona é de grau 1. No caso da probabilidade e da prova, a crença é gerada na mente de acordo com um grau de evidência na experiência de observação do passado - igual ou inferior a 1 , dado que pode existir uma contrariedade de causas (ou efeitos). Dado que uma prova não admite um grau maior de evidência - a não ser que se observe um curso de eventos contrários ao habitual a partir de um dado momento - também o grau de crença relativamente a ela é o maior possível, e por isso a prova gera uma certeza. Porém, a probabilidade envolve uma incerteza, dada a presença de várias causas ou efeitos possíveis no mesmo evento ${ }^{76}$. Por isso, o grau de evidência das conclusões de um raciocínio probabilístico - presente no tipo de conhecimento iii) - é menor do que o da prova.

Apesar disso, a certeza que resulta de uma demonstração é diferente da que resulta da constatação de uma probabilidade em grau máximo (que seria de 1

\footnotetext{
${ }^{75} \mathrm{~T}$ 1.3.11.2, itálico meu.

${ }^{76} \mathrm{~T}$ 1.3.11.2.
} 
dado que as observações do passado levam a mente a uma única conclusão: a inferência de uma e apenas uma relação causal entre dois ou mais objetos). Essa diferença reside no facto de que aplicado o princípio de contradição a cada um dos casos, conclui-se que existe apenas um resultado possível para uma demonstração, mas que qualquer conjunto de questões de facto pode ser o caso e, por isso, pode admitir um grau maior ou menor de probabildiade. No caso da prova e da probabilidade, é sempre possível que o futuro não seja como fora o passado. Pelo contrário, não é possível que o resultado de uma demonstração no passado seja diferente do resultado da mesma demonstração num tempo futuro, mesmo que inicialmente se possa errar na demonstração: ou $2+2=4$ ou $2+2 \neq 4$, o que significa que se $2+2=4$, não é possível que $2+2 \neq 4$ e vice-versa; mas apesar de a atividade gravitacional dos objetos ter sido sempre consistente, permanece aberta a possibilidade de num momento do futuro um objeto não se comportar de acordo com a lei da gravidade. Portanto, a diferença entre estes dois tipos de certeza reside no estatuto modal da conclusão do raciocínio, dada a aplicação do princípio de contradição: no caso da demonstração, ele é necessário e no caso da prova, contingente.

Entretanto, apesar desta distinção, o conhecimento de questões de facto consiste no estabelecimento de conexões necessárias entre objetos. Uma vez que apenas é necessário aquilo cujo contrário implica uma contradição, Hume entende que as conexões causais podem ser consideradas necessárias apenas no caso de o seu contrário ser iconcebível sem contradição. Mas não é necessário conceber a ocorrência do efeito a partir da conceção da ocorrência da causa, ou vice-versa: não é necessariamente o caso que se a causa ocorre, então o efeito ocorre, nem que se o efeito ocorreu, então a causa ocorreu.

Portanto, qualquer conjunção de questões de facto é possível ${ }^{77}$, porque qualquer conjunto de questões de facto é imaginável. Por isso, a priori - apenas pelo pensamento - qualquer coisa pode causar qualquer coisa ${ }^{78}$, quer dizer, nada impede que qualquer conjunto de questões de facto que se pode imaginar possa ser um conjunto de fenómenos que mantêm uma relação de causa-efeito entre si:

\footnotetext{
${ }^{77} \mathrm{~T}$ 1.3.6.1.

${ }^{78} \mathrm{~T}$ 1.3.14.5; $\mathrm{T} 1.3 .15 .1$.
} 
por exemplo, é possível (porque imaginável) que a primeira bola de bilhar não mova a segunda, ou o fogo não queima.

Hume explica que para que se aceitasse que o conhecimento de relações causais tem um caráter necessário como as proposições da Matemática (as relações de ideias) - em que o seu contrário não pode ser concebido sem contradição - seria necessário aceitar o princípio de que tudo o que passa a existir tem de ter uma causa (princípio a que me dou a liberdade de chamar de Princípio Geral da Causalidade $)^{79}$, sendo esta suposição também conhecida a priori. Ou seja, antes que se pudesse considerar uma relação causal particular entre duas questões de facto tão necessária como as proposições da Matemática (as relações de ideias), teria de ser aceite um princípio geral acerca de qualquer relação causal. Para o autor, o facto de aquele princípio geral não ser tal que o seu contrário é inconcebível sem contradição elimina desde logo a possibilidade de as conexões causais serem objetos de conhecimento a priori ${ }^{80}$.

Este princípio não é conhecido por intuição ${ }^{81}$, já que conceber as ideias nele envolvidas não força a aceitação de uma relação de implicação entre os predicados "começar a existir" e "ter uma causa, à qual deve a existência". O mesmo princípio também não é demonstrável, já que nenhuma das relações pelas quais as relações de ideias podem ser conhecidas está envolvida na proposição que expressa o princípio $^{82}$. Por outro lado, de acordo com o PS e ao P C , Hume explica que as ideias de causa e de efeito são separáveis e distinguíveis e, por isso, podem tanto ser concebidas como existir de forma separada e, portanto, conceber a ideia de causa não força a se conceber a ideia de efeito, nem vice-versa.

\footnotetext{
${ }^{79} \mathrm{~T}$ 1.3.3.1. De agora em diante designado por PGC.

${ }^{80}$ Entretanto, as posições dos comentadores em relação à questão de saber se Hume privilegiava a dedução como única forma de racionalidade ou se incluía a probabilidade/indução no campo da racionalidade dividem-se em três: i) os que julgavam que o propósito de Hume era exclusivamente explicativo ou descritivo e destituído de pretensões de justificação epistémica, ii) os que julgavam que Hume se mantinha um dedutivista, e, finalmente, iii) que julgavam que Hume considerava a indução ou raciocínio probabilístico uma forma genuína de racionalidade. No primeiro grupo estão comentadores como K. Smith (1941), Flew (1961, VI), Bennett (1966, XI), Beauchamp e Rosenberg (1981). No segundo grupo estão autores como Husserl (cf. 1923/4, pp. 255-6), Stroud (cf. 1977, pp. 52-4, 246), Mackie (cf. 1980a, pp. 15-20); esta é uma interpretação normativista da aplicação da necessidade lógica aos raciocínios formulados a partir dos princípios de associação. No terceiro grupo estão autores como Stanley (1935), Passmore (1968, II, podendo ser encarada como uma interpretação descritivista peculiar, por propor que Hume defendia uma fusão da lógica na psicologia ou na explicação psicológica dos raciocínios), Costa (1981), Garrett (1997, p. 27) Coventry (cf. 2006, p. 65; 2007, p. 37).

${ }^{81} \mathrm{~T} 1.3 .3 .1 ; \mathrm{T} 1.3 .14 .40$.

${ }^{82} \mathrm{~T}$ 1.3.3.2-3; $\mathrm{T}$ 1.3.14.40.
} 
Portanto, o contrário da sua conexão não implica contradição e, por isso, essa conexão não é necessária - pelo menos por um apelo àqueles princípios ${ }^{83}$. Portanto, este princípio não é objeto de nenhum tipo de conhecimento livre de dúvida, a saber, a intuição e a demonstração. Portanto, necessidade atribuída às conexões causais entre questões de facto tem de ser um dado a posteriori ${ }^{84}$.

Não tendo uma natureza a priori nem sendo intuitivo ${ }^{85}$, o conhecimento de relações causais entre questões de facto $^{86}$ - que se dá por afirmações universais como "todos os copos são frágeis" - depende de uma sequência numerosa e regular de experiências de observação, a que se acrescenta a atuação dos princípios de associação e o hábito. Porém, uma vez que esse raciocínio tem início na recordação dessa sequência de experiências (pela memória, condicionada pela experiência dos sentidos) e se restringe ao passado e ao presente, é inexplicável que as suas conclusões se estendam a casos futuros, a não ser que se suponha uma semelhança entre o futuro e o passado, ou a uniformidade da natureza. Portanto, a necessidade das conexões causais é explicada por uma aceitação prévia do princípio de que a natureza se comporta de tal forma que o futuro é como fora o passado (Princípio da Uniformidade da Natureza) ${ }^{87}$.

A necessidade da relação causal (tal como é efetivamente estabelecida por agentes cognitivos humanos) não pode estar nos próprios objetos observados caso contrário, seria possível descobri-la a partir de apenas uma sensação, o que não é o caso. Por esse motivo, também a simples conceção de uma sucessão de experiências de observação é incapaz de a mostrar ${ }^{88}$. Pelo contrário, a passagem dessa sucessão para uma nova ideia - a da causalidade - implica uma operação original da mente.

O conhecimento de questões de facto consiste essencialmente no cálculo de eventos causalmente encadeados no futuro a partir da sua ocorrência no passado. Estão envolvidos raciocínios a partir de uma experiência de observação

\footnotetext{
${ }^{83} \mathrm{~T}$ 1.3.3.3; $\mathrm{T}$ 1.3.6.1, 9 .

${ }^{84} \mathrm{~T} 1.3 .2-3,9$.

${ }^{85} \mathrm{~T}$ 1.3.4.3. Hume explica que caso o conhecimento das relações causais fosse intuitivo, bastaria uma única experiência observável para que se descobrisse essa relação.

${ }^{86}$ Este tipo de conhecimento pode aparecer tanto em raciocínios causais da vida quotidiana como no contexto da descoberta científica.

${ }^{87} \mathrm{~T}$ 1.3.6.4 (primeira referência que Hume faz a esse princípio); T 1.3.12.10 e 13. De agora em diante designado por PUN.

${ }^{88} \mathrm{~T}$ 1.3.6.3.
} 
constante e uniforme (a partir da qual os objetos aparecem à memória relacionados por semelhança e contiguidade no espaço e no tempo ${ }^{89}$ ), o exercício dos princípios de associação e o hábito. Este último princípio é aquele a partir do qual, mediante uma experiência numerosa de (conjuntos de) objetos semelhantes entre si, as suas ideias se fixam na mente e a transição entre as várias instâncias da experiência de observação se torna sucessivamente mais fácil e insensível.

O PUN não é demonstrável, porque o contrário da uniformidade da natureza - uma mudança no seu curso - é concebível sem contradição ${ }^{90}$. E uma vez que os raciocínios causais supõem o PUN, a sua origem não pode estar no exercício da faculdade do entendimento ${ }^{91}$. Assim, extinguem-se as possibilidades de esse princípio ser um fundamento do conhecimento de questões de facto ${ }^{92}$.

Hume conclui que a origem do PUN é a relação natural de causalidade (que supõe a de contiguidade e de semelhança), que baseia o funcionamento dos princípios de associação (os mesmos princípios, mas enquanto operam como relações filosóficas) no entendimento. Portanto, as relações filosóficas estabelecidas pelo entendimento (acerca de questões de facto) supõem as mesmas relações na sua versão natural: o facto de as ideias aparecem relacionadas de uma certa maneira à imaginação sem que tenha havido uma atividade prévia da mente parece ser uma condição para que esta possa começá-la e mantê-1a ${ }^{93}$.

Entretanto, o argumento sobre a origem da ideia de causalidade ou de relação causal, delineado ${ }^{94}$ e apresentado resumidamente, pode ser apresentado sob o seguinte modus tollens:

Se se tem conhecimento a priori da causalidade, é impossível conceber a causa separada do efeito.

Não é impossível conceber a causa separada do efeito.

Logo, não se tem um conhecimento a priori da causalidade ${ }^{95}$.

\footnotetext{
${ }^{89} \mathrm{~T}$ 1.3.6.3.

$90 \mathrm{~T}$ 1.3.6.5.

${ }^{91} \mathrm{~T}$ 1.3.6.6-7

${ }^{92} \mathrm{~T}$ 1.3.6.10.

${ }^{93} \mathrm{~T}$ 1.3.6.16.

${ }^{94}$ Cf. T 1.3.1-6.

${ }^{95}$ Millican sugere a mesma coisa com a noção de 'movimento-chave' (keymove), que seria, para o comentador, um argumento da forma modus tollens para concluir que a causalidade não é observável:

Se a causalidade é observável, então, o efeito deve poder ser inferido a partir da simples observação da causa.
} 
Como conclusão positiva deste argumento sobre a natureza da ideia de causalidade, Hume oferece duas definições de causa, ou de relação causal:

$\mathrm{C} 1$ : [U]m objeto, seguido de outro, tal que todos os objetos semelhantes ao primeiro são seguidos por objetos semelhantes ao segundo. ${ }^{96}$

$\mathrm{C} 2[U] m$ objeto seguido de outro, e cujo aparecimento sempre conduz o pensamento àquele outro. ${ }^{97}$

Apesar disso, Hume reconhece que as duas definições "diferem apenas por apresentarem aspectos diferentes do mesmo objeto" (cf. T 1.3.14.31). A primeira definição corresponde ao aspeto observável da relação causal - a concatenação de eventos - e a segunda, ao efeito dessa relação na mente - a inferência causal ${ }^{98}$. Entretanto, o motivo deste descontentamento é controverso ${ }^{99100}$.

Não se pode inferir o efeito a partir da simples observação da causa.

Logo, a causalidade não é observável (T 1.3.14.1-29 e I 7.2; cf. MILLICAN, 2007a, pp. 221-2).

${ }^{96}$ I 7.2.29. Cf. também T 1.3.14.31.

${ }^{97}$ Ibid. Cf. também T 1.3.14.35.

${ }^{98}$ Para uma leitura mais aprofundada sobre a questão de saber se Hume privilegiava alguma das definições em detrimento de outra, recomenda-se: ROBINSON, J. A. (1962). Hume's Two Definitions of "Cause". The Philosophical Quarterly, v. 12, n. 47, pp. 162-171; RICHARDS, T. J. (1965). Hume's Two Definitions of "Cause". The Philosophical Quarterly, v. 15, n. 60, pp. 247253; LESHER, J. H. (1973). Hume's Analysis of "Cause" and the 'Two-Definitions' Dispute'. Journal of the History of Philosophy, v. 11, n. 3, pp. 387-392; ROBISON, W. (1977). Hume's Causal Scepticism. In MORICE, G. P. (ed.), David Hume: Bicentennary Papers. Austin: University of Texas Press; GARRETT, D. (1993). The Representation of Causation and Hume's Two Definitions of 'Cause'. Noûs, v. 27, n. 2, pp. 167-190; BAÇ, M. (1999). Is Causation "In Here" or "Out There"? Hume's Two Definitions of "Cause". History of Philosophy Quarterly, v. 16, n. 1, pp. 19-35. Cf. também SMITH, 1941, pp. 88-99; FLEW, 1961, p. 123; MACKIE, 1980a, p. 20; BEAUCHAMP \& ROSENBERG, 1981, p. 12; GARRETT, 1997, 5.

${ }_{99}$ Os proponentes da interpretação do realismo cético procuram fundamentar uma interpretação realista em relação à causalidade para além do campo da regularidade observável julgam que Hume se mostra descontente com as definições justamente porque não alcançam esta causalidade, que, alegadamente, o filósofo defenderia (cf. COSTA, 1989, p. 176, 181; STRAWSON, 1989, p. 88; WRIGHT, 2000, p. 91). Por seu turno, Stroud concordaria com estes comentadores, reconhecendo que a insatisfação de Hume só pode ser explicada pela defesa de uma ideia de causalidade objetiva, e não regularista (cf. STROUD, 1977, p. 92). Mackie também concordaria com estes comentadores que Hume parte desta noção de causalidade, reconhecendo, ao mesmo tempo, que esta noção só está disponível apenas para racionalistas (dando o exemplo de Locke e Descartes). Porém, extamente por esta razão, Mackie considera este pressuposto um erro de Hume, pois haveria deturpado o seu propósito descritivo - de determinar as origens das ideias na mente em favor de um propósito normativo - de estabelecer a sua validade epistémica, seja em termos de verdade ou de justificação (MACKIE, 1980a, p. 12). Já para comentadores que defendem uma posição regularista, como Passmore, é exatamente esta conceção de causalidade que Passmore entendia que Hume pretendia contrariar (cf. PASSMORE, 1968, pp. 19-20). Por seu turno, Rosenberg e Beauchamp, para quem Hume não estava interessado em investigar o que é a causalidade em si mesma, mas apenas o que é uma inferência causal, sendo esta a razão pela qual Hume não afirma a existência de uma causalidade que ultrapassa as possibilidades da sua determinação por agentes cognitivos - portanto, que ultrapasse a conjunção constante (cf. BEAUCHAMP \& ROSENBERG, 1981, p. 17). 
Com efeito, que os raciocínios demonstrativo e probabilístico (causal) são de naturezas distintas. E enquanto a atenção estiver concentrada nas noções de necessidade e de possibilidade (ambas num sentido lógico), não há um critério para estabelecer distinções (mais subtis) entre os vários cursos de eventos possíveis - todos os que podem ser concebidos - no que respeita a uma expectativa relativamente à sua ocorrência, já que todos são igualmente possíveis ${ }^{101}$. Porém, o campo de eventos a serem considerados pode ser limitado àqueles que são (ou foram) o caso. Deste modo, é possível, pelo menos, determinar a probabilidade ${ }^{102}$ maior ou menor de um curso de eventos com base na frequência da sua ocorrência no presente e no passado, ainda que o futuro não seja obrigatoriamente (necessário no sentido lógico) semelhante ao passado ${ }^{103}$.

No caso do conhecimento de questões de facto - a posteriori - a noção de grau de evidência parece motivar a noção de grau de justificação, tal que quanto mais regular ou frequentemente os conjuntos de objetos são observados e mais semelhantes são entre si - enquanto instâncias da experiência de observação -

\footnotetext{
${ }^{100}$ Estes comentadores sustentam este pressuposto na convicção de que Hume o teria herdado do cartesianismo (cf. CRAIG, 1987, p. 69). Em particular, Strawson afirma que Hume segue Locke por combinar a crença na existência de objetos externos com a limitação cognitiva da mente para conhecer as suas propriedades, dada a diferença entre qualidades primárias e secundárias de acordo com a dependência que mantêm (ou não) em relação à mente. Portanto, Hume seria lockeano por ser um realista cético (cf. STRAWSON, 1989, p. 51). Por outro lado, Strawson afirma explicitamente que Hume teria partido de uma noção de causalidade como a de Malebranche, tal que "uma causa é verdadeirase o espírito percebe uma ligação necessária entre essa causa e seu efeito" (cf. MALEBRANCHE, 1674-5, 6.2.3, p. 250; STRAWSON, 1989, p. 109). O comentador está convicto de que apesar de procurar contrariar o ocasionalismo de Malebranche (a tese de que a única causalidade genuína, porque verdadeiramente necessária, constitui a vontade de Deus, e todas as causas físicas são suas instâncias contingentes), Hume mantinha a mesma noção de causalidade genuína - que seria obrigatoriamente inteligível, mesmo que estivesse vedada a possibilidade de acesso por parte dos agentes cognitivos. Por seu turno, Wright dedica-se consideravelmente a expor os aspetos em que Hume teria sido influenciado pelo cartesianismo, principalmente tal como teve acesso aos mesmos por meio da filosofia de Malebranche (cf. WRIGHT, 1983, pp. 4, 74-5, 79n10, 142-3, 177n12, 178n16, 180). Porém, este é um ponto que não pretendo discutir. Para mais leituras sobre o tema, consultar, por exemplo: DOXSEE, C. W. (1916). Hume's Relation to Malebranche. The Philosophical Review, v. 25, n. 5, pp. 692-710; CHURCH, R. W. (1938). Malebranche and Hume. Revue Internationale de Philosophie, v. 1, n. 1, pp. 143-161; THEAU, J. (1976). La critique de la causalité chez Malebranche et chez Hume. Dialogue, n. 15, pp. 549-64; MCCRACKEN, C. (1983). Malebranche and British Philosophy. Oxford: Clarendon, pp. 257-69; NADLER, S. (2000). Malebranche on Causation. In NADLER, S. (ed.; 2000). Cambridge Companion to Malebranche. Cambridge: Cambridge University Press; FOLLEY, N. (2003). Hume, Malebranche and the Last Occult Quality. Philosophical Topics, v. 31, n. 1/2, pp. 199-213; KAIL, P. (2008). Hume, Malebranche and Rationalism. Philosophy, v. 83, n. 325, pp. 311-332.

${ }^{101}$ IEH 5.1.7, 8; 12.3.28.

${ }^{102}$ Entendida como uma relação entre os casos passados e o que será o caso no futuro, supondo-se que os casos passados são o que permite determinar o caso no futuro (por semelhança).

${ }^{103} \mathrm{~T}$ 1.3.15.2.
} 
mais ativos são os princípios de associação e o hábito, no sentido de tornar a transição entre as ideias (desses conjuntos de objetos) sucessivamente mais suave e fácil. Por sua vez, quanto menos causas concorrerem para um mesmo efeito, maior é a probabilidade de um determinado curso de eventos.

As regras gerais que Hume prescreve para se julgar sobre causas e efeitos podem ser encaradas como generalizações com base no funcionamento da faculdade do entendimento, no sentido em que parecem ser as únicas regras que permitem distinguir entre cursos de eventos mais e menos prováveis, dado que a probabilidade é determinada quer pelas instâncias de observação, quer pela ação dos princípios do entendimento sobre aquelas. Para Hume, as regras permitem julgar sobre o grau de possibilidade de cursos de eventos no futuro com base nos cursos de eventos do passado ${ }^{104}$.

Deste modo, a necessidade atribuída às conexões causais é de uma natureza diferente da necessidade presente em demonstrações. Para esta segunda, é necessário apenas aplicar o $\mathrm{P} \sim \mathrm{C}$ (que parece estar subjacente ao próprio PS), princípio que se revela inoperativo quando se procura determinar a probabilidade de um evento. Para essa noção de necessidade concorre a experiência de observação e a atividade da mente, no exercício dos princípios do entendimento (princípios de associação e hábito).

Relativamente à crença, comece-se por explicar como surge na mente. Sendo o conhecimento de questões de facto de natureza a posteriori, não só é necessário que comece com a experiência de observação, como que esta seja o seu principal fundamento - aquilo em função do qual pode ser considerado conhecimento. Dado que a causalidade não é apreensível por intuição, a experiência de observação que fundamenta raciocínios causais não pode ser singular, mas requer-se que seja numerosa. Quando conjuntos de objetos contíguos no espaço e no tempo se apresentam de forma constante à mente e em virtude da sua semelhança e constância na memória, as suas ideias são avivadas na mesma faculdade - que aparecem associadas pelos princípios de associação (da imaginação). Esse avivamento é acompanhado pelo exercício do hábito no entendimento, que facilita a transição entre essas ideias, e crescente à medida que acrescem as experiências de observação. À medida que a vivacidade das ideias 
aumenta, surge um sentimento que determina a mente a prolongar a vivacidade das ideias do passado e do presente no futuro. Esse sentimento é tão mais vivo quanto menos circunstâncias contrárias o evento em questão envolver (na explicação do seu surgimento, isto é, da sua causa).

Este sentimento que é efeito do hábito sobre as ideias - na memória, e associadas pelo entendimento - mediante uma variedade de instâncias da experiência de observação - é a crença. Ela refere-se aos objetos que são associados pela imaginação, aos quais se postula uma relação que ultrapassa os dados da sensação e a própria conjunção constante: apesar de a semelhança e a situação no espaço e no tempo serem relações que a imaginação estabelece, elas restringem-se ao que a experiência de observação oferece à sensação. Pelo contrário, a causalidade é uma relação inobservável que se supõe manter-se entre os objetos da sensação, e é postulada aos objetos observados no passado, estendendo-se a ocorrências no futuro ${ }^{105}$.

Objetos de raciocínios causais podem despertar uma crença equivalente à que é desperta perante uma demonstração, tal que se torna praticamente impossível conceber o contrário da ocorrência de um determinado curso de eventos sem contradição ${ }^{106}$. A sua diferença reside no próprio objeto conhecido: o contrário de uma demonstração é inconcebível sem contradição, mesmo que a demonstração esteja incorreta ${ }^{107}$. Uma vez que essa não é a condição dos objetos do conhecimento probabilístico, é pela força das evidências empíricas e do exercício das faculdades da mente que a necessidade das relações causais pode parecer semelhante à de uma demonstração. Esta é, pelo menos, a conclusão a que se pode chegar com certeza acerca dos objetos dos dois tipos de conhecimento.

Porém, de um certo ponto de vista, o $\mathrm{P} \sim \mathrm{C}$ também pode ser aplicado a objetos da ciência empírica. É certo que, para Hume, esse conhecimento é acerca de perceções, que podem ou não ser causadas por objetos que existem exterior e independentemente da mente. Aparte da impossibilidade de responder a essa questão, as perceções são associadas de tal forma pela imaginação que lhes é

\footnotetext{
${ }^{104} \mathrm{~T}$ 1.3.15.3-10.

${ }^{105} \mathrm{~T}$ 1.3.7-8.

${ }^{106} \mathrm{~T}$ 1.3.12.2; T 1.3.13.20.

${ }^{107}$ Hume explica que mesmo a demonstração pode ser sujeita a revisão, dado o caráter falível das faculdades humanas. Assim sendo, nenhum tipo de conhecimento (demonstrativo e probabilístico) é irrevisível, o que explica o progresso mesmo nas ciências demonstrativas (cf. T 1.4.1).
} 
atribuída uma identidade, como se se tratasse de um mesmo objeto instanciado em observações que ocorrem num dado momento. A partir daí, as instâncias observáveis passam a ser encaradas como observações de um só objeto num tempo tx - a minha casa, a cidade do Rio de Janeiro, o sol, etc. Sob este ponto de vista, as relações causais que se descobrem entre os objetos observados são encaradas como generalidades intemporais acerca do comportamento desses objetos. Então, caso essas generalidades se refiram a objetos que existem exterior e independentemente da mente, o seu contrário é impossível, a não ser que seja descoberta a possibilidade de intervenção de circunstâncias que alteram o comportamento dos objetos em questão. Porém, pelo menos de acordo com a interpretação proposta no presente trabalho, Hume julgava ser impossível determinar com certeza se esse é o caso ${ }^{108}$.

Resta explicar em que consiste a crença. A causalidade é uma ideia nova, que se acrescenta à sucessão das observações, já que acrescenta uma qualidade que os objetos não apresentam na sensação - uma conexão necessária que faz com que um dos objetos seja capaz de produzir o outro. Mas é possível pensar numa relação causal que não gera uma crença. Por isso, a causalidade e a crença não se confundem.

A crença não é nem uma sensação, nem uma qualidade intuitivamente apreensível da sensação - portanto, não é a ideia dos objetos em cuja existência se acredita. Por outro lado, não acrescentando nada às ideias concebidas (dos objetos sobre cuja relação causal se desenvolve uma crença), também não é uma ideia nova - particular ou geral ${ }^{109}$ - gerada na continuidade da experiência de observação ${ }^{110}$. Antes, parece ser uma expectativa ou atitude perante um curso de eventos - previsto de acordo com as relações causais entre objetos observados no passado, de forma mais ou menos constante e regular. Portanto, cursos de eventos são o conteúdo das crenças, aquilo de que se tem uma crença - como chover ou não chover. Mas a crença, isto é, o estado em que se está quando se acredita em alguma coisa, em si mesma, não é o seu próprio conteúdo - como, por exemplo, a proposição "chove" ou a ideia de Pai Natal (ou, transformado numa proposição, a

\footnotetext{
${ }^{108}$ Tema que será desenvolvido nas secções 4.6 e 4.7 deste trabalho.

${ }^{109} \mathrm{~T}$ 1.3.14.12, 13. Apesar de não deixar explícito, certamente Hume não aceitaria que a crença pode ser uma ideia particular, dado que a causalidade (objeto da crença) não pode ser inferida a partir de apenas uma experiência de observação.
} 
proposição "O Pai Natal existe"). Ela não pode ser uma ideia porque, se se pensar na diferença entre uma proposição que merece assentimento e uma sobre a qual não se tem uma crença, ela não reside em nenhuma qualidade dos objetos descritos pela proposição, nem se acrescenta nenhuma ideia nova à proposição sobre a qual se tem uma crença. Se a crença não é uma ideia, então não é representativa. A crença constitui, então, o impulso a que a mente é levada mediante o exercício dos princípios de associação e o hábito, e consiste numa maneira de conceber uma ideia que é mais viva que a conceção de uma ideia em cujo objeto não se crế ${ }^{111}$.

\subsection{Simpatia, gosto e moral}

Dado o caráter interno e inobservável das paixões, é impossível ter acesso percetivo às mesmas. Porém, pela operação do mecanismo natural da simpatia ${ }^{112}$, é possível, para Hume, sentir uma paixão muito semelhante à que o outro sente, pelo avivamento da sua ideia a tal ponto que se torna uma impressão (interna, de reflexão) na mente do espectador ${ }^{113}$. Dito de forma mais simples, a simpatia consiste na capacidade de se colocar no lugar daquele que é observado ou julgado, de tal maneira que é possível experienciar o seu sentimento tal como se o espectador passasse pela mesma situação. Neste sentido, colocar-se no seu lugar significa, de alguma forma, simular a sua vivência. Nos parágrafos que se seguem, explico em que medida este mecanismo possui um valor intersubjetivo em dois sentidos, a que chamo de epistémico - referente à participação da faculdade da imaginação na geração das paixões - e moral - referente à sua relevância para o desenvolvimento da sensibilidade, isto é, de uma extensa capacidade de sentir.

Começo pelo primeiro. Na explicação de Hume para o funcionamento deste mecanismo psicológico, ressurge o destaque da operação da faculdade da

\footnotetext{
${ }^{110} \mathrm{~T}$ 1.3.7.2.

${ }^{111} \mathrm{~T}$ 1.3.5.6; $\mathrm{T}$ 1.3.6.15; $\mathrm{T}$ 1.3.9.8; $\mathrm{T}$ 1.3.11.13; $\mathrm{T} 1.3 .14 .20,22 ; \mathrm{T} 1.4 .2 .44 ; \mathrm{T} 1.3 .7 .5,6$; $\mathrm{T}$ Ap. 4 , $9,14,19$.

${ }^{112} \mathrm{Ou}$ o que hoje se entende comummente por empatia. Entretanto, K. Smith julgava que este mecanismo podia ser entendido como paralelo ao mecanismo de avivamento das ideias que gera as crenças na necessidade causal (cf. SMITH, 1941, p. 74).

${ }^{113}$ Cf. T 2.1.11.2, 3; T 2.3.6.8; T 3.2.1.2.
} 
imaginação, no exercício dos princípios de associação e consequente avivamento das ideias em questão.

Hume explica que a proliferação das paixões tem origem no eu. Uma vez que se dão neste, a ele se dirige a atenção, original e primeiramente. A partir do momento em que se reconhece a existência de um outro e com ele se estebelece uma relação, as paixões indiretas do amor do ódio afloram e proliferam. As paixões que respeitam diretamente ao eu compõem o campo do que Hume chama de interesse próprio ou do egoísmo: por exemplo, o que gosto de vestir ou comer, com quem mantenho intimidade, que lugares gosto de frequentar, onde quero morar, que carreira seguir, etc. Também parecem fazer parte deste escopo, como uma espécie de extensão deste, as paixões que respeitam àqueles com quem me relaciono e com quem, por esse motivo, mantenho uma preocupação o campo do Hume chama de generosidade limitada ou benevolência restrita ${ }^{114}$. Portanto, sem o mecanismo da simpatia, as pessoas seriam incapazes de desenvolver sentimentos além do amor e do ódio mais elementares. Ao invés, a proliferação das paixões é possível porque é possível desenvolver sentimentos acerca dos sentimentos (efetivos ou possíveis) dos outros - pois para isso, é necessário que estejam, de alguma forma, presentes à sua mente, e o que permite essa transferência é o avivamento da ideia do sentimento do outro ao ponto de se tornar uma paixão na mente do seu espectador. Por exemplo, o apreço pelos ricos e poderosos depende da simulação do seu agrado ao dispor de vastos recursos, da mesma forma que a compaixão para com alguém que sofre depende da simulação do seu desagrado ao se encontrar em determinada situação detestável. Passo a explicar duas maneiras como a imaginação está presente na geração das paixões.

Por um lado, Hume explica que as pessoas não simpatizam umas com as outras sempre na mesma medida, mas têm uma tendência natural a simpatizar com pessoas que mantêm uma relação consigo. Portanto, espontaneamente, há um limite na capacidade de simpatizar com os sentimentos dos outros. Devido à tendência da imaginação a passar tão mais facilmente entre duas ou mais ideias quanto mais estreitamente relacionadas estiverem (o que faz com que se avivem), qualquer objeto que se relacione de alguma forma com o eu será capaz de gerar uma paixão com maior intensidade e facilidade do que um objeto que não se 
relaciona com o mesmo. A facilidade em se gerar uma paixão é determinada pela concorrência das relações de semelhança, contiguidade e causalidade ${ }^{115}$. Por exemplo, é mais fácil simpatizar com os sentimentos de pessoas com quem mantenho uma semelhança cultural do que com as que estão inseridas numa cultura distinta. Também é mais fácil simpatizar com as desgraças que acontecem no país onde vivo do que num país distante. Por fim, é também mais fácil simpatizar com os sentimentos dos meus familiares do que com os de pessoas que não me são próximas. Além disso, percebe-se facilmente que a combinação destas relações facilita ainda mais o surgimento das paixões em questão: é o que acontece, por exemplo, quando simpatizo com um sentimento dos meus familiares, com quem, aliás, é muito comum que se compartilhe uma cultura.

Além disso, a relação de semelhança opera num sentido especial e mais geral, que é o de invariavelmente estarem em jogo estados mentais de seres humanos. Deste modo, Hume considera que o funcionamento do mecanismo de simpatia é assegurado pela uniformidade da natureza humana ${ }^{116}$.

Por outro lado, a paixão surge na mente por uma inferência causal. A partir da observação de gestos ou expressões faciais nos outros, infere-se não apenas que i) são motivados por paixões na sua mente, mas também que ii) esses motivos são os mesmos que, na minha mente, geram os que parecem ser os mesmos gestos ou expressões. Por exemplo, ao ver alguém a chorar, imediatamente infiro um estado mental de tristeza, ansiedade, raiva, desespero ou extrema alegria, devido à minha própria experiência, em que só choro numa situação desse tipo. Assim, estabelecem-se pares ação-motivo em que a paixão na mente do agente constitui a causa de um certo gesto ou expressão observável - encarado como seu efeito ou signo $^{117}$. A semelhança entre mim e os restantes seres humanos e a relação causal que experiencio na minha mente entre paixões e expressões exteriores permitem

\footnotetext{
${ }^{114} \mathrm{~T} 3.2 .2 .16 ; \mathrm{T} 3.3 .1 .23$.

${ }^{115}$ T 2.1.9.2, 5-13; T 2.1.11.6, 7, 11; T 2.2.2.15, 16 .

${ }^{116}$ Cf. T 2.1.11.5. Entretanto, como bem nota Monteiro, assim como o estudo dos objetos externos se torna possível devido à uniformidade da natureza (exterior), também as teorias sobre o homem supõem essa uniformidade (e o seu objeto é o homem; aliás, ele próprio é uma questão de facto): "Um mesmo fundamento empírico torna possíveis os dois tipos de ciência, natural e humana. (...) Abre-se assim a possibilidade de uma aplicação universal do método experimental, com o postulado de uma uniformidade sem fissuras recobrindo tanto o domínio natural quanto humano" (MONTEIRO, 1975, pp. 36-7, 50).

${ }^{117}$ Cf. T 2.1.11.2-4; T 3.2.1.2, 4, 8; IPM 5.2.18.
} 
uma inferência causal sobre as paixões dos outros a partir do seu efeito observável.

Deste modo, no sentido que denominei epistémico, além de reforçar as teses de Hume acerca do funcionamento da faculdade da imaginação em matérias como a influência do hábito na geração de crenças e o exercício dos princípios de associação $^{118}$, permite resolver o problema do acesso a um estado mental inapreensível. A simpatia permite uma aproximação à vida mental do outro, no sentido de determinar que paixão está presente à sua mente. Portanto, este é o mecanismo que permite que se saiba que o outro sente uma paixão e qual. Hume explica que só é possível que uma paixão afete um dado agente se estiver presente na sua mente. Aqui também parece possível perceber a importância especial da relação de causalidade no funcionamento do mecanismo de simpatia: trata-se de uma semelhança não apenas em aspeto físico, hábitos e práticas, mas também no funcionamento das mentes humanas.

No sentido que designei como moral, o valor intersubjetivo do mecanismo da simpatia mostra-se pelo seu papel na proliferação e intensificação das paixões entre os indivíduos, dirigidas tanto a si mesmo como aos outros. Por exemplo, em relação à estima que se tem pelos ricos e poderosos, Hume explica que a consideração que se tem por estes advém do reconhecimento dos prazeres, confortos e possibilidades que lhes estão reservados em virtude da riqueza e poder que detêm. Numa paixão como a inveja, a influência da simpatia também é clara: invejo alguém que detém uma qualidade ou uma objeto que certamente the agradam e que me traria um prazer particular (e, portanto, que desejo para mim), mas que não detenho. E é por ter a capacidade de me colocar no lugar do outro que sou capaz de sentir essas paixões - quer observe os seus efeitos (por exemplo, a opulência daquele que detém riqueza), quer simplesmente os imagine.

Neste ponto, também é visível a importância da faculdade da imaginação: ainda que a experiência de interação com o mundo e as outras pessoas seja uma condição para que desenvolva paixões em relação a estados presentes e futuros ou aos sentimentos dos que me rodeiam, após formado um imaginário na mente do agente, a faculdade imaginativa adquire uma certa autonomia em relação à experiência, pois basta-me imaginar um prazer ou desprazer como possível para 
que se gere uma certa paixão na minha mente. Pense-se, por exemplo, no caso de alguém que não conheço bem e que herdou uma mansão. Não é necessário saber se a pessoa em questão faz uso da mansão ou sequer se valoriza deter imóveis tanto quanto eu para supor um agrado que ela sente se eventualmente for esse o caso. Da mesma forma, não é necessário que tenha estado perante um cenário de guerra para me emocionar ao ver um filme que retrata um.

É devido a esta capacidade da natureza humana que a opinião dos outros importa a cada um. Da mesma maneira que se quer o que é agradável, quer-se ser agradável ou causar um agrado aos outros. Por isso, os agrados e desagrados dos outros seres humanos têm influência tanto na ação que cada um leva a cabo, quanto no que se pode chamar de auto-estima ou imagem que cada um tem de si mesmo $^{119}$. Por exemplo, Hume explica que uma pessoa que detém uma qualidade desprazerosa (para si e para os outros, sejam físicas ou interiores) tende a sentir algum grau de humildade em relação às mesmas qualidades. $\mathrm{O}$ mesmo vale para o orgulho: não é apenas por me causar um agrado que me posso orgulhar de uma qualidade que detenho, mas este sentimento é tão mais intenso quanto mais eu reconhecer essa qualidade como algo que agrada aos outros. Por isso, Hume considera que aquilo que, sendo outro a detê-lo, me causa a paixão do amor, sendo eu a detê-lo, causa orgulho ${ }^{120}$.

Além disso, a simpatia é determinante para a geração dos sentimentos morais de aprovação e reprovação. Dada a tendência à benevolência restrita e que a simples consideração do bem público, em si mesma, não é suficiente para gerar um sentimento moral, a preocupação que se tem por alguém que não está relacionada consigo explica-se por uma extensão da simpatia.

Esta extensão consiste num processo que envolve a separação de circunstâncias, na situação, que não são relevantes para o juízo moral ${ }^{121}$, e que,

\footnotetext{
${ }^{118}$ Cf. T 2.1.9.5; T 2.1.11.8.

${ }^{119}$ Cf. T 2.1.8.9.

${ }^{120}$ Cf. T 2.2.2.13, 14.

121 Apesar disso, vale notar que este é, talvez, o tópico desta teoria que mais desafia os seus comentadores, a saber, o da delimitação das circunstâncias determinantes para um juízo moral. Há uma razão textual para isso. Hume diz peremptoriamente que, no caso do juízo moral, a atenção deve estar voltada apenas para o objeto em si mesmo (cf. T 3.3.1.20). Já em relação ao juízo estético, Hume reconhece abertamente pelo menos que os sentimentos morais do espectador constituem um limite ou condição intransponível que condiciona a imparcialidade do juízo estético (cf. PG 33). Entretanto, tal como D. Townsend repara, o que Hume chama de 'ponto de vista desinteressado' parece corresponder a um ponto de vista em que se percebe quais os fatores que
} 
apesar disso, podem constituir um impecilho para o mesmo, pois não raras vezes contrariam as tendências mais espontâneas da mente. Através desta seleção de fatores, o agente é capaz de abstrair essas circunstâncias acidentais do caso em questão - por exemplo, um crime cometido num país espacial e culturalmente distante do seu -, gerando-se um sentimento moral pela simples consideração do crime e, no máximo, das suas motivações e seus efeitos. Esta extensão torna o agente capaz de ultrapassar as condicionantes naturais que o impedem de avaliar moralmente um acontecimento que não ocorre no estrito escopo do funcionamento mais espontâneo da simpatia, de tal forma que passa a ser capaz de dirigir sentimentos relativos ao interesse público, isto é, aquilo que é do interesse comum ou de $\operatorname{todos}^{122}$. Note-se, porém, que a pessoa com quem se simpatiza ainda mantém algo em comum consigo, a saber, o facto de pertencerem a uma mesma espécie e possuirem uma estrutura cognitiva e emotiva semelhante.

Com efeito, Hume reconhece a possibilidade da existência de um ser humano destituído do mecanismo da simpatia, isto é, que não disponha de uma capacidade de sentir, na sua própria mente, os sentimentos dos outros:

[A]lguém que nasça com um arranjo mental (...) perverso, com uma disposição tão empedernida e insensível que não tem paladar para a virtude e humanidade, nem simpatia por seus semelhantes, nem desejo de estima e aprovação, (...) deve ser considerado inteiramente incurável (...). Ele não tira nenhuma satisfação a não ser de objetos vis e sensuais ou da complacência com suas paixões malignas; não sente nenhum remorso que possa controlar suas inclinações perversas; nem

dividem as opiniões dos espectadores e quais os fatores que, mesmo condicionando a experiência, contribuem decisivamente para um juízo concreto - que é partilhado por todos (cf. TOWNSEND, 2001, p. 154, 165). W. Davie vai mais longe e considera que além de ser uma exigência demasiado irrealista para um ser humano, agir de acordo com ele (nos raros casos em que seria possível atingi-lo) nem sequer seria desejável. Com efeito, há casos em que considerar fatores pessoais e interessados é mais correto do que desconsiderá-los, e mesmo que alguém que não o fizesse poderia bem ser considerado "um tolo excêntrico" - sugerindo que estes elementos fazem parte da racionalidade no juízo de valor e na ação. Neste sentido, o juíz e agente mais razoável seria aquele que encontra um ponto de vista equilibrado e que tem os fatores interessados em conta nas situações apropriadas (cf. DAVIE, 1988, pp. 202-4). Por seu turno, P. Jones atribui esta necessidade ao facto de o objeto nunca aparecer separado de um contexto, ou seja, aparece sempre condicionado por uma série de fatores - que, ao condicionar o juízo, explica a variedade de juízos, pois gera um desacordo -, e cabe ao espectador descriminá-los, separá-los e selecionar os relevantes e os irrelevantes para o juízo (cf. JONES, 1982, p. 103; C 35). Por fim, R. Fogelin comenta que o que permite a Hume dispensar uma precisão ou exatidão absoluta do ponto de vista desinteressado é o facto de que a natureza humana, de que se tem essa noção vaga e abstrata, ainda que não seja absolutamente uniforme, é-o em grau suficiente para garantir um considerável acordo entre os sentimentos e as atividades do quotidiano (cf. FOGELIN, 1985, p. 127; C 17).

${ }^{122} \mathrm{~T}$ 3.2.1.11; T 3.2.2.19, 24. 
mesmo tem o senso ou gosto requerido para fazê-lo desejar um caráter melhor. (...) $)^{123}$

A consequência moral disto é clara. Esta pessoa seria incapaz de, por um lado, ter um caráter virtuoso - pois a intenção da sua ação jamais pode ser um desejo de bem-estar para a humanidade em geral -, por outro, ter e desenvolver um senso moral, pois é incapaz de sentir, por simpatia, o bem ou mal-estar dos restantes seres humanos, agindo exclusivamente em favor do interesse próprio. Por seu turno, também é possível a existência de alguém que, sendo ou não destituído do mecanismo de simpatia, age como se o motivo para a sua ação fosse a virtude, não a sendo - a que se pode chamar de patife esperto (wise knave) ${ }^{124}$. Esta pessoa detém conhecimento sobre as ações e motivos dos outros, assim como das regras gerais da moral, mas, seja sistemática ou topicamente, finge ser virtuoso. Uma instância mais simples ou leve desta patifaria é a mentira. Assim, a possibilidade da existência da mentira, do psicopata e do patife esperto é consequência daquelas considerações epistémicas acerca do surgimento das paixões por simpatia.

A possibilidade de existir este tipo de pessoa - a que se chama, nos dias de hoje, de psicopata - é uma consequência, por um lado, i) da natureza interna e inobservável das paixões e da natureza probabilística do conhecimento dos motivos para agir, assim como, por outro lado, ii) da noção de necessidade empírica ou de facto, que prevê sempre a possibilidade do seu contrário no futuro ou num presente desconhecido.

Apesar de ser comum que o mecanismo da simpatia funcione plena, ou pelo menos consideravelmente, estes dois casos contrariam as generalidades referentes à natureza humana no que respeita à ação: o psicopata tem uma disposição geral contrária à dos outros seres humanos, a saber, o referente a esse funcionamento pleno da simpatia; o patife esperto pode levar a cabo uma ação aparentemente aprovável, mas por um motivo que não é moral, portanto, contrariando a expectativa de que, dentre as ações que se observam, aquelas que se aprovam estão sempre associadas a um motivo virtuoso, isto é, a um desejo de cumprimento do bem público.

${ }^{123} \mathrm{C} 29$.

${ }^{124}$ IPM 9.1.22. 
A fim de distinguir os campos do valor estético e moral, por vezes, Hume refere-se ao agrado produzido pelo gosto e pelos valores morais como, respetivamente, beleza natural (de objetos da natureza, desde objetos inanimados como bens materiais ou lugares, a animais ou pessoas) e moral (da virtude ou vício $^{125}$ ). Além disso, mesmo referindo-se sempre separadamente a ambas, o autor chega ainda a afirmar que a moral está no campo do gosto, por dizer respeito aos sentimentos, isto é, ao que provoca um certo tipo de prazer ou desprazer portanto, o que define o seu subjetivismo em relação à beleza estética e à moral:

Os assuntos ligados à moral e à crítica $^{126}$ são menos propriamente objetos do entendimento que do gosto e do sentimento. A beleza, quer moral ou natural, é mais propriamente sentida que percebida. ${ }^{127}$

[O]s limites e atribuições da razão e do gosto são facilmente determinados. A razão transmite o conhecimento sobre o que é verdadeiro ou falso; o gosto fornece o sentimento de beleza e deformidade [campo da estética], de virtude e vício [campo da ética]. A primeira exibe os objetos tal como realmente existem na natureza, sem acréscimo ou diminuição; o segundo tem uma capacidade produtiva e, ao ornar [gilding] ou macular [staining] todos os objetos naturais com as cores que toma emprestadas do sentimento interno, erige, de certo modo, uma nova criação. ${ }^{128}$

Pelo menos consideradas isoladamente, estas duas ideias indiciam que Hume estaria comprometido com a tese de que todo o valor moral tem uma componente estética, ou seja, se atos virtuosos são belos e atos viciosos, feios (da mesma maneira que um quadro ou uma pessoa podem sê-lo). Porém, para o meu propósito no presente trabalho, aferir isto e tomar uma posição em relação à questão não é de particular interesse. Por essa razão, limito-me a constatar estas referências que, por si, indiciam que, nalguma medida, Hume pensava a estética e a moral sob um mesmo denominador. Para que isto fique mais claro, tenha-se em conta que Hume afirma mais que uma vez a origem subjetiva e emocional da beleza e da moralidade, que têm em comum o facto de consistirem em tipos ou formas de prazer (e a fealdade e o vício, tipos ou formas de desprazer):

\footnotetext{
${ }^{125}$ Cf. T 2.1.8.3; I 12.33; IPM Ap. 1.1.13; C 11, 16.

${ }^{126}$ Esta corresponde à ciência (empírica, experimental) que trata do gosto geral dos seres humanos, estabelecendo e compreendendo as regras para tal, e faz parte integrante da Ciência do Homem (cf. T 0.5$)$.

${ }^{127}$ I 12.33; itálico meu.

${ }^{128}$ IPM Ap. 1.21.
} 
O próprio sentiment [feeling] constitui nosso elogio ou admiração. Não vamos além disso, nem investigamos a causa da satisfação. Não inferimos que um caráter é virtuoso porque nos agrada; ao sentirmos que nos agrada dessa maneira particular, nós de fato sentimos que é virtuoso. Ocorre aqui o mesmo que em nossos juízos acerca de todo tipo de beleza, gostos e sensações. ${ }^{129}$

[S]ob o termo prazer, compreendemos sensações muito diferentes, e que não apresentam mais que uma distante semelhança umas com as outras, suficiente apenas para fazer que sejam expressas pelo mesmo termo abstrato. Uma boa composição e uma garrafa de um bom vinho produzem igualmente um prazer; mais ainda, sua excelência é determinada unicamente pelo prazer. Mas diremos por isso que o vinho é harmonioso, ou que a música é saborosa? De maneira semelhante, tanto um objeto inanimado quanto o caráter ou os sentimentos de uma pessoa podem nos dar satisfação. ${ }^{130}$

Portanto, parece claro para Hume que o gosto e a moral têm em comum a sua subsunção no subjetivismo dos valores, ou seja, a origem no binómio prazer/dor.

Existem ainda algumas instâncias em que Hume afirma um sentimentalismo generalizado, e não apenas em relação à moral e ao gosto. A meu ver, a mais explícita parece ser a seguinte:

$[\mathrm{N}]$ enhum objeto é desejável ou detestável, valoroso ou desprezível em si mesmo, mas adquire essas qualidades no caráter e constituição particualres da mente que os considera. Não há, portanto, argumentos ou razões diretas que possam ser utilizados com alguma força ou influência para diminuir ou aumentar o apreço que a pessoa tem por um objeto, para exercitar ou moderar suas paixões. ${ }^{131}$

\subsection{Razão e vontade}

O domínio do conhecimento (demonstrativo e probabilístico) é o que envolve a descoberta da verdade, que começa com a representação. Ao destacar dois tipos ou sentidos de razão e de verdade, Hume parece ainda identificar o domínio da verdade (e da representação) com o domínio da racionalidade:

\footnotetext{
${ }^{129} \mathrm{~T}$ 3.1.2.3.

${ }^{130} \mathrm{~T}$ 3.1.2.4.

${ }^{131}$ C 34. Cf. também C 8, 14, 15, 17, 35.
} 
A verdade e o erro consistem no acordo ou desacordo quer com as relações reais de ideias, quer com a existência e os factos reais. Portanto tudo o que não é suscetível deste acordo ou desacordo não pode ser verdadeiro ou falso e jamais pode ser objeto da nossa $r a z a \tilde{a} o^{132}$

A verdade pode ser de dois tipos, consistindo quer na descoberta das proporções das idéias consideradas enquanto tais, quer na conformidade de nossas idéias dos objetos com a existência real destes. É certo que a primeira espécie de verdade não é desejada meramente enquanto verdade, e que não é apenas a correção de nossas conclusões que nos dá prazer. Pois essas conclusões são tão corretas se descobrirmos a igualdade de dois corpos utilizando um compasso quanto se a conhecemos por meio de uma demonstração matemática. Embora no segundo caso as provas sejam demonstrativas e no primeiro apenas sensíveis, a mente, de maneira geral, aquiesce.com igual segurança nos dois casos. ${ }^{133}$

A razão é a descoberta da verdade ou da falsidade. A verdade e a falsidade consistem no acordo e desacordo seja quanto à relação real de idéias, seja quanto à existência e aos fatos reais. Portanto, aquilo que não for suscetível desse acordo ou desacordo será incapaz de ser verdadeiro ou falso, e nunca poderá ser objeto de nossa razão. ${ }^{134}$

O domínio da verdade, do conhecimento e da racionalidade (o que está 'de acordo com a razão') parece começar com a representação, e parece excluir estados de apresentação - impressões de sensação e de reflexão - afinal, pode perguntar-se se uma ideia corresponde ou se refere a uma impressão, mas para se responder à questão de saber a que se refere uma impressão - um objeto qualquer - já é necessário ter a ideia desse objeto. Sem essa ideia, a impressão permanece um estado original sem referência a nada a não ser ela mesma.

Deste modo, parece plausível concluir que i) este domínio é aquele em que está envolvida uma correspondência entre proposições que a) alegam a existência do conteúdo de uma ideia (por exemplo: uma cadeira existe) ou b) descrevem relações entre objetos (por exemplo: o sol nasce) e o mundo sensível; ii) em si mesmas, as impressões - de sensação e de reflexão - estão fora deste domínio e, portanto, não são racionais nem irracionais, nem suscetíveis de um valor de verdade.

\footnotetext{
${ }^{132} \mathrm{~T}$ 1.3.1.1; itálicos meus.

${ }^{133} \mathrm{~T}$ 2.3.10.2.

${ }^{134}$ T 3.1.1.9; itálicos do autor.
} 
Associando o domínio da verdade e da falsidade com o do raciocínio, das relações filosóficas e o conhecimento, parece que se pode dizer o que envolve um acordo ou desacordo entre uma ideia e uma impressão (o plano da representação) é o domínio em que a razão pode operar por meio de raciocínios ${ }^{135}$. Portanto, parece que dizer que algo é verdadeiro e justificado pela razão significa dizer que há um acordo entre ideias no interior das duas formas de conhecimento possíveis: demonstração (de relações de ideias) e conhecimento das causas (de questões de facto).

Por seu turno, o domínio da vontade, que Hume afirma ser o mais notável efeito das impressões de prazer e dor, é definida como "a impressão interna que sentimos e de que temos consciência quando deliberadamente geramos um novo movimento em nosso corpo ou uma nova percepção em nossa mente"136. Esta "[exerce-se] quando ou o bem ou a ausência de mal podem ser alcançados por meio de uma ação da mente ou do corpo" ${ }^{\text {137 }}$. Portanto, a vontade está associada ao desejo e inclinação perante um objeto ou curso de ação, e não da simples contemplação de ideias (relacionadas ou não). E uma vez que o desejo e a aversão constituem paixões, a vontade diz diretamente respeito às mesmas: é através delas que a vontade se exerce.

Trata-se de um domínio essencialmente sensitivo, no sentido em que envolve as paixões, uma vez que é através destas que a vontade se move (não constituíssem o desejo e aversão paixões (diretas)). Contrariamente às ideias (que compõem raciocínios e o conhecimento), as paixões - impressões de reflexão dirigidas a eus - são estados mentais de apresentação, não representativos (mas que podem ser representados ${ }^{138}$ ). Por essa razão, não têm, em si mesmas, valor de verdade:

[É] evidente que nossas paixões, volições e ações são incapazes de tal acordo ou desacordo, já que são fatos e realidades originais, completos em si mesmos, e que não implicam nenhuma referência a outras paixões, volições e ações. É impossível, portanto, declará-las verdadeiras ou falsas, contrárias ou conformes à razão. ${ }^{139}$

\footnotetext{
${ }^{135}$ Cf. 1.4, 1.6 para as definições de relação, raciocínio e conhecimento.

${ }^{136} \mathrm{~T} 2.3 .3 .2$.

${ }^{137}$ Cf. T 2.3.9.7

$138 \mathrm{~T}$ 2.3.3.5.

${ }^{139} \mathrm{~T}$ 3.1.1.9.
} 
Ao falar sobre o valor estético, afirma também:

Todo sentimento é correto, porque não tem referência a nada além de si mesmo, e é sempre real onde um homem tenha consciência dele. Mas nem todas as determinações do entendimento são corretas, porque têm referência a algo além de si mesmas, a saber, dizem respeito a fatos reais e nem sempre são conformáveis àquele padrão. Dentre mil opiniões diferentes que os homens possam ter sobre um mesmo assunto, há uma, e somente uma, justa e verdadeira, e a única dificuldade é fixá-la e assegurá-la. Ao contrário, mil sentimentos diferentes suscitados pelo mesmo objeto são todos eles corretos, porque sentimento algum representa o que existe realmente no objeto. Ele apenas marca uma certa conformidade ou relação entre o objeto e os órgãos ou faculdades da mente, e se essa conformidade não existisse realmente, jamais poderia haver sentimento. ${ }^{140}$

Portanto, é possível que um conjunto de conhecimentos em relação a certos objetos e/ou meios para obtenção de certos resultados se indiferentes ao agente, razão por que jamais se motivará a agir de acordo com os mesmos ou na sua direção ${ }^{141}$. Por exemplo, alguém que tenha conhecimento dos impactos ambientais nocivos do uso do plástico não vai mudar qualquer hábito na sua vida privada enquanto os dados de que dispõe não lhe causarem um afeto no sentido de agir perante isso. Passo, em seguida, para a explicação da influência destas considerações de Hume no seu sentimentalismo em relação aos valores e à motivação para a ação.

Entretanto, Hume procuraa responder à questão de saber qual a origem do valor (moral ou não moral) e de como se geram motivos para agir. Para responder a ambas as perguntas, Hume discute duas possibilidades: ou é a razão, ou são as paixões. Esta ambiguidade respeita à dúvida sobre se basta ou não ter conhecimento sobre o objeto avaliado para se encontrar nele um valor ou para constituir um motivo para agir. A sua conclusão favorecerá a segunda opção, dando primazia às paixões. Esta é a razão pela qual Hume defende, para a decisão para a ação, mas também para a moral e o gosto ${ }^{142}$, uma teoria anti-racionalista, e

\footnotetext{
${ }^{140}$ PG 7.

${ }^{141}$ Cf. T 2.3.3.3; T 3.1.1.10.

${ }^{142}$ Esclareço uma opção de referências aos textos de Hume. Como ficará mais claro em 1.13 e 14, sentimentos morais são consistem num tipo particular de paixões. Alguns argumentos e explicações de Hume sobre a decisão para a ação ficam mais claros quando se recorrer a exemplos e passagens que se encontram em T 3.1, onde explica a natureza do juízo moral. Lembro que é o próprio filósofo que se refere a T 2.3.2 (sobre a decisão para agir) a propósito daquela explicação
} 
sentimentalista ou, em termos contemporâneos, uma forma de não $\operatorname{cognitivismo~}^{143}$, isto é, que motivos para agir e valores (morais e outros) não residem em estados cognitivos ou descrições de facto, mas em estados emocionais ou sentimentos.

Em relação à origem dos juízos de valor, o filósofo inicia a sua argumentação afimando que uma vez que a mente só possui impressões e ideias os valores só se podem encontrar no campo das impressões (de sensação e reflexão) ou no das ideias (referentes a questões de facto e a relações de ideias) ${ }^{144}$.

O filósofo esclarece que o conhecimento demonstrativo não tem poder motivador na ação, a não ser de forma muito indireta e não por si mesmas, na medida em que os seus resultados podem ser úteis a conhecimentos e raciocínios sobre questões de facto, dirigindo-o. A este propósito, Hume dá o exemplo de um comerciante, que faz uso do seu conhecimento sobre operações matemáticas nas suas interações comerciais ${ }^{145}$.

Hume explica que numa ação - seja moral ou não moral -, quando a perspetiva de um prazer desperta um desejo (paixão direta) e o agente toma a decisão de agir de forma a obter o que deseja, considera o conhecimento (empírico, não demonstrativo) que detém acerca do próprio objeto do desejo e dos meios para atingi-lo ${ }^{146}$. Sendo acerca de questões de facto, Hume subsume este conhecimento em raciocínios causais ${ }^{147}$. Isto significa que de cada vez que se considera algo acerca do objeto que se deseja obter, tal é realizado por raciocínios causais. Por exemplo, imagine-se que pretendo dar uma festa. Além de o meu desejo ter um objeto - a festa, a companhia dos meus convidados -, concebo os meios necessários para realizá-la e raciocino sobre eles: onde será, o que apresentar aos convidados, que roupa vestir, etc. Tudo isto, para Hume, é subsumível em relações causais: entre mim e o que faço, entre a disposição dos objetos, todos os acontecimentos que ocorrerão a propósito da festa.

(cf. T 3.1.1.8). Além disso, o meu interesse não se restringe ao juízo e ação morais, mas abrange todo e qualquer juízo de valor. Por estas razões, na explicação que se segue, os exemplos e explicações serão apresentados de forma intercalada e como formando uma mesma explicação.

${ }^{143}$ Uma distinção mais exata entre estas duas posições será esclarecida em 3.1.1 do presente trabalho.

${ }^{144}$ Cf. T 3.1.1.2, 3.1.2.1

${ }^{145} \mathrm{Cf}$. T 2.3.3.2.

${ }^{146} \mathrm{~T}$ 2.3.3.2-3.

${ }^{147}$ Cf. T 1.3.2.2. 
Do caráter inerte da razão, Hume conclui que o interesse dos agentes em relação a qualquer estado de coisas do mundo envolve um afeto dirigido aos resultados de raciocínios causais, cálculos pragmáticos ou, numa palavra, um conjunto de crenças, sem os quais estes não são suficientes nem para produzir um juízo de valor, nem para levar o agente a uma ação efetiva:

[O impulso para agir] não decorre da razão, sendo apenas dirigido por ela. É a perspectiva de dor ou prazer que gera a aversão ou propensão ao objeto; (...) Nunca teríamos o menor interesse em saber que tais objetos são causas e tais outros são efeitos, se tanto as causas como os efeitos nos fossem inteiramente indiferentes. Quando os próprios objetos não nos afetam, sua conexão jamais pode lhes dar uma influência; e é claro que, como a razão não é senão a descoberta dessa conexão, não pode ser por meio dela que os objetos são capazes de nos afetar. ${ }^{148}$

[A]s ações não extraem seu mérito de uma conformidade com a razão, nem seu caráter censurável de uma contrariedade em relação a ela; [C]omo a razão nunca pode impedir ou produzir diretamente uma ação, contradizendo-a ou aprovando-a, tampouco pode ser a fonte da distinção entre o bem e o mal morais, os quais constatamos que têm tal influência. As ações podem ser louváveis ou condenáveis, mas não podem ser racionais ou irracionais. ${ }^{149}$

A razão, sendo fria e desinteressada, não é um motivo para a ação (...). o gosto, como produz prazer ou dor e com isso constitui felicidade ou sofrimento, torna-se um motivo para a ação e é o princípio ou impulso original do desejo e da volição. ${ }^{150}$

Adicionalmente, em relação à origem dos juízos de valor, Hume apresenta mais dois argumentos para provar o seu anti-realismo e anti-racionalismo. Em primeiro lugar, afirma que se fossem descobertos pela razão, teriam de sê-lo por meio de raciocínios demonstrativos ou causais, do que se segue que teriam de envolver pelo menos uma das sete relações que Hume elenca ${ }^{151}$. Exclui-se a primeira hipótese pelo simples facto de que demonstrações se referem a relações de ideias e, caso o valor das ações fosse demonstrável, teria de sê-lo por meio das

\footnotetext{
$148 \mathrm{~T} 2.3 .3 .3$.

149 T 3.1.1.10.

${ }^{150}$ IPM Ap. 1.21. Este argumento é equivalente ao que Hume apresenta acerca da possibilidade de o bem público ser, por si mesmo, suficiente para a instituição das regras da justiça: não pode sê-lo, devido à possibilidade de o bem público não afetar os agentes.

${ }^{151}$ Cf. T 1.1.5.
} 
relações pelas quais se efetua uma demonstração ${ }^{152}$. Sendo as ações (morais ou não morais) questões de facto $^{153}$, qualquer que seja o papel que a razão desempenha na decisão para agir e no surgimento de valores (morais ou não), tem de ser relativa a questões de facto e, por isso, envolver os raciocínios do segundo tipo - causais.

Mas este não é o caso. Os argumentos e exemplos de Hume vão no sentido de mostrar que aceitar o racionalismo implicaria aceitar o realismo em relação aos valores, isto é, que para que a razão seja capaz de discernir o valor de um objeto o que só poderia fazer estabelecendo relações entre os mesmos - o objeto tem de deter, em si mesmo, um que possa ser descoberto. Mas, Hume explica que isto levaria a uma circularidade, pois se os valores fossem objeto de conhecimento, para descobrir, por exemplo, que alguém é virtuoso, a virtude dessa pessoa e a virtude em si mesma já tem de existir ${ }^{154}$ - portanto, a possibilidade da descoberta do valor já supõe a sua existência prévia, que é o que está em questão. É por esta razão que, para Hume, a inferência da forma como as coisas são para a forma como devem ser (o chamado problema is-ought) não pode ser considerada válida. Antes, no juízo de valor, acrescenta-se uma relação (entre os objetos, sejam eles quais forem) que não está entre aquelas que Hume elenca como as que estão envolvidas no conhecimento ${ }^{155}$.

Em segundo lugar, Hume explica que se os valores morais residissem nos próprios objetos externos, teriam de ser igualmente atribuídos a animais e/ou objetos inanimados. Se a origem do valor fosse algum traço dos objetos enquanto relacionados entre si, a relação estabelecida entre os indivíduos e atos e em virtude do qual seriam virtuosos ou viciosos teria de ser estendida para além dos seres humanos. Para mostrar que este não é o caso, o autor apresenta dois claros exemplos, a partir da relação de causalidade: um arbusto que surgiu da queda de sementes de um outro, mais antigo, que o consuma mais tarde, não é considerado parricídio, apesar de o mais antigo ser causa do mais novo, da mesma forma que

\footnotetext{
${ }^{152}$ Cf. 3.3.1.18, 19.

${ }^{153}$ Cf. PG 25; IPM 1.1.10.

${ }^{154}$ Cf. T 3.1.1.25.

${ }^{155} \mathrm{~T}$ 3.1.1.20, 27.
} 
um progenitor é causa dos seus filhos. Da mesma forma, o incesto não é reprovado nos animais, mas apenas em pessoas ${ }^{156}$.

Portanto, Hume conclui, em relação à decisão para agir (moral ou não moral), que "[a] razão é, e deve ser, apenas a escrava das paixões, e não pode aspirar a outra função além de servir e obedecer a elas" ${ }^{\text {"157 }}$. Tal significa que, para o filósofo, a razão tem um papel passivo, e as paixões, um papel ativo ${ }^{158}$. Além disso, a resposta de Hume à questão de uma primazia entre razão e paixões, que, sendo de naturezas radicalmente distintas, não se podem opor. Antes, afirma que podendo o agente permanecer indiferente a qualquer conteúdo da razão que seja utilizado para esse fim, apenas uma paixão pode combater outra paixão, mediante força superior exercida na mente ${ }^{159}$. Por exemplo, alguém que fuma sabe invariavelmente dos seus malefícios e riscos que corre, mas só deixará efetivamente de fumar quando o seu desejo de parar de fumar for superior ao de fumar.

Em relação à origem dos juízos morais, o filósofo conclui que a aprovação e reprovação provêm de um sentimento, que constitui um tipo de prazer ou desprazer, mediante a contemplação de um caráter e efeito desta, e subsumindo na mesma conceção outro tipo de valores:

\footnotetext{
Por que uma ação, sentimento ou caráter é virtuoso ou vicioso? Porque sua visão causa um prazer ou desprazer de um determinado tipo. Portanto, ao dar a razão desse prazer ou desprazer, estamos explicando de maneira suficiente o vício ou a virtude. Ter o senso da virtude é simplesmente sentir uma satisfação de um determinado tipo pela contemplação de um caráter. O próprio sentimento [feeling] constitui nosso elogio ou admiração. (...) Não inferimos que um caráter é virtuoso porque nos agrada; ao sentirmos que nos agrada dessa maneira particular, nós de fato sentimos que é virtuoso. Ocorre aqui o mesmo que em nossos juízos acerca de todo tipo de beleza, gostos e sensações. ${ }^{160}$
}

Portanto, a nova relação que se estabelece entre os objetos não é, por exemplo, entre duas ações em si mesmas (como um esfaqueamento num homicídio ou a relação de causalidade entre um pai e um fillho), mas entre o objeto

\footnotetext{
${ }^{156}$ Cf. T 3.3.1.24, 25.

${ }^{157} \mathrm{~T}$ 2.3.3.4.

${ }^{158}$ Cf. T 3.1.1.7-8.

${ }^{159}$ Cf. T 2.3.3.4.

${ }^{160} \mathrm{~T}$ 3.1.2.3.
} 
avaliado e o agente, a saber, a do sentimento, isto é, a paixão que aquele (ou algum traço seu) gera neste. Esta explicação permite perceber que o fator primordial tanto dos juízos de valor (moral e não moral) como da sua eventual e posterior incorporação numa motivação para agir - quando esse juízo é acompanhado por um desejo e parte para uma ação efetiva.

Mas apesar do seu sentimentalismo, na decisão para agir (moralmente ou não), Hume atribui uma função dupla à razão, a saber, a de i) fazer acompanhar toda e qualquer paixão de uma ideia (pois todas as paixões são intensionais, isto é, têm necessariamente um objeto), e ii) disponibilizando meios para atingir o fim desejado, guiando, assim, o curso da ação de acordo com o desejo. Em conformidade com isto, Hume afirma que há dois sentidos em que se pode dizer que uma ação ou motivo para agir é irrazoável, contrária(o) à razão ou destituída(o) desta, ainda que de uma forma imprópria - pois não reflete esta conclusão sentimentalista, a saber, i’) quando há um erro no juízo, isto é, a paixão é baseada numa crença falsa, e ii') quando se empreendem meios insuficientes para a ação pretendida ${ }^{161}$. Um exemplo do primeiro caso seria: imagine-se que bebo uma bebida envenenada, que aceitei de alguém. Só a tomei por acreditar que estava própria para consumo. Um exemplo do segundo caso seria: imagine-se que preparo uma festa com muitos convidados e não peço ajuda nos preparativos. Ao levá-los a cabo, percebo que não tenho capacidade de finalizá-los a tempo de os convidados chegarem. $\mathrm{O}$ meu erro (do segundo tipo) foi não ter começado mais cedo ou não ter pedido ajuda. Hume considera que em casos como os que elenquei, assim que percebe o seu erro, o agente mostra uma indiferença em relação à antiga crença, o que resulta numa modificação da sua intenção e ação, fazendo acompanhar as suas paixões de novas ideias e crenças ou alterando as suas paixões ${ }^{162}$.

Em relação à função da razão no juízo de valor, pode dizer-se que se torna secundária também neste âmbito. Por um lado, sendo impressões de reflexão, as paixões são elementos intensionais da mente, isto é, são dirigidas a um objeto, do qual se tem de ter uma ideia. Nesse sentido mais elementar, o papel da razão é simplesmente o de colocar diante do agente os objetos relacionados de uma certa

\footnotetext{
${ }^{161}$ Cf. T 2.3.3.6; 3.1.1.12; IPM 1.1.9; Ap. 1.21.

${ }^{162}$ Cf. T 2.3.3.7.
} 
forma. Por exemplo, pessoas relacionadas comigo serão objeto de um sentimento que pessoas com as quais não me relaciono de forma alguma o serão ${ }^{163}$.

Por outro lado, o facto de o exercício da faculdade do conhecimento contribuir para uma mudança no sentimento estético mostra que a maneira como os objetos se relacionam para o agente determinam diretamente o seu sentimento. Isto fica mais claro se se lembrar que parte dos motivos que se tem para agir são morais. Da mesma forma que um desejo que não está vinculado à moral, que é determinante na decisão para agir, está necessariamente associado a uma conceção de ideias, também um valor moral o está - particularmente, exige que se conceba um caráter como causa de ações que são objeto de aprovação. Tal papel da razão também fica claro quando Hume discorre sobre a possibilidade do refinamento do gosto estético, quando afirma:

[A] mesma excelência nas faculdades, que contribui para o aprimoramento da razão, a mesma clareza de concepção, a mesma exatidão nas distinções, a mesma vivacidade de apreensão, são essenciais as operações do verdadeiro gosto e são seus acompanhantes infalíveis. ${ }^{164}$

Quando o crítico não tem delicadeza, julga sem nenhuma distinção e só é afetado pelas qualidades mais grosseiras e palpáveis do objeto: os toques mais finos não são notados e levados em conta. (...) Quando lhe falta bom senso, não é

${ }^{163}$ A este propósito, existe uma discussão mais recente sobre as implicações do argumento de Hume sobre a inércia da razão na decisão para a ação - por exemplo, para uma decisão acerca da posição de Hume sobre se o juízo moral tem uma influência direta (internalismo) ou não (externalismo) na ação, e sobre qual a relação disso com uma interpretação não-cognitivista ou cognitivista. Para uma leitura desta discussão, recomenda-se: BROWN, C. (1988). Is Hume an Internalist?.; COHON, R. (1996). Is Hume a Noncognitivist in the Motivation Argument?; COHON, R. (1997). The Common Point of View in Hume's Ethics. Philosophy and Phenomenological Research, v. 57, n. 4, pp. 827-50; COHON, R. (2010). Hume's Moral Sentiments as Motives. Hume Studies. v. 36, n. 2, pp. 193-213; DARWALL, S. (1993), Motive and Obligation in Hume's Ethics. Noûs, v. 27, n. 4, pp. 415-40; RADCLIFFE, E. (1996), "How Does the Humean Sense of Duty Motivate?". Journal of the History of Philosophy, v. 34, n. 3, pp. 383-407; RADCLIFFE, E. (2006), "Moral Internalism and Moral Cognitivism in Hume's Metaethics." Synthese, v. 152, n. 3, pp. 353-70; SHECAIRA, F. (2011), Hume and Noncognitivism. History of Philosophical Quarterly, n. 28, v. 3, pp. 267-287; STURGEON, N. (2001), "Moral Skepticism and Moral Naturalism in Hume's Treatise". Hume Studies, v. 27, n. 1, pp. 3-84; STURGEON, N. (2008), Hume's Metaethics: Is Hume a Moral Noncognitivist?”, in A Companion to Hume, ed. RADCLIFFE, E. (2008). Oxford: Blackwell, pp. 513-28. Esta discussão não se inclui no presente trabalho como objeto de discussão, pois não é suscetível de um paralelo direto com o juízo estético (que Hume não considerava ter relação com a ação). O mesmo vale para a discussão (essa, muito mais antiga e longa) acerca da questão da passagem de proposições 'is' para proposições 'ought', considerada por alguns comentadores uma evidência a favor da interpretação não cognitivista (cf. GARRETT, 1997, p. 189; STURGEON, 2008, pp. 517-18). ${ }^{164}$ PG 22. 
qualificado para discernir as belezas do propósito e raciocínio, as mais elevadas e excelentes. ${ }^{165}$

Uma consequência do sentimentalismo de Hume relativamente aos valores e à motivação para a ação é que não é possível convencer uma pessoa, simplesmente por meio de argumentos, a mudar o seu juízo de valor. Apenas quando esses argumentos a afetarem é que essa mudança será possível. Ao discorrer sobre a pessoa que não dispõe de um mecanismo de simpatia, Hume afirma:

[N]ão saberia como dirigir-me a alguém assim, ou por que argumentos poderia tentar reformá-lo. Se lhe falasse da satisfação interior que resulta das ações louváveis e humanas, do prazer delicado que existe no amor e amizade desinteressados, do contentamento duradouro que é a boa reputação e o caráter renomado, ainda assim ele poderia retrucar que estes podem ser prazeres para quem é suscetível a eles, mas, no que lhe tange, seu pendor e disposição são muito diferentes. (...) [M]inha filosofia não oferece remédio para um caso como este, e o máximo que eu poderia fazer é lamentar a condição infeliz de tal pessoa. ${ }^{166}$

${ }^{165}$ PG 23.

${ }^{166} \mathrm{C} 29$. 


\section{Causalidade: o debate sobre o Novo Hume}

\subsection{Introdução}

Relembro que a causalidade é aqui entendida como conexão necessária entre dois (ou mais) objetos tal que um tem o poder de criar o outro ou que este só existe devido à ocorrência daquele. O objeto cuja existência é, por assim dizer, responsável pela do outro é a sua causa, e este, seu efeito, em virtude desta relação necessária entre eles ${ }^{167}$. Esta parece ser a noção cuja origem Hume procura.

Deste modo, pode entender-se que a teoria causal de Hume pode ser examinada de acordo com três perspetivas fundamentais: i) a possibilidade de conceber ou formar uma ideia com sentido da causalidade, a que se pode chamar de semântical; ii) a possibilidade de conhecer a causalidade, a que se pode chamar de epistémica; iii) a determinação daquilo em que consiste a causalidade ou se, tal como definida, existe, a que se pode chamar de metafísica. Assim sendo, na filosofia de Hume, a causalidade pode ser tratada sob os três aspetos que enunciei no parágrafo acima: i') como objeto de uma ideia com sentido (questão semântica); ii') como objeto de conhecimento (questão epistémica); iii') como objeto que, em si mesmo, existe (questão metafísica). As variações entre as interpretações da teoria causal de Hume dão-se essencialmente devido a diferenças na interpretação de cada um destes elementos e, consequentemente, da sua conjugação ou combinação.

No presente capítulo, dividido em dois subcapítulos, procuro descrever e comentar diversas propostas de interpretação da teoria causal de Hume sob os três aspetos enunciados - anti-realista (2.1) e realista (2.2). O meu objetivo mais imediato é realizar um mapeamento historiográfico sobre o tema. Depois, é o de obter elementos para justificar a minha aceitação e rejeição de certos aspetos das propostas analisadas para, por fim, enunciar a proposta que julgo mais justa para a teoria da causalidade de Hume e, especialmente, para o tema do presente trabalho, a saber, do que, na filosofia de Hume, juízos causais e juízos de gosto têm em comum e em que se distinguem (que apresentarei no capítulo 4).

${ }^{167}$ Cf. 1.4 deste trabalho. 
A desproporção na extensão dos subcapítulos deve-se a duas razões. A primeira é que a principal proponente da interpretação que apresento e defendo no último capítulo do presente trabalho - A. Coventry - erige a sua proposta essencialmente a partir da rejeição da segunda proposta apresentada: o realismo cético. Por sua vez, este surgiu como reação às interpretações anti-realistas da teoria causal de Hume (que apresento de forma mais breve em 2.1). Portanto, para compreender a proposta de Coventry e as virtudes é necessário compreender o que motiva a sua rejeição do realismo cético, e para compreender este, é necessário compreender o sentido das suas objeções às interpretações anti-realistas.

A segunda razão é que os proponentes do realismo cético destacam aspetos da filosofia de Hume que julgo determinantes para a composição da proposta interpretativa que pretendo defender, a saber, de um desenvolvimento (com algumas alterações) do quasi-realismo tal como apresentado por Coventry. Porém, estes aspetos que pretendo incorporar na interpretação - e sob a qual analisarei a questão principal deste trabalho, sobre os juízos causais e de valor na filosofia de Hume - não estão presentes na proposta da autora, pois esta coloca-se, sob alguns aspetos, do lado dos anti-realistas. Portanto, é necessário compreender detalhes da proposta do realismo cético, para compreender as limitações que julgo haver na proposta de Coventry, mas também por que razões julgo pertinente incorporar esses aspetos ausentes na proposta da autora (e que aparentemente ela rejeitaria, por aceitar aspetos da interpretação anti-realista) naquela que pretendo defender.

Por fim, alerto para o sentido específico do termo 'metafísica (o)' presente no título, e principalmente no interior do subcapítulo 2.1. Não se trata de realismo/anti-realismo metafísico no sentido geral, isto é, da existência de objetos (em geral) e respetivas propriedades, mas sim da componente metafísica da teoria causal, ou seja, da determinação ontológica do que é a causalidade, ou daquilo em que esta consiste (para Hume, de acordo com os comentadores apresentados). No subcapítulo 2.2, o termo 'realismo metafísico' é utilizado em ambos os sentidos. Tento explicitar qual o sentido utilizado em cada instância, nas secções 2, 3, 4 e 6 desse subcapítulo, quando o termo aparece. Em 2.2.1 e 2.2.5, o mesmo é abordado exclusivamente no sentido geral, em virtude de ter sido utilizado pelos proponentes do realismo cético a favor da sua proposta de interpretação. Deste modo, explico com maior detalhe o que é tratado neste capítulo. 
Desde a década de 50 do século XVIII até à década de 30 do século XX, os autores que interpretaram da teoria causal de Hume mantiveram, invariavelmente, uma posição anti-realista em relação aos três aspetos fundamentais enunciados acima (semântico ou conceptual, epistémico e metafísico). Portanto, julgavam que tanto no que respeita às ideias com sentido como ao campo do conhecimento e do que existe, os objetos apenas exibem uma regularidade observável no seu aparecimento. Esta posição pode receber o nome de anti-realismo (pois nega a existência de propriedades em virtude das quais os objetos estariam necessariamente relacionados no sentido de a existência de um forçar a existência do outro), regularismo ${ }^{168}$ (por entender que a causalidade consiste na regularidade observável), reducionismo ${ }^{169}$ (por reduzir aquela causalidade a esta), ou ainda interpretação standard $^{170}$ da causalidade na filosofia de Hume (talvez pelo facto de ter sido a primeira e ter tido muitos defensores).

Dentre os autores que defenderam a posição standard estão John Leland, Henry Home - mais conhecido como Lord Kames (que dialogou com o próprio Hume, de quem era próximo) -, Thomas Reid, James Oswald, Thomas Brown, T. H. Green (na sua longa introdução ao Tratado, editado no século XIX), John Laird, A. H. Basson e Richard Taylor ${ }^{171}$. Entretanto, a partir da contribuição de Kemp Smith, certos aspetos desta interpretação começaram a ser questionados e alguns autores começaram a propor hipóteses alternativas ou, pelo menos, alguns autores se mostraram reticentes em dar uma resposta conclusiva a algumas questões ligadas à teoria causal de Hume, como, por exemplo, Barry Stroud, John Mackie, Tom Beauchamp e Alexander Rosenberg (na sua obra conjunta), Kenneth Winkler, Justin Broackes, Peter Millican, Simon Blackburn, Angela Coventry, e estou certa de que outros autores, dos quais não terei oportunidade de tratar no presente trabalho. Ainda assim, diversos autores continuaram a apresentar, sob este aspeto específico da filosofia de Hume, a primeira interpretação, como é o

\footnotetext{
${ }^{168}$ Cf. STRAWSON 1989; 2000.

169 Cf. BEAUCHAMP \& ROSENBERG, 1981.

${ }^{170}$ Cf. WINKLER 1991; BROUGHTON, 1983.

${ }^{171}$ As referências dos textos destes autores são: A. H. Basson, David Hume. Baltimore: Penguin Books, 1958; R. Taylor, "Causation", The Encyclopedia of Philosophy, v. 2, p. 58, e "Causation", In The Monist, 1963, p. 291. O escasso acesso que tive à interpretação destes autores foi por meio da obra de T. Beauchamp e A. Rosenberg (1981).
} 
caso de D. G. C. MacNabb, J. A. Robinson, Johnathan Bennett, John Passmore, James Noxon, Alfred J. Ayer, e outros, presumivelmente.

No subcapítulo 2.1, apresentarei de forma breve observações dos autores elencados, apesar de ciente de que a descrição e enumeração jamais poderiam ser exaustivas, e alertando o leitor de que o meu principal interesse é o de entender o sentido da discussão que culminou na proposta de Coventry, e a partir da qual pretendo tratar a questão central deste trabalho (razão pela qual esta autora será apresentada e discutida apenas no capítulo 4).

A proposta explícita do realismo cético parece ter surgido nos anos $1980^{172}$, contando com a contribuição de John P. Wright, Janet Broughton (ambos desde 1983), Donald Livingston (1984), Galen Strawson, Michael Costa (ambos a partir de 1989) e, mais recentemente, Peter Kail (a partir de 2001). O termo 'realismo cético' ficou consagrado pelo título da obra pioneira de Wright (The Sceptical Realism of David Hume). Além disso, a designação 'Novo Hume' (New Hume) também é conhecida como seu sinónimo, como se percebe ao ler a obra The New Hume Debate ${ }^{173}$ (2000, revista em 2007), inteiramente dedicada à discussão sobre a pertinência e solidez desta proposta. Com isso, o regularismo e as teses que o envolvem - quer como justificações, quer como consequências do mesmo - passam a ser também designados por 'Velho Hume' (Old Hume) - o que explica, em parte, o título deste trabalho.

O primeiro é o objeto do subcapítulo que aqui se introduz. Com efeito, os proponentes do realismo cético mostram-se perplexos e descontentes com o facto de que os regularistas ignoram diversas passagens dos textos que indiciam que o autor estava inclinado ao realismo causal (enumeradas em 2.2.1). As observações aparentemente sinceras de Hume acerca de 'poderes secretos' impressionam os realistas, que percebem que estas vão no sentido contrário ao que pretendem os anti-realistas: se fosse mesmo impossível formar pensamentos sobre esses objetos, como é que se poderia falar sobre eles? ${ }^{174}$ As principais passagens que, para estes

\footnotetext{
${ }^{172}$ De acordo com Kail, já no século XIX e início do séc. XX apareceram algumas propostas simpáticas à interpretação realista (sobre a causalidade em Hume; cf. KAIL, 2007b, p. 78)): cf. MAUND, C. (1937). Hume's Theory of Knowledge: A Critical Examination. London: Macmillan; KNIGHT, W. A. (1886). Hume. Edinburgh: Blackwood; CALDERWOOD, H. (1898). David Hume. Edinburgh and London: Anderson and Ferrier. Devido à falta de acesso a estas obras, não pude averiguar a exatidão da afirmação de Kail.

${ }^{173}$ Em especial, no artigo de Winkler (de 1991, reeditado na coletânea).

${ }^{174}$ Cf. KAIL, 2007a, p. 254.
} 
intérpretes, mostram que Hume parece aceitar, mesmo que implicitamente, o realismo causal são:

De fato, estou pronto a admitir que pode haver várias qualidades, tanto nos objetos materiais como nos imateriais, que desconhecemos completamente; e se queremos chamá-las de poder ou eficácia, isso pouco importa para o mundo. ${ }^{175}$

Quanto à afirmação de que as operações da natureza são independentes de nosso pensamento e raciocínio, eu o admito. Foi assim que observei que os objetos mantêm entre si relações de contigüidade e sucessão; que podemos observar vários exemplos de objetos semelhantes com relações semelhantes; e que tudo isso independe das operações das operações do entendimento e as antecede. ${ }^{176}$

Já observei que não há um só caso em que a conexão última entre os objetos pudesse ser descoberta por nossa razão ou por nossos sentidos, e que somos incapazes de penetrar tão profundamente na essência e estrutura dos corpos a ponto de perceber o princípio de que depende sua influência mútua. ${ }^{177}$

Parece-me evidente que, a essência da mente sendo-nos tão desconhecida quanto a dos corpos externos, deve ser igualmente impossível formar qualquer noção de seus poderes e qualidades de outra forma que não seja por meio de experimentos cuidadosos e precisos, e da observação dos efeitos particulares resultantes de suas diferentes circunstâncias e situações. ${ }^{178}$

[M]inha intenção nunca foi penetrar na natureza dos corpos ou explicar as causas secretas de suas operações. Além de isso estar fora de meu propósito presente, receio que tal empresa ultrapasse o alcance do entendimento humano, e que nunca poderemos conhecer os corpos senão por meio das propriedades externas que se mostram aos sentidos. (...) [C]ontento-me em conhecer perfeitamente a maneira como os objetos afetam meus sentidos e as conexões que eles mantêm entre si, até onde a experiência disso me informa. Esse conhecimento basta para a conclusão da vida; e basta também para minha filosofia, que pretende explicar tão-somente a netureza e as causas de nossas percepções, ou seja, de nossas impressões e idéias. ${ }^{179}$

Em geral, estes autores iniciam os seus argumentos pela identificação da sua posição adverária (que chamam de standard), que, em todos os casos, é o regularismo ou um pressuposto para o mesmo, e assumem uma postura de busca

\footnotetext{
${ }^{175} \mathrm{~T} 1.3 .14 .27$

${ }^{176} \mathrm{~T} 1.3 .14 .28$.

$177 \mathrm{~T} 2.3 .1 .4$.

${ }^{178} \mathrm{~T} 0.8$.

${ }^{179} \mathrm{~T}$ 1.2.5.26.
} 
por uma interpretação inovadora, propondo-se a encontrar uma articulação alternativa das evidências a fim de escapar a problemas que identificam nessa posição standard. Assim, a primeira pergunta que estes autores fazem é a de saber como enquadrar estas passagens numa interpretação regularista ou, no mínimo, como compatibilizá-las com a ideia de causalidade objetiva é sem sentido.

Motivados por esta perplexidade em comum, todos os proponentes desta interpretação apresentam um contributo positivo e inovador à proposta. Broughton aborda as questões da existência de uma ideia de causalidade objetiva com sentido e a sua relação com a posição que Hume haveria defendido sobre o próprio estatuto epistémico e metafísico da causalidade. Por sua vez, este último tópico é o principal foco da atenção de Costa. Por seu turno, Strawson e Wright foram os únicos proponentes desta interpretação que sugerem que existe um fundamento no sentido de uma justificação racional - no interior da própria teoria de Hume para a conclusão do realismo causal. E. Craig mantém uma posição mais marcadamente cética, afirmando que Hume assumia uma postura agnóstica em relação ao estatuto metafísico da causalidade, mas apresenta ou aceita os argumentos que são apresentados pelos proponentes do realismo cético ${ }^{180}$, razão pela qual julgo pertinente apresentá-lo em conjunto com aqueles, tendo o cuidado de fazer esta ressalva.

Finalmente, antes de passar a uma descrição detalhada da proposta interpretativa do realismo cético, vale o alerta para duas distinções que Simon Blackburn (defensor da posição quasi-realista, apresentada no capítulo 4) e Costa propõem sobre a ideia de causalidade que é discutida e sobre a qual os autores se posicionam. Por sua vez, isto permitirá que se perceba mais claramente as questões da epistemologia de Hume entre as quais se requer uma articulação para que a proposta seja coerente, isto é, o que está em jogo no movimento de oposição ao regularismo por parte destes autores.

Blackburn propõe uma distinção entre o que chama de nexo causal e colete de forças: o primeiro corresponderia a uma explicação dos eventos que se experienciam, que não remete necessariamente para um poder objetivo em virtude do qual a regularidade é tal como se observa (que seria o segundo). O ponto

\footnotetext{
${ }^{180}$ Prova disso é o facto de Strawson se apoiar diversas vezes nos seus comentários para apresentar os argumentos de Craig, concordando com estes ou prolongando-os.
} 
crucial nesta distinção é que o colete de forças é algo que garante a regularidade, e não meramente a explica, contrariamente ao nexo causal. Portanto, o que está em causa no debate sobre o Novo Hume é a aceitação da existência de algo que garante uma necessidade causal absoluta, em vez de uma explicação que assenta numa simples coincidência ou concatenação contingente de eventos, e cuja mudança obriga a descobrir e aceitar uma explicação alternativa para os factos ${ }^{181}$.

Por seu turno, Costa propõe que se encare o realismo causal como uma posição filosófica que congrega o que chama de o realismo dos poderes com o que chama de objetivismo causal, que consistiria na tese de que existem poderes causais genuínos entre os objetos da perceção $e$ esses poderes causais são exteriores e independentes da mente dos agentes cognitivos que (eventualmente) têm acesso aos mesmos. O realismo dos poderes consiste na tese de que a causalidade é uma propriedade que os objetos possuem (e, portanto, que conhecer causas é descobrir essas propriedades), ou seja, que os objetos mantêm uma relação entre si que ultrapassa a regularidade observável. O objetivismo causal consiste na tese de que as relações causais se mantêm entre os objetos mesmo que nenhum agente cognitivo tenha acesso às mesmas ${ }^{182} \mathrm{ou}$, dito de outro modo, que a causalidade (para além da simples regularidade observável) é uma propriedade de objetos que existem exterior e independentemente das mentes.

O objetivismo causal oferece uma resposta à questão metafísica do estatuto da causalidade (enquanto facto) em relação à mente, e opõe-se ao fenomenalismo - a tese de que tudo o que existe se resume aos objetos aos quais as mentes têm acesso, ou que não existe nada além disso. Ambas as posições ainda podem ser combinadas com o regularismo. Alguém pode aceitar que os objetos observáveis (que são exteriores e independentes da mente) mantêm uma regularidade independente da sua observação por agentes cognitivos, ou seja, que existe uma realidade exterior e independente da mente, em que os objetos que a compõem são regulares $^{183}$. Porém, pode aceitar, para além disso, que, eventualmente, a existência dessa regularidade constituiria apenas uma coincidência cósmica, ou que não existe uma razão em virtude da qual existe essa regularidade. Além disso,

\footnotetext{
${ }^{181}$ Cf. BLACKBURN, 1993a, pp. 97-9.

${ }^{182}$ Cf. COSTA, 1989, pp. 173-4.

${ }^{183}$ Mesmo sendo um opositor do realismo cético, Winkler nota a importância desta distinção (cf. WINKLER, 1991, p. 53)
} 
o objetivismo causal constitui uma instância do realismo metafísico, pois depende de que se aceite que existem, de facto, objetos externos e independentes (da mente), que possuem um número indeterminado de propriedades, dentre as quais a de estarem causalmente relacionados. O que Costa julga pertinente frizar é a distinção estas duas teses envolvidas no realismo causal, que aceitar a existência exterior e independente (da mente) dos objetos da perceção ainda deixa em aberto a questão de saber qual é a natureza da relação causal entre os objetos.

Por seu turno, o realismo dos poderes opõe-se ao regularismo ${ }^{184}$, pois aceitar que a causalidade constitui aquilo em razão do que a regularidade existe significa aceitar que existe algo para além dessa regularidade. É certo que, frequentemente, a aceitação desta tese leva à aceitação do realismo metafísico, a não ser que se esteja disposto a aceitar que o que explica a regularidade é alguma atividade da mente que a apreende. Por outro lado, a negação de ambas - que seria uma conjunção do fenomenismo com o regularismo - também é possível: alguém pode acreditar que os objetos da perceção não existem exterior e independentemente da mente e a regularidade do seu aparecimento é um mero acaso. Porém, esse algo pode ser de natureza subjetiva - como alguns intérpretes regularistas da filosofia de Hume julgam que é o caso. Já se se aceitar que esse algo é independente da mente (portanto, aceitar também o objetivismo causal), tem de residir nos próprios objetos - pois uma operação da mente é dependente da mente.

Os autores que propuseram esta interpretação avançam argumentos para mostrar que Hume defendia que a causalidade ultrapassa a regularidade observável - o que Costa chama de realismo dos poderes e Blackburn, de nexo causal $^{185}$. Particularmente, Wright e Strawson preocuparam-se em defender ainda que essa tese estaria associada à tese de que existem objetos subjacentes à perceção, exteriores e independentes (da mente) - o que Costa chama de objetivismo causal. Porém, nenhum autor a não ser Costa elaborava esta distinção, o que se reflete nalguma falta de clareza sobre se pretendem ou não incluir a questão metafísica na sua análise ${ }^{186}$. Mesmo Wright e Strawson se referem ao

\footnotetext{
${ }^{184}$ Por sua vez, estes parecem corresponder, respetivamente, à diferença entre o colete de forças e o nexo causal de Blackburn.

${ }^{185}$ Cf. KAIL, 2007b, p. 91; STRAWSON, 1989, pp. 97-8.

${ }^{186}$ É o caso de Broughton, Craig e Kail.
} 
realismo dos poderes como 'realismo causal' ou simplesmente 'realismo', ainda antes de o compararem explicitamente com o objetivismo causal.

A necessidade de manter clara a distinção entre realismo metafísico (o que há ou não há) e realismo causal (se há ou não causalidade além da regularidade, dentre o que eventualmente há) é o que torna a abordagem de Blackburn e Costa oportuna e útil para o debate. Essa distinção não é claramente elaborada por Hume, tampouco por nenhum outro comentador. Porém, julgo que os termos que utilizam na sua análise nem sempre são intuitivos, afinal, pelo menos no caso da causalidade, tanto 'realismo' como 'objetivismo' remetem para algo que de alguma forma existe fora e independentemente da mente. Dado que Hume se refere explicitamente a 'causalidade' como sinónimo de 'poder' ${ }^{187}$ ou ação de um objeto sobre outro, o regularismo (oposto ao realismo dos poderes) já é o antirealismo causal, o que retira sentido à distinção entre realismo dos poderes e realismo causal. Além disso, o termo 'nexo causal', de Blackburn, já supõe que tanto se pode chamar de 'causalidade' uma propriedade objetiva e imutável, como o simples fluxo casual de eventos. Por outro lado, não parece possível defender o realismo dos poderes (ainda utilizado os termos de Costa) num cenário fenomenalista - a não ser que se identifique a causa com a mente. Por isso, julgo mais intuitivo dizer que Costa aborda a distinção entre duas questões acerca do que Hume defenderia: i) se defenderia um realismo metafísico e ii) se sim, se também defende um realismo causal. Sob estes termos, julgo que o que Costa quer dizer é que Hume era um defensor um realismo causal e metafísico. Deste modo, considero-me livre para utilizá-los, ao invés daqueles que o comentador utiliza, mas farei referências contínuas aos mesmos para efeitos de uma melhor compreensão dos comentários.

Nas próximas secções, procuro descrever as propostas standard e do realismo cético, agrupando os comentários dos autores que contribuíram para a sua composição de forma a conseguir uma descrição consideravelmente homogénea das propostas interpretativas. Ao apresentar a primeira, explico os seus componentes iniciais - metafísico, epistémico e semântico - (2.1.1) e a rejeição do último por parte de alguns comentadores (2.1.2). A apresentação da segunda divide-se nos seguintes aspetos da proposta que estariam, para os seus 
proponentes, associados à mesma (como bases ou como consequências): uma reinterpretação da teoria das ideias de Hume (2.2.2); a compatibilização da escolha pelo realismo ou anti-realismo causal e o ceticismo em relação à fiabilidade do raciocínio causal (2.2.3); uma reinterpretação do que Hume pretendia ao oferecer as suas duas definições de causa (2.2.4); a relação entre a questão da existência de uma causalidade objetiva e a existência exterior e independente (da mente) dos objetos da perceção - ou, nos termos de Costa, a relação entre o realismo dos poderes e o objetivismo causal (2.2.5); finalmente, os motivos pelos quais se deve aceitar que Hume defenderia um realismo causal (2.2.6). Por último, esclareço que por simples preferência, chamarei de 'causalidade objetiva' aquilo que Strawson chama de Causalidade ${ }^{188}$.

\title{
2.1. Interpretação anti-realista
}

\subsubsection{Interpretação standard: anti-realismo conceptual e epistémico/metafísico}

Dentre as passagens que motivaram a interpretação standard estão:

\begin{abstract}
[A] necessidade é algo que existe na mente, e não nos objetos. E jamais poderemos formar a menos idéia dela se a considerarmos como uma qualidade dos corpos. ${ }^{189}$
\end{abstract}

[Não nos é possível] formar a menor ideia [de necessidade e poder] quando não a tomamos como a determinação da mente a passar da idéia de um objeto à idéia daquele que o acompanha usualmente. ${ }^{190}$

É a conjunção constant dos objetos, juntamente com a determinação da mente, que constitui uma necessidade física. ${ }^{191}$

\footnotetext{
${ }^{187}$ Assim como 'conexão necessária', 'força', 'energia' (Cf. T 1.3.14.4; I 7.2.29n17).

${ }^{188} \mathrm{O}$ autor explica que este termo utilizado com letra maiúscula denota aquilo a que Hume se referia pelos termos 'poder', 'energia', 'força', 'ligação', 'conexão necessária', 'princípios últimos' nos objetos. Strawson refere-se a uma causalidade não regularsta, na medida em que ultrapassa a regularidade observável e é inacessível pela observação, ou seja, num âmbito que ultrapassa as possibilidades de se formar uma ideia adequada da relação causal, com conteúdo descritivo - que corresponda a dados observáveis. Portanto, trata-se de uma causalidade concebida como aquilo em virtude do qual as regularidades são tais como se apresentam (cf. STRAWSON, 1989, p. 87).

${ }^{189} \mathrm{~T} 1.3 .14 .22$

$190 \mathrm{~T} 1.3 .14 .25$.

${ }^{191} \mathrm{~T}$ 1.3.14.33. Cf. também T 1.3.14.20; I 7.2.29.
} 
Alguns dos comentadores que fizeram os primeiros comentários à teoria causal de Hume mostram a sua interpretação regularista em afirmações vagas ou soltas ${ }^{192}$. Porém, na maioria dos casos, percebe-se que têm em conta, implícita ou explicitamente, o PC, a distinção entre os dois tipos de conhecimento (de relações de ideias e questões de facto), o PS e o $\mathrm{PP}^{193}$.

De maneira geral, o argumento que concluía que Hume seria um antirealista naqueles aspetos enunciados é formulado como se segue ${ }^{194}$. A mente apenas possui impressões e ideias e estas são cópias daquelas, de onde se assume que a única fonte de ideias são os sentidos (que fornecem as impressões, que, copiadas, geram ideias). Além disso, existem apenas duas formas de conhecimento: demonstrativo (sobre relações de ideias) e probabilístico (sobre questões de facto), de onde se divide o conhecimento no que envolve uma certeza lógica (demonstrativo) e o que a não envolve (probabilístico). E a partir do que é observável nos objetos, percebe-se que qualquer coisa pode ser a causa de qualquer coisa, pois todas as combinações de eventos são concebíveis sem contradição. Logo, o caráter de necessidade da relação causal atribuída aos objetos não pode residir nos mesmos (porque a observação não informa nada nesse sentido), mas constitui uma invenção, imposição ou ficção da mente. Passo agora para a descrição.

\footnotetext{
${ }^{192}$ É o caso, por exemplo, de Leland (cf. 1757, pp. 211-18), Oswald (cf. 1768, pp. 22, 211, 336-7) e, por vezes, Reid (cf. 1785, pp. 164-5). Porém, na sua obra de 1788, Reid tem em conta apenas a divisão das perceções da mente em impressões e ideias e a existência dos princípios de associação (cf. 1788, pp. 23-4).

${ }^{193}$ Cf. 1.1, 1.3 e 1.4 deste trabalho. Entretanto, como bem nota Garrett (cf. 1997, p. 105), o argumento de Hume não prescinde do PS (cf. 1.3 deste trabalho), afinal, uma conexão causal observável nos próprios objetos "equivaleria a uma demonstração, e implicaria a absoluta impossibilidade de que um objeto não se seguisse, ou fosse concebido como não se seguindo de outro (...)" (T 1.3.14.13; itálicos meus), portanto, constituiria uma relação de ideias e seria subsumível numa das relações presentes no conhecimento demonstrativo. Não obstante, como indicam os itálicos, também está presente o PP (cf. 1.3), pois afirma-se, implicitamente, que é possível que os dois objetos relacionados como causa e efeito não se apresentem conjugados. Portanto, a conjugação e aplicação destes dois princípios permite a Hume determinar o caráter modal da propriedade ou relação postulada (neste caso, a causalidade): o PS mostra que a causa e o efeito são separáveis, e o PP, que tal significa que aparecerem separados é uma possibilidade e, portanto, que a sua conexão não é necessária. Julgo que isto mostra o equívoco de Passmore ao observar que o PP não desempenhava nenhum papel especial na teoria causal de Hume (cf. PASSMORE, 1968, p. 36).

${ }^{194}$ Cf. Brown (1806, p. 47, 80, 94), MacNabb (pp. 49-67, 103-17), Passmore (1968, pp. 74-8, $115-$ 16), Noxon (1973, pp. 10, 19, 134-7), Bennett (1971, pp. 257-67, 294-312), Stroud (1977, pp. 7695), AYER (1980, pp. 111-44), Beauchamp \& Rosenberg (1981, pp. 3-32).
} 
Reid e Green atribuem simplesmente a Hume a posição regularista em relação à causalidade - aliás, esta é a razão pela qual a interpretação standard também se pode chamar de interpretação Reid-Green. Autores como Brown, Leland, D. G. MacNabb, J. Noxon e A. J. Ayer também adotaram esta posição. Algumas citações explícitas da mesma são:

[S]e a conexão necessária fosse verdadeiramente apenas um hábito surgido da frequência com que certos fenómenos se seguem a outros, os casos de exceção a uma sequência usual, ou na qual o balanço das possibilidades não nos inclinasse mais para uma do que para outra, poderia apenas enfraquecer o hábito. A sua explicação pela 'operação de causas ocultas' implica, como ele diz, uma oposição entre necessidade real e inconstância aparente, que, se a necessidade constituísse um hábito tal como pretende, seria impossível. ${ }^{195}$

Hume debruçou-se sobre a análise da relação causa-efeito, após o que concluiu que a ideia de força ou de actividade causal, na sua interpretação vulgar, não passava de um mito. Quanto a ele, não podia haver qualquer conexão necessária entre eventos distintos. Tudo o que aparece, então, é uma série de «perceções» fugazes sem qualquer objeto externo, sem qualquer sujeito permanente a quem possam pertencer e em que elas mesmas estejam ligadas umas às outras. ${ }^{196}$

Outros comentadores, em tom de veemente discordância - como Kames, Leland e Oswald - também concordam com esta interpretação ${ }^{197}$.

Alguns comentadores afirmam que para Hume, não se tem uma ideia de causalidade como propriedade intrínseca dos objetos observados (como T. Reid, J.

\footnotetext{
${ }^{195}$ Tradução minha do original: "[I]f necessary connection were in truth only a habit arising from the frequency with which certain phenomena follow certain others, the cases of exception to a usual sequence, or in which the balance of chances did not incline one way more than another, could only so far weaken the habit. The explanation of them by the ' operation of con cealed causes ' implies, as he here says, an opposition of real necessity to apparent inconstancy, which, if necessity were such a habit as he says it is, would be impossible." (GREEN, 1764, p. 61). Green apresenta este comentário na sua introdução ao Tratado, também pensa que Hume defendia uma teoria regularista da causalidade. A propósito da questão da possibilidade de compatibilização entre necessidade e liberdade (T 3.3.1), comenta. Mais tarde, P. Millican retoma e explora este problema e utiliza-o como evidência contra o realismo cético (cf. MILLICAN, 2007a, pp. 243-5).

${ }_{196}$ AYER, 1980, p. 45. Cf. também REID, 1785, p. 165, 205, 249; LELAND, 1757, p. 217; BROWN, 1806, pp. 97-9; MACNABB, 1951, p. 105, 106, 110, 112; NOXON, 1973, p. 134.

${ }^{197}$ LELAND, 1757, p. 211, 212, 218; HOME, 1758, pp. 186-8; OSWALD, 1768, pp. 112, 128-9, 132-3; BENNETT, 1971, pp. 296-7, 306; WINKLER, 1991, pp. 70-1 (sobre Kames, Leland, Reid e Oswald). A estes comentadores, pode acresentar-se Bennett.
} 
Leland (novamente) e R. Price), ou que a ideia que se tem da causalidade não é a de uma propriedade dos objetos (como D. G. C. MacNabb) ${ }^{198}$ :

$[\mathrm{N}]$ ão temos ideia da conexão que une o efeito à causa ou da força, poder ou energia, na causa, que produz o efeito (...) $[\mathrm{N}]$ em os objetos externos, nem a reflexão sobre as operações da nossa mente nos dão a ideia de poder. ${ }^{199}$

É verdade que [Hume] considera a ideia de conexão necessária uma parte essencial da ideia de relação causal entre objetos. Mas ele nega que a ideia de conexão necessária assente nos objetos seja uma parte essencial da nossa ideia de relação causal entre eles. ${ }^{200}$

Reid e Macnabb acrescentam que o termo 'poder' é sem significado e que a questão da existência de uma causalidade objetiva é sem sentido:

Percebemos que a regularidade da sucessão é uma propriedade real dos objetos. Não temos razão para duvidar que metais aquecidos de facto se expandem quando não os observamos, tanto como quando os observamos. Mas se atribuirmos mais do que regularidade aos objetos, falamos sem sentido.$^{201}$

Reid também observa que a única ideia genuína que se tem da causalidade corresponde à ideia regularista, isto é, de uma conjunção constante entre eventos semelhantes ${ }^{202}$.

Relativamente à componente epistémica, Passmore observa peremptoriamente que "não podemos descrever a natureza deste "laço" entre causa e efeito porque não existe tal laço para descrever"203 (Passmore).

Posto isto, o comentador acrescenta que a função das ciências é "impor conexões", jamais descobri-las ${ }^{204}$. No mesmo sentido, outros comentadores

${ }^{198}$ Cf. REID, 1785 , p. $164 ; 1788$, p. 9; 24; 1792, p. 3, 6; Cf. PRICE, 1758, p. 36; MACNABB, 1951, p. 105; WINKLER, 1991, p. 64.

${ }^{199}$ Tradução minha do original: "[W]e have no idea of that connexion which unites the effect to the cause or of the force, power, or energy in the cause, which produces the effect $(\ldots)[\mathrm{N}]$ either external objects give us the idea of power, nor reflection on the operations of our own minds." (LELAND, 1757, p. 211).

${ }^{200}$ Tradução minha do original: "It is true that [Hume] regards the idea of necessary connexion as an essential part of the idea of a causal relation between objects; but he denies that the idea of a necessary connexion residing in the objects is an essential part of our idea of a causal relation between them." (MACNABB, 1951, p. 106).

${ }^{201}$ Tradução minha do original: "Regularity of succession is, we find, a real property of objects. We have no reason to doubt that heated metals do in fact expand when we are not observing them, just as much as when we are. But if we ascribe more than regularity to the objects, we are talking nonsense." (MACNABB, 1951, p. 112). Cf. também REID, 1792, p. 6; MACNABB, 1951, p. 106. ${ }^{202}$ Cf. REID, 1788, p. 205, 212, 249; 1792, p. 8, 12.

${ }^{203}$ Tradução minha do original: "we cannot describe the nature of the 'tie' between cause and effect, because there is no such tie to describe" (PASSMORE, 1968, p. 75). 
concordam que no fundo, a atividade científica se limita a descrever o fenómeno psicológico da crença na existência de uma causalidade cuja ideia, a partir da experiência, se reduz a uma regularidade ou sucessão observável (como T. Brown, J. Noxon, K. Smith, Beauchamp e Rosenberg) ${ }^{205}$. Talvez as citações mais explícitas desta posição sejam:

A ideia de necessidade surge da 'determinação da mente a passer da causa para o efeito, adquirida pelo hábito (A 23) (...) [A conexão necessária] exige uma teorização psicológica, em vez de cosmológica. ${ }^{206}$

Hume nunca questionou que tenhamos uma ideia de conexão necessária. E é devido à sua segurança neste ponto que ao falhar encontrá-la no que se observa, indiretamente, procurou por ela noutro lugar, por um estudo da 'inferência' que se baseia nela. ${ }^{207}$

Decorrente das considerações epistémicas e semânticas, estes autores parecem interpretar metafisicamente as duas definições de causalidade que Hume apresenta, portanto, isto é, como afirmações sobre o que é a causalidade, de tal forma que a necessidade que se supõe presente numa relação causal não se encontra nos objetos tal como observados, mas constitui uma imposição da mente e, se se pode considerar que algum tipo de causalidade existe, é a que Hume imputa nas suas duas definições - que é de natureza regularista (mais eminentemente, $\mathrm{C} 1$ ) e subjetivista (mais eminentemente, $\mathrm{C} 2)^{208}$.

Por seu turno, Leland, assim como, aparentemente e mais tarde, A. H. Basson e R. Taylor, chegam a afirmar que Hume destitui a causalidade de qualquer elemento de necessidade genuína:

Pode mencionar-se, como outra instância da sua inconsistência, que ele [Hume] frequentemente faz equivaler poder e conexão necessária, e que argumenta que se há alguma conexão entre causa e efeito, qualquer que seja, tem de ser necessária. Pois o

\footnotetext{
${ }^{204}$ PASSMORE, 1968, p. 35.

${ }^{205}$ BROWN, 1806, p. 97; NOXON, 1973, p. 135; BEAUCHAMP \& ROSENBERG, 1981, pp. 8 9.

206 Tradução minha do original: "The idea of necessity arises from 'that determination of the thought, acquir'd by habit, to pass from the cause to the effect (A 23) (...). [N] ecessary connection calls for psychological rather than for cosmological theorizing." (NOXON, 1973, p. 136).

207 Tradução minha do original: "Hume never questioned that we do have an idea of necessary connexion; and it is because of this assurance on this point that on failing to find it in the observed, he has sought for it elsewhere, indirectly, through a study of 'inference' which rests upon it." (SMITH, 1941, p. 391).

${ }^{208}$ Cf. 1.4 deste trabalho.
} 
que não está necessariamente conectado com o efeito não pode ser chamado de causa. ${ }^{209}$

Entretanto, alguns destes autores não se alheavam ao facto de Hume fazer algumas afirmações que parecem contradizer a sua defesa do regularismo causal. Nelas, Hume parece referir-se a uma causalidade que ultrapassa a simples regularidade observável ou, nos termos de Strawson, Hume 'fala como um realista'. São estas:

De fato, estou pronto a admitir que pode haver várias qualidades, tanto nos objetos materiais como nos imateriais, que desconhecemos completamente; e se queremos chamá-las de poder ou eficácia, isso pouco importa para o mundo. ${ }^{210}$

Quanto à afirmação de que as operações da natureza são independentes de nosso pensamento e raciocínio, eu o admito. Foi assim que observei que os objetos mantêm entre si relações de contigüidade e sucessão; que podemos observar vários exemplos de objetos semelhantes com relações semelhantes; e que tudo isso independe das operações das operações do entendimento e as antecede. ${ }^{211}$

Já observei que não há um só caso em que a conexão última entre os objetos pudesse ser descoberta por nossa razão ou por nossos sentidos, e que somos incapazes de penetrar tão profundamente na essência e estrutura dos corpos a ponto de perceber o princípio de que depende sua influência mútua. ${ }^{212}$

Além destas, existem parágrafos em que Hume se refere repetidamente a 'poderes secretos' (secret powers) de uma forma natural ou como se aceitasse que existem $^{213}$.

Kames não esconde uma estranheza perante a tensão entre a impossibilidade de obter uma ideia clara ou adequada de causalidade para além da regularidade observável e a disposição de Hume a aceitar que a causalidade possa ultrapassar este escopo:

\footnotetext{
${ }^{209}$ Tradução minha do original: "It may be mentioned, as another instance of his inconsistency, that he frequently makes power and necessary connexion the same thing; and argues, that if there be any connexion between cause and effect at all, it must be a necessary one; for that cannot be called a cause, that is not necessarily connected with the effect." (LELAND, 1757, p. 217). Cf. também BEAUCHAMP \& ROSENBERG, 1981, p. 6.

${ }^{210} \mathrm{~T}$ 1.3.14.27.

${ }^{211} \mathrm{~T}$ 1.3.14.28.

${ }^{212} \mathrm{~T}$ 2.3.1.4.

${ }^{213}$ Cf. I 4.1.16, 21; I 8.1.14. Como ficará claro em 2.2, estas referências são utilizadas pelos proponentes do realismo cético como evidências a favor da sua interpretação (cf. COSTA, 1989, p. 180; BROUGHTON, 1987, p. 227).
} 
Apesar de nos seus Ensaios Filosóficos manter que "a necessidade existe apenas na mente, não nos objetos, e que não nos é possível sequer formar a ideia mais distante dela, considerada uma qualidade dos corpos", ainda assim, no curso do seu argumento, mais de uma vez descobre que ele mesmo detém uma ideia de poder, considerada uma qualidade dos objetos (...) Isto não é apenas deter uma ideia de poder como qualidade dos objetos, mas também deter a realidade desse poder. ${ }^{214}$

$\mathrm{O}$ autor prossegue o seu argumento enumerando evidências textuais da obra de Hume que vão no sentido da defesa de que não se tem conhecimento da conexão causal que, de facto, existe nos objetos. Disto, Kames conclui que Hume entra em contradição com a sua tese inicial ${ }^{215}$. Também J. Laird afirma que Hume não estaria autorizado a admiti-lo, o que, em princípio, indicia que pensava, à semelhança dos outros comentadores do seu tempo, que Hume prescrevia uma teoria regularista da causalidade. Mais recentemente, K. Winkler mostra estar de acordo com esta opinião ${ }^{216}$.

Por fim, alguns autores vão mais além. Ayer também comenta que Hume dava a causalidade objetiva por garantida, apesar de o resultado da sua investigação filosófica ir no sentido contrário. Por seu turno, Passmore observa que apesar de não reconhecer a existência de relações causais necessárias nos objetos em si mesmos, Hume estava forçado a reconhecer algumas relações causais como genuínas (como mais do que regularidades) - entre as faculdades da mente e as inferências ou entre aquelas e as regras gerais ${ }^{217}$.

Os comentários destes autores a respeito da existência da causalidade apresentam uma vicissitude que merece ser notada. Apesar de explicarem a conclusão (supostamente, da defesa do regularismo) a partir da afirmação de que a causalidade não se pode encontrar em nenhum aspeto observável dos objetos apreensíveis pelos sentidos, não fazem uma distinção explícita entre a questão da existência de uma causalidade fenoménica e a de uma causalidade como uma

\footnotetext{
${ }^{214}$ Tradução minha do original: "Though in his Philosophical Essays he continues to maintain, "That necessity exists only in the mind, not in objects; and that it is not possible for us even to form the most distant idea of it, considered as a quality in bodies"; yet, in the course of the argument, he more than once discovers, that he himself is possessed of an idea of power, considered as a quality in bodies (...) This is not only owning an idea of power as a quality in bodies, but also owning the reality of this power." (HOME, 1758, pp. 188-9).

${ }^{215}$ HOME, 1758, p. 189, 212.

${ }^{216}$ Cf. LAIRD, 1932, p. 119, apud SMITH, 1941, p. 88; WINKLER 1991, p. 85n10.
} 
propriedade dos objetos enquanto independentes da mente - uma propriedade intrínseca aos mesmos, mas que não se mostra aos sentidos nem é dedutível (pela razão demonstrativa). Uma explicação plausível para tal parece ser o que MacNabb e Passmore declaram: Hume haveria desistido de quaisquer pretensões metafísicas em nome de um propósito descritivo:

Antes de questionar se apenas corpos moventes ou apenas vontades detêm, realmente, poder - que é uma questão metafísica -, questionemos o que há nessas coisas que nos faz dizer que detêm poder - que é uma questão conceptual. ${ }^{218}$

Hume argumenta que a Metafísica é, em parte, sem sentido, em parte psicologia disfarçada. É sem sentido quando aborda essências, qualidades ocultas e por aí adiante. É psicologia quando se ocupa da causalidade, da substância, da identidade Deste modo, por exemplo, o metafísico alega descrever conexões necessárias e demonstrar que todo o evento tem uma causa. Mas na visão de Hume, esta tarefa (...) é impossível. Tudo o que podemos esperar fazer é descrever a forma como passamos a acreditar que uma coisa está necessariamente conectada a outra - o que constitui apenas psicologia descritiva. A análise da causalidade de Hume é um paradigma da filosofia, tal como ele gostaria que fosse. Verdadeira metafísica - a ciência da natureza humana, a ciência fundamental genuine substitui a falsa ou visionária. ${ }^{219}$

Disto se poderia pensar que, sendo assim, estes autores apenas chegaram a notar um regularismo epistémico, isto é, que apenas se tem acesso à regularidade observável, mas não a uma propriedade que seria responsável por aquela. Porém, julgo que esta conclusão não é justa. As afirmações de alguns destes autores são claras - destaque-se, por exemplo, Brown refere-se a qualidades dos objetos externos, por contraste com as qualidades da mente ${ }^{220}$, e Leland também fala em objetos externos e declara que Hume nega a existência da causalidade nas coisas

\footnotetext{
${ }^{217}$ Cf. PASSMORE 1968, pp. 31, 34; AYER, 1980, p. 74.

${ }^{218}$ Tradução minha do original: "Before asking whether only moving bodies, or only wills really have power, which is a metaphysical question, let us ask just what it is about these things that makes us say they have power; this last is a conceptual question." (MACNABB, 1951, p. 108).

219 Tradução minha do original: "Metaphysics, [Hume] argues, is in part nonsense, in part psychology in disguise - it is nonsense when it talks about essences, occult qualities and the like; it is psychology when it concerns itself with causality, substance, identity. Thus, for example, the metaphysician professes to describe the nature of necessary connexion and to demonstrate that every event has a cause. But on Hume's view this task (...) is an impossible one; all he can hope to do is to describe the way in which we come to believe that one thing is necessarily connected with another - which is just descriptive psychology. Hume's analysis of causation is a paradigm of philosophy as he would like it to be; true metaphysics - the science of human nature, the genuine fundamental science - replaces false, or visionary, metaphysics." (PASSMORE, 1968, p. 12).

${ }^{220}$ Cf. BROWN, 1806, p. 94.
} 
em si mesmas ${ }^{221}$. Além disso, tanto quanto sei, nenhum dos autores citados na presente secção estabelece, noutro momento da sua obra, a distinção entre os objetos enquanto fenómenos (objetos apreensíveis pelos sentidos e, portanto, para Hume, cognoscíveis) e enquanto existências independentes, com o fim de aplicála a uma proposta de interpretação da teoria causal de Hume.

\subsubsection{Rejeição de alguns elementos da interpretação standard}

Exponho agora duas variações da visão standard, a saber, a negação do anti-realismo na sua componente metafísica e conceptual. Ambas foram avançadas inicialmente por K. Smith. Beauchamp e Rosenberg mostram concordar com a primeira, e B. Stroud, com a segunda. Exponho-as por ordem.

K. Smith descarta a possibilidade de Hume ser um realista causal:

Em vez de assentar na relação de causa e efeito e pressupô-la, a inferência, em si, é idêntica a essa relação. Não é nada além da transição habitual de uma impressão para uma ideia vívida. ${ }^{222}$

Beauchamp e Rosenberg também descartam a pertinência do reconhecimento da existência de 'poderes secretos' nos objetos apelando ao facto de Hume introduzir um adversário - a quem se dirige com ironia - que acredita na existência da causalidade para além da regularidade observável:

O quê? A eficácia das causas está na determinação da mente? Como se as causas não operassem de modo inteiramente independente da mente, e não fossem continuar a sua operação mesmo que não existisse nenhuma mente para as contemplar ou para raciocinar a seu respeito. $O$ pensamento pode bem depender das causas para sua operação, mas não as causas do pensamento. Isso é inverter a ordem da natureza, tomando como secundário o que na realidade é primário. Para cada operação existe um poder proporcional; e esse poder tem de estar situado no corpo que opera. Se retirarmos o poder de uma causa, temos de atribuí-lo a outra. Mas retirá-lo de todas as causas e atribuí-lo a um ser que não está de modo algum relacionado com a causa ou com o efeito, se não porque os percebe, é um absurdo

${ }^{221}$ Cf. LELAND, 1757, p. 211.

222 Tradução minha do original: "Inference, instead of resting on the relation of cause and effect and presupposing it, is itself identical with that relation. It is nothing but the custom-bred transition from an impression to an enlivened idea." (SMITH, 1941, p. 123; 1905, p. 164; itálico meu). 
grosseiro, contrário aos princípios mais seguros da razão humana. $^{223}$

Porém, sendo defensores da interpretação regularista, estes autores acrescentam que a suposição de uma causalidade para além da regularidade observável é falsa ${ }^{224}$. Ainda assim, afirmam que a interpretação regularista se restringe aos objetos apreensíveis pelos sentidos, mantendo uma interpretação cética em relação à existência de propriedades nos objetos enquanto independentes da mente, neste caso, causais. Portanto, estes autores julgam que Hume é cético em relação à existência de propriedades em virtude das quais a regularidade observável se dá e aparece:

Hume é cético tanto em relação à crença na existência objetiva das conexões necessárias na natureza por parte do homem comum como dos racionalistas Neste sentido, Hume é cético em relação a certas teorias em que se concede a existência de conexões necessárias. Este ceticismo é focado na existência de conexões necessárias não mentais (...). Nenhuma das teorias de Hume sobre a causalidade contempla a existência de uma conexão necessária entre objetos como condição logicamente necessária para serem relacionados como causa e efeito. Ainda assim, admite que a ideia de uma conexão necessária objetiva é uma parte essencial da noção de relação causal no sentido costumeiro. ${ }^{225}$

Portanto, os autores estabelecem uma distinção entre a causalidade como propriedade intrínseca dos objetos e como relação causal. Em relação à primeira mantêm-se céticos, mas em relação à segunda, defensores do regularismo ${ }^{226}$.

Já K. Smith dá um tratamento àquelas afirmações de Hume diferente dos os autores até aqui mencionados e citados em mais um aspeto. $\mathrm{O}$ autor também analisa estas duas questões separadamente, mas nega a interpretação regularista

\footnotetext{
${ }^{223}$ T 1.3.14.26; cf. BEAUCHAMP \& ROSENBERG, 1981, pp. 16-7.

${ }^{224}$ Cf. BEAUCHAMP \& ROSENBERG, 1981, p. 9, 11.

${ }^{225}$ BEAUCHAMP \& ROSENBERG, 1981, pp. 34-5.

${ }^{226}$ Tradução minha do original: "Hume is sceptical about both the common man's and the rationalists' beliefs in the objective existence of necessary connections in nature. In this regard Hume is skeptical about certain views that posit the existence of necessary connections among objects. This skepticism focuses only on the nonmental existence of necessary connectedness (...) $[\mathrm{O}] \mathrm{n}$ neither of Hume's theories of causation is the existence of an objectively necessary connection between objects a logically necessary condition of their being related as cause and effect; yet, by his own admission, the idea of an objectively necessary connection is an essential part of causal relatedness in the ordinary sense of "cause" (BEAUCHAMP \& RONSENBERG, 1981, pp. 19-21).
} 
em relação a ambas (contrariamente a Beauchamp e Rosenberg, que mantinham o regularismo conceptual e epistémico, restrito a dados da experiência sensível).

Após afirmar que "[Hume] reconhece espontaneamente a existência de causas 'secretas', que agem independentemente da nossa experiência”"227, afirma explicitamente que Hume não é regularista ${ }^{228}$ :

Hume não é um defensor do que é usualmente entendido pela visão da causalidade como 'uniformidade'. Como cuidadosamente insiste, a causalidade é mais do que (...) sequência invariável. Distinguimos entre mera sequência e sequência causal. E o que as diferencia é que a ideia de necessitação (determinação ou agência) recai sob a segunda como element essencial. ${ }^{229}$

[O] que Hume se esforça por justificar não é a visão da causalidade ocmo uniformidade, mas aquela em que a agência causal - poder, eficácia, determinação - é totalmente pressuposta. É o fator da inferência, não da agência, que está a ser negado. ${ }^{230}$

Para K. Smith, Hume não pretendia negar a existência de propriedades em virtude das quais a regularidade se dá e se apresenta, mas apenas que o significado do termo e ideia é equivocado, tratar das inferências e respetivas causas ${ }^{231}$ :

[O] que ele pretende asserir não é que não há necessidade ou agência fora da mente, mas que o único sentido que podemos associar aos termos 'necessidade', 'eficácia', 'agência', 'poder' e 'energia' deriva do que é nada mais nada menos que um sentimento, isto é, do que só pode existir nalguma mente e que portanto não se pode, dessa forma, esperar ter qualquer tipo de entendimento ou compreensão do que, por esse processo de crença, somos capazes de localizar no campo das ocorrências externas. ${ }^{232}$

227 Tradução minha do original: "freely recognises the existence of 'secret' causes, acting independently of our experience" (SMITH, 1941, p. 88; 1905, p. 152).

${ }^{228}$ Cf. SMITH, 1941, p. 369.

229 Tradução minha do original: "[H]ume is no supporter of what is usually meant by the 'uniformity' view of causation. As he is careful to insist, causation is more than (...) invariable sequence. We distinguish between mere sequence and causal sequence; and what differentiates the two is that the idea of necessitation (determination or agency) enters into the latter as a quite essencial element." (SMITH, 1941, pp. 91-2).

${ }^{230}$ Tradução minha do original: "[W]hat Hume is here endeavouring to justify is not a uniformity view of causation, but a view in which causal agency - power, efficacy, determination - is presupposed troughout. It is the factor of inference, not that of agency, which is being denied." (SMITH, 1941, p. 393).

${ }^{231}$ SMITH, 1905, p. 172.

${ }^{232}$ Tradução minha do original: "[W] hat he intends to assert is not that there is no such thing as necessity or agency outside the mind, but that the only meaning which we can attach to the terms 'necessity', 'efficacy', 'agency', 'power', 'energy', is one which derives from what is no more than a feeling, i. e., from what is possible of existence only in some mind, and that we cannot therefore, by means of it, hope to have any kind of understanding or comprehension of what, 
O autor avança a interpretação de que esses poderes secretos seriam indesvendáveis, restringindo o campo de acesso da mente sob ideias com sentido à regularidade observável (que, com a impressão interna gerada por aquela, constituem as definições de causa dadas por Hume) - portanto, um ceticismo epistémico (o reconhecimento de uma impossibilidade de aceder à causalidade para além do que os dados da experiência sensível e os princípios de associação proporcionam $)^{233}$ :

Pelo conhecimento, não temos, pensa ele, a mais distante noção do que 'necessidade' significa; e isto vale tão rigorosamente para as suas operações como experienciadas numa mente como para as que acreditamos ocorrerem no mundo exterior. ${ }^{234}$

[Hume coloca] questões relativas a conhecimento, e não apenas crença [de tal forma que] descobrimos que a agência, necessidade e conexão causais, tais como exibidas à mente $\mathrm{e}$ assentidas mediante a crença, é, em si, misteriosa, tão pouco inteligível para nós como as relativas a dois objetos externos. ${ }^{235}$

Porém, apesar de concordar com os intérpretes anti-realistas na sua componente semântica, K. Smith concede que há uma crença na causalidade objetiva, que é natural ${ }^{236}$. Este aspeto da teoria causal de Hume foi defendido e desenvolvido por Stroud:

Temos a ideia não apenas de um evento de um certo tipo que se segue sempre a um evento de outro tipo em determinadas circunstâncias, mas também de uma conexão necessária entre eventos de dois tipos em determinadas circunstâncias. Claro que não é imediatamente óbvio em que consistem essa crença e essa

through the processes of belief, we none the less come to locate in external happenings." (SMITH, 1941, p. 397).

${ }^{233}$ Cf. SMITH, 1905, p. 162, 173; 1941, pp. 398-9. Como apresentarei mais extensa e claramente na seç̧ão 3.2.4, este é um dos aspetos essenciais da proposta interpretativa do realismo cético (ainda que a dívida em relação a K. Smith não seja reconhecida explicitamente por nenhum dos seus proponentes). Agradeço ao Prof. Plínio Smith pela chamada de atenção relativamente a esta antecipação de K. Smith.

${ }^{234}$ Tradução minha do original: "In the way of knowledge, we have not, he holds, even the most distant notion of what necessity signifies; and this holds as rigorously of its operations as experienced within the mind as of those which we believe to occur in the external world." (SMITH, 1941, p. 397).

${ }^{235}$ Tradução minha do original: "[Hume raises] questions which concerns knowledge, and not merely belief, [so that] we find that causal agency, necessary connexion, as this exhibited to the mind, and assented to in belief, is itself as mysterious, as little intelligible to us, as that between any two external objects." (SMITH, 1941, p. 399).

${ }^{236}$ Cf. SMITH, 1941, p. 395, 397, 405-10. Aliás, é maioritariamente na defesa da razão como instinto que reside a profunda originalidade da proposta de K. Smith. Este tópico será tratado em 2.2.6, quando explicar que os realistas céticos utilizaram este argumento para favorecer a sua interpretação. 
ideia. Qual é a diferença entre observer um A e vir a crer que ocorrerá um B, e observer um A e vir a crer que tem de ocorrer um B? Qual é a diferença entre ter a ideia de Bs que se seguem sempre de As e ter a ideia de uma conexão necessária entre As e Bs? $?^{237}$

Stroud nunca abandonou a sua interpretação regularista no sentido epistémico (ou talvez também metafísico ${ }^{238}$. Porém, empenha esforços não apenas para explicar que Hume nega o anti-realismo semântico ${ }^{239}$, isto é, que (neste caso) a ideia de causalidade se reduz à ideia da regularidade observável, como também que o filósofo aceitaria a posição contrária, isto é, a possibilidade de formar um pensamento genuíno sobre a causalidade ${ }^{240}$. Portanto, o comentador defende uma interpretação que conjuga um anti-realismo causal com um realismo semântico $^{241}$. A exposição da sua interpretação pode ser feita a partir de dois pontos cruciais: i) a abertura de uma "brecha" no PC e ii) a indagação sobre o que implica realmente acreditar numa relação causal como conexão necessária. Passo a explicar.

Stroud lembra que a ideia de contiguidade é condição necessária, mas não suficiente, para a constituição da ideia de causalidade - e corresponde à primeira definição de causalidade - e que relatos causais não são de impressões ou eventos do passado. Uma vez que é definida como conexão necessária, esta definição não reflete a noção de causalidade. É por isso que se requer a segunda definição, que aponta para a tendência da mente a passar de um objeto para aquele que se the sugere por hábito ${ }^{242}$ : uma impressão interna que explicaria a origem da ideia de conexão necessária, ou seja, o que faz com que se infira que um certo A tem de se

\footnotetext{
${ }^{237}$ Tradução minha do original: "We have the idea, not just of an event of one sort always following an event of another sort in certain circumstances, but of there being a necessary connection between events of two sorts in certain circumstances. Of course, it is not immediately obvious what that belief and idea come to. What is the difference between observing an A and coming to believe that a B will occur, and observing an A and coming to believe that a B must occur? What is the difference between having the idea of Bs always following As and having the idea of a necessary connection between As and Bs?" (STROUD, 1977, p. 78).

${ }^{238}$ Cf. também MACKIE, 1980a, pp. 25-6.

${ }^{239} \mathrm{O}$ que Bennett já antecipava, afirmando que Hume não estava interessado em negar o realismo semântico (cf. BENNETT, 1971, p. 259).

${ }^{240}$ Que é o que está aqui em questão, mas que se aplica também a ideias como da identidade pessoal ou dos objetos da perceção.

${ }^{241}$ Cf. STROUD, 1977, pp. 44, 76-82, 83, 86-7, 91; 1978, p. 41, 45; 1993, p. 257, 258, 260; 2006, p. 347.

${ }^{242}$ Cf. 1.2 deste trabalho.
} 
seguir de um certo $\mathrm{B}$, e não simplesmente que A se seguirá de $\mathrm{B}$, ou o que permite a distinção entre uma coincidência e um caso de causalidade genuína ${ }^{243}$.

Stroud observa que o facto de a análise da ideia de causalidade estar diretamente associada à teoria empirista das ideias obstrui a compreensão de que atribuir uma relação causal a dois objetos é ajuizar sobre os mesmos. As duas definições "oficiais" estão de acordo com aquela teoria. Porém, a ideia de uma causalidade objetiva constitui um contra-exemplo à mesma. Stroud alerta ainda que o PC constitui um princípio de ideias simples, e não de todas as ideias ${ }^{244}$, e que por isso, não é necessário aceitar que a ideia de causalidade provém da dita impressão interna na mente do agente. Portanto, se não se aceitar que a causalidade é uma ideia simples, não se aceita a necessidade de explicar o seu surgimento a partir do PC (pelo menos exclusivamente). Trata-se de uma ideia que não corresponde a uma impressão que se tem ou teve e, por isso, não é de uma impressão, mas de algo diferente de uma impressão. Stroud julga que quem pretender seguir estritamente as duas definições de causa e se restringir a origem das ideias ao PC, compromete-se com a interpretação de que não se tem genuinamente uma crença na causalidade objetiva porque não se tem dela qualquer ideia. Segundo esta - que chama de psicologista ${ }^{245}$, ao falar sobre a necessidade causal, o agente cognitivo fala, pelo menos em parte, da sua própria mente.

Mas Stroud pensa que não é necessário seguir estritamente a teoria das ideias. Os verbos que se utilizam no quotidiano são causais, e envolvendo uma conexão necessária, não podem referir-se apenas à regularidade, que se mostra dispersa, aleatória - pois a priori, todas as questões de facto são separáveis - e contingente - sendo separáveis, podem conectar-se de qualquer forma. Neste sentido, o comentador observa que apesar de só se ter acesso a impressões, não é a estas que se atribui uma conexão, mas sim àquilo que faz com que as impressões se repitam, a saber, uma conexão invariável (necessária) entre os objetos dos quais se tem uma impressão. Portanto, para Stroud, Hume concederia que apesar de que aquilo de que os agentes cognitivos falam e pensam quando falam e pensam em

\footnotetext{
${ }^{243}$ Cf. STROUD, 1977, pp. 43-4, 45, 78.

${ }^{244}$ Cf. 1.1 deste trabalho.

${ }^{245}$ Por seu turno, J. Broughton chama-a de interpretação psicológica, e à de Stroud, de epistémica (cf. BROUGHTON, 1987, p. 217, 218, 224).
} 
causalidade é uma propriedade dos objetos - em virtude da qual é imperativo que as questões de facto se conectem de uma e só uma forma ${ }^{246}$.

Tal como Beauchamp e Rosenberg, Stroud considera que esta crença (na causalidade objetiva), além de racionalmente injustificada, é falsa, e que tal se deve justamente ao facto de a referência da ideia e da crença na causalidade ser uma propriedade objetiva. Se se referisse à regularidade observável, a crença quotidiana seria, pelo menos, verdadeira. Mas Stroud insiste que não se tem evidências textuais disto. Pelo contrário, várias evidências apontam no sentido de que se tem uma crença equivocada e uma ideia fictícia da mesma, como, por exemplo, a sua classificação como ficção (que não se aplica só à causalidade, mas também a ideias como substância, identidade pessoal ou objeto externo) ou a ironia de Hume na passagem citada alguns parágrafos acima ${ }^{247}$. Por conseguinte, pode aceitar-se, sem inconsistência, que a ideia de causalidade tem outra origem, a saber, uma propensão da faculdade da imaginação a espalhar-se nos objetos externos ou a transferir-lhes propriedades que apenas existem na mente - que Winkler chamou de propensão projetiva ${ }^{248}$ :

[A] mente tem uma grande propensão a se espalhar pelos objetos externos, ligando a eles todas as impressões internas que eles ocasionam, e que sempre aparecem ao mesmo tempo que esses objetos se manifestam aos sentidos. ${ }^{249}$

[C]omo sentimos uma conexão habitual entre as idéias, transferimos esse sentimento aos objetos, pois nada é mais comum do que aplicar aos corpos externos todas as sensações internas que eles ocasionam. ${ }^{250}$

Neste sentido, Hume seria um teórico do erro, na medida em que as crenças em objetos ou relações que estão para além do escopo da observação pelos sentidos seriam ficções, e que é injustificado crer na existência de um objeto de uma ficção, onde se inclui a causalidade objetiva ${ }^{251}$. De resto, esta posição já parece antecipada por Passmore, quando afirma que apesar de não existirem

\footnotetext{
${ }^{246}$ Cf. STROUD, 1977, p. 45, 55, 83, 85-6, 258n7-8; 1978, p. 42.

${ }^{247} \mathrm{~T}$ 1.3.14.26.

${ }^{248}$ STROUD, 1977, pp. 52-4, 82, 86, 87; 1978, p. 44-5; WINKLER, 2007, pp. 65-6. Na secção 4.5 , esclareço em que sentido esta noção de projeção está de acordo com a noção proposta por Blackburn e é adequada às teorias causal e dos valores de Hume.

${ }^{249} \mathrm{~T}$ 1.3.14.25.

${ }^{250}$ IEH 7.2.29n7; itálico meu.

${ }^{251}$ Cf. STROUD, 1977, pp. 52-4; MACKIE, 1980a, p. 18.
} 
conexões causais objetivas, "se aprouver a alguém acreditar que tais conexões necessárias existem, além do campo das possibilidades da experiência, Hume autoriza-lhe que se satisfaça com esta fantasia"252.

Por fim, há ainda alguns comentadores que se mantêm agnósticos em relação à prórpia questão empírica de qual era, de facto, a posição de Hume em relação ao estatuto metafísico da causalidade. J. Mackie apresenta as evidências mais diretamente a favor de cada interpretação e comenta que as mesmas passagens nos textos de Hume são inconclusivas acerca dessa questão, pois podem inclinar o leitor para ambas as interpretações. Portanto, Mackie declara-se agnóstico em relação à posição que Hume tomara sobre a existência de uma causalidade além da regularidade observável ${ }^{253}$. Por sua vez, J. Broackes considera que se deve mesmo colocar a hipótese de que Hume nem tivesse uma posição em relação a esta questão ou que tenha julgado mais confortável deixar essa questão indeterminada, afinal, tal não seria requerido para cumprir o seu propósito de investigar a origem da ideia da causalidade ${ }^{254}$.

\subsection{Interpretação realista}

\subsubsection{Teoria das ideias: a inclusão das ideias relativas}

A maior parte dos proponentes do realismo cético estava ciente de que o sucesso da sua proposta exigia, de alguma forma, uma interpretação da teoria das ideias de Hume diferente da que identificam como standard. A questão de quão variados são os estados da mente exige uma definição do escopo da teoria das ideias - do que deve contar como uma ideia ${ }^{255}$. Por consequência, considerar que a filosofia de Hume autoriza a conclusão de que se pode ter uma ideia de algum tipo (mesmo que seja confusa ou relativa) da causalidade objetiva pode, pelo menos, dar-nos uma referência para a ideia e a crença de que essa causalidade

\footnotetext{
${ }^{252}$ Tradução minha do original: "if anyone likes to believe that such necessary connexions none the less exist, beyond the range of any possible experience, Hume will let him induldge his fancy“ (PASSMORE, 1968, p. 36).

${ }^{253}$ Cf. MACKIE, 1980a, pp. 20-21.

${ }^{254}$ Cf. BROACKES, 1993, p. 100, 109, 110.

${ }^{255}$ WINKLER, 1991, pp. 58-9.
} 
existe - que não é sem sentido. É para mostrar a pertinência desta conclusão que os proponentes do realismo cético se atêm a este tópico da filosofia de Hume.

De acordo com o que se lê na primeira secção do Tratado, o mapeamento da mente inclui apenas perceções, divididas em impressões e ideias, tal que, de acordo com o PC, as ideias são apenas cópias de impressões. Defender que este é o único princípio legítimo para a origem das ideias ou o único que tem valor semântico (quer dizer, que proporciona ideias com sentido), isto é, capaz de explicar o surgimento de ideias adequadas, significa defender que todos os estados da mente que não sejam copiados de uma impressão devem ser excluídos do campo das ideias adequadas. Isto faz com que se considere que uma vez que a única forma de uma ideia ser representativa é ser copiada de uma impressão, aquilo que não é a cópia de uma impressão é sem sentido. Além disso, os defensores desta interpretação consideram que seja lá o que forem, estes conteúdos da mente não são ideias, e considerá-los como tal é incorrer num erro.

Strawson chama esta interpretação - defendida pelos intérpretes regularistas - de teoria estrita das ideias ${ }^{256}$. Como bem notou Craig, os adeptos desta teoria pretendem que todo o pensamento seja subsumido nesta teoria portanto, que se restrinja ao campo do que é gerado a partir de impressões ${ }^{257}$. Ciente de que a componente semântica do anti-realismo constitui a maior ameaça à defesa do realismo cético - pois invalida o sentido do próprio pensamento ( $\mathrm{e}$ respetiva crença) da/na existência da causalidade objetiva, Kail faz notar a necessidade de restringir esta teoria ao campo que designa como genético, isto é, a um papel descritivo da origem das ideias ${ }^{258}$.

Para entender a proposta dos proponentes do realismo cético, consideremse as seguintes teses (respetivamente, dos campos semântico, epistémico e metafísico, aplicadas à questão da causalidade em Hume):

$\mathrm{S}_{\mathrm{C}}$ : a única ideia adequada que se tem da causalidade refere-se à regularidade observável;

$\mathrm{E}_{\mathrm{C}}$ : o conhecimento causal reduz-se ao campo da regularidade observável;

$\mathrm{M}_{\mathrm{C}}$ : a causalidade (em si mesma) reduz-se à regularidade observável.

\footnotetext{
${ }^{256}$ Cf. STRAWSON, 1989, p. 53; 2007, p. 33.

${ }^{257}$ Cf. CRAIG, 1987, p. 123.

${ }^{258}$ Cf. KAIL, 2007b, pp. 82-3.
} 
Craig, Strawson e $\operatorname{Costa}^{259}$ parecem estar cientes de que, no âmbito da interpretação regularista da causalidade em Hume ${ }^{260}$, a teoria empirista das ideias torna isomósficos os campos semântico, epistémico e metafísico, de tal forma que $\mathrm{S}_{\mathrm{C}}$ constitui a justificação para a conclusão $\mathrm{E}_{\mathrm{C}} \mathrm{e}$, por sua vez, para $\mathrm{M}_{\mathrm{C}}{ }^{261}$. De facto, do ponto de vista estritamente literal, esta é a única referência que a sua filosofia permite que esta ideia possua ${ }^{262}$. A passagem em que se percebe isto mais claramente é:

[O]u não temos nenhuma idéia de força e energia, e essas palavras são então absolutamente sem sentido, ou elas significam apenas aquela determinação do pensamento, adquirida pelo hábito, a passer da causa a seu efeito usual. ${ }^{263}$

Seguindo de forma estrita o critério empirista do significado, Hume nega que se tenha uma ideia adequada da causalidade devido à possibilidade de conceber a causa e o efeito separadamente. Com isto, a única impressão que a filosofia de Hume permite é a impressão interna, e "a necessidade ou poder que une causas e efeitos está na determinação da mente a passar daquelas a estes ou reciprocamente" 264 .

Deste modo, Strawson e Costa reconhecem que a interpretação regularista deve ser desconstruída pela rejeição da vigência hegemónica da teoria empirista das ideias na filosofia de Hume ${ }^{265}$. O objetivo geral destes autores é mostrar que a causalidade objetiva é pensável ou concebível (ou, nos termos de Kail, é um pensamento genuíno ${ }^{266}$ ). Para tal, requer-se 1) defender que a ideia de causalidade se refere à causalidade objetiva e não à simples regularidade observável,

${ }^{259}$ Cf. CRAIG, 1987, p. 70. Existem ligeiras diferenças entre Strawson (cf. 1989, pp. 14-15; 2007, p. 34) e Costa (cf. 1989, pp. 178-89), mas não são relevantes para o presente propósito.

${ }^{260}$ É também o caso da interpretação de filósofos positivistas, como Ayer, Mach ou Schlick. Particularmente, Craig acusa os positivistas de acharem que Hume defenderia uma versão embrionária da sua posição porque julgavam que a teoria (empirista) das ideias teria sido avançada com o intuito de subsumir todo o pensamento - o cognoscível, o que possui sentido e o pensável e que o PC era o único instrumento de análise de conceitos (CRAIG, 1987, p. 129).

${ }^{261}$ Se o argumento não passasse de $\mathrm{E}_{\mathrm{CH}}$ para $\mathrm{M}_{\mathrm{C}}$, teríamos a interpretação que Broughton chama de epistemológica.

${ }^{262}$ Esta observação também é feita por Costa (cf. COSTA, 1989, pp. 179-80).

${ }^{263}$ T Ap 26; cf. COSTA, 1989, pp. 175-7.

${ }^{264}$ T 1.3.14.23; cf. . COSTA, 1989, p. 179

${ }^{265}$ Cf. COSTA, 1989, pp. 179-80; STRAWSON, 1989, p. 15; 2007, p. 33.

${ }^{266}$ A este propósito, Kail nota que as ideias adequadas não envolvem uma espécie de buraco ou fosso entre o agente cognitivo e o mundo, e os anti-realistas pensam que este tipo de ideias não constitui um pensamento genuíno, pois pensamentos genuínos reduzem-se àqueles formados a partir de ideias que correspondem a algo no mundo observável; esta proposta é reducionista (KAIL, 2007a, p. 255). 
ultrapassando o escopo das definições que Hume oferece, e 2) encontrar uma alternativa plausível para a tese de que Hume subscreveria a teoria empirista das ideias, a fim de legitimar a existência de ideias que não estão sob o escopo do PC (onde se inclui a de causalidade) e, assim, defender que Hume não era um regularista.

Broughton foi pioneira em mostrar-se perplexa em relação à questão 1), a quem se seguiu Strawson. O objetivo da autora é mostrar que se tem uma ideia de causalidade nos objetos, ou que o conteúdo mental referente à causalidade objetiva pode ser genuinamente classificado como uma ideia. Ao distinguir dois tipos de interpretações vigentes relativamente à questão do sentido da ideia de causalidade objetiva $^{267}$ e tomando partido pela alternativa de Stroud, nega a tese que o verdadeiro sentido da ideia de causalidade seja a impressão interna da mente ${ }^{268}$, afirmando:

Sabemos o suficiente sobre o significado do que dizemos para saber que não reivindicamos nada acerca dos nossos sentimentos quando, por exemplo, negamos que haja conexões necessárias entre objetos. ${ }^{269}$

Quer dizer, para a comentadora, simplesmente não é o caso de que, quando falam e pensam em causalidade, os agentes cognitivos se referem apenas ao que está sob o escopo das definições que Hume oferece. Além disso, afirma ainda que é possível dar uma conceção definida daquilo a que os agentes cognitivos se parecem referir quando pensam ou falam em causalidade objetiva, a saber, pelo que chama o 'simples pensamento' (bare thought, termo também usado por Kail) de 'algo nos objetos que subjaz às regularidades que observamos' ou, como define mais tarde, a 'simples ideia' de causalidade: “a ideia complexa dos objetos como possuidores de características em virtude das quais manifestam as regularidades que observamos", não associada a impressões ${ }^{270}$.

Estes autores definem a causalidade objetiva, de maneira mais ou menos uniforme, como "o que quer que haja nos objetos que é aquilo em virtude do qual

\footnotetext{
${ }^{267}$ A psicológica e a epistemológica (tratadas na exposição da interpretação de Stroud, em 2.1.2). 268 Cf. STROUD, 1977, pp. 68-95; BROUGHTON, 1987, p. 235, 2007, p. 198; STRAWSON, $1989,3,6.5,12.1-2$.

${ }^{269}$ Tradução minha do original: "[W]e know enough about what we mean to know that we are not making a claim about our feelings when, for example, we deny that there are necessary connections between objects." (BROUGHTON, 1987, p. 225).
} 
a realidade é regular tal como é", ou "aquilo com o qual, se tivéssemos contacto, permitiria uma inferência a priori e tornaria impossível conceber a causa sem o efeito" ${ }^{271}$. Ao estabelecer a diferença entre nexo causal e colete de forças, Blackburn define este como "uma mola ou princípio secreto, uma causa última, 'da qual todo o curso regular e sucessão de objetos depende totalmente", ou "algo cuja existência num certo memomento garante as constâncias de um momento posterior" ${ }^{272}$. A noção mais próxima destas sugestões que se encontra nos textos de Hume seria "aquela circunstância na causa que lhe proporciona uma conexão com o seu efeito" 273 .

O principal interesse destes autores é uma aplicação desta concessão de Hume às ideias de causalidade para além da regularidade observável e de objeto externo, pois são estas que compõem a crença no realismo causal. Além disso, Craig ainda nota que a própria diferença entre os dois tipos de ideias constitui uma suposição, pois a ideia dos objetos subjacentes à perceção (tais como são em si mesmos) não é clara, nenhuma relação entre as perceções e objetos pode sê-lo, mas constitui sempre uma ideia que envolve algum grau de confusão ${ }^{274}$.

Deste modo, nota-se explicitamente a relação entre ideia não adequada, confusa e suposição ${ }^{275}$. Neste sentido, sob a teoria estrita das ideias, uma ideia

\footnotetext{
${ }^{270}$ Tradução minha do original: "the complex idea of objects as having features in virtue of which they manifest the regularities that we observe" (BROUGHTON, 2007, p. 198-9, 235, 238).

${ }^{271}$ Tradução minha do original: "that which, were we to be acquainted with it, would yield a priori inference and render it impossible to conceive cause without effect" (KAIL, 2007b, p. 84, 92, 99, 103).

${ }^{272}$ Tradução minha do original: "some secret spring or principle, some ultimate cause, 'on which the regular course and succession of objects totally depends"'; "something whose existence at one time guarantees constancies at any later time" (BLACKBURN, 2007, pp. 97-9); cf. 2.0 deste trabalho. Apesar de Blackburn não ser defensor do realismo cético (cf. 4.1, 4.5 deste trabalho), a definição de colete de forças é mais subtil que definições de causalidade objetiva que os proponentes desta interpretação avançam, pois inclui o elemento da necessidade presente na relação causal (cf. 1.4 deste trabalho), que não está evidente naquelas, podendo, por isso, ainda ser interpretadas como equivalentes ao que Blackburn chama de nexo causal.

${ }^{273}$ I 7.2.29; COSTA, 1989, p. 181; KAIL, 2003a, p. 44; 2007b, p. 84, 92; 2007b, p. 103; STRAWSON, 1989, p. 46, 118.

${ }^{274}$ Cf. CRAIG, 1987, p. 123.

${ }^{275}$ Cf. CRAIG, 1987, pp. 125-6. Craig acrescenta a esta distinção uma mais subtil. Com a distinção entre conceção e suposição, deve admitir-se a existência de dois tipos de ficções: i) cujo conteúdo é inteligível, quando se trata de perceções não efetivas; o seu conteúdo é representado por ideias claras; ii) cujo conteúdo é ininteligível ou suponível, quando se trata de objetos que não são possíveis perceções; o seu conteúdo é representado por suposições (ideias confusas). Esta distição sugere que Craig está ciente de que a primeira gera uma ambiguidade: se o critério para distinguir uma ideia de uma suposição fosse simplesmente o PC, ideias da imaginação fancy como uma montanha dourada ou um unicórnio estariam no mesmo pé de igualdade que ideias como a de objeto externo. Strawson também identifica suposições com fiç̧ões, esclarecendo que podem corresponder à forma como as coisas são, ainda que de forma inadequada (cf. STRAWSON, 1989,
} 
adequada é a que permite uma compreensão positiva do seu objeto (por cópia e combinação de elementos copiados, ou 'impressions material'), contrariamente ao que se passa no caso de ideias não adequadas, acrescentando que não se pode considerar que ter uma ideia não adequada seja o mesmo que não ter nenhuma ideia $^{276}$.

Craig nota que o facto de se poder, pelo menos, pensar que impressões são diferentes de objetos é sinal de que a suposição envolve um grau mínimo de representação, condição para que seja concebido (ainda que de forma confusa) ${ }^{277}$.

Estas passagens são indicadas como saída para o problema da restrição da teoria das ideias ao escopo das ideias copiadas de impressões: haveria uma brecha naquela teoria, estabelecida por Hume, ao reconhecer a existência e operatividade de ideias de objetos que não podem ser percebidos. Estes comentadores julgam que o filósofo prezava por essa distinção, e encaram tecnicamente os termos 'conceção', 'suposição', 'clareza', ‘confusão', tal que a conceção estaria reservada para as perceções (ou ideias formadas diretamente a partir de perceções, como a de montanha dourada) e a suposição, para objetos que não são perceções e respetivas propriedades - como seria o caso da causalidade objetiva.

Strawson vai um pouco além e identifica suposição com ideia relativa ${ }^{278} \mathrm{e}$ afirma que a cedência da existência de ideias relativas se aplica explicitamente à ideia de causalidade objetiva. O comentador explica que ter uma ideia relativa seria conceber indiretamente ou conceber algo (que já não constitui uma perceção ${ }^{279}$ ) como mantendo certas relações com aquilo de que temos ideias

p. 50). O comentador elabora ainda outras distinções mais finas, fazendo equivaler conceção a conceção genuína e as conceções não genuínas às conceções da imaginação fancy (como unicórnios e montanhas douradas), e concede que podem existir suposições genuínas: acerca de objetos inteligíveis, realmente acerca de algo (cf. ibid, 1989, p. 48). Note-se que aceitar isto implica aceitar um ceticismo em relação às próprias suposições: nunca se sabe quando uma suposição é genuína ou não.

${ }^{276}$ Cf. STRAWSON, 1989, p. 44, 46-7, 50, 69.

${ }^{277}$ CRAIG, 1987, p. 124.

${ }^{278}$ Costa nota a oposição entre conceção e suposição, mas não sugere diretamente esta identificação. Ao invés, delega ao leitor a leitura de D. Flage - que se empenhou muito em desenvolver o que seria uma ideia relativa e o espaço que esta noção tem na filosofia de Hume (que, curiosamente, não passa diretamente pela questão da causalidade; cf. COSTA, 1989, p. 181).

${ }^{279}$ Por essa razão a proposta realista já anuncia a demanda de abandonar a primeira premissa do argumento de Hume para mostrar que a mente não pode formar uma conceção de coisas que não são perceções. Também por isso fica clara a necessidade de exigir um tratamento técnico dos termos conceção e suposição: abrir a possibilidade de formar algum tipo de ideias para além da composição de elementos da perceção (perception material) implica abrir a possibilidade de existir 
$\operatorname{adequadas}^{280}$. Textualmente, há uma evidência de que Hume haveria defendido que a ideia de causalidade é relativa:

[A] idéia de poder é tão relativa quanto a de causa, e ambas contêm uma referência a um efeito ou a outro acontecimento que está constantemente conjugado ao primeiro. ${ }^{281}$

Se se aceitar, com Strawson, que ideias adequadas são objeto de uma conceão e as relativas, de uma suposição, tem-se mais uma evidência a favor desta interpretação:

Supomos que há entre [a causa e o efeito] alguma conexão, algum poder no primeiro objeto pelo quale le produz invariavelmente o segundo, e que opera com a maxima certeza e a mais forte necessidade. ${ }^{282}$

Sob a interpretação regularista - que segue a teoria empirista das ideias -, dizer que não existe um termo que possa significar ou referir algo nos objetos é fazer uma demanda metafisica negativa de que não há nada nos objetos que lhe corresponda. Strawson nota que essa passagem envolve uma confusão de questões semânticas e epistemológicas com uma questão metafísica, a partir da aceitação da assunção semântica empirista (demasiado estrita), a saber, de que o único conteúdo possível para uma ideia ou termo se restringe aos dados dos sentidos. Noutras palavras, restringe-se o campo da inteligibilidade (do que se pode conhecer) e do que existe àquilo que se é capaz de conceber a partir dos dados da experiência sensível. Relativamente à questão da causalidade, esta redução que os intérpretes regularistas propõem invalida a distinção entre i) a causalidade tal como é nos objetos, ii) a causalidade tal como pode ser conhecida e ii) a ideia que se tem da causalidade - portanto, a isomorfização dos três âmbitos de análise.

um meio de ultrapassar o campo das perceções - que é o que quer que aconteça na mente quando se forma uma ideia relativa.

280 cf. STRAWSON, 1989, p. 45, 137. Apesar de, como nota Broackes, Hume nunca ter expressado claramente a intenção de harmonizar a sua teoria das ideias por meio da noção de 'ideia relativa'. O autor chega mais longe e afirma que Hume não precisaria disso (cf. BROACKES, 1993, p. 106). Um dos meus objetivos no último capítulo do presente trabalho é mostrar que esta afirmação não é justa.

${ }^{281}$ I 7.2.29.n7. Por si só, esta evidência textual mostra que Winkler e Broackes não têm razão ao afirmar que Hume nunca utilizou a noção de 'ideia relativa' para tratar a questão da causalidade (WINKLER, 1991, pp. 80-1; cf. BROACKES, 1993, p. 107), apesar de ser a única instância em que o faz.

${ }^{282}$ I 7.2.27; itálico meu. 
Strawson reconhece que a teoria das ideias de Hume pressiona esta interpretação. Porém, julga que o seu ceticismo em relação ao que pode ou não existir motiva a aceitação de que se pode supor a existência de coisas como a causalidade objetiva, mesmo não estando esta ideia sob escopo do que é concebível claramente. O próprio Hume admite uma completa ignorância em relação aos princípios por trás da ação dos objetos externos ${ }^{283}$ :

O cenário do universo está em continua mutação, e os objetos seguem-se uns aos outros em sucessão ininterrupta, mas o poder ou força que põe toda essa máquina em movimento está completamente oculto de nossa vista e nunca se manifesta em nenhuma das qualidades sensíveis dos corpos. ${ }^{284}$

Enquanto limitarmos nossas especulações às aparências sensíveis dos objetos, sem entrarmos em investigações acerca de sua natureza e operações reais, estaremos a salvo de todas as dificuldades, e nenhuma questão nos embaraçará. (...) Se estendermos nossa investigação para além das aparências sensíveis dos objetos, receio que a maior parte de nossas conclusões sera dominada pelo ceticismo e pela incerteza. ${ }^{285}$

Sendo assim, Strawson julga haver o que chama de tensão do significado (meaning tension), que advém de uma aparente oposição entre três fatores:

a) a interpretação da teoria das ideias como teoria que abrange todo o campo do pensamento;

b) o ceticismo não comprometido em relação às possibilidades de conhecimento e ao que pode ou não existir (pois a veemência do plano

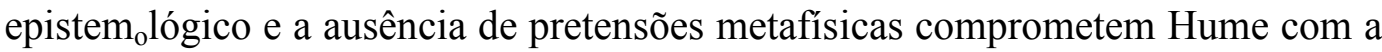
aceitação de que aquilo que é desconhecido pode ou não existir);

c) a tendência de Hume a referir-se a objetos em relação a cuja existência se mantém cético e que a sua teoria das ideias, a ser levada a sério, impossibilitaria (elemento textual que desperta o interesse dos proponentes do realismo cético).

As teses b) e c) estão em tensão na medida em que o ceticismo não comprometido representa uma postura de indiferença em relação a ambas as hipóteses metafísicas, ao passo que c) representa a escolha de uma daquelas ${ }^{286}$. As teses a) e b) estão em conflito porque para Hume ser cético, é necessário conferir

\footnotetext{
${ }^{283}$ Cf. STRAWSON, 1989, pp. 115-6. Note-se que aqui Strawson aponta para o realismo causal no sentido de Costa.

${ }^{284}$ EHU 7.1.8.

${ }^{285}$ T Ap 35-6; Cf. também T 0.8; IEH 5.2.22.
} 
tanta inteligibilidade à hipótese do realismo tanto quanto à do anti-realismo, o que, por sua vez, implica a possibilidade de conceber com um mínimo de sentido a ideias que a teoria empirista das ideias impossibilitaria - particularmente, a de objeto externo. Portanto, o ceticismo envolveria a falácia de equiparar todas as hipóteses metafísicas - o realismo direto, o realismo indireto e o anti-realismo quando, na realidade (pelo menos pela teoria empirista das ideias), apenas o antirealismo teria sentido. Finalmente, as teses a) e c) estão em conflito pela mesma razão que a tese a) mantém um conflito com a tese b): se a teoria empirista das ideias determina todo o campo de pensamento com sentido, é impossível uma referência genuína a um objeto de que não se tem uma ideia com sentido particularmente, a de objeto externo. Portanto, aceitando essa teoria das ideias, o pensamento de que os termos objetivistas se referem genuinamente aos supostos respetivos objetos torna-se uma ilusão.

Strawson julga que esta tensão não chega a ser uma inconsistência interna, atribuindo-lhe este nome por julgar possível a sua reconciliação:

\begin{abstract}
Não há inconsistência ou tensão na ideia de que podemos referir-nos a uma coisa da qual não temos nenhuma conceção com conteúdo descritivo - nos termos de Hume, a ideia de que podemos ter uma ideia 'relativa' de uma coisa, apesar de não podermos 'compreendê-la' de nenhuma forma. ${ }^{287}$
\end{abstract}

Entretanto, Strawson propõe que se conceda um conceito duplo de significado: i) um significado determinado pelo conteúdo empírico positivo de uma ideia adequada, ligado a uma impressão (de acordo com o PC) e ii) uma referência genuína por meio de uma ideia relativa - estabelecida por relação entre o objeto percetível e outro objeto, assim como com a mente (pelo seu efeito na mesma através do objeto percetível, que é a regularidade observável). O comentador classifica as ideia adequadas, com conteúdo empírico positivo, de acordo com a teoria empirista das ideias, como inteligíveis sob um inteiro acordo entre as perceções de que se dispõe e as faculdades - como (E)inteligíveis. Por sua vez, classifica as ideias relativas e a suposição do realismo que está fora do escopo

\footnotetext{
${ }^{286}$ Cf. STRAWSON, 1989, p. 117.

287 Tradução minha do original: “[T] here's no inconsistency or tension in the idea that we may refer to a thing of which we have no descriptively contentful conception - the idea that we may have a 'relative' idea of a thing, in Hume's terms, although we do not in any way 'comprehend' it.“(STRAWSON, 1989, p. 118).
} 
da teoria empirista das ideias, como inteligíveis sob uma teoria das ideias que abrisse espaço para a possibilidade de conceber objetos por relação às perceções, mas que o não são - como (R)inteligíveis. Sob esta classificação, ser concebivel é ser (E)inteligível e ser suponível é ser (R)inteligível, e o que é (R)inteligível é (E)ininteligível ${ }^{288}$.

Apresento agora algumas objeções que foram feitas a esta parte da proposta do realismo cético - em especial, a Strawson - que, por oposição, ajudam a esclarecê-la. Por exemplo, Broackes afirma que se Hume estivesse mesmo disposto a conceder a possibilidade das ideias relativas, teria dispensado o argumento que começa com a busca pela impressão à qual corresponde a ideia em questão $^{289}$. Esta objeção não me parece justa, afinal, a noção de ideia relativa só existe em função da noção de ideia adequada, que, por sua vez, é definida de acordo com a sua adequação ou inadequação ao PC.

Outra objeção, apresentada por Winkler, é que aceitando Hume que não há nada na mente a não ser perceções, deve ser impossível conceber coisas que não sejam perceções, o que faz com que, no máximo, se aceite que o campo das suposições ainda incluiria conteúdos mentais elaborados a partir de impressões. Kail chama esta objeção de ameaça semântica ao realismo, da qual os defensores deste tentam escapar legitimando uma definição não regularista de causalidade e a possibilidade das ideias relativas, e, de forma sagaz, observa ainda que quem faz essa objeção deve estar disposto a aceitar que só a teoria empirista das ideias é concebível $^{290}$. Além disso, quem estiver do lado de Winkler comprometer-se-ia com a tese de que as relações (mesmo as naturais) se reduzem a composições brutas de perceções - impressões e ideias que vêm de impressões ou são formadas diretamente a partir dessas ideias.

A meu ver, Winkler ainda ignora dois aspetos importantes: i) a distinção entre ideias e suposições torna-se verbal e irrelevante - o que não condiz com as evidências textuais em que Hume fala sobre elas como coisas distintas; ii) uma vez que o objetivo destes opositores do realismo cético é desqualificar a representatividade da ideia de causalidade objetiva, como explicariam a existência

\footnotetext{
${ }^{288}$ Cf. STRAWSON, 1989, p. 119, 122.

${ }^{289}$ Cf. BROACKES, 1993, p. 105.

${ }^{290}$ Cf. T 1.2.6.8; T 1.4.2.47; KAIL, 2007a, p. 254, 268; 2007b, p. 82-3; WINKLER, 2007, pp. 612.
} 
dessa suposição a partir das impressões sem que essa explicação redundasse novamente nas duas definições de causa (que o próprio Hume considerou imperfeitas) - portanto, oferecendo mais do que uma explicação da origem da ideia de causalidade?

Esta objeção leva a um problema que será tratado no último capítulo deste trabalho, a saber, o de quando é que, na filosofia de Hume, um estado mental deve ser considerado como algo que não ultrapassa o campo das perceções. Mas este leva a outro problema: se Hume considera que não existe nada na mente que não seja uma perceção, simultaneamente, como se explica o surgimento (na mente) de conteúdos que são excluídos do campo semântico relevante (do grupo das ideias ou de estados mentais com sentido)?

Com efeito, só se pode aceitar uma das seguintes hipóteses: ou a mente só tem perceções e aquilo que se pensa que é uma ideia relativa, na realidade, não o é, ou uma ideia relativa inclui elementos não percetivos e a mente não possui apenas perceções. O proponente da primeira hipótese (como parece ser o caso de Winkler) está comprometido em explicar de que maneira é que poderia haver um engano na consciência ou transparência em relação ao que constitui a causalidade objetiva (tal como sugeridas por Broughton e Strawson).

Por fim, Winkler e Millican concordam na objeção de que a definição destes autores é circular, pois utiliza o que está em questão para responder à questão de saber o que seria a causalidade objetiva. Winkler julga que o próprio Hume explica que as definições circulares - como aquilo 'pelo qual' ou 'em virtude do que' algo existe, que não têm valor explicativo por serem equivalentes e continuarem a exigir uma definição - só podem ser evitadas pelas duas definições oficiais ${ }^{291}$ :

[S] e uma causa for definida como aquilo que produz alguma coisa, é fácil observar que produzir é sinônimo de causar. Do mesmo modo, se uma causa for definida como aquilo por meio do que alguma coisa existe, isto estará sujeito à mesma objeção, pois o que significam palavras como por meio de quê? Se se disser que uma causa é aquilo após o que alguma coisa constantemente existe, teríamos entendido os termos, pois isso, na verdade, é tudo que sabemos do assunto. E essa constância forma a própria essência da necessidade, e dela não temos nenhuma outra idéia. ${ }^{292}$

\footnotetext{
${ }^{291}$ Cf. WINKLER, 1991, p. 63; MILLICAN, 2007a, p. 217 e p. 248.
}

${ }^{292}$ IEH 8.1.25n2; WINKLER, 1991, p. 63. 
Mas esta passagem não contraria a posição de Strawson. Antes, confirma que o significado que Hume dá ao termo 'causalidade' é o que Strawson propõe. Porém, também mostra que este não corresponde a nenhuma ideia adequada que se tenha (da causalidade), e que as únicas de que se dispõe estão sob o escopo das definições que Hume oferece. Julgo ser claro que nenhum proponente do realismo cético estava interessado em dar uma noção incorrigível de causalidade, ou cujo significado seria, no interior da filosofia de Hume, determinável por ideias adequadas. Estes autores pretendem mostrar justamente que o significado da ideia de causalidade não se resume à que os proponentes do anti-realismo causal reivindicavam e que Hume tinha consciência disso. Numa palavra, julgo que a passagem que Winkler utiliza nesta objeção confirma a interpretação epistemológica que os proponentes do realismo cético, que passo a descrever em seguida.

\subsubsection{O papel do PP na interpretação do realismo cético}

Alegando que ao propor o realismo cético como interpretação da epistemologia de Hume não se atribui necessariamente ao filósofo a posição de que se está justificado a acreditar na existência da causalidade objetiva ${ }^{293}$, Kail pretende, em vez disso, mostrar que é razoável pensar que Hume a tenha defendido pelo simples facto de essa possibilidade metafísica se manter em aberto. Neste sentido, uma das contribuições originais de Kail para a proposta interpretativa do realismo cético ${ }^{294}$ é relativa ao lugar do PP na filosofia de Hume - princípio pelo qual se pode determinar (pelo menos em parte) o que constitui uma possibilidade metafísica. Kail julga-se, então, justificado a defender que a existência da causalidade objetiva é possível e, portanto, que o realismo cético é, pelo menos, uma interpretação plausível (que é o que ele reivindica) ${ }^{295}$.

\footnotetext{
${ }^{293}$ Cf. KAIL, 2007a, p. 254. De resto, esta alegação não é exatamente verífica, pois Wright apresenta um argumento a favor dessa conclusão (cf. 2.2.7).

${ }^{294}$ Ao qual se acrescenta a conjugação do realismo cético com o projetivismo - tópico abordado em 4.5 .

${ }^{295}$ Cf. KAIL 2003a, p. 49.
} 
Kail reconhece como a objeção mais óbvia à proposta do realismo cético a de que o PP mostra que causa e efeito tal como os conhecemos (e podemos conhecer, quer dizer, apenas a regularidade observável) não estão necessariamente conectados, pois i) o que é concebível é possível e ii) é sempre possível sempre conceber a causa sem o efeito. Por isso, a necessidade causal tal como concebida pelos realistas céticos ${ }^{296}$ seria impossível (porque inconcebivel) ${ }^{297}$ :

[C]omo todas as idéias distintas são separáveis entre si, e como as idéias de causa e de efeito são evidentemente distintas, é fácil conceber que um objeto seja não-existente neste momento e existente no momento seguinte, sem juntar a ele a idéia distinta de uma causa ou princípio produtivo. Portanto, a separação da idéia de uma causa da idéia de um começo de existência é claramente possível para a imaginação. Uma vez, portanto, que não implica contradição ou absurdo, a separação real desses objetos é possível, e por isso não pode ser refutada por nenhum raciocínio baseado nas meras idéias. E, sem isso, é impossível demonstrar a necessidade de uma causa. ${ }^{298}$

Desta forma, o comentador reconhece que a alusão a esse princípio é suficiente para mostrar a impossibilidade e irrazoabilidade de inferir um poder genuíno a partir da regularidade, e que para conferir uma maior coerência a esta interpretação, os seus defensores devem compatibilizar este princípio com a aceitação de que existe essa necessidade, apesar de ser inconcebível ${ }^{299}$.

Reconhecendo a operatividade e importância do PP na epistemologia de Hume, Kail procura adequá-lo à interpretação do realismo cético, esclarecendo que esse princípio se aplica apenas a ideias adequadas. Quer dizer, Kail considera que para responder a esta dificuldade (de que a causalidade objetiva é inconcebível e, por isso, deve ser considerada impossível), não é necessário negar a importância do PP na epistemologia de Hume, basta restringi-lo ao campo das ideias adequadas ${ }^{300}$.

Portanto, apesar de, na consideração dos defensores da interpretação realista, a teoria das ideias permitir a inclusão das ideias relativas como pensamento genuíno, o PP está restrito às ideias adequadas, designação sob a qual

\footnotetext{
${ }^{296}$ Quer dizer, como uma propriedade dos objetos tal que a ocorrência de um(a) sem o(a) outro(a) seria inconcebível e implicaria contradição (cf. 2.2.2 deste trabalho).

${ }^{297}$ Aqui, fica evidente que Kail se coloca na posição de responder a um possível adversário que defendesse que o PP consiste num bicondicional (de acordo com a descrição feita em 1.2).

${ }^{298} \mathrm{~T}$ 1.3.3.3.

${ }^{299}$ Cf. KAIL, 2003a, pp. 46-7, 54-6.
} 
apenas recaem as ideias formadas a partir do $\mathrm{PC}^{301}$. Kail identifica como condição de uma ideia ou conjunto de ideias ser concebível poder(em) ser ou não separada(s) pela imaginação, ou seja, o que é genuinamente concebível é o que a imaginação é capaz de separar ${ }^{302}$. Kail acrescenta que pelo facto de as ideias só poderem ser consideradas adequadas mediante uma correspondência entre ideias e impressões, não é possível determinar nada quanto aos objetos que eventualmente subjazam às impressões não pode ser determinado - se existem e quais as suas propriedades. O comentador lembra que Hume deixou esta posição clara ao afirmar que o que está para além do campo das impressões é totalmente desconhecido:

Se estendermos nossa investigação para além das aparências sensíveis dos objetos, receio que a maior parte de nossas conclusões será dominada pelo ceticismo e pela incerteza. ${ }^{303}$

Quanto às impressões provenientes dos sentidos, sua causa última e, em minha opinião, inteiramente inexplicável pela razão humana, e será para sempre impossível decidir com certeza se elas surgem imediatamente do objeto, se são produzidas pelo poder criativo da mente, ou ainda se derivam do autor de nosso ser. (...) Podemos sempre fazer inferências partindo da coerência de nossas percepções, sejam estas verdadeiras ou falsas, representem elas a natureza de maneira correta ou sejam meras ilusões dos sentidos. ${ }^{304}$

[S] e a essência mais recondite das coisas viesse a abrir-se para nós, descobriríamos então um cenário do qual presentemente não podemos ter a menor idéia. Em lugar de admirar a ordem dos seres naturais, veríamos claramente que lhes teria sido absolutamente impossível apresentar, no mais ínfimo detalhe, qualquer outra disposição. ${ }^{305}$

Igualmente, ao identificar as ideias desses objetos com suposições e ao opor a noção de suposição (ideia relativa, que entolve algum grau de confusão) a ideia propriamente dita (que seria o mesmo que ideia adequada), Hume afirma ${ }^{306}$ :

$\mathrm{O}$ mais longe que podemos chegar no que diz respeito à concepção de objetos externos, quando se os supõe

\footnotetext{
${ }^{300}$ Cf. KAIL, 2003a, p. 57.

${ }^{301}$ Cf. KAIL, 2003a, p. 47, 49, 51, 54; FLAGE, 1982, p. 164.

${ }^{302}$ Em 4.6, esclarecerei que este requisito não deve ser considerado suficiente para se considerar, na filosofia de Hume, que uma ideia ou conjunto de ideias é concebível. Para isso, argumentarei (em parte, a partir do valioso contributo de T. Lightner para o tema) que também são necessários dois outros requisitos, a saber, i) um recurso a um leque de ideias simples que está disponível para nós, e ii) o princípio de contradição.

${ }^{303} \mathrm{~T} 1.2 .5 .26 \mathrm{n} 12$.

${ }^{304} \mathrm{~T}$ 1.3.5.2.

${ }^{305} \mathrm{D} 6.12$.

${ }^{306}$ Cf. 2.2.2; KAIL, 2003a, pp. 53, 55.
} 
especificamente diferentes de nossas percepções, é formar deles uma idéia relativa, sem pretender compreender os objetos relacionados. ${ }^{307}$

[C]omo podemos supor, mas nunca conceber uma diferença específica entre um objeto e uma impressão, jamais poderemos saber com certeza se as conclusões que formamos a respeito da conexão ou incompatibilidade entre impressões pode ser aplicada aos objetos; em contrapartida, qualquer que seja a conclusão que a esse respeito formemos acerca dos objetos, ela será com toda certeza aplicável às impressões. A razão disso não é difícil de se entender. Como se supõe que um objeto é diferente de uma impressão, não podemos ter certeza de que a circunstância sobre a qual fundamos nosso raciocínio é comum a ambos, supondo que formemos esse raciocínio partindo da impressão. Ou seja, é sempre possível que o objeto seja diferente da impressão quanto a essa circunstância particular. ${ }^{308}$

Kail está consciente de que há um problema em utilizar o PP para defender o realismo cético: é preciso ter a certeza de que as ideias concebidas são adequadas - não apenas em virtude de uma correspondência entre impressões e ideias, mas entre a impressão e o suposto objeto ao qual inere:

Para haver segurança na inferência de propriedades modais de objetos a partir de propriedades modais de impressões - a sua separabilidade -, temos de pensar que estas são adequadas, no sentido em que podemos estar certos de que não há mais nenhum facto escondido, cujo conhecimento mostraria que a possibilidade epistémica revelada pela separabilidade escamoteia uma impossibilidade metafísica. (...) Se impressões, enquanto experiências, nos dizem algo sobre "objetos externos", elas revelam, no máximo, as suas propriedades sensiveis, e não a sua estruura interna (ou, mais diretamente, as suas essências). Portanto, não podemos ter a certeza se a separabilidade dos objetos das impressões, a não ser que estejamos em posição de acreditar que há características escondidas dos objetos (as suas essências) que podem minar o movimento da separabilidade das impressões para a possibilidade metafísica da existência independente dos seus objetos. $^{309}$

\footnotetext{
${ }^{307} \mathrm{~T}$ 1.2.6.9.

${ }^{308} \mathrm{~T}$ 1.4.5.20

309 Tradução minha do original: "In order to be secure in inferring the modal properties of objects from the modal properties of impressions - their separability-we need to think that they are adequate in the sense that we can be sure that there is no further hidden fact, knowledge of which would show that the epistemic possibility revealed by separability conceals metaphysical impossibility. (...) if impressions qua perceptual experiences tell us anything about "external objects" they reveal at most their sensible properties and not their internal structure (or, more pointedly, their essences). So we cannot be sure that the separability of impressions ensures the separability of the objects of impressions unless we are in a position to believe that there are no hidden features of objects (their essences) which would spoil the move from separability of
} 
Neste sentido, o comentador reconhece que uma separação entre impressões apenas indicaria ou seria sinal de uma separação entre objetos mediante a assunção da possibilidade (assumida por Hume) de que essas ideias sejam adequadas, no sentido (mais forte) de representarem propriedades dos próprios objetos. E uma vez quer essa separação não se estende além do campo fenoménico (sendo um erro inferir propriedades dos objetos a partir das propriedades das impressões), nada se pode determinar em relação ao que escapa a esse plano. Deste modo, Kail observa que a conjunção das teses da determinação do que é possível a partir da capacidade de conceber objetos a partir da possibilidade de separá-los (portanto, do PP dependente do PS) com a restrição do PP às ideias adequadas configura o que chama de "arma cética", uma vez que a única conclusão justificada destas teses é que não é possível determinar nada acerca dos objetos dos quais não temos ideias adequadas. Por esta razão, não se pode despistar nem a possibilidade de existirem, nem de não existirem objetos além das impressões, tampouco alguma das suas propriedades (como manterem uma relação causal entre si, além do campo fenoménico). Aplicando esta análise diretamente à questão da causalidade objetiva, Kail conclui que o PP é compatível com a possibilidade da existência daquela ${ }^{310}$.

Deste modo, o comentador julga que o PP deve ser interpretado epistemicamente, isto é, como princípio para determinar o campo de possibilidades dentro dos limites das ideias adequadas e da faculdade da imaginação. Caso contrário, cometer-se-ia a petição de princípio de pressupor que se sabe quais são, concretamente, todas as possibilidades metafísicas, antes de definir o PP como critério fiável para distinguir o que é e o que não é (metafisicamente) possível. O seguinte exemplo de Kail é ilustrativo desta interpretação epistémica. Véspero e Fósforo são o mesmo indivíduo, mas Edmund não sabe disso e recebe a notícia de que Véspero faleceu. Como pensa que são dois indivíduos distintos, ainda consegue conceber que Fósforo continue vivo e faça algo que só os vivos podem fazer (como, por exemplo, tomar café). Apesar disso, o que Edmund concebe é (metafisicamente) impossível, e só é concebido 2003a, p. 52). 
porque Edmund não tem pleno conhecimento sobre ele(s) - pelo menos, não dispõe da informação necessária para não concebê-lo - de que são o mesmo indivíduo. Portanto, na epistemologia de Hume, o PP não permite determinar se é impossível que a causalidade objetiva (definida desta forma) exista e, portanto, a objeção dos adversários da interpretação realista não se aplica ${ }^{311}$.

Para Kail, esta interpretação epistémica do PP favorece a interpretação do realismo cético por mostrar a impossibilidade de negar a existência da causalidade objetiva por meio de ideias claras. Porém, essa impossibilidade explica-se por uma impossibilidade mais ampla, a saber, a de determinar o que quer que seja que está para além das possibilidades de se formação de uma ideia clara. Como dito, a incorporação deste princípio na análise é um elemento original da sua interpretação. Porém, todos os defensores da interpretação do realismo cético apresentaram evidências textuais em que Hume afirma o caráter incognoscível da causalidade objetiva, associado à impossibilidade de formar uma ideia clara da mesma (mesmo não associando, por sua vez, estes dois elementos a uma análise do lugar do PP nesta interpretação). Em seguida, apresentam-se estas evidências e como as mesmas se articulam com a defesa do realismo causal na epistemologia de Hume - o que perfaz a componente cética da sua interpretação.

\subsection{3. 'Causalidade inteligível’}

Concordando com K. Smith que Hume não pretendia negar a existência da causalidade objetiva, e com base numa reformulação ou extensão da teoria das ideias de Hume - que, aparentemente, abre espaço para ideias que não são cópias de impressões, os proponentes do realismo cético possuem base textual para rejeitar o argumento que vai das premissas $\mathrm{S}_{\mathrm{C}}$ e $\mathrm{E}_{\mathrm{C}}$ à conclusão $\mathrm{O}_{\mathrm{C}}$. Deste modo, longe de proporem uma leitura metafísica das duas definições de causa que Hume oferece - como dizendo respeito ao que a causalidade é - estes intérpretes reivindicam uma interpretação epistemológica das mesmas definições - como dizendo respeito aos limites do que se pode conhecer.

\footnotetext{
${ }^{310}$ Cf. KAIL 2003a, pp. 49, 51-7.

${ }^{311}$ Cf. KAIL, 2003a, pp. 50-2, 54-7; 2007b, p. 94-5, 97-8.
} 
Presumivelmente, Hume julga que nenhum dos aspetos incluídos nas definições é a causalidade em si, e que a sua definição perfeita e exata deve mostrá-la. Para estes comentadores, a explicação para este descontentamento é que o elemento que tornaria a definição perfeita ou absolutamente precisa seria o próprio poder que os objetos exercem entre si, a (s) propriedade (s) objetiva (s) que os objetos possuem em si mesmos - que tem como efeitos o que é descrito nas definições que Hume oferece. Caso tal fosse observável ou demonstrável, terse-ia uma ideia adequada de causalidade - de acordo com a distinção entre ideia adequada e ideia relativa, proposta na secção anterior.

Apesar da aparência de clareza, precisão e consistência nas definições que Hume oferece, imediatamente a seguir, o autor mostra-se descontente e consideraas imperfeitas, "porque [são extraídas] de elementos estranhos à causa"312.

[E]mbora ambas essas definições tenham sido extraídas de circunstâncias estranhas à causa, não podemos remediar essa inconveniência nem obter qualquer definição mais perfeita que possa apontar aquela circunstância na causa que lhe proporciona uma conexão com seu efeito [itálico meu]. ${ }^{313}$

Admitindo o facto de as duas definições não mencionarem a causalidade objetiva poder funcionar como argumento contra o realismo causal, a explicação que Costa oferece para a harmonização destas definições com a defesa do realismo cético é que o próprio Hume não as teria levado a sério, uma vez que captam (apenas) aquilo de que se tem uma ideia clara, mas seriam imperfeitas porque não captam a causalidade objetiva ${ }^{314}$.

Para mostrar que Hume persegue um ideal inteligível que se identifica com o conhecimento causal a priori, Wright e Strawson utilizam as seguintes citações de Hume ${ }^{315}$ :

[S]e a mente pudesse discernir o poder ou energia de uma causa qualquer, poderíamos prever seu efeito mesmo sem nenhuma experiência e estaríamos aptos, desde o primeiro momento, a

\footnotetext{
${ }^{312}$ Cf. T 1.3.14.31.

${ }^{313}$ IEH 7.2.29. A declaração de Hume acerca da imperfeição destas definições no Tratado é menos explícita do que na Investigação. Mais à frente na mesma secção, confessa: "[de] minha parte, devo confessar que sou incapaz de [oferecer uma definição mais precisa do que estas]" (cf. T 1.3.14.31).

${ }^{314}$ Cf. COSTA, 1989, p. 176, 181.

${ }^{315}$ Cf. STRAWSON, 1989, p. 109; WRIGHT, 2000, p. 91
} 
nos pronunciarmos com segurança sobre esse efeito, pelo simples recurso ao pensamento e raciocínio. ${ }^{316}$

[D]eve-se admitir que, quando conhecemos um poder, conhecemos a exata circunstância na causa que a capacita a produzir o efeito, pois esse poder e essa circunstância são supostamente sinônimos. Devemos, portanto, conhecer tanto a causa quanto o efeito, bem como a relação entre eles. ${ }^{317}$

Se possuímos, portanto, uma idéia de poder em geral, também temos de ser capazes de conceber alguma espécie particular desse poder. (...) [D] evemos ser capazes de situar esse poder em algum ser particular e de conceber esse ser como dotado de uma força e energia reais, que fazem que tal efeito particular resulte necessariamente de sua operação. Devemos conceber distinta e particularmente a conexão entre a causa e o efeito; devemos ser capazes de afirmar, pela simples observação de um deles, que deve ser seguido ou precedido pelo outro. Essa é a maneira correta de se conceber um poder particular em um corpo particular. [N]ada é mais evidente que o fato de que a mente humana não é capaz de formar uma tal idéia de dois objetos de modo a conceber uma conexão entre eles, ou a compreender distintamente o poder ou eficácia que os une. Uma tal conexão equivaleria a uma demonstração, e implicaria a absoluta impossibilidade de que um objeto não se seguisse, ou fosse concebido como não se seguindo de outro - e esse tipo de conexão já foi rejeitado em todos os casos. ${ }^{318}$

[Q]uanto à admirável força ou poder que faz que um corpo em movimento persista para sempre em sua continua mudança de lugar, e que os corpos nunca perdem a não ser quando a comunicam a outros, desta não somos capazes de formar a mais remota concepção. ${ }^{319}$

Strawson converge com Wright e Costa em relação ao motivo do descontentamento de Hume. Além disso, julga que a razão pela qual se deve rejeitar a tese de que Hume não estava interessado em determinar a causalidade para além das possibilidades da sua determinação por agentes cognitivos, ou mesmo que não acreditava na existência de algo mais do que a regularidade observável, é esta insatisfação de Hume com as suas definições de causa. Para o comentador, se aquele fosse o caso, Hume não associaria a imperfeição das

\footnotetext{
${ }^{316}$ IEH 7.1.7.

${ }^{317}$ IEH 7.1.17; itálico meu.

${ }^{318} \mathrm{~T} 1.3 .14 .13$.

${ }^{319} \mathrm{IEH} 4.2 .16$
} 
definições de causa à falta de "uma familiaridade com a natureza da causa e do efeito" ${ }^{320}$.

Para o comentador, a imperfeição das definições dever-se-ia ao facto de não mostrarem tudo o que Hume julga que a causalidade é - aquilo em virtude do qual as regularidades observáveis são tais como se podem observar, e da qual dependem. Nesse sentido, as duas definições de causa só incluiriam aquilo de que se pode ter uma ideia adequada e a sua falha consistiria em não darem acesso à causalidade tal como é em si mesma. As definições são imperfeitas porque não conseguem apontar "aquela circunstância na causa que lhe proporciona uma conexão com o seu efeito". Prova disso (para Strawson) é a pergunta de Hume: "[e] que exemplo mais forte da surpreendente ignorância e fraqueza do entendimento poderia existir do que esse ${ }^{321}$. Nesse sentido, julgo que se podem acrescentar outras citações de Hume:

\begin{abstract}
[A]ssim como somos totalmente ignorantes do poder do qual depende a atuação recíproca dos corpos, não somos menos ignorantes daquele poder do qual depende a atuação da mente sobre o corpo, ou do corpo sobre a mente, e igualmente incapazes de indicar o princípio último, em um caso ou outro, a partir de nossos sentidos ou de nossa consciência. ${ }^{322}$
\end{abstract}

Ignoramos, é verdade, o modo pelo qual os corpos operam uns sobre os outros. Sua força e energia é-nos inteiramente incompreensível. ${ }^{323}$

[N] as conjunções mais usuais de causa e efeito, somos tão ignorantes sobre o princípio último que une a causa e o efeito quanto nas mais insólitas e extraordinárias. ${ }^{324}$

Estas constatações de Hume tornam evidente a natureza epistémica do seu ceticismo em relação à causalidade. O argumento bibliográfico de Strawson é convincente: se Hume fosse um regularista, não consideraria que a definição possui um inconveniente, nem que os agentes cognitivos são ignorantes em relação à causalidade, já que a sua definição não deixaria nada fora do âmbito do que constitui a causalidade "tal como é em si mesma"325. A circunstância que

\footnotetext{
${ }^{320}$ IEH 7.1.18; cf. STRAWSON, 1989, p. 88.

${ }^{321}$ IEH 7.2.29; cf. STRAWSON, 1989, p. 156, 189, 192; COSTA, 1989, p. 182-3.

${ }^{322}$ IEH 7.1.21.

${ }^{323}$ IEH 7.1.25. No original: "we are ignorant, it is true, of the manner in which bodies operate on each other: Their force or energy is entirely incomprehensible" [itálico meu].

${ }^{324} \mathrm{~T}$ 1.4.7.6.

${ }^{325}$ Cf. I 7.2.29.n17; STRAWSON, 1989, p. 190; 2000, pp. 46-7.
} 
permitiria completar a definição (que não seria estranha à própria causalidade) seria o poder que os objetos objetivamente mantêm entre si.

Com efeito, as definições de causa oferecidas por Hume têm um significado sob a teoria empirista das ideias, pois são baseadas no que é observável pelos sentidos externos e interno. Apesar disso, a definição mais exata possível sob o ponto de vista dessa teoria é a que Hume oferece, exibindo os seus aspetos relevantes que recaem sob o escopo desta teoria. Porém, para Strawson, estas definições não devem suscitar a interpretação de que Hume é um regularista, isto é, que reduz a causalidade uma regularidade observável que suscita um sentimento na mente, uma vez que Hume nunca disse explicitamente que esses dois aspetos perfazem tudo o que a causalidade é (do ponto de vista metafísico, sem referência aos limites semânticos e epistémicos dos agentes cognitivos humanos). Antes, essas definições deixam de lado o aspeto metafisicamente essencial da causalidade - a circunstância objetiva em virtude da qual o efeito é, forçosamente, seguido da sua causa. Essa é a razão pela qual as definições são retiradas de elementos estranhos à própria causalidade - a regularidade observável e a determinação que esta gera na mente ${ }^{326}$.

Entretanto, Wright, Craig, Strawson e Kail ${ }^{327}$ partilham a convicção de que no seu argumento sobre a origem da ideia de causalidade e que se conclui com as duas definições de causa, Hume já pressupunha uma certa noção de causalidade, e o objetivo da investigação seria descobrir se se tem uma ideia adequada dessa causalidade. Esta noção corresponderia a uma causalidade genuína ou própria (por contraste com uma noção deflacionária ou imprópria) e seria necessária da mesma forma que uma demonstração, ou seja, que seria cognoscível a priori, tal que fosse impossível conceber o contrário das ideias dos objetos envolvidos, ou que essa conceção envolvesse uma contradição ${ }^{328}$ ou, pelo menos, em que está envolvido o mesmo tipo de certeza que numa demonstração. Strawson comenta

\footnotetext{
${ }^{326}$ Cf. STRAWSON, 1989, pp. 190-2; 2000, p. 45.

${ }^{327}$ Por seu turno, Mackie concorda com estes autores que o filósofo partia deste pressuposto no argumento sobre a origem da ideia de causalidade (cf. MACKIE, 1980a, p. 12, 28). Tal pressuposto estaria associado a um erro de Hume ao transformar um argumento que apenas tinha como pretensão descrever a origem daquela ideia numa análise sobre a justificação que se teria para formá-la, utilizando uma noção que só está legitimamente disponível a filósofos racionalistas, como Descartes, Locke ou Malebranche (cf. ibid, p. 12). Apesar disso, como apontei na secção 1.?, esta posição é combinada com um agnosticismo acerca da posição de Hume em relação à existência da causalidade objetiva (cf. ibid, pp. 20-1).
} 
que esta seria uma propriedade da causalidade (genuína) - a propriedade AP ( $A P$ propriety $\left.^{329}\right)^{330}$.

Independentemente de se aceitar ou não que Hume partia deste pressuposto, a resposta à questão de saber se se tem uma ideia adequada dessa causalidade é negativa: não se pode formar tal ideia, pois não existe nenhuma impressão que lhe corresponda. A razão disto é que o PC constitui o critério pelo qual se pode considerar uma ideia adequada. Os intérpretes regularistas limitavam-se a considerar que não se pode formar uma ideia da causalidade para além das que estão sob o escopo das duas definições que Hume oferece, pois supunham que a teoria empirista das ideias subsumia todo o pensamento. Além de tal ser explicitamente negado por Craig, o mesmo autor, a quem se juntam Broughton e Strawson (este, de forma mais extensiva) apontam evidências teóricas e textuais de que a filosofia de Hume permite a existência de ideias que não estão sob o escopo daquela teoria das ideias e explicam que a ideia de causalidade objetiva seria uma dessas - ideias relativas ${ }^{331}$.

Apenas Wright e Strawson ${ }^{332}$ vêem na exigência de um conhecimento causal a priori a explicação do descontentamento de Hume em relação às suas definições de causa. Winkler (proponente do anti-realismo e forte crítico da proposta do realismo cético) pensa que os 'poderes secretos' de que Hume fala nalgumas passagens dizem respeito a objetos e relações concretos que ainda não foram descobertos ${ }^{333}$ - o que Blackburn chama de nexos causais -, tal que:

[A]firmar que há poderes secretos é afirmar que caso tivéssemos contacto com esses objetos desconhecidos e os padrões pelos quais se comportam, poderíamos prever o futuro com enorme segurança. ${ }^{334}$

\footnotetext{
${ }^{328}$ Livingston, e Costa não fazem referência a este tópico da proposta de interpretação.

${ }^{329}$ Cf. STRAWSON, 1989, 11; p. 138-9.

${ }^{330}$ Cf. WRIGHT, 1983, pp. 156-8; 2000, p. 91; CRAIG, 1987, p. 97; STRAWSON, 1989, pp. 10914; KAIL, 2007a, pp. 256-62; KAIL 2007b, p. 121.

${ }^{331}$ Cf. CRAIG, 1987, p. 123, 129; BROUGHTON, 1987; STRAWSON, 1989, 6.5, 15.5.

${ }^{332}$ Livingston e Costa não fazem referência a este tópico. Por seu turno, e como procurei deixar claro em 3.2.2, a posição de Kail é ligeiramente mais contida: a definição de causalidade objetiva surge como fixador de referência, que imerge da noção de ideia adequada (sob o escopo das duas definições de causa).

${ }^{333}$ Cf. WINKLER, 2007, pp. 56-7.

${ }^{334}$ Tradução minha do original: "to say that there are secret powers is to say that were we acquainted with these unknown objects and their patterns of behavior, we could predict the future with greater reliability" (WINKLER, 2007, p. 74).
} 
Millican concorda com Winkler, mas avança a hipótese de que Hume se refere não a uma propriedade metafísica à qual não podemos ter acesso, mas sim a forças determináveis pela física newtoniana - inobserváveis, mas detetáveis pela observação do seu efeito e determináveis por meio da matemática ${ }^{335}$. Além deste comentador, Wright e Broughton e Strawson também exploram a hipótese de os 'poderes secretos', de que Hume fala recorrentemente, sejam as mesmas forças ${ }^{336}$.

Antes de passar ao próximo tópico, explico a minha discordância em relação ao pressuposto que Wright e Strawson defendem. A análise que Hume faz da origem das ideias e respetivas conclusões - em especial, o seu tom normativo nas observações que faz sobre ideias não adequadas - sempre sob um ponto de vista da razão demonstrativa, mostra que Wright está certo ao comentar que Hume partilhava com os cartesianos o interesse pela eliminação da dúvida, o que resulta na eleição das ideias claras e distintas como objetos de conhecimento. Porém, julgo que dificilmente esta conclusão se pode estender à conceção de causalidade.

Em primeiro lugar, a passagem de que Wright dispõe para concluir que Hume acreditava na existência de uma causalidade cujo conhecimento seria $a$ priori é deslocada do argumento principal de Hume sobre a natureza da ideia de causalidade ( $\mathrm{T}$ 1.3) e do próprio tópico, pois aparece no entorno de um argumento acerca da relação entre a alma e o seu poder (causal) sobre o corpo. A minha estranheza com o argumento de Wright pode ser resumida na seguinte pergunta: por que razão Hume reservaria esse tópico e essa secção para revelar essa convicção, quando poderia (e talvez, nesse caso, devesse) fazê-lo no argumento principal? Em vez disso, nesse argumento, Hume não diz explicitamente que está a partir desta conceção, mas apenas nega que haja um acesso a tal relação causal.

Em segundo lugar, a filosofia de Hume não permite, de forma consistente, que se desloque a noção de causalidade a não ser para a própria mente, contrariamente ao que se verifica nos cartesianos, que podiam transportá-la para o mundo externo (Descartes) ou Deus (Malebranche). Ao fazer do PC o único princípio que explica a origem das ideias (de novo, ao contrário dos cartesianos), mas mantendo a exigência da certeza como ideal de conhecimento, Hume fica

\footnotetext{
${ }^{335}$ MILLICAN, 2007a, p. 240, 242.

${ }^{336}$ Cf. WRIGHT, 1986, p. 238; STRAWSON, 1989, pp. 186-7; BROUGHTON, 1987, pp. 229-34. Não fazendo parte do meu propósito indagar sobre a influência de Newton em Hume, deixo apenas algumas indicações de leitura.
} 
fadado à conclusão de que a causalidade tem de ser inventada pela imaginação, o assentimento que se lhe dá se deve a princípios naturais da mente e, por fim, ao ceticismo.

Portanto, se Hume - ao contrário, por exemplo, de Malebranche ${ }^{337}$ - não diz explicitamente que parte de uma conceção apriorística de causalidade e não dispõe de um elemento na sua filosofia para onde possa transferir a propriedade AP, a convicção de que Hume acreditava numa causalidade genuína que seria apriorística e que, no mínimo, se desiludiu com a conclusão de que tal era inatingível, é arbitrária.

\subsubsection{Relação do realismo com o ceticismo}

A defesa da revisão da teoria das ideias e do ceticismo em relação à causalidade parecem ter uma ligação direta e intuitiva, afinal, este ceticismo parece derivar da própria distinção entre conceção e suposição. Mas, em relação à causalidade, os proponentes do realismo cético defendem que Hume simultaneamente defendia que a causalidade objetiva existe, mas não pode ser conhecida. Mantém-se, assim, uma questão bastante óbvia: como é que os proponentes do realismo cético chegaram à conclusão de que, apesar de a causalidade objetiva não poder ser conhecida, é possível defender o realismo causal? Colocando a questão do ponto de vista da própria teoria de Hume: se Hume defende que não é possível conhecer a causalidade objetiva, como pode estar certo da sua existência?

Como procurei explicar na secção anterior, a interpretação epistémica das duas definições de causa é uma parte essencial da proposta do realismo cético como interpretação da teoria causal de Hume, pois é um tópico que, na opinião dos seus proponentes, mostra a possibilidade de conciliação entre o realismo e o ceticismo. A resposta que oferecem à questão do motivo do descontentamento de Hume com as definições é que estas não alcançam a causalidade em si, mas apenas abrangem os seus efeitos observáveis (a regularidade observável e a

\footnotetext{
337 “[H]á uma tal ligção entre [a vontade de Deus] e o movimento de todos os corpos, que é impossível conceber que ele queira que um corpo seja movido e esse não o seja." (1674-5, 6.2.3, p. 246).
} 
determinação da mente). Nesta afirmação, fica premente a questão de saber como é que Hume aceitaria a existência de algo cujo acesso negara.

Nenhum proponente julga que pelo facto de Hume (eventualmente) ser realista, deixa de ser cético. Ao invés, estão conscientes de que devem integrar os principais aspetos da filosofia de Hume que motivam a inclusão do ceticismo na proposta, a saber, a insatisfação com as duas definições e os bem conhecidos argumentos contra o caráter a priori do raciocínio causal. Antes, o ceticismo em relação à causalidade é usado pelos proponentes de ambas as teses como evidência para a interpretação que defendem. Os proponentes do anti-realismo defendem que o ceticismo em relação à causalidade constitui evidência de que Hume acreditava que esta não existe causalidade objetiva (a afirmação $\mathrm{E}_{\mathrm{CH}}$ do argumento que tem como conclusão a afirmação $\mathrm{O}_{\mathrm{CH}}$ e que se junta à afirmação $\mathrm{O}_{\mathrm{CH}}$ ). Por seu turno, os proponentes do realismo cético julgam que, por várias razões, o ceticismo é mais compatível com o realismo do que com a posição contrária.

Para estes comentadores, precisamente por não se tratar de uma ideia adequada, a ideia da causalidade objetiva refere-se a algo que não pode ser conhecido. Como bem nota Craig, objetos de suposições não são possíveis objetos de conhecimento, mas nem por isso são sem sentido (o que se mostra pelas citações em que Hume diz que podemos supor, mas não conceber alguma coisa. No âmbito das ideias com conteúdo positivo (adequadas), o significado da ideia de causalidade - e respetivo termo - não ultrapassa os aspetos a que as definições se referem ${ }^{338}$.

Strawson explica que estas definições estabeleceriam o limite do que se pode conhecer, isto é, do que, para Hume, se pode atribuir aos objetos com base em ideias com conteúdo positivo. O comentador pensa que, na filosofia de Hume, um limite semântico sinaliza um limite epistémico. Neste caso, o facto de as ideias de conteúdo positivo não ultrapassarem a regularidade observável e a determinação na mente marcaria a incapacidade das faculdades em aceder a mais

\footnotetext{
${ }^{338}$ BROUGHTON, 1987, p. 235; STRAWSON, 1989, p. 155, 157, 174-5; COSTA, 1989 p. 188. Parece estar implícito na afimação de Craig (cf. CRAIG, 1987, p. 124). Este intérprete parece ainda sugerir que o valor de verdade de uma suposição é indeterminável: "something different in kind from any possible perception, so that reason, which operates by spotting relationships between ideas, cannot pronounce on it either way" (CRAIG, 1987, p. 126).
} 
do que esses aspetos no conhecimento da causalidade ${ }^{339}$. É o próprio Hume quem estabelece este limite às faculdades, imediatamente depois de oferecer as definições de causa:

Se examinarmos as operações dos corpos e a produção de efeitos a partir de suas causas, descobriremos que nossas faculdades, todas elas, jamais podem conduzir-nos, no que diz respeito ao conhecimento dessa relação, além da simples observação de que objetos particulares estão constantemente conjugados uns aos outros, e que, quando do aparecimento de um desses objetos, a mente é levada por uma transição habitual à crença no outro. (...)[N]ada sabemos acerca de qualquer tipo de causação além da simples conjunção constante de objetos e a conseqüente inferência de um ao outro. ${ }^{340}$

Portanto, uma vez que não se tem ideia (com conteúdo positivo) dos poderes causais tais como são em si e a definição de causalidade não ultrapassa o campo das ideias com conteúdo positivo, é correto considerar a definição imperfeita, e correta a conclusão de que não se tem um conhecimento da causalidade tal como é em si mesma - e da qual só se pode ter uma ideia relativa. Novamente, os limites do conhecimento são sinalizados pelos limites semânticos ${ }^{341}$.

Deste modo, Strawson considera que a imperfeição das definições das definições de causa confirma estas considerações relativas às limitações epistémicas e semânticas da mente: a causalidade objetiva (que, para o Hume de Strawson, existe, de facto) não pode ser capturada pelas ideias adequadas (de acordo com a teoria empirista das ideias) que se tem desta, pois resumem-se à conjunção constante (que, ainda que possa ser uma parte, não constitui tudo o que a causalidade é), e a imperfeição das definições espelha o ceticismo de Hume em relação à possibilidade de aceder à causalidade objetiva para além das possibilidades de se formar desta uma ideia relativa ${ }^{342}$.

Ao redirecionarem o significado dessa ideia dos objetos (em si mesmos) para a determinação interna da mente, sob a convicção de que só ideias adequadas constituem ideias genuínas, os proponentes do anti-realismo julgavam que a convicção de que aquela ideia se referia aos objetos constituía um erro ou engano.

\footnotetext{
${ }^{339}$ Cf. STRAWSON, 2000, pp. 45-6; COSTA, 1989, p. 181.

${ }^{340}$ I 8.21; cf. STRAWSON, 1989, p. 193.

${ }^{341}$ Cf. STRAWSON, 1989, p. 126, pp. 193-4.

${ }^{342}$ Cf. STRAWSON, 2000, pp. 46-7.
} 
Pelo contrário, Broughton avisa que o erro não está - como pensavam esses intérpretes - em qual é o significado da ideia de causalidade, mas sim nas possibilidades de acesso ao objeto ao qual se refere. Por isso, a autora entende que a revisão a ser feita não é semântica, mas epistémica. Nesse sentido, Broughton e Costa notam que existe uma referência correta e uma incorreta para a ideia (e respetivo termo) da causalidade objetiva: se se pretender referir o objeto de uma ideia adequada, incorre-se em erro, pois tal ideia não é possível; pelo contrário, se se pretender referir um objeto incógnito, isto é, algo que não pode conhecido (por não ser objeto de uma ideia adequada), tal referência é correta, pois está de acordo com o tipo de ideia que se pode ter desse objeto (uma suposição ou ideia confusa $^{343}$. Portanto, no âmbito da reflexão filosófica, o objeto da ideia da causalidade objetiva é um objeto sobre o qual se deve manter uma postura cética, reconhecendo que este não pode ser conhecido.

Por um lado, Hume seria cético porque, do ponto de vista da razão demonstrativa, ambas as hipóteses tanto relativas à causalidade objetiva como à existência exterior e independente (da mente) dos objetos da perceção são possíveis. Por essa razão, a postura de Hume em relação a estas questões seria, nos termos de Strawson, a de não se comprometer com nenhuma posição - por isso, chama o seu ceticismo de ceticismo sem compromisso (non-committal scepticism $)^{344}$. Portanto, a análise da razão demonstrativa forçaria Hume a não se posicionar - por meio de argumentos ou apoiado em razões demonstrativas sobre as mesmas.

$\mathrm{Na}$ abordagem de Wright, a compatibilização entre realismo e ceticismo parte de uma análise simultaneamente descritiva e normativa da origem das ideias, em que o comentador entende que a fonte da ideia em questão é capaz de justificála, sob a convicção de que toda a arquitetura da mente é descoberta por Hume por uma investigação que é, em si mesma, causal - das causas de certas ideias.

De acordo com o comentador, Hume seria um realista causal e metafísico porque existem disposições ou princípios da mente que explicam (e, por isso, justificam) a crença na existência exterior e independente (da mente) dos objetos

\footnotetext{
${ }^{343}$ Cf. BROUGHTON, 1987, p. 218, 235; COSTA, 1989, pp. 179-81. Este elemento enquadra-se bem com as passagens em que Hume admite a existência de propriedades desconhecidas (ou a sua possibilidade; BROUGHTON, 1983, p. 235-6).

${ }^{344}$ Cf. STRAWSON, 1989, p. 16, $18,58$.
} 
da perceção e na existência da causalidade objetiva. Ao mesmo tempo, Hume seria cético devido às conclusões da razão demonstrativa e dos sentidos, que apontam para a falsidade da crença na existência exterior e independente (da mente) dos objetos da perceção e respetiva propriedade de se relacionar causalmente com outros. Portanto, trata-se de um ceticismo em relação a certas faculdades da mente, por serem incapazes de levar a certas conclusões (neste caso, a do realismo causal e metafísico $)^{345}$. Uma citação que sintetiza esta postura de Wright é:

Hume baseia o seu ceticismo em relação aos sentidos na sua rejeição dos sentidos e a razão como fonts de crença na existência de objetos externos. Com efeito, ele considerou que a nossa conceção dos e a crença nos objetos materiais independents não provém da informação derivada da experiência. É este reflex nas 'imperfeições' dos sentidos humanos e da razão que oferecem a base central do seu ceticismo $(\ldots){ }^{346}$

Por isso, Wright julga que Hume defendia um realismo indireto, ou seja, que esses objetos existem (ou existem desse modo), mas o acesso que se tem aos mesmos é incompleto, pois estende-se apenas ao escopo das suas representações, que são diferentes daqueles objetos. Esta proposta será apresentada de forma mais detalhada nas secções que se seguem, em que procuro explicar os argumentos de Wright para mostrar que Hume seria um realista (indireto) metafísico e um realista causal.

O que permite aos proponentes do realismo cético defenderem esta interpretação é a distinção que fazem entre Hume defender o realismo causal e metafísico por meio de argumentos e simplesmente supô-lo na sua descrição dos raciocínios causais ou das limitações das definições de causa. Desta forma, estes intérpretes pensam que apesar do ceticismo (sob o ponto de vista da razão demonstrativa), Hume acredita - sem tentar provar, mas também sem questionar na existência exterior e independente (da mente) dos objetos da perceção, assim como na causalidade objetiva.

\footnotetext{
${ }^{345}$ Cf. WRIGHT, 1983, pp. 50-1.

${ }^{346}$ Tradução minha do original: "Hume bases his scepticism with regard to the senses upon his rejection of the senses and reason as sources of belief in the existence of external objects. He has regarded, in effect, that our conception of and belief in independent material objects does not arise from the information which derive from experience. It is this reflection on the 'imperfections' of
} 
A sua posição em relação à conjugação do realismo com o ceticismo de Hume pode ser ilustrada pela seguinte citação:

Pode supor-se que a tese de que não podemos saber se há ou não Causação na realidade, juntamente com (...) a tese de que não podemos (sequer) saber se há ou não um mundo externo, representam a posição estritamente cética de Hume em relação a relação a questões sobre conhecimento (apesar de ele nunca ter asserido aquela, mas apenas esta) (...) Por contraste, a tese de que há, de facto, uma realidade exterior, e que há algo como a Causação na realidade, representa a crença efetiva de Hume sobre como as coisas são. Claramente, a sua crença firme de que há uma realidade exterior, e de que há a Causação na realidade, é compatível com o seu ceticismo estritamente nãocomprometido em relação a questões de conhecimento, que simplesmente lhe diz que não se pode saber que esta crença é verdadeira. Acreditar em algo é acreditar que esse algo é verdadeiro, mas não saber que isso é verdade, ou pretender saber que o é. ${ }^{347}$

Com efeito, Strawson explica que o ceticismo não comprometido em relação à existência (exterior e independente da mente) dos objetos da perceção acarreta que, caso esses objetos existam (dessa forma), a causalidade pode ser uma das suas propriedades. Portanto, do ponto de vista da demonstração, ambas são incertas. Este ceticismo fundamenta-se na impossibilidade de obter ideias claras (sejam cópias de impressões ou produto de uma demonstração) de ambos. Antes, ambas permanecem possibilidades metafísicas, devido ao argumento que ficou conhecido como o do ceticismo indutivo de Hume - de que a ordem da natureza pode ser alterada a qualquer momento - e ao facto de o PGC e a tese da dupla existência serem concebíveis sem contradição. O comentador observa que Hume tanto defende a impossibilidade de oferecer uma demonstração da existência dos objetos externos e independentes e da causalidade objetiva (o ceticismo) como acredita na existência desta causalidade (o realismo causal e

the human senses and reason which provides the central basis for the scepticism (...)" (WRIGHT, 1983, p. 50).

347 Tradução minha do original: “[T] he view that we can’t know whether or not there is Causation in reality, together with (...) the view that we can't (even) know that there is or is not an external world, may be supposed to represent Hume's strictly skeptical position with respect to knowledge claims (although he never actually asserts [aquela], only [esta].(...)[B]y contrast, the view that there is indeed an external reality, and that there is such a thing as Causation in reality, represent Hume's actual belief about how things are. Clearly, his firm belief that there is an external reality, and that there is Causation in reality, is compatible with his strictly non-commital skepticism with respect to knowledge claims, which simply tells him that these belief cannot be known to be true. To believe something is to believe it to be true, but it is not to know that it's true, or to claim to know that it's true." (STRAWSON, 1989, p. 99). 
metafísico). Porém, mantém a componente epistémica do ceticismo causal, acreditando ser impossível obter ideias adequadas da causalidade devido à impossibilidade de conhecê-la a priori - o que, na filosofia de Hume, seria o mesmo que ser demonstrável ${ }^{348}$.

Por seu turno, para os proponentes do realismo cético, Hume não poderia manter a mesma paridade entre o ceticismo causal e metafísico e o anti-realismo causal, pois não seria possível defender que a causalidade é redutível à regularidade observável e ter uma postura cética em relação à natureza da causalidade - regularista ou realista. Portando, defendem que se Hume é cético, então não pode ser regularista ou que se Hume fosse regularista, não poderia ser cético em relação ao que se pode saber sobre a causalidade. O regularismo constitui uma resposta à questão da natureza da causalidade que, por si só, já implica a defesa da possibilidade de obter uma ideia clara da mesma - que consiste nas duas definições que Hume oferece, que expressam o que se sabe sobre a causalidade, e não o que a causalidade $e^{349}$.

Com isso, os defensores da interpretação anti-realista também negam o ceticismo epistémico envolvido no ceticismo metafísico e causal - a tese de que não é possível ter uma ideia adequada da causalidade em si mesma ${ }^{350}$. Por isso, o anti-realismo causal não poderia conviver com o ceticismo causal e metafísico, pois não se abre a possibilidade de que haja uma causalidade objetiva de cuja ideia adequada os agentes cognitivos não pudessem dispor, ou que não pudessem provar que é uma propriedade de objetos exteriores e independentes (da mente). Portanto, alguns destes autores - Strawson com mais veemência - notam explicitamente que, entre as duas teses relativas à natureza da causalidade (realismo e regularismo), o realismo é a mais compatível com o ceticismo.

Além disso, Strawson nota que é possível manter simultaneamente uma crença na existência efetiva da causalidade e uma defesa da impossibilidade de demonstrar a existência quer da causalidade, quer da existência dos objetos $\operatorname{externos}^{351}$. Por essa razão, o ceticismo é encarado como um indicativo de que Hume não é um regularista, e que o seu propósito não é metafísico, mas

\footnotetext{
${ }^{348}$ Cf. STRAWSON, 1989, pp. 99-100, 145.

${ }^{349}$ Cf. STRAWSON, 1989, p. 16, 193; WRIGHT, 2007, p. 88.

${ }^{350}$ Cf. STRAWSON, 1989, p. 17, 143; 2000, p. 34.
} 
epistemológico $^{352}$. Por fim, o ceticismo indicaria ainda que apesar de certos termos indicarem objetos que seriam, sob a teoria empirista das ideias, ininteligíveis, Hume não se refere aos mesmos de forma acidental, mas antes, como consequência da possibilidade de uma referência genuína dos termos ligados à causalidade objetiva e ao realismo metafísico ${ }^{353}$.

Por seu turno, Costa é menos radical que a de Strawson e afirma que apesar de não ser necessário atribuir uma posição realista a Hume para que possa ser considerado um cético, a natureza do seu ceticismo é melhor compreendida se lhe for atribuída a defesa do realismo causal. Para o comentador, defender que Hume é um realista causal combina melhor com o ceticismo em relação à existência do mundo externo e da natureza (regularista ou essencialista) da causalidade $^{354}$ : considerar que não existe mundo externo e não existe uma causalidade objetiva seria uma constatação de que se sabe qual a natureza dos objetos da perceção (subjetiva) e da causalidade (regularista). Ao invés, a limitação do conhecimento ao que a experiência fornece é mais compatível com a constatação de que há algo objetivo sobre o qual ter dúvidas. Além disso, o intérprete acrescenta que o ceticismo em relação ao raciocínio causal se enquadra melhor no cenário cético em relação ao estatuto metafísico dos objetos da perceção se se atribuir o realismo causal a Hume. Tem-se a constatação do filósofo referente à existência de uma crença generalizada na existência exterior e independente (da mente) dos objetos da perceção e de que a causalidade objetiva é acessível pela experiência (do vulgo, tal como notou Wright). Atribuir a Hume uma posição realista em relação à causalidade iria ao encontro de uma passagem em que Hume afirma que a verdadeira filosofia consiste nas opiniões do senso

\footnotetext{
${ }^{351}$ Que é relevante para a questão da natureza da causalidade na medida em que permite que se abra a possibilidade do objetivismo causal (utilizando os termos de Costa).

${ }^{352}$ Contra Strawson, Winkler afirma explicitamente que uma recusa em afirmar a existência ou não existência da causalidade objetiva é muito mais condizente com o ceticismo de Hume do que uma afirmação em qualquer dos sentidos (cf. WINKLER, 2007, p. 53).

${ }^{353}$ Cf. STRAWSON, 1989, p. 8, 15, 16, 95, 97 117, 120, 140, 168.

${ }^{354}$ Diversos comentadores julgam que Hume se identifica com a postura do cético extravagante, isto é, de que demonstrativamente, não há justificação possível para as crenças na existência de poderes secretos e do mundo externo (WINKLER, 2007, pp. 80-1) ou pelo menos a postura cética do filósofo consistiria em não se manter firme numa destas três posturas - a ausência de razões para acreditar na existência exterior e independente dos objetos da perceção (ceticismo extravagante), o realismo indireto da filosofia moderna (a tese da dupla existência) e o realismo direto (ingénuo) do senso comum (cf. COSTA, 1988, pp. 564-5).
} 
comum 'sistematizadas e corrigidas' (I 12.3.25) - pela conclusão (da razão) de que essas crenças são injustificáveis ${ }^{355}$.

Millican sugere que se se aceitar - como este intérprete aceita - que a reivindicação dos proponentes do anti-realismo não é necessariamente metafísica - como pensam os proponentes do realismo cético - mas apenas epistémica e semântica. Portanto, tratar-se-ia de uma constatação da natureza e dos limites das ideias e do conhecimento causal, e não da rejeição de que existe causalidade objetiva, o que é confirmado pela constatação (de Hume) de uma "deficiência de nossas idéias" ao tentar "conhecer o princípio operador último enquanto algo que residiria no objeto externo" ${ }^{\text {356 }}$. Esta observação de Millican sugere que ainda é possível, para os proponentes de um anti-realismo de natureza estritamente semântica e epistémica continuar a defender o ceticismo. Aliás, esta posição foi tomada por Stroud, Blackburn e P. Smith.

Mas, ao mesmo tempo que procuram uma justificação para o realismo causal, os autores parecem simplesmente atribuir uma maior razoabilidade (de forma mais ou menos acrítica) à conjuntura que é a que efetivamente constitui a crença natural mais geral, não apresentando uma boa razão para que não se aceite a alternativa contrária, a saber, a de que apesar de se ser cético em relação à confiabilidade do raciocínio causal, à existência do mundo externo e à existência de poderes causais, do ponto de vista do que a experiência informa, os raciocínios referem-se apenas a regularidades observáveis, não existe mundo externo e não existem poderes secretos e, portanto, acreditar no contrário constitui um erro. Direcionando a questão aos próprios comentadores, pode perguntar-se se uma preferência metafísica constitui uma boa razão para aceitar a opção de Costa e Strawson em vez daquela que Millican aponta. Como ficará claro em 2.2.7, a meu ver, essa preferência metafísica deve simplesmente ser considerada um ponto de partida para a construção do edifício de crenças e interações no mundo (por meio da ação), e que está além do campo das razões para acreditar.

Entretanto, para explicar a relação entre a restrição do PP a ideias adequadas com a questão do estatuto epistémico da causalidade objetiva, Kail observa que sendo um objeto além do que é possível observar e cuja conceção por

\footnotetext{
${ }^{355}$ Cf. COSTA, 1989, pp. 182-3.

${ }^{356}$ T 1.4.7.5, 6; cf. MILLICAN, 2007a, p. 229.
} 
meio de ideias claras é impossível, não é possível determinar por meio de ideias claras se a causalidade objetiva existe ou não. Esta impossibilidade explicar-se-ia pelas limitações das faculdades da mente. $\mathrm{O}$ comentador observa que a capacidade de conceber as ideias separadamente (ou de acordo com o PS, e não de outra forma) explica a incapacidade de compreender a causalidade objetiva. Kail associa o PP a uma contingência na limitação das nossas faculdades. Portanto, a sua interpretação é definida como epistémica em virtude destas limitações da faculdade da imaginação. Kail vai mais longe e afirma que essa incapacidade é uma contingência ${ }^{357}$.

Quer dizer, para o comentador, esta incapacidade deve-se a limitações nas faculdades da mente que poderiam não existir, ou não fossem efetivamente estas as limitações - mas antes dispuséssemos de faculdades ilimitadas -, seria possível conceber a causalidade objetiva. Retomando o esclarecedor exemplo de Edmund, o que Kail pretende mostrar é que apesar de Véspero e Fósforo serem, efetivamente, o mesmo indivíduo, é devido à ignorância de Edmund que a morte de um e a continuidade da vida do outro são concebíveis. Isto ilustra, para Kail, que mesmo no caso de a causalidade objetiva existir, a razão pela qual não se consegue concebê-la são os moldes e limites das faculdades da mente tais como são. Neste sentido, Kail explica que a legitimidade desta conclusão cética é justificada, devido a esses moldes e limitações ${ }^{358}$ :

[E]ste ceticismo [em relação à modalidade metafísica da causalidade objetiva] deve-se à nossa ignorância sobre a natureza modal do mundo fora da experiência, não à impossibilidade das próprias características modais relevantes em si." ${ }^{359}$

Mas apesar de o comentador reconhecer que não se pode determinar que a causalidade objetiva é impossível - como consequência de a operatividade dos princípios de raciocínio de que dispomos não permitir sequer determinar se existe algo para além das impressões, muito menos as suas propriedades - e do seu mérito de restringir o PP às ideias adequadas (explicando, assim, que a conclusão

\footnotetext{
${ }^{357}$ Cf. WRIGHT, 1983, p. 148; KAIL, 2007b, p. 83.

${ }^{358}$ Cf. KAIL, 2003a, pp. 56-7; 2007a, p. 256.

359 Tradução minha do original: "such skepticism [em relação à modalidade metafísica da causalidade objetiva] rests on our ignorance of the modal nature of the world outside of experience, not the impossibility of the relevant in re modal features.” (KAIL, 2003a, p. 56).
} 
anti-realista não tem fundamento), esta restrição é apresentada como meio para rejeitar uma interpretação anti-realista (de que a causalidade objetiva é impossível porque inconcebível).

\subsubsection{A relação entre realismo causal e metafísico}

Apesar de o foco do presente capítulo ser o das razões que levam os proponentes do realismo cético apresentam para considerar Hume um realista acerca da causalidade, o interesse em apresentar este tópico da interpretação do realismo cético está em esclarecer que algumas passagens referentes a esta questão podem trazer para uma decisão sobre a posição de Hume em relação à existência (ou não) da causalidade objetiva, ainda mais tendo em conta que esta parece ser encarada como uma propriedade dos objetos da perceção. Particularmente, Wright e Strawson esforçaram-se por explicar que Hume era um realista não apenas causal, mas também metafísico, ou seja, que acreditava que os objetos da perceção existem exterior e independentemente da mente e têm a propriedade intrínseca de se relacionar causalmente entre si.

Como apresentei em 2.2.4, Strawson considera que Hume é cético na medida em que não se compromete com uma defesa filosófica da existência ou não existência exterior e independente (da mente) dos objetos da perceção. Já admitindo a existência exterior e independente dos objetos da perceção desde o início da discussão em T 1.4.2, a sua preocupação não seria a de determinar o seu estatuto metafísico, mas uma decisão sobre a existência de uma ideia clara ou suposição da mesma. Por essa razão, a defesa da existência de uma ideia relativa dos objetos da perceção (enquanto externos e independentes) não teria qualquer implicação em relação a uma tese positiva quanto ao seu estatuto metafísico, e consistiria numa ficção indispensável, de cuja existência Hume está convicto, à exceção das horas filosóficas ${ }^{360}$.

É possível combinar as teses relativas à existência de relações causais objetivas e a crença na existência de um mundo externo da parte de Hume de quatro formas:

${ }^{360}$ Cf. STRAWSON 1989, p. 16, 46-7, 50; BROUGHTON, 2007, p. 204. 
i) fenomenalismo metafísico e regularismo causal, em que apenas existem perceções; esta hipótese está de acordo com a interpretação regularista da causalidade, afirmando, além disso, que os objetos da perceção não existem exterior e independentemente (da mente);

ii) fenomenalismo metafísico e realismo causal, em que não existe nada por trás ou subjacente às perceções, sendo estas os únicos objetos que, apesar disso, manteriam uma relação causal intrínseca entre si (contanto que não se defendesse uma teoria do eu como feixe, caso contrário, as perceções e a própria mente seriam, num certo sentido, o mesmo);

iii) realismo metafísico e regularismo causal: existem objetos exteriores e independentes da perceção, ou seja, em que as perceções não se identificam com os objetos; o mundo externo existe, mas a relação causal reduz-se à regularidade e, por isso, só se estabelece entre perceções; existem (de forma exterior e independente) os objetos da perceção, mas não algo em virtude do qual a regularidade é tal como se apresenta - portanto, a causalidade como propriedade desses objetos;

iv) realismo causal e metafísico: um realismo tanto causal como metafísico, de acordo com o qual o mundo externo existe e uma das suas propriedades é a de os seus objetos manterem uma relação causal real entre si.

Strawson reconhece que apesar de considerar o idealismo à maneira de Berkeley irrefutável, Hume também não lhe dá assentimento, pois 'produz nenhuma convicção, ${ }^{361}$. Além disso, o comentador julga que o filósofo assente à última forma de combinação (iv)), ou seja, que os objetos da perceção são exteriores e independentes (da mente) e a causalidade constitui uma propriedade desses objetos, apesar do seu ceticismo não comprometido com a determinação de qualquer propriedade positiva daquilo em virtude do qual a regularidade é tal como se apresenta.

Considerando a tese (de Hume) de que se tem uma ideia relativa dos objetos externos, Strawson entende que também não se pode ter uma ideia adequada desses objetos enquanto tais. De resto, isto está de acordo com as teses (de Hume) de que a exterioridade e independência dos objetos da perceção não são qualidades observáveis (pelos sentidos) nem demonstráveis - o que para 
Strawson, significa que são inteligíveis (R) e ininteligíveis (E). E se se pode formar uma ideia relativa de ambos - particularmente, de objetos que mantêm uma relação causal com as perceções -, parece razoável pensar que a causalidade é uma propriedade dos objetos que se supõem externos, e em virtude do que as regularidades são tais como se apresentam ${ }^{362}$.

O comentador chega a estabelecer uma relação clara de dependência entre o que Costa chama de objetivismo causal e realismo dos poderes, tal que é razoável supor que se existem objetos externos e independentes, então a experiência da regularidade observável é uma experiência da causalidade objetiva $e$, ao pensar e falar sobre a mesma, se lhe faz uma referência genuína. Portanto, o termo pode, de facto, referir-se àquela causalidade. Strawson admite que as respetivas crenças de Hume aparecem naturalmente conjuntas, apesar de nenhuma depender (logicamente) da outra. No entanto, chega a afirmar que Hume estava mais preparado para ser um cético extravagante em relação à existência exterior e independente (da mente) dos objetos da perceção - pelo menos temporária ou filosoficamente - do que em relação à causalidade. Em relação ao primeiro tópico, a sua posição é que Hume seria um realista em relação à existência exterior e independente (da mente) dos objetos da perceção, com momentos (filosóficos) de dúvida e ceticismo ${ }^{363}$. Reconhece ainda que:

Se supusermos que existem objetos externos especificamente diferentes das perceções que nos afetam, suscitam as nossas perceções e constituem a razão pela qual as nossas perceções são como são (...), pode supor-se, da mesma maneira, que a Causação Inteligível-R, mas Ininteligível-E, constitui o aspeto desses objetos externos que nos afetam, suscitam as nossas perceções e constituem a razão pela qual as nossas perceções são como são (...). Da mesma forma, pode supor-se que a Causação constitui a razão pela qual as nossas perceções têm um caráter tal que envolvem uma sucessão regular como a têm. ${ }^{364}$

\footnotetext{
${ }^{361}$ IEH 12.3.15; cf. IEH 12.1.15.n32; STRAWSON, 1989, p. 58.

${ }^{362}$ STRAWSON, 1989, p. 53, 128-9.

${ }^{363}$ Cf. STRAWSON, 1989, pp. pp. 4-5, 126, 208-9; STRAWSON, 2000, p. 49.

${ }^{364}$ Tradução minha do original: "If one supposes $(. .$.$) that there are external objects specifically$ different from perceptions that affect us and give rise to our perceptions and are the reason why our perceptions are as they are (...), one may equally well suppose that R-intelligible but Eunintelligible Causation is a feature of those external objects that affect us and give rise to our perceptions and are the reason why our perceptions are as they are (...). So too, one may suppose that the Causation is the reason why our perceptions have the regular-succession-involving character they do." (STRAWSON, 1989, p. 129).
} 
Portanto, para Strawson, a suposição da existência exterior e independente (da mente) dos objetos da perceção ou o facto de Hume a dar por garantida ${ }^{365}$, por si só, autorizaria a suposição da existência da causalidade objetiva, pelo facto de uma das suas propriedades ser a de que mantêm relações causais entre si e com a perceção. Com efeito, Hume reconhece que esta é uma postura comum ou geral, ainda que nenhum condicional esteja presente nesta consideração ${ }^{366}$. De qualquer forma, parece-me que Strawson o faz no sentido de mostrar que a existência exterior e independente (da mente) dos objetos da perceção é mais um fator que torna plausível a convicção de Hume na existência da causalidade objetiva.

Kail acrescenta que pela mesma razão se pode pensar que Hume aceitaria a validade das ideias relativas. Empenhado em combater a ameaça semântica no que respeita à questão da ideia da dupla existência, ou de um objeto para além das perceções, o comentador avança a proposta de que essa ideia consiste numa suposição - que Hume assume explicitamente - de um objeto semelhante às perceções, mas ao qual são aplicáveis diferentes relações:

\begin{abstract}
É uma questão de fato se as percepções dos sentidos são produzidas por objetos externos a elas assemelhados - como se decidirá essa questão? Pela experiência, certamente, como no caso de todas as outras questões de mesma natureza. Mas aqui a experiência permanence - e tem de permanecer - inteiramente calada. Nada está jamais presente à mente senão as percepções, e ela não tem como alcançar qualquer experiência da conexão destas com objetos. A hipótese dessa conexão não tem, portanto, nenhum fundamento no raciocínio. ${ }^{367}$
\end{abstract}

[S]upomos que os objetos externos se assemelham às percepções internas. (...). [A] ssim como supomos que nossos objetos em geral se assemelham a nossas percepções, assim também damos por suposto que cada objeto particular se assemelha à percepção por ele causada. ${ }^{368}$

O comentador observa que, estando de acordo com as citações em que Hume invoca a distinção entre conceção e suposição ${ }^{369}$, esta distinção - à qual Hume se refere mais vezes, de forma mais breve - deve ser interpretada como uma instância da operação da capacidade de formular ideias relativas. Conclui que

\footnotetext{
${ }^{365}$ Cf. STRAWSON, 1989, p. 5; T 1.4.2.

${ }^{366}$ Cf. T 1.4.2.21.

${ }^{367}$ IEH 12.1.12.

${ }^{368} \mathrm{~T}$ 1.4.2.54-5.

${ }^{369}$ Cf. T 1.2.6.9; T 1.4.5.19; T 1.4.5.20; cf. 3.2.1.
} 
esta ideia pode ser considerada coerente, no sentido em que é possível destacar um significado ou definição desta distinção. Com isto, pensa conseguir evitar a ameaça semântica - de falta de conteúdo para a ideia de objeto externo - e também contrariar a objeção de Blackburn de que as citações utilizadas pelos realistas céticos, em que Hume se refere claramente a ideias relativas, são demasiado escassas para justificar a aceitação efetiva do filósofo ${ }^{370}$.

Por seu turno, Wright foi quem mais se esforçou por argumentar a favor da interpretação de que Hume defenderia um realismo metafísico (conjugado com o realismo causal). Segue-se a sua explicação. O comentador mostra a sua interpretação sobre a postura de Hume em relação à existência exterior e independente (da mente) dos objetos da perceção através de um longo argumento no sentido de provar que Hume defenderia um realismo indireto, isto é, que esses objetos existem (ou existem dessa forma), mas os agentes cognitivos têm acesso aos mesmos através de ideias ou representações suas (e não um acesso direto). Esse caráter indireto dever-se-ia a limitações da mente, associadas a uma incapacidade de conceber clara e distintamente objetos que ultrapassam o âmbito das impressões (ainda que possam conceber outros objetos de forma confusa).

Wright explica que a existência do mundo exterior - ou, como descreve Strawson, de "algo que não são as perceções, que nos afeta e que as origina",371 constitui um pressuposto com que Hume inicia o seu argumento em T 1.4.2 particularmente, quando afirma que este "é um ponto que devemos dar por suposto em todos os nossos raciocínios" ${ }^{\text {372 }}$. Além disso, Wright alega que, na secção que Hume dedica à filosofia moderna ${ }^{373}$, Hume não apresenta o seu argumento no sentido de reduzir ao absurdo a posição dos filósofos modernos (o realismo indireto) - portanto, que não pretende mostrar que essa posição implica uma contradição.

Um dos primeiros argumentos de Hume nessa secção é o que conclui o caráter descontínuo das perceções entre si e a sua dependência relativamente à mente $^{374}$. Consciente disso, Wright serve-se de algumas passagens de Hume para

\footnotetext{
${ }^{370}$ Cf. BLACKBURN, 2000, pp. 101-2; KAIL, 2007b, pp. 60-2, 69, 72.

${ }^{371}$ Tradução minha do original: "something other than our perceptions, something which affects us and gives rise to our perceptions" (STRAWSON, 1989, p. 58).

${ }^{372}$ T 1.4.2.1; cf. WRIGHT, 1983, p. 54; STRAWSON, 2000, p. 35.

${ }^{373} \mathrm{~T} 1.4 .4$.

${ }^{374}$ Cf. T 1.4.2.3-10.
} 
mostrar que, o próprio autor, essa premissa já assenta na aceitação da existência exterior $^{375}$ :

A filosofia mais comum nos informa que a mente não pode conhecer nenhum objeto externo de maneira imediata, sem a interposição de uma imagem ou percepção. ${ }^{376}$

Podemos observer que todos os filósofos admitem, e alias é bastante óbvio por sis ó, que nada jamais está presente à mente além de suas percepções, isto é, suas impresses e idéias; e que só conhecemos os objetos externos pelas percepções que eles ocasionam. ${ }^{377}$

A mesa que vemos parece diminuir à medida que dela nos afastamos, mas a mesa real, que existe independentemente de nós, não sofre nenhuma alteração; não era, pois, senão sua imagem que estava presente à mente. ${ }^{378}$

Para o comentador, a independência dos objetos da perceção seria uma condição para a própria dependência das perceções. Portanto, Hume levaria a sério a ideia de que tal deve ser dado por certo no início da investigação. Aliás, para Wright, Hume procede acertadamente ao fazer isso, pois caso não o admitisse desde a premissa de que as perceções têm uma existência descontínua, "se ele negasse o nosso direito a acreditar no corpo, poderia haver um certo tipo de circularidade neste procedimento" 379 .

O comentador considera que para se dispensar legitimamente a conclusão de que os objetos têm uma existência exterior e independente, do facto de que os únicos objetos da mente são perceções, seguir-se-ia que os objetos da perceção não existem exterior e independente da mente. Mas este não é o caso, já que não mantendo uma relação de implicação, a primeira premissa não é suficiente para descartar aquela conclusão. Além disso, se não se admitir que existem tanto perceções descontínuas e dependentes (da mente) como objetos contínuos e independentes (da mente), ter-se-á de admitir que o que se tem presente à mente se aniquila com as interrupções da perceção ${ }^{380}$.

\footnotetext{
${ }^{375}$ Cf. WRIGHT, 1983, p. 40, 51, 53.

${ }^{376} \mathrm{~T}$ 1.4.5.15

$377 \mathrm{~T} 1.2 .6 .7$.

${ }^{378}$ IEH 12.9; WRIGHT, 1983, p. 51.

${ }^{379}$ Tradução minha do original e: "If he were denying our right to believe in body then there could be a kind of circularity in his procedure"; cf. WRIGHT, 1983, p. 40, 50-1, 55.

${ }^{380}$ Cf. WRIGHT, 1983, pp. 52-4. Portanto, Wright não considera a hipótese de não se ter uma resposta disponível para essa questão.
} 
Nesse sentido, o comentador propõe que se aceitem duas teses: i) que a tese da dupla existência depende (parece que logicamente) da tese relativa ao caráter dependente da perceção, que é, apesar disso, uma dependência de facto ${ }^{381}$ e o ponto de partida (científico, no sentido psicofisiológico) da discussão; ii) que Hume, de facto, aceitava a tese da dupla existência, o que supõe uma crença prévia na existência efetiva dos objetos da perceção (exteriores, ininterruptos e independentes), para além das perceções (interiores, interrompidas, dependentes) ${ }^{382}$.

Apesar disso, Wright nota que a crença na existência de objetos ininterruptos, independentes, exteriores, não depende logicamente da aceitação de que esses objetos são as perceções - portanto, não depende da aceitação do realismo direto. Nos termos em que Wright coloca a questão, acreditar na existência de objetos que têm um caráter ininterrupto e independente da mente é logicamente neutro, no sentido em que essa crença não implica nem acreditar que esses objetos são os objetos percebidos (realismo direto) nem objetos diferentes dos da perceção, ainda que mantenham uma relação com estes (realismo indireto). É a contradição com que o filósofo se depara quando considera a hipótese do realismo direto que o faz perceber a sua falsidade. Aliás, Wright considera que o realismo direto - protagonizado pelo senso comum - é falso ${ }^{383}$.

Wright também aceita que este mantém uma dependência psicológica relativamente ao realismo direto, tal que essa é a nossa posição natural, mas, na mente do filósofo, dá lugar ao realismo indireto quando as contradições do realismo direto são expostas. Portanto, a crença falsa em que o senso comum possui é a origem ou fonte psicológica do sistema filosófico. O realismo indireto (dos filósofos modernos) constitui uma correção do realismo direto (do senso comum), devido à consciência da contradição de que perceções não são ininterruptas, mas interrompidas e, por isso, dependentes da mente, não podendo identificar-se numericamente com os objetos da perceção (que são ininterruptos e independentes da mente) $)^{384}$.

\footnotetext{
${ }^{381}$ Para mais discussão sobre o estatuto desta dependência - necessário ou contingente, lógico ou de facto -, cf. COOK, 1968, p. 573; STRAWSON, 2011, p. 41.

${ }^{382}$ Cf. WRIGHT, 1983, p. 41, 59, 60.

${ }^{383}$ Cf. WRIGHT, 1983, pp. 43, 46, 47, 55-56, 59.

${ }^{384}$ Cf. WRIGHT, 1983, pp. 55-59.
} 
Em relação à questão de saber com que figura Hume se identificaria, Wright posiciona-se contra quem pensa que o ceticismo de Hume passa por minar o valor de verdade da crença no mundo exterior ${ }^{385}$, ou que defende outra posição a não ser a de que, em 1.4.2, Hume estaria, no núcleo da sua posição, do lado dos filósofos modernos ${ }^{386}$. Para o comentador, a aceitação da existência exterior e independente (da mente) dos objetos da perceção por parte de Hume não é nem do mesmo tipo da do senso comum, nem da do filósofo. O realismo indireto de Hume seria diferente do dos filósofos modernos, já que lhe faz algumas restrições. A primeira restrição é que a teoria é inverificável, devido ao facto de se tratar de uma suposição ou ideia que, de acordo com a teoria empirista das ideias, é inconcebível. A segunda é que a sua conclusão resulta de uma investigação de natureza psicofisiológica (ou, mais em geral, na própria aplicação do método empírico proposto para toda a Ciência do Homem) a partir do que o estímulo das perceções causa na mente humana ${ }^{387}$.

Com efeito, em T 1.4.2, Hume analisa três posturas possíveis em relação à existência exterior e independente dos objetos da perceção: 1) a crença do senso comum; 2) os filósofos modernos; 3) os céticos extravagantes. Os dois últimos correspondem a posições filosóficas - que, na conjuntura que Wright oferece, seriam os que reconhecem o caráter interrompido ou descontínuo das perceções, seguindo seriamente a conclusão da razão e dos sentidos. Os primeiros vivem convictos do realismo direto (nos termos de Wright e Strawson;) ou ingénuo (nos termos de Costa); os seguntos, do realismo indireto, a partir da tese da dupla existência, e os últimos, de que apenas se pode acreditar na existência das perceções $^{388}$.

A meu ver, a distinção entre a postura dos verdadeiros filósofos e a do senso comum pode ser descrita de forma clara através da distinção entre dependência causal e dependência existencial (metafísica), para a qual Hakkarainen chama a atenção ao descrever este problema na filosofia de Hume ${ }^{389}$. Para o senso comum, os objetos são percebidos tais como são em si mesmos, ou

\footnotetext{
${ }^{385}$ REID, T., An Inquiry into the Human Mind, in The Works of Thomas Reid, vol. 1, p. 96. (ref. de Wright).

${ }^{386}$ PRICE, H. H., Hume's Theory of the External World, p. 104.

${ }^{387}$ Cf. WRIGHT, 1983 , p. 53, 57-60.

${ }^{388}$ Cf. WRIGHT, 1983, p. 54; COSTA, 1988, p. 564; STRAWSON, 1989, p. 51.

${ }^{389}$ Cf. HAKKARAINEN, 2012b, p. 146.
} 
aquilo que se percebe (as perceções) corresponde àquilo que os objetos são em si mesmos. Portanto, o senso comum julga que tanto as perceções como os seus objetos são existencial e causalmente independentes da mente, e exteriores à mesma. Por seu turno, os filósofos reconhecem a independência existencial (metafísica) dos objetos da perceção (em relação à mente), mas uma dependência causal das perceções relativamente aos seus objetos. Tal é assegurado pelo próprio Hume, ao afirmar implicitamente que aquilo que se entende por objeto exterior e independente da mente consiste naquilo que mantém uma relação causal com a perceção $^{390}$.

Por outro lado, Wright observa que a adoção do ponto de vista do cético extravagante é impossível ${ }^{391}$, apoiando-se na afirmação de Hume de que não fosse a natureza mais forte que a filosofia, permaneceríamos eternamente pirrónicos ${ }^{392} \mathrm{e}$ que, portanto, do ponto de vista pragmático, a exigência de Winkler é vã ${ }^{393}$. Devido ao facto de o senso comum identificar percepções e objetos, a crença na existência exterior apenas é justificada para o filósofo, o que justifica, para Wright, a distinção que Hume estabelece entre ambos. O filósofo estaria justificado a acreditar na existência exterior porque o seu instinto é corrigido pela razão, contrariamente ao do senso comum (para quem a razão, neste tópico, parece não operar) - o que vai ao encontro da consideração de Hume de que a posição do filósofo consiste nas "as reflexões da vida ordinária, sistematizadas e corrigidas" 394 .

Por outro lado, Wright esclarece que a tese filosófica da dupla existência, não sendo fundada na experiência nem na razão demonstrativa, baseia-se, antes, nos princípios da imaginação estáveis e generalizáveis - que são do mesmo tipo que os responsáveis pelos raciocínios causais. Portanto, o conflito entre a crença natural (do realismo direto) e a conclusão da filosofia consistiria num conflito entre princípios da imaginação: os mais estáveis e os mais inconstantes (que, nas

\footnotetext{
${ }^{390}$ Cf. T 1.2.6.7.

${ }^{391}$ Como se viu em 3.2.3, a posição de que Hume encarava com seriedade a posição do cético extravagante parece ser a mais consensual.

392 T Ap 27.

${ }^{393}$ Contra Winkler, que comenta que se o ceticismo de Hume for encarado como uma recusa em fazer qualquer afirmação acerca do estatuto metafísico dos objetos da perceção e da causalidade, a crença na existência exterior e independente (da mente) dos objetos da perceção e da causalidade objetiva constituem uma fraqueza epistémica causada por certas disposições naturais da mente (WINKLER, 1991, p. 67).
} 
palavras de Hume, são os que produzem as ficções). Portanto, trata-se de um conflito interno da imaginação devido à diversidade dos princípios que a constituem, que se deve à incapacidade de conciliar duas crenças fundamentais à vida humana, que se contradizem ${ }^{395}$.

As palavras de Wright dão a entender que o facto de a tese da dupla existência (realismo indireto) ser apoiada - no sentido de ter a sua origem ou fonte - na crença do senso comum (realismo direto) leva a que, estando esta crença baseada na existência de uma propensão natural da imaginação, a crença na existência exterior e independente dos objetos da perceção seja considerada por Wright como justificada. Isto valeria para ambas as suas versões (filosófica e do senso comum), pelo simples facto de a sua fonte ser uma propensão inescapável da natureza humana - mais precisamente, da imaginação. A diferença entre essas crenças no que concerne ao seu valor de verdade seria que a crença do senso comum é falsa, mas a crença do filósofo moderno é - para Hume e desde o início da discussão - verdadeira ${ }^{396}$.

$\mathrm{Na}$ continuidade das considerações de Wright, e como se verá na secção 2.2.6, parece que Broughton utiliza as observações de Hume sobre a distinção entre as perspetivas dos filósofos (da verdadeira e da falsa filosofia) e do senso comum apenas para mostrar que Hume defendia a naturalidade da crença na causalidade objetiva ${ }^{397}$. A meu ver, este recurso da autora leva a crer que a autora subsume a causalidade objetiva nas propriedades dos objetos da perceção, exteriores e independentes (da mente) e, portanto, que também considerava Hume um defensor do realismo metafísico.

Wright acrescenta que o posicionamento de Hume e o seu direcionamento à questão da origem da crença na extistência exterior e independente dos objetos da perceção é elaborado sob este ponto de vista científico, englobando na sua análise, inclusivamente, a constância e coerência como caracteristicas da experiência percetiva a partir das quais, psicofisiologicamente (no cérebro), essa crença se gera na imaginação. Além disso, inclui ainda a resolução da contradição entre as conclusões dos sentidos (e, poder-se-ia dizer também, da razão

\footnotetext{
${ }^{394}$ Cf. IEH 12.3.25; cf. WRIGHT, 2000, p. 95.

${ }^{395}$ Cf. WRIGHT, 1983, p. 54, 55, 58.

${ }^{396}$ Cf. WRIGHT, 1983 , p. 58 , pp. 75-6.

${ }^{397}$ Cf. BROUGHTON, 2007, pp. 202-3.
} 
demonstrativa) e da imaginação na geração da noção de identidade numérica de um objeto não percebido e uma desconfiança em relação aos sentidos, ao ponto de pensarmos, efetivamente, que observamos a identidade numérica nos objetos, isto é, que "[a] ideia da existência continua das nossas impressões semelhantes, que tem origem na imaginação, efetivamente entra na nossa perceção do mundo ${ }^{398}$.

É também sob este ponto de vista que Wright interpreta a refutação do realismo direto do senso comum por parte de Hume. Encarado sob este ponto de vista psicofisiológico, a explicação da falsidade do realismo direto mostra-se quando se percebe que uma nova impressão implica uma "criação" de um ato mental que se aniquila uma vez cessada a impressão anterior e no qual - mesmo no caso das sensações - a impressão é considerada um objeto interno da mente ${ }^{399}$.

O resultado do processo pelo qual as ideias são associadas - e, mais especificamente, as que levam à crença na existência exterior e independente dos objetos da perceção - são relações naturais entre os seus objetos, que Wright afirma serem explicitamente consideradas por Hume do ponto de vista neurológico ${ }^{400}$. Aliada a isso, estaria a defesa da conceção de conhecimento como representação ou ideia adequada da parte de Hume, tal que:

Quando as idéias representam adequadamente seus objetos, todas as relações, contradições e concordâncias entre elas são aplicáveis também a estes. Tal é (...) o fundamento de todo o conhecimento humano. ${ }^{401}$

Portanto, o conhecimento constitui a aplicação simultânea de uma propriedade tanto a perceções como a objetos, e quando tal propriedade não se aplica a ambos, não se o tem. É a partir deste ponto que surge, para Wright, a componente cética da epistemologia de Hume. $\mathrm{O}$ autor assume que se tem várias ideias não adequadas (suposições), em relação a cujos objetos não se pode considerar que se tem conhecimento, por essa razão. Este seria o caso da existência exterior e independente dos objetos da perceção. O reconhecimento da tese da dupla existência permite a Hume rejeitar definitivamente a crença do senso

\footnotetext{
398 Tradução minha do original: "The idea of the continuous existence of our resembling impressions which has its origin in the imagination actually enters into our perception of the world" (WRIGHT, 1983, p. 70-1); cf. WRIGHT, 1983, pp. 60-71. Wright julga que este é um dos pontos em que Malebranche influenciou Hume positivamente.

${ }^{399}$ Cf. WRIGHT, 1983, p. 71.

${ }^{400}$ Cf. WRIGHT, 1983, p. 74.

${ }^{401}$ T 1.2.2.1; WRIGHT, 1983, p. 88.
} 
comum e legitimar a crença do filósofo. Caso contrário, para além de ter de considerar essa ideia não adequada, teria de assumir que a crença na sua existência é injustificada ${ }^{402}$.

Winkler procura rebater a proposta de Wright, em parte, alegando que a distinção entre ideia e suposição não é relevante na investigação de Hume que visa responder à questão da crença na existência exterior e independente (da mente) dos objetos da perceção. O comentador observa que ao falar da possibilidade das ideias relativas, Hume diz que geralmente, não se forma a ideia de um objeto especificamente diferente das perceções. Antes, são-lhes atribuídas diferentes relações, conexões e durações. Assim, ideias relativas seriam algo diferente de ideias que envolvem diversas relações e durações são coisas diferentes. Apesar disso, o comentador não oferece nenhuma pista para determinar em que consistiriam ideias relativas.

Além disso, em T 1.4.2, Hume afirma já ter mostrado o absurdo da ideia de algo especificamente diferente das perceções ${ }^{403}$ e dedica-se à explicação das segundas ideias (que envolvem as diferentes relações). Mesmo a dupla existência - inventada pelos filósofos modernos - envolve este segundo tipo de ideia, e não a ideia de algo especificamente diferente das perceções, de acordo com o que Hume (aparentemente) insiste ${ }^{404}$, ao afirmar que a) objetos externos são semelhantes a perceções, que b) só se pode conceber perceções e, por isso, c) objetos externos, tal como a filosofia moderna inventou têm de ser perceções. Nas palavras de Winkler:

\begin{abstract}
A noção de objetos que são especificamente diferentes de perceções é irrelevante, pois não podemos ter nenhuma ideia de objetos especificamente diferentes de perceções e, assim, acreditar neles. ${ }^{405}$
\end{abstract}

Consequentemente, a crença natural na existência exterior e independente (da mente) dos objetos da perceção não assentaria na suposição de objetos especificamente diferentes de perceções. Mas isto parece-me igualmente falso, porque se se entender ideia relativa como essa ideia da perceção à qual se

\footnotetext{
${ }^{402}$ Cf. WRIGHT, 1983, pp. 88-9.

${ }^{403}$ Cf. T 1.4.2.2.

${ }^{404}$ Cf. T 1.4.2.54, 57.

405 Tradução minha do original: "The notion of objects as specifically different from perceptions is irrelevant because we can have no idea of objects specifically different from perceptions, and therefore no belief in them." (WINKLER, 1991, pp. 78-9).
} 
acrescentam novas relações e durações, percebe-se que mesmo o realismo direto (do senso comum) impõe um caráter ininterrupto aos objetos da perceção, o que faz dessa ideia uma ideia relativa, cuja definição Winkler deveria oferecer para que a sua alternativa faça sentido.

\subsubsection{Argumentos a favor do realismo causal}

As razões que levam os proponentes do realismo cético a defender a sua posição são de diversas ordens. Por isso, considero-me livre para dividi-los em duas categorias. Os primeiros, chamo de contextuais, pois consistem em perplexidades destes autores em relação a certas afirmações (de Hume) incompatíveis com uma interpretação anti-realista. Portanto, tratam-se de razões associadas à necessidade de oferecer uma maior coerência interna entre várias teses defendidas pelo filósofo, aparte do facto de existirem afirmações que também apontam no sentido oposto. Os segundos, chamo de teóricos, pois consistem em tentativas de apresentar razões, a partir de certas teses do filósofo (também sujeitas a interpretação), para a sua defesa do realismo causal e metafísico, ou de responder à questão de saber se é possível justificá-los racionalmente, mesmo não considerando justificada as respetivas crenças. $\mathrm{Na}$ presente secção, apresento esses argumentos, começando pelos contextuais.

\section{Argumentos contextuais}

Além das evidências textuais que os proponentes do realismo cético apresentam a favor da sua interpretação (enumerados em 3.2.1), deve reconhecerse que Strawson foi quem mais se empenhou em mostrar textualmente que Hume aceitava o realismo, e não o anti-realismo causal.

A primeira evidência que apresenta (ao longo da sua obra) é que Hume parece dar por garantido o realismo causal mesmo em constatações céticas ${ }^{406}$ :

$[\mathrm{N}]$ as conjunções mais usuais de causa e efeito, somos tão ignorantes sobre o princípio ultimo que une a causa ao efeito quanto nas mais insólitas e extraordinárias. ${ }^{407}$

\footnotetext{
${ }^{406}$ Cf. STRAWSON, 1989, p. 59, 139, 143, 145, 161, 165, 174, 179; 2000, p. 41, 42.

${ }^{407} \mathrm{~T}$ 1.4.7.6.
} 
[N]enhum filósofo razoável e comedido jamais pretendeu indicar a causa última de qualquer operação natural, ou exibir precisamente a ação do poder que produz qualquer um dos efeitos particulares no universe. (...) Quanto às causas dessas causas gerais, entretanto, será em vão que procuraremos descobri-las; (...) Esses móveis princípios fundamentais estão totalmente vedados à curiosidade e à investigação humanas. ${ }^{408}$

Para Strawson, em passagens como estas, Hume fala como um realista, isto é, expõe as suas teses como se defendesse o realismo - neste caso, causal e metafísico. Assim como alega que o uso de termos respetivos à causalidade (para além da regularidade) e ao objeto externo sinaliza a existência de ideias relativas (desses objetos), Strawson alega que Hume 'escreve como um realista ${ }^{409}$. Esta observação vai de encontro à convicção de que Hume dá a existência da causalidade objetiva por garantida, o que significa que acredita na mesma sem a questionar. Isto seria sinal, para Strawson, de que a aceitação de Hume era de caráter não argumentativo, ainda que defenda que Hume também a aceitava como filósofo, ao pressupô-la nos seus argumentos (como é visível nas citações céticas que Strawson enumera ${ }^{410}$ ).

Além disso, há uma segundo grupo de evidências textuais, referentes à inclusão dos Diálogos numa interpretação da teoria causal de Hume. Strawson julga inequívoco que, nos Diálogos, Fílon seja o porta-voz de Hume. Além disso, o mesmo autor, assim como Wright e Kail, encontram passagens na mesma obra que mostram que Hume coloca a hipótese de haver uma ordem na natureza (que seria aquilo em virtude do que as regularidades são tais como se apresentam), ou que rejeita a existência do acaso, privilegiando a crença na existência de uma ordem na natureza, ainda que não se possa saber que tipo de ordem é essa (por exemplo, se foi conferida por uma divindade ou simplesmente explicável por leis da Física). Alegadamente, nessas passagens, Hume não teria duvidado da existência de relações causais objetivas, ao mesmo tempo que se mantinha cético

\footnotetext{
${ }^{408}$ IEH 4.2.12; Cf. também T 1.3.14.6; T 1.3.5.2; T 1.3.14.22, 29; T 1.3.6.15; T 1.4.7.5; I 4.2.16; I 5.2.22; IEH 7.1.8; IEH 7.1.18; IEH 8.1.5; IEH 12.12

${ }^{409}$ Cf. STRAWSON, 1989, p. 52, 59, 60, 101, 128, 133, 137, 202, 203; COSTA, 1989, pp. 177-8.

${ }^{410}$ Cf. STRAWSON, 1989, pp. 59-60.
} 
quanto às possibilidades de se determinar as suas propriedades concretas desses objetos $^{411}$.

Um terceiro argumento textual de Strawson é contra a hipótese de que Hume poderia ser irónico nestas afirmações, ao que o comentador assere que é implausível pensar que um cético afirmaria peremptoriamente que os objetos da perceção não existem exterior e independentemente (da mente) ou que não existe causalidade objetiva. Porém, também se pode pensar que um cético não ignoraria a questão de saber se existe causalidade objetiva, assim como seria plausível que um realista afirmasse peremptoriamente que os objetos da perceção existem exterior e independentemente (da mente) e existe causalidade objetiva. A este propósito, Broughton levanta a suspeita, acerca deste ponto, de que caso Hume julgasse que nos podemos livrar destas crenças, tê-lo-ia dito na descrição que oferece dos filósofos, e tê-lo-ia deixado claro para si mesmo. Deste modo, a autora encara o silêncio acerca destas questões como indício de que Hume mantinha tais crenças são, nalgum sentido, irresistíveis e naturais, indispensáveis à vida quotidiana ${ }^{412}$.

Strawson ainda acrescenta um quarto argumento textual para apoiar a sua interpretação. No interior da filosofia de Hume, existem evidências textuais a favor do realismo, que jamais existiriam se Hume fosse um regularista. Por um lado, Strawson está convicto de que esta distinção se deve ao facto de que Hume encara a regularidade como evidência da causalidade objetiva ${ }^{413}$ :

Uma tal conjunção constante prova suficientemente que uma parte é a causa da outra. ${ }^{414}$

[J]amais somos sensíveis a nenhuma conexão entre causas e efeitos, e (...) é apenas por nossa experiência de sua conjunção constante que podemos alcançar um conhecimento dessa relação. $^{415}$

Strawson também afirma que a causalidade objetiva se 'mostra' ou se 'manifesta' na regularidade observável. Aliás, vários proponentes do realismo

\footnotetext{
${ }^{411}$ Cf. STRAWSON, 1989, p. 96; 2000, p. 37; WRIGHT, 2000, p. 97; KAIL, 2007b, pp. 99-100. Como esclareci na introdução deste trabalho, não pretendo tomar uma posição sobre a contribuição desta obra para uma interpretação da teoria causal de Hume.

${ }^{412}$ Cf. STRAWSON, 1989, p. 133; BROUGHTON, 2007, p. 204.

${ }^{413}$ Cf. STRAWSON, 1989, pp. 156-7.

${ }^{414} \mathrm{~T}$ 1.3.15.9.

${ }^{415}$ T 1.4.5.30. Cf. também T 1.1.1.8; T 1.3.15.1, 5; STRAWSON, 1989, p. 160.
} 
cético afirmam explicitamente que a regularidade observável constitui um efeito da causalidade objetiva. A este propósito, Broughton afirma que o facto de Hume observar, na introdução do Tratado, que apesar de as essências das mentes e dos objetos ser desconhecida, pode conhecer-se as suas propriedades e relações tais como a experiência as mostra, a saber, por meio de regularidades ou conjunções constantes. Broughton interpreta esta passagem como indicativo de que as regularidades são a parte das essências ${ }^{416}$ dos objetos que a mente pode compreender ${ }^{417}$.

Por outro lado, Hume parece estabelecer uma distinção entre 'relações causais' e 'operações da natureza'. Como bem descreve Millican, com esta distinção, Strawson procura chegar à conclusão de que Hume defendia um subjetivismo em relação à primeira e um realismo em relação aos segundos ${ }^{418}$.

Esta observação está relacionada com uma razão teórica (a primeira que aqui apresento) que é apresentada por Strawson. O comentador julga que a tensão que se pode pensar que há entre o facto de Hume limitar o acesso à causalidade aos seus aspetos observáveis e a convicção de que a causalidade ultrapassa esse campo se resolve se se prestar atenção, nos textos, à distinção entre a conexão necessária como relaão que se estabelece entre objetos e os poderes causais em si mesmos. Com isso, julga conseguir uma base textual para compatibilizar: i) a convicção de Hume na existência dos poderes causais; ii) o seu ceticismo em relação à sua natureza; iii) as duas definições de causalidade; iv) a insatisfação de Hume devido à sua imperfeição. Nesse sentido, as definições de causa que Hume apresenta seriam definições das operações da natureza tais como são apreendidas por meio dos princípios de associação.

De acordo com Strawson, pelas constatações (de Hume) de que a necessidade está apenas na mente e não nos objetos ${ }^{419}$, o subjetivismo em relação à conexão necessária consistiria na referência de Hume à necessidade ou conexão necessária como subjetiva (por contraste com o estatuto metafísico realista dos poderes causais), e o objetivismo dos poderes causais seria apoiado por pela

\footnotetext{
${ }^{416}$ Strawson utiliza o termo 'natureza', mas ambas parecem significar o mesmo: a totalidade daquilo que a coisa é, forçosamente e em si mesma.

${ }^{417}$ Cf. BROUGHTON, 1987, pp. 206-7, 234; STRAWSON, 1989, p. 119, 160, 175, 178; COSTA, 1989, p. 186.

${ }^{418}$ Cf. MILLICAN, 2007a, pp. 156-60.

${ }^{419}$ Cf. T 1.3.14.20, 22; I 7.2.28; STRAWSON, 1989, pp. 88-9.
} 
referência às operações da natureza como independentes do acesso que se pode ter às mesmas:

Quanto à afirmação de que as operações da natureza são independentes de nosso pensamento e raciocínio, eu o admito. $^{420}$

O comentador acrescenta ao seu argumento textual que aquela distinção se enquadra na conceção de causalidade a priori, tal que o seu contrário não é possível, cuja necessidade (do ponto de vista objetivo) é equivalente à da matemática. Acrescenta ainda o paralelo que Hume faz (no Tratado) entre a necessidade causal e da matemática, do que conclui imediatamente que ambas seriam subjetivas $^{421}$ :

[A]s the necessity, which makes two times two equal to four, or three angles of a triangle equal to two right ones, lies only in the act of the understanding, by which we consider and compare these ideas; in like manner the necessity or power, which unites causes and effects, lies in the determination of the mind to pass from the one to the other. The efficacy or energy of causes is neither plac'd in the causes themselves, nor in the deity, nor in the concurrence of these two principles; but belongs entirely to the soul, which considers the union of two or more objects in all casos passados. ${ }^{422}$

Millican comenta que esta estratégia é implausível, pois Hume refere-se repetidamente àquelas noções como sinónimas, tanto no Tratado como na primeira Investigação $o^{423}$. Porém, a meu ver, este comentário de Millican não é inteiramente justo, pois mesmo sendo verdade que, em certo sentido, Hume faz equivaler necessidade e causalidade - já que esta corresponde a uma das duas noções de necessidade que se pode identificar na filosofia do autor - também é

\footnotetext{
${ }^{420} \mathrm{~T}$ 1.3.14.28. Strawson comenta este tópico fazendo referência a Beauchamp e Rosenberg, que notam que "De facto, Hume afirma que '[q]uanto à afirmação de que as operações da natureza são independents de nosso pensamento e raciocínio, eu o admito' (...), mas não quer dizer, com isto, que relações causais sejam independents do pensamento". Tradução minha do original: "Hume does say that "As to what may be said, that the operations of nature are independent of our thought and reasoning, I allow it' (...); but he does not here say that causal relations are independent of thought" (cf. BEAUCHAMP \& ROSENBERG, 1981, p. 17; STRAWSON, 1989, p. 89). Apesar deste comentário, em virtude da sua interpretação anti-realista, os autores não retiram disto a conclusão que Strawson retira.

${ }^{421}$ T 1.3.14.23. Cf. STRAWSON, 1989, pp. 148-9.

${ }^{422} \mathrm{~T}$ 1.3.14.23. A mesma evidência textual é utilizada por Passmore para justificar a ideia de que Hume entendia que qualquer necessidade era subjetiva (cf. PASSMORE, 1968, pp. 19-20), ainda que não tenha sido uma tese que Hume fizesse questão de acentuar - já que o seu propósito era essencialmente o de fazê-lo em relação à necessidade causal.

${ }^{423}$ Cf. T 1.4.5.33; I 8.2.25; MILLICAN, 2007a, pp. 227-8.
} 
verdade que nem toda a necessidade é causal. Ainda assim, não tenho dúvida de que mesmo mantendo uma distinção entre a relação causal (que depende da mente, que a elabora) e as operações da natureza (o que neste caso equivale à causalidade em si mesma), essa distinção não torna Hume um realista (pois não implica uma convicção de Hume em relação à existência da causalidade objetiva) mas sim um cético.

Um quinto argumento textual é apresentado por Broughton, e consiste na constatação de que a preocupação de Hume ao propor a sua ciência da natureza humana é descobrir relações causais objetivas, ou seja, que consistem 'naquilo em virtude do que a regularidade é tal como se apresenta':

Nada é mais meticulosamente investigado pela mente humana que as causas de todos os fenômenos. E não nos contentamos em saber as causas imediatas; prosseguimos nossa busca até chegarmos ao princípio original e ultimo. Não queremos parar antes de conhecer, na causa, a energia que faz agir sobre seu efeito, o laço que os conecta, e a qualidade eficaz de que esse laço depende. Essa é nossa meta em todos os nossos estudos e reflexes. E como devemos ficar desapontados, quando descobrirmos que essa conexão, laço ou energia se encontra unicamente dentro de nós mesmos, e não é mais que a determinação da mente, adquirida pelo costume, que nos leva a fazer uma transição de um objeto àquele que usualmente o acompanha, e da impressão de um à idéia vívida do outro! ${ }^{424}$

Para Broughton, esta passagem mostra que apesar das limitações das faculdades humanas em compreender a causalidade objetiva, a investigação científica de Hume (da Ciência do Homem) pressupõe a crença na causalidade objetiva $^{425}$.

O sexto e último argumento contextual que julgo valer a pena ser apresentado consiste na defesa de que o realismo causal seria a posição que mais se adequa (para Costa), se não a única (para Strawson) ao ceticismo de Hume. Uma vez que já foi explicada, não será repetida nesta secção. Passo, assim, para a apresentação dos argumentos teóricos.

\footnotetext{
${ }^{424} \mathrm{~T}$ 1.4.7.5; itálico meu.

${ }^{425}$ Cf. BROUGHTON, 2007, pp. 205-8; WRIGHT, 1986, pp. 426-30. Monteiro também concorda com esta tese, num artigo posteriormente comentado por Wright, devido à sua posição anti-realista
} 


\section{Argumentos teóricos}

Diversos proponentes do realismo cético afirmam explicitamente que, para Hume, a crença na causalidade objetiva é natural ${ }^{426}$. Além disso, nenhum parece reclamar uma certeza sobre a existência da causalidade objetiva nem dos objetos da perceção, chegando mesmo a admitir que a respetiva crença é injustificada pela razão demonstrativa ${ }^{427}$. Porém, Wright, Broughton e Strawson apelam a uma justificação para acreditar nas mesmas, desvinculada do critério dedutivo para validação de raciocínios.

Ao fazer isso, estes intérpretes parecem estar cientes de que, como bem notou Kail, a crença generalizada no realismo causal e metafísico não pode ser equiparada à defesa filosófica do ceticismo (também causal e metafísico) a não ser que se satisfaça a condição de lhe oferecer uma justificação ${ }^{428}$. Caso contrário, será sempre encarada como uma espécie de deslize ou fraqueza epistémica em relação às conclusões da razão. Passo à apresentação dos seus argumentos.

Julgo que as observações de Hume sobre a origem da crença na existência exterior e independente (da mente) dos objetos da perceção, abordadas em 3.2.5, tornam claro de que forma os proponentes do realismo cético se convenceram de ter encontrado evidências textuais de que Hume defendia filosoficamente o realismo causal e metafísico. Particularmente, Wright e Broughton procuram tornar evidente a confluência das teses de Hume relativas à causalidade objetiva e à existência exterior e independente (da mente) dos objetos da perceção. O argumento foi inicialmente apresentado por Wright (1983 e 1986), e seguido por Broughton (2007).

Nesse sentido, a par das outras evidências que apresentei nas secções anteriores, Wright subsume as observações de Hume sobre esta última questão na interpretação geral de que o filósofo defendia o realismo causal e metafísico do

acerca da inferência causal no âmbito da investigação científica (cf. MONTEIRO, J. P., 1981; WRIGHT, 1986).

${ }^{426}$ Cf. WRIGHT, 1983, pp. 150-5; LIVINGSTON, 1984, p. 155, 161; COSTA, 1989, pp. 181-2; BROUGHTON, 2007, p. 199. Aliás, isto já era sabido para K. Smith (cf. SMITH, 1941, pp. 405$10)$.

${ }^{427}$ Cf. STRAWSON, 1989, p. 8, 100; COSTA, 1989, p. 174; BROUGHTON, 2007, p. 198. Cf. também STROUD, 1977, pp. 52-4.

${ }^{428}$ Cf. KAIL, 2007a, pp. 253-4. 
ponto de vista filosófico ou como uma conclusão, de alguma forma, justificada. Ao confluir a explicação para as duas crenças, a análise da relação entre Hume e a filosofia e o senso comum, apresentada pelo filósofo na secção em que explica a crença na existência exterior e independente (da mente) dos objetos da percepção, transforma-se explicitamente numa análise semelhante, relativa à crença na existência da causalidade objetiva. Passo a uma explicação detalhada do argumento.

Não é difícil entender este paralelo. Há duas hipóteses quanto à existência da causalidade objetiva: i) é uma propriedade dos objetos como identificados com as perceções (cenário idealista), do que se segue que a causalidade seria, de alguma forma, dependente da mente, pois as perceções existem apenas enquanto a mente as apreende (mesmo que não seja a sua causa); ii) é uma propriedade de objetos que existem exterior e independentemente da mente, do que se segue que esses objetos mantêm não apenas uma relação causal com as perceções, isto é, seriam a causa das perceções de que dispomos, como entre si, e essa relação causal seria o substrato das relações causais que a mente estabelece apenas pelo acesso à regularidade observável e estabelecimento de regras gerais com base na mesma. E uma vez que Hume acredita tanto na existência exterior e independente (da mente) como na causalidade objetiva, percebe-se que toma partido pela segunda hipótese.

No que respeita apenas à questão da existência da causalidade objetiva, Wright nota que no processo de busca pela origem das ideias já se exibe a noção de causalidade, o que julga que seria visível inclusivamente na análise da origem da ideia de causalidade, em que Hume aborda a mente como objeto natural e de conhecimento científico, isto é, apreensível por meio de regras gerais baseadas na observação de regularidades. Na sua interpretação, o cientista descobre (pela própria indagação das causas) que a mente está programada para responder de uma determinada forma a certos estímulos. Nesse sentido, as crenças nas relações causais e na causalidade objetiva explicar-se-iam pelo funcionamento simultâneo e cooperativo das faculdades dos sentidos, memória e imaginação.

Wright julga que ao explicar esta segunda crença como uma forma de superação das deficiências operativas ou funcionais da razão e dos sentidos (por si só) para gerá-la, por parte da imaginação, Hume integra-a no tratamento da mente sob o ponto de vista científico que previa para a própria Ciência do Homem - a 
partir da observação de conjunções constantes (por semelhança e contiguidade), a partir da qual se inferem regras gerais sobre o funcionamento do objeto em questão $^{429}$. Neste sentido, Wright subentende que a própria identificação, descrição e generalização dos mecanismos das faculdades da mente que engendram um determinado estado da mente constitui a sua justificação.

$\mathrm{Na}$ interpretação de Wright, a explicação para ambas as crenças é feita pela constatação empírica (a partir da observação) de que existem princípios naturais da mente que levam a tais crenças. Por sua vez, mais do que explicar ou facilitar esta crença ${ }^{430}$, tal processo conferiria justificação às mesmas devido à própria conceção de ciência empírica que Hume oferece - que deve estabelecer regularidades sobre o comportamento da mente, pois este é o escopo sob o qual os limites do conhecimento humano devem ser estabelecidos. Portanto, Wright entende que existem dois princípios da imaginação que concorrem para a geração desta suposição.

Com efeito, uma vez que a experiência apenas mostra a conjunção constante (por semelhança e contiguidade no espaço e no tempo), mas nunca a causalidade - definida o um poder que um objeto tem sobre a existência de outro. Por isso, a expectativa de que o futuro seja como fora o passado - a partir da 'propensão, produzida pelo costume, a passar de um objeto à idéia daquele que o acompanha usualmente ${ }^{431}$ - tem uma origem inteiramente subjetiva. Por isso, Wright nota que é necessário a Hume postular um princípio para além do hábito para explicar a origem da crença na causalidade objetiva, de tal forma que esta resultaria da conjunção do princípio do hábito com outra propensão, a saber:

[A] mente tem uma grande propensão a se espalhar pelos objetos externos, ligando a eles todas as impressões internas que eles ocasionam, e que sempre aparecem ao mesmo tempo que esses objetos se manifestam aos sentidos (...) [A] mesma propensão é a razão por que supomos que a necessidade e o poder se encontram nos objetos que observamos, e não na mente que os observa. ${ }^{432}$

Como se percebe na citação, Hume confirma explicitamente que esta propensão é a responsável pela suposição da existência da causalidade geral. Este

\footnotetext{
${ }^{429}$ Cf. WRIGHT, 1983, p. 151, 154; 1986, pp. 426-30.

${ }^{430}$ Cf. KAIL, 2007a, p. 261.

${ }^{431}$ Cf. T 1.3.14.22.
} 
aspeto da epistemologia de Hume é reconhecido por todos os proponentes da interpretação realista ${ }^{433}$. Entretanto, também é fácil concluir que Hume concordaria com a afirmação de Wright de que os princípios ou propensões que enunciou são, de facto, os responsáveis pela suposição da existência da causalidade objetiva, por três motivos.

Em primeiro lugar, há a evidência bibliográfica de que a secção em que Hume explica que o hábito é o princípio que auxilia o funcionamento dos princípios de associação (que aglomeram a experiência constante em regularidades observáveis) na inferência causal (concreta, isto é, relativa a regularidades observáveis específicas, como o fogo ou a queda de um objeto) é a mesma em que afirma a precedência da crença na existência da causalidade objetiva em relação à propensão da mente a espalhar-se nos objetos externos ${ }^{434}$. Em segundo lugar, parece fácil concluir que esta propensão necessita da concorrência do princípio do hábito (que atua sobre os princípios de associação) para que o cientista possa elaborar uma inferência causal sobre o próprio fenómeno da crença na existência da causalidade objetiva. Em terceiro lugar, parece ser uma questão lógica que a propensão da mente em espalhar-se pelos objetos externos atua requer um objeto sobre o qual atuar. Uma vez que se trata de relações causais, faz sentido que para explicar este processo, naturalmente, o processo de geração da inferência causal parece ser necessário.

Para apoiar a tese de que esta propensão produz crenças justificadas, Wright recorre à distinção que Hume apresenta entre dois tipos de princípios ou propensões da imaginação:

[D]evo fazer uma distinção, na imaginação, entre os princípios permanentes, irresistíveis e universais - tais como a transição costumeira das causas aos efeitos e dos efeitos às causas - e os princípios variáveis, fracos e irregulares (...). Os primeiros são o fundamento de todos os nossos pensamentos e ações, de tal forma que, se eliminados, a natureza humaan imediatamente pereceria e desapareceria. Os últimos não são nem inevitáveis à humanidade, nem necessários, ou sequer úteis para a condução da vida. ${ }^{435}$

\footnotetext{
${ }^{432} \mathrm{~T}$ 1.3.14.25.

${ }^{433}$ Cf. WRIGHT, 1983, pp. 151-2; 2007, p. 94; LIVINGSTON, 1984, p. 153; BROUGHTON, 2007, p. 200. Apesar de defender outra interpretação (projetivista e anti-realista), Stroud também o reconhece (cf. STROUD, 1977, p. 82, 87).

${ }^{434} \mathrm{~T} 1.3 .14$.

${ }^{435} \mathrm{~T}$ 1.4.4.1.
} 
Por sua vez, acerca dos princípios irregulares aos quais se refere nesta citação, Hume afirma:

A natureza humana possui uma notável inclinação a atribuir aos objetos externos as mesmas emoções que observa em si própria; e a enxergar em todo lugar aquelas idéias que lhe estão mais presentes. É verdade que essa inclinação se elimina por uma pequena reflexão, e só persiste nas crianças, nos poetas e nos filósofos antigos. Nas crianças, por exemplo, em seu desejo de bater nas pedras que as ferem; nos poetas, na facilidade com que personificam todas as coisas; e nos filósofos antigos, nessas ficções da simpatia e da antipatia. ${ }^{436}$

Wright e Kail entendem que Hume aceitava que a propensão da imaginação a estender-se aos objetos externos ${ }^{437}$ faz parte do grupo daquelas que o filósofo considera naturais, isto é, que definem a mente como objeto subsumível em regras gerais de uma ciência empírica. Por sua vez, o critério de justificação que Wright defende para as crenças na existência exterior e independente (da mente) dos objetos da perceção e da causalidade objetiva assenta nesta distinção entre dois tipos de princípios ou propensões da imaginação, tal que uma crença é justificada se resulta de um princípio ou propensão regular e constante da imaginação, e injustificada se não for este o caso.

Por seu turno, a revisão que o filósofo faz da crença do senso comum no realismo direto, aplicada à questão da existência da causalidade objetiva, consiste no abandono da convicção de que a relação causal que se estabelece entre os objetos (que existem exterior e independentemente da mente) é uma propriedade observável nos mesmos, isto é, à qual se tem acesso por meio da observação, e não apenas por uma convicção referente à sua existência ${ }^{438}$.

Os comentadores concordam que os falsos filósofos mantêm a crença na existência da causalidade objetiva, mas pretendem-se tanto livres da crença de que têm um acesso percetivo à causalidade (que o vulgo mantém, além daquela crença, devido à falta de consciência do seu caráter inevitável e natural) como

\footnotetext{
${ }^{436}$ T 1.4.3.11. Cf. WRIGHT, 1983, p. 154.

437 À qual, daqui em diante, me referirei pelo termo 'propensão projetiva' (que, aliás, K. Winkler também utiliza; cf. WINKLER, 1991, pp. 65-6).

${ }^{438}$ Cf. WRIGHT, 1986, p. 235; KAIL, 2007b, pp. 108-9.
} 
detentores de uma ideia adequada da causalidade objetiva. À primeira, Broughton chama de crença mínima, e à segunda, de crença máxima ${ }^{439}$.

Por sua vez, os verdadeiros filósofos assumem uma postura diferente da dos que Hume considera os falsos filósofos, em três aspetos. Em primeiro lugar, concordam com eles no abandono da crença do senso comum, mas apenas sob o ponto de vista da razão, ou seja, na medida em que reconhecem que apesar do seu caráter inevitável e natural, essa crença é falsa, pois não é possível um acesso aos objetos externos por meio da observação. Em segundo lugar, retornam à posição do senso comum por cederem à crença de que aquilo que percebem imediatamente são os objetos tais como são em si mesmos e constatarem a sua inevitabilidade. Em terceiro lugar, mantêm uma posição tão realista como cética: são céticos em relação à natureza da própria causalidade - pois reconhecem que não podem ter uma ideia adequada da mesma - e realistas em relação à conclusão da existência da causalidade objetiva - pois é justificada não porque se tem conhecimento da mesma (como pensam os falsos filósofos), mas porque essa convicção resulta de princípios naturais da mente ${ }^{440}$.

Nesse sentido, Broughton observa que a comparação que Hume faz entre estes filósofos a Sísifo e Tântalo sugere que a sua vida é um tormento justamente porque perpetuam a sua investigação mediante a conviç̧ão de que têm um acesso à causalidade objetiva. Com isto, a autora considera que os filósofos modernos têm o mérito de resistir àquela crença do vulgo (realismo direto). Por seu turno, os verdadeiros filósofos (que seriam realistas céticos) chegam à conclusão (justa) de que não se tem acesso percetivo aos aspetos causais dos objetos, e que estes se encontram apenas na mente. Contrariamente aos falsos filósofos, e devido ao reconhecimento dessa limitação epistémica, não perseguem o objetivo de aceder à causalidade objetiva, deixando de reconhecê-la como referência de uma ideia adequada. É apenas no sentido em que voltam a considerar as perceções como únicos objetos de ideias adequadas ${ }^{441}$ que voltam à situação do vulgo ${ }^{442}$.

\footnotetext{
${ }^{439}$ Cf. BROUGHTON, 2007, p. 199.

${ }^{440}$ Cf. WRIGHT, 1986, p. 236, 238.

${ }^{441}$ Porém, como ambos os autores reconhecem, tal não significa um completo regresso à situação epistémica do vulgo, pois aqueles não voltam a manter crenças máximas (que o vulgo mantém). Considerar isto seria inconsistente com a descrição do vulgo, dos verdadeiros e dos falsos filósofos, para além de sugerir que os falsos filósofos seriam mais sensatos do que aqueles, ao se desprenderem das crenças máximas. Antes, Broughton observa que o que Hume sugere é que o verdadeiro filósofo encara as questões causais com indulgência e indiferença não por (voltar a)
} 
Broughton pretende mostrar que não há evidências textuais decisivas para responder à questão de saber se Hume considerava a crença na existência da causalidade objetiva irresistível, mas que julgava que as crenças causais desempenham um papel indispensável na investigação científica, em virtude do caráter inevitável da crença na existência da causalidade objetiva. Neste sentido, observa que a crença na existência da causalidade objetiva é resistível na mesma medida em que a crença na existência exterior e independente (da mente) dos objetos da perceção o é, ou seja, apenas nos momentos em que se reflete sobre os limites do entendimento. Hume parece pensar que não é possível resistir a essas crenças por um longo período de tempo:

Felizmente ocorre que, sendo a razão incapaz de dissipar essas nuvens, a própria natureza o faz, e me cura dessa melancholia e delírio filosóficos, tornando mais branda essa inclinação da mente, ou então fornecendo-me alguma distração e alguma impressão sensível mais vívida, que apagam todas essas quimeras. Janto, jogo uma partida de gamão, converso e me alegro com meus amigos; após três ou quarto horas de diversão, quando quero retomar essas especulações, elas me parecem tão frias, forçadas e ridículas, que não me sinto mais disposto a levá-las adiante. ${ }^{443}$

A comentadora observa que se Hume pensa que as crenças mínimas são tão irresistíveis como naturais, então pensa que não conseguimos prosseguir a vida sob a crença contrária - de que as questões de facto são factos brutos, que não mantêm uma relação entre si. Antes, para a autora, Hume considera que a vida comum requer que se mantenha a crença de que os objetos possuem aspetos em virtude dos quais se explicam as regularidades observáveis, mesmo estando certos de que não sabemos que aspetos são esses ${ }^{444}$. Apesar disso, confessa que não está

julgar que tem acesso àqueles aspetos causais, mas por reconhecer a impossibilidade de conhecer algo acerca dessas relações (pela perceção ou outra forma; cf. BROUGHTON, 2007, p. 203). Por seu turno, Wright observa que é isto que Hume tem em mente quando considera que a posição do verdadeiro filósofo consiste nas "reflexões da vida ordinária, sistematizadas e corrigidas" (o que, exatamente, o distingue tanto do falso filósofo como do vulgo; cf. I 12.3.25; WRIGHT, 1986, pp. 419-20).

${ }^{442}$ Cf. T 1.4.2.32; BROUGHTON, 2007, pp. 202-3.

${ }^{443} \mathrm{~T}$ 1.4.7.9.

${ }^{444}$ Cf. BROUGHTON, 2007, p. 199. 
“tão pronta como John Wright para atribuir a Hume a posição de que a 'crença na objetividade da conexão necessária' é 'necessária à sobrevivência humana",445.

Tendo reconhecido anteriormente (com Wright) que o caráter natural da convicção na existência da causalidade objetiva se deve à sua origem na propensão projetiva ${ }^{446}$, no seu comentário ao autor, estende-se essencialmente numa análise explicativa da convicção na existência da causalidade objetiva a partir da propensão projetiva ${ }^{447}$, sem referir explicitamente se seria justificada sob um ponto não demonstrativo. Porém, não é evidente que Broughton esteja convicta da capacidade justificadora do processo pelo qual se forma a crença na existência da causalidade objetiva, como Wright afirma explicitamente estar.

Apesar disso, nos seus primeiros artigos, Broughton anuncia implicitamente uma afinidade com a tese de que a crença na existência da causalidade objetiva é justificada, afirmando, por exemplo, que o critério de razoabilidade de uma crença relativa a questões de facto assenta na qualidade de vida que ela proporciona, ao invés de uma evidência decisiva para a aceitar, ou que o ceticismo em relação à justificação demonstrativa do raciocínio causal não implica a impossibilidade de justificar a conclusão de que existe causalidade objetiva $^{448}$. Ainda assim, a ausência de referências a essa questão no artigo em que comenta (parecendo aceitar) o argumento de Wright pode sugerir que, eventualmente, Broughton alterou a sua visão acerca deste ponto (afinal, passaram mais de duas décadas desde que começara a desenvolver a sua interpretação realista da teoria causal de Hume - entre 1983 e 2007).

Porém, julgo que vale a pena considerar dois pontos da análise de Broughton. Por um lado, a autora nota que:

Para Hume, é natural, para nós, formar crenças na existência de aspetos causais nos objetos, apesar de pelo menos algumas

\footnotetext{
${ }^{445}$ Tradução minha do original: "as ready as John Wright is to attribute to Hume the view that the 'belief in the objectivity of necessary connection' is 'required for human survival"" (BROUGHTON, 2007, p. 204).

${ }^{446}$ Cf. BROUGHTON, 1987, p. 235.

${ }^{447}$ Apesar de esta explicação é pertinente, será mais longamente abordada no último capítulo do presente trabalho, a propósito do papel da propensão projetiva na teoria dos juízos de Hume, de acordo com na interpretação que proponho.

${ }^{448}$ Cf. BROUGHTON, 1983, p. 14; 1987, p. 243.
} 
destas crenças poderem ser tais que a reflexão nos permite descartar. ${ }^{449}$

A meu ver, a expressão que coloquei em itálico sugere que a autora não descarta a hipótese de uma justificação não demonstrativa - eventualmente, ligada à qualidade de vida, que menciona em 1983. A meu ver, devido à constatação da naturalidade da propensão projetiva e a atenção que dedica, no artigo de 2007, a uma explicação de como a mesma funciona e à afirmação da autora de que a crença na existência da causalidade objetiva pode ser considerada indispensável a um tipo de vida que seria humano, pode pensar-se que a noção de qualidade de vida parece estar ligada ao funcionamento regular das faculdades ${ }^{450}$, ainda que suspensão dos princípios ou propensões em questão não comprometa a sobrevivência do agente.

Por outro lado, devido a este fator de discordância entre Broughton e Wright, julgo igualmente plausível pensar que justamente o facto de não comentar nada sobre uma mudança em relação à justificação da crença em questão indica que a autora manteve uma posição favorável àquela. Afinal, se a tivesse revisto, porque não declará-lo? Pode pensar-se exatamente o mesmo de Wright, que também deixa de referir a questão da justificação em 2000, apesar de não negar o seu argumento, apresentado na obra de 1983, o que tanto pode significar que reviu a sua posição, como que não a abandonou.

Ainda assim, vale notar que o argumento de Wright - eventualmente, também aceite por Broughton - subentende que a naturalidade dos princípios da mente constitui uma fonte fiável de uma crença, de tal forma que mesmo contradizendo as conclusões dos sentidos e da razão, a crença na existência da causalidade objetiva possa ser justificada por princípios tão naturais como aqueles pelos quais operam aquelas faculdades. Nesse sentido, Wright subsume a própria faculdade racional na vasta gama de faculdades naturais da mente. E uma vez que

\footnotetext{
${ }^{449}$ Tradução minha do original: "[F]or Hume, it is natural for us to form beliefs in the existence of causative features in objects, although at least some of these beliefs may be ones that reflection allows us to jettison" (BROUGHTON, 2007, p. 198; itálico meu).

${ }^{450}$ BROUGHTON, 2007, p. 204. A meu ver, é plausível pensar que até mesmo Hume poderia aceitar uma noção de qualidade de vida para o tipo de agentes cognitivos que somos. Algumas pistas que parecem ir nesse sentido são a constatação de Hume de que a busca pelo conhecimento científico (empírico) é motivado por um interesse, ou movido pela paixão do amor à verdade (cf. T 2.3.10.4, 11, 12), ou que o seguimento mais natural das tendências da faculdade da imaginação
} 
todas parecem ser consideradas em paralelo - pois todas possuem a característica de serem naturais e de o seu funcionamento gerar crenças -, a conclusão da razão não se pode sobrepor à da imaginação, desde que se tratem de resultados da atuação dos seus princípios regulares, permanentes e irresistíveis. Essa impossibilidade se deve à primazia do plano natural sobre o demonstrativo (no sentido de racionalidade dedutiva), de tal forma que toda a análise da questão da causalidade é interpretada como exercício de investigação científica - e os seus conteúdos, resultados que pertencem a uma certa ciência empírica ${ }^{451}$.

Passo agora ao argumento de Strawson. À apresentação das evidências textuais que julga suficientes para mostrar que Hume aceitava a distinção entre i) 'conexão necessária' e a regularidade observável (subjetivas) e ii) os poderes causais e as 'operações da natureza' (objetivos), soma-se a sua convicção de que Hume julga plausivel aceitar a existência da causalidade objetiva com base na observação da regularidade.

Convicto de que o que distingue as duas hipóteses é que o realismo é plausível, e o anti-realismo, implausível ${ }^{452}$. Para forçar a aceitação do realismo, e que poderia estar por trás da sua aceitação da parte de Hume, não fosse esta dogmática, que é como se segue:

i) tem de se aceitar que I) algo existe, logo, é necessário ser-se realista nalgum sentido;

ii) se se aceita que I) algo existe, então, a única coisa que se tem de aceitar para se estar racional, ou mesmo logicamente justificado a postular a causalidade objetiva é que II) nalgum sentido, a realidade cuja existência se admite é altamente regular;

iii) se se aceita isto, então há razão para supor que III) existe alguma razão pela qual a realidade é regular (qualquer que seja o grau de exatidão com que se concebe essa realidade).

provoca um prazer sensível à mente (cf. $\mathrm{T}$ 1.4.2.37), o que sugere que o seu contrário eventualmente lhe traz um desconforto ou desagrado.

${ }^{451}$ Neste caso, a mais geral de todas, a saber, a Ciência do Homem, que visa explicar os processos pelos quais a mente funciona em diversos domínios. Cada ciência que a compõe trata de um objeto distinto, mas a sua investigação é levada a cabo pelo único método ou critério que Hume julga fiável, a saber, a experiência ou observação (T 0.7). Neste sentido, a tese de Wright está de acordo com a consideração de Hume de que, em certo sentido, nem mesmo a lógica escapa a esta investigação empírica, enquanto ciência que explica o funcionamento da faculdade da razão (responsável pelos raciocínios causais e demonstrativos; cf. T 0.5). 
Com este argumento, Strawson pretende defender que: A) é razoável supor, de forma não específica, que há algo na natureza - diferente da própria regularidade - em virtude do qual ela o é, e B) é, em todo o caso, irrazoável negar dogmaticamente que há algo em virtude do qual a regularidade é tal como é ${ }^{453}$.

Noutras palavras, a conclusão do argumento de Strawson é que há razões para postular uma causalidade objetiva (A) e não há razões para não postulá-la (B). Ainda assim, o comentador alerta que o caráter mais razoável ou plausível da hipótese realista assenta numa maior probabilidade - pois nos Diálogos, Hume considera ambas igualmente prováveis ${ }^{454}$.

Pela leitura atenta do argumento, parece-me que Strawson quer dizer que uma vez que não há acesso à causalidade em si mesma, apenas se pode concluir a sua existência (ou não) a partir de indicativos pela observação, e uma vez que os objetos sobre os quais se elaboram raciocínios causais se apresentam de forma regular, entre as duas hipóteses, é plausível seguir a inclinação que está de acordo com a observação. Porém, além da óbvia acusação de circularidade da parte de Winkler e Millican ${ }^{455}$, o argumento que desenvolvo no próximo capítulo mostrará que tanto este tipo de argumento, como o que Wright e Broughton apresentaram para tentar conferir alguma justificação à crença na existência da causalidade objetiva - para legitimar a sua defesa filosófica - são vãos.

Por seu turno, em relação à contribuição de Kail para a justificação da interpretação do realismo cético, além da restrição do PP a ideias adequadas, Kail apela à distinção de princípios da imaginação para explicar a inoperatividade de certas conclusões da razão: as inferências causais são explicadas por princípios estáveis ou permanentes da imaginação, o que facilita que a assunção objetivista sobreviva a reflexões céticas. Porém, isto não chega para explicá-la totalmente. A meu ver, a única explicação que se poderia dar seria incluir a propensão projetiva nos princípios gerais da imaginação - apesar de esta consideração ultrapassar as palavras de Hume tanto sobre a propensão projetiva como sobre os princípios da imaginação.

\footnotetext{
${ }^{452}$ Cf. STRAWSON, 1989, p. 5, 10, 15, 23, 30, 91, 95, 96, 98.

${ }^{453}$ Cf. STRAWSON, 1989, p. 203-5; itálicos meus.

${ }^{454}$ Cf. STRAWSON, 1989, p. 96.

${ }^{455}$ Cf. 2.2.1 deste trabalho.
} 
Para o comentador, para se considerar Hume um realista, não se deve entender o realismo num sentido mais forte que o necessário. Para o comentador, não é necessário assumir mais do que i) a sua filosofia permite a conclusão de que a existência da causalidade objetiva e dos objetos da perceção (externos e exteriores à mente) é possível e ii) Hume mostra uma preferência pela tese da existência em detrimento da não existência destes ${ }^{456}$.

Kail defende que assentando na própria conclusão cética, esta preferência não prestaria qualquer função na vida prática, não constituindo sequer uma crença, mas uma assunção, suposição, algo que é presumido, justamente por isso: crenças tendem a guiar o comportamento de alguma forma, que as assunções não ${ }^{457}$ :

O realismo, concebido como anti-reducionismo em relação a significado e conteúdo, não apenas é compatível com o ceticismo, mas parece requirê-lo: uma grande ironia para aqueles que podem objetar às interpretações realistas de Hume por um apelo grosseiro ao ceticismo. ${ }^{458}$

A preferência minimal pelo realismo é simplesmente a preferência por aquilo que a posição metafísica que a nossa razão e propensões naturais nos trazem: a razão sugere agnosticismo, mas este é ultrapassado pelas propensões naturais. ${ }^{459}$

Pode parecer que no que toca à restrição do PP às ideias adequadas, esta proposta de Kail é apresentada como resposta a uma objeção que só poderia ser formulada por um adversário da interpretação realista que aceitasse que o PP consiste na forma de bicondicional, e que a sua proposta de conciliação do ceticismo com o realismo cético e a consideração de que o realismo seria o que chama de preferência metafísica parecem responder a um adversário que pudesse defender que esse princípio não pode ser mais que um condicional ${ }^{460}$. Porém, esta forma de apresentar a proposta tem um elemento artificial, pois é Kail que se coloca na posição de responder àquela objeção.

\footnotetext{
${ }^{456}$ Cf. KAIL, 2007a, p. 261.

${ }^{457}$ Apesar disso, a ideia de que a causalidade é percetível continua a ser um erro gerado pela propensão projetiva - tópico em que concorda com Stroud (cf. KAIL, 2007a, p. 262).

${ }_{458}$ Tradução minha do original: "Realism construed as anti-reducionism regarding meaning and content is not only compatible with scepticism but appears to require it: a great irony for those who might object to realist readings of Hume by a blunt appeal to skepticism.” (KAIL, 2007a, p. 255).

${ }^{459}$ Tradução minha do original: "The minimal preference for realism is simply a preference for what metaphysical position the combination of our natural propensities and reason delivers: reason suggests agnosticism but that is trumped by the natural propensities." (KAIL, 2007a, p. 261-2).

${ }^{460}$ Cf. 1.3 deste trabalho.
} 
Kail parte de uma assunção equívoca em relação ao seu possível adversário, como se os seus opositores fossem apenas os anti-realistas, ou como se fingisse que os céticos não estão entre eles. O comentador especula que a objeção que se poderia fazer à sua posição seria que não sendo o caso de não podermos conceber uma necessidade tal que a causa seja inconcebível sem o efeito e cognoscível a priori, não é possível essa necessidade.

Mas não se está a dizer que é impossível. Só é assim se se aceitar que o PP é um bicondicional - portanto, se além de se aceitar que o que é concebível é possível, se aceitar também que o que não é concebível é impossível. Na secção 4.6, procurarei mostrar que este princípio não deve ser interpretado desta forma. $\mathrm{O}$ problema da sua posição é que em vez de se ficar pelo reconhecimento de que é impossível determinar a existência e configuração do que está para além do campo fenoménico ou percetivo, avança para uma tentativa de justificar a posição realista na simples possibilidade da existência de algo além desse campo, e na assunção de que se está autorizado (pela natureza) a acreditar na existência desses objetos além do campo percetivo.

\subsubsection{Crítica ao realismo cético}

Nesta secção, procuro fazer algumas considerações críticas às interpretações anti-realista e realista da teoria causal de Hume.

Em relação à rejeição da interpretação do realismo cético, começo por refutar o argumento (teórico) de Wright para justificar a crença na existência da causalidade objetiva, passando, depois disso, à consideração dos argumentos apresentados por outros proponentes da interpretação (designadamente, Strawson e Kail). As razões disso são que o argumento de Wright é mais sólido que os restantes, mas também que as evidências textuais apresentadas (principalmente por Strawson e Broughton) podem ser interpretadas sob a minha proposta alternativa. 
$\mathrm{O}$ argumento de Wright não parece ter recebido atenção em toda a historiografia sobre Hume (pelo menos, a anglo-saxónica) ${ }^{461}$. O meu segundo propósito na presente secção é ocupar-me deste argumento, nos parágrafos que se seguem, com o objetivo de o invalidar pela apresentação de evidências textuais que apontam para uma interpretação que julgo oferecer uma maior coerência interna à epistemologia de Hume.

$\mathrm{O}$ argumento de Wright parece ser imune à objeção de que não existe, na epistemologia de Hume, nenhum critério ligado a padrões de racionalidade teórica (referente às possibilidades de se obter conhecimento) para essa crença (da qual, aliás, se vê que Kail procura desenvencilhar-se ao propor que o realismo cético seria uma preferência metafísica, irrelevante do ponto de vista epistémico, científico e pragmático ${ }^{462}$. Além disso, Wright parece estar certo ao afirmar que toda a investigação de Hume acerca da origem da ideia de causalidade é levada a cabo como investigação científica e sob o critério de cientificidade que Hume propõe para a Ciência do Homem, a saber, a regularidade observável. Porém, as estranhezas que se identificam na próxima seção, a partir de certos elementos dos textos de Hume, levam-nos à interpretação de que essa crença pode ser explicada (do ponto de vista científico, pela explicação dos processos da mente que levam à mesma), mas nunca justificada racionalmente.

Relembro que o argumento de Wright consiste em considerar que em razão da sua capacidade de produzir crenças gerais em todos os agentes cognitivos (humanos), os princípios da mente que são regulares, permanentes e irresistíveis são capazes de oferecer ou produzir crenças justificadas, e que uma vez que a fonte da crença na existência de uma causalidade objetiva é um desses princípios, esta crença é uma delas. Portanto, mesmo contradizendo as conclusões dos sentidos e da razão, a crença na existência da causalidade objetiva é justificada por princípios tão naturais como aqueles pelos quais operam aquelas faculdades.

\footnotetext{
${ }^{461}$ Uma proposta recente de rejeição do realismo cético é a de J. Hakkarainen. Porém, a sua leitura ignora o argumento de Wright que é aqui comentado, assim como a possibilidade de a própria regularidade observável servir como possível critério de justificação de crenças naturais, perpetuando uma primazia da razão dedutiva sobre a probabilística. Portanto, Hakkarainen não enfrenta a consequência do argumento de Wright, a saber, a de que a própria proposta da Ciência do Homem pode trazer consigo um critério de justificação de crenças que não podem ser justificadas pela razão nem pelos sentidos (cf. HAKKARAINEN, 2012a e 2012b). No que respeita à questão da existência da causalidade objetiva, esta consequência parece não ter sido encarada na literatura de comentário.
} 
Neste sentido, Wright subsume as duas formas de razão (dedutiva e empírica) na vasta gama de faculdades naturais da mente, asseverando que todas devem ser consideradas em paralelo, em virtude de possuírem igualmente a característica de serem naturais, e de o seu funcionamento gerar crenças. Segundo o comentador, toda a análise da origem de crenças (sejam elas quais forem) deve ser interpretada como exercício de investigação científica por parte de Hume, e os seus conteúdos, como resultados que pertencem a uma certa ciência empírica ${ }^{463}$. Deste modo, faz subsumir toda a análise filosófica do escocês em mais um exercício da razão empírica, responsável pela própria edificação da Ciência do Homem, sobrepondo-se, inclusive, ao emprego de uma racionalidade demonstrativa (dedutiva). O mesmo critério pelo qual se podem justificar raciocínios causais - a regularidade na observação - é aplicado a toda a mente e as suas faculdades para justificar todo e qualquer resultado das suas operações, sendo empregue de forma dupla. Com este argumento, Wright julga ter ido ir além da constatação de que Hume acreditava na existência de uma causalidade objetiva, tendo (aparentemente) oferecido uma justificação racional para o realismo causal.

Porém, existem, na epistemologia do filósofo, elementos que invalidam a pretensão de Wright, e, com isso, também o único argumento robusto que os proponentes do realismo cético apresentaram para defender que a crença na existência da causalidade objetiva seria racionalmente justificada. Se se puser em prática o propósito de Wright de subsumir a crença na existência de uma causalidade objetiva ao critério de justificação de raciocínios causais (a regularidade da observação), percebe-se que a relação entre as crenças em relações causais concretas e a faculdade responsável pelas mesmas é diferente da relação entre esta faculdade e a crença na existência da causalidade objetiva.

De acordo com a interpretação que proponho, deve concluir-se disto que não é possível aplicar o critério da regularidade da observação à crença na existência da causalidade objetiva para defender a sua justificação. Neste sentido,

\footnotetext{
${ }^{462}$ Cf. KAIL, 2007a, pp. 261-2.

${ }^{463}$ Neste caso, a mais geral de todas, a saber, a Ciência do Homem, que visa explicar os processos pelos quais a mente funciona em diversos domínios. Cada ciência que a compõe trata de um objeto distinto, mas a sua investigação é levada a cabo pelo único método ou critério que Hume julga fiável, a saber, a experiência ou observação (T 0.7). Neste sentido, a tese de Wright está de acordo com a consideração de Hume de que, em certo sentido, nem mesmo a lógica escapa a esta investigação empírica, enquanto ciência que explica o funcionamento da faculdade da razão (responsável pelos raciocínios causais e demonstrativos; cf. T 0.5).
} 
procuro mostrar que a crença na existência da causalidade objetiva está para além das possibilidades de justificação racional que a epistemologia de Hume oferece. Isto significa que essa crença não deve ser considerada racionalmente justificada nem injustificada, mas sim impassível de uma justificação racional. Parece tratarse de uma crença que - possivelmente, a par da crença na existência exterior e independente (da mente) dos objetos da percepção - confere uma espécie de pano de fundo a outras crenças e que, combinada com estas, configura uma rede ou emaranhado de crenças em relação a questões de fato. Esta crença deve ser considerada anterior ao plano em que é possível justificar crenças - o da racionalidade - e independente do mesmo. A razão disto é que nem o critério da regularidade nem o demonstrativo parecem oferecer uma justificação à crença na existência de uma causalidade objetiva, e estes são os únicos critérios de justificação de crenças de que a epistemologia de Hume dispõe.

A meu ver, há cinco elementos da epistemologia de Hume que julgo relevantes para esta conclusão.

Em primeiro lugar, Hume concede dois sentidos de razão e de verdade, delimitando o campo da racionalidade àquele em que se pode estabelecer um acordo ou desacordo entre ideias e impressões, ou ideias entre $\mathrm{si}^{464}$. De acordo com esta divisão, só existem duas formas de algo ser verdadeiro e justificado pela razão, a saber, mediante o acordo entre ideias no interior das duas formas de conhecimento possíveis: demonstração (de relações de ideias) e conhecimento das causas (de questões de fato). Hume termina a citação afirmando que este é o domínio da verdade e da racionalidade.

Por sua vez, este domínio parece ser aquele em que é possível formular raciocínios e parece identificar-se com aquele em que se estabelecem relações filosóficas ${ }^{465}$. Em particular, Hume ainda acrescenta que "a relação de causa e efeito é (...) a sétima espécie de relação filosófica, além de ser também uma relação natural"466, isto é, pode ser estabelecida de forma mais ou menos voluntária ou intencional, ou pode consistir na simples presença de dois objetos associados entre si (em que um é causa do outro). Hume considera ainda que:

\footnotetext{
${ }^{464}$ Cf. T 1.3.1.1; T 2.3.10.2; $\mathrm{T} 3.1 .1 .9 ; 1.14$ do presente trabalho.

${ }^{465}$ Cf. 1.4 deste trabalho, para as definições de relação e de raciocínio.

${ }^{466} \mathrm{~T}$ 1.1.5.9; assim como a de semelhança.
} 
[E]mbora a causalidade seja uma relação filosófica (...), é apenas enquanto ela é uma relação natural, produzindo uma união entre nossas idéias, que somos capazes de raciocinar ou fazer qualquer inferência a partir dela. ${ }^{467}$

Em segundo lugar, ao esclarecer que o entendimento não pode ser considerado a origem da crença na existência exterior e independente dos objetos da perceção, Hume mostra que esta faculdade não ultrapassa o plano da experiência ou observação:

[C]omo nada jamais está realmente presente à mente além de suas percepções, é impossível não apenas adquirirmos um hábito de outra forma que não seja pela sucessão regular dessas percepções, como também que qualquer hábito jamais exceda tal grau de regularidade. Por conseguinte, nenhum grau de regularidade em nossas percepções pode jamais servir de fundamento para inferirmos um grau maior de regularidade em alguns objetos que não percebemos; isso suporia uma contradição, a saber, um hábito adquirido de algo que nunca esteve presente à mente. (...) $\mathrm{O}$ que supomos neste caso, portanto, se não que esses objetos mantêm uma conexão usual apesar de sua aparente descontinuidade, e que as aparições irregulares são unidas por alguma coisa a que somos insensíveis? Mas como nossos raciocínios sobre questões de facto surgem unicamente do costume, e como o costume só pode resultar de percepções repetidas, a extensão do costume e do raciocínio para além das percepções nunca poderia ser um efeito direto e natural da repetição e da conexão constantes, devendo antes, surgir da cooperação de alguns outros princípios. $^{468}$

Em terceiro lugar, além de Hume afirmar que os sentidos jamais colocam a mente em contacto com a causalidade para além da regularidade observável ${ }^{469}$, também afirma que os sentidos não a colocam em contacto com o que subjaz à perceção - o objeto não percebido, tal como é em si mesmo:

\footnotetext{
${ }^{467} \mathrm{~T}$ 1.3.6.16.

${ }^{468} \mathrm{~T}$ 1.4.2.21. Esta é uma das razões textuais pelas quais se deve concluir que o raciocínio possui uma componente estritamente fenoménica, no sentido de dizer respeito essencialmente à repetição de regularidades do passado no futuro. Estas evidências são consistentes com dois momentos importantes da teoria causal de Hume, em que se refere a mais do que uma instância fenoménica na descoberta de relações causai, mostrando um certo desprendimento em relação à questão do estatuto metafísico das relações causais a serem descobertas. A primeira é que na sua explicação da origem da ideia de causalidade, ao explicar que o raciocínio causal seria empírica ou dedutivamente justificado se o princípio de que o futuro será como fora o passado (cf. T 1.3.6.5, 6$7,10)$ Hume não faz nenhuma menção ao estatuto metafísico (externo e independente da mente) desse futuro e desse passado. A segunda é a seção em que Hume apresenta as regras gerais para julgar causas e efeitos (cf. T 1.3.15) simplesmente como diretrizes para avaliar regularidades observáveis, não fazendo qualquer referência ao estatuto metafísico da causalidade.

${ }^{469}$ Cf. T 1.3; I 4, 7.
} 
[Os sentidos] são incapazes de dar origem à noção da existência contínua de seus objetos quando estes não mais aparecem a elas. Isso seria uma contradição em termos; seria supor que os sentidos continuam a operar, mesmo após terem cessado qualquer tipo de operação. (...) [T]udo o que eles nos transmitem é uma percepção singular, e jamais nos dão a menor indicação de algo além dela. ${ }^{470}$

Em quarto e último lugar, Hume julga ser impossível obter uma certeza relativamente à eventual semelhança entre percepções e objetos (que, apesar disso, supomos $^{471}$ ):

[C]omo podemos supor, mas nunca conceber uma diferença específica entre um objeto e uma impressão, jamais poderemos saber com certeza se as conclusões que formamos a respeito da conexão ou incompatibilidade entre impressões pode ser aplicada aos objetos; em contrapartida, qualquer que seja a conclusão que a esse respeito formemos acerca dos objetos, ela será com toda certeza aplicável às impressões. A razão disso não é difícil de se entender. Como se supõe que um objeto é diferente de uma impressão, não podemos ter certeza de que a circunstância sobre a qual fundamos nosso raciocínio é comum a ambos, supondo que formemos esse raciocínio partindo da impressão. Ou seja, é sempre possível que o objeto seja diferente da impressão quanto a essa circunstância particular. ${ }^{472}$

É uma questão de fato se as percepções dos sentidos são produzidas por objetos externos a elas assemelhados - como se decidirá essa questão? Pela experiência, certamente, como no caso de todas as outras questões de mesma natureza. Mas aqui a natureza permanence - e tem de permanecer - inteiramente calada. Nada está jamais presente à mente senão as percepções, e ela não tem como alcançar qualquer experiência da conexão destas com objetos. A hipótese dessa conexão não tem, portanto, nenhum fundamento no raciocínio. ${ }^{473}$

Portanto, apesar de ser uma questão de facto se os objetos tal como são em si mesmos, para além do campo da perceção, existem ou não ${ }^{474}$ - do que se pode pensar que a causalidade está incluída neste campo como propriedade destes objetos enquanto relacionados uns com os outros, pois estes podem e, na verdade, acredita-se, de fato, que possuem esta propriedade -, não há a garantia de uma

\footnotetext{
${ }^{470} \mathrm{~T} 1.4 .2 .3,4$.

471 1.4.2.54.

${ }^{472}$ T 1.4.5.20; itálico meu.

${ }^{473}$ IEH 12.1.12; itálico meu.

${ }^{474}$ Cf. I 12.1.12.
} 
correspondência entre estes objetos e uma sensação. Tal ocorre porque se trata de uma suposição e não de uma ideia adequada ${ }^{475}$.

A última evidência textual apresentada assevera a impossibilidade de uma certeza sobre o que ultrapassa o campo da experiência sensível tanto pelos sentidos, como pelo entendimento e pela razão demonstrativa. É sabido que Hume utiliza o Princípio de Possibilidade para mostrar que não se está perante um caso de necessidade no sentido lógico (das relações entre objetos abstratos, que obedecem ao princípio de contradição). Em particular, em relação a esta, pode dizer-se que a sua operatividade se limita ao campo da Álgebra e da Aritmética, em relação a questões de facto. Além disso, as operações desta última não permitem uma descoberta além da constatação de que a priori, qualquer coisa pode ser causa de qualquer coisa ${ }^{476}$ - conclusão que se estende à existência ou não de objetos externos ${ }^{477}$. Portanto, pode pensar-se que em relação à existência da causalidade objetiva, a sua operatividade se restringe ao mesmo tipo de constatação, a saber, de duas possibilidades interexcludentes, afinal, ela não oferece mais razões para acreditar mais numa do que noutra. Isto leva-nos à questão de saber se, eventualmente, esta crença poderia ser considerada injustificada - conclusão que, para descontentamento de Wright, seria resultado de um raciocínio demonstrativo.

Porém, a não ser que se defenda a interpretação Reid-Green ou que Hume seria um teórico do erro, pode pensar-se - a partir das sugestões de P. Stanley que a razão demonstrativa se revela incapaz de oferecer meios ou pistas no sentido de tornar uma crença relativa a objetos fora do seu escopo mais justificada que outra. De resto, não faz parte do propósito deste trabalho discutir se Hume privilegiava a validade dedutiva como critério de justificação de raciocínios - o que tornaria legítimo considerar que, do ponto de vista da razão demonstrativa, a crença na existência da causalidade objetiva (além do próprio raciocínio causal) é injustificada. Ao invés, assumo como pressuposto, como possível resposta a este problema, o ponto de vista de Stanley de que o critério de justificação para cada tipo de raciocínio cabe à própria faculdade responsável pelo mesmo, ainda que a

\footnotetext{
${ }^{475}$ Ao contrário de Flage, não acho que dizer que se trata de algo diferente de uma perceção significa negar a semelhança que eventualmente se mantém entre as ideias e os objetos (que eventualmente se relacionam causalmente; cf. FLAGE, 2007, p. 146).

${ }^{476}$ Cf. T 1.3.6.1, 1.3.15.1, 1.4.5.30.
} 
tentativa de aplicar os critérios de justificação e correção de raciocínios demonstrativos (que obedecem ao princípio de contradição) a raciocínios causais resulte num ceticismo ${ }^{478}$.

Recapitulando: com o primeiro conjunto de evidências, visava-se mostrar que na epistemologia de Hume existem dois tipos de raciocínio, definidos pelo emprego das relações filosóficas e que formam, por isso, dois planos de racionalidade distintos: o demonstrativo e o causal ou empírico. Por seu turno, a segunda, a terceira e a quarta evidências mostram os limites das faculdades dos sentidos, do entendimento e da razão demonstrativa em relação à determinação do que está para além do campo das possibilidades desses dois tipos de raciocínio. Isto é, o que está para além do campo da percepção: nenhuma dessas faculdades dá à mente um acesso ao que subjaz ao plano fenoménico. Talvez a incapacidade de a razão demonstrativa mostrar uma certeza relativa à existência deste plano seja ligeiramente mais obscura que a dos sentidos e do entendimento, pelo que esperamos que a explicação que demos o tenha clarificado.

Há três fatores que, sinalizando uma inadequação do objeto em questão - a existência da causalidade objetiva - a um tratamento científico da respetiva crença, tornam a interpretação de Wright que aqui se analisa estranha.

O primeiro é a ausência de evidências, nos textos de Hume, de que há uma passagem entre uma fase em que se raciocina sobre regularidades do passado e do futuro (e em que se espera a repetição daquele neste) para uma outra fase, em que para além disso, se acreditaria que há algo objetivo (que não é criado pela mente, mas faz parte dos próprios objetos) em virtude do qual essas regularidades existem ou se apresentam.

O segundo é que a reunião destas evidências justifica a conclusão de que a assunção da existência da causalidade objetiva não parece encaixar-se no escopo dos domínios a que Hume se refere na citação que apresentei ${ }^{479}$ : da verdade, da racionalidade e da justificação racional (nas suas duas formas).

O terceiro e último é que se o plano da racionalidade está restrito àquele em que se empregam relações fillosóficas e se todas as relações filosóficas se baseiam em relações naturais, ou seja, que estas são anteriores àquelas, pode

\footnotetext{
${ }^{477}$ Cf. T 1.4.2.42.

${ }^{478}$ Cf. STANLEY, 1935, pp. 427-8.
} 
concluir-se que o campo das relações naturais fornece uma espécie de base não racional para o próprio campo da racionalidade. Além disso, a propensão da mente a "espalhar-se" pelos objetos não é incluída nos princípios que engendram relações filosóficas (raciocínios). É verdade que também não são incluídos nos princípios que explicam as relações naturais. Apesar disso, nada na epistemologia de Hume parece constituir impedimento a interpretá-la assim.

Principalmente ao longo do primeiro livro do Tratado, Hume parece explicar os diversos processos mentais e convicções da mente, constatados a partir da observação, sem mostrar convicção de que o processo pelo qual se gera a crença na ou suposição da existência da causalidade objetiva seja posterior ao processo pelo qual se geram inferências causais. É certo que o contrário não seria possível, uma vez que o princípio do hábito (responsável pela expectativa da repetição do passado no futuro) é o princípio com o qual atua a propensão da mente a estender-se pelos objetos. Porém, a sua anterioridade em relação a este parece ser apenas lógica, e não temporal.

A reivindicação de Wright não é coerente nem com o conjunto de evidências que foram apresentadas nem com a própria experiência que se tem de elaborar raciocínios causais, enquanto referentes a um (suposto) poder intrínseco dos objetos da experiência. Ao recorrer ao critério da regularidade na observação (pelo qual se pode considerar um raciocínio causal um conhecimento) para justificar a convicção na existência da causalidade objetiva, o comentador trata o seu objeto (a alegada causalidade objetiva) como se a continuidade da experiência tornasse a sua existência tornasse mais provável. Um objeto de um raciocínio causal é considerado mais provável à medida que a experiência do agente cognitivo se torna mais numerosa e semelhante a sucessivas experiências passadas. Pode dizer-se que é mais provável o Sol nascer amanhã devido à numerosíssima experiência semelhante no passado de que se dispõe, e a ocorrência do nascer do Sol é tão mais provável quanto mais experiência dele se tiver. Mas a convicção na sua existência e no seu poder intrínseco sobre a experiência e sobre outros objetos (cuja existência exterior e independente da mente acredito mediante outros mecanismos) não se intensifica à medida que se tem mais e mais experiências do nascer do Sol. Ou seja, não acredito mais que

${ }^{479} \mathrm{~T}$ 3.1.1.1. 
existe causalidade objetiva à medida que a minha experiência observável (única forma de conhecimento de questões de facto) se torna mais numerosa, ou o facto de se ter cada vez mais experiências do nascer do Sol não torna mais provável que esse objeto detenha, intrinsecamente ou em si mesmo, esse poder. Se a proposta de Wright estivesse correta, a continuidade da experiência deveria convencer o agente cognitivo de que a existência da causalidade objetiva é mais provável do que o seu contrário, como o convence de qualquer outra probabilidade.

Ao defender que a naturalidade da crença na existência de poderes causais intrínsecos aos objetos a torna justificada, Wright tenta conferir justificação racional a uma crença que não tem qualquer possibilidade de ser justificada pelos dois critérios de racionalidade que a filosofia de Hume prevê: a regularidade, porque a operação do entendimento não ultrapassa o campo da experiência, e a necessidade presente na demonstração, porque a razão demonstrativa apenas assevera que tanto a existência como a inexistência de algo além do campo da experiência não implicam contradição. Quer dizer, do ponto de vista demonstrativo, não há mais evidência a favor de uma do que de outra hipótese.

Voltando ao exemplo do nascer do Sol, com o seu argumento, o comentador pensa o eventual poder intrínseco desse objeto e a experiência (fenoménica) do seu despontar no horizonte como se experienciá-lo repetidas vezes tornasse mais provável que o Sol mantenha relações causais intrínsecas com outros objetos. Para isso, quando se dispõe de uma experiência escassa, dever-seia ter menos convicção na existência desses poderes intrínsecos do que num momento em que se dispõe de uma experiência mais numerosa. Mas não há um momento em que se passa a acreditar na existência da causalidade objetiva. Antes, parece ser o caso de que a experiência, por si mesma, não contribui para essa convicção - como contribui para convicções sobre a repetição do passado no futuro - e que qualquer raciocínio causal já é acompanhada dessa convicção.

Além disso, considero que o argumento de Wright para justificar o realismo cético como proposta filosófica de Hume resulta de uma aplicação inapropriada do critério de justificação de raciocínios causais a um domínio que não é suscetível de justificação, ou para o qual qualquer tentativa de justificação falha. Em vez de ser utilizado como elemento a favor do caráter racionalmente justificado ou injustificado da crença na existência da causalidade objetiva, o seu caráter natural, permanente e irresistivel deve antes favorecer a interpretação de 
que esta pode apenas ser constatada, mas não é passível de justificação. Antes, esta suposição é anterior ao e independente do plano de justificação racional.

A razão disto é que tendo em conta os dois sentidos de razão citados e os correspondentes sentidos possíveis de justificação racional (sob os critérios da regularidade observável e de contradição), a suposição da existência da causalidade objetiva não parece ser racional nem irracional, isto é, não parece poder ser avaliada racionalmente, pois não faz parte de nenhum daqueles dois planos da racionalidade. Por isso, esta crença parece fazer parte do conjunto de crenças que não são nem mais nem menos racionais que as suas contrárias - que, neste caso, seria o regularismo causal (proposta à qual se opõe o realismo cético).

Deste modo, conclui-se que o realismo cético permanece destituído de argumentos a favor da tese de que Hume defendia filosoficamente uma posição simultaneamente realista e cética em relação à causalidade, pois a assunção da existência da causalidade objetiva (que, é certo, Hume dava por garantida) ${ }^{480}$ é impassível de justificação, isto é, o seu estatuto na epistemologia de Hume parece estar à parte ou além das possibilidades de justificação de crenças, não sendo nem justificada, nem injustificada. Talvez esteja mais próxima de uma assunção ou suposição acessória aos raciocínios causais concretos.

Portanto, o único argumento utilizado pelos proponentes do realismo cético (Wright) para tornar a sua interpretação uma verdadeira proposta filosófica não funciona, mantendo-se a proposta interpretativa do realismo cético sem elementos que permitam ir além da constatação de que Hume acreditava, de fato, na existência de uma causalidade objetiva. $\mathrm{O}$ argumento falha porque o critério de justificação para a crença na existência de uma causalidade objetiva só serve, legitimamente na epistemologia de Hume, para justificar a crença na existência de objetos que estão sob o alcance perceptivo - que não é o caso da existência ou não de propriedades em virtude das quais os objetos possuam, intrinsecamente, relações causais entre si. A meu ver, aquilo com que ficamos é, então, uma impossibilidade de oferecer uma justificação de tipo racional para a crença na existência de tais propriedades, pois a epistemologia de Hume parece só ter espaço para dois tipos de justificação epistémica - demonstrativo e causal -,

\footnotetext{
${ }^{480}$ Como bem nota Winkler, é por esta razão que uma tentativa de suspensão do juízo em relação ao estatuto metafísico da causalidade seria inviável (cf. WINKLER, 1991, pp. 80-1).
} 
sendo cada um desses campos restrito aos objetos sobre os quais as respetivas faculdades produzem raciocínios, ou seja, das relações abstratas e da perceção.

Nesste sentido, de acordo com a reunião de evidências textuais e os argumentos apresentados, a interpretação alternativa que me parece mais plausível para o lugar da crença na existência da causalidade objetiva na conjuntura epistémica de Hume é que ela deve ser considerada logicamente anterior e temporalmente contígua à relação natural de semelhança, isto é, que todos os raciocínios de causalidade supõem não apenas a relação natural de semelhança, como a convicção natural na existência da causalidade objetiva ${ }^{481}$. Esta crença parece estar para além do campo da racionalidade e da justificação de tipo racional. Assim, parece-me plausível pensar que, num sentido temporal, ela é concomitante às crenças causais geradas pelo entendimento - pois não parece haver um momento em que se passa de crenças em puras concatenações de fenómenos para crenças em relações causais exteriores e independentes da mente. Por seu turno, num sentido que se designou lógico, essa crença parece ser anterior àquelas, pois a consideração de Hume de que a crença na existência da causalidade objetiva se deve à propensão da mente para se "espalhar" nos objetos $^{482}$ não indica que haja exceções ao funcionamento dessa propensão: ela parece moldar a maneira como qualquer objeto é experienciado. Portanto, não é plausível pensar que o entendimento possa forjar crenças causais independentemente do funcionamento daquela propensão, e sim que funcionam concomitantemente desde o início da vida mental do agente cognitivo.

Por seu turno, os argumentos teóricos de Strawson e Kail para tentar justificar a interpretação do realismo cético dispensam uma crítica delongada. $\mathrm{O}$ primeiro comentador apela à simples evidência empírica da regularidade da experiência para a verdade da conclusão sobre a existência da causalidade objetiva - o que constitui uma óbvia petição de princípio, para a qual já Hume chamara a atenção ao discorrer sobre a natureza (racional ou não) do $\mathrm{PUN}^{483}$. Por seu turno, a justificação que Kail oferece para que se aceite a interpretação realista - de que se trata de uma preferência metafísica tão plausível quanto a contrária - que, como mostram as evidências textuais, teria sido a preferência do próprio Hume -

\footnotetext{
${ }^{481}$ Cf. T 1.3.14.25.

${ }^{482} \mathrm{~T}$ 1.3.14.25.
} 
é tão vã como as justificações de Strawson, ainda que por uma razão distinta. Com efeito, se, como bem notara ${ }^{484}$ não é possível determinar o que está para além do campo fenoménico, não é possível determinar se a causalidade objetiva existe. A explicação que procuro oferecer pode perfeitamente ser entendida como 'preferência metafísica', quer dizer, como parte de um arranjo no conjunto de ideias e conexões concebidas e objeto de crença de cada agente cognitivo. Aliás, arrisco a afirmar que essa designação descreve melhor a minha proposta de interpretação que a de Kail, uma vez que, de acordo com a proposta deste, a restrição ao campo fenoménico é apresentado como motivo para se aceitar legitimamente que existe uma causalidade objetiva - para justificar a dita preferência metafísica -, o que sugere uma certa obrigação em aceitar uma das conclusões em detrimento da outra. Mas se fosse assim, não se trataria de uma preferência, pois ao merecer mais assentimento que o seu contrário. Mas, para desgosto de Kail, não é este o caso, uma vez que essa restrição não permite eliminar a hipótese metafísica contrária ao realismo causal (ou seja, que apenas existe a regularidade observável).

Em relação aos argumentos que designei de contextuais, apresentados por Strawson, pode aceitar-se que Hume fala como um realista e que Hume faz afirmações que não condizem perfeitamente com a defesa do regularismo, mas não em virtude de defender o realismo causal como posição filosófica. Recorrendo a algumas evidências textuais, Broughton também alega que a investigação científica pressupõe a existência da causalidade objetiva na investigação. Porém, a meu ver, a explicação que proponho como alternativa a esta na presente secção cobre perfeitamente estas evidências textuais: Hume fala como um realista e a investigação científica pressupõe a existência da causalidade objetiva como efeito do facto de a mesma ser uma convicção que está além do campo da justificação epistémica e, sendo natural, está constantemente presente na vida mental dos agentes - Hume e todos os outros. Na secção 4.2, explicarei que esta convicção é gerada pela propensão projetiva - para a qual os teóricos do erro bem chamaram a atenção.

\footnotetext{
${ }^{483}$ Cf. GARRETT, 2014, p. 178.

${ }^{484}$ Cf. 2.2.3.
} 
Por fim, passo a uma breve consideração sobre os equívocos da interpretação anti-realista. A sua brevidade deve-se ao facto de esta interpretação - com ênfase na reducionista - já ter sido comentada pelos proponentes do realismo cético e reconstruída pelos teóricos do erro.

No que respeita ao que é diretamente útil para o propósito deste trabalho, pode dizer-se que há duas razões pelas quais a interpretação reducionista não é aceitável. A primeira é a desconsideração da propensão projetiva, para a qual os teóricos do erro chamam a atenção, que anula a componente semântica da interpretação reducionista, segundo a qual o sentido das proposições causais não é a descrição de relações causais intrínsecas.

A segunda é a bem notada por Kail, a saber, de que se a teoria das ideias de Hume for restrita às ideias geradas de acordo com o PC (claras, adequadas), não é possível determinar o que está para além do campo fenoménico. Se é assim, não é possível descartar a possibilidade da existência da causalidade objetiva. Por esta razão, o máximo que se pode admitir é que só se tem acesso à regularidade, mas não que a causalidade objetiva (que explica a regularidade) não existe. Isto leva-nos, no campo metafísico, à conclusão cética ${ }^{485}$.

Portanto, a interpretação proposta refuta tanto a interpretação realista como a teoria do erro. Com efeito, se a convicção da existência da causalidade objetiva não é suscetível de uma justificação epistémica, não pode ser considerada um erro ou equívoco, uma convicção injustificada ou irracional. Os mesmos comentadores também afirmam que a crença é falsa, por se apoiarem numa interpretação reducionista, a saber, de que a crença na existência da causalidade objetiva é falsa porque a crença verdadeira é a crença de que apenas existe a regularidade. Adotando uma interpretação cética sobre a existência da causalidade objetiva, não se admite que essa crença seja verdadeira ou falsa. Os desenvolvimentos da rejeição da teoria do erro (tanto na teoria causal como na teoria dos valores) e a sua relação com a propensão projetiva serão exploradas no capítulo 4 . 
${ }^{485}$ Cf. WINKLER, 1991, p. 53. 


\section{Teoria dos valores}

\subsection{Introdução}

Como bem observa J. Fieser ${ }^{486}$, a distinção que J. Mackie apresenta entre os planos ético (que chama de normativo) e metaético (e, se se puder dizer, metaestético $\left.{ }^{487}\right)^{488}$ pode ser utilizada para explicar a distinção entre dois âmbitos da teoria dos valores (moral e estético) de Hume - que pretendo generalizar a uma teoria dos valores em geral (também de Hume) - e clarificar quais as questões de interesse no presente capítulo. O plano ético (e estético) ou normativo diz respeito ao que se deve fazer ou ter como padrão de um certo valor - ao que assevera o valor de juízos. Por exemplo, juízos como 'deve fazer-se reciclagem,489 , 'é errado (ou mau) ser misógino', 'Homero é o poeta mais encantador da História' ou 'as aves amazónicas são belíssimas', são aceites sob critérios como, por exemplo, a preservação do planeta, a igualdade de género, a erudição no uso das palavras ou a combinação rara de cores e formas. Numa palavra, trata-se do plano em que um conjunto de valores concretos que uma pessoa ou sociedade segue ou que refletem o seu gosto estético efetivo - independentemente de qual for e do seu grau de refinamento.

Por seu turno, o plano metaético (e metaestético) é relativo à resposta à questão da natureza dos valores e respetivo juízo. Portanto, consiste num plano reflexivo em que se determina o estatuto metafísico de um valor: que tipo de coisa é um valor. Também se inclui neste plano uma resposta ao seu estatuto epistémico: se o valor é uma forma de conhecimento ou não. Além disso, trata-se de um plano independente do primeiro: com efeito, não é necessário considerar se os valores são um dado da razão, um facto observável ou um estado emocional de quem ajuiza para seguir certos valores no quotidiano (na ação e no juízo). Da mesma forma, responder à questão da natureza dos valores não implica qualquer prescrição concreta para a vida quotidiana. No caso da filosofia de Hume, essa resposta é: os valores são uma propriedade que, aparentemente, existe (apenas) na

\footnotetext{
${ }^{486}$ Cf. FIESER, 1989, pp. 94-5.

${ }^{487}$ Cf. MACKIE, 1977, p. 16.

${ }^{488}$ Paralelismo que Mackie também reconhece (cf. MACKIE, 1977, p. 15).
} 
mente do agente e/ou espectador, mas que é atribuída ao objeto avaliado como se constituísse uma propriedade intrínseca do mesmo, e surge mediante a experiência de confronto com esse objeto quando observado sob um certo ponto de vista (desinteressado). Esta resposta não diz absolutamente nada sobre quais são, concretamente, os valores que cumprem estes requisitos.

Aceitando esta distinção apontada por Fieser, no presente trabalho particularmente, no presente capítulo - ocupo-me exclusivamente de questões do plano metaético (e, se se pode dizer assim, metaestético). Nos subcapítulos e secções que se seguem, apresento e critico as interpretações que foram propostas por diversos comentadores da filosofia de Hume, a fim de responder a questões de três ordens distintas. A primeira ordem de questões pode chamar-se de metafisica: em que consistem os valores na filosofia de Hume ou, mais especificamente, se os valores constituem propriedades independentes da mente, isto é, se pertencem intrinsecamente aos objetos do juízo de valor. A segunda ordem de questões pode chamar-se de epistémica: se os juízos de valor têm um caráter proposicional, isto é, se consistem numa descrição de um facto ou se os juízos pelas quais se elabora um juízo de valor possuem um valor de verdade. A terceira ordem de questões pode chamar-se de semântica: qual o significado dos juízos sobre valores formulados e enunciados sob a forma 'S é P', e se esses juízos são descritivos de um facto ou (apenas ou também) expressões de um estado mental particular de quem o enuncia.

A proposta de interpretação que apresento neste trabalho consiste numa interpretação sobre o estatuto do juízo sobre questões de facto. Mas assim como esta interpretação, também as que apresento nas próximas secções se definem também pela resposta que os comentadores que as propuseram dão à questão metafísica: a sua maioria propõe versões de anti-realismo, enquanto os proponentes de uma interpretação que se baseia numa forma de realismo mantêm em comum com os seus oponentes elementos das interpretações relativas às questões epistémica e semântica. Portanto, responder a estas três questões permitir-me-á justificar uma proposta de interpretação alternativa à que Coventry apresenta, acrescentando-lhe elementos já propostos por outros comentadores,

\footnotetext{
${ }^{489} \mathrm{Ou}$, sob as outras formas que considerei em 2.1.1, 'é um dever de qualquer cidadão manter as ruas limpas', 'é bom manter as ruas limpas', 'manter as ruas limpas é certo' ou ainda 'a
} 
mas também elementos originais, perfazendo a interpretação a que chamo, no presente trabalho, de quasi-realismo cético - que, a meu ver, é a interpretação da filosofia de Hume que harmoniza de forma mais justa a sua teoria causal com a teoria dos valores.

Jonathan Harrison (1976) declara-se confuso acerca de qual a interpretação mais adequada da teoria dos valores de Hume: o autor diz não saber se Hume defende que juízos morais são a) sobre os sentimentos do espectador, b) sobre os sentimentos da humanidade, c) provenientes de um senso moral ${ }^{490}$, d) têm uma natureza proposicional ou, finalmente, e) têm uma natureza não proposicional, isto é, não são juízos genuínos ${ }^{491}$. De facto, há que reconhecer que as evidências textuais do que Hume entende pelas distinções morais e da beleza parecem apontar em diferentes direções.

O subcapítulo 3.1 é dedicado ao plano que designei como epistémico. Nele apresento as interpretações da teoria dos valores de Hume em relação a este aspeto da sua filosofia, a saber, o sentimentalismo, o cognitivismo e o não cognitivismo, explicando a distinção entre estas. $\mathrm{Na}$ secção 3.1.1, explico por que razão o sentimentalismo pode ser combinado tanto com uma interpretação cognitivista como com uma não cognitivista. Na secção 3.2.2, explico a proposta de interpretação cognitivista de acordo com os comentadores que a propuseram. Entre os seus defensores estão Páll Árdal, Peter Jones, David Norton, Corliss Swain e Don Garrett.

O subcapítulo 3.2 é dedicado ao plano que designei como semântico. Nele apresento as interpretações da teoria dos valores de Hume em relação a este aspeto, assim como algumas críticas tanto - minhas e dos comentadores entre si.

Após um esclarecimento sobre em que consiste cada uma das interpretações e como se associam entre si, na secção 3.2.1, apresento a

\footnotetext{
preocupação com a limpeza das ruas é uma virtude'.

${ }^{490}$ Porém, há que notar que nem todas estas opções são incompatíveis entre si. As opções a) e b) são incompatíveis, pois são respostas distintas à questão de saber qual a referência do juízo de valor (de que é que se fala quando se faz um juízo de valor); d) e e) são relativas à questão de saber se os juízos possuem valor de verdade ou não, isto é, de determinar o seu estatuto epistémico (se descrevem algo ou não), independentemente de se aceitar a) ou b) (ou seja, da resposta à questão de saber qual a referência dos juízos de valor). Por sua vez, c) não é incompatível com a) e b) (relativas à referência do juízo), nem com d) e e) (relativas ao seu estatuto epistémico), sendo relativa à origem desse juízo (na mente) ou de qual a capacidade cognitiva que permite formulá-lo: neste caso, um senso de moralidade.

${ }^{491}$ HARRISON, 1976, pp. 110-25.
} 
interpretação que designo por descritivista subjetivista (ou simplesmente subjetivista), defendida por Philipa Foot, Peter Jones e, mais recentemente, Don Garrett e Rachel Cohon, assim como as críticas a esta interpretação, formuladas por George Hunter, Páll Árdal, Barry Stroud e John Mackie. Em 3.2.2, apresento a interpretação que designo por descritivista causal, defendida por C. D. Broad, D. C. MacNabb, Nicholas Capaldi e Corliss Swain, assim como a crítica de Árdal a esta posição. Em 3.2.3, apresento a interpretação emotivista (primeira forma de não descritivismo), defendido por Thomas Reid, Antony Flew, H. Donald Hudson (mais simpatizante do que defensor), James Noxon e Alfred Jules Ayer, assim como as críticas a esta interpretação, formuladas por Norton, Pitson, Garrett, Stroud e Mackie. Em 3.2.4, apresento a chamada teoria do erro (segunda forma de não descritivismo), defendido por Barry Stroud, John Mackie e Robert Fogelin, que surgiu como crítica às posições emotivista e descritivista (tanto causal como subjetivista), assim como algumas críticas pessoais a esta interpretação, assim. Finalmente, em 3.2.5, apresento as minhas considerações acerca da teoria do erro que, a meu ver, mostram que não é a interpretação mais justa da teoria dos valores de Hume.

O subcapítulo 3.3 é dedicado à apresentação da proposta de interpretação da teoria dos valores de Hume em relação ao seu aspeto metafísico. Antes de dividir o subcapítulo, faço uma breve explicação sobre a tendência geral dos comentadores de defender que Hume é um anti-realista em relação aos valores. Em 3.3.1, apresento a posição contrária - de que o filosófo seria, ao invés, um realista (em relação aos valores) - tal como defendida por David Norton (com quem Swain concorda, sem desenvolver a interpretação) e Peter Kail. Em 3.3.2, apresento as razões pelas quais julgo que a interpretação realista é formulada de maneira equivocada.

A razão pela qual a sequência dos subcapítulos de 3.1 a 3.3 não segue a ordem apresentada nesta introdução é que a história da literatura de comentário à filosofia de Hume seguiu uma tendência muito uniforme de o interpretar como um anti-realista relativamente ao estatuto metafísico dos valores. Além disso, Norton - o primeiro dissidente em relação a esta tendência - justifica a sua interpretação com evidências e argumentos relativos ao plano epistémico. Por seu turno, a proposta de Kail mantém uma forte continuidade com a de Norton. Por esta razão, a proposta de interpretação realista é apresentada apenas em 3.3. 
No subcapítulo 3.4, procuro explicar que apesar de haver falhas nas interpretações da teoria do erro e do realismo, há que reconhecer que estas interpretações possuem alguns elementos que, associados entre si e a elementos novos, podem perfazer uma interpretação original e, a meu ver, livre das falhas que lhes atribuo. Estes elementos são a atribuição do valor ao objeto como se se tratasse de uma propriedade intrínseca do mesmo e a projeção como mecanismo explicativo dessa atribuição (assim como no caso da causalidade objetiva). O elemento novo com o qual pretendo associá-los é uma justificação para se considerar que essa atribuição não deve ser considerada um erro a ser eliminado, a saber, que essa propensão está além do que se pode considerar justificado e injustificado racionalmente e, por isso, deve ser considerada arracional.

Em relação à legitimidade de uma uniformidade entre as considerações sobre a teoria moral e estética - pelo menos, para tratar as questões da natureza epistémica dos respetivos juízos - vale uma explicação sobre a prática dos comentadores que se ocuparam das questões de natureza epistémica e semântica da teoria dos valores de Hume. Aparentemente, até às análises oferecidas por Brunet (1965) e Árdal (1966), os autores que se dedicaram ao comentário da teoria dos valores de Hume não se preocupavam particularmente em analisar a teoria estética do filósofo como parte integrante da sua teoria dos juízos de valor, ou sequer em estabelecer um paralelo vago entre as mesmas - salvo uma breve menção da parte de Green num contexto mais global da análise da teoria das paixões e outra feita por Broad no artigo em que propõe a sua interpretação sobre o significado de juízos morais na filosofia de Hume (1948). Por seu turno, Noxon (1961) e Jones (1970) também se ocupam desta questão, restringindo-a, desta vez, aos juízos estéticos. Quer dizer, estes comentadores acabaram por propor interpretações semelhantes por acidente, pois mantinham interesses distintos e particulares (aqueles com a teoria moral, estes com a teoria estética).

Por esta razão, na apresentação das interpretações emotivista e a descritivista, farei indicações precisas em relação a qual de ambas interessava o comentador em questão. Apesar disso, desde a década de 1960, a referência homogeneizada às duas teorias foi-se tornando mais frequente, mesmo sendo claro que o comentador mantém essencialmente um interesse particular (o que se vê claramente, por exemplo, nas contribuições de Brunet, Árdal e menos em Jones, 
que se concentra na estética, e todos os outros comentadores subsequentes, que se concentram na moral).

O objetivo do presente trabalho é desenvolver uma interpretação sobre juízos de valor que se aplique tanto ao valor moral como ao valor estético. Tal empreendimento é possível porque tal como apresentado em 1.5, os textos de Hume relativos a estes valores permitem este uso intercambiado, pois o filósofo reconhecia que apesar de se tratarem de valores distintos, tinham em comum o facto de a sua origem estar nas impressões de reflexão - tipos de prazer e desprazer. Além disso, na tradição de comentário ao filósofo, muitos autores que se ocuparam das questões a serem tratadas no presente capítulo - defensores das várias interpretações que apresentarei - e que tinham pelo menos algum interesse em comum com o que motiva o presente trabalho, reconheceram um paralelo entre os dois âmbitos - a saber, do valor estético (beleza e fealdade) e moral (virtudes e vícios) - e julgam-se justificados a fazer referências aos mesmos de forma intercambiada ${ }^{492}$. Por estas razões, tomo a liberdade de seguir o mesmo caminho.

$\mathrm{O}$ recorte bibliográfico deste capítulo restringe-se quase totalmente à primeira parte do terceiro livro do Tratado ${ }^{493}$ - que Mackie observa constituir a epistemologia moral do filósofo ${ }^{494}$, a segunda Investigação e alguns ensaios em que analisa as mesmas questões relativas à beleza ou ao gosto em geral essencialmente, "O Cético" e "Sobre o Padrão do Gosto" (salvo raras referências à primeira Investigação).

\subsection{Racionalismo e sentimentalismo, cognitivismo $\left(E_{C}\right)$ e não cognitivismo $\left(E_{\sim c}\right)$}

No plano metafísico - daquilo em que consistem os valores -, pode defender-se uma posição realista $\left(\mathrm{M}_{\mathrm{R}}\right)$, de acordo com a qual os valores

\footnotetext{
${ }^{492}$ Cf. GREEN, 1874, p. 58; BROAD, 1948, pp. 112-13; BRUNET, 1965, pp. 171, 321, 258, 280, 284-5, 494-5, 765, 861; ÁRDAL, 1966, p. 116-17, 122-3; NORTON, 1975, pp. 205-6; MACKIE, 1980b, p. 65, 72, 75; JONES, 1970; 1982, p. 109, 118, 120, 126; FOGELIN, 1985, p. 125; PITSON, 1989, 61, 62, 69, 82; BAIER, 1991, pp. 200-8 ; STROUD, 1993; GARRETT, 1997, p. 195; KORSGAARD, 1999, p. 13, 15; KAIL, 2007b, 7, 9; COHON, 2008, p. 119, 121, 123.

${ }^{493} \mathrm{~T} 3.1$.
} 
constituem propriedades independentes das mentes dos agentes cognitivos, ou anti-realista $\left(\mathrm{M}_{\sim \mathrm{R}}\right)$, de acordo com a qual os valores não constituem este tipo de propriedade, mas antes dependem da mente daquele que avalia os objetos em questão. A primeira posição parece implicar que essas propriedades pertencem aos objetos avaliados em si mesmos (ações, caracteres ou objetos estéticos). Além disso, também parece implicar que há um critério fora das mentes dos agentes cognitivos em virtude do qual se pode considerar que algo tem um determinado valor. Por esta razão, trato o objetivismo como a tese de que os valores residem nos próprios objetos avaliados, ao invés da mente de quem avalia - e, consequentemente, como uma tese realista. Por seu turno, o anti-realismo parece implicar a possibilidade de o valor residir (exclusivamente) na mente de cada indivíduo ou de uma generalidade de indivíduos.

A interpretação de acordo com a qual os objetos não possuem valor em si mesmos, mas apenas mediante a atribuição de um valor da parte de um agente ou conjunto de agentes - é dada como certa por quase todos os comentadores que se ocupam da teoria dos valores de Hume. Com efeito, Hume é explícito sobre a sua posição sobre o estatuto metafísico dos valores:

O vício e a virtude, portanto, podem ser comparados a sons, cores, calor e frio, os quais, segundo a filosofia moderna, não são qualidades nos objeto, mas percepções na mente. ${ }^{495}$

Embora temendo parecer excessivamente filosófico, gostaria de lembrar ao meu leitor a famosa doutrina, que se supõe plenamente provada nos tempos modernos, segundo a qual "gostos, cores e as demais qualidades sensiveis não estão nos corpos, mas meramente nos sentidos". O mesmo se passa com a beleza e deformidade, virtude e vício. Essa doutrina, entretanto, tira tão pouco a realidade dessas últimas qualidades quanto das primeiras (...). Mesmo que se reconheça que as cores só se encontram no olho, seriam tintureitos ou pintores menos considerados ou estimados por isso ${ }^{496}$

Os objetos não têm em si mesmos absolutamente nenhuma seventia ou valor. Eles tiram seu valor meramente da paixão. ${ }^{497}$

Deste modo, todas as posições apresentadas nos subcapítulos e secções que se seguem são conjugadas com uma interpretação anti-realista. De acordo

\footnotetext{
${ }^{494}$ Cf. 1980 , p. 1.

${ }^{495} \mathrm{~T} 3.1 .1 .26$

${ }^{496}$ C 17 n149; itálico meu.
} 
com os proponentes da interpretação cognitivista (apresentada na secção 3.1.2), apesar de Hume não considerar que os valores sejam objetivos, é possível encontrar um critério ou padrão em virtude do qual os juízos ou juízos sobre valores são verdadeiros ou falsos. Por sua vez, no subcapítulo 3.2, apresento diversas interpretações sobre o significado de juízos sobre valores: as descritivistas como consequência da cognitivista; o emotivismo e a teoria do erro como consequência da não cognitivista - apresentada nos próximos parágrafos.

\subsubsection{Sentimentalismo, não cognitivismo}

Em relação ao plano denominado epistémico da teoria dos valores de Hume, podem distinguir-se uma posição racionalista, de acordo com a qual os valores se podem descobrir pela razão, sendo uma forma de conhecimento, e uma posição sentimentalista (empirista), que nega a posição racionalista, e de acordo com a qual se tem acesso aos valores por uma emoção, sentimento ou paixão, que é um meio não representativo (pela razão, ou seja, por ideias), mas sim - portanto, os valores são sentidos e não conhecidos.

Apesar de estar pressuposta noutras passagens (enumeradas mais abaixo) e tal como nota Jones $^{498}$, talvez a evidência mais clara e sucinta da posição sentimentalista de Hume seja apresentada no ensaio "O Cético":

[A] mente não se contenta meramente com inspecionar.[os objetos dos valores], tal como são em si mesmos, mas também experimenta, como resultado dessa inspeção, um sentimento de deleite ou de insatisfação, de aprovação ou de condenação, e esse sentimento a determina a anexar-lhes o epíteto de belo ou disforme, desejável ou odioso. Ora, é evidente que esse sentimento deve depender da textura ou estrutura particular da mente, que torna possível que tais formas particulares operem de tal maneira particular e produzam uma simpatia ou conformidade entre a mente e seus objetos. Se a estrutura da mente e dos órgãos internos varia, o sentimento não mais ocorre, ainda que a forma permaneça a mesma. Como o sentimento é diferente do objeto, e surge da operação deste sobre os órgãos da mente, uma alteração nesta última deve fazer variar o efeito, e o mesmo objeto, apresentado a uma mente de todo distinta, não produz o mesmo sentimento. ${ }^{499}$

\footnotetext{
${ }^{497}$ C 18. Cf. também T 3.1.2.4.

${ }^{498}$ Cf. JONES, 1970, p. 53.

${ }^{499} \mathrm{C} 14$.
} 
Numa abordagem mais contemporânea das questões aqui tratadas, podem considerar-se duas teses que não devem confundir-se com o racionalismo e o sentimentalismo. São elas o cognitivismo, de acordo com o qual existe uma verdade sobre os valores - que pode ser conhecida - e o não cognitivismo, de acordo com o qual não existe esta verdade - pelo que não pode haver um conhecimento relativo a valores. Associada a esta distinção está a distinção entre os juízos serem ou não de natureza proposicional, ou poder-se ou não considerar que o que parecem proposições sobre valores não são proposições genuínas ${ }^{500}$. Para se considerar que sim, é necessário considerar que esse juízo envolve uma representação - uma ideia ou pensamento.

Portanto, os primeiros termos referem-se à fonte ou origem da própria avaliação, e os segundos, a um estatuto proposicional (ou não) dessa avaliação.

De acordo com a interpretação cognitivista, a possibilidade de obter um conhecimento dos valores deve-se à possibilidade de o juízo de valor ser verdadeiro ou falso, ou ser uma proposição genuína. Com efeito, se juízos de valor não se resumem aos sentimentos que os definem, envolvem uma representação e uma (pretensa) descrição de um facto (mesmo que seja um facto acerca de sentimentos, ou de certos objetos provocarem outros sentimentos mediante certas circunstâncias). Se é assim, existe um critério ou padrão em virtude do qual se pode considerar esse juízo verdadeiro ou falso. Por sua vez, o conhecimento que é possível obter acerca de valores corresponde à descoberta daquilo que corresponde a esse padrão ou critério de verdade: dos juízos sobre valores que são, efetivamente, verdadeiros.

Com efeito, a hipótese racionalista implicaria que o juízo estivesse exclusivamente no campo representativo, ou seja, das ideias. Na historiografia sobre o autor, os argumentos que Hume apresenta em $\mathrm{T} 3.1$ sobre a impossibilidade de um acesso ao valor por meio de ideias e raciocínios invalidam esta hipótese interpretativa. Por seu turno, a interpretação do sentimentalismo (oposta ao racionalismo), consiste numa resposta à questão de saber qual a natureza da própria atribuição de um valor, e resulta essencialmente da

\footnotetext{
${ }^{500}$ É nestes termos que Garrett e Cohon se exprimem em relação a este tópico da interpretação (cf. GARRETT, 1997, p. 188; COHON, 2008, p. 2).
} 
consideração das palavras de Hume de T 3.1 - mais especificamente, da tese de que uma vez que o campo da razão respeita às ideias, à representação e à verdade, a avaliação moral e estética se define por uma impressão de reflexão e estas são estados originais da mente, não representativos, então, a moral e a estética não fazem parte do campo da razão nem do conhecimento.

As principais evidências utilizadas a favor da interpretação não cognitivista - assim como, antes de esta ser considerada, o sentimentalismo - são:

[É] evidente que nossas paixões, volições e ações são incapazes de tal acordo ou desacordo, já que são fatos e realidades originais, completos em si mesmos, e que não implicam nenhuma referência a outras paixões, volições e ações. É impossível, portanto, declará-las verdadeiras ou falsas, contrárias ou conformes à razão. ${ }^{501}$

Ter o senso da virtude é simplesmente sentir uma satisfação de um determinado tipo pela contemplação de um caráter. O próprio sentimento [feeling] constitui nosso elogio ou admiração. ${ }^{502}$

Assim, o curso de nossa argumentação nos leva a concluir que, uma vez que o vício e a virtude não podem ser descobertos unicamente pela razão ou comparação de idéias, deve ser por meio de alguma impressão ou sentimento por eles ocasionados que somos capazes de estabelecer a diferença entre os dois. ${ }^{503}$

Ter o senso da virtude é simplesmente sentir uma satisfação de um determinado tipo pela contemplação de um caráter. ${ }^{504}$

[A] distinção entre vício e virtude não está fundada meramente nas relações dos objetos, nem é percebida pela razão. ${ }^{505}$

Esta posição também pode ser (e foi) sustentada pela tese de que os valores não constituem uma questão de facto (um 'objeto da razão' ${ }^{\text {,06 }}$ ):

Se o pensamento e o entendimento sozinhos fossem capazes de fixar os limites do certo e do errado, a qualidade de virtuoso ou vicioso teria de estar em algumas relações de objetos, ou então ser uma questão de facto, descoberta por nosso raciocínio. ${ }^{507}$

\footnotetext{
${ }^{501} \mathrm{~T}$ 3.1.1.9.

$502 \mathrm{~T} 3.1 .2 .3$.

${ }^{503} \mathrm{~T} 3.1 .2 .1$.

${ }^{504} \mathrm{~T}$ 3.1.2.3.

${ }^{505} \mathrm{~T} 3.1 .1 .27$.

${ }^{506}$ Cf. T 3.1.1.18.

${ }^{507}$ T 3.1.1.26. Cf. também T 3.1.1.18.
} 
Talvez devido a evidências como estas a posição sentimentalista seja facilmente confundida com a posição não cognitivista: aparentemente, se todo o campo da verdade e do conhecimento (questão que divide cognitivistas e não cognitivistas) se restringe ao que pode ser apreendido pela razão (questão que divide racionalistas e empiristas), atribuir os valores a um estado emocional daquele que ajuíza pode parecer condição suficiente para concluir que não existe uma verdade sobre os valores, ou que juízos de valor não podem constituir conhecimento.

Aparentemente, ninguém defendeu a posição não cognitivista (do âmbito epistémico) separada de uma proposta sobre o uso dos juízos sobre valores (do âmbito semântico). As formas da interpretação não cognitivista que surgiram são o emotivismo (apresentado em 3.2.1), a teoria do erro (apresentada em 3.2.4) e o quasi-realismo, tal como defendido por Coventry (apresentado apenas no capítulo 4). Árdal chama esta posição "bruta" de emocionismo, que consistiria na tese de que avaliar um objeto ou ação não consiste em elaborar um juízo, mas simplesmente em ter uma impressão de reflexão ${ }^{508}$. Portanto, para Árdal, esta posição não consistiria sequer em os juízos de valor serem expressivos em vez de descritivos (posição defendida pelos emotivistas e pelos teóricos do erro), mas sim que não haveria juízo de nenhum tipo. Se se entender que apenas juízos descritivos (de um facto) são genuínos, pode dizer-se que estas duas posições têm em comum o facto de não considerarem juízos de valor juízos genuínos.

Já as evidências utilizadas a favor da interpretação cognitivista passam, por exemplo, por ressaltar que valores são um tipo específico de questão de facto, que pode ser apreendido, conhecido ou objeto de um raciocínio, a partir de evidências como:

Tomemos qualquer ação reconhecidamente viciosa: o homicídio voluntário, por exemplo. Examinemo-lo sob todos os pontos de vista, e vejamos se podemos encontrar o fato, ou existência real, que chamamos de vício. Como quer que a tomemos, encontraremos somente certas paixões, motivos, volições e pensamentos. Não há nenhuma outra questão de fato neste caso. $\mathrm{O}$ vício escapa por complete, enquanto consideramos o objeto. Não o encontramos até dirigirmos nossa reflexão para nosso próprio íntimo e darmos com um sentiment de desaprovação,

${ }^{508}$ Cf. ÁRDAL, 1966, p. 194. 
que se forma em nós contra essa ação. Aqui está um fato, mas ele é objeto de sentimento [feeling], não de razão. ${ }^{509}$

[A] moralidade é determinada pelo sentimento, e define a virtude como qualquer ação ou qualidade mental que comunica ao espectador um sentimento agradável de aprovação; e o vício como o seu contrário. Passamos então a examinar uma questão de fato, a saber, quais ações têm essa influência. Consideramos todas as circunstâncias em que essas ações concordam e esforçamo-nos para extrair daí algumas observações gerais relativas a esses sentimentos. ${ }^{510}$

Em particular, Garrett nota que o fenómeno do valor na filosofia de Hume pode ser encarado como uma questão de facto, no sentido em que o sentimento envolvido no juízo de valor é, em si mesmo, um facto do qual se pode ter um conhecimento - o que implica a possibilidade de um acesso ao mesmo por meio da razão. Quando Hume se questiona sobre se a moral provém da razão, o sentido de "razão" é o de uma faculdade capaz de produzir inferências. Por esta razão, esta pergunta equivale à de saber se a moral provém de impressões ou de ideias ${ }^{511}$. Esta é uma concessão de Hume desde que identifica a sua origem com as impressões de reflexão ${ }^{512}$.

A propósito deste plano epistémico da análise que se segue neste capítulo, valem dois comentários adicionais. O primeiro é que a razão pela qual a notação escolhida se refere ao par cognitivismo/não cognitivismo é que a preocupação central do presente trabalho é com a questão da verdade dos juízos sobre valores ainda que esta verdade possa ser descoberta através da razão, ou seja, que se acrescente também uma componente racionalista à interpretação. Em segundo lugar, vale notar que nenhum autor que se ocupou da filosofia de Hume alguma vez tentou provar que o filósofo era um racionalista. Os comentadores que se ocuparam do papel da razão na formulação de juízos de valor na filosofia de Hume não deixam de considerar que Hume era um sentimentalista. O que acontece é que para mostrar que Hume seria defensor de uma posição cognitivista, o sentimentalismo de Hume seria moderado pela necessidade de um exercício da razão - conjugado com o das impressões de reflexão.

\footnotetext{
${ }^{509}$ T 3.1.1.26; itálico meu.

${ }^{510}$ IPM Ap. 1.10.

${ }^{511}$ Cf. T 3.1.1.3; GARRETT, 1997, p. 190, 193.

${ }^{512}$ Cf. T 3.1.1.26, citada acima.
} 
Quer dizer, estes comentadores pretendem mostrar o papel determinante que a razão possui na formulação do juízo, ainda que este nunca chegue a ser mais determinante que as impressões de reflexão. Portanto, tentam mostrar que o facto de ser um defensor de uma posição cognitivista torna Hume um sentimentalista moderado - quer dizer, alguém que julga que a natureza dos juízos de valor é, de facto, um estado emocional de quem o formula, mas que esse estado gera uma crença relativa a um determinado facto e, sucessivamente, uma pretensa descrição deste (por meio do juízo). Por sua vez, a razão entra como faculdade pela qual se gera essa crença e se pode pretender descrever esse suposto facto, através do juízo. Este uso da razão torna o sentimentalismo de Hume moderado, sem torná-lo um racionalista. Portanto, julgam que se deve abandonar a convicção de que Hume seria um sentimentalista não cognitivista. Ao invés, defendem a interpretação de que Hume seria um defensor de uma posição que conjuga sentimentalismo e cognitivismo - portanto, Hume seria um sentimentalista cognitivista, mas nunca um racionalista, isto é, mantendo que a filosofia de Hume não se torna um racionalista por ser cognitivista.

\subsubsection{Cognitivismo}

Essencialmente, para estes comentadores, esta interpretação torna-se pertinente a partir da associação de três elementos da filosofia de Hume. O primeiro é o facto de Hume expor e explicar o surgimento do valor respetivo juízo (estético e moral) como um mecanismo causal, em que mediante o confronto com um certo objeto, se identifica uma certa propriedade no mesmo mediante o efeito que provoca na mente - uma impressão de reflexão. Para estes comentadores, isto permite aceitar que existem factos sobre valores - portanto, algo que pode ser descrito e descoberto. Nisto está incluída a própria impressão de reflexão, pois esta ser desperta parece ser uma condição para que se possa considerar que se deu, efetivamente, a relação causal entre o objeto e a mente.

O segundo é a aquisição e uso da linguagem. Para estes comentadores, o meio pelo qual os agentes e espectadores têm acesso aos juízos uns dos outros é através da sua enunciação - portanto, no uso da linguagem, que supõe a sua aquisição prévia. Por outro lado, a influência mútua entre os juízos desses agentes 
e espectadores só é possível se os mesmos forem tornados públicos - mediante a comunicação entre aqueles em trocas no quotidiano.

Em terceiro lugar, os defensores da interpretação cognitivista notam a importância da possibilidade de correção dos juízos pela aquisição de um ponto de vista geral. Esta aquisição faz-se não apenas pela comunicação (que permite a influência mútua dos gostos e juízos entre os agentes e espectadores), mas também por um conhecimento das relações causais entre os objetos do juízo e os que ajuízam, assim como dos fatores que devem ser considerados determinantes para essas relações causais. Tal conhecimento exige a ativação ou o emprego dos princípios de associação e traduz-se na possibilidade de substituir regras gerais sobre os valores que não refletem as relações causais genuínas pelas que as refletem, sob o critério de o objeto estar ou não a ser observado sob um ponto de vista desinteressado (independente de relações particulares entre os espectadores e os objetos do juízo).

É por esta razão que ao introduzir um elemento cognitivista na sua teoria dos valores de Hume, a proposta dos cognitivistas torna Hume um sentimentalista moderado. Quer dizer, ao defender que Hume reconhece a existência de uma verdade no campo dos valores, este reconhecimento não o torna um racionalista (o que, de facto, estava longe das intenções e das palavras de Hume), apesar do reconhecimento da proeminência da razão e convoca o seu uso - , mas apenas introduz um elemento racionalista na formação do juízo que impede que se interprete Hume como um sentimentalista (empirista) radical - que não reconhece qualquer papel à razão nesse processo:

Em geral, todos os sentimentos de censura ou aprovação são variáveis, de acordo com nossa situação de proximidade ou de distância em relação à pessoa censurada ou elogiada, e de acordo também com a disposição presente da mente. Mas, em nossas decisões gerais, não levamos em conta essas variações, embora continuemos aplicando termos que expressam nosso agrado ou desagrado, exatamente como se permanecêssemos em um único ponto de vista. A experiência logo nos ensina esse método de corrigir nossos sentimentos, ou, ao menos, a corrigir nossa linguagem, se os sentimentos são mais obstinados e inflexíveis. Nosso criado, quando esforçado e leal, pode despertar sentimentos mais fortes de amor e afeição que os despertados por Marcus Brutus, tal como a história o representa; mas nem por isso dizemos que o caráter do primeiro é mais louvável que o do segundo. Sabemos que, se nos 
aproximássemos igualmente daquele famoso patriota, ele nos inspiraria um grau muito superior de afeição e admiração. ${ }^{513}$

Quando nossos juízos sobre as pessoas se baseiam unicamente na tendência de seu caráter a beneficiar a nós ou a nossos amigos, a sociedade e o convívio social contradizem a tal ponto nossos sentimentos, e as incessantes mudanças de nossa situação produzem em nós uma tal incerteza, que buscamos algum outro critério para o mérito e o demérito, que não admita tal variação. Assim desligados de nossa primeira atitude, o meio mais conveniente que temos de nos determinar novamente é por meio de uma simpatia com aqueles que têm um relacionamento com a pessoa que estamos considerando. Esta simpatia está longe de ser tão vívida quanto a que sentíamos quando o que estava em jogo era nosso próprio interesse ou o de nossos amigos particulares (...). Mas como é igualmente conforme a nossos princípios calmos e gerais, diz-se que tem igual autoridade sobre nossa razão, comandando nosso juízo e opinião. Censuramos tanto aquela má ação sobre a qual lemos nos livros de história quanto a que foi praticada em nossa vizinhança. Isso significa que sabemos, pela reflexão, que a primeira ação despertaria sentimentos tão fortes de desaprovação quanto a última, caso estivesse na mesma situação. ${ }^{514}$

[O] intercâmbio de sentimentos na vida e convivência sociais faz-nos estabelecer um certo padrão geral e inalterável com base no qual aprovamos e desaprovamos os caracteres e costumes. $^{515}$

Por fim, tem-se ainda a evidência da consideração de Hume, no ensaio "Sobre o Padrão do Gosto", de que há uma conjunção de fatores objetivos e subjetivos que permitem a descoberta do padrão ou critério pelo qual algo pode ser considerado belo em geral, ou mesmo uma obra de arte, a saber, o lugar e tempo certos, "perfeita serenidade da mente, concentração de pensamento", colocar "a fantasia numa situação e disposição adequada", o perfeito funcionamento dos órgãos e a delicadeza da imaginação ${ }^{516}$.

Os defensores da interpretação cognitivista da teoria dos valores de Hume adotam, como sua consequência, a interpretação descritivista - tanto na versão que designei por subjetivista como pela que designei por causal. Na presente secção, apresentam-se os elementos que compõem esta interpretação e que se

\footnotetext{
${ }^{513} \mathrm{~T}$ 3.3.1.16.

$514 \mathrm{~T} 3.3 .1 .18$

515 IPM 5.42; itálico meu.

${ }^{516}$ PG $10,11,14,16$.
} 
relacionam com aquelas evidências, a saber: a) que valores são qualidades dos objetos que mantêm uma relação causal com o sentimento (moral e estético), b) que a sua descoberta constitui uma forma de conhecimento, tornando razoáveis os juízos e a discussão sobre os mesmos; por fim, c) que este caráter cognoscível do fenómeno dos valores se deve à possibilidade da comunicação (pela transmissão de ideias pela linguagem e a transmissão das paixões pela simpatia). Da conjunção destes elementos resulta a conclusão de que juízos sobre valores possuem um valor de verdade e podem ser tão conformes ou contrários à razão como qualquer juízo descritivo ${ }^{517}$.

\section{Relação causal}

Para Norton, Hume não nega que a moralidade assente em relações, mas apenas em relações entre objetos externos, ou relações incompreensíveis - uma relação entre o agente e um dado puro da razão ou entre a vontade divina e a vontade humana. A virtude e o vício - qualidades morais - são os traços de caráter, presentes na mente do agente ${ }^{518}$ e cognoscíveis por um conhecimento causal, a posteriori, da relação entre motivos, ação e sentimento desperto no espectador $^{519}$. Neste sentido, o comentador reconhece o papel de cada um dos elementos presentes na dinâmica de formação dos sentimentos (relativos ao valor moral e estético) e respetivos juízos.

\footnotetext{
${ }^{517}$ No caso de Norton, estas duas teses são componentes de uma interpretação realista que abrange os campos epistémico e metafísico: "Hume é um realista moral, que acredita que a virtude e o vício possuem um estatuto objetivo, e um realista para quem tanto o sentimento como a razão desempenham papéis significativos"; Tradução minha do original: "Hume is a moral realist who believes that virtue and vice have objective status, and a realist for whom both sentiment and reason have significant roles to play." (NORTON, 1982, p. 109; itálico meu); "Podemos dizer, então, que (pelo menos no Tratado) é um realista moral em dois sentidos. Ele defende [1] a posição de que há distinções morais fundadas em existências reais, que são independents da mente do observador (posição metafísica). Também defende [2] que estas distinções podem ser conhecidas (posição epistémica)"; Tradução minha do original: "We can say, then, that Hume (in the Treatise, at least) is a moral realist in two senses. He holds [1] the view that there are moral distinctions grounded in real existences that are independent of the observer's mind (a metaphysical position). He also holds that [2] these distinctions can be known (an epistemological position)." (NORTON, 1982, p. 120). O aspeto metafísico da interpretação de Norton será apresentado na secção 3.3.1. Por agora, concentro-me no aspeto epistémico.

${ }^{518}$ Particularmente, Townsend (que, por seu turno, defende uma interpretação anti-realista do gosto) observa que isto consiste em o agente ter a capacidade de sentir intensamente as paixões em direção às ações que promovem o bem público, portanto, o que se avalia nesse agente são os seus sentimentos (cf. TOWNSEND, 2001, p. 139, 141).

${ }^{519}$ Cf. NORTON, 1975, pp. 204-5; 1982, p. 150; JONES, 1982, p. 103; PITSON, 1989, p. 81.
} 
Norton recorre a diversas evidências textuais do filósofo para apoiar a sua posição - e que o define como defensor da interpretação cognitivista. O comentador reivindica que os valores não devem ser identificados com os sentimentos, e que o vício e a virtude sejam considerados distintos do sentimento de aprovação e reprovação, sendo os seus correlatos objetivos ${ }^{520}$ :

Nada pode ser mais real, ou nos interessar mais, que nossos próprios sentimentos de prazer e desprazer; e se estes forem favoráveis à virtude e desfavoráveis ao vício, nada mais pode ser preciso para a regulação de nossa conduta e comportamento. ${ }^{521}$

[D]evemos afirmar que a impressão derivada da virtude é agradável, e a procedente do vício é desagradável. ${ }^{522}$

No mesmo sentido, ao afirmar que os sentimentos morais constituem sinais da virtude e do vício, Pitson também insinua que a virtude é diferente do sentimento moral ${ }^{523}$.

Em conformidade com esta interpretação, Jones ${ }^{524}$ afirma que a beleza é uma qualidade que se atribui a um objeto mediante um sentimento agradável, e que a apreensão da beleza consiste no reconhecimento das características do objeto em questão, incluindo o despertar do sentimento ${ }^{525}$ e concebe os valores como poderes $^{526}$ - de causar sentimentos (pressupondo que aqueles são objetivos e não subjetivos) ${ }^{527}$ :

Enquanto tipo particular de sentimento interior, o sentimento da beleza constitui uma paixão calma ou impressão secundária, prazerosa, mas indefinível. A beleza em si não é um sentimento, nem um nome de alguma propriedade estritamente percebida

\footnotetext{
${ }^{520}$ Cf. NORTON, 1982, pp. 111-12.

${ }^{521} \mathrm{~T} 3.1 .1 .26$

${ }^{522} \mathrm{~T}$ 3.1.2.2.

${ }^{523}$ PITSON, 1989, p. 78.

${ }^{524}$ Norton é o primeiro a reconhecer um paralelismo entre a sua interpretação cognitivista relativa à teoria moral de Hume - e a de Jones - relativa à teoria estética do filósofo (cf. NORTON, 1982, p. 109 n12; pp. 116-7 n21).

${ }^{525}$ Cf. JONES, 1982, p. 125.

${ }^{526} \mathrm{D}$. Baxter julga que considerar o valor um poder causal implica considerar que o objeto apenas possui esse valor quando o sentimento é efetivamente desperto. Antes, julga que o valor constitui o conjunto do objeto observado e a reação ao mesmo, e que o agente cognitivo o atribui ao objeto enquanto algo que lhe pertence enquanto objeto idêntico ao longo do tempo. Porém, é exatamente esta posição que tem a consequência que Baxter apontou - que, aliás, estranhamente, aceita (cf. BAXTER, 1990, pp. 111-13). Porém, esta posição tem o mesmo inconveniente de inviabilizar a existência de um padrão para os juízos de valor (reconhecida pelo próprio Hume).

${ }^{527} \mathrm{O}$ autor pensa basear-se em evidências do próprio Hume, que, no seu ver, trata o valor estético (principal foco da sua atenção) como um poder (cf. IPM Ap 1.14; C 14; T 3.3.1.8; T 2.1.8.2; 2.1.10.2).
} 
(visto ou ouvido), mas antes um "poder" nos objetos cuja presença é sentida. 528

Uma vez que a beleza "apenas é discernida por um gosto ou sensação", Hume reivindica que "o poder de produzir dor ou prazer perfazem, desta forma, a essência da beleza e da deformidade". A essência é um "poder" justamente porque a ocorrência de um sentiment (e um ponto de vista adequado, como veremos) é necessário para que seja detetado. Da mesma forma, falar da beleza como "efeito" da interação de um objeto com certas propriedades e uma mente devidamente afinada é apenas enfatizar a sua visão de que poderes são detetáveis apenas no seu exercício, isto é, neste caso, por meio do sentimento da beleza. ${ }^{529}$

Tal como Árdal e Norton reiteram, existem diversas evidências textuais em que Hume afirma que os sentimentos morais são efeitos dos traços de caráter, podem ser observados pela ação. Por sua vez, estas seriam consideradas sinais de motivos para agir (sentimentos morais, que são suas causas) ${ }^{530}$. Norton nota ainda que a conceção das paixões indiretas confirma isto, uma vez que elas são direcionadas a aspetos ou traços de pessoas (objetos das paixões indiretas). Algumas destas evidências são ${ }^{531}$ :

Por que uma ação, sentimento ou caráter é virtuoso ou vicioso? Porque sua visão causa um prazer ou desprazer de um determinado tipo. ${ }^{532}$

[A] virtude se distingue pelo prazer, e o vício, pela dor, produzidos em nós pela mera visão ou contemplação de uma ação, sentimento ou caráter. ${ }^{53}$

[E]sses sentimentos podem surgir (...) seja do simples aspect e aparência de um caráter ou paixão, seja da reflexão sobre sua tendência a trazer o bem da humanidade e dos indivíduos.

\footnotetext{
${ }^{528}$ Cf. IEH 7.1.27, 28; IEH 7.2.30. Tradução minha do original: "As a particular kind of inner feeling, the sentiment of beauty is a calm passion or secondary impression, pleasurable but otherwise indefinable; beauty itself is not a sentiment, nor the name of a strictly perceived (seen or heard) property, but rather a "power" (E.75, 79) in objects whose presence is felt." (JONES, 1982, p. 123).

${ }_{529}$ Tradução minha do original: "Since beauty "is discern'd only by a taste or sensation", Hume claims that "the power of producing pain and pleasure make in this manner the essence of beauty and deformity" ( $\mathrm{T}$ 2.1.8.2); the essence of beauty is a "power" precisely because the occurrence of a sentiment (and a proper viewpoint, as we shall see) is necessary to its detection. Similarly, to speak of beauty as the "effect" of the interaction of an object with certain properties, and a properly tuned mind, is only to emphasise his view that powers are detectable only in their exercise, that is, in this case, by means of the sentiment of beauty." (JONES, 1982, p. 126).

${ }^{530}$ Cf. ÁRDAL, 1966, p. 116, 122; NORTON, 1975, pp. 197-8; 1982, pp. 113-16.

${ }^{531}$ Cf. também T 3.1.1.16, 24; T 3.1.2.1, 5, 8; T 3.2.1.2; T 3.3.1.3, 15.

${ }^{532} \mathrm{~T}$ 3.1.2.3.

${ }^{533} \mathrm{~T}$ 3.1.2.11.
} 
Minha opinião é que essas duas causas se entrelaçam em nossos juízos morais, do mesmo modo que quase todos os tipos de beleza exterior. ${ }^{534}$

Se uma ação é virtuosa ou viciosa, é apenas enquanto signo de alguma qualidade ou caráter. Tem de depender de princípios mentais duradouros, que se estendem por toda sua conduta, formando parte do caráter pessoal. As ações que não procedem de nenhum princípio constante não influenciam o amor ou o ódio, o orgulho ou a humildade; e, conseqüentemente, nunca são levadas em conta na moral. ${ }^{535}$

A juntar a estas evidências, somam-se as definições de virtude oferecidas por Hume, que as estabelece como relação causal ${ }^{536}$. Além disso, note-se que, ao explicar o estabelecimento de um padrão para o gosto estético, Hume utiliza vocabulário causal:

[U]ma vez removidos esses obstáculos, as belezas naturalmente talhadas para despertar sentimentos agradáveis liberam imediatamente as suas energias, e enquanto durar o mundo, elas conservarão sua autoridade sobre as mentes dos homens. ${ }^{537}$

[A]lgumas formas ou qualidades particulares são calculadas para agradar, e outras para desagradar. (PG 12; itálico meu)

[É] preciso admitir que há certas qualidades nos objetos talhadas por natureza para produzir esses sentimentos particulares. $^{538}$

Esta interpretação resulta de uma leitura naturalista e causalista do fenómeno da atribuição de um valor, ou seja, que atenta para uma pretensão de Hume de explicar a origem dos valores exclusivamente a partir de causas humanas da parte de Hume. Esta explicação consiste em notar que entre o motivo para agir, a ação e o juízo do espectador, mantém-se uma série de relações causais: o juízo do espectador é causado pela ação (portanto, efeito da sua observação), que, por sua vez, é efeito do motivo (sentimento moral ou não moral, seu correlato objetivo $)^{539}$.

\footnotetext{
${ }^{534} \mathrm{~T}$ 3.3.1.27.

${ }^{535}$ T 3.3.1.4; Cf. também T 3.3.1.10; T 3.3.1.15; T 3.2.1.6.

${ }_{536}^{536}$ IPM Ap. 1.10.

${ }^{537}$ PG 11; itálico meu.

${ }^{538}$ PG 16; itálico meu.

${ }^{539}$ Cf. NORTON, 1975, p. 194; PITSON, 1989, p. 83.
} 
Por sua vez, Norton repara que o espectador é capaz de determinar o caráter da relação causal entre ação e motivo do agente de acordo com a sua capacidade racional e sensitiva (pelo mecanismo da simpatia). Para o comentador, "ter um determinado sentimento moral é o correlate subjetivo que funciona como sinal de um correlate objetivo", que, por seu turno, constitui "um estado de coisas publicamente acessível”. Este caráter público "é a causa ou ocasião do sentimento", e "pode constituir tal causa ou ocasião apenas porque a operação do entendimento o tornou acessível para nós"540.

Norton fundamenta esta proposta em três constatações: 1) sempre que assevera o papel passivo da razão na ação, friza que se trata da razão por si mesma ou sozinha; 2) a própria definição de impressão de reflexão implica que seja precedida por ideias, do que conclui uma relação causal indireta entre a razão e a ação; 3) a possibilidade de correção dos juízos, que Hume reconhece repetidamente, ao reconhecer a existência de um critério ou padrão objetivo para os juízos de valor - o que introduz a possibilidade do erro, pelo alcance de um ponto de vista geral $^{541}$.

Este ponto de vista é mencionado e explicado por Hume diversas vezes:

$[\mathrm{N}]$ em todo sentimento de prazer ou dor derivado de um caráter ou ação é do tipo peculiar que nos faz louver ou condenar. As boas qualidades de um inimigo são penosas para nós; mas, ainda assim, podem merecer nossa estima e respeito. É somente quando um caráter é considerado em geral, sem referência a nosso interesse particular, que causa essa sensação ou sentiment em virtude do qual o denominamos moralmente bom ou mau. É verdade que temos naturalmente uma tendência a confundir e misturar os sentimentos devidos ao interesse e os devidos à moral. Raramente deixamos de pensar que um inimigo é vicioso e raramente somos capazes de distinguir entre sua oposição e nosso interesse e sua vilania ou baixeza reais. Isso não impede, porém, que esses sentimentos sejam distintos neles mesmos; um homem dotado de serenidade e discernimento pode se proteger dessas ilusões. ${ }^{542}$

Essa parcialidade, portanto, e essa afeição desigual têm de influenciar não somente nosso comportamento e conduta social,

\footnotetext{
${ }^{540}$ Tradução minha do original: "Feeling a particular moral sentiment is the subjective correlate which functions as the sign of an objective correlate, some publicly available state of affairs. But the publicly available state of affairs is the cause or occasion of the feeling. Furthermore, according to Hume, it is able to be such a cause or occasion only because the operation of the understanding has made it available to us" (NORTON, 1982, p. 131).

${ }^{541}$ Cf. NORTON, 1975, p. 195, 200-3; 1982, p. 101, 108, 109n12, 133; JONES, 1982, p. 119.

${ }^{542} \mathrm{~T}$ 3.1.2.4.
} 
mas também nossas idéias de vício e de virtude (...) [A] natureza fornece, no juízo e no entendimento, um remédio para o que há de irregular e inconveniente nos afetos. ${ }^{543}$

Toleramos um certo grau de egoism nos homens, porque sabemos que isso é algo inseparável da natureza humana, e inerente à nossa estrutura e constituição. Por meio dessa reflexão, corrigimos aqueles sentimentos de censura que surgem tão naturalmente diante de qualquer oposição. ${ }^{544}$

Aliás, Garrett aponta este reconhecimento de Hume como um argumento a favor da interpretação cognitivista:

Censuramos tanto aquela má ação sobre a qual lemos nos livros de história quanto a que foi praticada outro dia em nossa vizinhança. Isso significa que sabemos, pela reflexão, que a primeira ação despertaria sentimentos tão fortes de desaprovação quanto a última, caso estivesse na mesma situação. ${ }^{545}$

[P]ara formar um juízo sobre o caráter moral de uma pessoa, limitamos nosso exame ao estreito círculo em que ela se move. (...) Quando formulamos juízos desse tipo, somos rapidamente obrigados a esquecer nosso próprio interesse, em razão das perpétuas contradições que encontramos na conversação e no convívio social com pessoas que não estão na mesma situação, nem têm o mesmo interesse que nós. O único ponto de vista em que nossos sentimentos coincide com os dos demais é o que se forma quando consideramos a tendência de uma paixão a trazer alguma vantage ou a causar algum dano àqueles que têm uma conexão imediata ou um relacionamento com a pessoa por ela movida. E, embora essa vantagem ou esse dano estejam freqüentemente bem distantes de nós, algumas vezes são bem próximos, e nos interessam fortemente em virtude da simpatia. Tal interesse, nós logo o estendemos a outros casos semelhantes; e quando estes são muito remotos, nossa simpatia é proporcionalmente mais fraca, e nosso elogio ou censura, mais tímidos e hesitantes. (...) Da mesma maneira, embora a simpatia seja muito mais fraca que nossa preocupação por nós próprios, e uma simpatia para com pessoas afastadas de nós seja muito mais fraca que para com pessoas contíguas ou vizinhas, desprezamos todas essas diferenças quando formamos juízos serenos a respeito do caráter dos homens. Além do fato de nossa própria situação quanto a esse aspect mudar com freqüência, diariamente encontramos pessoas que estamos em situação diferente da nossa, e que nunca poderiam sequer converser conosco em termos razoáveis se permanecêssemos constantemente naquela situação e naquele ponto de vista que nos são peculiares. Portanto, o intercâmbio de sentimentos na

\footnotetext{
${ }^{543} \mathrm{~T}$ 3.2.2.8-9.

${ }^{544} \mathrm{~T} 3.3 .1 .17$.

${ }^{545} \mathrm{~T}$ 3.3.1.18.
} 
sociedade e no convívio diário nos leva a formar um critério geral e inalterável com base no qual possamos aprovar ou desaprovar caracteres e maneiras. ${ }^{546}$

A correção dá-se por uma consideração das impressões de como os objetos são em si e das circunstâncias (externas e internas) em que afetam os espectadores. Neste sentido Garrett faz uso da analogia entre juízos morais e juízos dos sentidos, explicando que por um exercício reflexivo dirigido à nossa experiência, "aprendemos a distinguir as variações que se devem a circunstâncias e a disposições particulares da mente das que se deevem a alterações no objeto". Da mesma forma que nos juízos sobre propriedades sensíveis (como dimensões e cores), "estas impressões (...) servem de padrão inicial” para tais juízos, "exatamente como os sentimentos morais servem como padrão original para juízos sobre virtude e vício". Esse padrão, "é corrigido para incluir as variações previsíveis nas impressões que se devem a aspetos acidentais das circunstâncias externas" - como a distância em relação ao objeto -, "ou a circunstâncias internas" - como a saúde ou a doença -, fazendo-nos "considerer apenas como os objetos apareceriam sob o "pontos de vista fixos e gerais"”,547.

A este propósito, vale notar que para melhor ilustrarem a existência e a função de um padrão ou regra para juízos de valor, os proponentes da interpretação cognitivista notam que este é um traço que Hume admitia ser comum entre aqueles juízos e os dos sentidos (externos), como os referentes à cor ou à distância dos objetos no campo visual. Portanto, estes comentadores ressaltam uma analogia entre juízos de valor e juízos sobre qualidades secundárias, isto é, propriedades observáveis (ou juízos dos sentidos), a fim de mostrar que em ambos os casos é possível destacar e alcançar um padrão objetivo para determinar o valor de verdade dos juízos e corrigi-los:

\footnotetext{
${ }^{546}$ Tradução minha a partir de: "According to Hume, by reflecting on our own experiences we learn to distinguish those variations which are due to the particular circumstances and particular dispositions of our minds from those which are due to changes in the object. When we judge an object's size, color, etc., we do so on the basis of sense impressions-these impressions serve as the original standards for judgments of size, color, etc. just as the moral sentiments serve as the original standards for judgments of virtue and vice-but we correct for those predictable variations in impressions that are due to accidental features of the external circumstances (for example, lighting or our distance from the object) or to peculiar internal circumstances (for example, illness), and we consider only how the objects would appear from "steady and general points of view" (T 3.3.1.15). When we make these corrections we can separate the subjective effect from the quality in the object that is its cause."' (GARRETT, 1997, pp. 190-1). Cf. também T 3.3.3.2.

${ }^{547}$ SWAIN, 1992, p. 485.
} 
Não preciso estender-me sobre as considerações mais banais empregadas pelos céticos de todas as épocas contra a evidência dos sentidos, tais como as que derivam das falhas e imperfeições de nossos órgãos em um sem-número de ocasiões, a aparência torta de um remo na água, as diferentes perspectivas dos objetos conforme suas diferentes distâncias, as imagens duplas produzidas ao se pressionarem os olhos, e muitos outros fenômenos de natureza similar. (...) [Esses juízos] devem ter seu testemunho corrigido pela razão [itálico meu] e pelas considerações ligadas à natureza do meio, a distância do objeto e a disposição do órgão, para que se tornem, dentro de seu âmbito, os critérios próprios de verdade e falsidade. ${ }^{548}$

\section{Da mesma forma, ao discorrer sobre o ponto de vista desinteressado na}

moral, Hume nota a possibilidade de correções no juízo de valor assim como no juízo dos sentidos ${ }^{549}$. Árdal clarifica este paralelo:

[A] nossa situação em relação aos objetos varia no tempo, e os nossos humores podem alterar o efeito que um mesmo objeto tem sobre nós em diferentes momentos. Rapidamente aprendemos que alterações na nossa situação alteram a aparência das coisas. (...) Posso ter bebido água parada num momento de sede extrema, e ainda assim não ser inclinado a alegar que essa água estava deliciosa. Antes, percebo que a situação incomum de sede extrema possa ter tido algo a ver com a forma como a água me sabia naquele momento.

As aparências dos objetos podem variar de acordo com a nossa situação em relação a eles e a nossa própria condição. Algumas alterações nas aparências parece mais naturalmente explicável por uma alteração em nós ou na nossa posição. Diferenças nas cores aparentes dos objetos passam a ser atribuídas a alterações na luz ou nos nossos órgãos sensoriais como no caso da icterícia. Assim, mediante vasta experiência, começamos a delinear a distinção entre alterações que se devem a alterações em qualidades nos objetos e alterações que se devem à nossa situação ou condição especial, que possivelmente não é partilhada por outros. ${ }^{550}$

\footnotetext{
${ }^{548}$ IEH 12.6; itálico meu.

${ }^{549}$ Cf. T 3.3.1.16, citada acima.

${ }^{550}$ Tradução minha do original: "[O]ur situation in regard to objects varies from time to time, and our moods may also change the effect the same object has upon us at different times. We soon learn that changes in our situation alter the appearances of things. (...) I might have had a drink of stagnant water when plagued with extreme thirst, and yet I would not be inclined to claim that such water was delicious. I realize that the unusual condition of my extreme thirst may have had something to do witli the way the water tasted to me at the time. The appearances of objects vary according to our situation in regard to them and our own condition. Some changes in appearances seem to be most naturally explained by attributing the variation to a change in us or in our position. Differences in the apparent colours of objects come to be attributed to changes in the light, or, as in jaundice, to a change in our sense-organs. Thus, with wide experience, we begin to draw a distinction between changes due to a change of qualities in the object, and changes due to our special situation or condition which is perhaps not shared by others" (ÁRDAL, 1966, pp. 11819).
} 
Pitson também explica que os pontos de semelhança entre os dois tipos de juízo são: 1) assim como a apreensão do objeto que começa com a sensação proporciona uma ideia dos corpos, o gosto também permite a apreensão dos valores; 2) assim como as sensações variam de acordo com o seu objeto, também a virtude (diferentes virtudes) e a beleza (pode pensar-se em diversos tipos como pessoas, músicas, sabores ou pinturas) variam de acordo com tipos ${ }^{551}$; 3) ambos fazem parte da constituição original da mente; 4) ambos são corrigíveis. Por seu turno, Árdal acrescenta que o facto de haver a possibilidade de um padrão em virtude do qual se decide o valor de verdade de um juízo, adquirido neste plano intersubjetivo é suficiente para se considerarem todos os juízos como objetivos ${ }^{552}$.

O comentador acrescenta que a ideia de que há um senso moral não deriva das referências de Hume ao mesmo - pois, de facto, são escassas e não se fazem acompanhar de uma explicação detalhada - mas sim dos paralelos explícitos que Hume estabelece com os sentidos externos. Assim, julga que os dois tipos de correção possíveis para os juízos dos sentidos são igualmente aplicáveis ao senso moral $^{553}$.

Em perfeita concordância com esta analogia está uma interpretação da filosofia do gosto de Hume como uma teoria da perceção, em que atribuir um valor a um objeto significa ter uma perceção do mesmo, que origina o juízo, e que

\footnotetext{
${ }^{551}$ Cf. T 3.3.4.2.

${ }^{552}$ Cf. ÁRDAL, 1966, pp. 122-3; cf. PITSON, 1989, pp. 77-8, 79-84; SWAIN, 1992, pp. 484-5.

${ }^{553}$ Cf. IEH 12.1.7; PITSON, 1989, pp. 76-7, 80-1; KAIL, 2007b, 4.9.5. Para Dickie, Hume não apoiava o surgimento dos agrados e desagrados na existência de sentidos internos - assim como nos outros âmbitos (sentidos externos, faculdades), limitando-se à constatação do surgimento daqueles (cf. T 3.1.2.3), a fím de respeitar o seu próprio propósito de não ir além do que a investigação empírica permite em relação aos mecanismos que explicam os processos mentais dos quais trata (cf. DICKIE, 2006, p. 146). Com efeito, Garrett aponta esta como uma evidência a favor da interpretação cognitivista, uma vez que seria indicativo da existência de uma questão de facto à qual a mente responde com um sentimento (cf. GARRETT, 1997, pp. 190-1). Em primeiro lugar, apesar de Hume não se preocupar em definir explicitamente em que consiste o senso moral ou estético, as referências do filósofo aos mesmos são numerosas (cf. T 2.1.12.5; 3.1.1.10; $3.1 .1 .19,20 ; 3.1 .2 .3 ; 3.1 .2 .9 ; 3.2 .1 .1 ; 3.2 .1 .7 ; 3.2 .1 .17,18,19 ; 3.2 .2 .10 ; 3.2 .2 .20,21,24,25$; 3.2.6.11; 3.3.5.5; 3.3.6.3, 4; IEH 11.22 (sense of morals, sense of morality, sense of justice, sense of virtue and vice, sense of common interest, sense of moral good and evil); T 2.1.1.3; 2.2.11.2, 4; 3.3.1.8; 3.3.6.1; 1.3.10.1 (sense of beauty); IEH 5.2.10; 7.1.4; IPM 1.3, 9; PG 16 (internal sense); IPM 7.10n42.1 (sense of value)). Em segundo lugar, julgo que estas evidências permitem a conclusão de que Hume concebia a existência de um sentido interno e que esta não é uma cedência que torne o seu sistema inconsistente - basta lembrar que apesar de estabelecer um limite à investigação empírica sobre a explicação desses mecanismos, as próprias faculdades da memória e da imaginação são igualmente dadas como existentes, mesmo se não são incluídas na identidade
} 
este consiste na deteção da virtude e do vício como propriedades que se mostram ao senso moral por meio da experiência dos sentimentos morais, e que pode ser corrigido tal como os juízos dos sentidos e os juízos causais:

Também a perceção moral depende de sentimentos [feelings] não representativos, subjetivos, que funcionam como sinais da realidade externa. Ele [Hume] assegura que não há um órgão separado, mas uma vez tendo percebido uma ação humana pela perceção comum, o nosso senso moral responde com sentimentos que servem como sinais, e isto porque eles também são acompanhados por certas ideias concomitants: de duração e número, claro, mas também pelos concomitantes morais que são representativos da realidade moral extramental. ${ }^{554}$

Portanto, a função do senso moral é a de nos habilitar a discerner as qualidades ou caracteres que tornam ações virtuosas ou viciosas, assim como os sentidos corporais adequadamente corrigidos - nos oferecem informação sobre os aspetos duradouros dos objetos, por trás das suas aparências momentâneas. Numa palavra, a forma como o senso moral atua - por exemplo, em relação à virtude - é esta: uma certa qualidade da mente é agradável ou útil à pessoa a quem concerne ou a outras; os seus efeitos agradáveis ou úteis são-nos comunicados por meio do mecanismo da simpatia, pelo qual somos capazes de experienciar o prazer ou a satisfazação do próprio agente, ou de outros, como se fosse nosso; assim, por associação, estas impressões originam o sentimento prazeroso de aprovação, juntamente com as paixões do amor ou do orgulho. ${ }^{555}$

A referência de Hume [é] a um senso que, assim como os sentidos externos, apenas opera ajustadamente quando corrigido em conformidade com crenças que provêm da razão e da

pessoal. Em terceiro lugar, Dickie não refere que uma parte considerável do Tratado é dedicada à explicação (das causas) dos mecanismos das paixões (diretas e indiretas).

${ }^{554}$ Tradução minha do original: "Moral perception, too, is dependent upon nonrepresentative, subjective feelings which function as signs of external reality. There is no separate organ of moral perception, he grants, but once we have by ordinary perception perceived some human action, our moral sense responds with feelings of approbation and disapprobation. It is these feelings that serve as signs, and they do so because they are also accompanied by certain concomitant ideas: duration and number, of course, but also by the moral concomitants that are representative of extramental moral reality." (NORTON, 1982, p. 132). Halberstadt chega precisamente pelos mesmos meios que Norton à mesma conclusão relativamente ao valor estético (cf. HALBERSTADT, 1971).

555 Tradução minha do original: "The function of the moral sense, then, is to enable us to discern the qualities or character which render actions virtuous or vicious, rather as the bodily senses suitably corrected - provide us with information about the enruding features of objects which underlie their momentary appearences. In brief, the way in which the moral sense operates here e.g., in regard to virtue - is this: a certain quality of mind is agreeable or useful to the person concerned or to others; its agreeable or useful effects are communicated to us via the mechanism of sympathy, by means of which we are able to experience the pleasure or satisfaction of the agent himself, or of others, as our own; these impressions then give rise, by association, to the pleasurable sentiment of approbation, together with the agreeable passions of love or pride." (PITSON, 1989, pp. 81-2). 
experiência. O senso moral cumpre a sua função quando nos permite discerner as qualidades da mente ou caráter que tornam a ação (assim como as suas tendências) virtuosa ou viciosa. Ao fazê-lo, dá-nos informações (...) sobre suas causas e efeitos, de uma forma que evita que identifiquemos a teoria de Hume com a negação de que há algo nessas ações que corresponda aos nossos sentimentos morais. ${ }^{556}$

Portanto, o conhecimento dos valores - morais e estéticos (respetivamente, a virtude e a beleza) inicia-se com a perceção desse valor e pode ser corrigido e refinado, mediante a reflexão ou o uso da razão. Portanto, ainda que passe diretamente pelo despertar de um estado qualitativo no agente (o sentimento estético ou moral), estes comentadores julgam que o acesso que se tem aos valores constitui uma forma de conhecimento. Pitson chega mesmo a afirmar que os projetivistas erraram por prestarem pouca atenção ao senso (moral e estético), capaz de apreender as propriedades em questão (os valores) - outra evidência que Garrett julga estar a favor da interpretação cognitivista ${ }^{557}$. Portanto, os projetivistas, de alguma forma, não perceberam que o facto de ser captado por um senso (moral e estético) confere ao valor um estatuto epistémico mais forte do que aquele que the atribuem - deflacionário, pois afirmam que a crença na objetividade é falsa por não ser descoberta pela razão, mas antes, projetada ou fingida pela imaginação.

\section{Conhecimento}

Norton nota que o exercício da razão no âmbito dos valores requer não a existência de um senso delimitado na mente (ao contrário dos sentidos externos, salvo, talvez, o caso do tato), mas um funcionamento combinado de várias faculdades (como os sentidos, a memória e a imaginação) e uma comparação de diversas impressões e ideias, além da extensão da simpatia. Este consiste em informar sobre a distinção entre motivos interessados e desinteressados, quais os sinais e condicionantes de cada um, tornando o agente capaz de adotar um ponto

\footnotetext{
${ }^{556}$ Tradução minha do original: "Hume's reference here to a sense and one which, like the external senses, operates successfully only when corrected in accordance with beliefs arising from reason and experience. The moral sense performs its function when it enables us to discern those qualities of mind or character which make an action (together with its tendencies) virtuous or vicious. In doing so it provides us with information (...) about their causes and effects in a way which prevents us from equating Hume's theory with the denial that there is anything in these actions corresponding to our moral sentiments." (PITSON, 1989, p. 89).
} 
de vista geral - um ponto de vista que lhe permita conhecer (delimitando ideias e conexões) e sentir um agrado independentemente de o objeto ou a ação manter ou não relações consigo. Este ponto de vista fornece um discernimento acerca dos objetos sobre os quais a atenção se volta e se geram sentimentos. Logo, se os objetos forem apresentados de outra forma ou contendo elementos discerníveis, posteriormente, isto resultaria numa alteração dos sentimentos. À razão cabe fornecer regras gerais que servem para corrigi-los (mediante a confirmação de uma conformidade do sentimento com elas) e distinguir aqueles que podem parecer semelhantes, ou o contrário, descobre os traços de caráter que causam a ação, determinando se é ou não virtuosa, e permite eliminar o preconceito e a idiossincrasia da situação avaliada e moldar uma reação de acordo com essas regras gerais ${ }^{558}$.

Como observa Swain, esta relação causal envolve uma longa cadeia de eventos e variáveis internas que se traduzem numa pluralidade de efeitos. Por sua vez, o raciocínio causal sobre as ações e motivos é semelhante a todos os outros: se se percebe uma evidência contra a inferência a favor de uma certa causa, atribui-se-lhe outra. Portanto, uso da razão a fim de estabelecer regras gerais que servirão de critério para regular e corrigir os sentimentos consiste exercício do mesmo tipo de razão empregue noutras ciências empíricas (que perfazem a Ciência do Homem), o que parece ser o que estes comentadores julgam tornar o fenómeno dos valores (moral e estético) cognoscíveis, inteligíveis ${ }^{559}$.

Por sua vez, este conhecimento é a posteriori e científico e consiste na determinação de uma questão de facto - configurada pelo reconhecimento dos traços do objeto que provocam um certo sentimento como condicionantes para que esse sentimento não ocorra ou não se desperte na mente. Uma vez que Hume não previu a possibilidade de se gerarem diferentes efeitos de uma mesma causa, por mais complexa que seja a relação, se os efeitos forem diferentes, têm diferentes causas, ou há circunstâncias que interferem numa relação causal

\footnotetext{
${ }^{557}$ Cf. PITSON, 1989, p. 62; GARRETT, 1997, pp. 190-1.

${ }^{558}$ Cf. NORTON, 1975 , pp. 201-3; 1982, pp. 121, 128-32. Árdal vai mais longe e sugere que o próprio exercício da razão para atingir o ponto de vista geral é condição de Hume poder defender uma posição originalmente sentimentalista sem correr o perigo de resvalar no relativismo (cf. ÁRDAL, 1966, p. 118).

${ }^{559}$ Cf. BRUNET, 1965, pp. 164-5, 712, 766-7; SWAIN, 1992, pp. 482-3, 487.
} 
(supostamente) única; quando tal se verifica, não há uma regra absoluta e está-se no campo da preferência ${ }^{560}$.

Passo agora à explicação de como estes comentadores explicam que se dá este conhecimento (a posteriori, causal) dos valores na filosofia de Hume e sob a sua interpretação. Destacam-se três condições para que haja efetivamente uma objetividade (isto é, uma referência comum que possibilite um padrão e um valor de verdade para para os juízos): i) a existência de convenções na linguagem, ii) uma arquitetura mental uniforme entre os agentes e espectadores (que Norton também já reconhecia) e iii) a possibilidade de atingir um ponto de vista geral. Estas considerações são apresentadas como tais por Jones, e também são notadas por Swain. Por seu turno, Garrett acrescenta que iv) o processo de formação dos juízos de valor é de abstração, isto é, envolve a aplicação de ideias abstratas.

Com efeito, o uso da razão no desenvolvimento do gosto (estético e moral) consiste numa compreensão dos factos relevantes em cada situação para averiguar o valor de um objeto ou ação - portanto, na delimitação de ideias e conexões entre os objetos e entre estes e o espectador e/ou agente. Esta compreensão dá-se pela aquisição de um certo ponto de vista, que, por sua vez, só é possível mediante o exercício dos mecanismos da simpatia e da comparação e da formação de ideias abstratas - dos objetos e respetivos traços, que não são particulares, mas gerais, nas suas relações e no seu efeito (que por terem sempre o mesmo efeito ${ }^{561}$, se conclui que respeitam a uma generalidade). Por sua vez, o acordo ou desacordo entre os indivíduos depende do valor de verdade que atribuem a cada juízo sobre os valores, depende de cada indivíduo avaliar ou não o objeto ou ação de acordo com o ponto de vista requerido para ocasionar um juízo tão imparcial quanto possível e supõe a instauração de um critério em virtude do qual os juízos podem ser consideradas verdadeiras ou falsas (e os indivíduos podem concordar com as mesmas ou discordar delas). Estas trocas e relações performam um sistema intersubjetivo.

Passo a explicar de que forma estes comentadores entendem que há um conhecimento (causal) dos valores na filosofia de Hume, para depois explicar

\footnotetext{
${ }^{560}$ Cf. JONES, 1982, pp. 108-10, 115, 124.

561 Aqui entram na nossa consideração também as regras gerais, que nos fazem atribuir as mesmas causas aos mesmos efeitos (aplicado, neste caso, aos atos justos e injustos; cf. MONTEIRO, 1975, p. 69).
} 
como os mesmos entendem que tal conhecimento se adquire. Resgatando a observação de Norton de que as impressões de reflexão são efeitos de ideias, pode perceber-se que é uma sucessão deste tipo que está em causa no exercício dos princípios que são requeridos para a aquisição de um ponto de vista sob o qual algo pode ser considerado belo (em geral) e alguém ou um traço de caráter, virtuoso (em geral). A aquisição deste ponto de vista passa pelo conhecimento de regras gerais - sobre o que a generalidade dos homens julga - mas também (em princípio) pela experiência da impressão de reflexão em questão. Aliás, como bem lembra Capaldi, o próprio Hume reconhece-o explicitamente ${ }^{562}$ :

Caso alguém perguntasse por que os homens formam regras gerais e permitem que elas influenciem seu julgamento, mesmo contra a observação e experiência presente, eu responderia que, em minha opinião, isso se deve aos mesmos princípios de que dependem todos os juízos sobre causas e efeitos. ${ }^{563}$

A única forma de se eliminar essa dificuldade é admitir a influência de regras gerais. Mais adiante, observaremos algumas regras gerais pelas quais devemos regular nosso juízo sobre causas e efeitos. Essas regras se formam segundo a natureza de nosso entendimento, e conforme nossa experiência da operação deste nos juízos que formamos acerca dos objetos. Graças a elas, aprendemos a distinguir as circunstâncias acidentais das causas eficientes. Quando descobrimos que um efeito pode ser produzido sem a concorrência de alguma circunstância particular, concluímos que essa circunstância não faz parte da causa eficiente, por mais freqüente que seja sua conjunção com ela. Mas como essa conjunção freqüente necessariamente faz que tal circunstância tenha um efeito sobre a imaginação, apesar da conclusão oposta decorrente das regras gerais, a oposição desses dois princípios produz uma contrariedade em nossos pensamentos fazendo-nos atribuir uma das influências a nosso juízo e a outra, nossa imaginação. A regra geral é atribuída ao juízo, por ser mais extensa e constante; a exceção à imaginação, por ser mais caprichosa e incerta. ${ }^{564}$

Quando um caráter, sob todos os aspectos, é apropriado para beneficiar a sociedade, a imaginação passa facilmente da causa ao efeito, sem considerar que ainda faltam algumas circunstâncias para tornar completa a causa. As regras gerais criam uma espécie de probabilidade, que influencia às vezes o juízo, e sempre a imaginação. (...) $\mathrm{O}$ mesmo ocorre quando corrigimos as diferenças que se produzem em nossos sentimentos de virtude em razão das diferentes distâncias do

\footnotetext{
${ }^{562}$ Cf. CAPALDI, 1989, pp. 121-22.

${ }^{563} \mathrm{~T}$ 1.3.13.8.

${ }^{564} \mathrm{~T}$ 1.3.13.11.
} 
caráter virtuoso em relação a nós. As paixões nem sempre seguem nossas correções; mas essas correções são suficientes para regular nossas noções abstratas, sendo as únicas levadas em conta quando nos pronunciamos em geral a respeito dos graus de vício e de virtude. ${ }^{565}$

Jones lembra que Hume requer a operação da simpatia e da comparação para atingir o ponto de vista desinteressado no juízo moral - o que permite, para o comentador, aplicar o mesmo raciocínio ao juízo estético: a comparação ou "a variação de nossos juízos acerca dos objetos Segundo a proporção entre estes e aqueles com os quais os comparamos" permite que a consideremos medíocre "quando opomos uma coisa a outra da mesma espécie"566. Portanto, a simpatia permite a comunicação dos sentimentos, pela qual se tem um acesso sensitivo à sua posição e se pode associar esse sentimento à presença ou ausência de uma certa relação entre o objeto e os espectadores e/ou os agentes, e a comparação permite uma análise das circunstâncias em que o traço de caráter em questão está mais ou menos relacionado com o eu, permitindo estabelecer a medida do que consiste ser dependente ou independente do mesmo, ou ligado, relacionado ou não com ele ${ }^{567}$.

Há uma consideração de Garrett que, a meu ver, permite uma explicação mais completa do que envolve, do ponto de vista cognitivo, a operação da comparação e do conhecimento (causal) do valor. O comentador considera os juízos de valor (proposições sobre valores) como aplicação de um conceito ou ideia geral do valor em questão a um objeto ou caráter particular. Por sua vez, o estabelecimento de regras sobre o gosto dar-se-ia por abstração, isto é, pela criação de termos gerais através do hábito e de uma inferência a partir de particulares semelhantes.

O estabelecimento de uma regra ou referência do que constitui o valor (ou, como nota Norton, o seu correlato objetivo) parte de uma experiência - em

\footnotetext{
${ }^{565} \mathrm{~T} 3.3 .1 .20-21$.

${ }^{566}$ T 3.3.2.4. Cf. também T 3.2.2.2-4; JONES, 1982, pp. 127-8; KORSEGAARD, 1999, p. 18. Cf. também T 3.3.2.4; 2.2.8.2; 2.2.8.7; 3.2.7.8; 3.2.10.6; T 3.3.1.8, 20 e $23 ; 3.3 .6 .1 ; 2.2 .5 .16 ; 3.3 .5 .4$ Particularmente, acerca do gosto estético, Hume afirma: "É impossível continuar a praticar a contemplação de qualquer ordem de beleza sem ser frequentemente obrigado a formar comparações entre as muitas espécies e graus de excelência e a estimar a proporção entre elas." (PG 20).
} 
princípio, regular, ou no mínimo, variada - através da qual se comparam instâncias em que os valores surgem (em ações ou na experiência estética, pelo despertar de um sentimento no seu espectador) e em que grau ou medida. Por sua vez, da descoberta daquilo em que consiste a virtude - no caso da moral resultam termos (gerais) para designar o valor - no caso da moral e as duas definições que Garrett destaca - a partir da utilidade e do sentimento do espectador. Neste sentido, julgo oportuno lembrar que Hume afirma, a propósito da formação de ideias gerais, que:

É evidente que, ao formar a maior parte de nossas idéias gerais, se não todas elas, fazemos abstração de todo e qualquer grau particular e qualidade; e quem um objeto não deixa de pertencer a uma espécie particular cada cez que ocorre uma pequena alteração em sua extensão, duração e outras propriedades. ${ }^{568}$

Para Garrett, à medida que a imaginação estabelece as distinções necessárias nas situações avaliadas e o mecanismo de simpatia as vai acompanhando, os sentimentos vão-se alterando e, com isto, a configuração do ponto de vista geral e os juízos particulares dos espectadores. Neste processo que pode ser individual e plural - e nas trocas intersubjetivas (das relações humanas), são utilizados termos gerais, a bem da obtenção de uma referência comum e, nalguns casos, da própria efetividade de uma influência mútua.

Por seu turno, essas ideias e termos gerais são formados a partir da experiência e do hábito, que se faz acompanhar de e progride mediante sentimentos (morais e/ou estéticos) - supostamente, cada vez mais refindos. A dada altura, cria-se uma espécie de dialética entre sentimentos e regras, em função da criação e influência das noções gerais. Este processo valeria tanto para a determinação do que cada indivíduo considera como tendo um certo valor, como para a determinação do que a generalidade dos homens considera como tal - a edificação da Moral e da Crítica como ciências. Portanto, o que definiria o ponto de vista geral seria o agente desenvolver uma impressão de reflexão em relação a uma ideia abstrata (e não uma ideia particular, que passa a ser, para Garrett, marca do interesse e do preconceito), composta pelo que chama de revival set, isto é, um

\footnotetext{
${ }^{567}$ A este propósito, vale lembrar que Hume considera que a comparação tem o efeito contrário ao da simpatia, uma vez que coloca os objetos em contraste, por meio dos princípios de associação (cf. TOWNSEND, 2001, p. 151, 153).

${ }^{568} \mathrm{~T}$ 1.1.7.2; itálico meu.
} 
conjunto finito de ideias particulares às quais se pode recorrer para esclarecer o significado da ideia em questão ${ }^{569}$.

Cohon acrescenta que este processo permite um acesso ao valor de verdade das proposições sobre valores através de um recurso ao revival set das ideias (morais e estéticas) ${ }^{570}$. Em relação a juízos estéticos, Jones também faz uma observação que parece ir neste sentido, afirmando que para Hume, não é possível um tal juízo "sem algum conceito do objeto ao qual a beleza é atribuída", nem justificá-lo "sem um apelo ao tipo de beleza em questão",571.

\section{Comunicação e intersubjetividade}

Um fator determinante neste processo de abstração é o que Árdal e Jones resgatam, a saber, do uso e do papel da linguagem. Com efeito, uma instituição social pressupõe o funcionamento da linguagem ou a possibilidade de comunicação entre os seus membros. Portanto, parte da aprendizagem das descrições das relações causais entre objetos e espectadores dá-se pela aquisição de conhecimento e o uso das convenções linguísticas. A existência de convenções e regras permite uma objetividade e inteligibilidade da comunicação (portanto, um valor de verdade para os juízos). Além de este método permitir a descoberta de verdades sobre relações causais, a existência de uma regra garantiria a objetividade no contexto do gosto. Sendo possível determinar as circunstâncias em que o prazer estético surge, é possível debater o valor dos objetos com outros agentes e espectadores e averiguar a sua concordância ou discordância. Esta possibilidade é, para o comentador, o que oferece uma objetividade à discussão, ao juízo e à regra - portanto, uma uniformidade intersubjetiva fundamenta uma objetividade. $\mathrm{O}$ emprego destes princípios é determinante para atingir um ponto de vista geral - definido como um conjunto de descrições e situações, às quais se associam crenças e atitudes -, que se atinge pelo refinamento das descrições do modo como se apreende os objetos ${ }^{572573}$.

\footnotetext{
${ }^{569}$ Cf. 1.4 deste trabalho; GARRETT, 1997, pp. 196-204.

${ }^{570}$ Cf. GARRETT, 1997, pp. 195-6; COHON, 2008, p. 154.

${ }^{571}$ Tradução minha a partir de: "without some concept of the object to which beauty is ascribed", "without appeal to the type of beauty in question" (JONES, 1982, p. 124).

${ }^{572}$ Eventualmente, pode pensar-se que a diferença entre alguém que está sob este ponto de vista e um fingidor reside no facto de que o segundo conhece as conexões e circunstâncias mas não é afetado pelas mesmas por uma impressão de reflexão, contrariamente ao primeiro (que detém atitudes, disposições, crenças, sentimentos, associados a esse conhecimento). Transferindo esta
} 
Com efeito, Hume chega mesmo a afirmar que o processo de intercâmbio e correção dos juízos é necessário para que haja comunicação - portanto, que não parece haver comunicação sem esse processo:

Correções como essa são comuns para todos os sentidos; na verdade, seria impossível fazer uso da linguagem, ou comunicar nossos sentimentos uns aos outros, se não corrigíssemos as aparências momentâneas das coisas, desprezando nossa situação presente. ${ }^{574}$

O filósofo também afirma que a existência de um padrão para os juízos de valor tem uma utilidade prática de convivência e transmissão de conhecimento ${ }^{575}$.

Estas evidências textuais parecem confirmar a convicção de Pitson de que o ponto de vista desinteressado é o próprio padrão ou critério para os juízos, que permite uma referência ou objeto do mesmo além da mente. O comentador esclarece que para que os juízos morais sejam concernentes a objetos (e não a mentes), "tais juízos têm de transcender as aparências momentâneas que tais objetos nos apresentam aos sentidos", e que "a objetividade do juízo depende da objetividade do ponto de vista" ${ }^{576}$. No mesmo sentido, Cohon observa que defender uma interpretação anti-realista sobre os valores na filosofia de Hume não implica defender uma interpretação não cognitivista da mesma. Quer dizer, ainda é possível defender que juízos sobre valores possuem um valor de verdade, mas

consideração para as palavras de Hume, isto significaria que no caso do fingidor apenas a comparação teria operado, mas não a simpatia.

${ }^{573}$ BRUNET, 1965, pp. 264-5; ÁRDAL, 1966, p. 118, 122-3; CAPALDI, 1989, pp. 3, 15, 195, 215, 255, 284; JONES, 1982, pp. 93, 103, 115, 123, 128-31, 132; SWAIN, 1992, p. 482; COHON, 2008, pp.126-60. Cohon apresenta a grande peculiaridade de ter desenvolvido a configuração deste plano de acordo intersubjetivo como padrão ou critério em virtude do qual os juízos sobre valores possuem um valor de verdade defendendo, simultaneamente, uma interpretação descritivista subjetivista (cf. 2.2.2, onde apresento uma perplexidade relativa a esta conjunção de interpretações). Por seu turno, a autora concorda com Mackie no facto de que a existência deste plano não permite uma objetividade genuína (cf. MACKIE, 1977, p. 22), uma vez que a proposta de Hume sobre os valores se mantém anti-realista e acrescenta ser inequívoco que as evidências textuais mostrem que Hume rejeita explicitamente o realismo (no campo metafísico; COHON, 2008, p. 128 n1, 260). Já Capaldi e Swain parecem julgar que a intersubjetividade pode ser considerada uma forma de objetividade. Porém, Capaldi ainda mantém que mesmo sendo assim, Hume continua a ser um anti-realista (cf. CAPALDI, 1989, p. 16, 320, 321 n38, 341 n29, 370 n46). Na secção 4.5, retomarei este tópico, a fim de mostrar que esta ambiguidade nos deve levar à conclusão de que a intersubjetividade constitui uma "quasi-objetividade", ainda que considere a análise de Capaldi a mais ajustada entre as apresentadas.

574 T 3.3.1.16.

${ }^{575}$ Cf. T 3.3.3.2, citada acima.

576 Tradução minha a partir de: "such judgements must transcend the momentary appear- ances which those objects present to the senses. In each case, objectivity of judgement depends upon objectivity of viewpoint" (PITSON, 1989, p. 86). 
que este não é determinado em função de uma propriedade objetiva independente da mente dos agentes e espectadores ${ }^{577}$.

Entretanto, Árdal prossegue acerca da importância da linguagem na formação do ponto de vista geral, notando que este é um processo em que é necessária uma adesão prévia dos indivíduos às práticas linguísticas para aprender os padrões ou regras gerais - e usar cada termo para designar os mesmos estados mentais. Trata-se de uma aplicação das mesmas em avaliações particulares e trocas intersubjetivas para que, posteriormente, haja uma capacidade de revê-los e corrigi-los. Neste sentido, o comentador esclarece que para que haja comunicação relativa a valores morais e se estabeleça um padrão de juízo, "uma regra geral para o uso deve ser observada entre pessoas que falam uma língua”. Esta, “empregue para descrever aparências, gostos e desgostos pessoais", “deve ser objetiva no sentido em que as várias pessoas que usam essa língua devem aplicar a regra mais ou menos da mesma forma". Deste modo, "podemos aplicar um padrão ou regra geral intersubjetivo(a) mais ou menos definido(a)", estabelecido(a) tacitamente no próprio uso das regras. Retomando a comparação entre juízos morais e dos sentidos, Árdal prossegue:

Um objeto é vermelho se aparece como tal a um espectador, dadas condições normais de luz e o estado normal dos órgãos sensoriais do homem. Ao julgar sobre dimensões, temos padrões de comparação que podem ser aplicados por quem utiliza uma linguagem, e adota-se um sistema convencional de pesos e medidas. Mas não se sugere que alguém inventou ou estabeleceu um padrão para o uso de todas as palavras. (...) [A] experiência ensina-nos as vantagens da linguagem, e um acordo tácito para manter as regras da linguagem cresce. (...) Uma comunicação bem-sucedida em casos individuais depende de uma adesão geral a convenções que governam as regras da linguagem. ${ }^{.78}$

\footnotetext{
${ }^{577}$ Cf. COHON, 2008, p. 123.

${ }^{578}$ Tradução minha a partir de: "[T] he value of [moral language] depends largely upon the ease with which it allows us to communicate with our fellow men. In order that communication may be achieved, a general rule of usage must be observed by people speaking the language. It must be objective in the sense that the various people using the language must apply the rule more or less in the same way. This applies to all language, even the language used to describe appearances and purely personal likes and dislikes. (...) We can then apply some more or less definite intersubjective standard or general rule. An object is red if it appears so to any spectator, given normal conditions of light and the normal state of a man's sense-organs. In judging size, we have standards of comparison that may be applied by those using the language; a conventional system of weights and meas ures is adopted. But there is no suggestion that anyone has invented and deliberately laid down a standard for the use of all words. (...) [E]xperience teaches us the advantages of language, and a tacit agreement to abide by the rules of language grows up. (...)
} 
Deste modo, a linguagem expõe o padrão, critério ou referência fixa suficiente para a decorrência da discussão e um possível acordo entre indivíduos, encobrindo os fatores de desacordo, isto é, as variações de sentimentos individuais $^{579}$. A este propósito, vale lembrar que já se tendo mostrado um sentimentalista, Hume não julga que um conhecimento do padrão garanta que se despertem sentimentos correspondentes ao mesmo no agente e/ou espectador. É esta sobreveniência do sentimento relativamente aos conteúdos da razão que abre a possibilidade do fingidor ${ }^{580} \mathrm{e}$, presumivelmente, leva Hume a não incluir o despertar desse sentimento nas utilidades do padrão, limitando-se ao uso dos termos na vida quotidiana e à transmissão de conhecimento. Portanto, parece plausível pensar que o próprio padrão e uma eventual atribuição de um valor de verdade intrínseca ao juízo são parte constitutiva da própria comunicação. Entretanto, a correção parece ser consequência disto, pois corrigir envolve uma mudança de valor de verdade - para o que é necessário que esses juízos existam previamente e contenham em si uma atribuição de valor de verdade - e, eventualmente, também de critério.

Jones repara que o ponto de vista adotado é de tal maneira importante que o facto de se exigir um esforço da mente para o juízo estético - pelo uso da atenção e da faculdade da imaginação - modifica a relação causal entre a mente e o objeto, particularmente, do lado do efeito (pois só uma mente disposta de uma certa forma é capaz de atribuir ao objeto o valor em questão). O comentador esclarece que apesar de "nenhum argumento ser capaz de alterar os mecanismos psicológicos que habilitam o homem a ter os sentimentos que tem”, “é possível focar a discussão sobre as causas dos seus sentimentos, (...) alterando as perceções que tem do mundo, ativando uma nova sequência causal" ${ }^{1581}$. Com isto, o

Successful communication in individual cases depends upon a general adherence to the conventions that govern the rules of the language." (ÁRDAL, 1966, p. 119).

${ }^{579}$ Cf. JONES, 1982, p. 107; KORSGAARD, 1999, p. 14.

${ }^{580}$ Cf. 1.6 deste trabalho.

${ }^{581}$ Tradução minha a partir de: "No argument can change the physiological mechanisms which enable a man to feel the sentiments he does (T.211), but discussion can focus on the causes of his feelings, and by altering a man's perceptions of the world it can set off a new causal chain, which results in new sentiments. Perceptual judgments can thus be said to be mediate causes of our sentiments (T.462), in contrast to perceptions themselves, which Hume treats as immediate causes." (JONES, 1982, p. 123). A razão disso é que é apenas quando se atinge um certo ponto de vista que se consegue discernir os diferentes prazeres e perceber as diferenças entre o moral e o 
comentador julga mostrar que este ponto de vista é condição necessária para: 1) que haja uma certa relação causal entre o objeto e o espectador; 2) que os juízos tenham uma objetividade; 3) a comunicação ${ }^{582}$.

Garrett esclarece que é pelo facto de a razão operar ativamente na determinação dos valores - do que corresponde ou não aos sentimentos do espectador e a correção dos juízos - que é possível elaborar raciocínios sobre valores, e mesmo que certos sentimentos morais se despertem mediante o conhecimento que se tem das ações e motivos dos agentes. O comentador dá um exemplo claro. Leio uma notícia sobre a Madre Teresa no jornal, acerca da sua beneficência com outrem e, a partir desta experiência, sou capaz de raciocinar e estabelecer relações que incorporam um conhecimento tal que me permite saber que a Madre Teresa é virtuosa e, com isso, se gerar um sentimento de aprovação. Esta cadeia de raciocínios e sentimentos só se pode desenvolver porque se pode aceder aos valores através da razão, como objeto de conhecimento, ainda que o juízo moral só seja efetivo mediante o sentimento moral. Este conhecimento ou conjunto de inferências é possível a partir do momento em que disponho de uma ideia geral de um valor (ou estético) ${ }^{583}$.

Para estes autores, este processo permite a descoberta de uma natureza humana, definida por um conjunto de disposições a agir em vista do bem público, mediante certas condições comuns a uma mesma espécie (como, por exemplo, a perceção dos factos sob um ponto de vista geral ou um conhecimento da dinâmica entre as paixões e a faculdade da imaginação, descritas em T 2) - o que Norton chama de "psicologia realista". Em virtude desta natureza, existe um padrão ou critério objetivo para os juízos de valor, que os torna verdadeiros ou falsos. Portanto, caso não houvesse uma natureza humana relativamente fixa ou estável, uma constância nas características objetivas não seria suficiente para gerar um sentimento, pois existiria um elemento variável na relação - a interioridade de

não moral (JONES, 1982, p. 116, 122, 124). Por seu turno, Garrett não concordaria com isto, sob o pretexto de que sentimentos e juízos morais devem ser considerados distintos - posição que o comentador aparentemente só defende para conseguir abarcar na sua interrpretação tanto as evidências a favor da interpretação não cognitivista como cognitivista. Sob esta interpretação, os juízos surgiriam depois de um processo de aprendizagem (de aquisição de um ponto de vista geral), permanecendo possível um sentimento moral dirigido a uma ideia que não seria a ideia geral do bem comum (ou da beleza; cf. GARRETT, 1997, p. 203).

${ }_{582}$ Cf. T 3.3.1.15-18.

${ }^{583}$ Cf. GARRETT, 1997, p. 200. 
cada agente e espectador em tantas circunstâncias que anularia a possibilidade de uma regularidade na resposta a uma certa classe de objetos ${ }^{584}$.

Porém, esta natureza humana que se descobre não consiste nas disposições particulares de cada indivíduo, independentemente dos fatores que podem condicionar os diferentes juízos entre eles. Hume nota, pelo menos em relação ao juízo estético e moral, que se não se tiver nenhum fator destes em conta, a diferença dos juízos é constatável pela experiência. No caso do juízo estético, é isto que, aparentemente, justifica o famoso dito de que "os gostos não se discutem", e no caso da moral, é o que corresponde ao estado anterior civilização e ao exercício do entendimento que resulta na sua instauração ${ }^{585}$.

Se fosse este o caso, o estabelecimento das regras gerais dispensaria a consideração de um ponto de vista desinteressado, do destaque (pela separação) de circunstâncias determinantes ${ }^{586}$ e consistiria exclusivamente numa descrição que refletiria o juízo de uma maioria, sem ter em conta os fatores que condicionam os juízos. Pelo contrário, Hume inclui a necessidade de o agente se livrar do preconceito ${ }^{587}$ (tanto no raciocínio sobre relações causais de objetos entre

\footnotetext{
${ }^{584}$ Cf. NORTON, 1982, 1982, p. 135; SWAIN, 1992, pp. 465-6, 480, 484, 489 n9. Esta conclusão configura, para o comentador, uma resposta ao ceticismo moral, definido como o egoísmo. Por sua vez, o ceticismo moral a que Norton se refere é um egoísmo como o de Hobbes, segundo o qual não haveria um critério objetivo para definição dos valores (NORTON, 1975, pp. 190-2).

${ }^{585}$ Como bem lembra Monteiro, a generosidade limitada é o motivo pelo qual, pelo entendimento, percebemos que temos de levar a cabo comportamentos que, para satisfazer um desejo maior (o de viver em comunidade), outros têm de ser refreados. Há que neutralizar os aspetos que se afiguram como contrários à sociabilidade, e manter os elementos constitutivos da essência daquilo que virá a ser a sociedade, que se mostra de uma forma reduzida e, numa primeira instância, na família. Nela, a sociabilidade é gerada por um juízo do entendimento, fortalecida pelo hábito, e que determina os homens a crer nas vantagens da cooperação. Deste modo, a moralidade, que surge da continuidade da vida em sociedade, vem a ser, “(...) uma realidade que não é nem um pouco menos natural do que qualquer outra realidade natural" (MONTEIRO, 1975, p. 220) ou, como também chega a afirmar, um prolongamento do estado de natureza. Apesar disso, o simples juízo do entendimento não basta para motivar os indivíduos a organizarem a sua vida em sociedade. As vantagens têm de manifestar-se na experiência, pela qual os homens formam crenças em relação ao futuro. Estabelece-se uma relação causal como em qualquer outra questão de facto. Esta crença e este raciocínio provocam, naturalmente (pois ninguém quererá sofrer as consequências negativas do conflito), nos homens o desejo de continuarem associados, e é este desejo que os leva à ação, nunca a simples conceção, sem experiência, das vantagens possíveis. Mas apesar de constituir uma invenção, o sentido da justiça é algo sentido, com base na descoberta do artifício útil aos homens (pp. 40, 45-6, 57, 63, 72).

${ }^{586}$ A qual se pode pensar que tem a sua primeira instância no exercício do entendimento ao perceber que a continuidade da convivência humana assente apenas nas paixões mais imediatas impede uma convivência bem-sucedida para todos os indivíduos (pois resultaria numa violência extrema).

${ }^{587}$ Entendido como uma inferência, supostamente assente na relação filosófica de causalidade, baseada numa quantidade insuficiente de experiências ou que considera um número insuficiente de
} 
si como na aquisição do ponto de vista desinteressado), estabelece uma separação clara entre os traços do objeto que provocam um prazer estético e estende a sua simpatia a indivíduos com os quais não se relaciona diretamente (tal como expliquei acima, na presente secção), nos três tipos de juízos e raciocínios. Isto mostra que não é o simples facto de se julgar - e o resultado desse juízo - que conta (ou deve contar) como uma instância a ser incluída numa regra geral sobre os mesmos juízos e raciocínios.

Portanto, a natureza humana uniforme em virtude da qual é possível uma regra e um critério de verdade para os juízos de valor e à qual nos devemos referir é o que coloca os agentes sob o ponto de vista desinteressado, por um exercício da simpatia estendida e a distinção clara entre os fatores envolvidos no fenómeno (por comparação). Portanto, é a natureza humana que permite a todos emitirem um mesmo juízo, que reflete um mesmo sentimento dirigido a um mesmo objeto. É por isso que, como bem notam Townsend e Coventry, é o juízo do juíz refinado que deve contar como critério de verdade para os juízos, e não o simples juízo da maioria $^{588}$.

Para os defensores da interpretação cognitivista, a existência de uma tendência geral dos traços de caráter a causar um determinado efeito, o exercício da simpatia e a possibilidade de atingir um ponto de vista geral são o que assegura e a possibilidade de um acordo mediante uma partilha do ponto de vista geral (devido ao facto de uma generalidade de indivíduos ser afetada de uma mesma maneira) pode ser encarada como uma prova da sua objetividade ${ }^{589}$ : um sistema intersubjetivo. Deste modo, Swain acrescenta que o movimento, nas trocas linguísticas quotidianas, pelo qual o padrão pode ser estabelecido, depende diretamente da possibilidade de identificar relações causais - entre os objetos do valor e o sentimento na mente dos espectadores:

Se, por exemplo, as pessoas generosas não causassem tipicamente prazer a quem tratam generosamente, ou se pessoas cruéis não infligissem tipicamente dor em quem tratam cruelmente, jamais poderia surgir uma linguagem geral e

instâncias de observação para estabelecer a sua conclusão. Hume dá o exemplo do juízo de que um irlandês não possa ter espírito e um francês não possa ser consistente (cf. T 1.3.13.7).

${ }^{588}$ Cf. TOWNSEND, 2001, p. 204, 210; COVENTRY, 2006, p. 125, 145.

${ }^{589}$ Cf. ÁRDAL, 1966, p. 122; SWAIN, 1992, p. 466, 478, 480, 484. Em conformidade com isto, a autora afirma que em relação aos sentimentos não morais não há acordo intersubjetivo - o que acontece devido a variações internas e acidentais entre as pessoas que faz com que respondam de forma diferente - que causam um equivalente à preferência estética (cf. SWAIN, 1992, p. 479). 
sistema moral. Tal sistema de aprovação e reprovação não pode surgir a não ser que haja uma conexão entre as qualidades em questão e os seus efeitos em pessoas, assim como uma conexão entre essas qualidades e as nossas respostas a elas. Estas respostas nunca poderiam ser uniformes se as qualidades não tendessem a ter efeitos uniformes naqueles a quem se dirigem. $^{590}$

Sentimentos morais são sentimentos de aprovação para pessoas devido às suas qualidades. Estes sentimentos formam um padrão que corresponde a qualidades, e não a pessoas. Sentimos aprovação moral sempre que percebemos bondade e generosidade. Baseados na similaridade dos sentimentos, agrupamos instâncias de cada qualidade juntas e moldamos a nossa linguagem de acordo com estas similaridades que percebemos. $^{591}$

Este sistema intersubjetivo - que Swain chama de "sistema de avaliação"592 - é diferente dos sentimentos e juízos morais particulares, ações e motivações. Portanto, é o resultado de um conhecimento das causas, em que as qualidades do objeto estético ou os traços de caráter constituem as causas e os sentimentos do(s) espectador(es) constituem os seus efeitos ${ }^{593}$.

A este propósito, é oportuno acrescentar um comentário de Brunet. O comentador alerta que em relação ao gosto (moral e estético), há uma tensão ou conflito entre a sua natureza (emotiva) e a constatação da possibilidade de um padrão ou regra para o mesmo - que caracteriza como uma tensão entre paixão e razão. Este conflito resolver-se-ia (ao contrário do que julgava Foot) pelo que Mackie designa por universalidade subjetiva, que constitui o plano de objetividade possível para uma teoria dos valores (estético e moral) como a de Hume. Por seu turno, devido à menor uniformidade nos sentimentos humanos

\footnotetext{
${ }^{590}$ Tradução minha do original: "If generous people, for example, did not typically bring pleasure to those whom they treated generously, or if cruel people did not typically inflict pain on those whom they treated cruelly, there would arise no general language or system of morals at all. Such a system of praise and blame could not arise unless there were a connection between the qualities in question and their effects on people as well as a connection between these qualities and our responses to them. Our responses could not be uniform if the qualities did not tend to have uniform effects on those towards whom they were directed." (SWAIN, 1992, p. 481).

${ }^{591}$ Tradução minha do original: "Moral sentiments are feelings of approval for persons because of their qualities. These sentiments form a pattern that is responsive to qualities rather than to persons. We feel moral approval whenever we perceive kindness and generosity. On the basis of the similarity of the feeling, we group instances of each of these qualities together and mold our language upon the perceived similarities (...)" (SWAIN, 1992, p. 482).

592 Equivalente ao que chamo de sistema intersubjetivo. A substituição do termo deve-se à sua maior explicitude relativamente à sua natureza.

${ }^{593}$ Cf. SWAIN, 1992, p. 482.
} 
(pela combinação de condicionantes ao juízo) do que nos juízos causais e demonstrativos, esta objetividade é mais fraca do que a que se verifica naquele plano $^{594}$ :

$\mathrm{O}$ belo e o feio são, assim, relativos à natureza e ao funcionamento da mente do homem, de onde se explica a unidade do gosto apesar de certas deformações. ${ }^{595}$

Por seu turno, Brunet julga que o sentimento resulta de uma conformidade entre uma propriedade (ou conjunto de propriedades) de um objeto e a faculdade da imaginação e respetivos princípios. Quer dizer, uma vez que o sentimento "não representa nada (...) que esteja realmente no objeto", apenas exprime uma relação de conformidade entre o mesmo e as faculdades da mente. Apesar disso, o sentimento "resulta de uma reação do espírito ao objeto", e o princípio de que existem regras gerais para o gosto - contrastado com o princípio de igualdade entre os gostos, ou de que os gostos não se discutem - é "o da conformidade do belo à estrutura da natureza humana", isto é, da relação causal entre o objeto e a mente ${ }^{596}$.

\subsection{Descritivismo $\left(S_{D}\right)$ e não descritivismo $\left(S_{\sim D}\right)$}

Ao introduzir-se um elemento semântico na interpretação (de qual o significado dos juízos sobre valores), surge um leque de possibilidades interpretativas que passo a descrever. Antes de subdividir o presente subcapítulo em secções, apresento em que consiste cada uma das posições a serem apresentadas e explico a sua ordem de apresentação.

\footnotetext{
${ }^{594}$ Cf. BRUNET, 1965, pp. 280-1, 495, 861.

595 Tradução minha do original: "Le beau et le laid sont donc relatifs à la nature et au fonctionnement de l'esprit de l'homme: d'où l'unité foncière du goût, en dépit de certaines déformations" (BRUNET, 1965, p. 495).

${ }^{596}$ Tradução minha a partir de: "[Le sentiment] ne représente pas, on l'a vu, ce qui est réelement dans l'objet: «il exprime simplement une certaine conformité ou relation entre l'objet et les organes ou facultés de l'esprit; et si cette conformité n'existait pas réelement, le sentiment ne pourrait jamais se produire» (PG 7). Il en est ainsi des valeurs esthétiques comme des valeurs morales" (BRUNET, 1965, p. 495) e de: "Ce principe n'est autre, en effet, que celui de la conformité du beau à la structure de la nature humaine. La beauté est un sentiment. Elle n'est pas dans l'objet, elle est dans l'esprit. Mais elle résulte d'une réaction de l'esprit à l'objet." (BRUNET, 1965, p. 707).
} 
Para entender a legitimidade de todas as quatro propostas de interpretação apresentadas neste subcapítulo, vale relembrar a distinção entre sentimentalismo/racionalismo e cognitivismo/não cognitivismo e a relação destas últimas com as opções interpretativas relativas à questão semântica. Uma vez que nenhum comentador considera Hume um racionalista, deve explicar-se por que razão é possível terem surgido interpretações que combinam a interpretação sentimentalista tanto com o cognitivismo como com o não cognitivismo.

De acordo com o sentimentalismo, a natureza dos valores é um estado emotivo do espectador ou agente, e não um dado da razão. De acordo com o cognitivismo, juízos de valor constituem conhecimento (pelo que tem de se aceitar que possuem um valor de verdade). De acordo com o não cognitivismo, juízos de valor não constituem uma forma de conhecimento (pelo que tem de se aceitar que não são verdadeiros nem falsos).

Quem pretender conjugar o sentimentalismo com o cognitivismo, aceitará que é possível ter um conhecimento do estado emotivo presente em cada juízo de valor, porque é possível determinar o valor de verdade da proposição em questão. Quem pretender conjugar o sentimentalismo com o não cognitivismo, aceitará que esse conhecimento não é possível porque não há nenhum valor de verdade a ser determinado. Portanto, para este último, a relação do agente ou espectador com o estado emotivo que motiva o juízo de valor é de uma manifestação, um reflexo ou expressão desse estado emotivo.

Destas duas possibilidades de combinação, e dentre os comentadores que se ocupam das questões epistémica e semântica sobre a teoria dos valores de Hume, surge a divisão entre descritivistas e não descritivistas.

Para os descritivistas, um juízo sobre valores descreve um facto (que pode ser conhecido). Aqueles que julgam que o facto descrito é o próprio estado emotivo (que se tem ou não), designo por descritivistas subjetivistas (apresentados em 3.2.1), pois o juízo descreve, por assim dizer, um facto subjetivo, interno e particular. Aqueles que julgam que o facto descrito é uma relação causal entre os objetos avaliados e um espectador ou grupo de espectadores, designo por descritivistas causais (apresentados em 3.2.2), pois o juízo descreve um facto que consiste nessa relação causal.

Já para os não descritivistas, uma juízo sobre valores não descreve um facto, mas tem a função de expressar o estado emotivo de quem a enuncia. 
Aqueles que se limitam a constatar o caráter expressivo do juízo são os emotivistas ou expressivistas (apresentados em 3.2.3). Inicialmente, os defensores do emotivismo limitavam-se a constatar o caráter expressivo dos juízos sobre valores na teoria de Hume. Desde o surgimento da interpretação da teoria do erro (apresentada em 3.2.5, após as críticas que os seus defensores dirigem às interpretações emotivista e descritivista subjetivista, em 3.2.4), o emotivismo começou a ser incorporado em interpretações mais complexas como uma das suas componentes, o que se pode explicar pela necessidade de inclusão de elementos que não estavam presentes na primeira interpretação (apresentada em 3.2.3).

De acordo com os defensores do descritivismo subjetivista $\left(\mathrm{S}_{\mathrm{DS}}\right)$, os juízos descrevem o sentimento do indivíduo em questão, de tal maneira que professar uma avaliação moral ou estética nada mais é que um discurso autobiográfico. Sob esta interpretação, a referência do juízo é um estado estritamente particular (subjetivo) $)^{597}$.

Já de acordo com o descritivismo causal ou intersubjetivista $\left(\mathrm{S}_{\mathrm{DIS}}\right)$, os juízos de valor descrevem os sentimentos (morais e estéticos) da generalidade dos indivíduos. Os proponentes desta interpretação justificam-na, em parte, pela pertinência de se considerar que estes juízos se refeririam a uma relação causal entre o objeto avaliado (o caráter moral ou o objeto estético) e a mente do espectador (capaz de ter uma reação emotiva à propriedade do objeto que é apreciada ou depreciada) - aliás, visível nas definições que Hume oferece de virtude, que são estabelecidas de modo causal $^{598}$. Por outro lado, também procuram mostrar que o padrão ou critério de verdade em virtude do qual o juízo pode ser considerado verdadeiro ou falso constitui o resultado de interações entre os vários agentes e espectadores - de onde surge um plano intersubjetivo, isto é, de influência mútua entre os indivíduos, que permite um acordo na descrição. As designações que dei desta interpretação derivam destas duas razões.

De acordo com o emotivismo $\left(\mathrm{S}_{\sim \mathrm{DE}}\right)$, juízos sobre valores não devem ser considerados proposições genuínas, mas antes expressões não proposicionais de um estado subjetivo, sendo equivalentes a salvas de palmas ou aclamações

\footnotetext{
${ }^{597}$ Diversos autores chamam esta interpretação simplesmente de subjetivismo (cf. ÁRDAL, 1966, p. 6, 194; STROUD, 1977 - como sinónimo de psicologismo; MACKIE, 1977, pp. 17-18; AYER, 1980, pp. 162-3; HARE, 1997, p. 42). A razão pela qual alterei a sua designação é que me parece ficar mais claro que esta interpretação constitui uma forma de descritivismo.
} 
$(\text { cheers })^{599}$. Deste modo, o emotivismo é uma forma de não descritivismo. Esta é a primeira forma esta interpretação assumiu na história da literatura secundária sobre a filosofia de Hume, que apresento na secção 3.2.3.

Por fim, a teoria do erro - primeira versão do projetivismo ${ }^{600}\left(\mathrm{~S}_{\sim \mathrm{DTE}}\right)-$ consiste numa forma (refinada) de não descritivismo. Os seus defensores apresentam-na como alternativa ao cognitivismo subjetivista, pela rejeição da tese de que os juízos sobre valores possuem valor de verdade (portanto, do cognitivismo). Constitui também um desenvolvimento do emotivismo pela necessidade que os seus defensores viram de ter em conta um mecanismo fíctício da pretensão à objetividade presente no juízo. Porém, vale notar que é pelo facto de a componente emotivista sobrevalecer, de alguma forma, à componente descritiva que propõem (associada à pretensão de objetividade) que a teoria do erro se mantém uma proposta não cognitivista.

\subsubsection{Descritivismo subjetivista ou fenomenalista $\left(\mathrm{S}_{\mathrm{DS}}\right)$}

Passo à apresentação da interpretação descrtivista da teoria dos valores de Hume - que, a meu ver, pode ser subdividida em dois tipos, a que chamo de subjetivista ou fenomenalista e de causal ou intersubjetivista -, apresentando-as por ordem.

A principal evidência textual a favor da primeira destas interpretações (que designo por descritivista subjetivista) é:

[Q]uando declaramos que uma ação ou caráter são viciosos, tudo que queremos dizer é que, dada a constituição de nossa natureza, experimentamos uma sensação ou sentimento $[a$ feeling or sentiment] de censura quando os contemplamos. ${ }^{601}$

\footnotetext{
${ }^{598}$ Cf. IPM Ap. 1.10.

${ }^{599}$ Cf. STROUD, 1977, pp. 180-2.

${ }^{600}$ Apesar disso, os termos "projeção", "projetar", "projetivo", têm sido mencionados vagamente por outros comentadores além dos teóricos do erro, a propósito da tendência à atribuição de uma propriedade a um objeto que este não possui sem que, apesar disso, os comentadores em questão tenham desenvolvido uma interpretação em torno deste conceito (cf. NOXON 1973, p. 132; FLEW, 1976, p. 3-4; NORTON, 1982, p. 144; BROUGHTON, 1983, p. 220; BAIER, 1991, p. 98; BLACKBURN, 1993, p. 277).

${ }^{601} \mathrm{~T}$ 3.1.1.26. Talvez por disporem desta evidência textual, e ainda que se esforcem por negar a interpretação que designei por descritivista causal, os seus defensores não se preocupam em
} 
Em conformidade com esta evidência, Hunter (1962) parece ter sido o primeiro a defender esta interpretação, afirmando claramente que para Hume, "juízos morais são enunciados de facto" ${ }^{602}$, quer dizer, Hume defenderia que as impressões de reflexão mediante as quais se atribui um valor a um certo objeto são a própria questão de facto que é descrita por esses juízos - e, se for assim, os juízos têm um valor de verdade e, por consequência, juízos opostos serão contraditórios entre si:

A análise de Hume sobre os juízos morais (...) tem como consequência que se uma pessoa diz, de uma ação, que é totalmente virtuosa e outra diz, da mesma ação, que é totalmente viciosa, estas duas pessoas não se contradiriam entre si, uma vez que o que uma afirma é logicamente equivalente a 'Eu, Smith, sinto um tipo peculiar de sentimento, e não sinto um tipo peculiar de dor, ao contemplar esta ação', enquanto o que a outra diz é logicamente equivalente a ' $\mathrm{Eu}$, Jones, sinto um tipo peculiar de dor, e não sinto um tipo peculiar de prazer, ao contemplar esta ação', e ambos os enunciados podem ser verdadeiros. ${ }^{603}$

P. Foot (1965) considera que a conjuntura textual de Hume conspira a favor da interpretação de que o significado de juízos sobre valores se referem ao sentimento do falante. Para a comentadora, seria inconsistente, da parte de Hume, defender tanto que os juízos sobre valores são motivados por estados emotivos particulares dos agentes e que esses juízos são objetivos - quer dizer, que há um critério para decidir o valor de verdade de juízos que são motivados por estados mentais que não têm valor representativo. Com efeito, se as impressões de reflexão não são cópias de objetos observáveis, mas uma resposta emotiva aos mesmos, juízos proferidos em virtude daquelas não são verdadeiros nem falsos, porque a propriedade que se atribui aos objetos não pode ser representada por uma ideia ou conjunto de ideias. Por isso, esses juízos estão fora do campo do que é

fundamentar a sua escolha entre a interpretação que se apresenta nesta secção - descritivista subjetivista - e a emotivista.

602 Tradução minha do original: "moral judgments are statements of fact" (HUNTER, 1962, p. 149).

${ }^{603}$ Tradução minha do original: "Hume's analysis of moral judgments (...) has the consequence that if one person says of an action that it is wholly virtuous and another person says of the same action that it is wholly vicious, these two people would not be contradicting each other, since one is saying the logical equivalent of 'I [Smith] feel a peculiar sort of pleasure, and I do not feel a peculiar sort of pain, on contemplating this action', while the other is saying the equivalent of 'I [Jones] feel a peculiar sort of pain, and I do not feel a peculiar sort of pleasure, on contemplating this action', and both these statements could be true." (HUNTER, 1962, pp. 151-2). 
verdadeiro e falso (do conhecimento) e, por isso, também não há um critério em virtude do qual se esteja racionalmente obrigado a concordar ou não, nem há espaço para a contradição (entendida como a impossibilidade de uma juízo ser verdadeiro e o seu contrário ser falso). Portanto, juízos sobre valores seriam apenas reportações de sentimentos - apesar de a autora reconhecer que há momentos em que Hume parece inclinado a defender que estes juízos se referem ao sentimento da humanidade em geral - o que coloca Foot no grupo de defensores da interpretação descritivista subjetivista (que ocupa a presente secção). O que lhe permite decidir entre as duas interpretações é que se Hume pretendesse insistir na outra alternativa descritivista, não defenderia que valores estão aparte do campo das questões de facto (quando fala sobre homicídio voluntário). Apesar disso, sabemos que existe uma evidência textual contrária, utilizada a favor da interpretação descritivista causal ${ }^{604}$.

Jones também parece defender explicitamente a interpretação descritivista subjetivista - mais explicitamente, em relação ao valor estético:

Apesar de serem dependentes da constituição da nossa mente em si, um facto bruto sobre a nossa maquilhagem psicológica -, as impressões que recebemos das próprias questões de facto exteriores causam-nos um sentimento de um tipo ou de outro. Estes sentimentos são, em si mesmos, impressões, e são, efetivamente, factos sobre nós. Mas o ponto crucial é que estes sentimentos só são factos sobre nós, e são causados apenas pelas nossas impressões, cuja natureza é determinada pela reunião das condições do mundo exterior e a nossa fábrica interior. Proposições que reportam estes factos internos, a saber, os sentimentos que temos, são nada mais nada menos que os juízos morais e estéticos que aprovamos. ${ }^{605}$

Apesar disso, na sua obra de comentário de 1982, Jones parece ter revisto a sua posição, passando a afirmar que o significado de juízos estéticos não é apenas o sentimento, mas também a relação causal entre o objeto e o agente - o

\footnotetext{
${ }^{604}$ Cf. cf. 3.1.1; T 3.1.1.26; T 3.1.1.26; FOOT, 2001, pp. 76-8.

${ }^{605}$ Tradução minha do original: "Depending upon the constitution of our minds however, itself a brute fact about our psychological make-up, the impressions we receive from the external matters of fact themselves cause us to feel sentiments of one sort or another; these sentiments are themselves impressions, and are, indeed, facts about us. But the crucial point is that these sentiments are only facts about us, and they are caused only by our impressions, the nature of which is determined by the joint conditions of the external world and our internal fabric. Propositions which report these internal facts, namely, the sentiments we feel, are none other than the moral and aesthetic judgments we pass." (JONES, 1970, p. 59; itálico meu).
} 
sentimento entra como efeito, e as propriedades do objeto vistas sob um certo ponto de vista, como causas ${ }^{606}$.

Mais recentemente, a interpretação do descritivismo subjetivista também parece ter sido apoiada por Garrett (1997) e Cohon (2008). Após rejeitar (ainda que, diga-se de passagem, dogmaticamente) a interpretação descritivista causal, Garrett afirma que "Hume nos está apenas a dizer o que é que queremos dizer ou mostrar acerca de nós mesmos quando apresentamos enunciados morais (when we make moral utterances)", negando explicitamente que as evidências textuais a favor da interpretação cognitivista legitimem a conclusão de que o seu significado são relações causais ou o conhecimento a posteriori que se tem da regularidade das ações e motivos (por exemplo, que valores morais são o objeto dos sentimentos da generalidade dos homens) ${ }^{607}$.

Por último, apresento a proposta de Cohon - que é, sem dúvida, quem elabora a forma mais curiosa desta interpretação. De acordo com a autora, não se pode considerar que juízos sobre valores descrevem os sentimentos de uma generalidade, pois tal implicaria rejeitar a tese de que a razão é incapaz de descobrir ou dar acesso aos valores - portanto, implicaria aceitar que Hume é um racionalista. Ao invés, a comentadora explica que há um acesso não inferencial a um estado fenoménico - a saber, a forma como o objeto aparece à mente do indivíduo. Porém, a comentadora pretende afirmar simultaneamente que os juízos sobre os valores são descritivos sem afirmar que o que descrevem são impressões de reflexão ou uma relação causal:

Esta tese, que chamo de interpretação do senso moral, embate num dilema interpretativo tradicional: Hume julga mesmo que juízos morais são meras expressões de uma emoção, ou descrições dos sentimentos do observador? Sob a interpretação do senso moral, a resposta é 'nem uma, nem outra'. As nossas reações morais são sentimentos que ocorrem, mas os nossos juizos são crenças: ideias vivas copiadas de sentimentos que tivemos. ${ }^{608}$

\footnotetext{
${ }^{606}$ Cf. JONES, 1982, p. 113, 115, 116.

${ }^{607}$ Cf. GARRETT, 1997, pp. 191, 201-2.

${ }^{608}$ Tradução minha do original: "This thesis, which I call the moral sensing view, goes between the horns of a traditional interpretive dilemma: does Hume think moral judgments are mere expressions of emotion, or descriptions of the observer's sentiments? On the moral sensing view, the answer is "neither". Our moral reactions are occurrent sentiments, but our moral judgments are beliefs: lively ideas copied from the felt sentiments." (COHON, 2008, p. 2).
} 
Esta interpretação estaria simultaneamente enquadrada numa proposta anti-realista. Antes, os valores (moral e estético) constituem propriedades análogas a qualidades secundárias, que Cohon considera relacionais ou disposicionais, isto é, que apenas existem mediante uma relação entre o objeto e a mente. Este caráter fenomenal do juízo justifica-se i) pela analogia entre valores e qualidades secundárias $^{609}$ e ii) pelo facto de que ao contrário dos juízos causais atribuídos aos objetos da perceção enquanto exteriores e independentes da mente -, os juízos de valor não ultrapassam o campo das impressões (primeiras fontes das ideias morais, que, por sua vez, originam as impressões de reflexão). Por razões que apresento em 4.4, chegarei à conclusão de que a comentadora não pode deixar de considerar estes juízos descritivos de uma relação causal. Ainda assim, considero-a incluída no grupo de defensores do que chamei de descritivismo subjetivista pelo facto de continuar a considerar que o que é descrito é um estado interno e particular da mente - para a comentadora, uma ideia.

A este propósito, a comentadora explica que Hume dispõe de uma teoria da verdade tal que se permite um critério ou padrão em virtude do qual estes juízos possuiriam um valor de verdade, além do próprio estado subjetivo do agente cognitivo - o que lhe permite associar a sua teoria semântica a um elemento cognitivista. Com efeito, uma impressão de reflexão (como uma paixão moral) deriva de uma ideia. De acordo com as considerações de Hume sobre o campo da verdade, esta pertence ao domínio das ideias, pelo que conclui que as ideias que dão origem às paixões podem ser verdadeiras ou falsas. Mediante um exercício intersubjetivo, seria possível alterar essas ideias, construir um padrão ou critério de verdade para as mesmas e, assim, alterar sentimentos morais e corrigir os juízos ${ }^{610}$.

Vale notar que a defesa da interpretação descritivista subjetivista nos compromete com a defesa de uma posição cognitivista. Com efeito, para se defender que os juízos sobre valores se referem a sentimentos de quem as enuncia e significam que alguém tem ou não tem um determinado sentimento, é necessário aceitar que tais juízos possuem um valor de verdade - neste caso, determinado de acordo com o sentimento do agente ou espectador em questão. Por outro lado, se

\footnotetext{
${ }^{609}$ Cf. T 3.1.1.26.

${ }^{610}$ Cf. COHON, 2008, p. 108, 111, 117, 120, 123, 137.
} 
se defendesse que os juízos em questão não podem ser considerados verdadeiros ou falsos ou constituir um tipo de conhecimento, o agente ou espectador em questão ter ou não ter um determinado sentimento não poderia ser o critério para se determinar que o juízo é verdadeiro ou falso, nem constituir o significado do juízo, quando enunciada, e ser-se-ia obrigado a admitir que esse juízo tem uma função não descritiva, nem podem significar que o agente ou espectador tem ou não tem o dito sentimento.

Passo a apresentar as críticas que os defensores de outras interpretações sobre a teoria dos valores de Hume formularam a esta interpretação.

Tal como apresentei, Hunter parece ter sido pioneiro no reconhecimento de que o descritivismo subjetivista era uma interpretação demasiado contraintuitiva para ser defendida. Com efeito, o comentador nota que se se aceitar esta interpretação, bastaria que um falante tivesse um sentimento diferente da maioria para ambos os juízos serem simultaneamente verdadeiros e falsos:

Se [os dois juízos] fossem verdadeiros e a análise de Hume fosse correta, uma e a mesma ação seria simultaneamente e por completo virtuosa e viciosa, o que, no sentido usual dos termos, é absurdo. ${ }^{611}$

Em conformidade com esta crítica, Árdal aponta outros problemas. Com efeito, se se aceita que dois falantes que dizem "Maria é honesta" descrevem o sentimento do próprio falante, existem tantos critérios de verdade para a mesma quantos indivíduos houver. E se assim for, o seu significado muda de indivíduo para indivíduo e, deste modo, perde-se a referência que viabiliza um acordo ou desacordo, pois descrevem proposições distintas (cada uma delas,

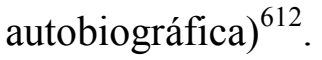

Acrescento um problema relacionado a evidências textuais. Se se aceitar a interpretação subjetivista, a uniformidade da natureza humana perde relevância para determinar o padrão do juízo, contrariamente ao que Hume afirma tanto no Tratado, como na segunda Investigação e no ensaio "Sobre o padrão do gosto".

\footnotetext{
${ }^{611}$ Tradução minha do original: "If [the judgements] were both true, and Hume's analysis were correct, then one and the same action would be both wholly virtuous and wholly vicious, which, in the ordinary senses of the words used, is absurd." (HUNTER, 1962, p. 152).

${ }^{612}$ Cf. ÁRDAL, 1966, p. 199.
} 
Um certo falante pode, inclusivamente, ser o único que tem aquele sentimento e o seu juízo mantém o seu valor de verdade ${ }^{613}$.

Aparentemente, a proposta de Cohon escapa a estas dificuldades. Porém, ainda parece muito contraintuitiva. Com efeito, a comentadora propõe que um juízo sobre valores seja considerado verdadeiro se corresponde à conclusão alcançada sob o ponto de vista geral. Considere-se o exemplo 'a Maria é honesta', que equivale, para Cohon, a 'parece-me que a Maria é honesta'. Caso o exercício intersubjetivo para alcançar um ponto de vista desinteressado seja bem sucedido e descubra que afinal, a Maria não é honesta, mas o meu sentimento relativamente à mesma não se alterar, qual seria a proposição que eu proferiria para manifestar a opinião moral sob o ponto de vista desinteressado? Além disso, se se aceitar esta proposta, não há qualquer diferença entre dizer 'não gosto da Maria' e 'a Maria é desonesta', pois a minha opinião (errada) reflete um sentimento interessado. Quer dizer, nem sequer haveria lugar na própria língua para uma distinção entre a expressão de um sentimento particular e uma descrição moral geral. Na ambição de conciliar uma interpretação cognitivista com uma rejeição do descritivismo causal e do critério subjetivista de verdade, a proposta de Cohon simplesmente não parece retratar convenientemente a relação entre o juízo moral efetivamente proferido e o que ocorre quando o ponto de vista se altera.

Além disso, como a própria comentadora admite, seria possível restringir a consideração de que a razão é capaz de descobrir os valores e elaborar raciocínios sobre os mesmos com a assunção de que "apenas um ser que possui sentimentos possui quaisquer conceitos morais",614, ou ainda considerar que a razão não é capaz de elaborar raciocínios por si só, necessitando da sua combinação com um sentimento $^{615}$. A comentadora não explica por que razão não se pode aceitar esta restrição, tampouco o que nos impediria de aceitar aquela conclusão inversa.

Stroud chama a atenção para o inconveniente de que sob esta interpretação- que designa por psicologismo -, os juízos sobre valores se reduzem

\footnotetext{
${ }^{613}$ Cf. ÁRDAL, 1966, p. 192.

${ }^{614}$ Cf. COHON, 2008, p. 137.

${ }^{615}$ Stroud sugere algo deste género ao afirmar que tanto juízos sobre valores como sobre relações causais têm um caráter expressivo - estas últimas, expressando crenças (que Hume admite serem mais do campo sensitivo do que cognitivo; cf. T 1.4.1.8; STROUD, 1977, p. 83). Não é o lugar de discutir alongadamente sobre este tópico, mas pretendo fazê-lo noutro momento e posso avançar que seria favorável à posição de Stroud.
} 
a juízos sobre estados internos do agente (sentimentos morais e/ou estéticos) ou autobiográficos, isto é, elas seriam sobre a mente do agente e não sobre o objeto em questão (a ação e/ou o agente moral):

Portanto, não estou a falar sobre algo na ação, mas apenas acerca de um sentiment que tenho. Reporto como as coisas são 'no meu peito'. Sob esta interpretação, todos os chamados 'juízos morais' são, na verdade, enunciados sobre a mente do falante. Os 'juízos morais' que faço são sobre mim, e quando tu dizes ' $\mathrm{X}$ é vicioso', estás a dizer que tens um certo sentimento dirigido a X. O discurso moral é autobiográfico. Esta posição é exatamente paralela à que chamei de 'psicologista' relativa a enunciados causais - de que são relatos de acontecimentos na mente da pessoa que os assere. ${ }^{616}$

Além disso, o comentador observa que esta interpretação não explica o que efetivamente se pretende dizer quando se emite um certo juízo de valor: pretendese falar dos próprios objetos, e não sobre um estado subjetivo:

[O cognitivismo subjetivista] deixa muito a desejar como posição acerca do que ' $\mathrm{X}$ é bom' efetivamente significa. (...) Ao dizer 'aquele ato foi vicioso, levado a cabo por um homem mau', certamente parecemos dizer algo acerca de uma ação e de um agente, e não algo acerca dos nossos sentimentos. ${ }^{617}$

Porém, não deixa de observar que esta interpretação possui a vantagem de, ao preservar o papel passivo da razão, manter o sentimentalismo intacto:

Com certeza esta interpretação [cognitivismo subjetivista] enfatiza a importância do sentimento nos juízos morais, uma vez que tais juízos seriam simplesmente falsos se os sentimentos apropriados não estivessem presents na mente, e também tem a consequência desejável de que juízos morais não se alcançam pela razão. ${ }^{618}$

\footnotetext{
${ }^{616}$ Tradução minha do original: "I am not then talking about something in the action, but only about a feeling I have. I am reporting how things are 'in my own breast'. On this view, every socalled 'moral judgment' is really a statement about the mind of the speaker. The 'moral judgments' I make are about me, and when you say ' $\mathrm{X}$ is vicious' you are saying that you have a certain sentiment towards X. Moral talk is autobiography. This view exactly parallels what I called the 'psychologistic' account of causal statements - that they are reports of happenings within the mind of the person asserting them." (STROUD, 1977, p. 180).

${ }^{617}$ Tradução minha do original: “(...) leaves a lot to be desired as an account of what ' $\mathrm{X}$ is good' actually means. (...) In saying 'That was a vicious act, done by an evil man' we certainly seem to be saying something about an action and an agent, and not something about our feelings." (STROUD, 1977, pp. 180-1).

${ }^{618}$ Tradução minha do original: "This interpretation certainly emphasizes the importance of feeling in moral judgments, since such judgments would be straightforwardly false if the appropriate feelings were not present to the mind. And it also has the desired implication that moral judgments are not arrived at by reasoning." (STROUD, 1977, p. 181).
} 


\subsubsection{Descritivismo causal $\left(\mathrm{S}_{\mathrm{DC}}\right)$}

Passo à apresentação da interpretação descritivista do segundo tipo, a saber, o que designo por causal.

A rigor, nenhuma evidência textual isolada suporta explícita e sucintamente esta interpretação. Antes, ela é, na maioria dos casos ${ }^{619}$, suportada pelas mesmas evidências textuais que foram reunidas pelos seus proponentes para apoiar a interpretação cognitivista ${ }^{620}$.

As interpretações de C. D. Broad (1930) e MacNabb (1941) parecem enquadrar-se nesta categoria:

Há um tipo específico de emoção que praticamente todos os seres humanos por vezes têm. Trata-se da emoção da Aprovação ou Reprovação (...) suscitada pela contemplação de certos objetos, e é dirigido aos mesmos. Entretanto, para Hume, a asserção " $x$ é bom" significa o mesmo que a asserção "x é tal que a sua contemplação suscitaria uma emoção de aprovação em direção a todos ou à maioria dos homens". A definição de "x é mau" seria o mesmo que "desaprovação" substituída por "aprovação". 621

[Proposições morais] são proposições psicológicas (...). Chamar uma ação de virtuosa ou viciosa significa que quando a consideramos de forma geral e sem referência aos nossos interesses particulares, a aprovamos ou desaprovamos, e que o que nos faz aprová-la ou desaprová-la, quando considerada assim, é simplesmente a sua tendência a promover a felicidade ou infelicidade de quem possa, de alguma maneira, ser afetado por ela. ${ }^{622}$

Mais recentemente, esta posição foi defendida por Swain (1992), que, na tentativa de apoiar e desenvolver a proposta de interpretação cognitivista da teoria

\footnotetext{
${ }^{619}$ A exceção é Garrett, que, infelizmente, não apresenta nenhum argumento que invalide esta interpretação e obrigue a aceitar a que adota (o descritivismo subjetivista).

${ }^{620}$ Por serem muito extensas e ser mais útil apresentá-las no decorrer da explicação que os proponentes daquela interpretação as apresentam para justificar a sua coerência, apresento-as de forma exaustiva em 2.3 .

${ }^{621}$ Tradução minha do original: "There is a certain specific kind of emotion which nearly all human beings feel from time to time. This is the emotion of Approval or Disapproval (...) by the contemplation of certain objects, and it is directed towards those objects. Now for Hume the statement " $\mathrm{x}$ is good" means the same as the statement " $\mathrm{x}$ is such that the contemplation of it would call forth an emotion of approval towards it in all or most men". The definition of "x is bad" would be the same with "disapproval" substituted for "approval"." (BROAD, 1930, pp. 84-5).

${ }^{622}$ Tradução minha do original: "[T]hese propositions are psychological propositions (...) By calling an action virtuous or vicious we mean that when we consider it generally and without reference to our own personal interests, we approve or disapprove of it, and that what makes us approve or disapprove of it, when so considered, is simply its tendency to promote the happiness or unhappiness of all who may be in any way affected by it." (MACNABB, 1941, p. 157).
} 
dos valores de Hume elaborada por Norton, afirma que o significado dos juízos morais é a existência (ou não) de uma qualidade objetiva atribuída ao objeto em questão (o agente e respetivo caráter, que causa o sentimento moral no(s) espectador(es)), apontando ainda a interpretação subjetivista como indesejável:

Somos deixados com um conjunto de juízos que temos todas as razões para crer que sejam objetivos. Primeiro, as impressões nas quais baseamos os nossos juízos são aquelas que são as mesmas para todos, de tal forma que estes juízos são intersubjetivamente válidos. Segundo, os juízos são baseados em impressões que tenham sido corrigidas pela reflexão dependem apenas de duas coisas: das qualidades do objeto que julgamos e de aspetos universais dos seres humanos. Quando este é o caso, não há razão para pensar que quando pretendemos julgar as qualidades do objeto com base nestas impressões corrigidas, não julgamos, realmente, sobre o objeto, mas reportamos factos acerca de nós mesmos. Quando (...) julgamos, na base destas impressões, que um objeto é vermelho, estamos, de facto, a emitir um juízo sobre uma qualidade desse objeto, e não apenas reportamos algo sobre nós mesmos. Da mesma forma, quando (...) julgamos que uma qualidade é uma virtude ou uma pessoa é virtuosa, efetivamente, emitimos um juizo sobre a qualidade e a pessoa, e não apenas reportamos algo sobre nós mesmos. ${ }^{623}$

Com efeito, pode pensar-se que Norton - cujo principal objetivo consiste mostrar que Hume reconhece um papel determinante à razão no ajuizamento sobre questões de facto e defenderia uma forma de realismo sobre os valores (respetivamente, questões de natureza epistémica e metafísica) - prescreveu a mesma interpretação, ao afirmar que o conhecimento sobre objetos do juízo é condição necessária para o surgimento do sentimento moral ${ }^{624}$. Porém, efetivamente, Norton não se posicionou explicitamente sobre esta questão semântica.

\footnotetext{
${ }^{623}$ Tradução minha do original: "[W]e are left with a set of judgments which we have every reason to believe are objective. First, the impressions on which we base our judgments are those which are the same in everyone, so that these judgments are intersubjectively valid. Secondly, the judgments that are based on impressions which have been corrected by reflection depend only on two things: on the qualities of the object we are judging, and on universal features of human beings. When this is the case, there is no reason to think that when we purport to judge the qualities of the object on the basis of these corrected impressions, we are not really judging the qualities of the object but are merely reporting facts about ourselves. When (...) we judge, on the basis of these impressions, that an object is red, we are, in fact, making a judgment about a quality of that object; we are not just reporting something about ourselves. Similarly, when (...) we judge that a quality is a virtue or that a person is virtuous, we are, in fact, making a judgment about the quality and the person; we are not just reporting something about ourselves." (SWAIN, 1992, p. 485; itálico meu).

${ }^{624}$ Cf. NORTON, 1975, p. 195; 1982, p. 133.
} 
A distinção de base entre o descritivismo e o não descritivismo é a consideração de que a única função do juízo sobre valores é descritiva e o reconhecimento (daquele, por contraste com este) de um valor de verdade para o juízo em questão e, portanto, se são ou não proposições genuínas, ou se juízos de valor têm ou não genuinamente um caráter proposicional. Portanto, de acordo com a interpretação não descritivista, esses juízos não têm um caráter (pelo menos, exclusivamente) descritivo, havendo algo que escapa às possibilidades de descrição $^{625}$.

Por seu turno, o que distingue o descritivismo subjetivista do causal é que sob o primeiro, o valor de verdade depende da sinceridade do falante ${ }^{626}$, e sob o segundo, depende de ser ou não o caso de uma generalidade de indivíduos ter um determinado sentimento. Portanto, a distinção entre as duas formas de descritivismo (subjetivista e causal) reside nas condições que permitem atribuir um valor de verdade ao juízo, isto é, no seu critério de verdade: sob a primeira tese, o seu valor de verdade é determinado de acordo com o sentimento do falante que profere ou pensa o juízo. Sob a segunda tese, este depende de ser ou não o caso de a humanidade em geral ou, pelo menos, a sua maior parte, deter o sentimento descrito na proposição como efeito da propriedade atribuída ao objeto (como, por exemplo, a virtude ou a beleza). Portanto, no primeiro caso, o discurso é totalmente autobiográfico, e no segundo, é indiferente se o falante em questão detém ou não o sentimento em questão.

Vale notar que os defensores da interpretação descritivista causal estão comprometidos com a defesa de uma posição cognitivista. Com efeito, para se defender que os juízos sobre valores descrevem ou se se referem a uma relação causal entre o objeto (observado sob um certo ponto de vista) e o espectador, é necessário considerar que há algo que torna o juízo verdadeiro que descreve essa relação causal (ou seja, que a torna um tipo de conhecimento), a saber, uma correspondência entre esse juízo e essa relação causal. Por outro lado, se se defendesse que os juízos em questão não podem ser considerados verdadeiros ou falsos ou constituir um tipo de conhecimento, não se poderia considerar que o que se quer dizer quando se enuncia um juízo sobre valores é que existe essa relação

\footnotetext{
${ }^{625}$ Cf. HARE, 1997, p. 42.

${ }^{626}$ Cf. NORTON, 1975, p. 203; STROUD, 1977, p. 181.
} 
causal, a não ser por um engano ou ficção - como explicam os teóricos do erro - e teria de se admitir que esses juízos não possuem uma função descritiva, nem podem significar que existe a dita relação causal. Apesar disso, nem todos os comentadores que defendem uma interpretação descritivista argumentaram a favor da interpretação cognitivista: é o caso de Hunter, Broad, MacNabb e Foot. Já Jones, Garrett e Cohon fizeram-no explicitamente, como ficou claro nesta secção e na secção 3.2.1.

Passo a apresentar uma crítica (a meu ver, convincente) de Árdal a esta posição. O comentador (que apesar de defender a interpretação cognitivista e o refreamento da interpretação sentimentalista, não defende nenhuma interpretação em relação ao significado dos juízos sobre valores) nota que se se aceitar que o significado de um juízo de valor for apenas uma generalidade acerca dos sentimentos da humanidade, ou uma relação causal entre objetos (ou ações e respetivos agentes) e espectadores, se torna indiferente o sentimento do falante ${ }^{627}$. Com efeito, havendo a possibilidade de proferir qualquer juízo sem deter um sentimento que lhe corresponda, aceitar esta interpretação implica aceitar que o falante não diz absolutamente nada sobre si ao enunciá-lo:

\begin{abstract}
Seria possível, para alguém, aprovar x e, ao mesmo tempo, acreditar que $\mathrm{x}$ não é bom, pois ao acreditar que x é bom, estaria a acreditar que na verdade da proposição sobre a aprovação de outra pessoa, assim como sobre a sua. A análise proposta tornaria impossível pensar que $\mathrm{x}$ é bom porque se aprova $\mathrm{x}$, sabendo ou acreditando que a nossa avaliação não está do lado da da maioria, uma vez que pensar que $\mathrm{x}$ é bom é acreditar numa proposição acerca das emoções da maioria das pessoas. Mas certamente se poderia pensar que mesmo sendo a minoria, se está certo na avaliação: pode pensar-se que outras pessoas são moralmente imaturas ou perversas nos seus juízos moral. ${ }^{628}$
\end{abstract}

Quer dizer, esta posição possui o inconveniente de não permitir uma distinção entre os casos em que os juízos são emitidos por falantes que detêm o

\footnotetext{
${ }^{627}$ Esta também é uma preocupação de Cohon, que julga imperativo que os juízos reflitam o sentimento do falante (cf. COHON, 2008, p. 138).

${ }^{628}$ Tradução minha do original: "[I]t would be possible for a person to approve of $\mathrm{x}$, and at the same time believe that $\mathrm{x}$ is not good, because in believing that $\mathrm{x}$ is good, one would be believing the truth of a proposition about other people's approvals as well as one's own. The proposed analysis would make it impossible to think that $\mathrm{x}$ is good because one approves of $\mathrm{x}$, knowing, or believing, that one is not concurring with most people's evaluations, since to think that $\mathrm{x}$ is good is to believe a proposition about most people's emotions. But surely one could think that one was both in the minority and in the right in one's evaluation: one might think that other people were morally immature, or perverse in their moral judgments." (ÁRDAL, 1966, p. 192).
} 
sentimento em questão e pelos fingidores. Uma vez que esta é a posição que pretendo defender, procurarei mostrar (na secção 3.4) que se lhe deve acrescentar uma cláusula, a fim de escapar deste inconveniente. Esta cláusula é que os juízos sobre valores devem ser considerados não apenas descritivos, mas também expressivos do sentimento quando quem as enuncia detém, efetivamente, o sentimento em questão - caso contrário, nada está a ser expresso.

\subsubsection{Emotivismo (S $\left.\mathrm{S}_{\sim \mathrm{DE}}\right)$}

Passo à apresentação da interpretação emotivista. Nos termos em que Hume coloca esta questão - ao estabelecer a diferença entre o campo da razão e da vontade -, o que estes juízos refletem está para além do campo da representação de objetos, refletindo (ou refletindo também) estados de apresentação, que não têm referência além de si mesmas ${ }^{629}$. Portanto, considera-se que os juízos sobre valores não são verdadeiros nem falsos, ou que, em rigor, não são proposições genuínas, uma vez que têm um caráter expressivo e não descritivo. Portanto, os juízos sobre valores não reportariam sentimentos particulares nem de uma generalidade - interpretações apresentadas, respetivamente, em 3.2.1 e 3.2.2 -, mas antes que não possuindo valor de verdade, não podem ser consideradas descritivas, mas apenas expressivas. Esta interpretação parece ser apoiada pelas evidências textuais a favor do não cognitivismo, às quais se junta a conclusão de que não se pode considerar que os juízos de valor têm um caráter descritivo mas, constatando-se que são proferidos, deve concluir-se que têm um caráter expressivo ${ }^{630}$.

De forma relativamente clara, Reid (1788) é o único dos primeiros comentadores da filosofia de Hume que deriva o emotivismo do não cognitivismo, e a associar este ao sentimentalismo (talvez até sem que Reid estivesse ciente desta distinção). Uma vez que o filósofo do senso comum parece ter sido o primeiro a comentar a teoria moral de Hume, esta parece ter sido a primeira interpretação da teoria dos valores de Hume.

\footnotetext{
${ }^{629}$ Cf. PG 7.

${ }^{630}$ Cf. AYER, 1980, pp. 162-3.
} 
Reid começa por atribuir a Hume tanto a posição de que a atribuição de um valor constitui um sentimento (portanto, constatando o seu sentimentalismo):

[Para o Sr. Hume,] a aprovação e reprovação morais não constituem juízos, que possam ser verdadeiros ou falsos, mas apenas sentimentos ou sensações agradáveis ou desagradáveis. ${ }^{631}$

A justificação que Reid oferece para o sentimentalismo é o não cognitivismo, isto é, com a tese de que juízos sobre valores não podem constituir conhemento, uma vez que não possuem um valor de verdade - pelo que não podem ser considerados proposições genuínas:

Com efeito, [o simples sentimento] não implica afirmação ou negação e, portanto, não pode ter as qualidades de verdadeiro nem de falso, que distinguem proposições de outras formas de discurso, e juizos de todos os outros atos da mente. ${ }^{632}$

Logo em seguida, Reid defende uma interpretação emotivista ${ }^{633}$, referindose ao significado de juízos morais (componente semântica) e não à natureza do próprio valor ou juízo moral (componente epistémica), como fizera acima, defendendo tanto o sentimentalismo como o não cognitivismo. De acordo com a primeira, juízos morais expressam um estado emotivo em vez de descrevê-lo, e de acordo com o sentimentalismo, atribuir um valor a um certo objeto é, em si mesmo, ter esse estado emotivo. Neste sentido, afirma que, para Hume, a diferença entre um juízo como "tal homem agiu dignamente, a sua conduta é

\footnotetext{
${ }^{631}$ Tradução minha do original: "[For Mr. Hume,] moral approbation and disapprobation are not judgments, which must be true or false, but barely, agreeable and uneasy feelings or sensations." (REID, 1788, p. 345; itálico meu).

${ }^{632}$ Tradução minha do original: "For it implies neither affirmation nor negation; and therefore cannot have the qualities of true or false, which distinguish propositions from all other forms of speech, and judgments from all other acts of the mind.” (REID, 1788, p. 346; itálico meu).

${ }^{633}$ Árdal afirma que Reid tem uma interpretação ambígua da teoria moral de Hume, uma vez que oscila entre uma interpretação emotivista e descritivista subjetivista. A sua leitura deste comentador supõe que o termo 'expressar', na terceira citação apresentada, é utilizada no sentido de 'descrever' - supondo, portanto, que o juízo sobre valores tem a função de descrever um sentimento (cf. ÁRDAL, 1966, pp. 208-9). Discordo desta interpretação das palavras de Reid, pois lendo-as com cuidado, nota-se que antes de afirmar que aceitar o sentimentalismo compromete Hume com a tese de que juízos sobre valores expressam (seja qual for o sentido desta expressão) um sentimento, Reid afirma que se se aceitar (como é, aliás, o seu caso) que juízos morais possuem um valor de verdade, "The first expresses plainly an opinion or judgment of the conduct of the man, but says nothing of the speaker. The secondonly testifies a fact concerning the speaker, to wit, that he had such a feeling." (REID, 1788, p. 350). Portanto, a meu ver, Reid parece afirmar que juízos morais, na filosofia de Hume, não têm uma função descritiva, mas a função de manifestar (sem descrever) um sentimento - o que se pode entender como afirmação de que são juízos expressivos, que não possuem um valor de verdade.
} 
altamente aprovável" e um juízo como "a conduta do homem despertou-me um sentimento muito agradável" é que:

Se, por outro lado, supusermos que a aprovação moral não consiste em nada mais que um sentimento agradável, ocasionado pela contemplação de uma ação, o segundo discurso mencionado acima tem um significado distinto, e expressa tudo o que significa a aprovação moral. ${ }^{634}$

A interpretação emotivista foi retomada por autores como Noxon, Hudson, Flew e Ayer ${ }^{635}$.

Hudson julga difícil decidir entre a interpretação de que juízos morais são expressões e a de que seriam descrições do sentimento de quem as enuncia, pelo facto de não haver evidências textuais que desmistifiquem totalmente a posição de Hume sobre a questão de qual, afinal, o seu significado ${ }^{636}$. Porém, declara-se mais simpático à primeira, afirmando a segunda não pode ser derivada (não se sabe porquê) do sentimentalismo:

$[\mathrm{M}]$ esmo sendo emotivos - pode mesmo dizer-se que particularmente sendo emotivos -, os juízos morais são logicamente distintos de declarações sobre factos psicológicos. E não penso que se possa mostrar que do facto indisputável de que Hume os concebeu daquela forma [sentimentalismo], se siga que ele pretendia fazer equivaler ' $X$ é vicioso' e 'Tenho tal e tal sentimento perante $X$ ' [descritivismo subjetivista]. ${ }^{637}$

Por seu turno, também Flew (também sobre os juízos morais) afirmara:

A primeira preocupação de Hume não era relativa à ideia de que juízos morais relatam algum tipo de facto sobre nós, mas antes que não podem ser analisados simplesmente em termos de algum tipo de asserção sobre a realidade objetiva, inteiramente independente de sentimentos e desejos humanos. (...) Sem

\footnotetext{
634 Tradução minha do original: "Such a man did well and worthily, his conduct is highly approvable"; "The man's conduct gave me a very agreeable feeling"; "If we suppose, on the other hand, that moral approbation is nothing more than an agreeable feeling, occasioned by the contemplation of an action, the second speech above mentioned has a distinct meaning, and expresses all that is meant by moral approbation." (REID, 1788, p. 351; itálico meu).

${ }^{635}$ Capaldi oferece uma considerável listagem dos autores que interpretaram Hume da mesma maneira - inclusivamente, chegando a afirmar que devido à influência declarada de Hume em Ayer, que era também um defensor da mesma teoria meta-ética (cf. CAPALDI, 1989, pp. 139-49). A razão pela qual estes autores não são aqui colocados é o facto de, na sua maioria, estarem longe do círculo de comentadores do filósofo e a falta das suas obras.

${ }^{636}$ HUDSON, 1964, pp. 247-8.

${ }^{637}$ Tradução minha do original: "[M]oral judgments even if emotive - one might say particularly if emotive - are logically distinct from statements of psychological fact, and I do not think that it can be shown to follow, from the indisputable fact that Hume made much of the feeling element in moral judgment, that he intended to equate ' $\mathrm{X}$ is vicious' with ' $\mathrm{I}$ have such-and-such a feeling for X'." (HUDSON, 1964, p. 248).
} 
dúvida, ele deveria ter dito, audaz e consistentemente, algo como: quando dizemos 'isto é errado', não afirmamos nada, nem sequer que temos certos sentimentos, mas antes manifestamos os nossos sentimentos. ${ }^{638}$

Finalmente, discordando abertamente da posição descritivista subjetivista, Ayer - que se ocupa apenas da teoria moral de Hume -, observa que esta teoria é melhor considerada como um emotivismo, "segundo o qual essas afirmações se destinam mais a exprimir os nossos sentimentos morais" do que como uma "teoria segundo a qual são afirmações de facto acerca da condição mental de cada um ou de outras pessoas" ${ }^{\prime 639}$.

Vale lembrar que a defesa da interpretação emotivista nos compromete com a defesa de uma posição não cognitivista. Com efeito, para se defender que os juízos sobre valores se reduzem a expressões de sentimentos de quem as enuncia, é necessário defender que não podem ser objeto de conhecimento e que não são verdadeiros nem falsos. Por outro lado, se se defendesse que os juízos em questão são verdadeiros ou falsos e podem ser conhecimento, não se poderia defender que se resumem a expressões de sentimentos de quem as enuncia, mas ser-se-ia obrigado a admitir que possuem, pelo menos em parte, uma função descritiva.

Passo agora à crítica ao emotivismo, começando pelas observações dos defensores da interpretação cognitivista (que devem aceitam a interpretação descritivistas) e depois apresentando as dos defensores da teoria do erro.

Os defensores da inclusão de um elemento cognitivista na interpretação da teoria dos valores de Hume apontam que além de as evidências a favor do nãocognitivismo serem escassas, aceitar esta interpretação ignoraria a possibilidade de correção dos juízos, que Hume claramente aceita ${ }^{640}$. Note-se que esta impossibilidade se configura de uma maneira descritiva e normativa: por um

\footnotetext{
${ }^{638}$ Tradução minha do original: "Hume's first concern was: not with the idea that moral judgments report some sort of fact about us; but rather with the contention that they cannot be analysed in terms simply of any sort of statement about some objective reality entirely independent of human sentiments and human desires. (...) No doubt he ought to have said, boldly and consistently, something like: that when we say 'This is wrong' we are not stating anything, not even that we have certain feelings, but rather we are giving vent to our feelings". (FLEW, 1963, pp. 180-1; itálico meu).

${ }^{639}$ AYER, 1980, pp. 162-3.

${ }^{640}$ Cf. T 3.1.1.18; NORTON, 1975, pp. 202-3; PITSON, 1989, pp. 80-1; GARRETT, 1997, pp. 190-1.
} 
lado, o uso da razão não poderia ser considerado uma explicação para a alteração do juízo (que, de facto, ocorre não raras vezes); por outro lado, não poderia haver uma regra ou critério pelo qual se pudesse considerar um juízo verdadeiro e outro falso.

Stroud observa que a interpretação emotivista também possui a vantagem de deixar o sentimentalismo de Hume intacto, ao preservar o papel ativo do sentimento no caráter expressivo do juízo:

[U]ma interpretação 'emotivista' destaca a importância dos sentimentos em 'juízos' morais, e ainda apresenta a vantage de que 'juízos' morais não resultam do raciocínio. ${ }^{641}$

Stroud e Mackie consideram que tanto o descritivismo subjetivista (que Stroud chama de psicologismo e Mackie chama de teoria disposicionaldescritiva) como o emotivismo devem ser rejeitados como interpretações unívocas para responder à questão semântica sobre os valores. Os comentadores concordam que apesar da vantagem apontada, as interpretações do descritivismo subjetivista e do emotivismo possuem a desvantagem de não explicar ou incluir a pretensão à objetividade, ou, como Mackie lhe chama, uma maneira objetivista de falar $^{642}$, presente no uso dos juízos sobre valores na vida comum ${ }^{643}$ (o que os proponentes da interpretação descritivista causal julgam ser o que os falantes fazem legitimamente):

Nem o psicologismo nem o emotivismo isoladamente parecem plausíveis como interpretações do significado de 'X é bom', e não apenas porque são demasiado simples ou grosseiras. Elas poderiam ser combinadas num tipo de psicologismo mais realista e sofisticado, de acordo com o qual ao dizer ' $X$ é bom', estou simultaneamente a reportar a presenta de um certo sentimento e a expressá-lo - estou, por assim dizer, a aplaudir $X$, ao mesmo tempo que assiro que tenho um sentiment positive em relação a $X^{644}$

\footnotetext{
${ }^{641}$ Tradução minha do original: "[An] 'emotivist' view emphasizes the importance of feelings in moral 'judgments', and it also has the desired consequence that moral 'judgments' are not arrived at by reasoning." (STROUD, 1977, p. 182).

${ }^{642}$ Cf. STROUD, 1977, pp. 180-2; MACKIE, 1980b, pp. 69-70, 73-5.

${ }^{643}$ Brunet também reconhecia esta prática da vida quotidiana, apesar de a restringir ao senso comum - o que leva a crer que o comentador supõe que os filósofos se livrariam deste equívoco ao compreender a natureza epistémica do valor, de forma semelhante ao que ocorre em relação à crença na existência exterior e independente dos objetos da perceção, descrita em T 1.4.2 (cf. BRUNET, 1965, p. 280).

${ }^{644}$ Tradução minha do original: "Neither psychologism nor emotivism alone looks plausible as an account of what ' $\mathrm{X}$ is good' means, and not only because they are too simple or crude. They could be combined into a more realistic and more sophisticated kind of psychologism according to
} 
Não deve defender-se o emotivismo, o prescritivismo nem sequer a mistura de ambas por si sós, são plausíveis, mas uma interpretação que combine um ou ambos estes elementos com o reconhecimento de um elemento semântico descritivo. ${ }^{645}$

Deste modo, Stroud e Mackie julgam que a interpretação que representa de forma justa aquilo em que, de facto, os agentes julgam que consiste um valor (uma propriedade do objeto, como uma ação, objeto inanimado ou pessoa) é o projetivismo (ou, nos termos dos comentadores, teoria da projeção ou da objetificação), que inclui as dimensões emotivista, prescritivista (no caso de Mackie) e objetificante ou projetivista (que, por assim dizer, simula uma descritividade desses juízos).

Por seu turno, Mackie propõe que se inclua ainda, numa interpretação mais refinada do fenómeno dos valores na filosofia de Hume, um terceiro elemento, (que chama de prescritivo ou prescritivista ${ }^{646}$ ), tal que a função dos juízos sobre valores - especialmente as morais - e que os distingue dos descritivos, é a de prescrever uma ação. Estas duas posições são pensadas como opções nãodescritivistas e, portanto, são incompatíveis com a interpretação descritivista $^{647}$. Aliás, Brunet também enfatiza esta componente na teoria dos valores de Hume, associando-a à possibilidade de um conhecimento do gosto (moral e estético) e à existência de um padrão para os juízos, a partir do gosto de uma elite de indivíduos que dispõem de faculdades mais refinadas - os bons críticos $^{648}$ :

O domínio das proposições suscetíveis de uma justificação científica não se limita às ciências ditas experimentais. Os juízos de valor também podem constituir objeto de uma tal justificação. A estética pode constituir uma ciência enquanto «sistema de verdades... formado por conhecimentos racionais bem ligados», e normativo «em virtude do conteúdo desses conhecimentos». Aliás, não há, na apreciação estética,

which in saying ' $X$ is good' $I$ am both reporting the presence of a certain feeling and simultaneously expressing that feeling-I am, as it were, cheering for $X$ while also stating that $I$ have a positive feeling towards it" (STROUD, 1977, p. 182; itálico meu).

${ }^{645}$ Tradução pópria de: "Neither emotivism nor prescriptivism on its own, nor even a mixture of these two alone, is plausible, but a view combining one or both of these with a recognition of an element of descriptive meaning (...)." (MACKIE, 1980b, p. 74).

${ }^{646}$ Que, de acordo com Hare, já é suficiente para se considerar que os juízos (pelo menos, morais) já não são exclusivamente descritivos, pois tem-se um elemento de incitação à ação que escapa à simples descrição (cf. HARE, 1997, p. 45).

${ }^{647}$ Cf. MACKIE, 1980b, pp. 69-70, 73-4.

${ }^{648}$ Cf. BRUNET, 1965, pp. 712, 766-7. 
unicamente um juízo de valor: este não consiste numa noção abstrata, mas compreende (...) uma realidade vivente. Desta forma, o juízo de valor torna-se um juízo sobre a realidade, elemento positivo. Tornando-se um facto, o valor em si pode ser objeto de juízos válidos e verdadeiros à maneira dos critérios empiristas. ${ }^{649}$

\subsubsection{Projetivismo e teoria do erro ( $\left.\mathrm{S}_{\sim \mathrm{DTE}}\right)$}

Passo à exposição das interpretações da teoria moral de Hume (aplicáveis, na maior parte dos casos, à sua teoria estética) desenvolvidas por Stroud e Mackie. Não deixa de ser curioso notar que apesar de manterem a mesma posição, estranhamente, não há, na obra de Mackie (de 1980), posterior à de Stroud (de 1977), nenhuma menção ou remissão a este. Por sua vez, apesar de não apresentar elementos originais à interpretação projetivista, Fogelin admite concordar com Stroud e Mackie ${ }^{650}$.

O que define a sua originalidade é o reconhecimento de que ao invés de se pretender falar sobre o próprio sentimento ou simplesmente expressá-lo, os falantes mantêm uma ilusão de que se referem ao objeto e não a um estado subjetivo. Assim, o projetivismo tal como apresentado por eles pretende-se uma interpretação que concilia os elementos textuais a favor da interpretação não descritivista com a constatação de uma pretensão (natural) de descrever um objeto como possuidor de um valor que, na realidade, não possui.

Os comentadores partilham uma perplexidade de base: todos constatam a necessidade de incluir uma espécie de pretensão à objetividade ${ }^{651}$, presente no discurso ou nos juízos sobre valores. Além disso, propõem a mesma solução para o problema de não se incluir esse aspeto da teoria de Hume numa interpretação da mesma, a saber, o projetivismo. De forma sucinta, as suas interpretações podem

\footnotetext{
${ }^{649}$ Tradução minha do original: "Le domaine des propositions suceptibles d'une justification scientifique ne se limite pas aux sciences dites experimentales. Les jugements de valeur peuvent aussi faire l'objet d'une telle justification. L'esthétique peut être science en tant que «système de vérités... formé de conaissances rationelles bien lieés», et normative «par le contenu de ses connaissances». Il n'y a d'ailleurs pas uniquement un jugement de valeur dans l'appréciation du beau: celui-ci n'est pas une notion abstraite, mais comprend (...) une réalité vivante; le jugement de valeur se complique ainsi d'un jugement de réalité, élément positif. La valeur elle-même devient un fait, elle peut être l'objet de jugements valides et véritables au moyen de critères empiristes." (BRUNET, 1965, pp. 164-5).

${ }^{650}$ Cf. FOGELIN, 1985, p. 143.
} 
ser definidas pela reunião dos seguintes aspetos: i) o anti-realismo em relação à natureza metafísica dos valores; ii) o sentimentalismo e o não cognitivismo em relação à natureza epistémica dos valores; iii) uma dualidade entre a natureza genuína do valor (não proposicional) e o seu uso no discurso da vida comum (como se fosse proposicional) por meio de uma ficção, entendida como falha ou erro. É devido a este último ponto que, a meu ver, ambos os comentadores ${ }^{652}$ são interpretados como defensores da teoria do erro ${ }^{653}$.

Como já foi adiantado na introdução do presente capítulo, esta proposta enquadra-se no grupo de interpretações sobre o estatuto semântico de juízos sobre valores. Porém, os pontos i) e ii) denotam a combinação deste aspeto com um aspeto metafísico e epistémico. É importante notar esta combinação pois o caráter equívoco, fictício ou erróneo do juízo sobre valores (ou do seu uso) justifica-se exatamente pela posição que os comentadores assumem relativamente ao estatuto epistémico e metafísico: não cognitivista e anti-realista. Quer dizer, é porque consideram que os valores não residem nos objetos e não conferem um papel especial à razão no acesso aos mesmos que, falando com propriedade, os pronunciamentos sobre valores não são proposicionais, ainda que, por meio de uma ficção ou engano, pareçam sê-lo. Portanto, aquilo que torna o projetivismo uma teoria do erro - esta dualidade entre o estatuto fictício e genuíno dos juízos sobre valores - é o que torna a(s) proposta(s) de Stroud e Mackie uma forma de não cognitivismo. Referindo-se a estes autores, Pitson define o projetivismo da mesma forma:

Hume atribui-nos a crença de que a virtude e o vício existem como contrapartes destes sentimentos e, além disso, para Hume, esta crença é errada. Isto pode ser descrito como a posição projecionista de Hume. ${ }^{654}$

\footnotetext{
${ }^{651}$ Que Coventry chama de discurso realist-sounding, que consiste em falar sobre os objetos como se possuíssem as propriedades que lhes são atribuídas. A sua interpretação é descrita na seç̧ão 4.1. ${ }^{652}$ A este propósito, devo adiantar que Stroud não é tão explícito como Mackie neste sentido, mas empenhar-me-ei em mostrar que este também deve ser considerado um teórico do erro, indicando, ao mesmo tempo, em que sentido Stroud oferece uma interpretação mais completa do fenómeno em questão do que Mackie. Talvez por esta razão Coventry identifique mais claramente Mackie como teórico do erro (cf. COVENTRY, 2006, p. 30).

${ }^{653}$ Cf. PITSON, 1989, p. 79.

${ }^{654}$ Tradução minha do original: "Hume ascribes to us the belief that virtue and vice exist as the counterparts to these sentiments; and, in addition, (...) this belief is, for Hume, a mistaken one. (...) [T]his may be described as the Projectionist account of Hume" (PITSON, 1989, p. 61).
} 
A este propósito, este comentador esclarece que na interpretação projetivista - de Stroud, Mackie e Fogelin -, está presente um paradoxo entre a natureza da ideia e crença em questão e uma suposição que vai no sentido contrário: uma vez que não provém de uma descoberta de propriedades objetivas, constitui uma "invenção" da imaginação, o que levaria a supor que a crença na sua objetividade seria eliminada e corrigida ${ }^{65}$. No entanto, surpreendentemente, em vez disso, esta crença mantém-se ${ }^{656}$.

Apesar de, como Garrett nota, tanto na sua teoria dos valores como na sua epistemologia em geral, Hume se referir diversas vezes a proposições, asserções e juízos $^{657}$, Stroud, Mackie e Fogelin concordam que Hume não estava suficientemente interessado em ou preocupado com questões de significado para formular explicitamente a sua posição sobre o significado e o uso que se faz dos juízos sobre valores na vida comum ${ }^{658}$. Apesar disso, estes comentadores parecem seguir a valiosa recomendação de Capaldi acerca do que fazer para se interpretar a teoria dos valores de Hume: procurar harmonizar elementos divergentges para formar um todo sistemático e coerente ${ }^{659}$. Neste sentido, Mackie declara explicitamente que a sua intenção é propor uma interpretação sobre o significado de juízos de valor, para a qual haveria espaço na epistemologia de Hume, que, como bem formula Stroud, trata da questão de saber "qual é a relação entre os sentimentos que tenho 'no meu peito' e os [pronunciamentos de valor] que faço?"

Os autores constatam que uma conjunção do descritivismo com o emotivismo (e, no caso do Mackie, também com o prescritivismo) não seria consistente, pois considerar-se-ia que os juízos sobre valores simultaneamente são e não são genuínos, são descritivos e expressivos. O cognitivismo subjetivista (componente descritiva) só parece poder incorporar uma interpretação global da

\footnotetext{
${ }^{655}$ Razão pela qual Pitson está convencido de que Hume não está autorizado a defender ambos os lados do paradoxo - tanto no caso da causalidade como no dos valores (cf. PITSON, 1989, p. 65). ${ }^{656}$ Cf. PITSON, 1989, p. 61, 64.

${ }^{657}$ Cf. GARRETT, 1997, p. 190. Cf. T 1.1.7.9, 1.1.7.14, 1.2.6.3; T 3.1.1.3, 9, 15, 19 n69, 26; T 3.1.2.2, 4; T 3.2.1.18; T 3.2.2.22; T 3.2.5.13; T 3.3.1.3, 16, 21; T 3.3.2.10; IPM 3.38 n13; 4.22; 6.33 ; C 35 .

${ }^{658}$ Em conformidade com isto, Pitson nota que o interesse de Hume residia essencialmente nas perceções (cf. PITSON, 1989, p. 65).

${ }^{659}$ Cf. CAPALDI, 1989, p. 114 CF.
} 
teoria dos valores de Hume associado à consideração de que o comportamento dos agentes na vida comum se define pela pretensão à objetividade no discurso e na maneira de julgar. Deste modo, Stroud e Mackie consideram que a componente em falta na interpretação é a consideração da tendência ao uso dos valores em juízos como se se tratassem de proposições genuínas - portanto, sob a ficção de uma objetividade, isto é, de que os valores pertencem ao próprio objeto avaliado , apontando uma solução interpretativa que inclua esta componente como um aspeto determinante da explicação dos juízos de valor. Julgam, assim, oferecer uma proposta de interpretação completa do mesmo fenómeno, que melhor congrega os quatro elementos apresentados:

Quando contemplo ou observo uma ação, tenho um certo sentiment de aprovação em direção a ela. Ao dizer ou acreditar que $\mathrm{X}$ é virtuosa, estou, efetivamente, a atribuir uma característica objetiva à própria $\mathrm{X}$, muito embora, para Hume, não haja, realmente, tal característica a ser encontrada 'em' $X$ [pretensão à objetividade]. Ao dizer que $\mathrm{X}$ é virtuosa, não estou a observar algo sobre o meu sentiment [cognitivismo subjetivista], mas faço a observação apenas devido ao sentiment que tenho [emotivismo]. ${ }^{661}$

Apesar de o único facto robusto neste âmbito ser que o falante e os outros têm ou teriam certos sentimentos, que há um sistema interpessoal de sentimentos em relação a ações, caracteres, etc, tendemos a projetar estes sentimentos nas ações ou caracteres que os suscitam, ou interpretar certo tipo de imagem destes sentimentos neles, de tal forma que pensamos em tais ações e caracteres como objetiva e intrinsecamente possuidores de aspetos distintamente morais. Mas estes aspetos são ficções. Estas ficções são projeções de sentimentos. ${ }^{662}$

\footnotetext{
${ }^{660}$ Tradução minha do original: "what is the relation between the sentiments I feel 'in my own breast' and the [pronuncements of value] I make?" (STROUD, 1977, p. 180); Cf. STROUD, 1977, p. 182; MACKIE, 1980b, p. 70, 72, 73, 74; FOGELIN, 1985, pp. 140-1.

${ }^{661}$ Tradução minha do original: "I contemplate or observe an action or character and then feel a certain sentiment of approbation towards it. In saying or believing that $\mathrm{X}$ is virtuous $\mathrm{I}$ am indeed ascribing to $\mathrm{X}$ itself a certain objective characteristic, even though, according to Hume, there really is no such characteristic to be found 'in' $X$. (...) In saying that $X$ is virtuous I am not just making a remark about my own feeling, but I make the remark only because I have the feeling I do." (STROUD, 1977, p. 184).

${ }^{662}$ Tradução minha do original: "Although the only hard fact of the matter is that the speaker and others have or would have certain sentiments, that there is an interpersonal system of sentiments with regard to actions, characters, and so on, we tend to project these sentiments onto the actions or characters that arouse them, or read some sort of image of these sentiments into them, so that we think of those actions and characters as possessing, objectively and intrinsically, certain distinctively moral features; but these features are fictitious. [T]hese fictitious features are projections of sentiments." (MACKIE, 1980b, p. 71). Cf. também STROUD, 1977, p. 182, acima.
} 
Ambos os comentadores definem explicitamente em que consiste uma projeção. Mackie explica que efetivamente, os juízos sobre valores são utilizados como se tivessem um caráter descritivo, chamando essa atribuição de objetividade de objetificação ou projeção, e envolve diretamente uma crença falsa na objetividade dos valores, e a teoria do erro consiste na tese de que a atribuição de uma objetividade aos valores constitui uma ficção, uma crença falsa. Projetar é, assim, atribuir uma objetividade aos valores que não existe, e pensar e falar nos objetos como se tivessem os valores que lhes são atribuídos é fingir - por isso significa objetificar significa que Mackie utilize a expressão teoria da objetificação como sinónimo de projetivismo. Por seu turno, Stroud chama clara e repetidamente a sua interpretação de projetivismo ou teoria da projeção e que os valores (como a causalidade) são projeções. Portanto, o projetivismo consiste nesta interpretação que resulta da combinação das interpretações a) emotivista, b) cognitivista subjetivista e c) o elemento objetificante, que passa pelo uso objetivista dos valores em juízos (que constitui uma ficção) ${ }^{663}$.

Passo agora a explicar os elementos que tornam Mackie e Stroud teóricos do erro. Definitivamente, os comentadores parecem estar comprometidos com uma teoria do erro ${ }^{664}$, ainda que Mackie seja mais explícito que Stroud, que não é tão conciso e explícito nessa tomada de posição. Em relação a este, vale notar que no principal texto que dedica ao tema dos juízos de valor ${ }^{665}$, não menciona uma vez sequer que as projeções são falsas e/ou injustificadas. Além disso, a breve menção que faz ao possível valor de verdade de juízos sobre valores aparece no contexto da caracterização da interpretação psicologista. Dado que a parte dessa interpretação que Stroud pretende descartar é a da referência autobiográfica dos juízos sobre valores (o seu caráter autobiográfico), e não ao seu critério de verdade, não parece haver razões para pensar que Stroud descarta que o valor de verdade desses juízos dependa da adequação entre o sentimento expresso no juízo e o íntimo do agente em questão - se, efetivamente, tem ou não esse sentimento. Porém, só parece ficar claro que Stroud considera o ato projetivo sob um ponto de

${ }^{663}$ Cf. STROUD, 1977, pp. 184-6, 240, 244, 246, 247, 268n15, pp. 269-70; MACKIE, 1980b, pp. 72-74.

${ }^{664}$ Apesar de, aparentemente, Coventry não o ter descrito como tal. As suas considerações sobre a posição de Stroud serão expostas na seç̧ão 4.1 deste trabalho.

${ }^{665}$ STROUD, 1977, VIII. 
vista racional (de uma análise da razão) quando faz uma retrospetiva de todo livro $^{666}$.

Apenas Mackie afirma explicitamente que pretende rejeitar o cognitivismo, associado a um realismo. Em relação a Stroud, esta conclusão parece poder ser retirada da sua afirmação de que para se conseguir uma interpretação adequada, o emotivismo (forma de não cognitivismo) deve ser combinado com o psicologismo e a constatação da pretensão à objetividade ${ }^{667}$. Este mesmo movimento é promovido por Mackie, ao afirmar que as componentes prescritivista e emotivista devem ser conjugadas com a descritivista ${ }^{668}$.

Por sua vez, esta interpretação combinada é inconsistente com uma componente descritivista - que Stroud chama de psicologismo -, pois exclui uma componente cognitivista. Com efeito, o não cognitivismo prevê que os juízos sobre valores não sejam consideradas proposições genuínas, pois não descrevem sentimentos, mas expressam, mostram ou refletem-nos, e o cognitivismo, que os juízos sobre valores sejam proposições genuínas, isto é, que podem ser verdadeiros ou falsos mediante do sentimento presente na mente do agente e a sua sinceridade ao proferir o juízo. A única forma de compatibilizar estas duas componentes da interpretação parece ser aceitando que há um uso fíctício do juízo como se fosse uma proposição genuína, o que supõe que as projeções constituem ficções, crenças racionalmente injustificadas ou mesmo falsas ${ }^{669}$. Por sua vez, esta consideração só parece fazer sentido no âmbito de uma interpretação em que se considera que há, nos juízos (neste caso, sobre os valores), um contraste entre um aspeto genuíno e outro fictício, e que o é considerado genuíno é o do reconhecimento do caráter não proposicional, não descritivo e não representativo daqueles juízos.

Estes comentadores também subsumem a relação causal no escopo da projeção, de tal forma que se parece considerá-la uma transferência de uma propriedade subjetiva para os objetos da experiência, ou seja, uma atribuição indevida de uma propriedade que o objeto não mostra possuir, associando

\footnotetext{
${ }^{666}$ STROUD, 1977, XII, especialmente pp. 239-49.

${ }^{667}$ Cf. STROUD, 1977, p. 182.

${ }^{668}$ Cf. MACKIE, 1980b, pp. 73-4.

${ }^{669}$ Cf. STROUD, 1977, pp. 245-50; MACKIE, 1980b, p. 72; KAIL, 2007b, p. 148.
} 
explicitamente a projeção ao ato de se "espalhar nos objetos externos" (que Hume refere a propósito da atribuição de uma objetividade à relação de causalidade):

O processo da projeção ou objetificação aqui postulado seria uma instância da 'grande propensão a espalhar-se nos objetos externos' da mente humana e seria análogo ao processo pelo qual Hume explica a nossa crença em conexões entre causas e efeitos, igualmente fictícias. ${ }^{670}$

É fácil imaginar que [a interpretação projetivista] serve de base para a explicação associacionista dos fenómenos morais - e fálo de uma forma que invoca uma das ideias preferidas de Hume, a saber, de que a mente "se espalha" nos objetos que contempla. 671

Apesar de ficar relativamente claro que os autores subsumem tanto a causalidade como o valor estético e moral no escopo da projeção, Stroud chega a afirmá-lo de forma ligeiramente mais explícita:

Como é que a aparência de uma destas coisas na mente tem o efeito de nos suscitar pensamentos (ou "ideias") de vício, de beleza, de causação ou de quaisquer outras qualidades ou relações que atribuímos aos objetos, se, para Hume, tais qualidades e relações não pertencem nem podem pertencer aos "objetos tais como existem na natureza"? ${ }^{672}$

Posteriormente, Stroud direcionou esta explicação para uma indagação sobre aquilo em que consistiria essa projeção no escopo da filosofia de Hume. Portanto, procura responder à questão de saber quais as evidências textuais que permitem uma resposta à questão de saber em que consiste projetar - ou, nos termos de Mackie, esse ato de objetificar. Para tal, o comentador retoma a distinção entre os campos da razão e do gosto e associa as passagens sobre a propensão projetiva à capacidade da faculdade do gosto de realizar uma nova criação. Retomem-se essas passagens:

\footnotetext{
${ }^{670}$ Tradução minha do original: "The process of projection or objectification postulated here would be an instance of the human mind's 'great propensity to spread itself on external objects' (I iii 4) and would be closely analogous to the process by which Hume explained our belief in equally fictitious necessary connections between causes and effects." (MACKIE, 1980b, p. 72; itálico meu); T 1.3.14.25.

${ }^{671}$ Tradução minha do original: "[I]t is easy to imagine how it could serve as the basis of associationist explanation of moral phenomena - and it does this in a way that invokes one of Hume's favourite ideas, i.e., that the mind "spreads itself" on the objects it contemplates." (FOGELIN, 1985, p. 143).

${ }^{672}$ Tradução minha do original: "How does the appearance of one of those things in the mind have the effect of giving us thoughts (or "ideas") of vice, of beauty, of causation, or of any other qualities or relations we ascribe to objects, when according to Hume those qualities and relations
} 
[A] mente tem uma grande propensão a se espalhar pelos objetos externos, ligando a eles todas as impressões internas que eles ocasionam, e que sempre aparecem ao mesmo tempo que esses objetos se manifestam aos sentidos. ${ }^{673}$

[C]omo sentimos uma conexão habitual entre as idéias, transferimos esse sentimento aos objetos, pois nada é mais comum do que aplicar aos corpos externos todas as sensações internas que eles ocasionam. ${ }^{674}$

[O] gosto fornece o sentimento de beleza e deformidade [campo da estética], de virtude e vício [campo da ética] (...) [e] tem uma capacidade produtiva e, ao ornar [gilding] ou macular [staining] todos os objetos naturais com as cores que toma emprestadas do sentimento interno, erige, de certo modo, uma nova criação. ${ }^{675}$

Com efeito, Hume admite esta objetificação, ao afirmar explicitamente que se "[pensa] que a qualidade agradável está no objeto, não no sentimento, e isso meramente “676. Portanto, Stroud explica que "a operação da projeção” consistiria, nos termos de Hume, em acrescentar um novo "ingrediente" na conceção do objeto, isto é, em transferir ou aplicar uma propriedade subjetiva e não representativa - um sentimento - aos objetos, orná-los e colori-los com essa propriedade. Deste modo, consegue-se uma explicação naturalista da ficção da objetificação, que é esta capacidade da imaginação de dar ao objeto a aparência de possuir intrinsecamente a propriedade que lhe é aplicada ${ }^{677}$. Stroud julga que essa nova criação consiste no objeto contendo essa propriedade que lhe é transferida:

Eventualmente, a "nova criação" é uma conceção de um mundo que contém ações boas e más, caracteres admiráveis e desprezíveis, e objetos belos e feios. É apenas porque naturalmente temos certos sentimentos ou impressões e, mais importante, apenas por causa da "faculdade produtiva" da mente, de "ornar e macular" este mundo com o que esses sentimentos nos dão, que algum dia podemos e vimos a pensar dessas formas. ${ }^{678}$

do not and cannot actually belong to "objects as they really stand in nature"?"(STROUD, 1993, p. 258; itálico meu); Cf. IPM Ap. 1.21; COVENTRY, 2006, p. 43.

${ }^{673} \mathrm{~T}$ 1.3.14.25.

${ }^{674}$ IEH 7.2.29n17.2; itálico meu.

${ }^{675}$ IPM Ap. 1.21.

${ }^{676} \mathrm{C} 15$; itálico meu.

${ }^{677}$ Cf. STROUD, 1993, pp. 257-8, 264.

${ }^{678}$ Tradução minha do original: "The "new creation" is eventually a conception of a world containing good and evil actions, admirable and contemptible characters, and beautiful and ugly objects. It is only because we naturally get certain feelings or impressions, and, even more importantly, only because of the mind's "productive faculty" in "gilding or staining" the world with what those feelings give us, that we ever come to think in those ways at all". (STROUD, 1993, p. 259). 
Entretanto, Stroud possui um mérito adicional em relação a Mackie, a saber, o de acentuar o caráter natural da tendência à projeção. $\mathrm{O}$ autor considera esta tendência projetiva um mecanismo natural da mente, pelo que se pode concluir que julga o próprio juízo - enquanto projetivo - como um exercício natural dessa tendência. Esta é uma consideração que aparece entremeada no texto dos proponentes desta interpretação, e também fica clara na consideração de Stroud sobre o projeto (de Hume) de explicar o mecanismo pelo qual se formulam os juízos, entendido como um projeto naturalista: de fazer ciência natural sobre a mente humana ${ }^{679}$.

Fogelin também parece sugerir isto, acrescentando ainda a consideração de que a pretensão à objetividade - que chama de caráter disposicional do juízo -, é explicada pela natureza humana, insere a causalidade no plano do gosto (moral e estético), uma vez que se traduz no proferimento de juízos com a mesma forma que os juízos que descrevem relações causais ${ }^{680}$.

Porém, Mackie também possui um mérito adicional que falta a Stroud, a saber, o de ter notado que a objetificação se dá num plano intersubjetivo, em que os sentimentos dos agentes têm a capacidade de se moldar e reforçar entre si. A objetificação, que consiste na ficção de uma objetividade dos valores, serve um propósito social, de ter uma função motivadora num plano intersubjetivo ${ }^{681}$ :

\begin{abstract}
Esta projeção ou objetificação não é apenas uma artimanha da psicologia individual. (...) Há um sistema em que os sentimentos de cada pessoa tanto modificam como reforçam os de outros; os supostos aspetos morais objetivos tanto auxiliam como refletem esta comunicação de sentimentos, e todo o sistema de pensamentos para o qual a objetificação - a crença falsa - nos aspetos fictícios contribui, floresce, em parte, porque tem uma função social. ${ }^{62}$
\end{abstract}

A existência de um padrão interpessoal é o que permite que juízos sobre valores tenham um valor motivacional geral, isto é, quando é válido não apenas

\footnotetext{
${ }^{679}$ Cf. STROUD, 1977, p. 171, 186, 187, 198, 232, 233, 240, 245; 1993, p. 259, 264, 271 n8.

${ }^{680}$ Cf. FOGELIN, 1985, pp. 141-2; STROUD, 1977, p. 187, 198.

${ }^{681}$ MACKIE, 1980b, pp. 71-2.

${ }^{682}$ Tradução minha do original: "This projection or objectification is not just a trick of individual psychology. (...) [T]here is a system in which the sentiments of each person both modify and reinforce those of others; the supposedly objective moral features both aid and reflect this communication of sentiments, and the whole system of thought of which the objectification, the
} 
para alguns agentes, mas para todos ${ }^{683}$. Por sua vez, Fogelin acrescenta uma observação que, a meu ver, esclarece o que Mackie quer dizer com esta observação. Com efeito, ao enunciar juízos sobre valores, cada agente gera uma cadeia de associações - e até, possivelmente, raciocínios - da parte dos seus espectadores (tanto efetivos como possíveis). Por sua vez, estas associações traduzem-se em concordância ou discordância para com o que os agentes proferem, gerando-se este sistema intersubjetivo de influência mútua entre agentes e espectadores. Fogelin julga que este "sistema" constitui um bom motivo para não se desqualificar nem a interpretação subjetivista, nem a emotivista:

Dado o quadro associacionista geral da posição de Hume, tanto o subjetivismo como o emotivismo poderiam servir de base para explicar como as apreensões morais de uma pessoa se relacionam com as de outra. Quando digo que algo é vicioso, dou conhecimento dos meus sentimentos ao falar sobre eles (subjetivismo) ou ao expressá-los (emotivismo). Por meio da simpatia, isto inicia uma sequência de associações exatamennte do mesmo tipo que Hume está interessado em traçar. Desta forma, os pronunciamentos morais de uma pessoa podem relacionar-se com os de outra. Elas podem, pelo menos, concordar ou discordar. Então, sugiro que nem o subjetivismo nem o emotivismo parecerão implausíveis no context da filosofia associacionista da mente tal como Hume defende $(\ldots){ }^{684}$

Comparando os méritos de Stroud e Mackie, pode dizer-se que o primeiro se empenhou mais em destacar a analogia entre a projeção dos valores e a projeção da relação causal, além de ser mais enfático na questão da naturalidade da projeção do que Mackie. E defendendo um projetivismo generalizado e tendo destacado mais a naturalidade da projeção da causalidade do que dos valores, parece legítimo concluir que as observações que faz sobre a primeira da

false belief in the fictitious features, is a contributing part, flourishes partly because (...) it serves a social function." (MACKIE, 1980b, p. 72; itálico meu).

${ }^{683}$ MACKIE, 1980 b, p. 68.

${ }^{684}$ Tradução minha do original: "[G]iven the general associationist framework of Hume's position, both subjectivism and emotivism could be used as the basis for explaining how one person's moral apprehensions are related to another's. When I say that something is vicious, I make known my feelings by speaking about them (subjectivism) or by expressing them (emotivism). Via sympathy (...) this can initiate a train of associations of the very kind that Hume is fond of tracing out. In this way, one person's moral pronouncements can be related to another's. They can at least seem to agree or disagree. I am suggesting then, that neither subjectivism nor emotivism will seem implausible in the context of a thorough-going associationist philosophy of mind of the type that Hume champions." (FOGELIN, 1985, p. 142). Esta obvservação está em perfeita continuidade com as observações de Mackie e Stroud sobre a insuficiência das mesmas interpretações para oferecer uma interpretação adequada dos juízos de valor. 
causalidade se aplicam (pelo menos em grande parte) à projeção dos valores. Por seu turno, ambos têm o mérito de ter incluído (ainda que de forma muito breve) o valor estético nas suas considerações, o que indicia que o propósito deste trabalho não é um tópico que lhes tenha passado totalmente despercebido. Por fim, julgo que se deve reconhecer um mérito a Mackie que não está presente em Stroud, a saber, da ênfase no caráter intersubjetivo da projeção, o que oferece um fator decisivo para se perceber a origem e o sentido de um padrão para juízos de valor. Esta consideração será determinante para se entender a origem e a legitimidade das regras sobre objetos cujas propriedades (como a causalidade e os valores) merecem o estatuto de projeção - devido à conclusão (essencialmente epistémica) de que não se encontram (nem podem encontrar) nos objetos da experiência sensível.

Vale notar que a defesa da teoria do erro nos compromete com a defesa de uma posição não cognitivista. Com efeito, apesar de os juízos sobre valores serem expressivos (e não descritivos), quem as enuncia está plenamente convencido de que ao enunciá-lo, descreve um facto (uma propriedade intrínseca ao objeto que é avaliado) - portanto, mantém uma ilusão de objetividade. Mas para se considerar que os juízos sobre valores são expressivos de um sentimento de quem os enuncia e que a pretensão à objetividade constitui uma ficção, engano ou erro, é necessário rejeitar que possam ter um valor de verdade, constituir um tipo de conhecimento e ser (pelo menos genuinamente) descritivas. Por outro lado, se se defendesse que esses juízos são descritivos, não se poderia defender que se resumem a expressões de sentimentos de quem as enuncia, nem se poderia defender que consistui uma ilusão acreditar que ao enunciar esse juízo, se descreve um facto.

Porém, há que notar que mesmo mantendo-se uma proposta não cognitivista, a ilusão que os agentes e espectadores possuem de que descrevem um facto - ao invés de expressar um sentimento - não se resume ao momento em que emite o juízo, mas explica-se pelo facto de que o objeto é concebido como possuidor da propriedade que, erradamente, lhe é atribuída. Ainda assim, nenhum dos defensores desta interpretação explicou isto com a maior clareza, ficando este aspeto da interpretação escamoteado na sua proposta sobre o significado dos juízos. Kail possui o mérito de ter ressaltado este aspeto - como procurarei explicar na próxima secção. 


\subsubsection{Críticas à teoria do erro}

$\mathrm{Na}$ presente secção, apresento os pontos de fragilidade que identifico nas interpretações projetivista (de tipo anti-realista) e realista acerca dos valores na filosofia de Hume, fazendo-o por ordem.

A meu ver, a interpretação projetivista de tipo anti-realista possui o mérito de compatibilizar a componente expressiva dos juízos sobre valores e o seu uso objetificante na vida comum (o discurso realist-sounding). Porém, o facto de, nesta interpretação, esta prática ser considerada geradora de crenças falsas, torna-a vulnerável em dois sentidos, que passo a explicar.

Sendo uma proposta não cognitivista, a teoria do erro (interpretação projetivista proposta por Mackie e Stroud) não permite considerar que juízos de valor possuam um valor de verdade genuíno, pois para estes comentadores, restringindo-se o campo da verdade ao campo do que é percetível pelos sentidos externos, os comentadores são obrigados a considerar que o discurso sobre os valores é sistematicamente falso. Quer dizer, Mackie e Stroud não consideram que possa haver uma verdade e uma falsidade (nem, portanto, um conhecimento) sobre os valores, pois confrontados com o que Hume reconhece como campo da verdade e da falsidade (o campo das ideias, que representam direta ou indiretamente $^{685}$ objetos da experiência). Como considera Mackie, a distinção entre juízos de valor e juízos sobre causalidade está mais nítida: apenas os segundos são verdadeiros ou falsos, e os primeiros, quando confrontados com o campo da verdade e da falsidade que Hume reconhece, são invariavelmente falsos, pois a propriedade atribuída ao objeto em questão (a beleza ou a virtude) não é observável nem resultado de um raciocínio. Já Stroud não se atém a esta separação, chegando apenas a insinuar que os próprios juízos sobre causalidade teriam uma componente expressiva. De qualquer forma, não deixa de estar do lado de Mackie ao afirmar que os juízos sobre valores seriam invariavelmente falsos, pois não têm, genuinamente, um valor de verdade, sendo expressivos, constituindo um erro considerar o contrário $^{686}$. Da mesma forma, estes

\footnotetext{
${ }^{685}$ Quer dizer, a representação direta seria aquela em que as ideias presentes na mente têm um correspondente com um objeto da experiência sensível efetiva do agente cognitivo em questão, e a indireta, o conjunto de conhecimentos ou juízos de que o agente cognitivo em questão dispõe e em cuja verdade confia (por testemunho), mas do qual não teve uma experiência sensível efetiva.

${ }^{686}$ Cf. 3.2.4.
} 
comentadores teriam de admitir que na medida em que se referem aos objetos ou a propriedades intrínsecas (sob a influência da propensão projetiva), os juízos sobre relações causais também são invariavelmente falsos, podendo ser verdadeiros ou falsos apenas mediante a correção da sua referência: dos objetos ou propriedades intrínsecas para regularidade observável, que se restringe ao campo das impressões.

Como bem notou Capaldi, a proposta do projetivismo anti-realista possui uma fragilidade que resulta de se insistir "que a verdade resulta apenas de estruturas independentes dos seres humanos e da intersubjetividade"687. Esta fragilidade consiste no reconhecimento da existência de um plano intersubjetivo de influência e acordo mútuo ainda assim não permitir que este seja considerado um critério genuíno em virtude do qual se pode conferir um valor de verdade a um juízo. Com efeito, o projetivismo anti-realista constitui a chamada teoria do erro em virtude de os seus defensores considerarem que a crença na objetividade dos valores é falsa - de onde se segue, para eles, que é um erro considerar que os valores lhes são intrínsecos. Esta constatação tem uma consequência contraintuitiva. Tome-se, por exemplo, os juízos "a Maria é honesta" e "a rosa é bela". Se se aceitar que a crença de que os objetos possuem valor em si mesmos, é falsa e que qualquer juízo consista numa pretensa descrição de um objeto como possuidor de um valor - como a honestidade da Maria e a beleza da rosa -, e deve aceitar-se que todas os juízos particulares sobre valores são falsas.

Há ainda um aspeto da interpretação da teoria do erro que fíca escamoteado na discrepância que os seus proponentes concebem entre juízos de valor e juízos causais e parecem constituir pressupostos desta interpretação. Tratase de uma consideração tácita de Stroud e Mackie sobre o que Hume considerava ser o campo da verdade e da racionalidade, que restringe o campo dos juízos às sensações, excluindo as impressões internas deste campo. Com isto, os únicos juízos que possuem um critério verificador são os juízos sobre relações causais entre objetos inanimados, inviabilizando que se considere que um juízo seja considerado verdadeiro ou falso em virtude de uma correspondência com uma impressão (interna). Uma vez que o único critério em virtude do qual um juízo sobre questões de facto pode ser verdadeira é a sensação, juízos sobre valores (que 
refletem ou não alguma impressão interna) não possuem valor de verdade, ou se o possuem, esse valor é sistematicamente o falso, de onde surge o caráter ficcional da atribuição de um valor de verdade a estes juízos.

Uma vez que Hume concede um espaço para um caráter representativo dos juízos sobre valores - e, por consequência, o seu valor de verdade -, há que aceitar que pelo menos alguns juízos sobre valores possuem o valor de verdade verdadeiro. Mas isto leva-nos à conclusão contraintuitiva de que apesar de estes juízos serem, nalgum sentido, verdadeiros, o único veredito destes comentadores é que são falsos, pois se não descrevem propriedades intrínsecas (que é a convicção a que a propensão projetiva conduz a mente), não podem ser verdadeiros. Para escapar a esta conclusão, os defensores do projetivismo anti-realista poderiam oferecer um elemento complementar à interpretação que explicasse como é que a crença na objetividade dos valores pode ser falsa, mas alguns juízos sobre valores podem ser verdadeiros. Deste modo, poderiam afirmar que elas devem ser considerados verdadeiros num plano diferente daquele sob o qual devem ser consideradas falsos. Elas poderiam ser considerados falsos enquanto descrições genuínas de propriedades objetivas, mas verdadeiros pelo facto de corresponderem ao padrão intersubjetivamente construído para juízos sobre valores.

Mas a verdade é que nem Stroud, nem Mackie nem Fogelin o fizeram. Além disso, para preservar o caráter normativo da sua interpretação, se o tivessem feito, teriam de admitir que o plano sob o qual o valor de verdade desses juízos pode ser o verdadeiro ou o falso (ou seja, o segundo plano, em que esse valor de verdade é variável) tem um valor deflacionário em relação ao plano sob o qual os juízos sobre valores são invariavelmente falsos (ou seja, o primeiro). Portanto, teriam de admitir que o plano sob o qual esses juízos devem ser considerados invariavelmente falsos é o plano genuíno do valor de verdade, e que, no máximo, o segundo teria um valor pragmático (talvez de garantir a sociabilidade ou permitir o acordo). Caso contrário, já não poderiam afirmar que é um erro conferir uma objetividade aos valores, do que resultaria na descaracterização da sua interpretação como teoria do erro.

${ }^{687}$ CAPALDI, 1989, p. 151. 
Além disso, aceitando que juízos de valor são uma instância dos juízos causais e que ações e pessoas estão entre os objetos entre cujas relações causais atribuimos uma objetividade, a interpretação que valer para a tendência a projetar a objetividade das relações causais entre objetos inanimados deve servir para a tendência a projetar as mesmas relações entre os objetos estéticos e morais e os sentimentos do espectador, assim como as chamadas qualidades secundárias ${ }^{688}$.

A meu ver, a componente não cognitivista da interpretação projetivista de Mackie e Stroud não é a mais ajustada, uma vez que há evidências textuais para se considerar que os juízos de valor são, efetivamente, verdadeiros ou falsos. Portanto, julgo que, na filosofia de Hume, se deve aceitar que tanto os juízos sobre causalidade como os juízos sobre valores são verdadeiros ou falsos. Com isto, proponho que este seja considerado um sexto aspeto que a causalidade e os valores mantêm em comum na filosofia de Hume: é possível um conhecimento sobre ambos, porque os respetivos juízo são verdadeiros ou falsos. Numa palavra, julgo que um uma interpretação cognitivista em relação ao estatuto epistémico dos juízo sobre valores (e não só sobre relações causais) permite acrescentar este sexto aspeto que a causalidade e os valores mantêm em comum na filosofia de Hume.

\subsection{Realismo e anti-realismo}

Na maioria das interpretações da filosofia de Hume, as evidências textuais sobre os valores não se encontrarem nos objetos, mas serem dependentes de um sentimento desperto na mente foram interpretadas de maneira literal, isto é, como provas de que Hume negava explicitamente que os valores constituam propriedades intrínsecas dos objetos aos quais se-os atribui. Como antecipei em 3.1, esta posição justificou e foi compatibilizada com diversas posições acerca das restantes componentes (que designei por epistémica e semântica), a saber: i) de que os juízos sobre valores não possuem valor de verdade e não podem ser objeto de conhecimento (não cognitivista); ii) de que os mesmos juízos possuem valor de verdade - designadamente, determinado pela própria efetividade dos sentimentos dos agentes (cognitivista); iii) de que descrevem o sentimento de um agente

${ }^{688}$ Aliás, esta constitui a interpretação global de Stroud (cf. 3.2.4); cf. CAPALDI, 1989, p. 151. 
particular (subjetivismo) ou de um conjunto de indivíduos (intersubjetivismo), de que não são descritivas, mas apenas expressam o sentimento do agente que profere o juízo (emotivismo) ${ }^{689}$; iv) de que apesar de serem meramente expressivos, os agentes proferem os juízos de valor sob a ilusão de que descrevem propriedades intrínsecas dos objetos (teoria do erro ${ }^{690}$ ).

Porém, alguns comentadores julgavam que apesar de parecer defender uma posição anti-realista, a filosofia de Hume tinha espaço para se considerar que o filósofo defendia que os valores são, de alguma forma, independentes da mente. $\mathrm{Na}$ próxima secção, apresento esta proposta interpretativa para, nas secções seguintes, criticá-la e explicar a interpretação que aceito, a saber, de que Hume é inequivocamente anti-realista, apesar de ser possível manter uma interpretação cognitivista e descritivista da sua teoria dos valores.

\subsubsection{Realismo $\left(M_{R}\right)$}

Em relação à evidência textual em que Hume compara os valores às chamadas qualidades secundárias, os defensores da interpretação realista julgam que em vez de favorecer uma interpretação anti-realista ${ }^{691}$ esta deve favorecer a sua interpretação, ao invés de uma interpretação anti-realista - seja projetivista ou não ${ }^{692}$.

Para Pitson, o problema do uso da comparação dos valores com as qualidades secundárias pelos projetivistas é que estes autores fazem uma leitura equivocada da teoria das qualidades secundárias de Locke ${ }^{693}$. Da parte de Hume, o equívoco estaria em operar com uma distinção demasiado simples entre qualidades dos objetos e qualidades da mente, em que da ideia de que não são propriedades dos objetos, Hume conclui que são das perceções ${ }^{694}$.

\footnotetext{
${ }^{689}$ Cf. 3.1 e 3.2 deste trabalho.

${ }^{690}$ Cf. STROUD, 1977, p. 44, 46, 82; 1993, p. 259; MACKIE, 1980b, p. 72; FOGELIN, 1985, p. 117,$144 ; 3.2 .4$ deste trabalho.

${ }^{691}$ Cf. T 3.1.1.26; C $17 \mathrm{n} 1 ; 3.1$ deste trabalho.

${ }^{692}$ Cf. NORTON, 1982, p. 112, PITSON, p. 67; KAIL, 2007b, p. 108. Por seu turno, Blackburn argumenta contra esta associação, alegando, essencialmente, a falta de empenho de Hume em assinalá-la e os inconvenientes que ela traria para uma interpretação expressivista da teoria dos valores de Hume (cf. BLACKBURN, 1993).

${ }^{693}$ Cf. PITSON, 1989, p. 68, 89.

${ }^{694}$ Cf. PITSON, 1989, p. 69-70.
} 
A fim de esclarecer este equívoco e explicar de que forma seria possível defender que Hume estaria mais comprometido com a tese de que as qualidades secundárias são objetivas do que subjetivas, Pitson lembra a distinção entre qualidades absolutas e relativas, presente no ensaio "O Cético":

[E]stabelecemos uma qualidade como a beleza a um objeto apenas em relação aos sentimentos produzidos, em nós, por esse objeto. ${ }^{695}$

A propósito da comparação entre as propriedades objetivas e a beleza de um círculo, prossegue com a sua alternativa:

\begin{abstract}
A beleza e a virtude são aquelas qualidades dos objetos que os dispõem a suscitar o sentimento apropriado em nós, isto é, a aprovação. Ainda assim, o próprio Hume insiste em escrever sobre estas propriedades como se pertencessem à mente, em vez de aos próprios objetos. ${ }^{696}$
\end{abstract}

Para Pitson, isto desmistifica o sentido puramente subjetivista da interpretação de que os valores são apenas da mente.

Desta forma, o comentador aponta, muito brevemente, duas soluções de interpretação. Uma seria considerar que o valor é um estado de coisas complexo, que envolve o objeto e um observador, que possui uma certa constituição que condiciona a sua apreensão daquele ${ }^{697}$. A este propósito, Pitson julga que Hume chega a falar nestes termos:

Perguntemo-nos, então, em primeiro lugar, onde está o fato que aqui consideramos condenável; procuremos apontá-lo, determiner o momento de sua ocorrência, descrever sua natureza ou essência, explicar o sentido ou faculdade que o apreende. Ele reside na mente da pessoa que é ingrata; esta, portanto, deve senti-lo, deve ter consciência dele. Mas nada existe em sua mente exceto a paixão da honestidade ou uma absoluta indiferença, e não se pode dizer destas que sejam atos condenáveis sempre e em qualquer circunstância. Só o são quando dirigidas contra pessoas que anteriormente expressaram e demonstraram boa vontade conosco. Em conseqüência, podemos inferior que $\mathrm{o}$ ato moralmente condenável da ingratidão não consiste em nenhum fato particular e individual, mas decorre de um complex de circunstâncias que, ao se

\footnotetext{
${ }^{695}$ Tradução minha do original: "[W]e ascribe a quality such as beauty to an object only in relation to the sentiments produced in us by that object." (PITSON, 1989, pp. 68-9).

${ }^{696}$ Tradução minha do original: "[B] eauty and virtue are those qualities of objects which dispose them to give rise in us to the appropriate sentiment, i.e., of approbation. Yet Hume himself persists in writing of these properties as though they belong to the mind, rather than to objects themselves." (PITSON, 1989, p. 68).

${ }^{697}$ Cf. PITSON, 1989, p. 70.
} 
apresentarem ao espectador, provocam o sentimento de censura, em razão da peculiar estrutura e organização de sua mente. ${ }^{698}$

Neste sentido, parece que Pitson afirma que evidências textuais como esta deveriam servir para fundamentar uma posição intermédia, que teria em conta fatores objetivos e subjetivos e em que o valor resultaria de uma relação entre os mesmos. Esta opção também é defendida por Kail - cuja proposta explico depois de apresentar a posição de Norton - que parece ter sido o primeiro a desafiar a interpretação anti-realista da teoria dos valores de Hume.

A outra solução seria considerar que os juízos morais e estéticas são dos objetos na medida em que é possível reunir um conjunto de circunstâncias em que o sentimento surge ${ }^{699}$ - aceite por Norton. Neste sentido, Pitson considera que estas circunstâncias perfariam o correlato objetivo dos valores:

Se o papel dos sentimentos morais é o de nos capacitar a perceber a virtude e o vício, segue-se que a relação entre as distinções morais e os sentimentos correspondentes não pode ser de identidade. ${ }^{700}$

Em 1975 e, mais tarde, em 1982 $2^{701}$, o comentador avançou a proposta diametralmente oposta, a saber, que Hume fosse interpretado como um defensor do realismo moral ${ }^{702}$, ou seja, de que o filósofo considerava que os valores existem exterior e independentemente dos agentes cognitivos e respetivos juízos. A sua estratégia é focada no aspeto causal da análise que Hume faz do fenómeno, a que acresce a apresentação de evidências textuais que (supostamente) apoiam a sua posição, e vai no mesmo sentido que a sua conclusão acerca da componente epistémica da teoria do gosto de Hume, de que o filósofo deve ser interpretado como um defensor do cognitivismo.

Norton pretende associar as interpretações do realismo epistémico e do cognitivismo à tese de que a virtude e o vício constituem os correlatos objetivos

\footnotetext{
${ }^{698}$ IPM Ap. 1.6.

${ }^{699}$ Cf. PITSON, 1989, p. 71.

700 Tradução minha do original: "If the role of the moral sentiments is to enable us to become aware of virtue and vice it follows that the relation between moral distinctions and the corresponding sentiments cannot be one of identity." (PITSON, 1989, p. 78).

${ }^{701}$ Wright chega a citar uma passagem da segunda Investigação para ilustrar que Hume era um realista científico (cf. IPM 1.1-2; WRIGHT, 1983, p. 21, 111; COHON, 2008, p. 97), mas não chega a afirmar que seria um realista no sentido metafísico.
} 
dos sentimentos e são independentes dos agentes e respetivos juízos, a que chama de "realismo moral ontológico"703. O comentador fundamenta esta associação na tese de que a virtude e o vício (valores morais) são diferentes da aprovação e reprovação (sentimentos relativos aos valores) e não são sentimentos particulares do espectador, mas as causas desses sentimentos (componente metafísica). A virtude e o vício seriam, então, os traços de caráter inferidos a partir da observação da ação (por um espectador), e sendo os correlatos objetivos dos sentimentos (causalmente dependentes daqueles), constituiriam objetos independentes da sua mente.

O comentador sempre foi explícito em relação à posição que assume acerca da teoria moral de Hume. Vejam-se algumas citações, já apresentadas na secção 2.2.1:

[S]e acompanharmos a referência de Hume ao 'caráter', percebe-se que ele crê que a virtude e o vício possuem uma base em aspetos da realidade que são independents da mente da pessoa que enuncia que ações ou caracteres são virtuosos ou viciosos (...) A posição de Hume sobre as paixões indiretas também suporta a alegação de que ele pensava que a virtude e o vício tinham um estatuto objetivo ou uma existência independente das mentes dos observadores. ${ }^{704}$

[Hume] defende a posição de que há distinções morais fundadas em existências reais, que são independentes da mente do observador (posição metafísica). ${ }^{705}$

Os itálicos assinalados nas citações acima tornam claro que o interesse de Norton é determinar o estatuto metafísico do valor em relação ao espectador, uma vez que afirma, em todas elas, que a virtude e o vício existem independentemente daquele. Porém, é difícil pensar que ao afirmar que a virtude e o vício existem

\footnotetext{
${ }^{702}$ Nesta secção, generalizo, tanto quanto possível, as considerações dos comentadores tratados (maioritariamente, Norton e Kail) relativamente à moral ao campo do valor estético. Norton reconhece-o, ainda que brevemente (cf. NORTON, 1975, pp. 205-6).

${ }^{703}$ Cf. NORTON, 1975, p. 194. Esta é exatamente a noção de realismo que Cohon explica que Hume claramente procura refutar (cf. COHON 2008, p. 99, 260).

${ }^{704}$ Tradução minha do original: "[I]f we follow up Hume's reference to "character", we can see that he believes virtue and vice have a basis in aspects of reality that are quite independent of the mind of the person who pronounces actions or characters to be virtuous or vicious. (...) Hume's account of the indirect passions lend further support to the claim that he thought virtue and vice had objective status or had existence independent of the minds of observers." (NORTON, 1982, p. 113; itálico meu).

${ }^{705}$ Tradução minha do original: "[Hume] holds the view that there are moral distinctions grounded in real existences that are independent of the observer's mind (a metaphysical position)." (NORTON, 1982, p. 120; itálico meu).
} 
independente da mente do espectador ${ }^{706}$, Norton pretende defender que os traços de caráter teriam um valor determinado e em si mesmos mesmo se não existissem possíveis espectadores, pois só existem espectadores porque existem agentes que são onde reside o valor moral (o seu caráter).

Norton não deixa claro se pretende defender que um traço de caráter é independente i) do juízo de espectadores particulares ou ii) da existência de (quaisquer) espectadores que, colocados sob um ponto de vista desinteressado, ajuizariam sobre o seu valor.

O sentido i) foi tratado na secção 2.2.2. Ao deslocar o valor do sentimento de espectadores particulares para uma característica relativamente fixa - fundada numa generalidade sobre a natureza humana, cognoscível por uma ciência empírica -, Norton encontra um critério em virtude do qual um valor pode ser determinado independentemente desses sentimentos particulares, uma vez que um sentimento particular desviante (quer dizer, à margem dessa regra) não constitui motivo para que seja alterada.

O sentido ii) parece ainda ter dois sentidos distintos. Os valores podem ser independentes da existência do espectador na medida em que ii') o valor existiria mesmo se não existisse qualquer espectador ou na medida em que ii'") o valor faz parte de um objeto que é exterior e independente da mente do espectador, no mesmo sentido em que qualquer objeto da perceção pode ser considerado como tal. Por um lado, traços de caráter e sentimentos estéticos são estados mentais de um agente, o que supõe a sua existência e, consequentemente, também a possibilidade de serem observados por espectadores. Além disso, Norton esclarece desde o início do seu comentário que a sua interpretação tem em consideração o facto de a moral ser um fenómeno que existe em virtude da natureza humana. Portanto, o comentador mostra não ser alheio à necessidade de restringir as suas considerações a um mundo onde existem agentes, que são humanos ${ }^{707}$.

Por isso, julgo que o comentador está consciente da impossibilidade de considerar os valores independentes da mente do espectador no sentido ii'). Pelo contrário, Norton parece aceitar a independência dos valores em relação à mente do espectador no sentido ii' '):

\footnotetext{
${ }^{706}$ Jones parece ter a mesma convicção como pressuposto (apesar de não se dedicar a desenvolvêla; cf. JONES, 1970, p. 59; 1982, p. 5).
} 
Já sugeri que para Hume, a virtude e o vício constituem aspetos publicamente acessível do mundo do homem (...), e que estes são aspetos que servem de ocasião ou causa de sentimentos específicos. Por sua vez, estes sentimentos chamam-nos a atenção para estes correlatos objetivos e dos seus caracteres morais particulares Os sentimentos em questão são, num sentido óbvio, privados: constituem afeções que uma pessoa particular sente. Noutro sentido, eles não são privados: os sentimentos de dois ou mais indivíduos podem ser de caráter idêntico, não apenas por partilharem a mesma causa, mas porque a operação da simpatia garante este tipo de uniformidade. $^{708}$

Com efeito, esta citação sintetiza toda a interpretação de Norton, que pode ser descrita da seguinte forma. O traço de caráter em que consiste o valor é simultaneamente privado e público. É privado por constituir um sentimento na mente do agente - o que mantém em comum com o sentimento que gera no espectador (seu correlato subjetivo) -, e público por se tornar obervável através do seu efeito (a ação) e poder integrar uma regra geral (se constituir o sentimento da generalidade dos homens), cognoscível a partir da observação desse efeito.

Porém, Norton explica todas as componentes da sua interpretação de uma só vez - como se percebe na citação acima. Quer dizer, a sua justificação para aceitar uma interpretação cognitivista sobre os juízos de valor, o seu caráter cognoscível e real (no sentido metafísico) é que a virtude e o vício consistem não nos sentimentos do espectador, mas nos seus correlatos objetivos - os traços de caráter do agente. A afirmação do comentador dá a entender que é em virtude de ser observável através da ação que é independente da mente.

Inexplicavelmente, Norton não utiliza o argumento de Hume sobre a independência metafísica entre a causa e o efeito - com recurso ao PP e ao PS para explicar este estatuto independente dos valores em relação aos sentimentos. Com efeito, Norton entende que o que está subjacente à atribuição de um valor é uma referência à ação como efeito do que realmente constitui o objeto e a causa

\footnotetext{
${ }^{707}$ Cf. NORTON, 1975, pp. 190-1.

${ }^{708}$ Tradução minha do original: "I suggest that for Hume virtue and vice are publicly available aspects of man's world (...), and that they are aspects which serve as the occasion or cause of specific feelings. These feelings in turn make us aware of these objective correlatives and of their particular moral character. The feelings in question are in an obvious sense private: they are affections of the particular person who feels. In another sense they are not private: the feelings of two or more individuals may be of an identical character, not only because they share the same cause, but also because the operation of sympathy insures this kind of uniformity." (NORTON, 1982, p. 112n15; itálico meu).
} 
do sentimento de aprovação ou reprovação - o motivo ou traço de caráter. Sendo assim, a cadeia causal entre agente e ação pode subsistir sem que esta, por sua vez, se relacione com um espectador - que tem um determinado sentimento perante a ação e o (suposto) motivo do agente. Portanto, é possível que o agente tenha motivos que causariam um sentimento no espectador sem que esse sentimento se desperte de facto. Nesse sentido, parecer haver uma independência ontológica entre os valores e o espectador e, por isso, o comentador poderia, com coerência, ter argumentado a favor da tese de que o valor e o sentimento são independentes (da mente) devido à independência metafísica mútua entre a causa e o efeito.

Capaldi considera que caso Norton tivesse reconhecido que a origem do critério de verdade dos juízos sobre valores é o acordo intersubjetivo relativo a uma resposta dos agentes cognitivos a certas qualidades ou traços dos objetos dos juízos de valor, teria percebido que a origem deste plano intersubjetivo é de natureza social e, consequentemente, é dependente da existência e da mente dos agentes cognitivos ${ }^{709}$. Ao invés:

A tese realista colapsa quando começamos a perceber que a perspetiva é regulada por regras gerais sociais que não se baseiam na estrutura do mundo externo e objetivo, mas refletem os interesses da sociedade ao longo do tempo. ${ }^{710}$

A análise que Cohon oferece do ponto de vista desinteressado (que oferece o padrão ou critério de verdade para os juízos) permite uma caracterização metafísica deste padrão intersubjetivo ao qual Capaldi se refere. Quer dizer, é possível uma aproximação do padrão intersubjetivo ao ponto de vista desinteressado de tal forma que se tem uma maior clareza sobre o seu estatuto metafísico, pelo menos que seja compatível com uma interpretação que simultaneamente é alternativa ao realismo e não se identifica com o anti-realismo associado ao sentimentalismo.

Com efeito, Cohon lembra que a interpretação de que existe um critério para determinar a verdade dos juízos de valor - a natureza humana, em virtude da

\footnotetext{
${ }^{709}$ Cf. CAPALDI, 1989, pp. 151-2; FLEW, A., David Hume, Philosopher of Moral Science, p. 152.

${ }^{710}$ Tradução minha do original: "The realist thesis collapses when we begin to realize that the perspective is controlled by general social rules which are not grounded in the structure of the external objective world but reflect the interests of society over time." (CAPALDI, 1989, p. 151).
} 
qual é possível estabelecer um ponto de vista desinteressado - não garante que as propriedades descritas nos juízos que lhes são correspondentes existam independentemente da mente dos agentes e espectadores. Quer dizer, defender uma interpretação cognitivista não nos obriga a defender uma interpretação realista da filosofia de Hume. Pelo contrário, a refutação do realismo por Hume dá-se exatamente pela defesa deste ponto de vista ${ }^{711}$. Como bem observa Cohon, é possível compatibilizar a interpretação cognitivista com uma interpretação da componente metafísica de Hume alternativa à que Norton, Swain e Kail propõem. E de facto, ao apresentar como justificação para a sua defesa de que os valores existem independentemente da mente a existência de um critério de verdade para os juízos, Norton parece cometer o erro de julgar que a sua interpretação cognitivista garante uma defesa consistente da interpretação realista da teoria dos valores de Hume.

A comentadora serve-se da analogia entre propriedades morais e qualidades secundárias na sua interpretação, nomeadamente, para tornar evidente que para Hume, juízos sobre essas qualidades e juízos de valor descreveriam o modo como os objetos aparecem ao espectador, estando o seu valor de verdade condicionado a uma correspondência ou incorrespondência entre o sentimento ou sensação do indivíduo em questão e a conclusão do desenvolvimento de um ponto de vista geral $^{712}$. Esta proposta de Cohon é compatível com a de Capaldi, pois a comentadora não coloca em questão que o ponto de vista geral oferece o critério em virtude do qual se pode determinar o valor de verdade do juízo sobre valores, mas esse ponto de vista é, em si, uma generalização das tendências dos agentes quando colocados numa situação hipotética de desvinculação do interesse próprio. Portanto, a meu ver, é possível encarar o critério que Capaldi chama de intersubjetivo - o ponto de vista desinteressado - como um plano que existe em virtude da existência dos mesmos, e que reflete uma generalidade exclusiva desses agentes, gerada por interações entre esses agentes (trocas intersubjetivas).

Apesar disso, Kail parece julgar que considerar os valores propriedades relacionais constitui uma forma de realismo, ainda que reconheça que deverá ser considerado mais fraco que a forma de realismo que concede a existência dos

\footnotetext{
${ }^{711}$ Cf. COHON, 2008, pp. 6, 58, 98, 123, 262-6.

${ }^{712}$ Cf. COHON, 2008, p. 111, 137.
} 
valores como objetos independentes da mente. Para Kail, a saber, as propriedades em questão teriam um caráter disposicional, na medida em que ter essa propriedade consiste em poder ser percebido como tal. Portanto, é da natureza destas propriedades serem despertas mediante uma relação entre o sujeito e o objeto, mantendo, assim, o seu caráter (pelo menos, parcialmente) objetivo ${ }^{713}$. Deste modo, Kail desenvolve a sua proposta interpretativa, a que chama de realismo mitigado. Norton também chegou a afirmar que "virtue and vice are relational (...) properties" ${ }^{\text {714 }}$. Quer dizer, os valores (neste caso, morais, mas também estéticos) seriam propriedades que apenas existem em virtude de uma relação ou contacto entre o agente e/ou espectador e a ação, mas não como propriedades que o objeto possui independentemente da existência da mente. Por isso, não é surpreendente que Kail tenha comentado que Norton define objetos que suscitam os sentimentos como seus correlatos objetivos sem especificar como se dá a relação entre estes e os agentes e espectadores ${ }^{715}$.

Por seu turno, ao mesmo tempo que concorda com Norton na interpretação de que os valores constituem os correlatos objetivos dos sentimentos gerados no espectador, Kail acrescenta três elementos à interpretação realista da teoria dos valores de Hume que parecem servir um propósito de esclarecer a relação entre os objetos avaliados e o seu espectador.

O primeiro é um desenvolvimento da conceção dos valores como propriedades relacionais. Quer dizer, Kail reconhece que mesmo que se considere que os valores constituem os correlatos objetivos dos sentimentos, o valor só surge efetivamente mediante um juízo. E por sua vez, este só surge mediante uma conceção do objeto sob o ponto de vista desinteressado, em que se percebe o modo como os seus traços afetam a generalidade dos agentes e/ou espectadores independentemente de fatores particulares. Por essa razão, os valores não seriam totalmente indepentendes da mente, mas propriedades que são atribuídas aos objetos mediante esse contacto peculiar entre estes e o agente/espectador. $\mathrm{O}$ segundo é a consideração de que a projeção dos sentimentos ou impressões do agente e/ou espectador tem um caráter funcional, ou seja, cumpre a função de mostrar ou tornar o valor presente na mente, mesmo forjando uma crença falsa (a

\footnotetext{
${ }^{713}$ Cf. PITSON, 1989, p. 69; KAIL, 2007b, p. 150.

${ }^{714}$ Cf. NORTON, 1975, p. 205.
} 
de que o valor reside no objeto, independentemente da mente $\left.{ }^{716}\right)$. Estes dois aspetos são claros na seguinte citação:

[O] prazer constitui uma forma de tornar uma gama de valores relacionais percetíveis para criaturas, itens que são bons para ela. A dor constitui a forma como o perigoso se torna percetível para a criatura. Estas sensações servem este propósito à falta de um entendimento dos bens e males relacionais, ou mesmo uma crença de que tais objetos constituem bens e males relacionais. $\mathrm{O}$ facto de ser experienciado pelo aspeto prazeroso faz o objeto parecer essencialmente desejável, e sendo experienciado de modo doloroso, motiva aversão. Desta forma, bens e males relacionais são 'descobertos' por criaturas a quem falta um entendimento dos mesmos enquanto tais valores relacionais, e motivam ações apropriadas. Prazeres e dores morais estão para as virtudes e vícios como aspetos objetivos que são valores relacionais, da mesma forma que como prazeres e dores corporais estão para valores relacionais como alimentação saudável ou temperaturas prejudiciais à saúde. ${ }^{717}$

O terceiro elemento - que mostra a peculiaridade da interpretação de Kail - é o recurso à projeção e à propensão projetiva como explicação da atribuição do valor ao próprio objeto, que retém de Stroud e Mackie. Kail explica que apesar de os objetos possuírem o valor como propriedade relacional, efetivamente, os agentes e/ou espectadores atribuem-no aos objetos como se se tratasse de uma propriedade essencial dos mesmos, isto é, como se fosse uma propriedade dos mesmos independentemente da mente e do seu juízo. Assim, o comentador explica:

O elementos projetivo na posição é uma tentativa de explicar a fenomenologia das nossas avaliações, de se nos serem apresentados objetos desejáveis ou desprezíveis. (...) [Somos] informados pela experiência - pela qual a nossa atenção e apreciação é dirigida a tais objetos quando os consideramos essencialmente valiosos. Temos tais experiências: a fenomenologia da estética e do gosto parece recalcitrante em, por um lado, nos dar experiências valorosamente neutras e, por

\footnotetext{
${ }^{715}$ Cf. KAIL, 2007b, p. $205 \mathrm{n} 1$.

${ }_{717}^{716}$ Cf. KAIL, 2007b, pp. 150, 204-44, 223.

${ }^{717}$ Tradução minha do original: "[P] easure is a way of rendering salient to creatures a range of relational values, items that are good for the creature. Pain is a way in which the harmful is rendered salient to the creature. These sensations serve this purpose in the absence of an understanding of the relational goods and evils or even a belief that those objects are relational goods or evils. The fact of being experienced under a pleasurable aspect makes the object appear essentially desirable, being experienced under a painful mode motivates aversion. In that way relational goods and evils are 'discovered' to creatures lacking any understanding of them as such relational values, and motivate appropriate action. Moral pleasures and pains stand to virtues and vices as objective features that are relational values, as bodily pleasures and pains stand to relational values such as healthy foodstuffs or unhealthy temperatures.” (KAIL, 2007b, pp. 205-6).
} 
outro lado, atitudes independentes como gostar de algo, em direção a elas. ${ }^{718}$

Deste modo, o comentador subsume estes aspetos no que designa por realismo mitigado: 1) valores são o correlato objetivo do que é útil e agradável para os agentes humanos em geral; 2) eles são concebidos como propriedades dos objetos independentes da existência da mente (essencially valuable); 3) esta maneira de conceber essas propriedades (descrita em 2)) deve-se à propensão projetiva, definida como a tendência a tomar uma propriedade relacional de um objeto por uma propriedade essencial, criando-se uma crença falsa; 4) as impressões projetadas possuem um valor funcional, que consiste em a) tornar aquelas propriedades (que têm um valor relacional) salientes para os agentes e b) gerar atitudes em relação a esses objetos; 5) corrigir essa crença falsa consiste apenas em perceber que o valor é projetado ${ }^{719}$.

\subsubsection{Críticas à interpretação realista}

Passo agora a uma crítica à interpretação realista sobre os valores na filosofia de Hume. A meu ver, o problema desta interpretação é que não é possível defender com coerência que os valores são propriedades relacionais ou disposicionais e que são independentes da mente e/ou juízo do agente e/ou espectador. Começo por Norton, que parece ter um propósito mais ambicioso do que Kail.

Com efeito, as propriedades relacionais, por definição, não são independentes, mas sim dependentes da existência e do juízo do espectador e/ou agente, pois para se dar uma relação ou contacto entre objeto e espectador, ambos

\footnotetext{
${ }^{718}$ Tradução minha do original: "The projective element in the account is an attempt to explain the phenomenology of our evaluations, of our being presented with objects that are desirable or aversion-worthy (...). [We are] (...) informed by (...) experience whereby our attention and enjoyment is directed towards such objects by our finding them as essentially valuable. We have such experiences: the phenomenology of the aesthetic and the gustatory seems recalcitrant to there being value-neutral experiences on the one hand and independent attitudes such as likings directing towards them." (KAIL, 2007b, p. 242).

${ }^{719}$ Cf. KAIL, 2007b, p. 241. Esta interpretação possui um traço adicional (perfazendo 6 no total), a saber, o do caráter motivacional (para a ação) da crença gerada pela propensão projetiva. Porém, uma vez que não me proponho a analisar esse aspeto da discussão do projetivismo como interpretação da filosofia de Hume, deixei esse aspeto de parte na presente descrição, privilegiando os aspetos que estão diretamente envolvidos nos pontos que discuto.
} 
têm de existir. Por outro lado, um cenário em que existem tanto os objetos avaliados como os seus espectadores mas em que estes não chegam a elaborar, efetivamente, um juízo, parece demasiado esdrúxulo para ser tido em conta. De qualquer forma, os agentes e/ou espectadores elaborarem efetivamente um juízo parece ser uma condição para que essa relação ou contacto seja efetiva - pelo menos, em que as propriedades se mostram. Além disso, se se pretende defender que essas propriedades são independentes da mente, tem de se defender que são mais do que relacionais: por exemplo, que o facto de o padrão dos juízos não se alterar com a simples incoincidência de alguns juízos particulares mostra que há uma certa independência do valor em relação aos agentes e/ou espectadores porque apenas alguns deles apreendem esse valor - e é em virtude disso que o seu juízo é verdadeiro e que o de quem não o descobre é falso.

De facto, uma independência do padrão em relação a juízos particulares é condição da existência de uma objetividade no juízo, quer dizer, de uma referência fora do espectador e/ou agente em virtude da qual o juízo é verdadeiro ou falso. Com efeito, se esse padrão fosse determinado por cada juízo particular, cair-se-ia no relativismo, devido à pluralidade de juízos e preferências. Porém, a meu ver, isto induziu Norton ao erro de pensar que esta independência é de natureza metafísica. Quer dizer, Norton apenas apresenta elementos que lhe permitem defender a interpretação cognitivista, o que não é suficiente para garantir uma interpretação realista consistente, uma vez que identificar o critério em virtude do qual os juízos sobre valores são verdadeiros ou falsos com a natureza humana já contradiz o propósito de defender uma interpretação realista da teoria dos valores de Hume, pois a natureza humana não é independente da mente dos agentes humanos - na qual residem os correlatos objetivos dos valores.

Norton poderia, fundamentalmente, apoiar a sua conclusão numa interpretação realista sobre o estatuto dos objetos da perceção, ou seja, considerar que dada a existência de seres humanos capazes de juízos de valor, os valores são independentes da mente do espectador e respetivo juízo na medida em que são parte integrante de um objeto externo a ele e independentemente do mesmo (no caso do valor moral, o agente ou, no caso do valor estético, o objeto belo). Norton deixa o seu leitor apenas com a consideração solta de que os valores são publicamente acessíveis, ao passo que sentimentos são estados privados dos espectadores, e que em virtude do seu caráter público, são independentes da mente 
do espectador. Os traços de caráter também são estados privados (dos agentes), e só se tornam públicos em virtude da sua conexão causal com a ação.

A meu ver, a interpretação seria mais consistente se Norton se tivesse apoiado na ideia de que é em virtude de estes constituírem objetos externos e independentes da mente que se pode considerar que os traços de caráter são simultaneamente estados privados dos agentes - ainda que causem um efeito publicamente acessível e sejam suscetíveis de uma regra geral ou de um conhecimento - e independentes da mente do espectador que, eventualmente, ajuiza sobre o seu valor ${ }^{720}$. Mas mesmo que tivesse incorporado este elemento, a independência dos valores em relação à mente não seria suficiente para que se pudesse considerar esta interpretação uma forma genuína de realismo. Com efeito, no caso da moral, mesmo se apresentasse a interpretação de que Hume acreditava na existência exterior e independente tanto dos objetos da percepção como dos valores e afirmasse que os traços de caráter são parte integrante de alguns desses objetos (as outras pessoas), o simples facto de localizar os valores num aspeto exclusivo de outros agentes humanos - e, particularmente, da sua mente - mostra que a existência dos correlatos objetivos dos valores é dependente (e não independente) da mente, ainda que cada mente constitua um objeto exterior a e independente de outra(s).

No caso do juízo estético, essa concessão realista também não seria proveitosa para o propósito de defender uma interpretação realista dos valores, uma vez que as qualidades dos objetos que são apreciadas esteticamente são qualidades sensíveis - o gosto de um vinho, a combinação de cores de um quadro, as formas de um rosto. Essas qualidades são apreciadas mediante um processo que

\footnotetext{
${ }^{720}$ Implicitamente, Baxter também sugere isto, ao afirmar que se se pretender considerar os valores como propriedades que o objeto detém independentemente da sua consideração efetiva por um agente cognitivo, a atribuição do valor ao objeto em questão como algo que o constitui como objeto idêntico ao longo do tempo, e como qualquer outra propriedade atribuída aos objetos que causam a sensação, deve ser explicada pelo mesmo mencanismo pelo qual Hume explica a atribuição de uma existência exterior e independente aos objetos da perceção, a saber, uma confusão da semelhança com a identidade (cf. T 1.4.2.35; BAXTER, 1990, p. 114, 116). Já Kail julga que o facto de os valores constituírem uma propriedade relacional é suficiente para defender uma forma mitigada de realsimo sobre os valores, pois efetivamente, o objeto não deixa de possuir a propriedade intrínseca de, mediante o contacto com uma mente, produzir um determinado efeito, a saber, a perceção de qualidades como as cores ou sons e os valores (cf. KAIL 2007b, p. 205). Talvez Swain também tenha querido dizer isto ao dizer que só se pode considerar se Hume é um realista em moral se se considerar a sua metafísica. Apesar disso, a comentadora só confronta esta proposta de Norton a questão das qualidades primárias e secundárias e o problema da identidade pessoal (cf. SWAIN, 1992, pp. 488, $490 \mathrm{n} 12$ ).
} 
já está, em parte, determinado pela mente (os sentidos). Portanto, resgatando a confissão de Norton de que os valores seriam qualidades relacionais, isto é, resultado de uma combinação de disposições dos objetos e dos agentes e/ou espectadores, pode concluir-se que sem esses agentes, aquelas qualidades não seriam experienciadas pelos agentes e/ou espectadores e, consequentemente, permaneceriam apenas potenciais objetos de um juízo estético.

Aliás, é nestes termos que Kail desenvolve a sua análise ao considerar os valores qualidades relacionais. O comentador defende que nessa relação de disposições (do agente e/ou espectador para sentir um agrado ou desagrado, e no objeto, para mostrar certas propriedades aos sentidos desse agente e/ou espectador), o facto de os valores possuírem um correlato objetivo é suficiente para se aceitar que a posição de Hume é uma forma de realismo (mesmo que mitigado ou fraco). Ou seja, aceita-se o realismo mitigado em virtude da existência desses correlatos objetivos. Mas da mesma maneira que se pode afirmar isto, também pode afirmar-se que o facto de os valores possuírem um correlato subjetivo é suficiente para se aceitar a posição sentimentalista, isto é, de que os valores não consistem numa propriedade do objeto, mas num estado subjetivo desperto com base na sua observação. Ou seja, é igualmente válido aceitar o sentimentalismo com base na existência de um correlato subjetivo.

Portanto, apesar da sofisticação terminológica que Kail mostra (principalmente em 2007b), a sua proposta é tão vaga como as propostas que surgiram mediante as primeiras leituras das obras de Hume. Quer dizer, o inconveniente da proposta de Kail é que se torna trivial. Dado que reconhece tanto a existência dos correlatos objetivos como da existência de disposições nos agentes/espectadores que os condicionam a destacar certas propriedades nos objetos de juízos de valor, a posição de Kail poderia ser tanto uma forma de realismo como de anti-realismo. Apesar disso, a meu ver, é de se reconhecer o seu mérito em incorporar o projetivismo na sua interpretação para explicar a atribuição do valor aos objetos como propriedade independente da mente. 


\subsection{Uma possível conciliação}

Resta apenas, perante as interpretações e respetivas críticas apresentadas, refletir sobre a questão de qual parece ser a opção interpretativa mais ajustada para a teoria dos valores de Hume.

Julgo que se pode considerar que a proposta realista em relação à sua componente metafísica - apresentada por Norton e Kail - já foi devidamente despistada: a rigor, Norton não está a defender que os valores sejam independentes da mente num sentido forte, e Kail apresenta uma proposta que tanto poderia ser chamada de realismo como de anti-realismo mitigado, o que a torna mais um jogo de palavras do que uma proposta diferenciada das restantes. $\mathrm{O}$ desafio é decidir com que elementos epistémicos e semânticos se deve conjugar o elemento metafísico anti-realista. Nos próximos parágrafos, apresento as razões pelas quais julgo que uma interpretação cognitivista (em relação à componente epistémica) e descritivista (que se lhe segue), apesar de não se excluir um elemento expressivo, em relação à componente semântica para a teoria dos valores de Hume é mais justa que a não cognitivista e expressivista.

Ainda nos anos 1960, Noxon repara que se por um lado, no caso dos juízos morais, existem evidências que permitem privilegiar a interpretação cognitivista em detrimento da não cognitivista - excluindo-se, com isso, a possibilidade de se interpretar Hume como defensor do emotivismo moral. Como bem nota o comentador, o mesmo não ocorre no caso dos juízos estéticos.

Com efeito, em relação às componentes que designei epistémica e semântica, restringindo a atenção às palavras de Hume no Tratado, percebe-se que o filósofo apenas é claro na defesa do sentimentalismo, isto é, da tese de que atribuir um valor a alguma coisa consiste em sentir uma certa impressão de reflexão (posição acerca da questão epistémica ${ }^{721}$ ). Portanto, Hume não coloca claramente a questão da possibilidade de os juízos de valor serem verdadeiros ou falsos, mas sim sob a perspetiva do papel da razão no juízo. Por seu turno, a única vez em que Hume se refere ao significado de juízos sobre valores, refere-se ao

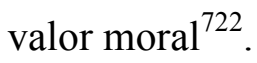

\footnotetext{
${ }^{721}$ Cf. 3.1.1.

${ }^{722}$ Cf. T 3.1.1.26.
} 
Apesar disso, o comentador reconhece que o ensaio "Sobre o Padrão do Gosto" 723 introduz um elemento que permite decidir entre uma posição cognitivista e não cognitivista - particularmente, em favor daquela. Em relação à possibilidade de decisão entre uma interpretação que contempla a possibilidade de um padrão e um valor de verdade para juízos estéticos e para a interpretação de que esses juízos descrevem um facto (a saber, a reação da mente perante um certo objeto), as evidências textuais não deixam espaço para hesitação. Afinal, Hume reconhece, desde o Tratado, que apesar de o juízo ser motivado por impressões de reflexão e conter uma componente expressiva ${ }^{724}$, há um padrão em virtude do qual se pode considerar um juízo verdadeiro e outro falso, a saber, respetivamente aquele que é e aquele que não é formulado sob o ponto de vista desinteressado ${ }^{725}$. Alcançar este ponto de vista torna-nos capazes de ter sentimentos que agradariam igualmente a qualquer pessoa. O que é necessário para que tal aconteça é nos despirmos de todos os elementos de interesse e particularidade possíveis.

Hume mantém a posição inicial de que mesmo considerando o valor estético é determinado pelo sentimento e não pela descoberta de propriedades dos objetos - quer dizer, que atribuir um valor a um objeto consiste em ter um certo sentimento perante o mesmo. Mas acrescenta que apesar disso, é possível determinar a maior ou menor tendência de um certo objeto e respetivo(s) traço(s) provoca no espectador, o que leva Hume a acrescentar explicitamente a exigência de um padrão para os juízos estéticos. Quer dizer, se, no Tratado e na primeira Investigação, uma posição cognitivista sobre juízos estéticos dependia diretamente das evidências a favor da mesma posição na moral e da suposição de

\footnotetext{
${ }^{723}$ Vale lembrar que mesmo no ensaio "O Cético", Hume repete a defesa do sentimentalismo referindo-se aos valores em geral -, com concisão e clareza ímpares na sua obra (cf. C 14). ${ }^{724}$ Cf. T 3.1 .

${ }^{725}$ Como bem repara Limongi, esta proposta neste ensaio tem justamente a função de dissipar o iminente ceticismo em que nos vemos, decorrente do relativismo que se antevê nas constatações de Hume sobre a natureza sensitiva dos valores - que apresenta nesse ensaio e também no "Cético". Quer dizer, não fosse a proposta de uma regra para os juízos que permita avaliar a sua verdade ou falsidade, ver-nos-íamos condenados à constatação de que todos os gostos têm o mesmo valor (relativismo) e sem um critério que permitisse resolver disputas e atribuir-lhes um valor de verdade (ceticismo; cf. LIMONGI, 2006, pp. 107-10). Aliás, pode pensar-se que este ceticismo fora temido pelo próprio Hume, aquando do desespero cético que o acomete no fim do primeiro livro do Tratado, em que afirma: "Sinto-me desconfortável ao pensar que aprovo um objeto e desaprovo um outro, que chamo alguma coisa de bela e outra de feia, que tomo decisões acerca da verdade e da falsidade, da razão e da insensatez, sem saber com base em que princípios o faço." (T 1.4.7.12), o que, como nota Campelo, sinaliza uma abrangência do desespero cético (pelo menos momentâneo) aos princípios sobre o gosto e a moral (cf. CAMPELO, 2020, p. 7).
} 
uma homogeneidade nas considerações de Hume sobre juízos morais e estéticos, com "Sobre o Padrão do Gosto", esta defesa fica plenamente clara. Nesse ensaio, Hume introduz o elemento teórico que permite a conclusão de que os juízos estéticos podem, efetivamente, constituir conhecimento, a saber, o da possibilidade de determinar regras gerais sobre o gosto e de procurar (e atingir) um ponto de vista desinteressado, que define o que é genuinamente merecedor do valor estético, ou que pode constitui-lo para todos - apesar de restringir esta generalidade ao grupo de quem é capaz de observar o objeto em questão sob esse ponto de vista.

Apesar da sua análise acurada, Noxon não reconhece abertamente que esta exigência de um padrão para os juízos estéticos compromete o intérprete a rejeitar a interpretação emotivista e privilegiar uma interpretação descritivista ou a conciliar estes elementos, limitando-se a afirmar que os padrões "não são puramente subjetivos, se chamá-los assim implica que sejam expressões do sentimento pessoal ou da fantasia individual", mas sim "generalizações acerca de aspetos das obras de arte que, em virtude de as possuírem, têm sido "universalmente [considerados] como [agradáveis] em todos os países e épocas"”.

Por outras palavras, o que Noxon parece afirmar é que se não se tivesse este ensaio em conta, a interpretação mais ajustada da teoria dos juízos estéticos de Hume seria a de que juízos estéticos são expressões de sentimentos do espectador (emotivismo), por ser a consequência mais intuitiva da única posição que deixa clara, a saber, a de que atribuir um valor a um certo objeto consiste em ter um sentimento perante o mesmo (o sentimentalismo).

Deste modo, para Noxon, o ensaio "Sobre o Padrão do Gosto" apresenta a conceção tardia e ponderada de Hume sobre o juízo estético em relação a esta posição, em que "[seria] razoável prever-se que Hume conceberia juízos de valor estético como expressões do gosto pessoal e preferência individual, ${ }^{, 726}$.

Estas observações de Noxon são convincentes. Julgo pertinente comentálas, pois uma reflexão mais atenta sobre elas torna clara a razão pela qual julgo

\footnotetext{
${ }^{726}$ Traduções minhas do original: "are not purely subjective, if calling them so implies that they are expressions of personal feeling or individual fancy", mas sim "generalizations about the features of works of art which, by virtue of possessing those features, have "been universally found to please in all countries and in all ages"” e de: "one might reasonably predict that Hume would construe aesthetic judgments of value as expressions of personal taste and individual preference" (NOXON, 1961, pp. 158-9; PG 9; itálico meu).
} 
que tanto juízos de valor estéticos como morais devem ser interpretados como possíveis tipos de conhecimento - portanto, por que razões aceito uma interpretação cognitivista sobre a teoria dos valores de Hume (sobre a sua componente epistémica).

Começo pelas afirmações - com as quais concordo - de que não é possível decidir entre uma interpretação emotivista e descritivista sem a leitura de "Sobre o Padrão do Gosto" e de que a interpretação mais intuitiva sobre a questão de saber se é possível um juízo de valor (estético) constituir conhecimento é a resposta negativa, ou seja, o emotivismo. A razão disso é há uma combinação de evidências textuais no Tratado que facilmente induzem à interpretação de que os juízos de valor (tanto morais como estéticos) não são verdadeiras nem falsas - do que se pode facilmente inferir que, sendo assim, não são descritivas, mas expressivas.

Em primeiro lugar, no Tratado, Hume afirma tanto que os valores morais não constituem uma questão de facto - evidência utilizada pelos proponentes da interpretação não cognitivista -, como que constituem uma questão de facto interna ou subjetiva, isto é, que impressões de reflexão são questões de facto evidência utilizada pelos proponentes da interpretação cognitivista.

Em segundo lugar, Hume restringe o campo da verdade e da racionalidade ao campo das ideias e raciocínios sobre questões de facto e relações de ideias. Se se aceitar que a interpretação de que o sentimento moral não constituir uma questão de facto se aplica ao sentimento presente nos juízos estéticos, esta restrição destitui os juízos que envolvem esses sentimentos de um valor de verdade.

Em terceiro lugar, até ao ensaio "Sobre o Padrão do Gosto"727, Hume não foi além da constatação de que atribuir uma propriedade estética a um objeto (a beleza ou a fealdade) consiste em ter um sentimento mediante a observação desse objeto, tanto quando se refere a estes isoladamente como quando são comparados a juízos morais. Por seu turno, são justamente as evidências textuais em que Hume faz este tipo de afirmações que justificam o paralelo entre a natureza dos

\footnotetext{
${ }^{727}$ Designadamente, o Tratado, as duas Investigações, a Dissertação sobre as Paixões e os Diálogos sobre a Religião Natural (ambos de 1757, assim como o ensaio "Sobre o Padrão do Gosto"), e diversos ensaios compilados no que se conhece hoje como os Ensaios Morais, Políticos e Literários.
} 
juízos estéticos e morais. Porém, em relação aos primeiros, Hume não vai além do sentimentalismo, não afirmando explicitamente nada sobre a possibilidade de juízos estéticos constituírem ou não um conhecimento (a decisão entre cognitivismo e não cognitivismo), muito menos sobre o que se quer dizer quando se enuncia um juízo sobre o valor estético de um objeto (a decisão entre descritivismo e emotivismo).

Porém, a partir de "Sobre o Padrão do Gosto", Hume afirma explicitamente que é possível estabelecer regras gerais e um conjunto de conhecimentos sobre o modo como espectadores são afetados pelos objetos estéticos. Além disso, Hume também concede que haja um padrão em virtude do qual os raciocínios que resultam em regras gerais sobre o gosto constituem, de facto, conhecimento, a saber, o bom senso, que leva um espectador a ser um bom juíz.

Se se aceitar que o sentimentalismo moral que Hume defende explicitamente no Tratado se aplica ao sentimento e ao juízo estéticos, e se descartar a evidência textual em que Hume rejeita que esses sentimentos (supondo que os sentimentos estéticos seguiriam a regra dos sentimentos morais) constituam questões de facto em favor da evidência textual em que Hume admite que são questões de facto internas - de onde se segue a possibilidade de obter um conhecimento sobre eles -, pode aceitar-se que já no Tratado, Hume tenha concedido que podem constituam objetos de conhecimento.

Por seu turno, as evidências introduzidas em "Sobre o Padrão do Gosto", a juntar às (raras) constatações de Hume sobre o sentimentalismo em textos anteriores a esse ensaio, permitem estabelecer um paralelo direto entre os juízos estéticos e morais no que é relevante para decidir entre uma interpretação cognitivista e não cognitivista da teoria dos valores de Hume: ambos os juízos consistem na atribuição de uma propriedade ao objeto avaliado mediante um sentimento desperto na mente do espectador e ambos possuem um critério em virtude do qual podem ser considerados verdadeiros e, portanto, conhecimento.

Por um lado, algumas evidências utilizadas para apoiar a posição não cognitivista (principalmente no caso da moral) atestam tanto a natureza emotiva 
do valor como a impossibilidade do valor de verdade dos respetivos juízos ${ }^{728}$. Apesar disso, não referem a questão do significado dos juízos em questão. Aliás, na única evidência textual que aponta neste sentido, consta que os juízos morais constituem descrições desses sentimentos (o que é incompatível com a tese de que não possuem valor de verdade $)^{729}$. Portanto, esta evidência textual favorece claramente a interpretação subjetivista. Porém, o defensor da interpretação cognitivista poderia alegar que esta evidência é, no mínimo, consistente com as evidências a favor da sua posição, oferecendo um critério em virtude do qual os juízos morais podem ser consideradas verdadeiras ou falsas - a saber, o facto de o(s) espectador(es) ter ou não o sentimento em questão.

Ainda no caso da moral, além das evidências textuais apresentadas pelos diversos comentadores e enumeradas em 3.1.2, há outras que mostram que Hume se referia ao processo pelo qual se formam juízos de valor como um processo causal, isto é, como o resultado de uma relação causal entre os objetos desse juízo e o seu espectador. Disto se segue, de acordo com a sua epistemologia, que podem ser conhecidos, ajuizados ou descritos como tais, e que os juízos que o refletem possuem um valor de verdade. A seguinte passagem, relativa ao que Hume chama de evidência moral, mostra que Hume considerava que em virtude de manter a mesma conexão necessária que os objetos de outros âmbitos de conhecimento, o curso das ações humanas constitui um objeto passível de conhecimento, em virtude de manterem relações causais com os seus motivos e com outras ações:

Existe um curso geral da natureza nas ações humanas, assim como nas operações do sol e do clima. Existem também caracteres peculiares a diferentes nações e a diferentes pessoas, e outros que são comuns a toda a humanidade. O conhecimento desses caracteres se funda na observação da uniformidade das ações deles decorrentes; e essa uniformidade constitui a própria essência da necessidade. ${ }^{730}$

[A]ssim como a união entre os motivos e as ações tem a mesma constância que a união entre quaisquer operações naturais, assim também sua influência sobre o entendimento é a mesma, determinando-nos a inferir a existência de uns da existência dos outros. Se for assim, não haverá nenhuma circunstância conhecida, que faça parte da conexão e produção das ações da matéria, e que não se encontre também em todas as operações

\footnotetext{
${ }^{728}$ Cf. T 3.1.1.9; PG 7; cf. 1.6 deste trabalho.

${ }^{729}$ Cf. T 3.1.1.26; 3.2.1 deste trabalho.

${ }^{730}$ T 2.3.1.10. Cf também T 2.3.1.11.
} 
da mente; por conseguinte, será um absurdo manifesto atribuir necessidade àquelas e recusá-las a estas. ${ }^{731}$

[Q]uando consideramos quão adequadamente as evidências naturais e morais se aglutinam, formando uma cadeia única de argumentação, não hesitaremos em admitir que têm a mesma natureza e derivam dos mesmos princípios (...). [A mente] não está menos certa do resultado futuro que se estivesse conectado com as impressões presentes da memória e dos sentidos por uma cadeia de causas aglutinadas por aquilo que costumamos chamar uma necessidade fisica. ${ }^{732}$

No caso do valor estético, acrescente-se uma outra evidência, a par da consideração de que é possível estabelecer regras gerais sobre o modo como grupos de indivíduos (se não a humanidade em geral) apreciam esteticamente um determinado objeto. Esta evidência é que Hume pensava e descrevia o próprio fenómeno da apreciação estética de um dado objeto constitui um processo causal:

[A]lgumas formas ou qualidades particulares são calculadas para agradar, e outras para desagradar, e se falham em seu efeito numa instância particular qualquer, isso se deve a algum aparente defeito ou imperfeição no órgão. (...) [A]lguns objetos [são] naturalmente calculados para proporcionar prazer (...). ${ }^{733}$

Esta é a relação causal que cabe ao crítico descobrir e que pode ser descrita em juízos estéticos.

Por último, tem-se ainda o facto de Hume ter fornecido um conjunto de regras gerais para raciocinar sobre causas e efeitos, sem especificar as ciências particulares cuja investigação se faria pelo cumprimento dessas regras ${ }^{734}-$ de onde julgo que se possa concluir que essas regras valeriam indiscriminadamente para quaisquer ciências (sobre questões de facto), onde se incluem a Moral e a Crítica.

Com efeito, não reconhecer que o facto de Hume admitir que a razão tem um papel determinante no gosto e na moral e incluir a moral e a crítica no campo do conhecimento científico implica uma revisão da posição de que atribuir um

\footnotetext{
${ }^{731} \mathrm{~T}$ 2.3.1.14.

732 T 2.3.1.17.

${ }^{733}$ PG $12-13$.

${ }^{734}$ Cf. T 1.3.15. Parece ser justamente este paralelo, aceite por mim e pelos defensores de uma interpretação cognitivista da teoria dos juízos de valor de Hume, que nos separa de defensores da interpretação não cognitivista, como é o caso de Guimarães, que aponta este como ponto nevrálgico da sua discordância com Coventry ao propor um padrão para os juízos (cf. GUIMARÃES, 2009, pp. 476-7).
} 
valor a um objeto ou traço de caráter não envolve uma descrição (e uma pretensão descritiva) e não tem um valor de verdade. Este é o inconveniente que as interpretações não cognitivistas (a emotivista e a teoria do erro) têm em comum.

O valor de verdade destes juízos pode ser determinado mediante a imersão num ponto de vista desinteressado, que, em si mesma, consiste numa investigação de causas - quais os traços do objeto que afetam todos os espectadores, quais são condicionados por um certo traço dos espectadores, quais os traços do espectador que são constantes na formação de um certo juízo de valor, etc.

Deste modo, a meu ver, em relação à componente epistémica, pode dizerse que a proposta cognitivista permite preservar um leque mais vasto de elementos e evidências textuais do filósofo do que a não cognitivista. Particularmente, aceitar a segunda ignora não só a existência como a importância do padrão para os juízos: a sua criação a partir das trocas intersubjetivas e a necessidade do acordo, o seu emprego na linguagem e nas instituições, assim como a sua utilidade para a edificação de ciências como a Moral e a Crítica (incluídas no conjunto de ciências que perfazem a Ciência do Homem ${ }^{735}$ ).

Em relação à possibilidade de os juízos sobre relações causais possuírem um valor de verdade (e, portanto, poderem constituir objetos de conhecimento) não há controvérsia, dado que Hume estabeleceu claramente que o campo da razão e da verdade consiste naquele em que há uma correspondência (ou não) entre ideias e impressões, de tal forma que se essa correspondência se verificar, o juízo é verdadeiro, e se não se verificar, é falso ${ }^{736}$. A meu ver, o desafio é encarar a questão de saber como é que, sendo motivadas ou geradas por paixões (impressões de reflexão) - que em si mesmas, em virtude de se tratarem de estados mentais apresentacionais (e não representacionais), não têm um valor de verdade - os juízos sobre valores podem não ser exclusiva e meramente expressivos, mas antes ter um valor de verdade. Esta questão desdobra-se noutra, a saber, a da possibilidade de um critério que permita decidir o valor de verdade desses juízos, perante a impossibilidade de haver um critério para isso, que seja independente da mente dos agentes.

\footnotetext{
${ }^{735}$ Cf. T 0.5 .

${ }^{736}$ Cf. T 1.3.1.1; T 2.3.10.2; T 3.1.1.9; 1.14, 2.2.8 deste trabalho.
} 
Nos parágrafos que se seguem, apresento seis evidências textuais a favor da conclusão de que os juízos sobre valores possuem valor de verdade - do que se pode concluir que podem ser objeto de conhecimento e que uma interpretação justa da teoria dos valores de Hume deve incluir uma componente cognitivista (sobre a sua componente epistémica dos juízos de valor na filosofia de Hume). Por consequência, deve excluir-se o expressivismo e a teoria do erro do horizonte de possibilidades de interpretação e aceitar uma interpretação descritivista (em relação à componente semântica dos mesmos juízos).

A primeira evidência textual remete para a classificação das paixões como impressões de reflexão e para o modo como surgem e funcionam na mente. Com efeito, as paixões distinguem-se de outras perceções (como impressões de sensação e ideias) por constituírem impressões de reflexão.

Retomando a definição dessas impressões, vale relembrar que, para Hume, elas constituem impressões que i) são originadas a partir de impressões de sensação e de ideias e ii) são agradáveis (se forem um tipo de prazer) ou desagradáveis (se forem um tipo de dor). Quer dizer, o que as define em relação a outras impressões é o facto de serem originadas por ideias e manterem uma relação direta com as impressões do prazer e da dor, pois estas impressões estão sempre presentes nas ideias a partir das quais se formam aquelas (com uma vivacidade mais pálida que no momento da sensação original ${ }^{737}$ ). Deste modo, uma certa sensação que seja acompanhada da sensação de prazer ou dor, mantémse copiada (na memória) e, ao ser relembrada, produz certas impressões mediante o estabelecimento de relações (pela imaginação) entre o eu e o objeto dessa impressão (como a esperança no caso de um objeto agradável cuja repetição se crê ser provável ou a alegria perante a sua repetição efetiva, o medo no caso da repetição de uma sensação dolorosa ou a tristeza perante a repetição efetiva dessa sensação, etc $\left.{ }^{738}\right)$. A este propósito, relembrem-se as palavras de Hume relativamente ao surgimento mecânico das paixões na mente:

Primeiramente, uma impressão atinge os sentidos, fazendo-nos perceber o calor ou o frio, a sede ou a fome, o prazer ou a dor,

\footnotetext{
${ }^{737}$ Cf. T 1.1.2.1; T 2.1.9.1; 1.11 do presente trabalho.

${ }^{738}$ Hume dedica praticamente todo o livro II do Tratado à explicação de como surgem as paixões. Para o presente trabalho, o que importa ressaltar é que apesar de as paixões surgirem a partir das ideias, também elas originam novas ideias, que podem ser objeto de conhecimento como as de objetos inanimados.
} 
de um tipo ou de outro. Em seguida, a mente faz uma cópia dessa impressão, que permanece mesmo depois que a impressão desaparece, e à qual denominamos idéia. Essa idéia de prazer ou dor, ao retornar à alma, produz novas impressões, de desejo ou aversão, esperança ou medo, que podemos chamar propriamente de impressão de reflexão, porque derivadas dela. Essas impressões de reflexão são novamente copiadas pela memória e pela imaginação, convertendo-se em idéias - as quais, por sua vez, podem gerar outras impressões ou idéias. Desse modo, as impressões de reflexão antecedem apenas suas idéias correspondentes, mas são posteriores às impressões de sensação, e delas derivadas. ${ }^{739}$

Para complementar esta evidência, noto que a explicação do funcionamento do mecanismo da simpatia permite compreender de que forma as paixões de outras pessoas só se podem transmitir e ser-nos conhecidas. Inicialmente, e mediante a assunção de uma natureza humana uniforme (o que faz com que se creia as outras pessoas se assemelham a nós, tanto em aspeto exterior como na mente), os comportamentos e expressões das outras pessoas permitem ter uma ideia da suposta paixão que os/as causou. Posteriormente e mediante o seu avivamento, essa ideia converte-se numa impressão na mente do espectador e este pode experimentar uma paixão muito semelhante à que se desperta na outra pessoa $^{740}$.

A segunda evidência textual é o facto de as relações pelas quais se compõem raciocínios serem estabelecidas pela faculdade da imaginação. De acordo com a distinção mais completa ou rigorosa que Hume oferece para as ideias da memória e da imaginação, i) as ideias da memória serem mais vivas que as da imaginação e ii) a memória mantém a ordem e posição das ideias, contrariamente à imaginação ${ }^{741}$. Em ambos os casos, a mente só consegue estabelecê-las mediante relações ${ }^{742}$ : no caso da memória, da semelhança, do espaço e do tempo (cuja ordem é mantida intacta) e no caso da imaginação, tanto o reposicionamento aleatório das ideias ou respetivas partes (pela imaginação fancy) como a causalidade (estabelecida pelo entendimento) constituem relações

\footnotetext{
${ }^{739} \mathrm{~T}$ 1.1.2.1; itálico meu.

${ }^{740} \mathrm{Cf}$. T 2.1.11. Com efeito, sem este mecanismo e a assunção de uma natureza humana uniforme, as ciências da Moral e da Crítica seriam impossíveis. De facto, este mecanismo é o elemento da epistemologia de Hume que assegura a transmissão das paixões de mente para mente e, por consequência, a possibilidade de formular generalizações sobre os gostos e sentimentos morais.

${ }^{741}$ Cf. T 1.1.3.1, 3.

${ }^{742}$ Cf. T 1.1.5; 1.4 deste trabalho.
} 
que só a faculdade da imaginação - nestas duas modalidades ${ }^{743}$ - pode estabelecer.

A conclusão desta evidência é que da mesma forma que os objetos de que se têm sensações, também pode haver (e, de facto, há) ideias ou representações das paixões ${ }^{744}$. Quer dizer, a partir do momento em que constituem uma memória, as paixões já constituem objetos que podem ser representados e que podem incorporar raciocínios.

Portanto, a primeira evidência deixa claro que para Hume, as paixões podem constituir objetos de raciocínio, uma vez que podem ser copiadas, representadas. A segunda evidência mostra como, na filosofia de Hume, as paixões podem ser objetos de raciocínios, ou seja, como podem ser objeto da faculdade que opera na aquisição de conhecimento (já desde a rememoração). Desta forma, a segunda evidência explica a primeira.

Da mesma forma, e de acordo com o reconhecimento (de Hume) de que o campo da verdade e da racionalidade se restringe ao campo das ideias (pois só estas mantêm uma relação de correspondência ou incorrespondência com as sensações), as paixões também cabem neste campo. Com efeito, é possível afirmar que alguém (ou um determinado grupo de pessoas) tem, efetivamente, uma certa paixão, em que condições a tem (ou têm) e a explicação mecânica do seu surgimento (particular ou geral). Portanto, a relação de correspondência entre a paixão que a(s) pessoa(s) tem (ou têm) e uma ideia (que o próprio ou um espectador tem da mesma) torna possível uma descrição dessas paixões que alguém tem ou não tem, por meio de juízos - que são verdadeiros ou falsos. Portanto, é possível apresentar, construir ou criar juízos e raciocínios sobre paisões, que as descrevem. Por conseguinte, como qualquer proposição, também estes serão verdadeiros ou falsos.

A terceira evidência respeita à definição das questões de facto como objeto de conhecimento a posteriori. Apesar de Hume não definir explicitamente estes objetos de conhecimento - mas apenas por contraste com as relações de ideias -, refere-se às mesmas como objetos que podem ser conhecidos por raciocínios

\footnotetext{
${ }^{743}$ Exclui-se aqui a demonstração pelo facto de esta estar restrita às relações de ideias, sobre as quais não versa o presente trabalho.
} 
probabilísticos - portanto, de raciocínios causais, que partem dos dados dos sentidos e da memória ${ }^{745}$.

A quarta evidência textual é o reconhecimento (de Hume) de que as paixões constituem questões de facto - ou seja, objetos de conhecimento $a$ posteriori. Portanto, apesar de descartado o racionalismo sobre os valores, em favor da tese de que os juízos de valor (tanto moral como estético) são fundados nas paixões ${ }^{746}$, Hume reconhece que as paixões constituem uma questão de facto e, como tais, o conhecimento que se tem das mesmas é de tipo causal (como, aliás, praticamente todo o conhecimento que se pode ter destes objetos):

$\mathrm{O}$ vício nos escapa por completo, enquanto consideramos o objeto. Não o encontraremos até dirigirmos nossa reflexão para nosso próprio íntimo e darmos com um sentimento de desaprovação, que se forma em nós contra essa ação. Aqui há um fato, mas ele é objeto de sentimento [feeling], não de razão. ${ }^{747}$

[O] que se entende por liberdade quando esse termo é aplicado a ações voluntárias? Com certeza, não estamos querendo dizer que as ações têm tão pouca conexão com motivos, inclinações e circunstâncias que não se sigma deles com um certo grau de uniformidade, e que esses mesmos motivos, inclinações e circunstâncias não apóiem uma inferência que nos permite concluir a existência das ações, pois esses são fatos simples e reconhecidos. ${ }^{748}$

[A] moralidade é determinada pelo sentiment, e define a virtude como qualquer ação ou qualidade mental que comunica ao espectador um sentimento agradável de aprovação; e o vício como o seu contrário. Passamos então a examinar uma simples questão de facto, a saber, quais ações têm essa influência. Consideramos todas as circunstâncias em que essas ações concordam e esforçamo-nos para extrair daí algumas observações gerais relativas a esses sentimentos. ${ }^{749}$

A este propósito, há que fazer ainda um comentário relativo à possibilidade de se pensar que Hume não reconhece às paixões o estatuto de questões de facto. Apesar de as primeiras duas evidências apresentadas acima

\footnotetext{
${ }^{744}$ Apesar de Hume reconhecer a impossibilidade de oferecer uma definição exaustiva destas impressões - em virtude do seu caráter não representativo, mas sensitivo (cf. T 2.2.1.1; T 2.3.1.2; 1.11 do presente trabalho).

${ }^{745}$ Cf. T 1.3.6.12; $\mathrm{T}$ 1.3.7.2-3; $\mathrm{T}$ 1.3.12.23; $\mathrm{T}$ 1.4.2.14, 21; IEH 4.1.3, 4, 6; IEH 4.2.14; IEH 4.2.17-19; IEH 5.1.3, 6; IEH 7.2.29; IEH 9.1; IEH 12.2.22; IEH 12.3.24; 1.4 deste trabalho.

${ }^{746}$ Cf. 1.13 deste trabalho.

${ }^{747}$ T 3.1.1.26; itálico meu.

${ }^{748}$ IEH 8.1.23.
} 
serem as únicas a favor da interpretação de que as paixões que motivam os juízos morais não constituem questões de facto e do maior número de evidências a favor da interpretação contrária ${ }^{750}$, há que apresentar razões para que se dê preferência àquela, em detrimento desta. Ou seja, há que encarar a questão de saber se, afinal, Hume considera mesmo as paixões questões de facto ou não.

A meu ver, há uma razão para se dar uma resposta afirmativa a esta questão que está na própria base da epistemologia de Hume, a saber, a classificação dos objetos que animam a vida mental: desde o início do Tratado, Hume afirma que a mente é composta por perceções, que estas se dividem em impressões e ideias, e que as impressões se dividem em sensações e impressões de reflexão (e as ideias, em ideias de relações de ideias e de questões de facto).

Associada a estas evidências está o reconhecimento do campo da verdade e da racionalidade como o da correspondência entre ideias, tanto referentes a questões de facto (que envolvem ideias e impressões) como de relações de ideias (que envolvem apenas ideias). Ora, se Hume afirma que as paixões podem ser consideradas questões de facto, certamente aceitaria que a correspondência (ou incorrespondência) que permite determinar se um certo juízo é verdadeiro ou falso é a que se verifica (ou pode verificar) entre uma ideia (ideias concretas como, por exemplo, as de justiça ou de beleza) e uma impressão de reflexão.

Considere-se então que i) as paixões (a partir das quais surgem os juízos morais e estéticos) são impressões de reflexão, que são um tipo de impressão e, como tais, podem ser representadas por ideias (e, por isso, objetos de raciocínio), e que ii) o campo das questões de facto constitui o dos objetos de conhecimento $a$ posteriori - a partir das impressões -, ou seja, por questões de facto entende-se os possíveis objetos de conhecimento a posteriori. Se assim for, a conclusão mais razoável destas evidências é que as paixões são um dos grupos de impressões a partir das quais se formam as ideias que compõem o conhecimento a posteriori, ou seja, que paixões são questões de facto.

A quinta evidência é que desde o início do Tratado, Hume reconhece à Moral e à Crítica o estatuto de ciência e compreende-as no conjunto de ciências que compõem a Ciência do Homem (a investigação geral dos princípios que

\footnotetext{
${ }^{749}$ IPM Ap. 1.10.

${ }^{750}$ Cf. 3.1.1 deste trabalho.
} 
explicam o funcionamento da mente) - e, em relação ao seu objeto, esclarece que estas ciências se ocupam dos gostos e sentimentos:

Se, portanto, as ciências da matemática, filosofia da natureza e religião natural mostram tal dependência em relação ao conhecimento do homem, o que se pode esperar das outras ciências, cuja conexão com a natureza humana é ainda mais estreita e íntima? A única finalidade da lógica é explicar os princípios e operações de nossa faculdade de raciocínio e a natureza de nossas idéias; a moral e a crítica tratam de nossos gostos e sentimentos; e a política considera os homens enquanto unidos em sociedade e dependentes uns dos outros. Essas quatro ciências, lógica, moral, crítica e política, compreendem quase tudo possamos ter algum interesse em conhecer, ou quase tudo que possa servir para aperfeiçoar ou adornar a mente humana. ${ }^{751}$

O filósofo confirma ainda esta conceção ao afirmar explicitamente, a propósito da falsa oposição entre as noções de liberdade e necessidade, que o tipo de necessidade que os objetos dessa ciência mantêm é do mesmo tipo que a necessidade dos objetos físicos - o que Hume chama de evidência moral. Portanto, Hume afirma que os valores, motivos e ações podem ser encadeados em explicações causais, tal como quaisquer outros objetos da experiência, sendo ambos passíveis do mesmo tipo de raciocínio:

Não há nenhum filósofo cujo juízo esteja tão preso a esse sistema fantástico da liberdade que não reconheça a força da evidência moral, e não a tome como um fundamento razoável para suas ações, tanto na especulação como na prática. Ora, a evidência moral não é mais que uma conclusão acerca das ações dos homens, derivada da consideração de seus motivos, temperamentos e situações. Assim, quando vemos certos caracteres e figuras traçados sobre o papel, inferimos que a pessoa que os produziu queria afirmar certos fatos: a morte de César, o sucesso de Augusto, a crueldade de Nero; (...) O mesmo tipo de raciocínio está presente na política, na guerra, no comércio, na economia; de fato, está tão completamente entranhado na vida humana que é impossível agir ou sequer subsistir um só momento sem recorrer a ele. (...) Temos aqui uma cadeia em que se conectam causas naturais e ações voluntárias; (...) e [a mente] não está menos certa do resultado futuro que se estivesse conectado com as impressões presentes da memória e dos sentidos por uma cadeia de causas aglutinadas por aquilo que costumamos chamar uma necessidade física. A experiência da mesma união tem o mesmo efeito sobre a mente, quer os objetos unidos sejam motivos, volições e ações, quer sejam figuras e movimentos. ${ }^{752}$

\footnotetext{
${ }^{751} \mathrm{~T} 0.5$.

${ }^{752}$ T 2.3.1.16-17. Cf. também IEH 8.1.19; IPM Ap. 1.10. Isto vai contra a convicção de Kail, para quem a ambição de estabelecer um paralelo entre juízos causais e sobre valores morais é
} 
Além disso, o filósofo também se refere à Crítica e à Moral como tipos de conhecimento, mantendo, implicitamente, a convicção que deixara explícita na introdução:

Se acaso um autor escrevesse um tratado, do qual uma parte fosse séria e profunda e a outra leve e engraçada, todos condenariam uma mistura tão estranha e o acusariam de desprezar todas as regras da arte e da crítica. ${ }^{753}$

O vício e a virtude, portanto, podem ser comparados a sons, cores, calor e frio, os quais, segundo a filosofia moderna, não são qualidades nos objetos, mas percepções na mente. E essa descoberta da moral (...) deve ser vista como um progresso considerável nas ciências especulativas (...). ${ }^{754}$

Impedir as tiradas da imaginação e reduzir cada expressão à verdade e exatidão geométricas seria inteiramente contrário às leis da crítica. (...) Se alguns escritores negligentes ou irregulares agradaram, não foi por transgressões à regra ou à ordem, mas apesar delas. Eles possuíam outras belezas que podiam se conformar à justa crítica; (...) Se nosso prazer proviesse realmente das partes de seu poema que denominamos falhas, esta não seria objeção à crítica em geral, mas objeção somente àquelas regras particulares da crítica que estabelecem esses aspectos como falhas e os representam como universalmente censuráveis. ${ }^{755}$

[S]eria ótimo se pudéssemos expor os ardis dessa seita tão facilmente nos estudos mais abstratos de lógica e metafísica como o fazemos nas ciências mais práticas e mais inteligíveis da política e da moral. $^{756}$

Por fim, a sexta evidência permite explicar como é possível este conhecimento relativo às paixões (tanto na Moral como na Crítica) ou qual a sua configuração. Trata-se do reconhecimento de que i) existe um padrão de verdade e de correção para os juízos (causais e sobre valores), descrito por regras gerais

infundada, pelo facto de Hume não reconhecer um valor explicativo aos valores morais (no sentido causal; cf. KAIL, 2001, p. 44). Com efeito, nos parágrafos seguintes ao citado, Hume apresenta vários exemplos de valores que podem ser inferidos como causas das ações dos outros (a aquiescência de um príncipe, a coragem de um exército, a confiança na lealdade e habilidade de um patrão no gerente do seu negócio), assim como incorporadas em explicações causais que envolvem causas físicas ("a obstinação do carcereiro, assim como os muros e barras" de uma prisão; cf. T 2.3.2.15, 17).

${ }_{753}^{753}$ T 2.2.8.18; itálico meu.

${ }^{754}$ T 3.1.1.26; itálico meu.

${ }^{755}$ PG 9.

${ }^{756}$ IPM 5.1.3; itálico meu. 
acerca dos sentimentos despertos nos agentes e espectadores e ii) estas regras e este padrão são descobertos a posteriori, isto é, pela experiência regular.

Em relação à primeira constatação, acerca de qualquer juízo sobre questões de facto:

Somente nossa experiência dos princípios que governam a natureza humana pode nos assegurar da veracidade dos homens.

[A] experiência [é] o verdadeiro critério deste, bem como de todos os outros juízos (...). ${ }^{757}$

Especificamente, acerca dos juízos causais:

Eis toda a LÓGICA que penso dever empregar em meu raciocínio. E talvez sequer ela fosse muito necessária, pois poderia ter sido suprida pelos princípios naturais de nosso entendimento. $^{758}$

Acerca dos juízos morais:

$[\mathrm{P}]$ ara chegarmos a um julgamento mais estável das coisas, fixamo-nos em algum ponto de vista firme e geral; e, em nossos pensamentos, sempre nos situamos nesse ponto de vista, qualquer que seja nossa situação presente. ${ }^{759}$

[O] intercâmbio de sentimentos na vida e convivência social faz-nos estabelecer um certo padrão geral e inalterável com base no qual aprovamos e desaprovamos os caracteres $e$ costumes. ${ }^{760}$

Quando nossos juízos sobre as pessoas se baseiam unicamente na tendência de seu caráter a beneficiar a nós ou a nossos amigos, a sociedade e o convívio social contradizem a tal ponto nossos sentimentos, e as incessantes mudanças de nossa situação produzem em nós uma tal incerteza, que buscamos algum outro critério para o mérito e o demérito, que não admita tanta variação. ${ }^{761}$

Finalmente, acerca dos juízos estéticos:

É natural, para nós, procurar um padrão do gosto, uma regra pela qual se possam reconciliar os vários sentimentos dos homens, ou ao menos garantir uma decisão confirmando um sentimento e condenando o outro. ${ }^{762}$

\footnotetext{
${ }^{757} \mathrm{~T}$ 1.3.9.12.

${ }^{758} \mathrm{~T} 1.3 .15 .11$.

${ }^{759} \mathrm{~T}$ 3.3.1.15.

${ }^{760}$ IPM 5.2.42; itálico meu.

${ }^{761}$ T 3.3.1.18; itálico meu.

${ }^{762}$ PG 6.
} 
Dentre mil opiniões diferentes que os homens possam ter sobre um mesmo assunto, há uma, e somente uma, justa e verdadeira, e a única dificuldade é fixá-la e assegurá-la. (...). ${ }^{763}$

[Há] certamente uma espécie de senso comum que se opõe ao provérbio [de que os gostos não se discutem] ou, ao menos, serve para modificá-lo e restringi-lo. ${ }^{764}$

[Devemos] reconhecer a existência, em alguma parte, de um padrão verdadeiro e decisivo, ou seja, [a sua] existência real e a matéria de fato. ${ }^{765}$

Em relação à segunda constatação, acerca dos juízos causais:

[O]bservaremos algumas regras gerais pelas quais devemos regular nosso juízo sobre causas e efeitos. Essas regras se formam segundo a natureza de nosso entendimento, e conforme nossa experiência da operação deste nos juízos que formamos acerca dos objetos. ${ }^{766}$

Acerca dos juízos morais:

A experiência logo nos ensina esse método de corrigir nossos sentimentos, ou, ao menos, de corrigir nossa linguagem, se os sentimentos são mais obstinados e inflexíveis. ${ }^{767}$

[C]onsidere-se o assunto $a$ posteriori e, pesando as conseqüências, investigue-se se o mérito da virtude social não se deriva, em grande medida, das emoções humanitárias com que afeta os espectadores. Parece ser um fato que o aspecto da utilidade, em todos os assuntos, é uma fonte de louvor e aprovação; que essa utilidade é constantemente citada em todas as decisões morais relativas ao mérito ou demérito de ações. ${ }^{768}$

Finalmente, acerca dos juízos estéticos:

O fundamento de tais regras é o mesmo que o de todas as ciências práticas, a experiência, e elas não passam de observações gerais sobre aquilo que tem sido universalmente considerado como agradável em todos os países e épocas. ${ }^{769}$

Uma causa óbvia por que muitos não sentem o sentimento próprio de beleza é a falta daquela delicadeza de imaginação requerida para proporcionar sensibilidade a essas emoções mais finas. $^{770}$

\footnotetext{
${ }^{763}$ PG 7.

${ }^{764}$ PG 8

${ }^{765}$ PG 25.

${ }^{766} \mathrm{~T}$ 1.3.13.11.

${ }^{767}$ T 3.3.1.16, itálico meu.

${ }^{768}$ IPM 5.2.44

${ }^{769}$ PG 9.

${ }^{770}$ PG 14; itálico meu.
} 
[É] preciso admitr que há certas qualidades nos objetos talhadas por natureza para produzir esses sentimentos particulares. ${ }^{771}$

É unicamente pela comparação que podemos estabelecer epítetos de elogio ou de censura e aprender como atribuir o grau devido a cada um deles. ${ }^{772}$

Portanto, a consideração de Hume de que existe este padrão - mediante o estabelecimento de regras gerais pela faculdade do entendimento - segue a proposta de Hume em relação ao conhecimento de causas, apresentada desde o Tratado $^{773}$, pois este padrão é comum aos três tipos de juízos.

Ao confrontar estas seis evidências com aquelas em que se percebe uma identificação do campo da verdade e da racionalidade com aquele em que é possível uma correspondência entre ideias e impressões ${ }^{774}$, torna-se razoável considerar que Hume julgava possível formular raciocínios causais e obter um conhecimento (a posteriori) das paixões (que motivam juízos morais e de gosto) exatamente do mesmo tipo que das restantes questões de facto, a saber, probabilístico e restrito a um apelo à regularidade observável ${ }^{775}$. Deste modo, a meu ver, pode concluir-se que na filosofia de Hume, juízos sobre valores têm um valor de verdade, de acordo com a correspondência ou incorrespondência entre o juízo e certas paixões.

Em relação à coponente semântica da interpretação, resta esta explicar por que razão a interpretação mais ajustada é a que designei por descritivista causal, tal como proposta por Jones.

Com efeito, se os juízos de valor possuem um valor de verdade, um juízo sobre valores constitui (pelo menos em parte) uma descrição (verdadeira ou falsa) de um facto. E dado que, para Hume, juízos sobre questões de facto refletem relações causais, descrever um facto significa descrever uma relação causal neste caso, entre o objeto avaliado e o seu espectador ${ }^{776}$.

\footnotetext{
${ }^{771}$ PG 16; itálico meu.

772 PG 20.

773 T 1.3 .

${ }^{774}$ Cf. 1.14 deste trabalho.

775 Aliás, praticamente todo o livro II do Tratado se ocupa de aplicar o raciocínio causal - cuja natureza fora analisada no livro I - à dinâmica das paixões (morais e não morais). Nesse contexto, Hume refere-se às paixões como objetos de conhecimento e de raciocínio causal (cf. T 2.1.10.10).

${ }^{776}$ Comentadores como Árdal, Jones, Capaldi, Swain e Cohon tentaram de recorrer à interpretação cognitivista para justificar a descritivista. Cf. 3.2.1 deste trabalho.
} 
Por outro lado, também parece plausível aceitar que isoladamente, a proposta descritivista não é suficiente para explicar uma diferença que julgo ser da máxima importância, para a qual procuro chamar a atenção. Se se aceitar apenas a interpretação descritivista (isto é, sem incluir um elemento expressivista na mesma), não há nenhuma diferença entre "matar por diversão é errado", dito por alguém que reprova esse ato e dito por alguém cujos sentimentos não correspondem a esse juízo. Esta apenas descreve uma regra geral da ciência Moral ou uma máxima para cuja aceitação se pode educar alguém. Aquele que a profere sem que os seus sentimentos lhe correspondem pode mesmo ser um fingidor - que finge agir em conformidade com um juízo que, por algum interesse, diz ser o seu (que vale tanto no caso do juízo estético como moral). Ou seja, se não se aceitar que além de descrever um facto, os juízos sobre valores também expressam um sentimento (apesar de não o fazerem no caso de quem o profere não ter o sentimento adequado a ele), não se reconhece a diferença entre o caso em que esses sentimentos correspondem às regras gerais e o caso em que não the corresponde, isto é, entre emitir um juízo sobre um valor como um juízo que expressa o sentimento de quem a profere e como máxima à qual os sentimentos de alguém se podem adequar.

Portanto, em relação à questão de saber se esses juízos são descritivos ou expressivos, estando satisfeita a condição para que possam ser genuinamente verdadeiros ou falsos, aceito que estes juízos são invariavelmente descritivos e, no caso de os sentimentos de quem as profere num juízo lhes corresponderem (em princípio, na maior parte dos casos), também expressivos. Além disso, descartamse as posições emotivista e da teoria do erro, uma vez que dependem da interpretação de que os juízos sobre valores não podem ter um valor de verdade.

Aceite a interpretação descritivista, resta indagar o que é descrito nesses juízos - tarefa da qual me ocupo em 4.2. Com efeito, quando se trata de juízos sobre relações causais, o objeto cujas propriedades tornam o juízo verdadeiro ou falso tem ou não tem essas propriedades independentemente da mente e da crença dos agentes ou espectadores. Já o juízo sobre valores pode corresponder a uma paixão efetiva de um agente ou à de vários agentes ou espectadores. Sendo assim, é necessário indagar se o que torna o juízo sobre valores verdadeira é uma paixão efetiva de um agente ou de uma generalidade: se, por exemplo, matar é errado se a ação em questão e o traço de caráter que a motiva provocam o sentimento de 
reprovação em quem a enuncia ou se a provoca numa certa generalidade de espectadores. Portanto, trata-se de decidir qual o critério para determinar se esses juízos sejam verdadeiros ou falsos.

A meu ver, a resposta a esta questão deve ser a segunda, ou seja, que as paixões que tornam o juízo verdadeiro ou falso não são as do agente que o enuncia, mas sim as que são descritas pelas regras gerais sobre a moral e o gosto. As razões para isso são duas:

i) é possível estabelecer estas regras gerais (quinta evidência a favor da interpretação de que os juízos têm um valor de verdade) e o facto de estes consistirem no juízo dos juízes desinteressados - o que ficará mais claro na secção 4.3 ; ii) aceitar a interpretação subjetivista ${ }^{777}$ implica aceitar que o valor de verdade dos juízos é variável de espectador para espectador desconsidera as evidências sobre a possibilidade e utilidade das regras gerais torna irrelevante a identificação dessas regras com o sentimento dos juízes desinteressados.

Deste modo, julgo ajustado manter a proposta mista de Jones - que apresentei em 3.2.2 - de que juízos sobre valores têm um elemento descritivo (de uma relação causal entre o objeto avaliado e o seu espectador), mas também expressivo (de um sentimento de quem as profere, nos casos em que o seu sentimento lhe corresponde). Por seu turno, o juízo emitido por alguém cujos sentimentos não se adequam à mesma pode ser, de forma mais justa, chamada de regra geral - verdadeiro ou falso, mediante o seu acordo ou desacordo com os sentimentos dos agentes e/ou espectadores que avaliam o objeto sob o ponto de vista desinteressado. Quer dizer, por um lado, o juízo descreve o que se presume ser uma descrição verdadeira da questão de facto de que se trata (seja uma relação causal, seja um valor). Porém, nos casos em que o agente não só descreve, mas a sua crença ou sentimento acompanha a descrição, esse juízo também expressa essa crença ou sentimento.

Em suma, ao associar os três elementos da interpretação (metafísico, epistémico e semântico), tem-se uma interpretação tal que os valores e respetivos juízos resultam do reconhecimento uma relação causal e refletem-na num juízo. Quer dizer, a relação entre um traço do objeto avaliado e o espectador motiva a atribuição do valor ao mesmo, sob a forma de juízo. 
Por sua vez, a crença quotidiana relativa à atribuição do valor a um objeto é que ele lhe pertence intrinsecamente. Porém, é possível uma correção deste erro, ao se perceber que o valor é uma propriedade que resulta do confronto entre o objeto (observado sob o ponto de vista desinteressado) e o seu espectador (que o observa sob esse ponto de vista ${ }^{778}$ - tópico que me ocupará na secção 4.5.

\footnotetext{
${ }^{777}$ Cf. 3.2.1 deste trabalho.

${ }^{778}$ Esta dualidade de perspetivas é paralela à que está presente na atribuição de uma exterioridade e independência aos objetos da perceção pelo vulgo e pelo filósofo - proposta por Kail (cf. KAIL, 2007b, 7.1.2) e é aceite na presente interpretação. Apesar disso, a posição do filósofo que Hume descreve na secção "Da filosofia moderna" (cf. $\mathrm{T}$ 1.4.4) é a do realismo indireto, e a que se pretende defender aqui é uma forma de anti-realismo. Porém, o que importa reter é a existência de uma perspetiva quotidiana e uma filosófica ou reflexiva, que consiste numa correção da primeira perspetiva. Não obstante, esta correção não consiste numa postura de abandono da primeira perspetiva, e sim numa tomada de consciência da verdadeira natureza do valor.
} 


\section{A interpretação do quasi-realismo cético}

\subsection{Introdução}

A meu ver, o início do debate sobre a pertinência do projetivismo como opção interpretativa das teorias causal e dos valores de Hume pode ser demarcado pela contribuição de Stroud $^{779}$. Estando integrada numa tentativa de descrever a origem de ideias ou convicções de que não se tem ideias claras, Stroud e Mackie (primeiros proponentes do projetivismo como interpretação da teoria causal e dos valores de Hume) conjugavam-na com uma interpretação anti-realista (de ambas as teorias do filósofo). Em virtude desta interpretação, consideravam-na um mecanismo que proporciona, por assim dizer, uma ilusão constante de descrição de relações intrínsecas entre os objetos, entendidos como exteriores e independentes da mente. Por sua vez, Kail procurou conjugar esta proposta com uma interpretação realista das mesmas teorias do filósofo, procurando mostrar que o mecanismo que pode ser chamado de projetivo na filosofia de Hume proporciona, no caso da causalidade, uma crença injustificada, apesar de verdadeira, e no caso dos valores, uma crença falsa, mas corrigível.

A opção interpretativa que pretendo defender no presente trabalho - que Angela Coventry, sua proponente, chama de quasi-realista $\left(\mathrm{S}_{\sim \mathrm{DQR}}\right)-$ pretende-se uma alternativa ao projetivismo na sua versão não descritivista e não cognitivista, relativamente à natureza e significado dos juízos sobre causalidade e sobre valores. Tal como apresentada por Blackburn (como proposta filosófica geral) e Coventry (como interpretação da filosofia de Hume), esta interpretação é distinta da teoria do erro (primeira versão do projetivismo) na proposta de rejeição da consideração normativa sobre as crenças forjadas pela propensão projetiva

\footnotetext{
${ }^{779}$ Entre os comentadores que entraram explicitamente no debate, além de Stroud (cf. 1977, 1993), estão Mackie (cf. 1980b), Pitson (cf. 1989), Blackburn (cf. 1993a), Millican (cf. 2000), Winkler (cf. 2000), Wright (cf. 2000), Coventry (cf. 2006), Millican (cf. 2007), Kail (cf. 2007b) e Cohon (cf. 2008). Apesar disso, ainda previamente ao início deste debate ou relativamente à margem do mesmo, o termo 'projeção', 'projetivismo' ou 'projetar' já despontava nos textos de alguns comentadores que não se ocuparam ativamente desta noção (cf. FLEW, 1961, p. 118, 123; 1976, p. 3-4; PASSMORE, 1968, p. 116; NOXON 1973, p. 132; BEAUCHAMP \& ROSENBERG, 1981, p. 10; NORTON, 1982, p. 144; BROUGHTON, 1983, p. 220; WRIGHT, 1983, p. 90; STRAWSON, 1989, pp. 6, 105, 150, 231-2). Quer dizer, estes comentadores já utilizavam esporádica e vagamente este termo, sem que oferecessem uma definição do mesmo.
} 
(designação dada por Winkler ${ }^{780}$ ). Coventry reivindica que este mecanismo não seja considerado um erro, em virtude da sua naturalidade.

A fim de explicar, discutir e propor alterações a esta interpretação, na secção 4.1, exponho a interpretação quasi-realista das teorias causal e dos valores de Hume, apresentando a combinação de elementos que Coventry julgava seremlhe essenciais ou distintivos, no seu conjunto, em relação a outras interpretações (realista, anti-realista e projetivista), a saber: i) uma interpretação regularista da teoria causal, ii) o projetivismo, iii) o não cognitivismo, e, finalmente, iv) a defesa da possibilidade de um padrão imaginário para os juízos (causais e de valor).

Em 4.2, concentro-me no tópico iv) e tenho três objetivos. O primeiro é apresentar a diferença que Coventry concebia entre as regras gerais e o padrão para determinar o valor de verdade dos juízos. O segundo consiste em explicar as características que Coventry julga que este padrão cumpre na filosofia de Hume, acrescentando alguns comentários e evidências textuais que, a meu ver, acrescentam elementos determinantes à proposta ou, pelo menos, contribuem para a sua compreensão. Ambas as propostas já se antevêem na proposta avançada por Dabney Townsend - com quem, apesar disso, Coventry não dialoga. $\mathrm{O}$ terceiro consiste na consideração do caráter intersubjetivo do padrão e das regras gerais para os juízos de valor.

Entretanto, ao longo do restante capítulo, proponho algumas alterações à interpretação proposta por Coventry e procuro compatibilizá-las com outras conclusões, retiradas a partir das interpretações de outros comentadores.

Assim, na secção 4.3, apresento duas críticas à interpretação de Coventry. A primeira - breve - é que a comentadora não reconheceu que a proposta de uma interpretação cognitivista e de um critério ou padrão para os juízos a compromete com a defesa de uma forma de descritivismo (nem mesmo conjugada com uma forma de expressivismo, como procurei defender em 3.4). A segunda é que ignora evidências que apontam para uma interpretação cética sobre a existência (ou não existência) da causalidade objetiva, em vez de uma interpretação anti-realista. Uma alteração nesta componente da interpretação tem como consequência que a interpretação quasi-realista se tornaria cética - de onde, em parte, se explica a

\footnotetext{
${ }^{780}$ Cf. WINKLER, 1991, p. 562, 564.
} 
designação da interpretação proposta neste trabalho e o seu título: quasi-realismo cético.

A estas duas críticas corresponderão duas propostas de alteração. A primeira é o reconhecimento de uma dimensão cognitivista e descritiva para os juízos em questão. A segunda é uma componente cética relativamente à existência (ou não existência) da causalidade objetiva. Uma vez que identifiquei os juízos sobre valores como um tipo especial de juízos sobre relações causais (cf. 3.4), esta conclusão cética alastra-se à teoria dos valores de Hume, uma vez que as relações causais que envolvem a atribuição de um valor (pela mente) a um objeto não parecem escapar à dúvida cética relativa à causalidade para além da regularidade observável, como procurarei mostrar.

Em 4.4, apresento um conjunto de elementos comuns aos juízos sobre relações causais e sobre valores, notados por comentadores como Barry Stroud, Don Garrett, Tony Pitson e Angela Coventry. A estes, acrescento a possibilidade de ambos os tipos de juízos serem verdadeiros ou falsos, e descritivos (consequência do que defendi em 3.4) mostrando de que forma este elemento pode ser harmonizado com os restantes, notados por aqueles comentadores.

Na secção 4.5, procuro, em primeiro lugar, reconduzir a noção de projeção na filosofia de Hume à conceção que Simon Blackburn tinha da mesma - aliás, atribuindo a Hume a originalidade de ter sido o primeiro filósofo projetivista.

Em segundo lugar, explico de que forma o reconhecimento da existência e operatividade da propensão para "se espalhar nos objetos externos" e o seu poder de criar convicções que não são fundadas em ideias claras (como a causalidade objetiva, a existência exterior e independente dos objetos da perceção e o valor) se enquadram nas interpretações i) realistas e anti-realistas (relativas à componente metafísica), ii) cognitivistas e não cognitivistas (relativas à componente epistémica) e ii) descritivistas e não descritivistas (relativas à componente semântica).

Por seu turno, a secção 4.6 é dedicada, em primeiro lugar, ao exame da distinção precisa entre ideias claras e ideias relativas na filosofia de Hume. A partir de um diálogo com Daniel Flage e os seus interlocutores, o meu objetivo é determinar os requisitos que uma ideia deve cumprir, na filosofia de Hume, para ser considerada relativa (por contraste com uma ideia clara) para, depois, explicar que algumas ideias cumprem aqueles requisitos, pelo que devem ser consideradas 
relativas (na filosofia de Hume). Tais ideias são a causalidade objetiva (onde se inclui a relação causal estabelecida entre os objetos de juízos de valor e a mente que lhos atribui), a existência exterior e independente (da mente) dos objetos da perceção e o padrão para os juízos.

Além disso, e em segundo lugar, a partir de um diálogo com os comentários de Teceryum Lightner e Peter Kail, procuro mostrar que sendo o Princípio de Conceptibilidade restrito ao escopo das ideias claras ${ }^{781}$, as ideias relativas (que seriam sem sentido) sinalizariam objetos cuja existência (ou não existência) é indeterminável.

Destas considerações, concluo que as ideias que existem na mente em virtude da propensão projetiva fazem parte do campo de ideias que, de acordo com aqueles requisitos, devem ser consideradas relativas.

$\mathrm{Na}$ secção 4.7 - última do capítulo -, exponho o principal elemento distintivo da minha proposta em relação à proposta de Coventry, a saber, a compatibilização da interpretação quasi-realista com o ceticismo - em detrimento de uma interpretação regularista ou realista sobre a causalidade. Além disso, explico de que forma as minhas conclusões céticas derivam da interpretação (apresentada em 4.6) de que há espaço, na filosofia de Hume, para ideias relativas, pois constituem ideias de objetos cuja existência não pode ser determinada - que fogem ao escopo do PP.

Por fim, ainda na mesma secção e em tom de conclusão, explico em que medida i) uma conclusão cética em relação à existência (ou não existência) da causalidade objetiva, ii) o projetivismo e iii) a inclusão dos juízos de valor no campo dos juízos causais têm uma consequência cética na teoria dos valores de Hume, a saber, relativa à relação causal (intrínseca ou não) entre os objetos dos juízos de valor e a mente que lhes atribui esse valor. Portanto, explico de que forma estes elementos perfazem o que chamo de quasi-realismo cético - como interpretação da filosofia de Hume.

${ }^{781}$ Cf. 2.2 .3 deste trabalho. 


\subsection{Descrição da proposta quase-realista de Angela Coventry}

Coventry - assim como Stroud - é das escassas comentadoras que declaradamente propõem uma interpretação que abrange as teorias causal e dos valores de Hume. A autora intitula-a de quasi-realismo, uma vez que se trata da aplicação da teoria que recebeu o mesmo nome por parte de Blackburn, e que fora proposta como teoria da natureza da causalidade, dos valores e respetivos juízos $^{782}$, às mesmas teorias de Hume. A comentadora propõe esta interpretação como forma de resolver duas questões na filosofia de Hume, que entende terem sido inconvenientemente tratadas pelos comentadores até então.

A primeira é a conceção normativa ou normativizante das crenças e juízos causais e de valor dos teóricos do erro, de acordo com a qual atribuir um valor de verdade (verdadeiro ou falso) a esses juízos constitui um erro ou engano, uma vez que não possuem um valor de verdade genuíno - que, no limite, pode sugerir a necessidade de uma revisão da forma como pensamos e nos referimos às relações causais e aos valores (cuja força deriva do seu caráter natural, não podendo ser alterado). Por sua vez, a conclusão de que esses juízos não possuem um valor de verdade genuíno deriva da conclusão de que as propriedades da causalidade e dos valores não são objetivas, isto é, não pertencem aos objetos em si mesmos ou independentemente de um contacto de agentes cognitivos com os mesmos, e este engano explica-se pela propensão projetiva. Esta propensão a atribuir propriedades aos objetos que eles não possuem também leva à ilusão de que os juízos proferidos sobre essas propriedades são descritivos, quando, na realidade, são expressivos (ou seja, mostram o sentimento que resulta dessa propensão, mas não representam ou descrevem nenhum facto) ${ }^{783}$.

A segunda questão que Coventry pretende resolver com a interpretação quasi-realista é a compatibilização da conclusão de que os objetos não possuem as ditas propriedades com a possibilidade de os juízos sobre as mesmas serem genuinamente verdadeiras ou falsas - quer dizer, que seja possível um conhecimento sobre essas propriedades sem que se tenha de admitir que essas propriedades são intrínsecas aos objetos ou independentes da mente. Ou seja, a

\footnotetext{
${ }^{782}$ Blackburn desenvolveu esta proposta filosófica foi essencialmente nas obras Essays on Quasirealism (1993), Spreading the Word (1984) e Ruling Passions (1998).

${ }^{783}$ Cf. COVENTRY, 2006, 3.5; p. 44-5, 51, 114, 139.
} 
comentadora propõe uma conciliação entre uma interpretação anti-realista (na sua componente metafísica) e uma interpretação cognitivista (na sua componente epistémica), quer dizer, em que se reconhece a possibilidade de um conhecimento e de um valor de verdade genuíno para os juízos sobre as propriedades em questão (causalidade e valores). Neste sentido, a autora observa que há elementos na filosofia de Hume que ainda não foram considerados compatíveis com uma interpretação anti-realista, a saber, i) a associação de uma teoria da verdade à de um padrão imaginário (produzido pela faculdade da imaginação), ii) a associação deste padrão com a possibilidade da correção dos juízos, baseados em estados subjetivos (como a crença, o sentimento moral ou estético) e regras gerais e, finalmente, iii) o papel das ideias abstratas neste processo $^{784}$.

Para Coventry, o primeiro equívoco (dos teóricos do erro, ao admitir as crenças derivadas da propensão projetiva como um erro) pode ser superado pela consideração de que a propensão projetiva tem, na filosofia de Hume, um valor exclusivamente explicativo, não devendo sugerir a possibilidade (muito menos a necessidade) de qualquer revisão ou correção do pensamento e da linguagem, uma vez que se trata de uma propensão natural - quer dizer, o seu caráter natural anularia a conclusão normativa dos teóricos do erro ${ }^{785}$.

\footnotetext{
${ }^{784}$ Cf. COVENTRY, 2006, pp. 116-17.

${ }^{785}$ Cf. COVENTRY, 2006, p. 63. Em relação à causalidade, este é um aspeto que a comentadora mantém em comum com os defensores do realismo cético (cf. WRIGHT, 1983, pp. 150-5; LIVINGSTON, 1984, p. 155, 161; COSTA, 1989, pp. 181-2; BROUGHTON, 2007, p. 199). O motivo pelo qual estes comentadores consideram que esta propensão não conduz a crenças falsas também é o mesmo, a saber, que essas crenças não são falsas porque existe um facto a ser descrito. $\mathrm{O}$ que os distingue Coventry é o facto que julgam haver para descrever: para aqueles, os objetos independentes e exteriores à mente, para a comentadora, o arranjo de questões de facto que é descrito por uma regra geral, instituída por um acordo intersubjetivo e pelo exercício da faculdade da imaginação (tal como será apresentado na próxima secção do presente trabalho). Kail - único proponente do realismo cético que se ocupou da questão dos valores - também subscreve esta crítica aos teóricos do erro, porém identificando o facto a ser descrito pelos juízos sobre valores numa característica geral da mente, a saber, a de uma propensão geral ao prazer, ou hedonismo metafísico (cf. KAIL, 2007b, pp. 112, 177, 187-9) - que não será longamente abordado neste trabalho. Porém, vale notar que de facto, Coventry nega que as propriedades atribuídas aos objetos em virtude da propensão projetiva não são intrínsecas aos objetos - mesmo sendo possível descrever o dito facto que julgo justo chamar de intersubjetivo. Portanto, a comentadora continua comprometida com a aceitação de que é falso dizer ou pensar que essas propriedades são intrínsecas aos objetos. Mas não é nada mais que isto que Mackie afirma. A suposição que motiva a oposição da comentadora em relação à interpretação da teoria do erro - de que se sugere a possibilidade de uma correção do pensamento e da linguagem - é falsa, pois Mackie (principal representante da mesma e a quem Coventry mais se refere) nunca chegou a afirmar isto. Aliás, a comentadora refere-se a Stroud como defensor da mesma interpretação apenas uma vez e nunca menciona o nome de Fogelin. Porém, Stroud desmente esta suposição reconhecendo a propensão projetiva como natural e inevitável (cf. STROUD, 1977, p. 83; 1993, p. 249, 264, 270).
} 
O segundo equívoco (generalizado na historiografia humeana, da associação constante da interpretação anti-realista a uma interpretação não cognitivista) pode ser resolvido pela consideração e combinação daqueles elementos da filosofia de Hume, que mostram a maior pertinência da interpretação cognitivista em detrimento da não cognitivista, sem necessidade de admitir uma interpretação realista (apresentados na secção que se segue) ${ }^{786}$.

Assim, o quasi-realismo consiste numa interpretação de acordo com a qual não só a tendência a atribuir um valor de verdade a um juízo sobre causalidade e sobre valores não constitui um erro (devido à naturalidade da propensão projetiva) ${ }^{787}$, mas também existe esse valor de verdade (que pode ser verdadeiro ou falso), sem que se tenha de aceitar que as propriedades sejam objetivas. Esta dupla crítica - à teoria do erro e à desconsideração dos elementos cognitivistas na filosofia de Hume - tem como consequência uma interpretação descritivista (na sua componente semântica) - quer dizer, de acordo com a qual os juízos sobre causalidade e sobre valores descrevem um facto, apesar de não se tratar de um facto objetivo, quer dizer, relativo a propriedades que os objetos possuam independentemente da mente.

Deste modo, a comentadora assegura uma interpretação de natureza antirealista em relação à natureza das propriedades em questão (não existem nos objetos em si mesmos), mas não está disposta a conceder que a maneira como os agentes concebem ou pensam e falam sobre essas propriedades seja apenas expressiva e falaciosa (enquanto pretensa descrição) ${ }^{788}$. Por essa razão, julga que os teóricos do erro possuem o mérito de terem salientado a importância da propensão projetiva para explicar a atribuição de uma objetividade a essas propriedades, mas falhou ao considerar os juízos proferidos devido a essa propensão um erro ou engano, assim como a entendê-los como meramente $\operatorname{expressivos}^{789}$.

\footnotetext{
${ }^{786}$ Cf. COVENTRY, 2006, p. 44, 46, 62, 63, $64,72$.

${ }_{788}^{787}$ Kail partilha desta convicção de Coventry (cf. KAIL, 2007b, p. 205).

788 Pelo facto de manter a componente emotivista e descritivista, Coventry parece defender a posição que Jones esboça na afirmação isolada mencionada em 3.2.1. Esta posição foi defendida em 3.4 .

${ }^{789}$ Apesar disso, não deixa de ser intrigante que Coventry não tenha abandonado explicitamente a interpretação não cognitivista. Além disso, a comentadora nunca admite explicitamente que a sua interpretação mereça ser chamada de cognitivista, tampouco de não cognitivista. Vale notar que ao pretender, por um lado manter a noção blackburneana de projeção (como mecanismo não
} 
Portanto, a comentadora pretende compatibilizar a tese de que os objetos não possuem relações causais nem valor em si mesmos, ou seja, estas não propriedades intrínsecas dos objetos. São antes propriedades da mente (no caso da causalidade, uma determinação a conceber os objetos como necessariamente conectados e, no caso dos valores, um sentimento agradável ou desagradável) transferidas para os objetos em virtude de uma propensão para tal. Por esta razão, pensamos, falamos e comportamo-nos como se os objetos fossem, de facto, detentores destas propriedades, quando não o são - o que chama de discurso realist-sounding ${ }^{790}$. E uma vez que o que se afirma sobre esses objetos é determinado pelo estado mental que lhe é projetado, os juízos em questão têm um caráter expressivo, quer dizer, expressam ou mostram esse estado mental (no caso da causalidade, a determinação da mente, e no caso dos valores, o sentimento estético ou moral). Apesar disso, não é por descreverem propriedades intrínsecas dos objetos que o que se profere sobre esses objetos é destituído de um valor de verdade. Ao invés, os juízos em questão têm um valor de verdade em virtude da possibilidade de se criarem regras gerais sobre como esses objetos se apresentam na experiência quotidiana e, assim, é possível estabelecer um critério ou padrão para esses juízos.

Coventry apresenta a sua interpretação como intermediária entre a realista e a anti-realista, em vez de uma variante de uma destas, em virtude das componentes que partilha com ambas, assim como daquelas que rejeita nas mesmas interpretações. Por um lado, a comentadora alega, que a sua interpretação nem deve ser considerada realista em virtude da rejeição da objetividade das propriedades em questão, nem deve ser considerada anti-realista, uma vez que reconhece um valor de verdade para os juízos e a possibilidade de um conhecimento das propriedades em questão. Por outro lado, afirma que a interpretação quasi-realista mantém, da interpretação realista, a concessão de um padrão ou critério sob o qual se pode considerar um juízo (sobre causalidade ou sobre valores morais e estéticos) verdadeiro ou falso, e da interpretação antirealista, que as propriedades em questão são subjetivas, em vez de objetivas,

descritivo), assim como uma componente expressivista na sua interpretação, mantendo, por outro lado, a proposta de um critério em virtude do qual os juízos teriam um valor de verdade, a comentadora mostra-se do lado do cognitivismo, sem, porém, descartar explicitamente a opção contrária (cf. COVENTRY, 2006, p. 43). 
sendo a propensão projetiva a razão pela qual podemos supor que os objetos detêm essas propriedades em si mesmos, ou concebê-los como se esse fosse o caso.

O elemento concreto que a comentadora julga decisivo para se considerar a sua interpretação uma posição intermédia entre o realismo e o anti-realismo é o facto de discordar de algo sobre o que os defensores destas posições concordam, a saber, que a única forma de aceitar que os juízos sobre os valores em questão possuem um valor de verdade genuíno é aceitando que essas propriedades existem independentemente da mente. Portanto, apenas se pode defender esta posição se se aceitar a posição realista - o que também implica que o defensor da posição antirealista estaria comprometido com a negação de um valor de verdade genuíno para esses juízos.

Por seu turno, a designação 'quasi-realista' deve-se ao facto de que conjugando, na filosofia de Hume, a rejeição da objetividade da causalidade e dos valores com a existência de um critério ou padrão em virtude do qual os juízos sobre a causalidade e os valores sejam verdadeiros ou falsos, a comentadora oferece uma interpretação geral dos juízos sobre questões de facto (na filosofia de Hume, bem entendido) em que os comportamentos quotidianos, as trocas intersubjetivas, os juízos enunciados e o próprio pensamento ocorrem exatamente da mesma forma como ocorreriam se os objetos detivessem, de facto, as propriedades que lhes são atribuídas. Quer dizer, sendo o que explica estes comportamentos, juízos e pensamentos, a propensão projetiva permite uma imitação ou simulação de um mundo cujos objetos detivessem, efetivamente, aquelas propriedades. Nisto consiste o que Coventry chama de caráter mimético da propensão projetiva ${ }^{791}$.

Esta consideração do movimento mimético da mente também mostra porque é que a interpretação de Coventry deve ser considerada anti-realista: apesar de a mente, por meio da propensão projetiva, ter a capacidade de forjar um arranjo de ideias, relações e crenças que simula um cenário realista (em que os objetos possuem intrinsecamente as propriedades que lhes são atribuídas), Coventry continua a negar que essas propriedades sejam independentes da mente

\footnotetext{
${ }^{790}$ Cf. COVENTRY, 2006, p. 64, 67.

${ }^{791}$ Cf. COVENTRY, 2006, p. 43; KAIL, 2007a, p. 258; 2007 b, pp. 106-8.
} 
e a distinguir este movimento da mente da existência efetiva dessas propriedades (independentes) $)^{792}$.

Entretanto, há um aspeto da exposição das posições de Coventry que talvez explique que a comentadora defina a sua interpretação como intermédia entre as interpretações realista e anti-realista, e que dificulta o reconhecimento de que a sua interpretação deve ser compreendida como anti-realista - restringindo este termo ao que designa uma das componentes da interpretação, a saber, a da existência ou não das propriedades em questão. Talvez devido à frequência com que a interpretação anti-realista fora associada a uma interpretação não cognitivista na historiografia sobre o filósofo, a comentadora se refira aos comentadores seus oponentes (defensores do realismo e do não cognitivismo) de maneira demasiado e indevidamente simplificada, descrevendo as componentes epistémica e semântica sob a designação que deveria caber apenas à componente metafísica, e não à interpretação como um todo.

Deste modo, descreve a interpretação realista como aquela de acordo com a qual os objetos possuem em si mesmos as propriedades em questão (componente metafísica, realista propriamente dita), há a possibilidade de um conhecimento e um valor de verdade genuíno para os juízos sobre essas propriedades (componente epistémica, não designada como tal) e, finalmente, os juízos são descritivos desse facto que pode ser conhecido e sobre o qual se podem apresentar proposições verdadeiras (componente semântica, também não definida como tal). Por sua vez, a interpretação anti-realista é definida como aquela segundo a qual os objetos não possuem em si mesmos as propriedades em questão (componente metafísica, anti-realista propriamente dita), não há a possibilidade de um conhecimento e um valor de verdade genuíno para os juízos sobre essas propriedades, havendo apenas sentimentos dirigidos aos objetos em questão (componente epistémica, não designada como tal) e, finalmente, os juízos são expressivos, e não descritivos de um facto (componente semântica, também não definida como tal $)^{793}$.

\footnotetext{
${ }^{792}$ Para justificar esta consideração, a comentadora enumera diversos autores que discutiram a posição de Blackburn, argumentando a favor de se considerá-la uma forma de realismo (cf. Tappolet (1992), Gillard (1996), D. Heiker (1996), Rosen (1998), Wetphal (1998)) e, outros, de anti-realismo (cf. Rasmussen (1985), Fine (1986), Price (1986), Solomon (1987), Garner (1993), Haldane e Wright (1993); cf. COVENTRY, 2006, pp. 57-8).

${ }^{793}$ Cf. COVENTRY, 2006, pp. 44-5, 47, 63-4, 105-6.
} 
Em suma, de acordo com a divisão de componentes pelas quais se tem vindo a apresentar as questões tratadas no presente trabalho, a interpretação de Coventry reúne traços que a tornam singular na historiografia do filósofo - apesar de a maior parte dos mesmos já estar presente nas interpretações apresentadas nos capítulos 2 e 3. São estes uma componente anti-realista (metafísica), uma componente cognitivista (epistémica), uma componente tanto descritivista como emotivista (semântica) e, finalmente, a componente projetivista (de natureza tanto epistémica como semântica $)^{794}$. A componente cognitivista - que conjuga reflexões sobre o papel das regras gerais, das ideias abstratas e de um padrão ideal, subjacente ao padrão criado pela instituição das regras gerais, constitui a maior novidade nesta sequência de interpretações do filósofo. Passo a explicá-lo na próxima secção, para, depois, expor as razões pelas quais concordo com esta distinção e com a posição de que o padrão para os juízos não são as regras gerais, mas o que está por trás do seu estabelecimento ou descoberta, a saber, o veredito dos juízes refinados, delicados ou de bom senso.

\subsection{Características do padrão}

A distinção entre as regras gerais e o padrão ideal de verdade e correção para os juízos é determinante para se entender a diferença entre aquilo que é considerado, efetivamente, verdade num certo momento e aquilo que faz com que o juízo seja verdadeira independentemente de se considerá-lo num certo momento ou não. Coventry avança a hipótese de que as regras gerais cumpram a primeira função, e o padrão, a segunda. Este corresponde a uma ideia que move a própria revisão das regras gerais, e que torna o juízo verdadeira ou falsa independentemente do que é, efetivamente, considerado verdadeiro agora, mas que nunca será descoberto.

$\mathrm{Na}$ presente secção, procuro, em primeiro lugar, explicar esta distinção, a fim de mostrar que aquelas não podem ser consideradas o padrão, tal como o propuseram Coventry e Townsend. Em segundo lugar, procuro apresentar as

\footnotetext{
${ }^{794}$ Lembro que neste contexto de comentário à filosofia de Hume, projeção é encarado como o processo ou artifício da mente que consiste em atribuir aos objetos propriedades que, de facto, são
} 
características que Coventry propôs para este padrão, de modo a mostrar como é possível um padrão genuíno para juízos sobre propriedades que não são objetivas (ou, pelo menos, não se apresentam como tais), como é o caso das questões de facto na filosofia de Hume.

Com efeito, aceitar a possibilidade de um padrão para os juízos não torna Hume um racionalista, por dois motivos. Por um lado, devido à rejeição de qualquer princípio ou enunciado a priori para a investigação de questões de facto $^{795}$. Por outro lado, o posicionamento do padrão no juízo do espectador refinado permite conciliar o sentimentalismo com a convicção de que do ponto de vista epistémico, os juízos não valem todos o mesmo - isto é, alguns parecem mais acertados e mais dignos de constituir um padrão para os demais espectadores do que outros, o que torna evidente, pelas discordâncias constantes entre os agentes e/ou espectadores, que e os gostos são discutíveis.

A meu ver, há duas razões textuais que deixam claro que não se deve considerar que as regras gerais constituam o padrão para os juízos, ainda que juízos concretos sejam verdadeiros ou falsos num dado momento da História mediante a sua conformidade ou não com uma regra geral.

Em primeiro lugar, Hume refere-se separadamente às regras gerais e a um padrão genuíno para tais juízos, isto é, sem associá-los explicitamente, ou sem afirmar que as regras gerais constituam o próprio padrão. Antes, refere-se ao mesmo como o ponto de vista que permite o acordo intersubjetivo, mas que resulta de um exercício de uma imaginação delicada, que consiste em perceber os contornos de cada objeto ou situação que condicionam o juízo de valor, e as regras gerais parecem consistir em enunciados gerais concretos que resultam deste exercício, isto é, posteriores à descoberta do padrão:

[C]omo o prazer e o interesse de cada pessoa particular é diferente, é impossível que os homens jamais pudessem concordar em seus sentimentos e juízos, a menos que escolhessem algum ponto de vista comum, a partir do qual pudessem examinar seu objeto, e que pudesse fazer esse objeto o mesmo para todos eles. Ora, quando julgamos um caráter, o único interesse ou prazer que parece o mesmo para todo espectador é o da própria pessoa cujo caráter está sendo examinado, ou o daqueles que têm alguma conexão com ela. E

modos ou estados da mente (desejos, emoções, expectativas, hábitos) de tal maneira que os interpretamos como se tivessem essas propriedades (cf. COVENTRY, 2006, p. 30).

795 JONES, 1982, p. 108, 113; TOWNSEND, 2001, p. 126, 127-8, 129, 159, 164, 197. 
embora esses interesses e prazeres nos afetem de maneira mais fraca que os nossos, são mais constantes e universais, e por isso, contrabalançam estes últimos até mesmo na prática, além de serem os únicos admitidos na especulação como critérios de virtude e de moralidade. Apenas eles produzem essa sensação ou sentimento particular de que dependem as distinções morais. $^{796}$

Quando os órgãos são finos o bastante para não deixar que nada lhes escape e, ao mesmo tempo, exatos o bastante para perceber cada ingrediente da composição, a isso chamamos delicadeza de gosto (...). Aqui as regras gerais têm o seu uso, pois são obtidas a partir de modelos estabelecidos e da observação do que agrada e desagrada, quando este se apresenta sozinho e num grau elevado. E se as mesmas qualidades, em contínua composição e em grau menor, não afetam os órgãos com sensível deleite ou insatisfação, dizemos que tal pessoa não pode ter nenhuma pretensão a essa delicadeza. Produzir tais regras gerais ou tais reconhecidos parâmetros de composição é como encontrar a chave presa à correia de couro que justificou o veredito dos parentes de Sancho e confundiu os pretensos juízes que os condenaram. Mesmo que o barril jamais tivesse sido esvaziado, o gosto daqueles permaneceria igualmente delicado, e o destes, embotado e lânguido. ${ }^{797}$

[S]ó um senso forte, unido a um sentimento delicado, aprimorado pela prática, aperfeiçoado pela comparação e despido de todo preconceito, pode dar aos críticos um direito a esse caráter valoroso; e a confluência de tudo isso no veredito, onde quer que se encontre, é o verdadeiro padrão de gosto e beleza. $^{798}$

Portanto, as regras gerais parecem constituem generalizações empíricas, ao passo que o critério ou padrão (que nunca é explicitamente identificado com as mesmas) é apresentado como aquilo que permite resolver desacordos e o que se

\footnotetext{
${ }^{796}$ Cf. T 3.3.1.30. Além disso, Hume também se chega a referir-se às regras gerais como enunciados concretos - é o caso das regras gerais que determinam a propriedade, a saber, a determinação dos bens particulares que devem ser atribuídos a cada pessoa (cf. T 3.2.3.1). Apesar disso, também é verdade que há algumas evidências a favor da interpretação de que as regras gerais constituam o próprio padrão - apesar de indiretas (cf. T 3.3.1.18; PG 23). Deste modo, parece mais acertado pensar no padrão como aquilo em virtude do qual as regras gerais concretas podem ser revistas, corrigidas e substituídas - como tentarei mostrar ao longo desta secção.

${ }^{797}$ PG 16. Lembre-se o exemplo a que a citação se refere: dois parentes de Sancho provam um vinho, um declarando que tinha gosto de couro, e o outro, que o vinho tinha gosto de ferro, tendo sido ridicularizados pelos seus juízos. Ao esvaziar o barril, veio a descobrir-se que continha uma chave presa a um porta-chaves de couro, o que explicava o gosto de couro e de ferro que os dois homens detetaram (cf. PG 15).

${ }^{798}$ Cf. PG 23. Cf também PG 21.
} 
alcança mediante um ponto de vista desinteressado, sem menção direta às regras gerais - ainda que este ponto de vista permita instituí-las.

Em segundo lugar, se as regras gerais fossem o padrão, seria sem sentido Hume afirmar que os juízes que possuem bom senso ou são capazes de determinar o padrão para os juízos são muito raros. Se as regras gerais fossem o padrão, este seria ditado pelo juízo da maioria - que, para Hume, dificilmente parece poder ser composta por juízes refinados.

Com efeito, à medida que experiencia mais objetos, este espectador analisa cada objeto separando cada componente sua cada vez mais cuidadosamente e percebendo quais as que condicionam e dividem os juízos e quais as que não condicionam o juízo, e quais as alterações que se dão quando se considera e não considera cada uma destas partes. E uma regra geral pode descrever, exatamente, que num dado tempo e lugar, aquilo que era apreciado pela maioria é o que o espectador desinteressado identifica como tosco, ou seja, que a maioria dos espectadores tinha mau gosto. Por outro lado, o juízo deste espectador pouca ou nenhuma influência tem na mente de um espectador tosco, pois apresentar-lhe um enunciado que descreve em que consiste a justiça ou quais os objetos que podem ser considerados genuinamente artísticos, ou quais as qualidades que um vinho deve reunir para ser bom, de nada servirá se esse espectador tosco não tiver a capacidade de separar as diversas partes do objeto apreciado, pelo que o seu juízo permanecerá intacto $^{799}$.

Deste modo, de acordo com a interpretação que Townsend e Coventry apresentam, regras gerais constituiriam os enunciados em que se esclarece o que foi constatado até então pela observação ou cálculo, e o padrão seria uma noção de exatidão, de correspondência mais ou menos perfeita (nas ciências demonstrativas, na Filosofia Natural) ou do máximo desinteresse possível no ponto de vista sob o qual se ajuíza sobre o valor de um objeto, ação ou caráter, que surge no próprio processo de estabelecimento das regras gerais (na Moral e na Crítica), mas que não é o mesmo que uma regra geral.

Nesta interpretação, o padrão surge naturalmente quando se distinguem os fatores que condicionam diretamente o juízo dos que não condicionam, aqueles

\footnotetext{
799 Tal como Hume atesta, a virtude e uma disposição a esse exercício não podem ser ensinadas sem uma disposição prévia (cf. C 29; 1.6 deste trabalho).
} 
que podem ser separados da situação de observação e os que não podem, e se estabelece que caso os fatores particulares sejam abstraídos da situação de observação, se constata que há objetos que agradam a todos os espectadores - e não apenas a um grupo, vasto ou restrito. Este só pode ser estabelecido por aquele que tem a capacidade de proceder a essa separação mais subtil, e para simular os sentimentos que se geram em cada uma dessas situações (mediante a influência do fator em questão e mediante a sua exclusão da situação). Esta descoberta é distinta da simples constatação de que num certo tempo e lugar, certos objetos, ações ou caracteres são apreciados, e outros, depreciados. Com efeito, pode haver uma regra geral de acordo com a qual o gosto ou a aprovação moral não são os mesmos que correspondem ao padrão, isto é, ao juízo daquele que se dedica atentamente à consideração de todas as componentes ou partes do objeto em questão que merecem ou não consideração para o juízo. Aliás, como bem nota Townsend, é por esta razão que o retrocesso no gosto e na moral é possível ${ }^{800}$.

Portanto, o juízo do juíz atento ou desinteressado estabelece o padrão porque este é quem tem a capacidade de descobrir os elementos do objeto ou que o envolvem que determinam todo e qualquer espectador a apreciá-lo. Por sua vez, o condicionamento dos juízos mediante certos fatores tem é capaz de dividir as opiniões dos vários juízes (toscos e refinados), justamente porque o espectador que esteja sob o seu efeito terá um juízo diferente daquele que tem um juízo condicionado por outro fator: por exemplo, a cultura ou a proximidade em relação a um artista ou agente moral. Esta capacidade vai além da capacidade de coleção de instâncias particulares e a subsunção das mesmas em ideias e enunciados gerais sobre o que é apreciado num dado lugar e momento da História, pois estas generalidades podem incluir tanto os gostos que são toscos como, eventualmente, os finos. O único critério que a regularidade observável tem de cumprir para poder constituir uma generalidade sobre o gosto ou sobre valores morais é a apreciação por todos ou grande parte dos agentes e espectadores, ao passo que para ser considerado genuinamente artístico ou moral, o objeto deve ser apreciado sob o ponto de vista desinteressado.

Esta seria a diferença entre constatar o que aparece regularmente à observação e os requisitos que as generalizações devem seguir para serem

${ }^{800}$ Cf. TONWSEND, 2001, p. 202. 
consideradas aceitáveis ${ }^{801}$, entre o que é valorizado em cada época e lugar em concreto e quais os fatores que devem ser considerados num juízo desinteressado - aquele que é o mesmo para todos (para o que se exige a exclusão dos ditos fatores que influenciam o juízo, ou o tornam interesssado). As regras gerais restringem-se a enunciados gerais específicos mediante a observação, e não dependem de uma delicadeza daquele que coleta essas informações empíricas. Já o padrão depende dessa capacidade de separação e da sensibilidade (que se traduz na capacidade de simular emoções) do observador ${ }^{802}$.

Vale acrescentar um requisito além da dependência ou independência da delicadeza do espectador desinteressado (ou crítico, ou observador), a saber, o do caráter incompreensível ou uma confusão inerente à própria ideia de padrão. Quer dizer, Hume parece julgar que este padrão resulta do exercício da própria delicadeza do gosto e do raciocínio, mas em si mesmo, o padrão não é inteiramente compreendido. Nas palavras de Hume, a propósito da possibilidade de um critério ou padrão para enunciados da Geometria:

[Para corrigir juízos sobre proporções], fazemos a suposição de um critério imaginário de igualdade que possa corrigir com exatidão tanto as aparências desses corpos como o procedimento de medição, reduzindo inteiramente as figuras a essa proporção. Tal critério é claramente imaginário. (...) $\mathrm{O}$ mesmo se passa em muitas outras áres. Um músico que vê sua audição se tornar a cada dia mais refinada, e que corrige a si próprio pela reflexão e atenção, prolonga o mesmo ato da mente, ainda que seu objeto esteja além do seu alcance, mantendo a noção de uma terça ou uma oitava completas, sem ser capaz de dizer de onde extraiu seu critério. Um pintor forma a mesma ficção a propósito das cores; um mecânico, a propósito do movimento. Para um, a luz e a sombra; para o outro, a rapidez e a lentidão são imaginados como passíveis de uma comparação e uma igualdade exatas e para além do julgamento dos sentidos. (...) É por meio dessas correções, e levando adiante a mesma ação da mente (...) que formamos a vaga idéia de um critério perfeito para essas figuras, sem que sejamos capazes de explicá-lo ou compreendê-lo. ${ }^{803}$

Townsend explica que no caso das ciências da Moral e da Crítica, este padrão ideal constitui a própria noção de natureza humana, isto é, uma noção abstrata de um conjunto de características comuns a todos os seres humanos que

\footnotetext{
${ }^{801}$ Que Hume propõe em T 1.3.15.

${ }^{802}$ Cf. TOWNSEND, 2001, p. p. 204, 210; COVENTRY, 2006, p. 125, 145.

${ }^{803} \mathrm{~T}$ 1.2.4.24, 25 .
} 
lhes permitiria ter sentimentos semelhantes, o que incluía a capacidade de se colocarem sob o ponto de vista desinteressado (ou o mais desinteressado possível) $)^{804}$.

$\mathrm{Na}$ secção 4.6, quando explico porque se deve admitir que a filosofia de Hume tem espaço para ideias relativas, esta explicação deixará claro que este padrão se encaixa nos requisitos para que uma ideia seja considerada relativa. Além disso, também procurarei deixar claro que admiti-lo constitui uma condição para que as regras gerais possam ser revisíveis e corrigíveis.

Entretanto, passo a apresentar as características que Coventry propõe para o padrão. Aceitando pacificamente que a conceção de verdade envolvida na filosofia de Hume é a de verdade como correspondência ${ }^{805}$, e para sustentar a componente cognitivista da sua interpretação da filosofia de Hume, Coventry estabelece que o padrão imaginário para estabelecer regras gerais ou verdades sobre a causalidade, a virtude ou vício moral ou a beleza ou fealdade possui certas características, que se complementam entre si: i) é conhecido a posteriori; ii) envolve ideias abstratas; iii) consiste num exercício natural da imaginação.

Começo pela explicação do caráter a posteriori (i) do padrão sobre relações causais e valores, que se mostra pela necessidade de recorrer à experiência para conhecer questões de facto.

Em relação ao conhecimento de relações causais, Hume deixou clara a necessidade de estabelecer regras gerais a partir da conclusão de que o seu conhecimento é a posteriori. Com efeito, é pelo facto de o contrário de nenhuma questão de facto implicar contradição que se torna necessário determinar quais as relações causais que efetivamente se mantêm e quais não se mantêm a partir da observação constante de regularidades que se apresentam no mundo empírico. Mediante estas observações, é possível determinar o modo como os objetos se comportaram até então à observação, ou o modo como se comportam ou se relacionam causalmente entre si tanto quanto é possível observar.

\footnotetext{
${ }^{804}$ Cf. TOWNSEND, 2001, p. 159, 172. Esta tese também é proposta por Cohon, relativamente ao juízo moral (cf. COHON, 2008, pp. 6, 98, 123, 262-6).

${ }^{805}$ Cf. COVENTRY, 2006, p. 118. Dentre outros autores que também o aceitam estão Walsh (cf. 1972, p. 101), Wright (cf. 1983, p.20) e F. Schmitt (cf. 1995, p. 1, 145).
} 
É verdade que Hume admite que este critério nas ciências demonstrativas é o único perfeitamente exato ${ }^{806}$. Porém, as referências a um padrão a propósito do conhecimento de questões de questões mostram que Hume concediam uma certa vagueza ao padrão para os respetivos juízos ${ }^{807}$.

Em relação aos juízos de valor (morais e estéticos), Hume apresenta a possibilidade de observar o objeto em questão - o objeto estético, a ação moral ou o caráter do agente moral analisado - como processo análogo à investigação que se leva a cabo na descoberta das relações causais entre objetos inanimados. A diferença entre este processo e o processo pelo qual se estabelecem as regras gerais sobre relações causais entre objetos inanimados é que no caso da descoberta do ponto de vista desinteressado, o que se descobre é a circunstância ou conjunto de circunstâncias em que os objetos causam um determinado sentimento a um espectador. Esta circunstância é aquela em que apenas os fatores que estão presentes na situação ou objeto e que vão agradar ou desagradar todos os espectadores e aqueles que podem interferir na geração desse sentimento são ignorados. Daí a designação 'desinteressado': despido de todo e qualquer fator que possa alterar, enfraquecer ou deturpar o sentimento no espectador.

Este processo não é exclusivo da faculdade da imaginação, porque a experiência e o processo de separação e estudo dos fatores passa diretamente por experimentar e simular sentimentos distintos, isto é, mediante a influência daqueles fatores e sem a sua influência ${ }^{808}$. Portanto, não se trata de um processo exclusivamente racional - se o fosse, o espectador que se dispusesse ao processo de refinamento do gosto ou do senso moral não obteria nenhum resultado, além de descobrir quais os fatores mediante cuja influência se sente e não se sente determinada paixão (agradável ou desagradável).

A propósito do paralelo entre as regras gerais relativas a relações causais e a sentimentos morais e estéticos, vale lembrar que, como alguns comentadores

\footnotetext{
${ }^{806} \mathrm{~T}$ 1.3.1.5.

${ }^{807}$ Cf. também T 3.1.2.8, T 3.3.1.18, T 3.3.1.30, T 3.3.3.2. Apesar disso, pode pensar-se que um ponto de vista totalmente desinteressado não seria operativo para julgar sobre um valor, uma vez que se perderia todo e qualquer fator que envolve a própria experiência do objeto, ou sequer desejável (cf. 1.5 deste trabalho).

${ }^{808}$ Cf. TOWNSEND, 2001, p. 158.
} 
bem notaram, Hume se refere à atribuição de um valor a um objeto como resultado de uma relação causal entre o objeto e o espectador ${ }^{809}$.

Além disso, lembre-se ainda que Hume considerava que todo o conhecimento a posteriori consistia num conhecimento de causas e que a Moral e a Crítica estavam incluídas nas ciências empíricas previstas no âmbito geral da Ciência do Homem, que visava determinar os objetos de cada área do conhecimento de acordo com a maneira como a mente podia aceder aos mesmos.

Por seu turno, o caráter abstrato do padrão (ii), sobre relações causais e valores) justifica-se pela aquisição de ideias gerais no processo de descoberta e/ou estabelecimento das regras gerais e do padrão. Quer dizer, tanto no processo referente a relações causais entre objetos entre si como a valores, estabelecer uma regra geral passa por adquirir ideias gerais sobre os objetos causalmente relacionados, sejam as relações causais entre os objetos (pretensamente) externos, sejam, em relação aos valores, as circunstâncias em que a aprovação do objeto ocorre ou se apresenta regularmente, ou as reações em quem observa e conhece o fenómeno.

Portanto, as regras e o padrão consistem em enunciados gerais - onde estão inevitavelmente presentes ideias gerais - sobre o comportamento dos objetos entre si ou sobre a relação que têm sobre os sentimentos humanos mediante circunstâncias determinadas ${ }^{810}$. O padrão é abstrato porque no processo de generalização, as circunstâncias supérfluas e os casos concretos são ignorados em favor de um enunciado que descreva o que possuem em comum e de determinante para a ocorrência do fenómeno em questão.

Aliás, a possibilidade de adquirirem este caráter geral é o que permite que os enunciados gerais que resultam desta investigação causal se possam aplicar a circunstâncias particulares e podem ser considerados e adotados (tanto no juízo como na conduta) por espectadores. A partir do momento em que o conceito em questão se consolida, este torna-se, de certa forma, independente de juízos particulares - de um certo agente cognitivo. É por essa razão que o conceito tem um real poder de correção sobre os juízos e não se altera constantemente: se o sentimento de cada agente fosse determinante (e indiferente o seu grau de

\footnotetext{
${ }^{809}$ Cf. 3.1 .2 deste trabalho.

${ }^{810}$ Cf. IPM 9.8.
} 
refinamento) para esse conceito, dada a diferença constante entre os sentimentos e juízos entre os agentes, o conceito estaria em constante mudança. Ao invés, ao incorporar uma regra geral e tornar-se um padrão, um certo par "circunstânciasentimento no agente" torna-se independente dos estados mentais de agentes particulares - pelo menos alguns (aqueles cujos sentimentos não se coadunam com as regras gerais). Portanto, o simples facto de que alguns juízos se tornam o padrão para outros juízos confere uma espécie de independência adquirida ao padrão - que tem um correspondente no mundo das questões de facto, a saber, as qualidades que originaram os sentimentos nos agentes e os próprios agentes ${ }^{811}$.

Além disso, este processo de generalização (isto é, de obtenção destas ideias gerais) é permeado pelo exercício de princípios da imaginação, como os de associação, o hábito ou capacidade de separação das ideias. Esta consideração é clara relativamente aos raciocínios causais. No caso dos juízos de valor, percebese nas considerações de Hume sobre a aquisição do ponto de vista desinteressado, sobre a noção causal do próprio valor (entre o objeto e a mente do agente ${ }^{812}$ ).

Por fim, o caráter natural das regras gerais (sobre relações causais e valores) mostra-se em dois sentidos. O primeiro, apresentado por Coventry, consiste no facto de que a formação do padrão para os juízos surge como resultado natural no processo de abstração inerente à formação desse padrão e da descoberta de regras gerais.

O segundo (não mencionado pela comentadora, mas que julgo igualmente pertinente) prende-se com o facto de os mesmos princípios da imaginação pelos quais é possível estabelecer regras gerais (de associação e hábito, que supõe a capacidade de separação das ideias) e que desencadeiam, naturalmente, a formação do padrão (nas mentes dos espectadores delicados) constituírem os princípios mais gerais ou constantes da imaginação. Relembro a passagem, em que Hume afirma:

[D]evo fazer uma distinção, na imaginação, entre os princípios permanentes, irresistíveis e universais - tais como a transição costumeira das causas aos efeitos e dos efeitos às causas - e os princípios variáveis, fracos e irregulares (...). Os primeiros são o fundamento de todos os nossos pensamentos e ações, de tal forma que, se eliminados, a natureza humana imediatamente pereceria e desapareceria. Os últimos não são nem inevitáveis à

${ }^{811}$ Cf. GARRETT, 1997, p. 197; TOWNSEND, 2001, p. 166.

${ }^{812}$ Cf. 3.1.2, 3.4 deste trabalho. 
humanidade, nem necessários, ou sequer úteis para a condução da vida. ${ }^{813}$

Quer dizer, os raciocínios que resultam do exercício destes princípios são naturais, ou elaborar estes raciocínios consiste no exercício natural da faculdade da imaginação (o entendimento).

A propósito destes três aspetos enunciados para caracterizar as regras gerais sobre relações causais e sobre valores, vale acrescentar que para Hume, estas regras gerais compõem um edifício de conhecimento sobre a questão de facto de que se ocupam. Por sua vez, ao considerar que todo o conhecimento é sujeito a um novo juízo probabilístico - o que levantar a suspeita de que haja alguma margem para erro nos raciocínios que compõem esse conhecimento (que parece ser o significado das palavras de Hume de que "todo o conhecimento degenera em probabilidade") -, Hume mostra que todo o conhecimento (incluindo o demonstrativo) é suscetível de uma correção. Posteriormente a esta suspeita, é possível encontrar o erro cometido (caso o haja, evidentemente) e substituir o raciocínio ou conclusão inicial pelo juízo em que o erro foi retificado. Nas palavras de Hume:

Em todas as ciências demonstrativas, as regras são certas e infalíveis; mas quando as aplicamos, nossas faculdades, falíveis e incertas, têm uma grande tendência a delas se afastar e a cair em erro. Por isso, em todo raciocínio, devemos conferir e controlar nosso primeiro juízo ou crença mediante um novo juízo; e devemos ampliar nossa visão para abranger uma espécie de história de todos os casos em que nosso entendimento nos enganou, comparando-os àqueles em que seu testemunho foi legítimo e verdadeiro. Nossa razão deve ser considerada uma espécie de causa, cujo efeito natural é a verdade; mas esse efeito pode ser freqüentemente impedido pela irrupção de outras causas, e pela inconstância de nossos poderes mentais. Desse modo, todo conhecimento degenera em probabilidade; e essa probabilidade é maior ou menor, segundo nossa experiência da veracidade ou falsidade de nosso entendimento e segundo a simplicidade ou complexidade da questão. ${ }^{814}$

Em todo juízo que podemos formar acerca da probabilidade, bem como do conhecimento, devemos sempre corrigir o primeiro juízo, referente à natureza do objeto, por meio de outro juízo, referente à natureza do entendimento. É certo que um homem inteligente e com uma longa experiência deveria ter, e

${ }^{813} \mathrm{~T}$ 1.4.4.1.

${ }^{814} \mathrm{~T}$ 1.4.1.1. 
geralmente tem, uma segurança maior acerca de suas opiniões que um homem tolo e ignorante, e que nossas opiniões possuem graus diferentes de autoridade, perante nós mesmos, proporcionalmente aos graus de nossa razão e experiência. Tal autoridade jamais é completa, sequer no homem mais inteligente e experiente; pois até este deve ter consciência de muitos erros cometidos no passado, e teme sempre repeti-los no futuro. Surge aqui, portanto, uma nova espécie de probabilidade, para corrigir e regular a primeira, e para fixar seu critério e proporção corretos. Assim como a demonstração está sujeita ao controle da probabilidade, assim também a probabilidade está sujeita a uma nova correção por um ato reflexivo da mente, cujo objeto é a natureza de nosso entendimento, bem como nosso raciocínio baseado na primeira probabilidade. ${ }^{815}$

Este juízo seria, no caso do juízo causal, o equivalente ao juízo do espectador atento ou desinteressado é um juízo que resulta do exame dos juízos causais de que já se dispõe, em que se indaga sobre a justeza das próprias operações do entendimento sobre a experiência. E Hume não menciona que este juízo seria uma nova regra geral, que deveria substituir a vigente. Portanto, apesar de Hume antecipar a sua lista de regras gerais com a afirmação de que se seguem as regras de acordo com as quais algo pode ser considerado genuinamente uma causa $^{816}$, este juízo sobre a natureza do entendimento é anunciado como aquilo que permite corrigir os erros nos raciocínios probabilísticos e demonstrativos que se consideravam corretos, o que indicia uma revisão das regras gerais vigentes.

Desta forma, tem-se uma terceira razão textual para aceitar que as regras gerais não constituem o padrão dos juízos, a saber, que estas considerações sobre a correção das regras gerais por raciocínios e juízos que atestam falhas nos raciocínios anteriores (que deram origem àquelas regras, e em virtude das quais elas podem ser consideradas verdades num certo âmbito de conhecimento) seria supérflua, bastando, para a correção das regras, a constatação de que o juízo da maioria se alterou - motivando, assim, a alteração da regra. Ao invés, parece ser por este juízo sobre o entendimento - que explicita as falhas dos juízos e raciocínios anteriores - que as regras gerais (e não apenas as suas instâncias) aceites até então podem passar a ser consideradas falsas ou insuficientes (assim como todos os juízos que estejam em conformidade com elas), dando lugar a

\footnotetext{
${ }^{815} \mathrm{~T}$ 1.4.1.1, 5. Cf também T 1.2.4.23.

${ }^{816}$ Cf. T 1.3.15.2.
} 
novas regras gerais, que passam a ser consideradas verdadeiras. Há muitos exemplos deste movimento: a passagem da geometria euclidiana à não euclidiana, a descoberta de novas verdades científicas, a descoberta de que a escravatura é errada. Se aceitássemos que a filosofia de Hume apenas teria espaço para se considerar que estas alterações se motivam apenas pela descoberta de que o juízo da maioria deixou de ser aquele que era até então, as considerações sobre a análise atenta e refinada da imaginação perderiam o valor e estar-se-ia entregue apenas ao juízo da maioria, independentemente do refinamento das suas faculdades no ato do juízo.

Portanto, em princípio, se a analogia entre o critério exato que se pode criar para os raciocínios da Geometria for justa, talvez este juízo sobre o entendimento possa ser entendido como uma ideia abstrata das operações mais infalíveis do entendimento. Esta noção teria a capacidade de corrigir o primeiro juízo (instituído como regra geral) pela deteção de uma falha nessas operações, que resulta numa falha no juízo, em relação a essa ideia, ou, no caso de se tratar de instâncias de observação novas, do reconhecimento de uma necessidade de compará-las com as regras gerais de que se dispõe (para incluí-las ou rejeitar a regra geral), tendo em vista uma operação perfeita do entendimento (a par da ideia de uma igualdade perfeita ou das notas perfeitas do músico).

Isto mostra um constante elemento de revisibilidade em todo o conhecimento, isto é, que todo o conhecimento tem um caráter revisível. Este parece ser o sentido da consideração de Coventry de que as regras gerais são contingentes: são-no porque podem mudar, e o que ocorre quando mudam é que foi feita uma correção ou revisão das conclusões iniciais. Porém, há que notar que o que muda são as regras gerais concretas, descobertas ou estabelecidas na própria prática das ciências empíricas em que esse padrão imaginário se aplica, e não os princípios da mente pelos quais somos capazes de descobrir e sistematizar tais regras gerais. Quer dizer, estes princípios da mente fundam cada ciência empírica que se ocupa de estabelecê-las e sistematizá-las e configuram aquilo parte do que se entende por uma natureza humana relativamente estável ou fixa. Já os raciocínios e conclusões a que se chegam mediante essa atividade científica podem estar errados, como Hume já reconhecera ao afirmar que todo o 
conhecimento "degenera em probabilidade" ${ }^{, 817}$. Devido a esta distinção, concordo com P. Smith que enquanto se ocupa desses princípios da mente, essa ciência não implica "praticamente nenhuma revisão sobre suas explicações do funcionamento do entendimento humano", mas sim nas "contradições e imperfeições reveladas pela sua ciência empírica" ${ }^{\$ 18}$ - que classifica como cética justamente em virtude da consciência destas imperfeições e limites.

Entretanto, a consideração do caráter revisível das regras gerais é consistente com a existência e operatividade de um padrão imaginário (que não se confunde com aquelas). Com efeito, Hume atribui este caráter revisível à imperfeição das faculdades da mente. Quer dizer, se as faculdades não fossem falíveis, não haveria espaço para suspeitas relativamente ao erro nos raciocínios. Mas o motivo que nos pode levar a duvidar da verdade dos enunciados de que dispomos no momento é o mesmo que nos pode levar a conceber o contrário, pois que se trata de uma questão de facto: apesar desta imperfeição, as verdades de que se dispõe no momento podem, de facto, ser as verdades definitivas, pois o facto de se ter errado até agora não garante que se continue a errar. Mas uma vez que já se dispõe desse padrão imaginário, mantém-se a consciência ou a suspeita de que pode não se estar diante da verdade definitiva. Quer dizer, este padrão imaginário parece ser o que mantém essa consciência ou suspeita viva, além dos repetidos insucessos no passado.

Finalizo esta secção a questão da objetividade das regras gerais. Com efeito, principalmente em relação aos valores, pode sempre perguntar-se se as alterações não se devem inevitavelmente a mudanças na própria consideração dos agentes, uma vez que os valores dependem da sensibilidade dos agentes, e se, portanto, não é indevido encarar estas mudanças como correções, ou se essas correções não são genuínas, e sim simples alterações.

Julgo pertinente acrescentar uma observação sobre o estatuto metafísico deste padrão - subjetivo ou objetivo. Por um lado, é certo que, na filosofia de Hume, não se trata de um padrão objetivo: no caso da causalidade, porque esta relação não se encontra diretamente nos objetos, mas constitui uma construção da faculdade do entendimento (que pode ou não corresponder ao modo como os

\footnotetext{
${ }^{817} \mathrm{~T} 1.4 .1 .1,3$.

${ }^{818}$ Cf. SMITH, 2015, p. 199; Cf também SMITH, 1995, pp. 223-53.
} 
objetos se comportam independentemente da mente, como procurarei deixar claro na secção 4.7); no caso dos valores, além da razão anterior, porque toda (no caso da moral) ou parte (no caso da estética) da relação causal que é determinada já se encontra na ou já envolve a mente do espectador, pelo que todo e qualquer enunciado depende, pelo menos em parte, da mente do espectador ou de um conjunto de espectadores. Além disso, procurei descartar as propostas de interpretação realista da filosofia de Hume nos capítulos anteriores ${ }^{819}$.

O padrão reflete a forma como a faculdade do entendimento processa os dados da experiência a partir das relações que é capaz de estabelecer mediante a sua própria natureza, isto é, as suas tendências e princípios. Portanto, enquanto estabelecidas pelos agentes que conhecem, as regras não refletem o modo como os objetos se comportam independentemente da mente - no caso da causalidade, porque não é certo que a forma como são experienciados corresponda à forma como os objetos se comportam entre si independente da mente; no caso dos valores, porque dependem da mente para existir. Portanto, dependem de uma estrutura cognitiva que é partilhada por (pretensamente) todos os indivíduos da espécie, pelo que refletem relações que podem (em princípio) ser estabelecidas e reconhecidas por todos os agentes ou espectadores.

Por outro lado, o padrão não pode ser subjetivo, caso contrário, a verdade seria variável de pessoa para pessoa ${ }^{820}$, e não se captaria o sentido do que ocorre, efetivamente, nas trocas discursivas quotidianas, a saber, o acordo e desacordo e como se pode criar um padrão que resolva este último.

Por isso, as regras e o padrão parecem ter uma natureza intersubjetiva, mantendo uma efetividade e utilidade nos discursos quotidianos, garantindo a possibilidade do acordo e desacordo, a razoabilidade da discussão e, portanto, constituindo um guia para se considerarem juízos verdadeiros ou falsos ${ }^{821}$. Porém, não se tratando de uma descoberta da forma como os objetos são

\footnotetext{
${ }^{819}$ Cf. 2.2.8, para a causalidade, e 3.4, para os valores.

${ }^{820}$ Tal como Árdal bem notou. Cf. 3.2.1 deste trabalho.

${ }^{821}$ Cf. T 1.3.13.11; T 3.3.3.2; CAPALDI, 1989, p. 151, 321; 3.2 .1 deste trabalho. Por seu turno, Fieser julga que apesar de ser conjugado com uma filosofia anti-realista, o reconhecimento de um padrão de verdade para os juízos de valor da parte de Hume (neste caso, morais, os que o comentador se propõe a analisar) pode ser classificado como uma forma fraca de objetivismo, uma vez que ainda se permite o acordo intersubjetivo (FIESER, 1989, pp. 104-5).
} 
independentemente da influência ou ação da mente sobre o mesmo, não pode ser considerados objetivos.

Na secção 4.7, procuro mostrar que esta verdade forjada pela faculdade da imaginação pode, legitimamente, ser considerada uma verdade. Com efeito, uma vez que aceito a interpretação de que juízos de valor constituem uma forma de

juízos causais. Por sua vez, a partir de uma interpretação cética relativamente à possibilidade da existência (ou não existência) da causalidade objetiva, procuro mostrar que a mesma conclusão se deve aplicar à relação entre os objetos dos valores e a mente que ajuiza. A relação desta interpretação cética com a componente projetivista consiste no facto de que devido à impossibilidade de acesso a esse modo objetivo como os objetos se comportam independentemente da mente, a presunção da objetividade nunca passará de uma projeção, isto é, algo que se presume ser de um certo modo, sem se saber (nem poder saber) se o é efetivamente. Disto concluirei que há que manter um elemento cético na interpretação tanto da teoria causal como na teoria dos valores de Hume.

Entretanto, na próxima secção, explico quais as componentes da interpretação quasi-realista (apresentada por Coventry) com as quais concordo, a saber, a distinção entre regras gerais e o padrão para os juízos e a componente projetivista, assim como o motivo da minha discordância com a sua componente anti-realista.

\subsection{Críticas ao quasi-realismo de Coventry}

Ao propor um critério de verdade comum aos juízos sobre relações causais e sobre valores, Coventry pretende escapar à componente normativa da proposta da teoria do erro, de acordo com a qual a propensão projetiva forja crenças falsas. Este constitui um avanço em relação àquela proposta, pois permite explicar de que forma, apesar de serem sistematicamente falsas enquanto pretensas descrições de uma propriedade objetiva, há um sentido em que são genuinamente verdadeiras ou falsas.

Porém, a comentadora não contempla, na sua teoria, nenhuma componente descritiva para os juízos sobre questões de facto, mas mantém que os juízos têm 
um caráter expressivo ${ }^{822}$. Com efeito, esta seria uma consequência da possibilidade de serem considerados verdadeiros ou falsos.

Além disso, a comentadora negligencia evidências textuais que, a meu ver, tornam pertinente uma interpretação cética sobre a causalidade objetiva na filosofia de Hume, em vez de realista ou anti-realista ${ }^{823}$. Uma alteração nesta componente da teoria causal de Hume tem implicações na aceção de verdade a ser concedida: deixa de ser relativa a simples regularidades que não supõem um objeto detentor da relação causal (com outros objetos) como sua propriedade intrínseca, passando a deixar em aberto a hipótese de a regularidade supor esta propriedade. Com isto, mantém-se também em aberto se as regras gerais são ou não relativas a objetos que detêm essa propriedade intrínseca ou se se reduzem a descrições de regularidades - como pretende Coventry ${ }^{824}$.

Na secção 4.7, apresento estas evidências e mostro como a existência de um padrão de verdade genuíno para os juízos é mais consistente com a tese de que a possibilidade de a causalidade objetiva existir se mantém em aberto. Deste modo, julgo que a componente anti-realista da proposta quasi-realista deve dar lugar a uma interpretação cética relativamente à existência (ou não existência) da causalidade objetiva.

Passo agora a explicar a razão teórica pela qual concordo com a proposta de Coventry sobre a distinção entre regras gerais e o padrão de verdade para os juízos. Mantendo a proposta de que existe um padrão de verdade para os juízos sobre questões de facto, resta compatibilizar esta posição com a posição cética relativamente à causalidade objetiva.

Para este efeito, tomem-se juízos como "banhar o corpo com água é prejudicial à saúde" (seja lá o que isso signifique do ponto de vista biológico e/ou físico-químico) e "o Sol gira em torno da Terra". Estes enunciados estavam de acordo com as regras gerais da sua época e, por isso, eram legitimamente considerados verdadeiros. Porém, de acordo com o padrão mais abstrato de verdade, são falsos.

\footnotetext{
${ }^{822}$ Cf. COVENTRY, 2006, pp. 44-5, 65, 114; 4.1 deste trabalho.

${ }^{823}$ Como bem notou Craig, esta é uma das dificuldades da interpretação quasi-realista (cf. CRAIG, 2000, p. 117).

${ }^{824}$ Tal como concluí na secção 4.2 .
} 
Aceitando que a possibilidade de a causalidade objetiva existir se mantém em aberto (como mostrarei na secção 4.7), se aceitasse que o padrão de verdade para os juízos são as regras gerais, e se se estiver no cenário metafísico em que ela, de facto, existe, aqueles enunciados só passariam a ser falsos quando a regularidade da experiência mostrasse os efeitos contrários aos que se julgavam os mais regulares (e, por isso, efetivos). Ao invés, se se aceitar que o padrão constitui uma noção vaga da correspondência entre a experiência e o modo como os objetos se comportam independentemente do acesso que a mente tem aos mesmos, uma revisão e correção das regras gerais (mediante aquele padrão) permite a conclusão de que constituía uma ilusão ou erro genuíno considerá-los verdadeiros. Se se aceitasse que as regras gerais configuram o padrão, tal aceitação não teria sido genuinamente um erro, desde que a regra geral descrevesse a experiência efetiva de que se dispunha na época.

Entretanto, na próxima secção, enumero as características que os juízos causais e os juízos de valor possuem de acordo com os comentadores que se ocuparam deste paralelo, para, posteriormente, acrescentar a componente cognitivista da interpretação proposta neste trabalho (e que segue as sugestões de comentadores como Jones, Norton, Townsend, Coventry e Cohon).

\subsection{Juízos causais e juízos de valor}

Tal como apresentado na introdução do presente trabalho, o principal objetivo deste trabalho consistia em explorar o sentido e a justeza da analogia entre juízos sobre valores e juízos sobre relações causais na filosofia de Hume, estabelecida e aceite por diversos comentadores desde Stroud. Neste sentido, após analisar as correntes de interpretação empenhadas em responder às questões que denominei metafísica, epistémica e semântica relativamente àqueles dois âmbitos, nos parágrafos que se seguem, reúno as características que foram sendo reconhecidas na historiografia do filósofo, comentando sobre a sua pertinência e, finalmente, acrescentando outras que me parecem pertinentes, necessárias para que a interpretação que proponho neste trabalho seja coerente. 
Com efeito, Stroud e Mackie - proponentes da teoria do erro - apresentam uma comparação entre os valores (moral e estético ${ }^{825}$ ) e a causalidade ${ }^{826}$. Passo a enumerar os aspetos que Stroud apresenta a favor da tese de que há um forte paralelo entre as teorias da causalidade e dos valores de Hume.

Realizando uma análise permeada pela preocupação em determinar como funciona uma projeção em geral, em primeiro lugar, Stroud ressalta a necessidade de uma definição dupla da virtude e da causalidade ${ }^{827}$ : uma pelas circunstâncias em que se despertam e outra pelo efeito que essas circunstâncias têm na mente. Este é um aspeto também ressaltado por Garrett. Com efeito, Hume oferece duas definições de virtude $^{828}$. Uma apela para a utilidade para o próprio e para os outros:

[O] mérito pessoal consiste inteiramente na posse de qualidades mentais úteis ou agradáveis para a própria pessoa ou para outros. ${ }^{829}$

Por seu turno, a outra definição aponta a virtude como qualidade que provoca um sentimento no espectador:

[A] hipótese que adotamos é clara. Ela afirma que a moralidade é determinada pelo sentiment, e define a virtude como qualquer ação ou qualidade mental que comunica ao espectador um sentiment agradável de aprovação; e o vício como o seu contrário. ${ }^{830}$

Vale acrescentar que Hume também dá definições da beleza e da fealdade como propriedades que produzem um certo efeito (agradável ou desagradável):

\footnotetext{
${ }^{825}$ Apesar de, na sua obra de comentário de 1977 , apenas se referir à teoria moral, no seu último texto de comentário a esta questão (de 1993), o comentador já inclui o valor estético na sua análise e não faz qualquer retificação em relação à obra. Portanto, os seus comentários no artigo de 1993, repetindo-o brevemente no seu artigo de 2006 (cf. STROUD, 2006, pp. 346-7) parecem estar em perfeita continuidade com os da obra de 1977.

${ }^{826}$ Cf. STROUD, 1977, pp. 176-8, 184-6; 1993, p. 253, 259; MACKIE, 1980a, p. 18; 1980b, pp. $71-2$.

${ }^{827}$ Cf. T 1.3.14.31, 35; I 7.2.29; 1.4 deste trabalho.

${ }^{828}$ Acerca da inclusão da questão do valor estético neste paralelismo, como alguns comentadores notaram, se se pode pensar que os princípios - que descrevem detalhadamente aqueles aspetos objetivos e a sua relação com os sentimentos dos espectadores - constituem condições necessárias, mas não suficientes, para o valor atribuído ao objeto (cf. PITSON, 1989, pp. 72-3; DICKIE, 1996, p. 128, 130), a meu ver, é igualmente plausível acrescentar que aquilo que está subjacente ao estabelecimento desses princípios e escapa a qualquer definição a partir de qualidades objetivas é aquilo que protagoniza as segundas definições de causalidade e de virtude, que não define, mas inclui esse elemento subjetivo numa definição - um agrado ou desagrado ou uma determinação que origina a crença - na mente de um agente ou espectador.

${ }_{829}^{8}$ IPM 9.1.1.

${ }^{830}$ IPM Ap. 1.10; GARRETT, 1997, pp. 190-1.
} 
[A] beleza é uma ordenação e estrutura tal das partes que, pela constituição primitiva de nossa natureza, pelo costume, ou ainda pelo capricho, é capaz de dar prazer e satisfação à alma. Esse é o caráter distintivo da beleza, constituindo toda a diferença entre ela e a deformidade, cuja tendência natural é produzir desprazer. (...) [A] beleza não é mais que uma forma de produzir prazer, enquanto a deformidade é uma estrutura de partes que transmite desprazer. (...)[A] única coisa comum à beleza natural e à moral (...) é esse poder de produzir prazer; e como um efeito comum supõe uma causa comum, é claro que o prazer deve, nos dois casos, ser a causa real e influente da paixão. ${ }^{831}$

A propósito dos dois últimos aspetos enunciados, Garrett também nota que a necessidade de um recurso ao mecanismo da simpatia para explicar o acesso aos valores - que nos escapam inteiramente ao considerarmos os factos em questão na elaboração do juízo ${ }^{832}$ - mostra que se pode traçar um paralelismo entre os juízos de valor e os juízos sobre relações causais: da mesma forma que estes não requerem apenas um conhecimento das circunstâncias em que se pode considerar que um objeto é causa de outro, mas é necessário que se desperte um sentimento na mente do agente, de passar de um objeto a outro com sucessiva facilidade, também o juízo sobre valores não pode dar-se sem que se desperte um sentimento - agradável ou desagradável - em relação ao objeto em questão ${ }^{833}$.

Por outro lado, este é, para o comentador, um indício de que há um valor de verdade no juízo que se pode descobrir (é uma proposição genuína ${ }^{834}$ ) - o que está em perfeita consonância com a sua conclusão de que apesar de a origem dos juízos de valor ser o sentimento desperto na mente do espectador, os valores podem ser objetos da razão e do conhecimento.

O comentador nota, em segundo lugar, que as propriedades em questão - o valor e a necessidade causal - não se encontram nos objetos que se experienciam. Esta é uma conclusão que Pitson considera paradoxal, e uma das que Stroud mantém em comum com os restantes defensores da interpretação projetivista. Chamemos a este aspeto o caráter sensitivo da causalidade e dos valores.

\footnotetext{
${ }^{831} \mathrm{~T} 2.1 .8 .2,3$.

${ }^{832} \mathrm{~T}$ 3.1.1.26.

${ }^{833}$ GARRETT, 1997, p. 203.

${ }^{834}$ GARRETT, 1997, pp. 190-1.
} 
Perante a questão de saber se a origem das ideias e dos juízos em questão (sobre causalidade e sobre valores) está nos objetos ou na mente, a resposta de Hume é, em relação a ambos, a segunda ${ }^{835}$.

Em terceiro lugar, Stroud nota a tese de que da mesma forma que a simples sucessão de eventos é diferente de uma conexão causal entre eles, também o são a consideração das circunstâncias em que se gera a atribuição de um valor e a efetiva geração desse valor. Stroud entende que é isto que escapa à avaliação fria e neutra dos acontecimentos, como se percebe na descrição que Hume oferece do assassinato premeditado ${ }^{836}$.

Em quarto lugar, a propriedade é atribuída ao próprio objeto, como se lhe pertencesse intrinsecamente, razão pela qual ambas devem ser classificadas como projeções. Chamemos a estes aspetos o caráter objetificante e projetivo - que, neste caso, são sinónimos, pois projetar consiste em atribuir a um objeto uma propriedade que ele (aparentemente) não possui - da causalidade e dos valores ${ }^{837}$.

Em quinto lugar, Stroud repara que em ambos os casos os juízos não se limitam a ser uma representação de objetos no mundo externo, mas mantêm um elemento sensitivo ou emotivo (uma impressão de reflexão). Quer dizer, não se limitam a uma pretensa descrição de objetos observados (ou observáveis).

Com efeito, e de acordo com a segunda definição de causalidade, o juízo causal requer uma determinação na mente para se inferir a existência ou ocorrência de um objeto a partir de outro, como efeito da observação de uma conjunção constante. Da mesma forma, e de acordo com a segunda definição de virtude, também o juízo moral requer um sentimento de aprovação ou reprovação como efeito da observação de ações e a inferência dos motivos dos respetivos agentes $^{838}$. Da mesma forma, e como mencionei alguns parágrafos acima, também para o juízo estético Hume julgava necessária uma relação causal entre o objeto apreciado e a mente - na qual se despertaria um sentimento ${ }^{839}$. Stroud chega a dizer claramente que juízos causais, morais e estéticos, têm em comum o facto de

${ }^{835}$ Cf. MACKIE, 1980b, p. 72; PITSON, 1989, p. 64; FOGELIN, 1985, pp. 140, 141-5 CF.; COVENTRY, 2006, p. 133.

${ }^{836}$ Cf. T 3.1.1.26.

${ }^{837}$ Cf. 4.4 deste trabalho . Este aspeto é partilhado por Coventry (cf. COVENTRY, 2006, p. 43, 44, $63,65)$.

${ }^{838}$ Cf. IPM Ap. 1.10 .

${ }^{839}$ Cf. T 2.1.8.2-3. 
expressarem sentimentos. Por este motivo, chamemos a este último aspeto o caráter expressivo dos juízos sobre a causalidade e os valores.

Um sexto aspeto que mantêm em comum com os juízos sobre relações causais é que ambos possuem valor de verdade, podem ser objeto de conhecimento e é necessária a participação da razão para a formulação de ambos os tipos de juízo. Relembrando o que procurei mostrar na secção 3.4, Hume define o campo da verdade sobre questões de facto (entendidas como objeto de conhecimento a posteriori) como aquele em que há uma correspondência entre um juízo ou ideia e uma impressão. As paixões constituem um elemento da relação causal que está presente no surgimento dos juízos de valor, a saber, como efeito das propriedades de um certo objeto (um objeto estético, uma ação ou um traço de caráter) na mente dos espectadores. Assim sendo, tanto estas como qualquer outro efeito presente numa relação causal entre outro tipo de objetos podem ser objeto de raciocínios e de conhecimento, razão pela qual os juízos que as descrevem têm um valor de verdade. Portanto, ambos os tipos juízos têm uma componente descritiva. Este aspeto da interpretação é partilhado pelos defensores da interpretação cognitivista e também Coventry - que, apesar disso, não reconheceu que a sua proposta de um padrão genuíno (ainda que imaginário) para ambos os tipos de juízos a comprometia com o abandono da interpretação $\operatorname{cognitivista~}^{840}$. De resto, há três outros aspetos comuns aos juízos de valor e sobre relações causais que são consequências deste aspeto. Passo a enumerá-los.

Por um lado, existe um padrão em virtude do qual se pode determinar o valor de verdade para cada juízo sobre questões de facto e corrigir o conjunto de conhecimentos que se obtém das mesmas. Este padrão constitui uma ideia abstrata da imaginação em virtude da qual se consideram regras gerais sobre cada âmbito de conhecimento (Filosofia Natural, Crítica e Moral) verdadeiras ou falsas mediante um acordo ou desacordo entre ideias e impressões referentes à experiência regular, ou entre emoções despertas pela consideração do objeto ao qual se atribui um valor e a sensibilidade do espectador desinteressado e respetivas ideias. Também é em virtude desta que é possível corrigi-las. A correção dá-se, no primeiro caso, quando alguma nova experiência desafia a regra geral vigente, e no segundo, quando se descobre alguma falha no ponto de vista 
em virtude do qual se atribui um dado valor a um objeto - particularmente, quando algum fator relevante para a avaliação fora negligenciado ou algum fator que mereceria ser negligenciado pareceu determinante.

Por outro lado, e tal como procurei explicar em 4.3 a propósito da conceção de padrão que Coventry propõe na sua interpretação, como em qualquer exercício da faculdade do entendimento que culmina na descoberta ou estabelecimento de regras gerais, está envolvida, no processo de formação das regras gerais sobre relações causas e sobre valores a formação de ideias gerais e o emprego dos respetivos termos (tanto na própria regra, como nas trocas intersubjetivas). Portanto, resgata-se a consideração da comentadora de que o padrão para ambos os tipos de juízos tem um caráter abstrato, pois envolve a formação de ideias que supõem a separação das circunstâncias e instâncias particulares em que a propriedade em questão se manifesta, em favor de um enunciado que descreva o modo como se manifesta no geral ${ }^{841}$.

Por fim, deve admitir-se que ambos os tipos de juízos envolvem uma crença. Com efeito, se ambos os tipos de juízos descrevem uma relação causal, podem ser objeto de crença. Quer dizer, mediante uma experiência constante, forma-se uma impressão interna que inclina a mente a um certo curso de eventos em vez de outro (àquele de que se tem a experiência constante) e a atribuir aos objetos em questão a propriedade que explica esse curso de eventos. Deste modo, e exigindo uma experiência constante, o processo pelo qual se estabelecem regras gerais, ativa o funcionamento dos princípios de associação entre ideias (formadas a partir das impressões dos objetos em questão, sejam de sensação ou de reflexão), determina a mente a transitar suavemente entre as ideias e, enfim, a atribuir a esse objeto a propriedade de causar um certo efeito - seja noutros objetos, seja na mente.

Vale lembrar que os cinco aspetos em comum entre a causalidade e os valores, apresentados (essencialmente) por Stroud e Mackie, estão integrados numa interpretação que conjuga uma componente (metafísica) anti-realista, uma (epistémica) não cognitivista e uma componente (semântica) projetivista. Esta interpretação não previa a possibilidade de que os juízos sobre valores - mas

\footnotetext{
${ }^{840}$ Cf. COVENTRY, 2006, p. 115.
}

${ }^{841}$ Cf. COVENTRY, 2006, pp. 133, 
apenas os juízos sobre relações causais - fossem genuinamente verdadeiros ou falsos, mantendo a explicação de que a projeção dos valores nos próprios objetos constituía um engano ou erro.

É neste contexto que se inserem os cinco aspetos comuns aos dois tipos de juízos. Porém, a interpretação que proponho no presente trabalho inclui uma componente cognitivista (epistémica), ou seja, a interpretação de que na filosofia de Hume, juízos sobre valores, assim como juízos sobre relações causais, possuem valor de verdade constituem, em parte, um tipo de conhecimento - incompatível com as considerações de que os juízos sobre valores se excluem do grupo dos juízos descritivos.

Nesse sentido, há que explicar em que medida estes seis elementos podem ser mantidos harmoniosamente numa mesma interpretação, que seja alternativa à da teoria do erro, ou como se podem integrar elementos de uma interpretação projetivista - originalmente, de natureza não cognitivista - numa interpretação de tipo cognitivista. Nos parágrafos que se seguem, mostro em que medida a proposta de integração dos aspetos que Stroud aponta para descrever a semelhança entre juízos causais e juízos de valor (o segundo, o terceiro, o quarto e o quinto apresentados nos parágrafos acima) numa interpretação cognitivista - a fim de incluir os dois aspetos que apontei (o sexto e o sétimo apresentados nos parágrafos acima) - perfaz uma proposta ajustada das teorias causal e dos valores de Hume.

É possível harmonizar o segundo aspeto apontado por Stroud com a interpretação de que tanto os juízos causais como os juízos de valor são verdadeiros ou falsos. Quer dizer, a constatação de que a causalidade, a beleza e a virtude não residem nos objetos não impossibilita que os juízos sobre aquelas propriedades sejam verdadeiros ou falsos.

Com efeito, no caso dos valores, o facto de não constituírem propriedades dos objetos enquanto independentes da mente não impede a existência de um padrão de verdade para os juízos, uma vez que é possível, pelo menos, conceber um ponto de vista sob o qual todos os agentes aprovarão um mesmo objeto mediante a desconsideração de diversos elementos de interesse ${ }^{842}$. Este ponto de

\footnotetext{
${ }^{842} \mathrm{Na}$ secção 4.3, discorri sobre a irrazoabilidade de se considerar a possibilidade de desconsiderar todo e qualquer elemento de interesse.
} 
vista é aquele em virtude do qual se pode considerar um juízo sobre um certo valor verdadeiro ou falso: verdadeiro se estiver de acordo com esse ponto de vista, e falso se não o estiver.

No caso da causalidade, o facto de se estar em tal situação de impossibilidade de determinar se esta constitui ou não uma propriedade intrínseca dos objetos não impede que pelo menos se reconheça que apesar desse desconhecimento, todo e qualquer juízo sobre relações causais é verdadeiro ou falso - se não constituir uma propriedade objetiva, ainda pode ser verdadeiro se corresponder, efetivamente, a uma regularidade observável, e falso se não the corresponder; se tal propriedade existir, é verdadeiro se descreve essa propriedade, e falso se não a descrever ${ }^{843}$. Como bem comenta Fieser, a componente metafísica da interpretação não interfere nas componentes sobre a possibilidade de um conhecimento das propriedades em questão, tampouco de qual o significado dos juízos que (supostamente) as descrevem ${ }^{844}$.

Por seu turno, esta consideração também pode trazer uma pista sobre a compatibilização da interpretação cognitivista com a componente projetivista da filosofia de Hume (quarto aspeto apresentado na presente secção).

Em primeiro lugar, deve admitir-se - concordando com Kail - que os teóricos do erro estão corretos ao considerar a atribuição de uma objetividade aos valores um erro. Com efeito, o padrão de verdade possível para tais juízos tem um caráter intersubjetivo: é possível conceber um ponto de vista sob o qual todos os espectadores considerarão certos objetos como possuidores de um certo valor, pois certos objetos, considerados sob esse ponto de vista, possuem, de facto, propriedades sensíveis capazes de produzir um efeito no espectador desinteressado, a saber, um sentimento agradável ou desagradável. Porém, esse ponto de vista incorpora em si a mente do espectador como recetor desse efeito, pelo que a consideração do valor não é independente dos espectadores (nem, no caso da moral, dos agentes). Portanto, considerar que o valor é uma propriedade

\footnotetext{
${ }^{843}$ No caso da causalidade, procurarei mostrar, na secção 4.7, que Hume está comprometido com uma posição cética em relação à existência da causalidade objetiva - portanto, esta pode, de facto, constituir uma propriedade intrínseca dos objetos. Já no caso dos valores, mesmo constituindo propriedades intrínsecas dos agentes, jamais se pode considerar que os valores constituem propriedades objetivas, pois o valor constitui uma propriedade que apenas se mostra mediante a relação entre esse objeto e a mente (de um eventual espectador).

${ }^{844}$ FIESER 1989, p. 98; Em relação à causalidade, cf. CRAIG, 2000, pp. 116-17.
} 
objetiva como, presumivelmente, uma relação causal que os objetos (supostamente) mantêm entre si, constitui um erro ou uma crença falsa.

Ainda assim, a meu ver, se se aceitar que há um critério ou padrão em virtude do qual os juízos sobre valores podem ser considerados verdadeiros ou falsos, a justificação da interpretação de que os juízos sobre valores não são descritivos pela componente projetiva da filosofia de Hume (pelos proponentes da teoria do erro) continua equivocada, uma vez que supõe que a descrição apresenta nos juízos em questão não é genuína, nem sequer num sentido intersubjetivo.

No caso da causalidade, essa atribuição não deve ser considerada um erro ou crença falsa, uma vez que o objeto pode, de facto, possuir as propriedades que lhe são atribuídas - tal como ficará claro na secção 4.7 deste trabalho.

Em relação ao quinto aspeto, o facto de os juízos terem uma componente expressivo não impossibilita que também tenham uma componente descritiva, nem vice-versa. Tal como Stroud explica, se a crença pode mais ser definida como um estado sensitivo do que cognitivo - como efeito do avivamento das ideias na mente -, então os juízos causais mantêm em comum com os juízos de valor o facto de nenhum ser isento de uma impressão. A impressão que motiva a crença e, por sua vez, o juízo causal, é distinta da que motiva o juízo de valor. Deste modo, retém-se a observação de Stroud pretende de que ambos os tipos de juízos expressam alguma impressão, mas acrescenta-se que não são meramente expressivos, mas sim descritivos. Assim, num juízo de valor que seja sincero (em princípio, na maior parte dos casos) estão envolvidas duas impressões internas - a dá essa inclinação à mente e a paixão que motiva o juízo. Eventualmente, no caso de o agente ou espectador não ter uma crença nem uma paixão dirigida ao objeto ou fenómeno em questão, o juízo será meramente descritivo e não expressará nada - que seria o caso de uma descrição emitida sem qualquer crença da parte de quem a faz, ou do juízo de um fingidor (no caso da moral, a figura do patife esperto, isto é, daquele cujos sentimentos não se adequam ao bem público, mas que procura fazer passar a impressão contrária aos demais sobre o seu sentimento moral $)^{845}$.

Esta consideração (relativa ao aspeto semântico da interpretação) associase ao primeiro aspeto, sobre a dupla definição de causalidade e de virtude (a que 
se pode juntar a definição causal de beleza). Com efeito, é o facto de Hume definir tanto a virtude como a beleza e a causalidade que torna pertinente considerar que ambos os tipos de juízos são sobre relações causais ${ }^{846}$ : estas, sobre relações entre os objetos entre si; a beleza, entre objetos considerados belos e a mente do espectador (idealmente, desinteressado) que os considera; a virtude, entre traços de caráter de agentes e a mente de um espectador (idealmente, desinteressado). Além disso, o conhecimento que Hume reconhece ser possível sobre as questões de facto é de tipo causal. Portanto, se o filósofo descreve os fenómenos em questão (da causalidade, da moralidade e da beleza) sob um ponto de vista causal e reconhece que são questões de facto, deve reconhecer que há um padrão de verdade para tais juízos e que os juízos sobre essas propriedades têm uma componente descritiva.

Por outro lado, aceitando estes aspetos apresentados por Stroud, Garrett e Pitson, cuja convicção de base para descrever o que juízos causais e juízos de valor possuem em comum na filosofia de Hume - de que a projeção dos valores é uma instância da projeção geral da causalidade (partilhada por Mackie e Fogelin) -, resta averiguar, perante estes paralelos ou aspetos comuns, quais as diferenças entre os juízos causais e os juízos sobre valores, ou seja, porque é que juízos de valor não são exatamente o mesmo que juízos causais.

Resta finalizar a presente secção com a consideração do que distingue juízos causais de juízos de valor. A diferença entre estes juízos permite complementar a compreensão da interpretação de que juízos de valor são um tipo de juízo causal. Eles distinguem-se pelos objetos cuja relação é descrita no juízo em questão. Mais concretamente, há dois traços distintivos ou sentidos em que os seus objetos são distintos. Passo a explicá-los.

O primeiro sentido ou traço distintivo é que no caso dos juízos causais, é descrita uma relação que se mantém nos objetos entre si, e no caso dos juízos de valor, é descrita uma relação entre um certo objeto (ou mesmo uma pessoa um traço de caráter seu) e a mente (de uma generalidade de agentes ou espectadores). No caso dos juízos sobre relações causais entre objetos inanimados (pelo menos

\footnotetext{
${ }^{845}$ Tal como tentei mostrar na secção 3.4 deste trabalho e seguindo a proposta de Jones.

${ }^{846} \mathrm{Tal}$ como Norton e Swain propuseram - apesar de sob o equívoco de que, com isso, conseguiriam mostrar que Hume considerava que a relação causal em questão era independente da mente de quem as considera (cf. 3.3.2 deste trabalho).
} 
maioritariamente), não está incluído o efeito que um determinado objeto tem sobre a mente dos agentes. No caso dos juízos sobre valores, a mente faz parte da relação causal que é descrita - que é, justamente, entre objetos a cujas propriedades a mente é sensível e a impressão (interna) que causam na mesma, originando a atribuição de um valor ao objeto. Portanto, esta relação é dependente da mente, pelo simples facto de que a relação causal descrita é entre um certo objeto e a mente. Portanto, a mente - ou um traço da mesma - entra na relação (no efeito), o que não ocorre no caso dos juízos causais. Aliás, é por esta razão que a interpretação realista da teoria dos valores de Hume é inaceitável.

O segundo sentido ou traço distintivo é que além de a mente não estar envolvida nas relações causais entre objetos inanimados, mas o estar nas relações causais descritas por juízos de valor, os dois tipos de juízo distinguem-se pelo facto de que no segundo caso, um dos elementos da relação causal descrita no juízo em questão é uma impressão de reflexão. Portanto, nos juízos de valor, estão envolvidas duas impressões internas: a que gera a crença e a impressão de reflexão ${ }^{847}$. Já nos juízos causais, só está envolvida a impressão interna que gera a crença.

Com efeito, sendo tipos de juízos sobre relações causais, descrevem o poder que um certo objeto, tipo ou conjunto de objetos tem sobre outro. Mas o efeito descrito constitui uma paixão, ao contrário do que ocorre no caso de um juízo que descreve uma relação causal entre objetos inanimados, como a gravidade ou o movimento das bolas de bilhar. No caso da relação entre alguns objetos (e respetivas propriedades) e a mente, o efeito que está envolvido na relação é a paixão que se desperta no(s) agente(s).

No caso dos juízos sobre relações causais, Hume distingue a simples ideia ou juízo da crença (no sentido de um juízo à qual se dá assentimento ou em cujo conteúdo se crê) pela interveniência de uma impressão interna, que condiciona a mente a passar de uma ideia a outra com tanta mais facilidade quanto maior for a semelhança entre elas e reconhece que, devido a isto, a crença consiste mais num

\footnotetext{
${ }^{847}$ Esta também é uma diferença entre os juízos de valor e os juízos sobre qualidades secundárias (cf. COHON, 2008, p. 104). Talvez seja este o sentido da afirmação de Hume de que "beleza e deformidade, mais do que doce e amargo, não [são] qualidades dos objetos, mas [pertencem] inteiramente ao sentimento, interno ou externo (...)." (PG 16).
} 
estado sensitivo do que racional ${ }^{848}$. Mas por mais que se possa considerar que a formação de uma crença - que pode ser expressa num juízo sobre relações causais, como, por exemplo, 'chove' ou 'não chove' - é impulsionada por uma impressão de reflexão (e não apenas de sensação), o juízo descreve uma relação entre os diversos objetos envolvidos na relação causal entre esses objetos (como o movimento das bolas de bilhar e a chuva - seja ela redutível à regularidade observável ou não), e não entre os objetos da experiência em questão e a mente. Portanto, para Hume, trata-se de explicar qual é a diferença entre conceber uma conjunção aleatória de questões de facto e crer que uma determinada relação entre questões de facto se mantém no futuro e independentemente da mente. A única interveniência da mente neste processo é contingente - estar inclinada ou não a esperar que o futuro seja como fora o passado, ou que os objetos da experiência continuem a existir após a sua ausência.

$\mathrm{Na}$ próxima secção, procuro explicar a aceção de projetivismo ou de projeção a ser mantida na interpretação proposta neste trabalho, assim como a maneira como os defensores das restantes interpretações com as quais me propus dialogar (realista, anti-realista e não cognitivista) integram esta noção na interpretação que propõem.

\subsection{Projetivismo}

Tal como adiantei na introdução ao presente capítulo, o debate sobre a pertinência do projetivismo como opção interpretativa das teorias causal e dos valores de Hume foi levado a cabo pelos defensores de três interpretações distintas, a saber, a teoria do erro (Stroud, Mackie e Fogelin), o quasi-realismo (Blackburn e Coventry) e o realismo (Kail) sobre a teoria causal e dos valores de Hume $^{849}$.

\footnotetext{
${ }^{848}$ Cf. T 1.4.1.8.

${ }^{849}$ Apesar disso, o debate incluía explicitamente o termo 'projeção' num leque mais amplo de autores, em virtude de se terem envolvido na discussão (cf. MACKIE, 1980a, p. 6, 18; STROUD, 1977 , pp. $45,86,87,184-5,186,239,247,260$; 1993, p. 263, 264, 267; 2006, pp. 346, 7; BROUGHTON, 1983, p. 220; STRAWSON, 1989, p. 6, 105, 150, 231, 232; PITSON, 1989; WINKLER, 2007; COVENTRY, 2006; BLACKBURN, 1993; MILLICAN, 2007a, p. 213). A exceção parece ser Wright, que comentou sobre as evidências a favor da interpretação sem se
} 
As evidências dos textos de Hume que suscitam a conclusão de que há um mecanismo projetivo são as relativas ao que Winkler bem chamou de propensão projetiva são:

[A] mente tem uma grande propensão a se espalhar pelos objetos externos, ligando a eles todas as impressões internas que eles ocasionam, e que sempre aparecem ao mesmo tempo que esses objetos se manifestam aos sentidos. ${ }^{850}$

[C]omo sentimos uma conexão habitual entre as idéias, transferimos esse sentimento aos objetos, pois nada é mais comum do que aplicar aos corpos externos todas as sensações internas que eles ocasionam. ${ }^{851}$

$[\mathrm{O}]$ gosto fornece o sentimento de beleza e deformidade [campo da estética], de virtude e vício [campo da ética] (...) [e] tem uma capacidade produtiva e, ao ornar [gilding] ou macular [staining] todos os objetos naturais com as cores que toma emprestadas do sentimento interno, erige, de certo modo, uma nova criação. ${ }^{852}$

Portanto, a interpretação projetivista define-se pelo reconhecimento da existência de um mecanismo que explica a atribuição de uma propriedade aos objetos da experiência que não são objetivas. Quer dizer, a conceção dos objetos é condicionada ou moldada pela operação da propensão projetiva, de tal forma que esta propriedade que é transferida da imaginação para aquele é incorporada no raciocínio e na linguagem, ou seja, pensa-se e fala-se nesses objetos como se detivessem estas propriedades, quando este não é o caso ${ }^{853}$. Tal como diversos comentadores da filosofia de Hume se empenharam em mostrar, este mecanismo atua tanto no caso da causalidade como dos valores. Quer dizer, de acordo com

referir explicitamente desta forma à interpretação projetivista (cf. WRIGHT, 1983, pp. 151-2; 2000, p. 94).

${ }^{850} \mathrm{~T}$ 1.3.14.25

${ }^{851}$ IEH 7.2.29n7; itálico meu.

${ }^{852}$ IPM Ap. 1.21; itálico meu . Cf. também C 15 . Note-se que nas duas primeiras citações apresentadas, Hume especifica que se atribuem as impressões internas - sugerindo a inclusão das impressões de reflexão - a objetos externos. A meu ver, estas afirmações sugerem que a propensão projetiva induz a mente a atribuir um caráter exterior e independente (da mente) a propriedades que não se mostram no próprio objeto, mas apenas na mente - onde se inclui a própria existência exterior e independente do objeto, a causalidade e os valores (apesar de esta última ser decisivamente falsa).

${ }^{853}$ Isto não significa que a atribuição da objetividade das propriedades da causalidade e dos valores seja errada - como julgam os proponentes da teoria do erro. Trata-se do mecanismo explicativo dessa atribuição. Sob a interpretação defendida neste trabalho, esta atribuição não é errada, a não ser a do caráter observável dos valores. Quanto à relação causal entre os objetos dos valores e os que simplesmente se relacionam causalmente entre si, a epistemologia de Hume não parece ter elementos para se descobrir se essas crenças são verdadeiras ou falsas, mas sim para um 
esta interpretação, tanto a relação causal entre objetos como os valores constituem propriedades que são pensadas e das quais se fala no quotidiano como se fossem observáveis ou intrínsecas (independentes da mente), quando não o são ${ }^{854}$.

Vale ainda notar que tal como Kail bem comenta, há dois sentidos em que a projeção pode ser entendida na filosofia de Hume, a saber, como processo (explanatory projection) e como conteúdo (feature projection), ou seja, pode distinguir-se o processo da projeção da projeção como conteúdo mental, quer dizer, estas seriam as duas dimensões daquilo a que se chama projeção na filosofia de Hume. No primeiro sentido, a projeção consiste na operação da propensão projetiva, que resulta na transferência de uma certa propriedade (como uma certa relação causal ou um certo valor, como a beleza ou a virtude) do campo da imaginação para o objeto percebido, fazendo com que este (concebido como exterior e independente da mente) pareça conter as propriedades que lhe são transferidas e as práticas quotidianas (de raciocínio e de discurso) se dêem como se essa propriedade fosse, de facto, objetiva. No segundo sentido, a projeção consiste no próprio objeto enquanto concebido como possuidor dessa propriedade, atribuída ao mesmo mediante a operação da propensão projetiva. Assim, pode dizer-se que a projeção como processo consiste na explicação ou razão pela qual se gera a projeção como conteúdo, ou, dito de outro modo, esta consiste no resultado do processo da operação ${ }^{855}$.

Efetivamente, a propensão projetiva atua tanto na atribuição de uma objetividade às relações causais como aos valores ${ }^{856}$. Por sua vez, esta propensão é tão natural e irresistível na mente como os princípios de associação e o hábito, pelos quais é possível estabelecer as regras gerais, que descrevem as conclusões a que uma mente atenta e empenhada retira a partir da observação de regularidades (e no caso dos juízos de valor, também sensível) conclui. Portanto, por meio da propensão a atribuir uma objetividade a propriedades que não se mostram como tais e à capacidade de estabelecer relações (naturais e filosóficas) entre os objetos

ceticismo: a impossibilidade de determinar se essas crenças são verdadeiras ou falsas. Este tópico será desenvolvido na secção 4.7 .

${ }^{854}$ Ainda assim, não deixa de ser estranho que Hume não tenha incluído esta propensão nos princípios naturais, regulares e irresistíveis da mente (cf. T 1.4.3.11). Ainda assim, alguns comentadores reconhecem-no (cf. WRIGHT, 1983, p. 154; WINKLER, pp. 65-6).

${ }^{855}$ Cf. KAIL, 2007b, pp. 3-4.

${ }^{856}$ T 1.3.14.25; IPM Ap. 1.21. 
observáveis, o próprio funcionamento da arquitetura cognitiva dos agentes e/ou espectadores proporciona-lhes um cenário fenoménico que simula aquele em que, presumivelmente, estas propriedades fossem descobertas, e não inventadas ou forjadas pela faculdade da imaginação a partir dos dados da experiência. Uma vez que estas capacidades da imaginação garantem as trocas discursivas, a atividade científica e a continuidade das crenças quotidianas, isto é, que toda a vida quotidiana se passa como se se tivesse efetivamente feito tal descoberta, proponho que se aceite que sendo configurada pela propensão projetiva e oferecendo um cenário que simula um cenário em que (presumivelmente) os objetos se comportam da maneira como julgamos que se comportam, esta intersubjetividade seja interpretada e chamada de quasi-objetividade, e que o critério ou padrão seja interpretado e chamado de quasi-objetivo.

Aliás, este sentido de simulação, forjamento ou fingimento de uma objetividade (de um "como se" estivéssemos diante de uma propriedade objetiva) constitui aquele sentido que Blackburn confere à própria posição projetivista, isto é, que o filósofo julga intrínseco à mesma. Nas suas palavras:

De acordo com o projetivismo, falamos e pensamos como se o mundo detivesse um certo tipo de factos, enquanto que a verdadeira explicação do que fazemos é que temos certas reações, hábitos e sentimentos, que expressamos e discutimos esse discurso. Hume foi, claramente, um projetivista em filosofia moral, e é plausível ver a sua metafísica da causalidade como essencialmente idêntica. ${ }^{857}$

$[\mathrm{H}]$ onramos o primeiro grande projetivista chamando de 'Projeção Humeana' o mecanismo pelo qual aquilo que inicia a vida como um estado psicológico não descritivo acaba por ser expresso, pensado e considerado sob uma forma proposicional. $^{858}$

Além disso, a interpretação projetivista adquiriu contornos diversos na literatura de comentário à filosofia de Hume. As diferentes posições que a projeção assume nas interpretações da filosofia de Hume explicam-se pelas

\footnotetext{
${ }^{857}$ Tradução minha do original: "According to projectivism we speak and think 'as if the world contained a certain kind of fact, whereas the true explanation of what we are doing is that we have certain reactions, habits or sentiments, which we voice and discuss by such talk. Hume was quite clearly a projectivist in moral philosophy, and it is plausible to see his metaphysics of causation as in essence identical." (BLACKBURN, 1993a, p. 216). Cf também 1993, p. 152, 175.

${ }^{858}$ Tradução minha do original: "[W]e honour the first great projectivist by calling 'Humean Projection' the mechanism whereby what starts life as a non-descriptive psychological state ends up expressed, thought about, and considered in propositional form.” (BLACKBURN, 1993a, p. 5).
} 
diferenças nas interpretações no que respeita às três componentes que destaquei como relevantes para compreender a teoria causal e dos valores de Hume metafísica, epistémica e semântica. Por seu turno, a constatação da existência deste mecanismo e da convicção que os agentes e/ou espectadores têm de que as propriedades transferidas são, efetivamente, objetivas, integra as componentes da interpretação que designei por epistémica e semântica ${ }^{859}$. Quer dizer, devido à transferência de uma propriedade subjetiva para o objeto, os agentes crêem na sua objetividade e é a essa propriedade que se referem quando pensam e falam sobre os objetos. Ou seja, o objeto é concebido como possuidor dessa propriedade e nas trocas discursivas, e é ao objeto concebido dessa forma que se referem e sobre o qual falam ou, eventualmente, debatem.

Nos parágrafos que se seguem, o meu primeiro objetivo é explicar de que forma, para os comentadores que mais se ocuparam desta proposta interpretativa, se dá o mecanismo da projeção. O meu segundo e último objetivo é explicar de que forma se articulam as projeções da causalidade e dos valores com as três componentes para interpretar as teorias causal e dos valores de Hume (metafísica, epistémica e semântica), de acordo com os comentadores que as propuseram.

Além das principais evidências a favor da existência da propensão projetiva, há uma outra evidência, que, para Stroud, pode ser interpretada como a explicação que Hume oferece para o funcionamento deste mecanismo ${ }^{860}$ :

[C]omo sentimos uma conexão habitual entre as idéias, transferimos esse sentimento aos objetos, pois nada é mais comum do que aplicar aos corpos externos todas as sensações internas que eles ocasionam. ${ }^{861}$

Este é talvez o aspeto mais relevante da análise de Stroud sobre a analogia entre juízos de valor e juízos sobre relações causais, pois é aquele a partir do qual o comentador discorre sobre aquilo em que consiste a projeção, ou seja, sobre o que é que, afinal, é projetado quando se ajuiza sobre o valor de um objeto ou a relação causal que mantém com outro (s). O comentador afirma que a nova criação envolvida no gosto ${ }^{862}$ consiste numa suposição de que os objetos são intrinsecamente relacionados causalmente ou intrinsecamente valiosos - de que

\footnotetext{
${ }^{859}$ Cf. CRAIG, 2000, pp. 113-14.

${ }^{860}$ Cf. STROUD, 1993, p. 259.

${ }^{861}$ IEH 7.2.29n7; itálico meu.
} 
contêm, intrinsecamente, o valor que se lhes atribui. Trata-se de transformar um sentimento numa propriedade dos objetos, ou de lhas atribuir mediante esse sentimento. A criação resultaria dessa transferência de sentimentos para os objetos, ou o seu exercício resultaria do facto de a mente se espalhar pelos objetos externos, atribuindo-lhes uma propriedade que não lhes pertence. E uma vez que se trata de uma propensão natural, Stroud julga justo interpretar este processo como mais uma cadeia causal acerca do funcionamento da mente. Dentre os textos dos vários defensores da interpretação projetivista ${ }^{863}$, a que parece mostrar esta consideração de forma mais clara $\mathrm{e}^{864}$ :

[É] essa impressão, ou aquilo de que constitui uma impressão, aquilo que, de alguma forma, "nos espalhamos" nos, "transferimos" para ou "conjugamos" com os objetos diante de nós e, assim, passamos a "imaginar" ou "supor" que estão causal ou necessariamente conectados. No caso da moral, primeiro, o entendimento descobre e julga as questões de facto relevantes no caso, e depois, a partir da contemplação do todo, sente alguma nova impressão de afeção ou repulse, estima ou desprezo, aprovação ou reprovação [T 1.3.12.6; IPM 1.11]. De novo, há uma certa "propensão" em ação, que começa a partir da impressão ou sentimento e, de alguma forma, nos leva além do que nos chega apenas pela observação e pelo entendimento. Trata-se da imaginação, que, em todos estes casos, exibe (...) [a] "nova criação" [que, eventualmente, resulta numa] conceção do mundo como contendo ações boas e más, caracteres admiráveis e desprezíveis e objetos belos e feios. É apenas porque temos, naturalmente, certos sentimentos e impressões e, mais importante ainda, apenas por causa da "faculdade produtiva" da mente para "ornar e macular" o mundo com aquilo que esses sentimentos nos dão, que algum dia podemos pensar dessa maneira. (...) Hume estabelece o mesmo paralelo para explicar a formação dos juízos morais e estéticos que estabeleceu, anteriormente, para a conexão necessária. ${ }^{865}$

\footnotetext{
${ }^{862}$ Cf. IPM Ap. 1.21.

${ }^{863}$ Stroud, Mackie, Fogelin, Blackburn, Coventry e Kail.

${ }^{864}$ Cf. também STROUD, 1977, p. 240; BLACKBURN, 1993a, p. 5 (citada acima); COVENTRY, 2006, COVENTRY, 2006, 3.5; p. 44-5, 51, 139; FOGELIN, 1985, p. 143; MACKIE, 1980b, p. 71; KAIL, 2007b, pp. 222, 261-2.

${ }^{865}$ Tradução minha do original: "[I] th that impression, or what it is an impression of, that we somehow "spread" on or "transfer" to or "conjoin" with the objects now before us, and so come to "imagine" or "suppose" that they are causally or necessarily connected. In the case of morals, the understanding first discovers and judges the relevant matters of fact in the case, and then "the mind, from the contemplation of the whole, feels some new impression of affection or disgust, esteem or contempt, approbation or blame" [T 1.3.12.6; IPM 1.11]. There is again a certain "propensity" at work which starts from that impression or sentiment and somehow takes us beyond the deliverances of observation and the under-standing alone. It is the imagination which in all these cases exhibits (...)[t]he "new creation" [which, eventually, result in] a conception of a world containing good and evil actions, admirable and contemptible characters, and beautiful and ugly objects. It is only because we naturally get certain feelings or impressions, and, even more
} 
Como consequência da operação desta 'faculdade produtiva', os agentes e/ou espectadores são tão incapazes de conceber um certo objeto ou ato separado do valor que lhe é atribuído como a ocorrência de uma causa sem o seu efeito ou vice-versa. Com efeito, Hume admite que mesmo não sendo logicamente impossível a existência e ocorrência de um objeto sem a (s) de outro, ou sendo esta (s) apenas empiricamente necessária (s), ao formar determinadas crenças sobre relações causais entre diversos objetos, a mente torna-se quase tão incapaz de conceber o seu contrário (que é sempre possível) como se se tratasse de uma necessidade demonstrativa:

É natural que os homens, em seu modo comum e descuidado de pensar, imaginem perceber uma conexão entre os objetos que constataram estar constantemente unidos; e como o costume tornou difícil separar idéias, eles tendem a imaginar que essa separação é em si mesma impossível e absurda. ${ }^{866}$

De resto, tanto Hume como todos estes comentadores reconhecem a impossibilidade de os agentes e/ou espectadores recusarem um assentimento às convicções geradas pelas propensões mais naturais da mente (tais como a propensão projetiva). Com efeito, ao reconhecer uma distinção entre a posição do vulgo e do filósofo em relação à objetividade de propriedades como a causalidade ou as propriedades percebidas pelos sentidos, Hume afirma que o filósofo rapidamente se distrai da conclusão de que as propriedades em questão não são observáveis e que se tratam de propriedades transferidas da imaginação para os objetos observados $^{867}$ :

Felizmente ocorre que, sendo a razão incapaz de dissipar [as nuvens do ceticismo], a própria natureza o faz, e me cura dessa melancolia e delírio filosóficos, tornando mais branda essa inclinação da mente, ou então fornecendo-me alguma distração e alguma impressão sensível mais vívida, que apagam todas essas quimeras. Janto, jogo uma partida de gamão, converso e me alegro com meus amigos; após três ou quatro horas de diversão, quando quero retomar essas especulações, elas me

importantly, only because of the mind's "productive faculty" in "gilding or staining" the world with what those feelings give us, that we ever come to think in those ways at all. (...) Hume draws the same parallel to explain the formation of moral and aesthetic judgments as he drew earlier with thoughts of necessary connection.” (STROUD, 1993, p. 259).

$866 \mathrm{~T}$ 1.4.3.9.

${ }^{867}$ Cf. CRAIG, 2000, pp. 116-17. 
parecem tão frias, forçadas e ridículas, que não me sinto mais disposto a levá-las adiante. ${ }^{868}$

Em relação à afinidade que os juízos causais mantêm com os juízos de valor e à dúvida que se poderia ter sobre a aplicabilidade desta evidência à questão da convicção na objetividade dos valores, vale notar que em nenhuma delas se encontra uma reflexão ou movimento textual que permita explicar como, a partir das palavras de Hume, se pode concluir que o filósofo estaria comprometido com a aceitação de que tanto a causalidade como os valores (estético e moral) são projetivos. Por esta razão, e apesar de quase todos os comentadores mencionados ${ }^{869}$ terem defendido aquela afinidade de forma explícita e de Stroud se ter esforçado por explicar, vale acrescentar essa reflexão que não está presente nas suas contribuições, com base numa comparação dos próprios termos empregues pelo filósofo nessas evidências textuais, que suportam aquela conclusão.

Com efeito, o facto de Hume afirmar que a propensão projetiva induz a mente a atribuir aos objetos não apenas a causalidade, mas também sons e odores $^{870}$ sugere que coloca as propriedades sensíveis no campo das projeções, isto é, no campo das propriedades que não são objetivas, mas que mesmo assim são atribuídas aos objetos. Por outro lado, o filósofo afirma que os valores são comparáveis a propriedades sensíveis como a cor, o calor ou o som $^{871}$. Assim, Hume atesta que os valores são comparáveis às propriedades sensíveis, pelo facto de não constituírem propriedades observáveis e independentes da mente e que a causalidade e as propriedades sensíveis constituem projeções, pelo facto de serem atribuídas aos objetos mesmo não constituindo propriedades observáveis e independentes da mente ${ }^{872}$. E se se aceitar que a propensão para supor a existência da causalidade objetiva é a mesma que explica a suposição da objetividade dos valores, e se essa propensão for encarada como natural, os seus efeitos devem ser igualmente prementes na mente.

\footnotetext{
$868 \mathrm{~T}$ 1.4.7.9.

${ }^{869}$ Stroud, Mackie, Fogelin e Kail.

${ }^{870}$ Cf. T 1.3.14.25; 3.3.1 deste trabalho.

${ }^{871} \mathrm{Cf}$. T 3.1.1.26; 3.1.1 deste trabalho.

${ }^{872}$ Tal como apresentei ao longo do capítulo 3 deste trabalho, esta comparação serviu à defesa de diversas posições sobre o estatuto metafísico e epistémico dos valores.
} 
Passo agora ao segundo objetivo da exposição da noção e funcionamento da propensão projetiva na filosofia de Hume, a saber, a explicação de como os seus proponentes a harmonizam em interpretações mais amplas nas teorias causal e dos valores do filósofo. Stroud e Mackie - pioneiros no apelo às evidências sobre a existência de uma propensão projetiva - integram a noção de projeção na interpretação da teoria do erro ${ }^{873}$.

Em relação à componente metafísica, os comentadores adotam uma posição anti-realista em sobre causalidade e aos valores, quer dizer, julgam que na fillosofia de Hume, a causalidade se reduz à regularidade observável e os valores não constituem propriedades objetivas. Em relação à componente epistémica, julgam que a causalidade, tal como pode ser conhecida, se reduz à regularidade observável (sendo este o objeto de conhecimento sobre questões de facto) e os valores não constituem questões de facto, razão pela qual os juízos sobre valores não são verdadeiros nem falsos, contrariamente às proposições sobre relações causais. Em relação à componente semântica, os comentadores julgam que uma vez que os juízos sobre valores não são verdadeiros ou falsos (ao contrário das proposições sobre relações causais, que podem sê-lo), estes juízos não são genuinamente descritivos, mas sim expressivos. Porém, ao reconhecerem a operatividade da propensão projetiva na convicção sobre a objetividade dos valores, os comentadores consideram que os agentes permanecem numa ilusão, erro ou ficção de que a causalidade não se reduz à regularidade observável e os valores são propriedades intrínsecas dos objetos, isto é, independentes da mente. Para estes comentadores, a projeção constitui um erro e a crença na objetividade da causalidade e dos valores é falsa, uma vez que os objetos não possuem essas propriedades.

Tal como apresentei em 3.2.4, este aspeto da interpretação é o que diferencia a proposta dos projetivistas das propostas psicologista ou disposicionaldescritivismo e do emotivismo (como lhes chamavam Stroud e Mackie), tal que os juízos (tanto sobre valores como sobre relações causais) descrevem ou são acerca de uma suposta propriedade dos objetos que não lhes pertence ou que eles não possuem - e por isso projeções são, para aqueles autores, ficções ${ }^{874}$.

\footnotetext{
${ }^{873}$ Cf. 3.2 .4 e 3.2 .5 deste trabalho.

${ }^{874}$ Cf. STROUD, 1977, p. 244, 246, 250; MACKIE, 1980b, pp. 71-2.
} 
Já Coventry concorda com os teóricos do erro na defesa de uma componente metafísica anti-realista. Em relação à componente semântica, também concordam com aqueles em relação à consideração de que os juízos sobre valores têm um caráter expressivo (emotivismo), mas que os agentes concebem os objetos e referem-se aos mesmos como se tais propriedades fossem intrínsecas. Porém, em relação à consideração de que essa convicção constitui um erro, discordam de Stroud e Mackie. Esta discordância é motivada pela consideração de que os juízos sobre valores - tal como os causais - possuem um valor de verdade genuíno, do que se segue que aqueles juízos não são destituídos de um valor de verdade. $\mathrm{Ou}$ seja, o facto de Coventry (a partir da filosofia de Blackburn, e seguindo a sua interpretação sobre a filosofia de Hume) propor um critério sob o qual tanto os juízos sobre relações causais como os juízos sobre valores possuem um valor de verdade genuíno (pela descoberta de regras gerais sobre os domínios em questão, a saber, as ciências naturais, a Moral e a Crítica) motiva a sua discordância em relação ao caráter erróneo ou fictício da projeção. Como explica a comentadora, os critérios para determinar o valor de verdade de ambos os tipos de juízos são estabelecidos por meio do exercício da faculdade da imaginação e resultam da formulação de regras gerais e da possibilidade de formulá-las ${ }^{875}$.

Para Kail, na filosofia de Hume, aceitar que a causalidade e os valores são projeções (propriedades que são atribuídas aos objetos como intrínsecas sem que sejam observadas nos mesmos) não é incompatível com a defesa de uma interpretação realista, segundo a qual essas propriedades pertencem efetivamente (pelo menos, em parte) aos objetos. Por essa razão, apesar de concordar com os teóricos do erro na componente projetivista da sua interpretação, discorda da sua consideração de que a projeção constitui um erro. Quer dizer, ao contrário daqueles comentadores, julga que a crença na objetividade destas propriedades não constitui um erro. Assim, a interpretação de Kail pode ser descrita em duas componentes: i) a causalidade e os valores são projeções e ii) essas propriedades são, efetivamente, objetivas (pelo menos em parte, no caso dos valores). Portanto, a primeira componente descreve a posição projetivista (partilhada com os

\footnotetext{
${ }^{875}$ Cf. COVENTRY, 2006, pp. 30, 42-4, 138.
} 
defensores da teoria do erro) e a segunda, a posição contrária à que estes comentadores defendiam (anti-realista) ${ }^{876}$.

Antes de descrever a solução deste comentador, há que fazer um breve esclarecimento. Stroud e Mackie não se preocuparam em estabelecer a distinção entre i) crer na objetividade da causalidade e dos valores (no sentido de independentes da mente) e ii) crer no seu caráter observável, uma vez que defendem uma interpretação anti-realista sobre a causalidade e os valores. Quer dizer, para estes comentadores, a crença forjada pela propensão projetiva é falsa porque os objetos não possuem as propriedades que lhes são atribuídas - sejam elas observáveis ou não. Portanto, a crítica à operação da propensão projetiva acompanha simultaneamente a crítica ao racionalismo e ao realismo sobre a causalidade e os valores. Coventry não concorda com a atribuição de um caráter fictício ou falso à crença na objetividade dos valores, mas devido à falta desta distinção, não se confronta diretamente com a pertinência desta atribuição no caso da crença no caráter observável dessas propriedades. Quer dizer, com a preocupação de propor um certo grau de objetividade (que, a meu ver, se designa melhor por intersubjetividade ${ }^{877}$ ), esta crítica passa despercebida. É justamente a partir deste aspeto que se pode compreender a tentativa de compatibilizar a interpretação projetivista e realista sobre as teorias causal e dos valores de Hume por parte de Kail.

Tendo esta distinção presente, Kail nota que ambas são forjadas pela propensão projetiva. Porém, para o comentador, apenas a segunda crença é falsa, pois como Hume se esforçou por mostrar, a causalidade e os valores não constituem propriedades observáveis nos objetos, mas resultam de paixões (no caso dos valores) e da operação da faculdade da imaginação e das relações que esta é capaz de estabelecer (tanto no caso da causalidade como dos valores). Por seu turno, julga que a crença na objetividade da causalidade e dos valores (a primeira) - no sentido de os objetos, em si mesmos e independentemente da

\footnotetext{
${ }^{876}$ Cf. 2.2.3, 2.3.7, 3.2.4 e 4.4 deste trabalho.

${ }^{877}$ Seguindo a terminologia e a proposta de Mackie, de que 'objetividade' se refere a propriedades dos objetos que sejam independentes da mente, e de que 'intersubjetividade', por definição, não pode ser considerada uma forma de objetividade, por mais que envolva valor de verdade e conhecimento (cf. MACKIE, 1977, p. 22; 3.1.2 deste trabalho). Neste caso, trata-se, justamente, de um plano de verdade e de conhecimento baseado num critério intersubjetivo.
} 
mente, serem detentores destas propriedades - é verdadeira, razão pela qual não se considera um teórico do erro.

Em relação à causalidade, Kail julga que apesar de não ser observável (como o concebe o senso comum), a causalidade - definida como um poder entre dois objetos tal que seria cognoscível a priori e o seu contrário seria inconcebível (portanto, envolveria uma contradição) - existe. Por um lado, a justificação que se teria para chegar a esta conclusão é que de acordo com o PP, o contrário da conjunção dos objetos (que supostamente se relacionam causalmente) é possível, em virtude de ser concebível. Porém, uma consequência da restrição deste princípio ao campo das ideias adequadas é que apenas se pode determinar a possibilidade ou impossibilidade daquilo de que se tem uma ideia clara, ou seja, que constitui a cópia de uma impressão. A propensão projetiva teria a função de colmatar esta falha epistémica da mente. Deste modo, mantém-se a componente cética da interpretação do realismo cético (sobre a teoria causal de Hume) - um ceticismo epistémico, quer dizer, a conclusão sobre a impossibilidade de conhecer a causalidade objetiva. Por outro lado, o reverso da conclusão sobre a insuficiência do PP para determinar se a causalidade objetiva existe é que a possibilidade contrária se mantém. Quer dizer, se as faculdades da mente proporcionassem um acesso à mesma por meio de uma ideia clara, confirmar-se-ia uma das duas hipóteses metafísicas.

Uma vez que tal não é possível, não se pode descartar a possibilidade de a causalidade objetiva não existir. Apesar disso, a propensão projetiva é de tal forma natural que impele a mente à crença de que a causalidade objetiva existe, atuando como processo mimético, que simula um cenário fenoménico em que seria possível o conhecimento dessa causalidade (por ideias claras). A esta inclinação, Kail chama de preferência metafísica, uma assunção ou pressuposto inquestionado - mantendo-se, assim, a componente metafísica da interpretação do realismo cético (sobre a teoria causal de Hume) ${ }^{878}$.

${ }^{878}$ Cf. KAIL, 2003a, p. 47, 49, 51, 54; 2007a, p. 261; 2007b, pp. 106-8, 110-16, 117, 120, 123 , $169,218,223,228,232,242-3 ; 2.2 .2$ e 2.2.6 deste trabalho. Por seu turno, Kail comenta que o hábito e a disposição psicológica que decorre deste e que determinam a mente a esperar que o futuro seja como fora o passado mimetiza um acesso adequado à causalidade i) pela imediatez ou caráter não reflexivo da transição da ideia da causa para a do efeito e ii) pela incapacidade de conceber uma sem a outra quase como se se tratasse de uma impossibilidade lógica. Deste modo, há duas tendências ou mecanismos naturais ou instintivos que substituem a faculdade intelectual de que os racionalistas dispunham para explicar o conhecimento da causalidade objetiva, a saber, 
Em relação aos valores, Kail julga que a propensão projetiva gera uma crença no caráter independente dos valores (em relação à mente e aos agentes) paralela à crença na objetividade e caráter observável da causalidade. Porém, contrariamente ao que ocorre no caso da causalidade, para Kail, a crença na objetividade dos valores é falsa, pois não constituem propriedades intrínsecas dos objetos (assim como não são propriedades exclusivamente subjetivas), mas sim propriedades relacionais - que existem mediante a relação ou contacto entre os agentes e os objetos. Quer dizer, apesar de a natureza dos juízos de valor ser emotiva e não cognitiva, os objetos sobre os quais se ajuíza têm de possuir certas propriedades suscetíveis de serem detetadas pela mente mediante um contacto com as mesmas para que se efetive a atribuição do valor ao mesmo, que se pode descobrir pela obtenção do ponto de vista desinteressado - o que está de acordo com a posição que Hume atribui à filosofia moderna em relação às qualidades secundárias (com as quais Hume compara os valores) e a conceção dos valores como resultado de uma relação causal entre certos traços dos objetos e a mente. A crença na sua objetividade é parcialmente falsa, sendo substituída pela conclusão moderada de que os valores não são inteiramente objetivos nem subjetivos, mas sim propriedades relacionais - posição que chama de realismo mitigado. Portanto, para Kail, se no caso da causalidade a propensão projetiva tem o papel de simular um acesso à mesma por meio de ideias claras e de colmatar uma falha epistémica dos agentes, no caso dos valores, a projeção tem a função de tornar salientes as qualidades do objeto, mesmo gerando a convicção de que os valores constituem propriedades objetivas - o que, aliás, não é surpreendente, se se admitir que é a mesma propensão que gera a convicção na existência da causalidade objetiva.

$\mathrm{Na}$ próxima secção, explico porque se pode aceitar que a filosofia de Hume abriga a existência de ideias relativas, e que entre estas ideias, estão aquelas que são forjadas pela propensão projetiva.

i) a automatização da transição fácil, e ii) a incapacidade de conceber causa e efeito separadamente. (cf. KAIL, 2007a, p. 258; 2007b, pp. 86-7, pp. 106-8). 


\subsection{Conceção (ideia adequada) e suposição (ideia relativa)}

O primeiro objetivo desta secção é indagar se a conceção de Hume de ideia relativa corresponde à que Locke e Berkeley tinham da mesma (cf. 1.2 deste trabalho), e em que medida esta é parte fundamental de uma interpretação cética sobre as teorias causal e dos valores de Hume. Para tal, reúno duas discussões que se desenvolveram de forma independente, a saber: i) sobre os requisitos que perfazem uma ideia clara; ii) sobre aquilo em que consiste uma ideia relativa na fillosofia de Hume e se o filósofo aceitava pacificamente a existência destas como algo distinto das perceções. O segundo objetivo consiste em mostrar quais as implicações da teoria das ideias na filosofia de Hume sobre o PP e, por sua vez, de que forma a teoria das ideias de Hume tal como esclarecida nesta secção abona decisivamente a favor de uma interpretação cética da mesma filosofia, por contraste com uma interpretação realista ou anti-realista, em relação aos objetos que excedem o escopo das possibilidades de observação. O terceiro objetivo é mostrar que esta interpretação tem como consequência, na teoria dos valores de Hume, que as ideias do padrão para os juízos (a natureza humana) e da relação causal entre a mente e o objeto do juízo de valor também devem ser interpretadas como relativas.

Para se compreender em que consiste, ao certo, uma ideia relativa na filosofia de Hume, vale começar pela constatação de que se se reconhece que apenas existem na mente ideias que correspondam diretamente a impressões, não se poderia pensar em nada que possuísse relações distintas daquelas que se estabelecem aos objetos efetivos das impressões.

Com efeito, Hume reconhece a existência de tais ideias ${ }^{879}$. Se assim não fossem, não seria possível, por exemplo, pensar na centésima parte de um grão de areia, para depois concluir que não se pode concebê-lo. Quer dizer, se elas fossem cópias perfeitas de impressões, seria misteriosa a sua exclusão do campo das ideias com sentido (como vimos que Hume faz ao restringir o campo do sentido às

\footnotetext{
${ }^{879}$ Cf. FLAGE, 2007, p. 146. Como Yolton nota, ao considerar que não é possível conceber um grão de areia de um tamanho que já não fosse visível aos olhos de um ser humano funcional, Hume não está a dizer que a partir de um certo ponto, todas as ideias têm a mesma configuração (por exemplo, um polígono com 1000 lados e um com 1001 lados, e assim por diante) ou o mesmo tamanho (por exemplo, a centésima parte de um grão de areia e a centésima-primeira parte do mesmo grão, e assim por diante; cf. YOLTON, 1980, p. 8).
} 
ideias copiadas de impressões), pois para descobri-lo, bastaria resgatar o conjunto concreto de ideias adequadas ao qual se reduzem ${ }^{880}$. Além disso, as ideias relativas seriam passíveis de uma clarificação, isto é, poderiam deixar de ser confusas e tornar-se claras em virtude da apresentação da coleção de ideias adequadas que as compõem. Com isto, seria possível deixar de ter as ideias de causalidade objetiva, de objeto externo, por meio dessa correção - o que contradiz a afirmação de Hume sobre a sua naturalidade e inevitabilidade.

Resta descobrir o que configura essas noções e se merecem a designação de ideias (no sentido genuíno). Por conseguinte, será possível indagar sobre o seu caráter inteligível ou ininteligível.

Se se atentar apenas para o facto de Hume restringir o campo das ideias claras às ideias que provêm de impressões, e se pensar que as ideias relativas são todas aquelas que não são adequadas, tem-se que uma ideia é relativa a partir do momento que se somam relações a essas impressões. Nesse caso, qualquer ideia sobre a qual se estabelece uma relação tem de ser considerada relativa, pois qualquer movimento de ultrapassagem do campo das impressões configuraria a formação de uma tal ideia.

Nesse sentido, ao definir as ideias da memória como aquelas em que 'uma impressão complexa é a causa original de uma ideia positiva particular e que se lhe assemelha' ${ }^{881}$, Flage notou que uma definição das ideias relativas simplesmente a partir do estabelecimento de relações sobre as perceções teria como consequência que até estas ideias das mesmas (a partir das relações de anterioridade temporal e semelhança com as impressões) teriam de ser consideradas relativas ${ }^{882}$. O simples armazenamento das ideias já envolve relações de semelhança, de anterioridade temporal e de causalidade, assim como, de forma oblíqua, a formação de qualquer ideia da imaginação fancy. Por exemplo, a ideia

\footnotetext{
${ }^{880}$ Vale notar que Yolton desconfia da exclusividade da pictorialidade como critério de conceção de ideias (não ideias claras, mas ideias no geral), alegando que noções como as da geometria e o PP não podem ser consideradas ideias copiadas de impressões (cf. YOLTON, 1980, pp. 4-5). Porém, não chega a avançar que uma categoria alternativa para as ideias copiadas de impressões seria a de 'ideia relativa', tampouco que estas constituem ideias relativas.

${ }^{881}$ Paráfrase da seguinte definição, no original: "'the complex impression that is the (original) cause of a particular positive idea ' $\mathrm{m}$ ' and which exactly (or closely) resembles ' $\mathrm{m}$ '" where ' $\mathrm{m}$ ' is a variable ranging over positive ideas (mental images)" (FLAGE, 1984, p. 168).

${ }^{882}$ Cf. FLAGE, 1984, pp. 171-3; 1985, p. 173. A posição que Flage apresenta no seu artigo de 2007 (incluído na reedição do New Hume Debate) corresponde a uma revisão da sua posição inicial, a saber, de que na filosofia de Hume, as ideias da memória são, de facto, ideias relativas.
} 
de um unicórnio parte necessariamente pelo menos de uma comparação com a ideia de cavalo e a sua presença na minha mente implica que tenha alguma ideia de cavalo adquirida por uma impressão no passado.

Além disso, uma vez que Hume considera concebível qualquer conjunto de ideias de questões de facto concebível, certas ideias claras seriam simultaneamente também ideias relativas: claras em virtude do critério de inteligibilidade das conceções genuínas (a precedência por impressões) e relativas em virtude do facto de integrarem uma relação. Tal seria o caso das lembranças, da regularidade observável e das ideias da imaginação fancy (por simples combinação).

Porém, esta definição de ideia relativa entra em contradição com as palavras mais explícitas de Hume sobre as ideias relativas (ou suposições), a saber, que são "especificamente diferentes de nossas percepções", não são compreendidas (pois não respeitam a nenhuma impressão) e que, ao formar essas suposições, se "apenas atribuímos relações, conexões e durações diferentes [aos objetos especificamente diferentes das impressões]" ${ }^{, 883}$.

Entretanto, pode pensar-se que o significado de "especificamente diferente das nossas perceções" pode significar i) diferente das perceções que efetivamente detemos ou ii) ser diferente de uma perceção. Seguem-se duas razões pelas quais a segunda hipótese é mais razoável.

Como Friedman bem apontou a Flage, Hume jamais reconheceu este caráter às ideias da memória ${ }^{884}$. E pode acrescentar-se que também nunca o admitiu em relação a ideias da regularidade observável nem às ideias da imaginação fancy. As únicas ideias às quais Hume atribui explicitamente um caráter relativo são a ideia de causalidade objetiva e de objeto externo. Relembrem-se as respetivas evidências textuais:

O mais longe que podemos chegar no que diz respeito à concepção de objetos externos, quando se os supõe especificamente diferentes de nossas percepções, é formar deles

\footnotetext{
${ }^{883}$ Cf. T 1.2.6.9, ou ainda "relações, contradições e concordâncias entre ideias" (cf. T 1.2.2.1).

${ }^{884}$ Cf. FRIEDMAN, 1993, p. 182. A discussão em torno da questão de saber se as ideias da memória podem e devem ser consideradas relativas estendeu-se a outras questões mais específicas, tais como se a memória contém ideias simples ou se o critério de força e vivacidade esgota a distinção entre as ideias da memória e da imaginação. Para um acesso à discussão completa, cf. FLAGE, 1984, 1985, 1989; FRIEDMAN, 1993a, 1993b; TRAIGER, 1985.
} 
uma idéia relativa, sem pretender compreender os objetos relacionados. ${ }^{885}$

[A] ideia de poder é tão relativa quanto a de causa, e ambas contêm uma referência a um efeito ou a outro acontecimento que está constantemente conjugado ao primeiro. ${ }^{886}$

Além disso, pode acrescentar-se uma razão teórica forte para negar que as ideias relativas constituam simplesmente ideias constituídas pelo relacionamento das ideias. Trata-se dos experimentos de pensamento aos quais Hume faz referência para explicar que a ideia de causalidade - além da regularidade - não é observável nem demonstrável, que levam à conclusão de que a ideia de causalidade é criada pela faculdade da imaginação. Recorrendo ao PP, Hume resgata os requisitos da separabilidade e de contradição para afirmar que qualquer conjunção de questões de facto é clara e distintamente concebível e, por conseguinte, concluir que qualquer coisa pode causar qualquer coisa:

Quando vejo, por exemplo, uma bola de bilhar movendo-se em linha reta em direção a outra, mesmo supondo-se que o movimento da segunda bola seja acidentalmente sugerido à minha imaginação como resultado de seu contato ou impulso, não me seria porventura possível conceber uma centena de outros diferentes resultados que se seguem igualmente bem daquela causa? Não poderiam ambas as bolas permanecer em absoluto repouso? Não poderia a primeira bola recuar em linha reta ou saltar para longe da segunda em qualquer curso ou direção? Todas essas suposições são consistentes e concebíveis. Por que, então, deveríamos dar preferência a uma suposição que não é mais consistente ou concebível que as demais? Todos os nossos raciocínios a priori serão para sempre incapazes de nos mostrar qualquer fundamento para essa preferência. ${ }^{887}$

Tudo o que é pode não ser. Nenhuma negação de um fato pode envolver uma contradição. A não-existência de um ser qualquer é, sem exceção, uma idéia tão clara e distinta quanto sua existência. A proposição que afirma que ele não existe, embora falsa, não é menos concebivel e inteligível do que a que afirma que ele existe. $\mathrm{O}$ caso é diferente com as ciências propriamente ditas. Nelas, toda proposição que não é verdadeira é confusa e ininteligível. Que a raíz cúbica de 64 é igual à metade de 10 é uma proposição falsa e não pode jamais ser distintamente concebida. Mas que César, ou o arcanjo Gabriel, ou outro ser qualquer jamais tenha existido, pode ser uma proposição falsa,

\footnotetext{
${ }^{885}$ T 1.2.6.9; itálico meu.

${ }^{886}$ IEH 7.2.29n7.

${ }^{887}$ IEH 4.1.10; itálico meu.
} 
mas é ainda assim perfeitamente concebivel e não implica nenhuma contradição.

Portanto, a existência de um ser qualquer só pode ser provada por argumentos que partam de sua causa ou de seu efeito; e argumentos desse tipo fundam-se inteiramente na experiência. Se raciocinarmos a priori, qualquer coisa pode parecer capaz de produzir qualquer coisa. ${ }^{888}$

Com efeito, ao considerar a ideia do contrário da existência de César - a sua não existência - uma ideia clara e distinta, Hume mostra não considerar que qualquer ideia concebida a partir de uma relação (neste caso, de contrariedade) deva ser considerada relativa. Tampouco aquela ideia provém da experiência, pois a negação da existência de César (mesmo se tivéssemos vivido para estar em condições de observá-lo) não é observável. Da mesma forma, em relação ao exemplo do choque das bolas de bilhar, Hume afirma que eventos alternativos são tão concebíveis como o evento regularmente observado - o choque entre as bolas e subsequente movimento -, de onde se percebe o recurso aos mesmos requisitos que no exemplo anterior para mostrar a possibilidade da ocorrência do contrário do evento em questão. $\mathrm{O}$ apelo a ideias que se referirem a objetos observáveis (como César ou as bolas de bilhar) para mostrar a contingência das regularidades causais mostra que Hume considerava estas ideias adequadas (e lembre-se que o PP se restringe a ideias claras).

Ora, da mesma forma que os eventos alternativos aos observados, também as ideias da memória pelas quais se concebe claramente o evento cuja repetição de facto se espera têm de ser consideradas claras. Caso contrário, não se poderia comparar a conceção do choque das bolas de bilhar, ou do pôr-do-sol ou qualquer questão de facto com o seu contrário.

Portanto, Hume não poderia manter-se fiel ao PP nem fazer uso do mesmo nestes exemplos se não considerasse claras e distintas as ideias da memória, da imaginação fancy (como a existência do arcanjo Gabriel, pelo menos para quem nunca viu um) e da causalidade. O que estas ideias mantêm em comum é o facto de se referirem a objetos que foram ou poderiam ser observados (como, respetivamente, o pôr-do-Sol ou César). Neste sentido, Flage sugere que se chame as ideias claras aquelas que têm um conteúdo pictórico, e que as ideias relativas

\footnotetext{
${ }^{888}$ IEH 12.3.28-29; itálico meu.
} 
se designem por ideias que não têm um conteúdo puramente pictórico ${ }^{889}$. Neste sentido, uma ideia relativa seria, então, uma ideia cujo conteúdo não constitui apenas ou não se esgota nas impressões, o que significa, para Flage, que "não contém nenhuma imagem (...) da entidade que sinaliza, e que se refere a esta coisa da qual não se tem uma ideia positiva" ${ }^{\$ 90}$, e que "sinaliza um objeto como aquilo que mantém uma determinada relação com um objeto concebido diretamente (uma ideia positiva)" ${ }^{\prime 891}$. Deste modo, a noção de ideia relativa na filosofia de Hume parece ser a mesma que nas filosofias de Locke e Berkeley, a saber, de um objeto desconhecido em virtude de não se possuir uma ideia clara do mesmo e, portanto, sobre cuja existência não se tem certeza ${ }^{892}$.

Vale notar que esta definição deixa transparecer a necessidade (ou, pelo menos, a pertinência) de dois requisitos para que as memórias, a regularidade observável e as ideias da imaginação fancy não sejam incluídas no campo das ideias relativas, a saber: i) não ter apenas um conteúdo imagético e ii) a relação não ser estabelecida apenas sob esse conteúdo imagético (como é o caso daquelas ideias $)^{893}$. Se se aceitar esta sugestão, torna-se mais razoável aceitar que as ideias relativas não são de impressões, e que o que Hume entende por algo ser “especificamente diferente" das perceções seja não constituir uma perceção.

Dado que se tem ideias mediante as relações que são estabelecidas pela imaginação ${ }^{894}$, nem todas as ideias provêm de impressões. Porém, o que define se a ideia é adequada ou relativa é remeter ou não diretamente para uma possível impressão. Portanto, ainda que as relações estabelecidas sobre as impressões não estejam dadas na própria impressão, o que torna as ideias adequadas é o facto de corresponderem a impressões - mesmo no caso da causalidade, em que Hume oferece duas definições da mesma a partir do que é observável pelos sentidos (a regularidade observável e a determinação da mente a passar de uma ideia para

\footnotetext{
${ }^{889}$ Cf. FLAGE, 1982, p. 164, 168-169.

${ }^{890}$ FLAGE, 1982, p. 164.

${ }^{891}$ FLAGE, 2007, pp. 145-6.

${ }^{892}$ Cf. FLAGE, 2007, p. 146; KAIL, 2007b, p. 95; 1.6 deste trabalho.

${ }^{893} \mathrm{O}$ facto de a definição de ideia puramente pictórica / não puramente pictórica não deixar claros estes requisitos pode explicar-se pelo facto de que desde 1981 (quando o propôs pela primeira vez) até ao artigo de 2007, Flage defendia com a maior convicção que aquelas ideias são relativas. Assim, este esclarecimento permite compatibilizar a noção de 'puramente pictórico' com a proposta final de Flage, de que aquelas ideias devem ser excluídas do campo das ideias relativas deixando implícito que seriam consideradas claras.

${ }^{894}$ Cf. T 1.1.4.7; $\mathrm{T}$ 1.1.5.1.
} 
outra de maneira suave e insensível). Mas se as relações forem empregues para construir a noção de um objeto apenas a partir de relações que não se mantêm entre os objetos observáveis (como a causalidade objetiva e um substrato exterior e independente dos objetos da perceção), é pelo facto de este objeto construído por meio das relações estar relacionado com as impressões (no primeiro caso, explicando a regularidade, e no segundo, causando impressões tão indistinguíveis que se crê tratar-se de um só e mesmo objeto ${ }^{895}$ ) que se mantém nelas um resquício de um conteúdo pictórico.

Portanto, o que distingue uma ideia clara (uma conceção genuína) de uma ideia relativa ou confusa (uma suposição) é a presença (no primeiro caso) ou ausência (no segundo caso) de ideias de objetos que, pelo menos, poderiam ser observados, devido ao seu conteúdo pictórico ou imagético (como a cidade do Rio de Janeiro ou montanhas douradas).

Deste modo, o princípio de contradição constituir um requisito para que se considere que uma ideia é concebida claramente, este constitui um entre outros requisitos (nomeadamente, o leque de ideias simples disponível para o agente, a memória e o PS). Além disso, este parece ser, na filosofia de Hume, o único pelo qual se estabelece uma barreira nas possibilidades metafísicas, isto é, que permite demarcar a impossibilidade - pois Hume considera impossível o que é contraditório $^{896}$.

Nos parágrafos que se seguem, explico de que modo a restrição do PP ao escopo das ideias claras - que não se esgota no pensamento que não envolve contradição - justifica uma interpretação cética de Hume em relação à existência da causalidade objetiva.

De acordo com o PP, pode determinar-se o que é (metafisicamente) possível a partir do que se pode conceber claramente. Quer dizer, a clareza de uma ideia constitui um critério para determinar o que pode existir, ou ter uma ideia clara de um certo objeto autoriza a conclusão de que a sua existência é possível ${ }^{897}$.

Porém, o mesmo não ocorre no caso das evidências textuais em que Hume afirma que ser inconcebível implica a impossibilidade da existência dos objetos

\footnotetext{
${ }^{895}$ É por esta razão que apesar de se basear em relações que são, costumeiramente, estabelecidas pelo entendimento às perceções, as ideias confusas ou relativas devem ser todas atribuídas à imaginação fancy, e não à imaginação como faculdade geral de associar ideias.

${ }^{896}$ Cf. T 1.2.2.1.
} 
em questão, que não são unívocas. Por um lado, Hume parece conceder que $\operatorname{sim}^{898}$ :

Quando as idéias representam adequadamente seus objetos, todas as relações, contradições e concordâncias entre elas são aplicáveis também a estes. Tal é (...) o fundamento de todo o conhecimento humano. Ora, nossas idéias são representações adequadas das mais diminutas partes da extensão; e, não obstante todas as divisões e subdivisões que possam ter sido necessárias para se chegar a essas partes, elas jamais poderão se tornar inferiores a algumas idéias que formamos. A conseqüência evidente disso é que tudo que parece impossível e contraditório pela comparação entre essas idéias tem de ser realmente impossível e contraditório, sem escapatória. ${ }^{899}$

Como podemos formar a idéia de uma montanha de ouro, concluímos que uma montanha assim pode realmente existir. Não somos capazes, porém, de formar a idéia de uma montanha sem vale, e por isso a vemos como impossivel. ${ }^{900}$

Vale notar que ainda assim, nesta última evidência textual, Hume apenas afirma que algo parece impossível a partir da impossibilidade de conceção, e não que efetivamente o é. Entretanto, a este propósito, vale um comentário acerca da formulação do PS por Hume sob a forma de um bicondicional ${ }^{901}$. Se se aceitar, com base nestas evidências, que Hume aceitava ambos os princípios, o PP pode ser definido por um bicondicional, tal que se algo é concebível claramente, então é possível, e se algo é possível, então é concebível claramente (que equivale a dizer que se não é concebível claramente, então é impossível). A este suposto princípio inverso ao $\mathrm{PP}^{902}$, T. Lightner chama de Princípio da Inconceptibilidade ${ }^{903904}$. Aceitar que Hume defendia esta conjunção de princípios implica aceitar que para Hume, o campo daquilo que efetivamente existe se esgota nas possibilidades de se

\footnotetext{
${ }^{897}$ Cf. T 1.2.2.8; T 2.1.2.8; $\mathrm{T}$ 1.2.4.10; $\mathrm{T}$ 1.2.5.3; $\mathrm{T}$ 1.3.6.5; 1.5 deste trabalho.

898 Cf. LIGHTNER, 1997, p. 115. Há ainda alguns casos em que Hume menciona inconceptibilidade e impossibilidade sem inferir claramente uma a partir da outra (cf. T 1.2.1.2-4; T 1.2.2.6-7; T 1.3.14.11-12; $\mathrm{T}$ 1.4.4.12-14; $\mathrm{T}$ 1.4.5.10-11; $\mathrm{T}$ 1.4.5.23).

${ }^{899} \mathrm{~T}$ 1.2.2.1.

${ }^{900} \mathrm{~T}$ 1.2.2.8; itálico meu.

${ }^{901}$ Cf. 1.3 deste trabalho.

902 Que Lightner chama não de Princípio de Possibilidade, mas de Princípio de Conceptibilidade (cf. LIGHTNER, 1997, p. 118).

903 Entre os comentadores que julgam que Hume aceitavam ambos os princípios estão ANDERSON, R. F. (1966), Hume's First Principles. Lincoln, Nebraska: University of Nebraska Press, p. 5, apud LIGHTNER, 1997, p. 130 n9; CASULLO, 1979, p. 212; PAP, A. (1958), Semantics and Necessary Truth. New Haven: Yale University Press, p. 80-81; PAPPAS, 1991, p. 52 (implicitamente). Já Wright julga que apesar de o aplicar, rejeita-o (WRIGHT, 1983, p. 92, 103; 1991, pp. 149-62), e R. Reid julga que Hume não pretendia adotá-lo (cf. REID, 2007, p. 170).
} 
conceber ideias claras. Além disso, se se aceitar a primeira interpretação sobre a adesão de Hume ao PI, a existência dos objetos das ideias relativas deve ser considerados impossível, contrariamente ao caso de se aceitar a segunda interpretação, em que os mesmos objetos devem ser considerados possíveis.

Com efeito, afirmar que tudo o que é diferente é separável e que tudo o que é separável é diferente implica aceitar que as propriedades dos objetos cujas ideias são elaboradas, compostas e combinadas não escapam às capacidades cognitivas para tal - lembre-se o exemplo de Kail relativo a Véspero e Fósforo, em que o não reconhecimento de que são o mesmo indivíduo se deve à incapacidade de separar a ideia de um da ideia de outro ${ }^{905}$.

Por seu turno, a evidência textual em que Hume afirma ser impossível existir uma montanha sem um vale em virtude da incapacidade de concebê-lo mostra que Hume aceita que o que é contraditório é impossível, além de aceitar que aquilo que não implica contradição é possível. Portanto, para Hume, a contradição parece ser uma marca inequívoca da impossibilidade, e a ausência de contradição, da possibilidade.

Por outro lado, também há evidências que mostram que Hume concedia a possibilidade de existirem certos objetos que são inconcebíveis de forma clara ${ }^{906}$ :

Admite-se prontamente que outros seres podem dispor de muitos sentidos que não podemos conceber, porque as idéias deles nunca nos foram apresentadas da única forma pela qual uma idéia pode ter acesso à mente, a saber, por um efetivo sentimento ou sensação. ${ }^{907}$

$\mathrm{Na}$ seguinte passagem, Hume chega a afirmar que tanto o vácuo sem matéria como a matéria sem vácuo são inconcebíveis, sem, apesar disso, inferir disso que alguma destas hipóteses é impossível:

[É] impossível conceber seja um vácuo e uma extensão sem matéria, seja um tempo em que não houve sucessão ou alteração em uma existência real. ${ }^{908}$

\footnotetext{
${ }^{904}$ Cf. LIGHTNER, 1997, p. 118.

${ }^{905}$ Cf. 2.2 .3 deste trabalho.

${ }^{906}$ Cf. LIGHTNER, 1997, p. 122.

907 IEH 2.7.

${ }^{908} \mathrm{~T}$ 1.2.4.2. Hume também afirma, um pouco mais à frente, que "não podemos formar qualquer ideia de vácuo" (T 1.2.5.1).
} 
Da mesma forma, afirma explicitamente que não é possível formar ideias de objetos distintos de perceções, sem acrescentar que, por isso, a sua existência seja impossível ${ }^{909}$.

Se se aceitar que Hume apenas aceitava o PP, mas concedia que o campo das possibilidades metafísicas não se esgota na capacidade de se conceber objetos de forma clara, mantém-se apenas o primeiro condicional, quer dizer, que se algo é concebível, é possível ${ }^{910}$. Quer dizer, de acordo com estas evidências textuais, na filosofia de Hume, o campo das possibilidades da conceção e o campo da possibilidade (e impossibilidade) metafísica não seriam coextensivos.

Com efeito, se estas evidências forem consideradas suficientes para defender que Hume aceita o PI, deve aceitar-se que o único requisito com que Hume está comprometido para que se considere ideia concebível é o seu contrário não implicar contradição. Por isso, também deve aceitar-se que as ideias de causalidade e de objeto externo são adequadas (claras, conceções genuínas) e que é inexplicável que o filósofo tenha considerado possível existirem sentidos distintos daqueles de que dispomos.

A meu ver, há dois motivos para se rejeitar o Princípio de Inconceptibilidade na filosofia de Hume. O primeiro prende-se com a eventualidade de que os requisitos para que uma ideia seja clara não se resumam à ausência de contradição. O segundo é que há diversas evidências que favorecem mais uma interpretação cética sobre a existência da causalidade do que o contrário, e esta interpretação seria reforçada pela recusa desta conclusão.

Nos próximos parágrafos, explico o primeiro motivo, que consiste em mostrar que há outros requisitos que uma ideia tem de cumprir, na filosofia de Hume, para poder ser considerada uma conceção genuína, além de o seu contrário não implicar contradição. Na secção 4.7, explicarei o segundo motivo, mostrando como esta insuficiência favorece uma interpretação cética sobre a existência da causalidade objetiva na filosofia de Hume - que diversas outras evidências mostram ser mais justa que uma interpretação realista ou anti-realista.

Com efeito, as questões de facto cujas ideias se tem na memória e a partir das quais se podem formar ideias da imaginação fancy, mas também raciocínios

${ }^{909}$ Cf. T 1.2.6.8; T 1.4.2.54, 56, citadas acima na presente secção. 
indutivos, não envolvem contradição, e é, em parte, por essa razão que podem existir e ser objeto de uma impressão. A outra razão é que os sentidos de que dispomos permitem essas impressões. Porém, os objetos de impressões de sentidos de que não dispomos também não envolvem contradição e não são concebíveis, devido à falta desse sentido - como a visão de ondas de calor. O mesmo parece acontecer no caso da causalidade, que não consiste num objeto possível das impressões, tampouco o seu contrário implica contradição. Por isso, a ideia que a mente pode formar dessa relação ou propriedade tem necessariamente de partir das impressões e de relações que um objeto concebido analogamente às mesmas supostamente mantém com elas.

Porém, a distinção que Hume estabelece entre conceção genuína (ou ideia clara) e suposição (ou ideia confusa) assenta no facto de que a ideia provém das impressões, ao passo que a suposição consiste numa noção de algo especificamente diferente das impressões, construída pela sobreposição de relações entre o suposto objeto e as impressões ${ }^{911}$. Portanto, o que caracteriza a ideia ou conceção genuína é a sua precedência nas impressões, e a ideia relativa, ser construída pelas relações entre o suposto objeto e as impressões. E Hume afirma explicitamente que tanto a ideia de causalidade como a ideia de existência exterior são relativas. Portanto, aceita que são construídas por meio de relações que os supostos objetos mantêm com as impressões, por contraste com uma ideia que tem uma correspondência direta com a experiência dos sentidos.

Portanto, se se aceitar que Hume aceitava o PI, tem de se sobrepor o critério da não contradição ao critério da precedência pelas impressões para definir uma ideia clara. Dito de outro modo, deve aceitar-se que apesar de a ideias de causalidade objetiva e de existência exterior serem reconhecidamente ideias relativas, constituem ideias claras ou conceções genuínas, uma vez que não implica contradição. Mas, por sua vez, isto é incoerente com a afirmação de que a ideia de causalidade objetiva uma ideia clara ou conceção genuína - para o que teria de se tratar de um objeto de uma impressão, o que Hume nega explicitamente ao atribuir a crença na mesma causalidade à propensão projetiva ${ }^{912}$. Ou seja,

\footnotetext{
${ }^{910}$ Os comentadores que aceitam esta interpretação são Ligthner (cf. LIGHTNER, 1997, p. 114, 125, 128) e Kail (cf. KAIL, 2003a, p. 47, 49, 51, 54).

${ }^{911}$ Cf. FLAGE, 1982, pp. 160-161.

${ }^{912}$ Cf. T 1.3.14.25.
} 
aceitar que o PP constitui um bicondicional compromete a própria distinção entre ideias claras e confusas, assente na precedência pelas impressões, e não na ausência de contradição - pelo menos, exclusivamente.

Antes de apresentar uma resposta a esta questão, vale um comentário sobre uma evidência textual em que Hume parece, efetivamente, conceder que a única coisa que escapa às capacidades de conceção pela mente é a contradição ou aquilo cujo contrário implica contradição:

Aquilo que nunca foi visto, ou de que nunca se ouviu falar, pode ainda assim ser concebido; e nada há que esteja fora do alcance do pensamento, exceto aquilo que implica uma absoluta contradição. ${ }^{913}$

Ainda assim, julgo que o facto de Hume utilizar o termo 'pensamento' em vez de 'conceção' é determinante. Nem mesmo as ideias relativas podem conter uma contradição. Portanto, Hume pode, com isto, afirmar que a única coisa que escapa tanto à capacidade de formar ideias claras quanto confusas é a contradição. Se se aceitar esta interpretação desta passagem, não é necessário conceder que Hume restringia as possibilidades de conceção (num sentido genuíno) ao que não implica contradição.

Mas aparte da possível ambiguidade do significado e importância desta passagem, a própria forma como Hume distingue conceções (ou ideias claras) de suposições (ou ideias confusas) mostra que há outro requisito, a saber, deter ideias de objetos da experiência dos sentidos na mente. Portanto, é necessário ter um certo leque ou variedade de ideias que se possam combinar em conceções genuínas. Neste sentido, Lightner notavelmente reparou na necessidade de se acrescentar alguns constrangimentos ao $\mathrm{PP}$, o primeiro dos quais seria o de dispor de um leque de ideias (nomeadamente, ideias simples, que possam ser combinadas em ideias complexas). Além disso, uma vez que todas as ideias resgatadas pela mente para as conceções estão na memória, também é necessário que a faculdade da memória esteja em funcionamento. Por último, a capacidade para conceber ideias claras também inclui a capacidade para separar ideias ${ }^{914}$. Ou seja, de acordo

\footnotetext{
913 IEH 2.4; itálico meu.

${ }^{914}$ Cf. LIGHTNER, 1997, p. 125. Aliás, este aspeto fora notado por diversos outros comentadores (cf. STROUD, 1977, p. 47; GARRETT, 1997, pp. 64-6; KAIL, 2003a, p. 47). Já em relação à ausência de contradição, Winkler observa que mesmo esta mantém um elemento subjetivo, isto é, a contradição é-o para nós ou trata-se de uma contradição que somos capazes de perceber (cf.
} 
com a sugestão de Lightner, temos que as condições para que algo seja concebível claramente são: i) um determinado leque de ideias simples (a partir das quais se pode compor ideias complexas); ii) a faculdade da memória; iii) a capacidade de separar ideias. Uma vez que permite tanto aferir o que é possível como o que é impossível, vale acrescentar uma quarta: iv) o princípio de contradição ${ }^{915}$.

De facto, as seguintes passagens atestam que apesar de Hume reconhecer que a mente está limitada ao conjunto de ideias de que dispõe efetivamente, a capacidade de separar ou distinguir essas mesmas ideias é ilimitada:

Nada há mais livre que a imaginação humana, e, embora não possa ir além daquele inventário original de ideias fornecidas pelos sentidos internos e externos, ela dispõe de poder ilimitado para misturar, combinar, separar e dividir essas idéias em todas as variedades de ficção e miragens. ${ }^{916}$

Para aferir em que consiste uma ideia clara, esta capacidade de conceção pode ser pensada de duas formas: i) como uma capacidade ideal, em que o agente disporia do número e variedade máxima possível de ideias simples (todas as ideias simples que existem), da memória e das capacidades de separação e de deteção de contradições mais apuradas possíveis, ou ii) como a capacidade que cada agente possui para construir ideias complexas (com base nas ideias simples de que efetivamente dispõe), a memória e as capacidades de separação e deteção da ausência de contradição tais como o agente delas dispõe. Isto acarreta a possibilidade de que ora funcionem melhor, ora pior - portanto, que algumas ideias possam parecer, nalgum momento, inseparáveis, sem sê-lo num momento posterior. O mesmo vale para a contradição e, ainda que talvez em menor grau, para a lembrança.

WINKLER, 2007, p. 81). Este comentário sugere a possibilidade de que não a detetemos - o que é bem ilustrado pelo exemplo de Véspero e Fósforo, de Kail (cf. KAIL, 2003a, pp. 50-1, 2.2.3 deste trabalho) e da Conjetura de Goldbach, de Stroud: enquanto esta conjetura ainda estava por descobrir, pensar nas operações que a envolvem trazia uma aparência de contradição (cf. STROUD, 1977, p. 50). Com estes casos-exemplo, os comentadores pretendem mostrar que os princípios (tanto de separabilidade como de contradição) podem ser mal empregues devido a alguma falha na conceção ou cálculo que elaboremos.

${ }^{915}$ Lightner discute os requisitos para que uma ideia seja claramente concebível mantendo mais ou menos implícito que este princípio também constitui uma condição para tal - pois se a contradição nos informa sobre o que é impossível, aquilo que não implica contradição é, de alguma forma, concebível. Porém, o comentador não chega a listar explicitamente estas quatro condições (cf. LIGHTNER, 1997, pp. 122-28). Ao invés, só se refere a ele para desmistificar a relevância da interpretação de que Hume aceitaria que tudo o que não é claramente concebível é impossível (cf. LIGHTNER, 1997, pp. 116, 119, 120-1, 128).

${ }^{916}$ IEH 5.2.10. 
Com efeito, se a mente dispusesse de todas as ideias simples possíveis (cenário i)), da memória no funcionamento mais pleno possível e sob o mais pleno domínio do PS e da capacidade para detetar contradições, as únicas ideias que não seriam concebíveis (no sentido genuíno) seriam aquelas cujo contrário implica contradição (genuinamente, isto é, para além do que nos parece implicar contradição, como, por exemplo, que $2+2 \neq 4$, se estivermos corretos(as) em pensar que $2+2=4$ ). Portanto, se fosse este o caso, o campo das ideias inconcebíveis, das ideias cujo contrário implica contradição e das impossibilidades seriam coextensivos. Uma vez que Hume concede que haja objetos inconcebíveis mas cujo contrário não envolve contradição (no caso da existência da causalidade objetiva e dos objetos externos e independentes da mente) ou é possível (no caso dos sentidos de outros seres vivos), deve aceitar-se que a condição da mente que define corretamente em que consiste uma ideia clara na filosofia de Hume é a segunda (ii)). Por esta razão, concordo com Lightner que aceitar que a definição de ideia clara devesse partir de uma condição ideal da mente e respetivas faculdades implicaria que Hume estivesse, efetivamente, comprometido com a aceitação do PI (reverso do PP), ou seja, que o PP constitui um bicondicional, e não um condicional simples ${ }^{917}$.

Portanto, o campo do que é concebível claramente não se esgota no campo daquilo cujo contrário implica contradição. Antes, o que compõe a totalidade desse campo é o que é possível conceber i) mediante o leque de ideias simples de que a mente dispõe no momento, ii) de acordo com a sua memória, iii) mediante a sua capacidade de separação das ideias e, finalmente, iv) ausente de contradição. Dentre estes requisitos, o único cujas evidências apontam para uma implicação metafísica é a contradição. Portanto, esta evidência textual apenas confirma esta interpretação, não constituindo ameaça ao descarte do PI da parte de Hume.

Deste modo, a partir da análise das evidências e discussões na literatura de comentário reunidas nesta secção, concluo que na filosofia de Hume, o conjunto das ideias que não são claramente concebíveis em virtude de alguma falha na capacidade de separá-las ou na falta de ideias simples para tal, ou ainda numa falha na memória, consiste no campo das ideias que não são concebidas claramente, mas a partir de cuja conclusão Hume não ousa afirmar que a

\footnotetext{
${ }^{917}$ Cf. LIGHTNER, 1997, pp. 125-8.
} 
existência dos objetos aos quais (presumivelmente) corresponderiam é impossível. Por seu turno, o princípio de contradição constitui um requisito especial em relação aos outros três, pois tem a capacidade de nos informar sobre o que é impossível - contrariamente àqueles. Ainda assim, uma conceção que apenas cumpra o requisito de contradição não pode ser considerada uma ideia clara, devido à falta dos restantes requisitos.

As ideias que Hume reconhece serem relativas são-no devido à falta de uma impressão, a partir da qual se pudesse ter uma ideia clara do objeto em questão. É o caso da ideia de causalidade objetiva (e, como se verá na próxima secção, também da existência do mundo externo), que simultaneamente cumpre o requisito de contradição, mas não cumpre o requisito da precedência de uma impressão correspondente. É devido à falta dessa impressão que a mente só pode conceber as ideias em questão a partir de relações que mantêm com as mesmas. O que define estas ideias como relativas é, assim, o facto de simultaneamente não serem precedidas por uma impressão (nem pode sê-lo) e não implicarem contradição com as ideias claras de que se dispõe.

Resta indagar se estas considerações sobre se os critérios apresentados para considerar uma ideia relativa - o conteúdo não pictórico e a relação entre o objeto de que se tem a ideia relativa e um objeto de que se tem uma ideia clara assim como a conclusão de que a ideia de causalidade objetiva e de objeto externo constituem, para Hume, ideias relativas, tem alguma consequência na sua teoria dos valores. A meu ver, há duas consequências, que passo a explicar.

Com efeito, Hume admite que "[se pensa] que a qualidade agradável está no objeto, não no sentimento, e isso meramente ${ }^{\text {“918. }}$. Por um lado, relembro como procurei mostrar na secção 4.4 - que Hume parece entender este "objeto" como objeto externo, e que não faz distinção (no sentido metafísico) entre os objetos a que se atribuem relações causais e objetos a que se atribuem valores (ambos seriam objetos exteriores e independentes da mente), e que aceitei a interpretação de que os juízos de valor são um género especial de juízos causais (que relatam relações entre propriedades identificadas nos objetos e a mente).

Em primeiro lugar, se se aceitar que o juízo se refere a objetos concebidos como externos (pela operação da propensão projetiva), que não se distingue das 
restantes relações causais a não ser pela dependência em relação à mente - e não pelo seu grau de necessidade (que Hume pensa ser o mesmo) - e que esta relação pode ser pensada como intrínseca aos objetos aos quais se atribui o valor, a ideia de causalidade envolvida no juízo de valor pode ser pensada como relativa. Com efeito, tal como a ideia de causalidade entre objetos entre si, esta ideia cumpre os dois requisitos indicados como aqueles que perfazem, na filosofia de Hume, uma ideia relativa, a saber i) ter um conteúdo não pictórico e ii) ser concebida a partir de ideias claras.

Considere-se tanto o cenário em que os agentes estão sob a ilusão de que os objetos detêm o valor que lhes é atribuído, como o cenário após uma correção que leva à conclusão de que os mesmos constituem propriedades que apenas se manifestam mediante uma relação entre o objeto e a mente (como tentei apresentar em 3.3.3 e 3.4). Em nenhum dos casos a relação causal tem conteúdo pictórico. Com efeito, enquanto concebida como propriedade intrínseca dos objetos, constitui uma ideia falsa - pois é certo, para Hume, que os valores não constituem propriedades objetivas. Por outro lado, mesmo quando se corrige, por um exercício reflexivo, esta crença forjada pela propensão projetiva, apenas se tem ideias claras da propriedade que desperta o sentimento agradável ou desagradável e desse sentimento. Nas seguintes passagens, Hume esclarece que nem mesmo a ideia de causalidade presente na relação entre a vontade e os movimentos do corpo é clara:

Dado, portanto, que os objetos externos, tal como aparecem aos sentidos, não nos dão idéia alguma de poder ou conexão necessária por sua operação em casos particulares, vejamos se essa idéia pode ser derivada da reflexão sobre as operações de nossas próprias mentes e copiada de alguma impressão interna. Pode-se dizer que a todo instante estamos conscientes de um poder interno, quando sentimos que, pelo simples comando de nossa vontade, podemos mover os órgãos de nosso corpo ou direcionar as faculdades de nosso espírito. Um ato de volição produz movimento em nossos membros ou faz surgir uma nova idéia em nossa imaginação. Essa influência da vontade nos é dada a conhecer pela consciência. Dela adquirimos a idéia de poder ou energia, e ficamos certos de que nos próprios e todos os outros seres inteligentes estamos dotados de poder. Essa idéia, então, é uma idéia de reflexão, dado que a obtemos

${ }^{918} \mathrm{C} 15$. 
refletindo sobre as operações de nossa própria mente e sobre o comando que a vontade exerce tanto sobre os órgãos do corpo como sobre as faculdades da alma. (...) (...) O movimento de nosso corpo segue-se ao comando de nossa vontade; disso estamos conscientes a cada instante. Mas os meios pelos quais isso se realiza, a energia pela qual tudo isso está tão longe de nossa consciência imediata que deve para sempre escapar às nossas mais diligentes investigações. ${ }^{919}$

Nesta passagem, Hume faz introduzir a dúvida cética presente em exemplos como a bola de bilhar nas considerações sobre a ação, a saber, sobre a impossibilidade de determinar se há alguma relação de causalidade entre dois objetos de que se tem uma ideia clara ${ }^{920}$ - onde se pode incluir a ação moral, afinal, Hume não especificou que se trataria apenas da ação não moral

Portanto, Hume não só admite que supomos deter um poder sobre os movimentos do nosso corpo, como também que não se tem uma ideia clara desse poder. A este propósito, há dois pontos que merecem ser notados. Por um lado, Hume julga que nos podemos considerar a nós mesmos como detentores de um poder - esse poder seria uma propriedade nossa, localizado na nossa mente. Por outro lado, a menção à vontade e ao exercício da mesma sobre as "faculdades da alma" sugere que além de movimentos corporais (como, por exemplo, levantar o braço ou dirigir-se à secretária para trabalhar), Hume talvez também esteja disposto a incluir ações morais nesses movimentos (que, por mais subtis que sejam, implicam algum tipo de movimento).

Mas, a meu ver, o mais relevante para determinar se a ideia da relação causal envolvida na atribuição de um valor pode ser considerada ou não uma ideia relativa surge da consideração de Hume sobre o caráter desconhecido desta relação. Com efeito, mesmo uma ação se tratando de um movimento cuja causa é um desejo ou intenção - redutível a uma paixão -, a relação causal entre essa paixão e a ação efetiva que levamos a cabo é-nos desconhecida. Portanto, temos acesso à paixão que a origina, assim como à ação em que resulta, mas não ao meio pelo qual a paixão permite levar a ação a cabo. Portanto, esta relação causal não é

\footnotetext{
919 IEH 7.1.9-10; cf. também T 2.3.1.15-17.

${ }^{920}$ Ao contrário do que julga Kail, para quem uma boa razão para não procurar paralelos entre a teoria causal e dos valores de Hume é que há uma assimetria entre o tratamento da questão da moralidade e da questão da necessidade causal, a saber, confessa ignorância em relação a poderes
} 
mais inteligível por se dar na nossa própria mente, podendo, assim como qualquer outra, reduzir-se a uma conexão constante - neste caso, entre paixões e movimentos do nosso corpo, que, em princípio, contariam como objetos da perceção para alguém além de nós.

A meu ver, se nem no caso das nossas próprias ações Hume concede que se tem acesso à relação causal que se mantém entre a intenção e a ação em si, tratando-se a relação causal entre traços de caráter e, no caso dos objetos estéticos, uma relação entre o objeto e a mente, fica claro que o filósofo não considera que as relações causais que dependem da mente são mais inteligíveis que aquelas que se mantêm entre objetos (pretensamente) entre os objetos da perceção. Portanto, estas relações causais permanecem, do ponto de vista da sua inteligibilidade, no mesmo pé de igualdade: impassíveis de nos oferecer uma ideia clara e, ainda assim, relacionadas com objetos de ideias claras - no caso das nossas ações, as ideias da nossa própria intenção e da nossa ação (que talvez se possa pensar que, em princípio, contaria como objeto de sensação ou de impressão interna), e no caso dos próprios juízos, entre o objeto ou o respetivo traço e a nossa sensibilidade.

Portanto, se Hume aceita que esta ideia não é clara, e se se aceita que a noção de clareza se prende com ter impressões, deve aceitar-se que em nenhum dos dois cenários detemos uma ideia da causalidade com conteúdo pictórico. Além disso, ao reconhecer que é uma ideia que provém da experiência, reconhece também que assim como a ideia de causalidade tratada no âmbito do conhecimento a posteriori em geral, esta ideia de causalidade só pode ser obtida pela experiência constante. A relação que esta ideia mantém com as ideias claras é a mesma que a ideia de causalidade no movimento das bolas de bilhar, a saber, o que está por trás e que explica a regularidade observável.

Por seu turno, tendo reconhecido simultaneamente que as ideias de causalidade objetiva, de objeto externo e de um valor intrínseco nos objetos (que conduz a uma crença falsa) são forjadas pela propensão projetiva e (pelo menos nos dois primeiros casos) também relativas, pode dizer-se que o mecanismo da projeção forja ideias relativas: a propensão projetiva leva a mente a atribuir ao

secretos relativamente a algum tópico relacionado com a decisão ou o juízo morais contrariamente ao que ocorre no caso da causalidade (cf. KAIL, 2001, p. 36, 43). 
objeto da experiência uma propriedade que, pelo menos do ponto de vista das ideias claras, só existe na mente, e estas propriedades são justamente aquelas de que se tem uma ideia não pictórica e de que não se pode ter uma experiência.

Em segundo lugar, Hume parece oferecer uma pista no mesmo sentido em relação ao padrão para juízos. No âmbito do conhecimento da geometria, Hume afirma que o padrão imaginário criado para avaliar igualdades exatas não pode ser compreendido $^{921}$

Por um lado, aceitou-se - tanto dos proponentes do realismo como de Flage e seus interlocutores - que as ideias relativas não são ininteligíveis, e que ser ininteligível significa não poder ser compreendido - por contraste com as ideias claras, são inteligíveis e, portanto, são inteligíveis. Se é assim, significa que a ideia em questão não corresponde a uma impressão. Assim, o requisito sobre a pictorialidade parece estar cumprido.

Por outro lado, aceitou-se também a interpretação - de Coventry - de que o padrão para juízos sobre questões de facto é criado da mesma forma dos juízos da geometria - isto é, a partir de correções sucessivas de experiências constantes. Deste modo, pode pensar-se que a ideia deste padrão não só se origina a partir de ideias claras - que compõem os vários âmbitos de conhecimento de questões de facto - como mantém uma relação com os mesmos, a saber, o de constituir a razão pela qual os juízos (que exibem ideias claras) são verdadeiros ou falsos, isto é, correspondem ou não aos objetos da experiência. Aliás, a própria possibilidade constante de serem corrigidos mostra este caráter relativo: se se tivesse uma ideia clara de tal critério, saber-se-ia com certeza (isto é, ter-se-ia uma ideia clara de) qual a verdade sobre todos os âmbitos de conhecimento acerca de questões de facto. Este critério é, tal como repararam (pelo menos) Townsend e Cohon, uma noção vaga da natureza humana, isto é, de capacidades cognitivas comuns, que permitem um acordo dos sentimentos entre os vários agentes e espectadores (pelo menos, quando colocados sob um certo ponto de vista) ${ }^{922}$.

De facto, tal como Hume explica ao introduzir o mecanismo da simpatia, o conhecimento que temos da mente e das paixões dos outros agentes dá-se indiretamente, mediante a suposição da semelhança nas nossas disposições

\footnotetext{
${ }^{921}$ Cf. T 1.2.4.25; secção 4.2 deste trabalho.

922 Cf. 4.2 deste trabalho.
} 
cognitivas e inferências causais sobre a origem das manifestações emotivas que $\operatorname{apresentam}^{923}$. Por outro lado, a ideia de natureza humana parece ser geral e abstrata, pois supõe a desconsideração de elementos particulares em favor de um núcleo comum (a arquitetura cognitiva que partilhamos). Deste modo, parece corresponder à noção de ideia relativa sobre a qual indaguei nesta secção formada a partir da experiência e do hábito, sem conteúdo pictórico, impassível de se tornar uma, mas relacionada com ideias claras (neste caso, as ideias das próprias operações mentais).

$\mathrm{Na}$ próxima secção, procurarei mostrar que uma resposta negativa à questão de saber se Hume aceitava o PI - de que tudo o que é inconcebível é impossível -, conjugada com a distinção entre ideias claras e relativas tratada nos parágrafos acima, justifica a minha interpretação de que Hume deve ser considerado um cético em relação à existência da causalidade objetiva. Sucintamente, o que procuro defender é que a possibilidade da existência da causalidade objetiva não pode ser descartada, devendo ser mantida em aberto, uma vez que a ideia em questão (da propriedade dos objetos estarem relacionados causalmente) é relativa, ou seja, não constitui uma ideia clara, mas não autoriza a conclusão de que a existência do seu objeto é impossível.

\subsection{Ceticismo}

Resta explicar por que razão considero que em relação à sua componente metafísica, a teoria causal de Hume deve ser entendida como cética, e a sua teoria dos valores, como uma forma sofisticada de anti-realismo. Em seguida, mostro como esta componente metafísica se articula com as componentes epistémica e semântica das mesmas teorias, de forma a tornar pertinente a interpretação que chamo de quasi-realismo cético, como alternativa à interpretação quasi-realista que Coventry desenvolveu.

Entretanto, nos próximos parágrafos, explico o segundo motivo pelo qual é implausível que Hume aceite o PI. A meu ver, as evidências a favor da interpretação de que se deve considerar que Hume concedia que os objetos das

${ }^{923}$ Cf. T 2.1.11; 1.12 deste trabalho. 
ideias relativas não existem devem ser desconsideradas, em favor das evidências a favor da interpretação de que essa existência é possível. Ao afirmar que "não temos razão para acreditar na existência do que excede o campo do que podemos formar uma ideia" (ou seja, uma ideia adequada, conceção genuína), Hume mostra-se reticente sobre a afirmação de que algo é impossível pelo facto de ser inconcebível $^{924}$.

Esta interpretação permite incluir pelo menos duas posições de Hume - e respetivas evidências textuais, a saber, sobre as questões da existência exterior e independente (da mente) dos objetos da perceção e da causalidade objetiva, que permaneceriam negligenciadas caso esta fosse aceite em detrimento daquela. Quer dizer, a vantagem que se obtém ao optar por esta escolha interpretativa é que aceitar a interpretação contrária nos compromete a atribuir a Hume a defesa de que não existem nem causalidade objetiva, nem objetos exteriores e independentes da mente - que, devido à propensão projetiva, se está convicto de que possuem a propriedade de se relacionarem causalmente entre si. Portanto, o que me proponho a explicar nos próximos parágrafos é que aceitar que Hume defendia o PI implica aceitar que Hume defenderia uma posição regularista (sobre a existência da causalidade) e fenomenalista (sobre a existência dos objetos da perceção).

Com efeito, a partir de evidências relativas à operatividade da propensão projetiva e da crença do vulgo em propriedades (supostamente) objetivas que, na verdade, constituem projeções da mente, parece claro que para Hume, a convicção de que os objetos da perceção possuem a propriedade de se relacionar causalmente entre si - para o que se exige que os considerem exteriores e independentes (da mente) - é difundida na mente de todos. Essas evidências são:

[A] mente tem uma grande propensão a se espalhar pelos objetos externos, ligando a eles todas as impressões internas que eles ocasionam, e que sempre aparecem ao mesmo tempo que esses objetos se manifestam aos sentidos. Assim, como observamos que certos sons e odores sempre acompanham determinados objetos visíveis, naturalmente imaginamos uma conjunção, também espacial, entre os objetos e as qualidades, embora essas qualidades sejam de uma natureza que não admite tal conjunção (...) [A] mesma propensão é a razão por que supomos que a necessidade e o poder se encontram nos objetos que observamos, e não na mente que os observa, muito embora não nos seja possível formar a menor idéia dessa qualidade

${ }^{924}$ Cf. T 1.3.14.36. 
quando não a tomamos como a determinação da mente a passar da idéia de um objeto à idéia daquele que o acompanha usualmente [apelo a uma ideia não adequada]. ${ }^{925}$

É natural que os homens, em seu modo comum e descuidado de pensar, imaginem perceber uma conexão entre os objetos que constataram estar constantemente unidos; e como o costume tornou difícil separar as idéias, eles tendem a imaginar [apelo a uma ideia não adequada] que essa separação é em si mesma impossivel e absurda. ${ }^{926}$

$\mathrm{O}$ vulgo, que toma as coisas tal como lhe aparecem à primeira vista, atribui a incerteza dos resultados a uma incerteza nas causas, que as priva ocasionalmente de sua influência habitual, embora não sofram impedimentos em sua observação. ${ }^{927}$

Estas evidências mostram que Hume considerava que manter uma convicção tanto na existência exterior e independente (da mente) dos objetos da perceção como na semelhança entre perceções e objetos ${ }^{928}$ e na existência de uma propriedade específica destes objetos, a saber, a de manterem relações causais entre si - explicada pela propensão projetiva - constitui uma atitude natural.

Em relação à existência exterior e independente (da mente) dos objetos da perceção, Hume caracteriza mais de uma vez a convicção que se tem na mesma como uma suposição (termo dedicado às conceções confusas ou ideias relativas) e explica que ela é possível manter tal convicção em virtude de o seu contrário não implicar uma contradição:

A suposição da existência contínua dos objetos ou percepções sensíveis não envolve contradição. Podemos facilmente ceder à nossa inclinação para tal suposição. ${ }^{929}$

À luz da evidência de que Hume supõe que o que envolve contradição é impossível $^{930}$, pode concluir-se que a possibilidade de se ter e manter uma crença na existência exterior e independente dos objetos da perceção é acompanhada da própria possibilidade de esses objetos existirem. Além disso, uma leitura atenta da secção que Hume dedica a esta questão ${ }^{931}$ mostra que o filósofo jamais negou esta

\footnotetext{
${ }^{925} \mathrm{~T}$ 1.3.14.25; itálico meu.

${ }^{926}$ T 1.4.3.9; itálico meu. Cf. também T 1.3.14.27; T 1.4.2.12, 14, 43.

${ }^{927} \mathrm{~T}$ 1.3.12.5; IEH 8.1.13.

${ }^{928}$ Cf. T 1.4.2.54.

${ }^{929}$ T 1.4.2.40; itálico meu.

$930 \mathrm{~T}$ 1.2.2.1.

${ }^{931} \mathrm{~T} 1.4 .2$.
} 
existência, tampouco a sua possibilidade. As seguintes evidências textuais mostram que Hume faz o mesmo tipo de concessão em relação à causalidade objetiva:

Quanto às impressões provenientes dos sentidos, sua causa última é, em minha opinião, inteiramente inexplicável pela razão humana, e será para sempre impossivel decidir com certeza se elas surgem imediatamente do objeto, se são produzidas pelo poder criativo da mente, ou ainda se derivam do autor de nosso ser. (...) Podemos sempre fazer inferências partindo da coerência de nossas percepções, sejam estas verdadeiras ou falsas, representem elas a natureza de maneira correta ou sejam meras ilusões dos sentidos. ${ }^{932}$

Esta passagem indica que Hume aceita que estes objetos existem ou não existem - que é verdadeiro ou falso que existem. Além disso, da mesma forma que a existência exterior e independente (da mente) dos objetos da perceção, a coerência que a suposição da existência da causalidade objetiva mantém com os dados da experiência - que é o mesmo que dizer que não implica uma contradição com eles - permite que se creia na mesma.

Por seu turno, o que define uma ideia relativa é remeter para um objeto construído a partir de relações distintas daquelas que se mantêm entre as impressões. Apesar disso, uma vez que a mente não consegue conceber algo diferente das perceções a não ser estabelecendo uma relação com as mesmas, as ideias relativas são construídas a partir das perceções - e, por isso, coerentes com elas (pois a mente não é capaz de pensar a contradição). Uma vez que uma das ideias é de um objeto não percebido, a questão de saber se o objeto mantém-se em aberto - no caso da causalidade, objetiva, se de facto constitui a explicação da regularidade, e no caso da existência exterior, se há uma relação causal entre os objetos externos e as impressões ${ }^{933}$.

Em relação à própria possibilidade da existência da causalidade objetiva, as evidências que indicam uma suspeita de Hume em relação à mesma notavelmente interpretadas pelos defensores da interpretação do realismo cético como asserções de natureza epistémica - teriam de ser interpretadas como

\footnotetext{
${ }^{932} \mathrm{~T}$ 1.3.5.2; itálico meu.

${ }^{933}$ Cf. FLAGE, 1982, pp. 167-8; 2007, p. 146, 152-3, 155 n20.
} 
asserções de natureza metafísica (como propuseram os defensores da interpretação regularista ${ }^{934}$ ). São exemplos destas evidências:

Se estendermos nossa investigação para além das aparências sensíveis dos objetos, receio que a maior parte de nossas conclusões será dominada pelo ceticismo e pela incerteza. ${ }^{935}$

Se realmente não temos nenhuma idéia de um poder ou eficácia em nenhum objeto, nem de uma conexão real entre causas e efeitos, de pouco servirá provar que uma eficácia é necessária em todas as operações. (...). De fato, estou pronto a admitir que pode haver várias qualidades, tanto nos objetos materiais como nos imateriais, que desconhecemos completamente; e se queremos chamá-las de poder ou eficácia, isso pouco importa para o mundo. ${ }^{936}$

$[\mathrm{N}]$ as conjunções mais usuais de causa e efeito, somos tão ignorantes sobre o princípio último que une a causa e o efeito quanto nas mais insólitas e extraordinárias. ${ }^{937}$

[C]omo a conjunção constante entre os objetos constitui a essência mesma da causa e efeito, a material e o movimento podem, em muitas ocasiões, ser consideradas as causas do pensamento, até onde podemos ter alguma noção dessa relação. ${ }^{938}$

É uma questão de fato se as percepções dos sentidos são produzidas por objetos externos a elas assemelhados - como se decidirá essa questão? Pela experiência, certamente, como no caso de todas as outras questões de mesma natureza. Mas aqui a natureza permanece - e tem de permanecer - inteiramente calada. Nada está jamais presente à mente senão as percepções, e ela não tem como alcançar qualquer experiência da conexão destas com objetos. A hipótese dessa conexão não tem, portanto, nenhum fundamento no raciocinio. ${ }^{939}$

[S]e a essência mais recôndita das coisas viesse a abrir-se para nós, descobriríamos então um cenário do qual presentemente não podemos ter a menor idéia. ${ }^{940}$

A meu ver, estas evidências em relação à existência exterior e independente (da mente) dos objetos da perceção e da causalidade objetiva devem ser interpretadas como suspeitas de Hume relativamente à existência de certos

\footnotetext{
${ }^{934}$ Cf. 2.2 .7 e 2.1.2 deste trabalho.

${ }^{935} \mathrm{~T}$ 1.2.5.26n12.

${ }^{936} \mathrm{~T} 1.3 .14 .27$.

${ }^{937} \mathrm{~T}$ 1.4.7.6.

${ }^{938} \mathrm{~T}$ 1.4.5.33; itálico meu.

${ }^{939}$ IEH 12.1.12; itálico meu.

${ }^{940}$ D 6.12; itálico meu. Cf. também T 1.3.6.15; T 1.3.14.6, 22, 29; T 2.3.1.4; IEH 4.2.12, 16; IEH

5.2.22; IEH 7.1.8; IEH 7.2.26; IEH 7.2.28-9; IEH 8.1.5, 21.
} 
objetos ou respetivas propriedades, com base no facto de não se possuir ideias claras dos mesmos, mas sim ideias confusas ou relativas. Estas evidências perderiam o sentido caso se concedesse que Hume aceitava o PI, pois deveriam ser desconsideradas ou interpretadas como asserções metafísicas. Tal como Strawson bem notara - apesar de defender a interpretação do realismo cético -, estas passagens sugerem que os limites semânticos sinalizam ou são "sintoma" dos limites epistémicos, quer dizer, que a impossibilidade de formar ideias adequadas ou claras da causalidade objetiva deve-se a uma impossibilidade de as faculdades conhecerem ou proporcionarem acesso à mesma, e não que aqueles limites semânticos permitem a conclusão de que a existência da causalidade objetiva deve ser rejeitada ${ }^{941}$. Antes, deve admitir-se que por mais vívida que seja a convicção na sua existência - assim como na existência exterior e independente (da mente) dos objetos da perceção -, a conceção que a mente tem da mesma não constitui um conhecimento, mas uma suposição que tanto pode ser verdadeira como falsa.

Apesar de 'os objetos externos mantêm relações causais entre si' ser verdadeiro ou falso - pois existem ou não existem estas relações e esses objetos -, é impossível determinar o seu valor de verdade, em virtude do facto de ser impossível obter uma ideia clara dos mesmos. Portanto, o ceticismo de Hume consistiria em recusar haver razões para afirmar ou negar a existência da causalidade objetiva, pelo facto de ser impossível abarcar a ideia da mesma no campo das ideias adequadas ${ }^{942}$. Portanto, a existência das entidades designadas pelas ideias relativas permanece possível ${ }^{943}$.

Ainda assim, a mente é livre para manter ambas as crenças, uma vez que se cumpre o único requisito da capacidade para conceber (que é uma capacidade da mente) que, para Hume, sinaliza uma impossibilidade metafísica, a saber, não implicar uma contradição. Uma vez que não contradiz os dados da experiência, as suposições às quais a propensão projetiva impele a mente podem conviver com as restantes crenças.

\footnotetext{
${ }^{941}$ Cf. STRAWSON, 1989, p. 126, pp. 193-4; WINKLER, 1991, p. 53.

${ }^{942}$ Cf. WINKLER, 2000, p. 63.

${ }^{943}$ Cf. THOMAS, 1982, p. 152 (implícito); FLAGE, 2007, p. 138. Por esta razão, não concordo com Flage que uma boa descrição do objeto da ideia relativa de objeto externo seria "aquilo que causa, mas não se assemelha a [uma perceção]" (FLAGE, 2007, p. 146). Esta consideração não é consistente com a concessão cética do comentador.
} 
A partir das considerações tecidas nesta secção e na anterior, conclui-se que apesar de o escopo do PP se restringir às ideias adequadas (que surgem na mente pelo PC), aquele princípio não esgota o conjunto de objetos cuja existência deve ser considerada possível. Com efeito, o PP assegura que tudo o que é concebível claramente é possível. Ora, existem ideias na mente que não são claras - as ideias relativas. O facto de não haver evidências de que Hume conceda que o que não é concebido claramente seja impossível - mas apenas uma parte do que não pode sê-lo, a saber, o que implica contradição -, a filosofia de Hume parece prescindir do PI - inverso ao PP. Com isto, Hume mantém - e pode manter intacta a possibilidade de que a causalidade objetiva exista.

Passo às considerações sobre a implicação desta conclusão cética na interpretação da teoria dos valores de Hume que chamo de quasi-realismo cético, a saber, de que sendo um tipo de juízos causais, os juízos de valor estão sujeitos à mesma conclusão cética.

Ao distinguirem estes juízos de acordo com este critério e reconhecendo a possibilidade de os juízos sobre relações causais serem verdadeiros ou falsos, Stroud, Mackie e Coventry parecem interpretar a restrição de Hume do campo da verdade e da racionalidade ao campo das impressões e ideias como uma definição fenomenalista, isto é, que o que torna um juízo verdadeiro é a correspondência com uma impressão - e não com o que, eventualmente, está por trás da mesma.

Tal como procurei mostrar em 3.4, as evidências textuais de Hume sobre a possibilidade de as paixões serem objeto da razão e constituírem questões de facto, assim como o tratamento causal do surgimento das paixões e dos juízos, mostram que é pertinente entender os juízos de valor como descritivos, ou seja, como juízos sobre questões de facto. E uma vez que todos os conhecimentos $a$ priori constituem juízos que descrevem relações causais, aqueles juízos estariam incluídos neste campo.

Por seu turno, tal como procurei mostrar nos parágrafos acima, a restrição do PP às ideias claras e o caráter indeterminável dos objetos das ideias relativas conduziram à conclusão de que a existência (ou não existência) da causalidade objetiva - que se supõe, pela operação da propensão projetiva, uma propriedade intrínseca, e não redutível à regularidade observável - é indeterminável, ou seja, que não se pode saber se existe ou não. 
Por outro lado, e tal como procurei mostrar na secção anterior, parece razoável pensar a dúvida cética sobre a causalidade objetiva se instala no campo dos valores, ao explicar - da mesma forma como o faz relativamente ao exemplo do movimento das bolas de bilhar - que apesar de se ter, na mente, uma ideia clara da ação e do seu motivo, não se tem uma ideia clara da relação causal entre elas. Além disso, Hume parece reconhecer que a causalidade atribuída aos objetos e sucessiva impressão de reflexão é da mesma natureza que a causalidade atribuída a dois objetos (pretensamente) extra-mentais. Prova disso é a evidência textual em que Hume afirma que a evidência moral mostra que a necessidade que se mantém entre os objetos e a mente que lhes atribui um valor e entre os objetos extra-mentais é da mesma natureza - a saber, que tanto quanto se pode ter ideias claras da mesma, se reduz à regularidade observável. Além disso, a propensão projetiva é apresentada tanto como explicação da convicção na existência da causalidade objetiva como de valores objetivos.

Deste modo, a meu ver, também parece razoável concluir que tal dúvida cética se aplica à relação causal entre os objetos dos juízos de valor e a mente que lhes atribui esse valor.

Pode pensar-se que esta conclusão é inconsistente com o próprio antirealismo de Hume relativamente aos valores, afinal, parece deixar em aberto a possibilidade de os valores constituírem propriedades objetivas. Segue-se a resposta a esta questão, para explicar a razoabilidade desta consideração.

Em primeiro lugar, lembre-se que no presente trabalho, a noção de realismo sobre os valores que é aceite é aquela segundo a qual os valores constituem propriedades independentes da mente ${ }^{944}$. Em segundo lugar, resgate-se a distinção de Costa entre realismo dos poderes e objetivismo causal: o primeiro corresponde à tese de que a causalidade consiste numa propriedade além da regularidade observável e que a explica - em virtude do que essa regularidade se apresenta; o segundo corresponde à tese de que tal propriedade é independente da mente ${ }^{945}$.

Ora, a propensão projetiva induz à ilusão de que os valores constituem tanto propriedades que explicam a regularidade independentes da mente. Por outro

\footnotetext{
${ }^{944}$ Cf. COHON 2008, p. 99, 260.

${ }^{945}$ Cf. COSTA, 1989, pp. 173-4.
} 
lado, se se admitir que Hume é um anti-realista em relação aos valores e que parte da relação causal que é descrita nos respetivos juízos se encontra na mente, ainda é possível manter a posição de que apesar de a segunda tese componente do realismo causal que Costa enumera seja negada, ainda se pode aceitar a primeira. Quer dizer, pode aceitar-se que os objetos mantêm uma relação com as mentes tal que mediante o contacto com aqueles, se desperta uma reação naquelas (as impressões de reflexão que definem o valor atribuído ao objeto), e que tal relação constitui aquilo em virtude do que as reações são regulares, mesmo que só se possam manifestar mediante tal contacto. Portanto, ignorando a dúvida sobre a exterioridade e independência (da mente) dos objetos aos quais se atribui o valor, pode manter-se uma convicção numa relação causal genuína (isto é, além da regularidade) entre objetos e mentes (ou, no caso da moral, apenas entre mentes ou propriedades das mesmas, como são os traços de caráter).

Porém, a dúvida cética que Hume dirige à causalidade entre a ação e os motivos (assim como entre as bolas de bilhar) é relativa ao tipo de necessidade causal que se mantém entre os mesmos: se é redutível à regularidade observável ou se constitui aquilo em virtude do que tal regularidade se apresenta - o que Costa chama de realismo dos poderes. Portanto, mesmo sendo certo que os valores não constituem propriedades independentes da mente, ainda é dúbio se a relação causal que se descreve ao atribuir um valor aos mesmos se reduz à regularidade ou pressupõe um poder efetivo entre os objetos e a mente, ou aquilo em virtude do qual a regularidade em questão se apresenta.

Quer dizer, no caso de os objetos da perceção serem exteriores e independentes da mente e de a causalidade constituir uma relação que ultrapassa a regularidade observável - que se mantém em aberto -, a relação causal descrita nos juízos de valor não passa a ser independente da mente. Nesse caso, ainda resta saber se as relações causais se reduzem à regularidade observável ou não.

Com efeito, mesmo ignorando a hipótese de, para Hume, os valores constituírem propriedades independentes da mente, continua a ser duvidoso se resultam de um poder dos objetos de manifestarem uma certa propriedade mediante um contacto com a mente ou se se reduzem a uma regularidade observável. Neste sentido, apesar de também se manter a possibilidade metafísica da não existência dos objetos aos quais se atribui um valor, no caso de, efetivamente, existirem e terem como uma das suas propriedades a de se 
relacionarem causalmente entre si, tal relação não passa a ser independente da mente, mantendo-se, ao invés, dependente da mesma. Já as relações causais que se estabelecem entre os objetos (pretensamente) exteriores e independentes da mente podem, de facto, sê-lo, no caso de tais objetos existirem e terem como uma das suas propriedades a de se relacionarem causalmente entre si. Esta posição parece ser sugerida por Cohon, ainda que menos explicitamente do que procuro apresentar:

Neste esboço de uma conceção humeana sobre propriedades disposicionais (...), não se assume que Hume nega que existam necessidades causais nos objetos. Porém, assume o que parece ser verdadeiro: que para Hume, nunca estamos epistemicamente autorizados a atribuir tais necessidades a objetos, nem temos qualquer ideia delas. Poderia haver, na mente humana, um poder secreto para criar desejos e motivos para buscar objetos prazerosos, um poder cuja existência é independente de uma relação causal observada entre crenças hedónicas e tais desejos e motivos. Mas não podemos conhecer nada sobre tal poder secreto, nem apelar a isso na nossa teoria sobre a causação dos motivos. Se um apetite geral para o prazer não é concebido como esse poder incognoscível, qualquer reivindicação sobre ele seria, na melhor das hipóteses, uma fantasia sem fundamento e, na pior, um enunciado sem sentido. $\mathrm{O}$ único tipo de poder que temos fundamento para atribuir a alguma coisa é o que descreve a probabilidade, baseada na regularidade observada. E para existir, esse poder - essa propriedade disposicional - depende da regularidade observada, que constitui a relação causal tal como a compreendemos. ${ }^{946}$

De resto, o mesmo mecanismo projetivo que explica a atribuição do valor ao objeto em si mesmo é também responsável pela atribuição da causalidade aos objetos em si mesmos (alguns dos quais são os objetos dos juízos de valor).

\footnotetext{
${ }^{946}$ Tradução minha do original: "This sketch of a Humean account of dispositional properties (...) it is not assumed that Hume denies that causal necessities in objects exist. It does, however, assume what seems true: that on Hume's view we are never epistemically warranted in attributing such necessities to objects, and have no idea of them. There could be a secret power in the human mind to create cravings and motives pursue pleasant objects, a power whose existence is independent of any observed causal relation between hedonic beliefs and such cravings and motives. But we can know nothing about such a secret power, and could not appeal to it in our theory of the causation of motives. If a general appetite to pleasure is thought to be that unknowable power, any claim about it would be at best a fantasy without foundation, and at worst a nonsensical utterance. The only sort of power we have grounds to attribute to anything is the one that describes a probability based on observed regularity. And that power- that dispositional property - depends for its existence on the observed regularity which is the causal relationship as we understand it." (COHON, 2008, p. 58). Porém, vale notar que a comentadora não desenvolve dois tópicos que julgo determinantes, a saber: i) em que medida o ceticismo de Hume relativamente à relação causal entre os objetos do valor e o juízo (na mente de um espectador) se
} 
Portanto, a propensão projetiva explica a operação geral de atribuir uma propriedade que surge mediante o confronto entre o objeto em questão e o espectador a esse objeto como se o possuísse como propriedade intrínseca. Essa propriedade é a causalidade, e sendo o valor o reflexo de uma relação causal entre objeto e espectador, é atribuído ao objeto como uma relação especial. A sua peculiaridade reside no facto de que estão envolvidas paixões ou impressões de reflexão, estão ausentes no caso da atribuição da causalidade que não respeita valores (a causalidade investigada pelas ciências ou que é atribuída aos objetos na vida comum). Por seu turno, a peculiaridade da relação causal entre os objetos extra-mentais é que no caso de, efetivamente, serem exteriores e independentes da mente, tal relação sê-lo-á também, o que não ocorre no caso das relações causais descritas na atribuição de um valor.

Deste modo, ambos os tipos de juízos descrevem relações que efetivamente, são ou não são redutíveis à regularidade observável, e são ou não são independentes da mente. O seu caráter projetivo deve-se ao facto de que não podendo, enquanto propriedades intrínsecas, ser concebidas claramente, são objeto de ideias relativas.

Em relação ao caráter revisível do padrão, pode aceitar-se que sendo resultado de raciocínios probabilísticos (sobre o acerto da faculdade do entendimento nos raciocínios e conhecimentos adquiridos até então), é sempre incerto se aquilo que é considerado verdadeiro num dado momento corresponde ao que é, de facto, verdadeiro: que está de acordo com o modo como os objetos se comportam independentemente da mente ou para além da regularidade observável, ou se o ponto de vista sob o qual o espectador desinteressado avalia os objetos morais e estéticos é, de facto, o mais desinteressado possível ${ }^{947}$. Mas este caráter revisível deve-se, justamente, à imperfeição das faculdades e à impossibilidade de contactar com os objetos para além do campo fenoménico ou fora de um contexto - que condiciona o juízo.

Deste modo, e para tentar responder à questão de saber se Hume seria cético em relação aos valores, proponho que se resgate a noção que Mackie

distingue do ceticismo causal propriamente dito, nem ii) quais as bases de uma aplicação desta interpretação à teoria sobre o valor estético.

${ }^{947}$ Cf. JONES, 1982, p. 122. 
propôs - e que Fieser mantém ${ }^{948}$ - entre os planos normativo e metaético (ou metaestético): o primeiro, o das regras gerais concretas vigentes num certo momento e lugar da História, e o segundo, o da natureza dos valores e respetivo juízo (que inclui a questão da objetividade e da verdade sobre os mesmos).

Dada a operatividade das regras gerais em cada momento e lugar da História e o facto de que aquelas exibem o que deve ser considerado verdadeiro e falso (nesse momento e lugar da História), Hume não deve ser considerado um cético em relação ao primeiro plano. Mas em relação ao plano metaético (ou metaestético), o filósofo mantém a posição de que os valores não constituem propriedades objetivas. Por outro lado, mantém (pelo menos, de acordo com as interpretações cognitivistas da sua filosofia), a posição de que os juízos sobre valores são verdadeiros ou falsos.

Deste modo, e concordando com o comentador, neste plano (aliás, aquele sobre o qual se trata este trabalho), Hume pode ser considerado um cético num sentido fraco, em virtude de não reconhecer a existência de um valor independente da mente - sendo um anti-realista -, mas mantendo a concessão de um padrão ou critério em virtude do qual se pode considerar um juízo sobre um valor verdadeiro ou falso - portanto, a possibilidade de esse juízo constituir, pelo menos em parte, uma forma de conhecimento.

De resto, a propensão projetiva proporciona convicções (verdadeiras ou falsas) que compõem a vida, as atividades e as trocas quotidianas (a natureza humana, a causalidade objetiva e o objeto exterior). Caso estas convicções sejam falsas, os juízos serão, num certo sentido, sistematicamente falsos e Coventry estará certa ao propor um padrão imaginário ou construído e cujo escopo se reduz ao campo fenoménico.

Apesar disso, estas convicções proporcionam um cenário que simula aquele tal como se não se teria uma ideia relativa dos seus objetos (da natureza humana, da causalidade objetiva e do objeto exterior) - mas que não é possível descobrir se é verídico ou não, isto é, o cenário que Kail designou de preferência metafisica, e que designei quasi-objetivo.

\footnotetext{
${ }^{948}$ Cf. FIESER, 1989, pp. 94-5; 3.0 deste trabalho.
} 


\subsection{Considerações finais}

Após apresentar, considerar e analisar as evidências textuais das obras de Hume, assim como as propostas interpretativas relativas às três componentes que me propus tratar neste trabalho, procurei mostrar as falhas ou incoerências que identifico nas interpretações realista e anti-realista relativamente à existência da causalidade objetiva, assim como nas propostas não cognitivistas e realista em relação à existência independente da mente dos valores na filosofia de Hume.

Ainda antes do capítulo 4 - onde se condensa a interpretação que funde os dois âmbitos de análise, procuro antecipar alguns elementos da proposta interpretativa que julgo mais justa e coerente sobre a teoria causal e dos valores de Hume, que designei de quasi-realismo cético - e cuja maior dívida é para com Angela Coventry.

$\mathrm{Na}$ secção 2.2.7, procurei justificar que a crença na existência da causalidade objetiva está para além do campo da racionalidade e justificação epistémica, pelo que nem a crença na sua existência nem na sua não existência podem ser consideradas injustificadas. Na secção 3.3.2, procurei mostrar que a interpretação realista da teoria dos valores de Hume parte de um equívoco nas próprias definições de realismo e anti-realismo (no caso de Norton), ou de uma escolha irrelevante de uma posição em detrimento da outra (no caso de Kail). No subcapítulo 3.4, argumentei a favor de uma interpretação anti-realista, cognitivista e descritivista, sem descartar um elemento expressivo nos juízos sobre valores.

No capítulo 4, a interpretação do quasi-realismo cético consolidou-se a partir da exposição dos pontos de continuidade entre a interpretação que proponho mantém e as propostas de Stroud e Coventry (essencialmente, mas também de Jones, Garrett e Townsend). Neste sentido, nas secções 4.3 (em continuidade com 4.1 e 4.2) e 4.4, procurei mostrar os pontos de concordância e discordância com os mesmos comentadores nas secções.

Entretanto, a exposição das componentes que considero originais na proposta geral parte de um exame da noção de projeção - como mecanismo e conteúdo mental que proporciona crenças que não são justificadas ou injustificadas ( $\operatorname{secção~4.5)~-~o~que~complementa~a~conclusão~da~secção~2.2.7.~Em~}$ relação ao seu valor de verdade, no caso da existência da causalidade objetiva procurei justificar o seu caráter indeterminável a partir da restrição do PP às ideias 
claras e distintas (formadas a partir do PC) e do caráter relativo da ideia da causalidade objetiva (secção 4.6). Já no caso do valor de verdade dos juízos sobre valores, concordei com Kail e os proponentes da teoria do erro que enquanto pretensa descrição de uma propriedade observável nos objetos, esses juízos são falsos, mas que nem por isso se torna impossível ou irrazoável considerar que possam ser verdadeiros. Esta possibilidade deve-se à aplicação da dúvida cética relativa à causalidade objetiva às relações causais que se mantêm entre os objetos do valor e a mente que ajuíza (secção 4.7). Por sua vez, e em continuidade com o subcapítulo 3.4, procurei mostrar a pertinência de se considerar o padrão para os juízos uma noção relativa da imaginação fancy, de caráter abstrato (secções 4.2 e 4.6).

Para finalizar, e uma vez que nenhum empreendimento filosófico se pode, razoavelemente, dar por completo, gostaria de expor algumas considerações sobre duas questões que, tendo sido suscitadas pela reflexão e escrita deste trabalho, me suscitam curiosidade e julgo merecerem uma consideração no futuro.

A primeira prende-se com a classificação da crença em relação a outros estados mentais. Com efeito, Hume admite que a crença surge na mente a partir da operação contínua da imaginação e de uma insensibilização da passagem de uma ideia para a que se lhe segue habitualmente - de uma impressão interna ou determinação da mente, mas também chega a defini-la como uma certa maneira de conceber uma ideia ${ }^{949}$. Porém, Hume nunca oferece uma classificação precisa para a crença. Isto não permite responder à consideração de Stroud de que os juízos sobre relações causais expressariam uma crença ${ }^{950}$ : expressam exatamente o quê?

A segunda prende-se com a possibilidade de confrontar a interpretação que propus acerca da existência de ideias relativas na filosofia de Hume com as noções de identidade pessoal e de Deus, uma vez que parecem cumprir os requisitos destacados para que uma ideia tenha um caráter relativo - não ser objeto de impressões e ser constituída a partir de uma relação com ideias claras e distintas - no caso da identidade pessoal, de constituir o substrato das perceções

\footnotetext{
${ }^{949}$ Cf. 1.10 deste trabalho.

${ }^{950}$ Cf. STROUD, 1977, p. 83; 1993, p. 253, 259.
} 
ou aquilo a que se referem ${ }^{951}$, e no caso de Deus, por negação de propriedades que se podem observar e atribuir a questões de facto ${ }^{952}$.

${ }^{951}$ T 1.4.6.2, 4; Ap. 25.

${ }^{952}$ Cf. IEH 2.6. 


\section{Referências}

\section{Fontes primárias}

BERKELEY, G. (1710). Tratado sobre os Princípios do Conhecimento Humano.

Coleção Os Pensadores. São Paulo: Abril Cultural, 1973

HUME, D. (1739/40). A Treatise of Human Nature.T. H. GREEN \& T. H.

GROSE (eds.). London: Longmans, Green and CO., 1874

(1739/40). A Treatise of Human Nature. In https://davidhume.org/

(1739/40). Tratado da Natureza Humana. Trad. de Déborah Danowski.

São Paulo: UNESP, 2001

(1741-77). Essays Moral, Political and Literary. In

https://davidhume.org/

(1741-77). A Arte de Escrever Ensaio e Outros Ensaios. Trad. Márcio

Suzuki \& Pedro Pimenta. Iluminuras: São Paulo. 2009

(1748/1777). An Enquiry concerning Human Understanding. In https://davidhume.org/

(1751/1777). An Enquiry Concerning the Principles of Morals. In https://davidhume.org/

(1748/1777). Investigações sobre o Entendimento Humano e sobre os

Princípios da Moral. Trad. José Oscar de A. Marques. São Paulo: UNESP, 2004

(1779). Dialogues Concerning Natural Religion. In

https://davidhume.org/

(1779). Diálogos sobre a Religião Natural. Trad. José Oscar de A.

Marques. São Paulo: Martins Fontes, 1992

LOCKE, J. (1690). Ensaio sobre o Entendimento Humano. Coleção Os Pensadores. São Paulo: Abril Cultural, 1973

MALEBRANCHE, N. (1674-75). A busca da verdade. Trad. Plínio J. Smith. São

Paulo: Discurso Editorial; Paulus, 2004

REID, T. (1764) An Inquire into the Human Mind on the Principles of Common Sense. Edinburgh

(1785). Essays on the Intellectual Powers of Man. BROOKES, D. R. (ed.; 2002). Pennsylvania: Pennsylvania State University Press 
(1788). Essays on the Active Powers of Man. HAAKONSEN, K.;

HARRIS, J. (eds.; 2010). Edinburgh: Edinburgh University Press

(1792). Of Power. The Philosophical Quarterly, v. 51, n. 202, 2001, pp.

$1-12$

\section{Fontes secundárias}

ÁRDAL, P. S. (1966). Passion and Value in Hume's Treatise. Edinburgh: Edinburgh University Press

(1977). Covention and Value. In TWEYMAN (ed.; 1995). Hume's

Critical Assessments. London; New York: Routledge, v. IV, pp. 78-98

ATKINSON, R. (1976). Hume on The Standard of Morals. The Southwestern Journal of Philosophy, v. 7, n. 2, pp. 25-44

AYER, A. J. (1980), Hume, Publicações Dom Quixote, Lisboa, 1981

BAIER, A. (1991). A Progress of Sentiments: Reflections on Hume's Treatise.

Cambridge; London: Harvard University Press

BAXTER, D.1 L. M. (1990). 'Hume on Virtue, Beauty, Composites, and Secondary Qualities'. Pacific Philosophical Quartely, 103-118

BEAUCHAMP, T. L., ROSENBERG, A. (1981). Hume and the Problem of Causation. New York: Oxford University Press

BELL, M. (2000). Sceptical doubts concerning Hume's causal realism. In READ, R.; RICHMAN, K. A. (eds.; 2007). The New Hume Debate: revisited edition. London: Routledge, pp. 122-137

BENNETT, J. (1971). Locke, Berkeley, Hume: Central Themes. Oxford: Clarendon Press

BLACKBURN, S. (1990). Hume and thick connexions. In READ, R.; RICHMAN, K. A. (eds.; 2007). The New Hume Debate: revisited edition. London: Routledge, pp. 100-112

(1993a). Essays in Quasi-realism. New York; Oxford: Oxford University Press

(1993b). Hume on the Mezzanine Level. Hume Studies, v. 9, n. 2, pp. $273-288$

(1998). Rulling Passions: A Theory of Practical Reasoning. Oxford: Oxford University Press 
BRICKE, J. (1988). Hume, Motivation and Morality. Hume Studies, v. 14, n. 1, pp. $1-24$

BROACKES, J. (1993). Did Hume Hold a Regulatity Theory of Causation?.

British Journal for the History of Philosophy, v. 1, n. 1, pp. 99-114

BROAD, C. D. (1930). Five Types of Ethical Theory. London: Routledge and Kengan Paul.

BROUGHTON, J. (1983). Hume's Skepticism About Causal Inferences. Pacific Philosophical Quarterly, v. 64, n. 1, pp. 3-18

(1987). Hume's Ideas About Necessary Connection. Hume Studies, v. 13, n. 2 , pp. $217-244$

(2007). 'Our aim in all our studies'. In READ, R.; RICHMAN, K. A. (eds.; 2007). The New Hume Debate: revisited edition. London: Routledge, pp. $198-210$

BROWN, C. (1994). From Spectator to Agent: Hume's Theory of Obligation.

Hume Studies, v. 20, n. 1, pp. 19-36

BROWN, T. (1806). Observations on the Nature and Tendency of the Doctrine of

Mr. Hume Concerning the Relation of Cause and Effect. 2nd ed. Edinburgh

BRUNET, O. (1965). Philosophie et Esthétique chez David Hume. Paris: Librairie A-G Nizet

CAMPELO, W. (2020). A questão do ceticismo moral em David Hume: conexões epistemológicas e ontológicas. Modernos \& Contemporâneos, v. 4, n. 8, pp. 4-15 CAPALDI, N. (1989/1992). Hume's Place in Moral Philosophy. New York; Berlin; Bern; Frankfurt; Paris; Wien: Peter Lang

COHON, R. (2008). Hume's Morality: Feeling and Fabrication. Oxford: Oxford University Press

COSTA, M. (1981). Hume and Justified Belief. Canadian Journal of Philosophy, XI, pp. 219-228

(1986). Hume and Causal Inference. Hume Studies, v. 12, n. ?, pp. 141159

(1989). Hume and Causal Realism. Australasian Journal of Philosophy, v. 67, n. 2, pp. 172-190

(1998). Hume on the Very Idea of a Relation. Hume Studies, v. 24, n. 1, pp. $71-94$ 
COVENTRY, A. (2006). Hume's Theory of Causation: A Quasi-Realist Interpretation. New York: Continuum

(2007). Hume: A Guide for the perplexed. London; New York:

Continuum

(2009). The Delicate Causalist: Reply to my Critics. Manuscrito, v. 32, n.

2, pp. $500-517$

CRAIG, E. (1987). One Way to Read Hume. In The Mind of God and The Works of Man. Oxford and New York: Oxford University Press, pp. 69-130

(2007). Hume on causality: Projectivist and realist? In READ, R.;

RICHMAN, K. A. (eds.; 2007). The New Hume Debate: revisited edition. London: Routledge, pp. 113-121

DAVIE, W. (1976). Hume's Catalog of Virtue and Vice. The Southwestern Journal of Philosophy, v. 7, n. 2, pp. 45-57 (1987). Hume's Apology. Hume Studies, v. 13, n. 1, pp. 30-46 (1988). A Personal Element in Morality. Hume Studies, v. 14, n. 1, pp. $191-205$

(1998). Hume‘s General Point of View. Hume Studies, v. 24, n. 2, pp. 275-294

DICKIE, G. (1996). The century of Taste: The Odyssey of Taste in the Eighteenth Century. Oxford: New York, Oxford University Press

DURLAN, K. (2009). A Few Questions About Angela Coventry's Hume's Theory of Causation: A Quasi-realist Interpretation. Manuscrito, v. 32, n. 2, pp. 495-500

FIESER, J. (1989). Is Hume a Moral Skeptic?. Philosophy and Phenomenological Research, v. 1, n. 1, pp. 89-105

(1992). Hume's Classification of the Passions and Its Precursors. Hume Studies, v. 18, n. 1, pp. 1-13

FLAGE (1981). Hume's Relative Ideas, Hume Studies, v. 7, n. 1, pp. 55-73

(1982). Relative Ideas Revisited: A Reply to Thomas. Hume Studies, v. 8, n. 2 , pp. $158-171$

(1984). Hume on Memory and Causation. Hume Studies, $10^{\text {th }}$ Anniversary Issue, pp. 168-88

(1985). Perchance to Dream: A Reply to Traiger. Hume Studies, v. 11, n.

2, pp. $173-82$ 
(1989). Remembering the Past. Hume Studies, v. 15, n. 1, pp. 236-46 (1993). On Friedman's Look. Hume Studies, v. 19, n. 1, pp. 187-197 (2007). Relative ideas re-viewed. In READ, R.; RICHMAN, K. A. (eds.; 2007). The New Hume Debate: revisited edition. London: Routledge, pp. 138-155 FLEW, A. (1961), Hume's philosophy of belief, London: Routledge and Kegan Paul (1963). On the Interpretation of Hume. Philosophy, v. 38, pp. 178-182 FOGELIN, R. (1985). Hume's Skepticism in the Treatise of Human Nature. London; Boston: Routledge \& Kegan Paul FOOT, P. (1963). Hume on Moral Judgement. In COHON, R. (ed.; 2001). Hume: Moral and Political Philosophy. Aldershot; Burlington; Singapore; Sydney, pp. $75-80$

FRIEDMAN, L. (1993a). Another Look at Flage's Hume. Hume Studies, v. 19, n. 1, pp. 177-186

(1993b). Reply to Flage. Hume Studies, v. 19, n. 1, pp. 199-202

GARRETT, D. (1997). Cognition and Commitment in Hume's Philosophy. New York; Oxford: Oxford University Press (2014). Hume. Oxon, New York: Routledge

GUIMARÃES, L. (2009). Comments on Angela Coventry's Hume's Theory of Causation: A Quasi-Realist Interpretation. Manuscrito, v. 32, n. 2, pp. 471-478 HARRISON, J. (1976). Hume's Moral Epistemology. Oxford: Clarendon Press HAAKONSSEN, K. (1978). Hume's Obligations. Hume Studies, n. 4, v. 1, pp. 717

HAKKARAINEN, J. (2012a). Hume's Scepticism and Realism. British Journal for the History of Philosophy, v. 20, n. 2, pp. 283-309

(2012b). Why Hume cannot be a Realist. The Journal of Scottish Philosophy, vol. 10, n. 2, pp. 143-161

HALBERTSTADT, W. H. (1971). A Problem in Hume's Aesthetics. The Journal of Aesthetics and Art Criticism, v. 30, n. 2, pp. 209-14I

HARE, R. M. (1997). Sorting Out Ethis. Oxford: Oxford University Press HOME, H. (1751). Essays on the Principles of Morality and Natural Religion. Indianapolis: Liberty Fund, 2005

HUDSON, W. D. (1964). Hume on Is and Ought. The Philosophical Quarterly, v. 14 , n. 56 , pp. $246-52$ 
HUNTER, G. (1962). Hume on Is and Ought. Philosophy, v. 37, n. 140, pp. 148152

HUSSERL, E. (1923/4). Le Positivisme de Hume - à la fois accomplissement du scepticisme et pas préliminaire décisif conduissant à une science transcendantale fondamentale. In Philosophie Première: Histoire Critique des Idées. Trad. Arion K. Kelkel. Paris, PUF, 1970, pp. 219-260

JOHNSON, O. (1987). . Hume Studies, v. 13, n. 2, pp. 343 -359

JONES, P. (1970). Another look at Hume's views of Aesthetic and Moral Judgements. Philosophical Quarterly, v. 20, n. 78, pp. 53-59

(1976). Hume's Aesthetics Reassessed. The Philosophical Quarterly, Hume Bicentenary Issue, v. 26, n. 102, pp. 48-62

(1982). Hume's Sentiments: Their Cicerionian and French Context.

Edinburgh: Edinburgh University Press

KAIL, P. (2001), Projection and Necessity in Hume, European Journal of Philosophy, v. 9, n. 1, pp. 24-54

(2003a), Conceivability and Modality in Hume: A Lemma in an Argument in Defense of Skeptical Realism, Hume Studies, v. 29, n. 1, pp. 43-61 (2003b), Is Hume a Causal Realist?, British Journal for the History of Philosophy, v. 11, n. 3, pp. 509-20

(2007a). How to Understand Hume's Causal Realism. In READ, R.; RICHMAN, K. A. (eds.; 2007). The New Hume Debate: revisited edition. London: Routledge, pp. 251-269

(2007b), Projection and Realism in Hume's Philosophy, Oxford; New York: Oxford University Press

(2007c), Review of Angela Coventry. Hume's Theory of Causation: A Quasi-realist Interpretation. Hume Studies, v. 33, n. 1, pp. 190-192 (2010), Response to my Critics. Hume Studies, v. 36, n. 1, pp. 97-107 KORSGAARD, C. (1999). The General Point of View: Love and Moral Approval in Hume's Ethics. Hume Studies, v. 25, n. 1\&2, pp. 3-42

LAIRD, J. (1932). Hume's Philosophy of Human Nature. London (1939). Hume's Account of Sensitive Belief. Mind, v. 48, n. 192, pp. 427445

LELAND, J. (1757) A View of the Principal Deistical Writers, Vol. I, 3rd edn, London: Benjamin Dod 
LIGHTNER, D. (1997). Hume on Conceivability and Inconceivability. Hume Studies, v. 23, n. 1, pp. 113-13

LIMONGI, I. (2006). O fato e a norma do gosto: Hume contra um certo ceticismo. Analytica, v. 10, n. 1, pp. 108-24

LIVINGSTON, D. W. (1984). Hume's Philosophy of Common Life. Chicago: University of Chicago Press

(1985). Theism and the Rationale of Hume's Skepticism About Causation. Idealistic Studies, v. 15, n. 2, pp. 151-64

LOEB, L. E. (1977). Hume's Moral Sentiments and the Structure of the Treatise. Journal of the History of Philosophy, v. 15, n. 4, pp. 395-403

(2001). Hume's Explanation of Meaningless Beliefs, The Philosophical Quaterly, v. 51, n. 203, pp. 145-164

MACKIE, J. L. (1977). Ethics: Inventing Right and Wrong. London: Pelican Books

(1980a), Hume's Account of Causation. In The Cement of the Universe: A Study of Causation, Oxford, New York: Oxford University Press, pp. 3-28 (1980b), Hume's Moral Theory. London and New York: Routledge

MACNABB, D. G. C. (1951). David Hume: His Theory of Knowledge and Morality. London: Hutchison House (?)

MILL, S. (1843). Sistema de Lógica Dedutiva e Indutiva. Coleção Os Pensadores. São Paulo: Abril Cultural, 1974

MILLICAN, P. (2007a). Against the 'New Hume'. In READ, R.; RICHMAN, K. A. (eds.; 2007). The New Hume Debate: revisited edition. London: Routledge, pp. $211-252$

(2007b). Introduction to The Enquiry Concerning Human Understanding. In MILLICAN, P. (ed.; 2007). An Enquiry concerning Human Understanding. Oxford: Oxford University Press MONTEIRO, J. P. (1975). Teoria, Retórica, Ideologia. São Paulo: Ática (1981). Hume's Conception of Science. Journal of the History of Philosophy, v. 19, n. 3, pp. 327-42

NORTON, D. F. (1975). Hume's Common-sense Morality. Canadian Journal of Philosophy, v. 5, n. 4, pp. 523-543

(1982). David Hume: Common-sense Moralis, Skeptical Metaphysician. Princeton: Princeton University Press 
(1985). Hume's Moral Ontology. Hume Studies, v. 11 (suplement), pp. 189- 214

NOXON, J. (1961). Hume's Opinion of Critics. The Journal of Aesthetics and Art Criticism, v. 20, n. 2, pp. 157-62

(1973). Hume's Philosophical Development: A Study of his Methods.

Oxford: Oxford University Press

NUYEN, A. T. (1984). David Hume on Reason, Passions and Morals. Hume

Studies, v. 10, n. 1, pp. 26-45

OSWALD, J. (1768) An Appeal to Common Sense in Behalf of Religion, Vol. I, 2nd edn, London: J. Hughs

OTT, W. (2006). Hume on Meaning. Hume Studies, v. 32, n. 2, pp. 233-52

PASSMORE, J. (1968). Hume's Intentions, London: Duckworth

PITSON, A. E. (1989). Projectionism, Realism, and Hume's Moral Sense Theory.

Hume Studies, v. 15, n. 1, pp. 61-92

PRICE, R. (1758). A Review of the Principal Questions in Morals, ed. D.D.Raphael, Oxford: Clarendon Press, 1948

PRICE, K. B. (1950). Does Hume's Theory of Knowledge Determine his Ethical Theory?. The Journal of Philosophy, n. 47, v. 15, pp. 425-34

PENELHUM, T. (1975). Hume. London; Basingstoke: The Macmillan Press

RADCLIFFE, E. (1994). Hume on Motivating Sentiments, the General Point of View, and the Inculcation of "Morality". Hume Studies, v. 20, n. 1, pp. 37-58

READ, R. The new antagonists of 'the New Hume'. In READ, R.; RICHMAN, K. A. (eds.; 2007). The New Hume Debate: revisited edition. London: Routledge, pp. 167-197

SHECAIRA, F. (2011). Hume and Noncognitivism. History of Philosophical Quarterly, n. 28, v. 3, pp. 267-287

SCHLIESSER, E. (2010). Philosophical Relations, Natural Relations, and Philosophic Decisionism in Belief in the External World: Comments on P. J. E. Kail, Projection and Realism in Hume's Philosophy. Hume Studies, v. 36, n. 1, pp. $67-76$

SHAW, D. (1992). Reason and Feeling in Humes Action Theory and Moral Philosophy. Hume Studies, v. 18, n. 2, pp. 349-68

(1993). Humes Moral Sentimentalism. Hume Studies, v. 19, n. 1, pp. 31- 
SMITH, N. K. (1905a). The Naturalism of Hume (I). Mind, v. 14, n. 54, pp. 149173

(1905b). The Naturalism of Hume (II). Mind, v. 14, n. 55, pp. 335-347

(1941), The Philosophy of David Hume, London: McMillan

SMITH, P. (1995). O ceticismo de Hume. Belo Horizonte: Edições Loyola (2015). Como Hume se tornou cético?. In O Método de Ooposição na

Filosofia Moderna. São Paulo: Alameda, pp. 183-206

STANLEY, P. (1935). The Scepticisms of David Hume. The Journal of

Philosophy, v. 32, n. 16, pp. 421-431

STRAWSON, G. (1989). The Secret Connexion: Causation, Realism, and David Hume. Oxford: Oxford University Press, 2014

(2000). David Hume: Objects and power. In READ, R.; RICHMAN, K. A. (eds.; 2007). The New Hume Debate: revisited edition. London: Routledge, pp. $31-51$

STROUD, B. (1977). Hume. London; New York: Routledge and Kegan Paul (1978). Hume and the Idea of Causal Necessity. Philosophical Studies, v. 33 , pp. $39-59$

(1991). Hume's Scepticism: Natural Instincts and Philosophical Reflection. Philosophical Topics, v. 19, n. 1, pp. 271-91

(1993). 'Gilding or staining' the world with 'sentiments' and 'phantasms'.

Hume Studies, v. 19, n. 2, pp. 253-72

(2006). The Constraints of Hume's Naturalism. Synthese, v. 152, n. 3, pp.

$339-51$

STURGEON, N. (2008), Hume's Metaethics: Is Hume a Moral Noncognitivist?", in RADCLIFFE, E. (ed.; 2008). A Companion to Hume. Oxford: Blackwell, pp. $513-28$

SWAIN, C. G. (1992). Passionate Objectivity, Noûs, v. 26, n. 4, pp. 465-490

TAYLOR, J. (2002). Hume on the Standard of Virtue. The Journal of Ethics, v. 6, n. 1, pp. $43-62$

(2008). Hume on beauty and virtue. In RADCLIFFE, E. (ed.), Companion to Hume. Malden; Oxford; Carlton; Blackwell Publishing Ltd, pp. 273-92

(2010). Gilding and Staining and the Significance of Our Moral Sentiments. Hume Studies, v. 36, n. 1, pp. 89-96 
TIDMAN, P. (1994), Conceivability as a test for Possibility, American Philosophical Quarterly, v. 31, n. 4, pp. 297-309

THOMAS, M. (1982), Hume's Relative Ideas Rejected, Hume Studies, v. 8, n. 2, pp. $149-157$

TOWNSEND, D. (2001). Hume's Aesthetic Theory: Taste and sentiment, London; New York: Routledge

TRAIGER (1985), Flage on Hume's Account of Memory, Hume Studies, v. 11, n. 2, pp. 166-172

WILSON, F. (2009). Reflections on Angela Coventry's Hume's Theory of Causation. Manuscrito, v. 32, n. 2, pp. 479-93

WINKLER, K. (1991). The New Hume. In READ, R.; RICHMAN, K. A. (eds.; 2007). The New Hume Debate: revisited edition. London: Routledge, pp. 52-87 WINTERS, B. (1979). Hume on Reason. Hume Studies, v. 5, n. 1, pp. 20-35 WRIGHT, J. P. (1983). The Sceptical Realism of David Hume. Manchester: Manchester University Press (1986) 'Hume's Academic Scepticism: A Reappraisal of His Philosophy of Human Understanding', in Stanley Tweyman (ed.), David Hume - Critical Assessments, vol. 2, London: Routledge. pp. 222-47, 1995 (1987). Hume vs. Reid on Ideas: The New Hume Letter. Mind, v. 96, n. 383, pp. 392-398

(1991). Hume's Rejection of the Theory of Ideas. History of Philosophical Quarterly, v. 8, n. 2, pp. 149-162 (2000). Hume's causal realism: Recovering a traditional interpretation. In In READ, R.; RICHMAN, K. A. (eds.; 2007). The New Hume Debate: revisited edition. London: Routledge, pp. 88-99

YABLO, S (1993). Is Conceivability a Guide to Possibility?. Philosophy and Phenomenological Research, v. 53, n. 1, pp. 1-42

YOLTON, J. (1980). Hume’s Ideas. Hume Studies, v. 6, n. 1, pp. 1-25 